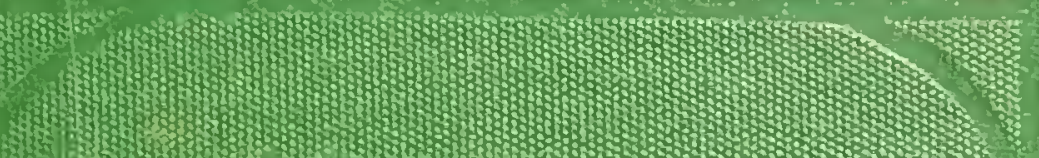

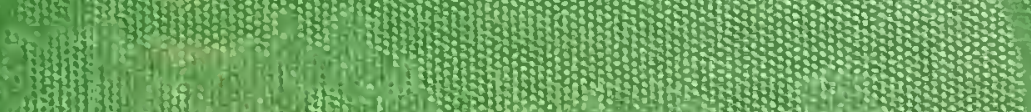
13. 2.13

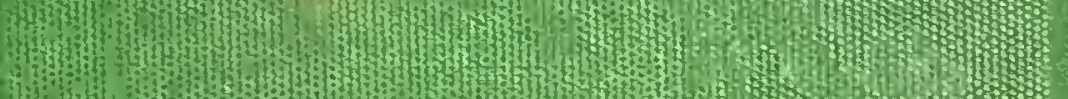
13 1.3. (3) 13. 1. 1.

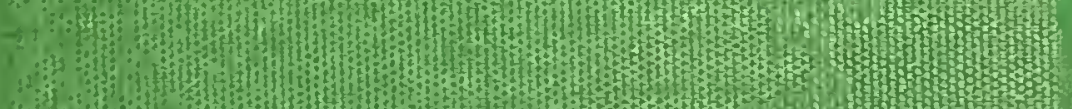

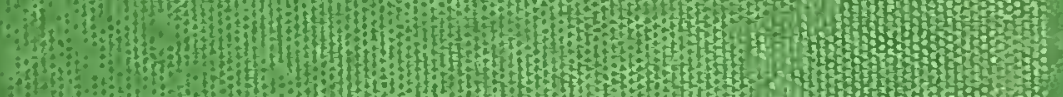
Ant Hat 3. 19.

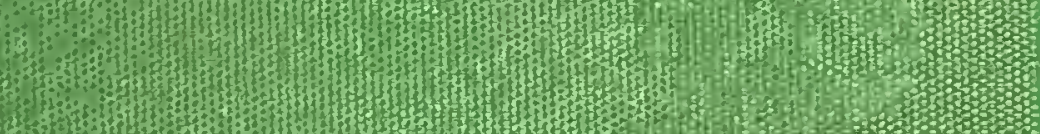

31. Hot $303 \%$

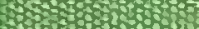

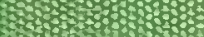
$303 \%$ 3. Shot Sto . Hotos 3. H. 3. b37\% 1.85\% 35 3035 \%5:

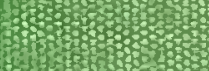
H. 7303 3. S3 $73^{3}$

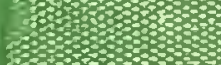




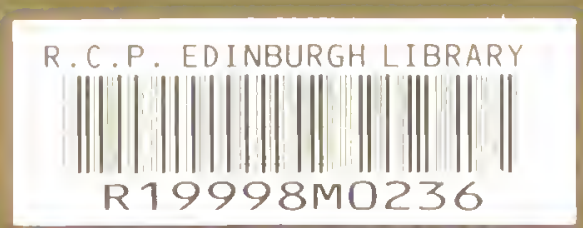




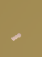

$\checkmark$

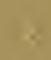

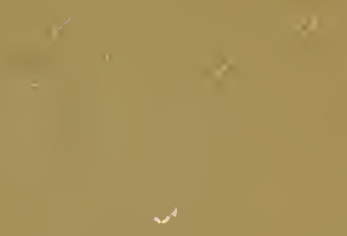

;

$\%$ 


$$
102.24
$$



Digitized by the Internet Archive in 2015

https://archive.org/details/b21723916 


\section{THE EFEECTS}

or

\section{CROSS AND SELF FERTIJISATION}

IN THL

\section{VEGETABLE KINGDOM.}

Br CHARLES DARWIN, M.A., F.R.S., ETC.

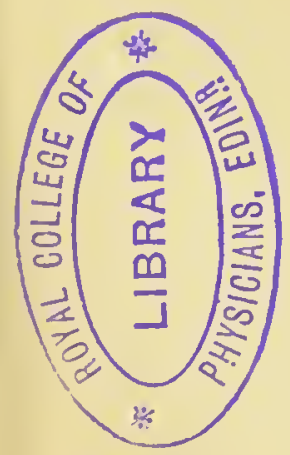

$$
\text { LONDON : }
$$

JOHN MURRAY, ALBEMARIE S'TREE'T. 1876. 
ON 'IHE ORIGIN OF SPECIES BY MEANS OF NATURAJ,

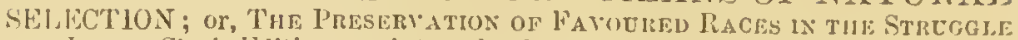
For LiFs. Sistli Edition. sixteenth Thousand.

MURTAX.

'PHE DESCENT OF MAN, AND SELECIION IN RELATION 'IO SEX. With Illustrations. Second lidition, revised and angmented. Eleventh Thousand. JLI:KAL.

'LHE VARLATIUN OF ANIMALS AND PLANTA UNDER DOMESTICATION. With Illustrations. Second Edition, revised. Fourth T'housand. 2 vols.

Murray.

'THE FXPRESSION OF 'THE EMO'IONS IN MAN' ANT AN13ALS. With Plotographic and other Illustrations. Ninth Thousand.

ON THE VARIOUS CONTRIVANCES BY WHICH BRITISH A.VI FOREISN ORCHIISS ARE FERTILISEI) BY INSECIS. Second kition, revised. With Wuodeuts. MurRax.

INSECIIVOROUS PLANTS. With Illustrations. Thivd Thousand.

'I'HE MOVEMEN'TS AND HABITS OF CLIMBING

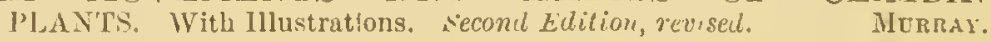

'THE FFIECTS OF CROSS AND SELF FERTILISATION IN THE VEGETABLE KINGDON.

MันRАร.

A NATURALIS'T'S VOYAGF ROUND 'THE WORLD; or',

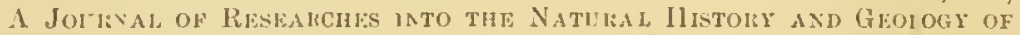
TII: Cooxtrulss visited during the Foyage of II.M.S. 'Betgre? under the command of Captain FinzRoy, R.N. Thi teenth Thousand. Mlukax.

() 5 'I'HE S'IRUCTURE AND DIS'TRIBUTION OF CORAL IEElis. Seccnd, dition, revised.

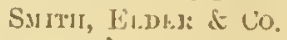

(:EOLOGICAL OBSERVATIONS ON THE VOI.CANIC ISLANDS AND PARTS OF SOUTH AMERICA, visited during the Voyge of II.M.S. 'Beagle.' Second kdition.

SมrTI, Li.uen: \& Co.

A MONOGRAPH OF 'IHE CIRRIPEDIA. With numerous Illinstritions. 2 vols. 8 vo.

RaX SOCHETr, IIALDWTCLE.

A MONOGRAPH UF THE FOSSIL LEPADIDA OR I'EDUNCULATED CIRRIPEDS OF GREAT BRITAIN.

Pal.antogiaplical Societr, 1951.

1 MONOGRAPIH OF THE FOSSIL BALANIDAE ANDD TERRUC'IDA OF GREA'L BRITAIN.

PaILONTOGRAPIICAL SOCINT, 1854.

liACTE AND ARGUMENTS FOR DARWIN. By FriTz Nlubilir. From the German, with Additions by the Author. Translated by W. S. DAl.LAS, F.L.S. With lllustrations. l'ost sro.

MIURLAI. 


\section{O NTE TTS.}

\section{CHAPTER I.}

INTRODUCTORy Remaris.

Various means which favour or determine the cross-fertilisation of plants - Benefits derived from cross-fertilisation - Sclf-fertilisation favourable to the propagation of the specics - Brief history of the subject - Object of thic experiments, and the manner in which they were tried-Statistical value of the measurcmentsThe experiments carried on during several successive generations - Nature of the relationship of the plants in the later gcnerations - Uniformity of the conditions to which the plants were subjected - Some apparent and some real causes of errorAmount of pollen employed - Arrangement of the work -

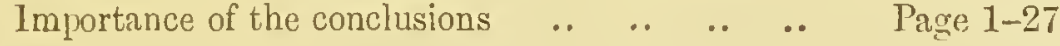

\section{CHAPTER II.}

\section{Convolvulace}

Ipomœa purpurea, comparison of the height and fertility of the crossed and self-fertilised plants during ten successive generations - Greater constitutional vigour of the crossed plants The effects on the offspring of crossing different flowers on the same plant, instead of crossing distinct individuals - The effects of a cross with a fresh stock - The descendants of the self-fertilised plant namcd Hero-Summary on the growth, vigour, and fertility of the successive crossed and self-fertilised generations - Small amount of pollen in the anthers of the self- 
fertilised plants of the later gcnerations, and the stcrility of their first-produced flowers - Uniform coluur of the flowers produced by the self-fertilised plants - The advantage from a cross between two distinct plants depends on their differing in constitution

\section{CHAPTER III.}

Scrophulariacee, Gesmeriacede, Labiate, etc.

Mimulus luteus; height, vigour, and fertility of the crossed and sclf-fertilised plants of the first four generations - Appcarance of a new, tall, and highly self-fertile varicty - Offspring from it cross betwecn self-fertilised plants - Effects of a cruss with a fresh stock - Effects of crossing flowers on the same plantSummary on Mimulus lutcus - Digitalis purpurea, superiority of the crossed plants - Effects of crossing flowers on the same plant - Calceolaria - Linaria vulgaris - Verbascum thapsus Vandellia nummularifolia - Cleistogene flowers - Gesncria pendulina - Salvia coccinca - Origanum vulgarc, great increase of the crosscd plants by stolons - Thumbergia alata .. $\quad 63-97$

\section{CHAPTER IV.}

Crucifera, Papaveracede, Resedace e, etc.

Brassica oleracca, crossed and self-fertilised plants - Great effect of a cross with a fresh stock on the weight of the offspring - Ibcris umbcllata - P'apavcr vagum - Eschscholtzia californica, scedlings from a cross with a fresh stock not more rigorous, but more fertilc than the self-fertilised scedlings - Reseda lutea and odorata, many individuals sterile with their own pollen - Viola tricolor, wonderful effects of a cross - Adonis astivalis Dclphiuium consolida - Tiscaria oculata, crossed plants hardly taller, but morc fertilc than the self-fertilised-Dianthus caryophyllus, crossed and self-fertilised plants compared for four generations - Grcat effects of a cross with a fresh stockUniform colour of the flowers on the sclf-fertilised plants -

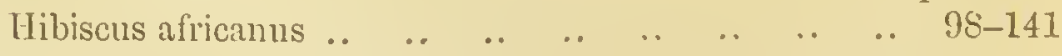




\section{CHAPTER V.}

Geraniace a, Leguminose, Onagracez, etc.

Pelargonium zonale, a cross between plants propagated by cuttings does no good - Tropxol tum minus - Limnanthes douglasii Lupiuus luteus and pilosus-Phaseolus multiflorus and vulgaris - Latljyrus odoratus, varieties of, never naturally intercross in England - Pisum sativum, varieties of, rarely intercross, but a cross between them highly beneficial-Sarothamnus scoparius, wonderful effects of a cross-Ononis minutissima, cleistogene flower's of - Summary on the Leguminose - Clarkia elegans - Bartonia aurea - Passiflora gracilis - A pium petruselinum - Seabiosa atropurpurea - Lactuea sativa - Specularia speculum - Lobelia ramosa, advantages of a eross during two generations - Lobelia fulgens - Nemoplila insignis, great advantages of a eross - Borago oficinalis - Nolana prostrata.

Page 142-1s7

\section{CHA P T E R V I.}

Solataced, Primulacede, Polygonez, etc.

Petunia violaeea, erossed and self-fcrtilised plants compared for four generations - Effeets of a cross with a fresh stock - Uniform colour of the flowers on the self-fertilised plants of the fourth generation - Nicotiana tabacum, crossed and self-fertilised plants of equal height - Great effects of a cross with a distinct sub-variety on the height, but not on the fertility, of the off." spring - Cyclamen persicum, crossed seedlings greatly superior to the sclf-fertilised - Anagallis eollina - Primula veris Equal-styled variety of Primula veris, fertility of, greatly inereased by a cross with a fresh stock-l'agopyrum esculentum - Beta vulgaris - Canna warscewiczi, erossed and self-fertilised plants of equal height - Zea mays - Phalaris canariensis. 


\section{CHAPTER VII.}

Summary of the Heighy axd IVeights oi the Crossed and Seyf-fertirised Piant's.

Number of species and plants measured - Tables given - Preliminary remarks on the offspring of plants crossed by a fresh stock - Thirteen cases speeially considered - The effects of crossing a self-fertilised plant cither by another self-fertilised plant or by an intercrossed plant of the old stock - Summary of the results - Preliminary remarks on the crossed and selffertiliscd plants of the sane stoek - 'l'he twenty-six exceptional cases eonsilered, in which the crossed plants did not exceed greatly in height the self-fertilised - Most of these cases shown not to be real exceptions to the rule that cross-fertilisation is benefieial - Summary of results - Relativc weights of the

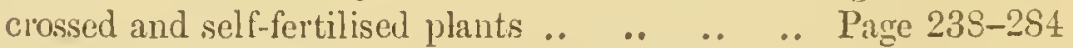

\section{CHAPTER VIII.}

Dhrerexce between Crossed and Self-rentrlised Plants in Cosstitutional Vigour and in other Respects.

Greater eonstitutional vigour of crossed plants - The effects of great crowding - Competition with other kinds of plants - Self-fertilised plants more liable to premature death - Crossed plants generally flower before the self-fertilised - Negative effects of intererossing flowers on the same plant-Cases described'I'ransmission of the good effects of a eross to later generations - Effects of crossing plants of closely related parentage Uniform colour of the flowers on plants self-fertilised during several generations and cultivated under similar conditions.

$285-311$

\section{CHA P T E IX.}

'line EFFects of Cross-fertulisation and Sely-hertulisation on the Ploduction ol Seeds.

Fertility of plants of crossed and self-fertilised parentage, both lots being fertilised in the same manncr-Fertility of the parentplants when first crossed and self-fertilised, and of their crosserl 
and self-fertilised offspring when again crossed and self-fertilised - Comparison of the fertility of flower's fertilised with their own pollen and with that from other flowers on the same plant — Self-sterile plants - Causes of self-sterility - The appearance of highly self-fertile varieties - Self-fertilisation apparently in some respects beneficial, independently of the assured production of seeds - Relative weights and rates of germination of seeds from crossed and self-fertilised flowers .. Page 312-355

\section{CHAPTER X.}

\section{Means of Fertilisation.}

Sterility and fertility of plants when insects are excluded - The means by which flower's are cross-fertilised - Structures farourable to self-fertiiisation - Relation between the structure and conspicnousness of flowers, the visits of insects, and the advantares of cross-fertilisation - The means by which flowers are fertilised with pollen from a distinct plant - Greater fertilising power of such pollen - Anemophilous species - Conversion of anemophilous species into entomophilous - Origin of nectar Anemophilous plants generally have their sexes separated Conversion of diclinous into hermaphrodite flowers-Trees olten have their sexes separated ..

\section{CHAPTER XI.}

'lie Habits of Insects in relation mo the Fertilisation of Flowers.

Insects visit the flowers of the same species as long as they can Cause of this habit-Means by which bees recognise the flowers of the same species - Sudden secretion of nectarNectar of certain flowers unattractive to certain insects - Industry of bees, and the number of flowers visited within a short time - Perforation of the corolla by bees - Skill shown in the operation - Hive-bees profit by the holes made by humble-bees - Effects of habit - The motive for perforating fluwer's to save time - Flowers growing in crowded masses chiefly perforated. 


\section{CHAPTER XII.}

Gejeral, Results.

Cross-fertilisation proved to be beneficial, and self-fcrtilisation injurious - Allied speeies differ greatly in the means by which eross-fertilisation is favoured and self-fertilisation avoided The benefits and evils of the two processes depend on the degree of differentiation in the sexual elements - 'T'he evil effects not due to the combination of morbid tendeneies in the parents Nature of the conditions to whieh plants are subjected when growing near together in a state of nature or under culture, and the effects of sueh conditions - Theoretieal considerations with respect to the interaetion of differentiated sexual elementsPractieal lessons - Genesis of the two sexes - Close correspondenee between the effects of cross-fertilisation and self-fertilisation, and of the legitimate and illegitimate unions of heterostyled plants, in comparison with hybrid unions Page 436-469

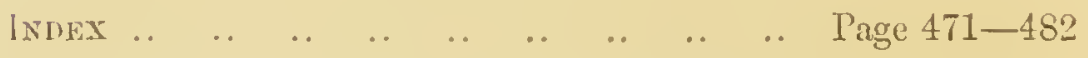




\section{ERRATA.}

PAGE

35, Table VI., bottom of second column, for " $495 \cdot 13$ " read " $495 \cdot 25$."

121, twelve lines from bottom of page, for " fertilised " read " self-fertilised."

162, Table LVII., bottom of third column, for " $158 \cdot 76$ " read "158 75." 

THE

EFEETS

OF

\section{CROSS AND SELF-FERTILISATION.}

CHAPTER I.

INTRODUCTORY REMARKS.

Various means which favour ol determine the cross-fertilisation of plants-Benefits derived from cross-fertilisation-Self-fertilisation favourable to the propagation of the species-Brief history of the subject-Object of the experiments, and the manner in which they were tried-Statistical value of the measurements-The experiments carried on during several successive generations-Nature of the relationship of the plants in the later generations-Uniformity of the conditions to which the plants were subjected-Some apparent and some real causes of error-Amount of pollen employed-Arrangement of the work-Importance of the conclusions.

THere is weighty and abundant evidence that the flowers of most kinds of plants are constructed so as to be occasionally or habitually cross-fertilised by pollen from another flower, produced either by the same plant, or generally, as we shall hereafter see reason to believe, by a distinct plant. Cross-fertilisation is sometimes ensured by the sexes being separated, and in a large number of cases by the pollen and stigma of the same flower being matured at different times. Such plants are called dichogamous, and have been divided into two sub-classes: proterandrous species, 
in which the pollen is mature before the stigma, and proterogynous species, in which the reverse occurs; this latter form of dichogany not being nenty so common as the other. Cross-fertilisation is also ensured, in many cases, by mechanical contrirances of wonderful beauty, preventing the impregnation of the flowers by their own pollen. There is a small class of plants, which I have called dimorphic and trimorphic, but to which Hildebrand has given the more appropriate name of hetcrostyled; this class consists of plants presenting two or threc distinct forms, adapted for reciprocal fertilisation, so that, like plants with separate sexes, they can hardly fail to be intercrossed in each generation. The male and female organs of some flowers are irritable, and the insects which touch them get dusted with pollen, which is thus transported to other flowers. Again, there is a class, in which the ovules absolutely refuse to be fertilised by pollen from the same plant, but can be fertilised by pollen from any other individual of the same species. There are also very many species which are partially sterile with their own pollen. Lastly, there is a lirge class in which the flowers prescnt no apparent obstacle of any kind to self-fertilisation, nevertheless these plants are frequently intercrossed, owing to the prepotency of pollen from another individual or varicty over the plant's own pollen.

As plants are adapted by such diversified and effective means for cross-fertilisation, it might have been inferred from this fact alone that they derived some great arlvantage from the process: and it is the olject of the present work to show the nature and importance of the benefits thus derived. 'There are, howerer, some exceptions to the rule of plants being constructed so as to allow of or to favour cross-fertilisation, for some 
few plants seem to be invariably self-fertilised; yet even these retain traces of having been formerly adapted for cross-fertilisation. These exceptions need not make us doubt the truth of the above rnle, any more than the existence of some few plants which produce flowers, and yet never set seed, shonld make us doubt that flowers are adapted for the production of seed and the propagation of the species.

We should always keep in mind the obvious fact that the production of seed is the chief end of the act of fertilisation; and that this end can be gained by hermaphrodite plants with incomparably greater certainty by self-fertilisation, than by the union of the sexual elements belonging to two distinct flowers or plants. Yet it is as unmistakably plain that innumerable flowers are adapted for cross-fertilisation, as that the teeth and talons of a carnirorous animal are adapted for catching prey; or that the plumes, wings, and hooks of a seed are adapted for its dissemination. Flowers, therefore, are constructed so as to gain two ubjects which are, to a certain extent, antagonistic, and this explains many apparent anomalies in their structure. The close proximity of the anthers to the stigma in a multitude of species favours, and often leads, to self-fertilisation; but this end could have been gainerl far more safely if the flowers had been completely closed, for then the pollen wonld not have been injured by the rain or devoured by insects, as often happens. Moreover, in this case, a very small quantity of pollen would have been sufficient for fertilisation, instead of millions of grains being produced. But the openness of the flower and the production of a great and apparently wasteful amount of pollen are necessary for cross-fertilisation. These remarks are well illustrated by the plants called cleistogene, which bear on the 
same stock two kinds of flowers. The flowers of the one kind are minute and completely closed, so that they cannot possibly be crossed; but they are abundantly fertile, although producing an extremely small quantity of pollen. The flowers of the other kind produce much pollen and are open; and these can be, and often are, cross-fertilised. Hermann Nüller has also made the remarkable discovery that there are some plants which exist under two forms; that is, produce on distinct stocks two kinds of hermaphrodite flowers. The one for'm bears small flowers constructed for self-fertilisation; whilst the other bears larger and much more conspicuous flowers plainly constructed for cross-fertilisation by the aid of insects; and without their aid these produce no seed.

The adaptation of flowers for cross-fertilisation is a subject which has interested me for the last thirtyseven years, and I have collected a large mass of observations, but these are now rendered superfluous by the many excellent works which have been lately published. In the year 1857 I wrote* a short paper on the fertilisation of the kidney bean; and in $1862 \mathrm{my}$ work 'On the Contrivances by which British and Foreign Orchids are Fertilised by Insects' appeared. It seemed to me a better plan to work out one group of plants as carefully as I could, rather than to publish many miscellaneous and imperfect observations. My present work is the complement of that on Orchids, in which it was shown how admirably these plants are constructed so as to permit of, or to favour, or to necessitate cross-fertilisation. The adaptations 
for cross-fertilisation are perhaps more obvious in the Orchidex than in any other group of plants, but it is an error to speak of them, as some authors have done, as an exceptional case. The lever-like action of the stamens of Salvia (described by Hildebrand, Dr. W. Ogle, and others), by which the anthers are depressed and rubbed on the backs of bees, shows as perfect a structure as can be found in any orchid. Papilionaceous flower's, as described by various authors-for instance, by Mr. T. H. Farrer-offer innumerable curious adaptatious for cross-fertilisation. The case of Posoqueria fragrans (one of the Rubiacer), is as wonderful as that of the most wonderful orchid. The stamens, according to Fritz Müller,* are irritable, so that as soon as a moth visits. a flower, the anthers explode and cover the insect with pollen; one of the filaments which is broader than the others then moves and closes the flower for about twelve hours, after which time it resumes its original position. Thus the stigma cannot be fertilised by pollen from the same flower, but only by that brought by a moth from some other flower. Endless other beautiful contrivances for this same purpose could be specified.

Long before I had attended to the fertilisation of flowers, a remarkable book appeared in 1793 in Germany, 'Das Entdeckte Geheimniss der Natur,' by C. K. Sprengel, in which he clearly proved by innumerable observatious, how essential a part insects play in the fertilisation of many plants. But he was in advance of his age, and his discoveries were for a long time neglected. Since the appearance of my book on Orchids, many excellent works on the fertilisation of flowers, such as those by Hildebrand, Delpino, Axell, 
and Hermann Müller,", and numerous shorter papers, have been published. A list would occupy several pages, and this is not the proper place to give their titles, as we are not here concerned with the means, but with the results of cross-fertilisation. No one who feels interest in the mechanism by which nature effects her ends, can read these books and memoirs withont the most lively interest.

From my own observations on plants, guided to a certain extent by the experience of the breeders of animals, I became convinced many years ago that it is a general law of nature that flowers are adapted to be crossed, at least occasionally, by pollen from a distinct plant. Sprengel at times foresaw this law, but only partially, for it does not appear that he was aware that there was any difference in power between pollen from the same plant and from a distinct plant. In the introduction to his book (p. 4) he says, as the sexes are separated in so many flowers, and as so many other flowers are dichogamous, "it appears that nature has not willed that any one flower should be fertilised by its own pollen." Nevertheless, he was far from keeping. this conclusion always before his mind, or lie did not

* Sir Jolin Tubbock has given an interesting summary of the whole subject in his 'British Wild r'lower's considered in relation to Inscets,' 1875. Hermaun Miiller's work 'Die Befruchtung der Blumen dureh Inscliten,' 1873 , cuntains an immense number of original observations and gencralisntions. It is, moreover, invaluable as a repertory with referenees to almost everything whieh has been published on the subject. His work differs from that of all otlicrs in speeifying what kinds of insccts, as far as known, visit the flowers of crch speeies. He likewise enters on new ground, by showing not ouly that Howers are alapted for their own good to the visits of certrin inserts; but that the iusects themiselves arc execllently adapted for procuriug nectar or pollen from certain llowers. The ralne of H. Miiller's work can hardly be over-estimated, and it is mucli to be desired that it slonlel be translated into linglisl. Severin Axell's work is written in Swedisl, so that I have not been able to read it. 
see its full importance, as may be perceived by anyone who will read his observations carcfully; and he consequently mistook the meaning of various structures. But his discoverics are so numcrous and his work so excellent, that he can well afford to bear a small amount of blame. A most capable judgc, $\mathrm{H}$. Müller, likewise says :* "It is remarkable in how very many cases Sprengel rightly perceived that pollen is necessarily transported to the stigmas of other flowers of the same species by the insects which visit them, and yet did not imagine that this transportation was of any scrvice to the plants thcmselves."

Andrew Knight saw the truth much more clearly, for he remarks, $\uparrow$ "Nature intended that a scxual intcrcourse should takc place between ncighbouring plants of the same species." After alluding to the various means by which pollen is transported from flower to flower, as far as was then imperfectly known, he adds, "Nature has something more in view than that its own proper males should fecundate each blossom." In 1811 Kölreuter plainly hinted at the samc law, as did afterwards another famous hybridiser of plants, Herbert. $\neq$ But none of these distinguished observers appear to have been sufficiently impressed with the

* "Dir Befruehtung der Blumen,' 1873, p. 4. His words are: "Ls ist merkwürdig, in wie zahlreichen Fällen Sprengel richtig erkannte, dass dureh die Besuehenden Insekten der Bliithenstaub mit Nothwendigkeit auf dio Narben inderer Bluition derselben Art ijbertragen wird, ohne auf die Vermuthung zu kommen, lass in diester Wirkung der Nutzen des Insektenbesuehes für die Pflanzen selbst gesucht werden miisse."

$\dagger$ 'Philosophical 'Transactions,' 1799, p. 202.
† Kölrenter, 'Mém. de l'A ead. de St. Pétersbouro,' tom. iii. 1809 (published 1811), p. 197. After silowing how well the Malvaceæ are adapterl for eross-fertilisation, lie asks, "An id aliquid in reeessu habeat, quod hujuseemodi flores nunquam proprio suo pulvere, sod semper eo aliarum sur speciei impregnentur, merito quaritur? Certe natura nil facit frustru." Herbert, 'A maryllidaeer, with n 'Treatise on Cross-bred Vegetables,' 1837. 
truth and generality of the law, so as to insist on it and impress their belief on others.

In 1862 I summed np my observations on Orchids by saying that nature "abhors perpctual self-fertilisation." If the word perpetual had been omitted, the aphorism would have been falsc. As it stands, I believe that it is true, though perhaps rather too strongly expressed; and I should have addcd the self-cvident proposition that the propagation of the spccics, whether by self-fertilisation or by cross-fertilisation, or asexually by buds, stolons, \&c. is of paramount importance. Hermann Müller has done excellent servicc by insisting repeatedly on this latter point.

It often occurred to me that it would be advisable to try whether secdlings from cross-fcrtilised flowers were in any way supcrior to those from self-fertilised flowcrs. But as no instance was known with animals of any cril appearing in a single generation from the closest possible intcrbreeding, that is between brothers and sisters, I thought that the same rule would hold good with plants; and that it would be necessary at the sacrifice of too much time to self-fertilise and intercross plants during several successive generations, in order to arrive at any result. I ought to have reflccted that such elaborate provisions favouring crossfertilisation, as we sce in innumerable plants, would not have been acquired for the sake of gaining a distant and slight advantage, or of avoiding a distant and slight evil. Morcover, the fertilisation of a flower by its own pollen corresponds to a closer form of interbreeding than is possible with ordinary bi-sexnal mimals; so that an earlier result might have been expeeted.

I was at last led to makc the experiments reeorded in the present volume from the following eircumstance. 
For the sake of detcrmining certain points with respect to inheritance, and without any thought of the effects of close interbrecding, I raised close together two large beds of self-fertilised and crossed scedlings from the same plant of Linaria vulgaris. To my surprisc, the crossed plants when fully grown were plainly taller and more vigorous than the sclf-fertilised oncs. Bees incessantly visit the flower's of this Linaria and carry pollen from one to the other; and if insects are excluded, the flowers produce cxtremely few secds; so that the wild plants from which my seedlings were raised must have becn intercrossed during all previous generations. It seemed therefore quite incredible that the difference between the two beds of scedlings could have been due to a single act of self-fertilisation; and I attributed the result to the sclf-fcrtilised sceds not having been well ripened, improbable as it was that all should have bcen in this state, or to some other accidental and incxplicable cause. During the next year, I raised for the same purpose as before two large beds close together of self-fertilised and crossed scedlings from the carnation, Dianthus caryophyllus. This plant, like the Linaria, is almost sterilc if inscets are excluded; and we may draw the same inference as before, namely, that the parent-plants must have been intercrossed during every or almost every previous generation. Nevertheless, the self-fertilised seedlings were plainly inferior in height and vigour to the crossed.

My attention was now thoroughly aroused, for I could hardly doubt that the difference betwcen the two beds was duc to the one sct being the offspring of crosscd, and the other of sclf-fertilised flowers. Accordingly I selected almost by hazard two other plants, which happened to be in flower in the grecnhousc, namely, 
Mimulus luteus and Ipomoea purpurea, both of which, unlike the Linaria and Dianthus, are highly selffertile if insects are excluded. Some flowers on a single plant of both species were fertilised with their own pollen, and others were crossed with pollen from a distinct individual; both plants being protected by a net from insects. The crossed and self-fertilised seeds thus produced were sown on opposite sides of the same pots, and treated in all respects alike; and the plants when fully grown were measured and compared. With both species, as in the cases of the Linaria and Dianthus, the crossed seedlings were conspicuously superior in height and in other ways to the selffertilised. I therefore determined to begin a long series of experiments with various plants, and these were continued for the following eleven years; and we shall see that in a large majority of cases the crossed beat the self-fertilised plants. Several of the exceptional cases, moreover, in which the crossed plants were not victorious, can be explained.

It should be observed that I have spoken for the sake of brevity, and shall continue to do so, of crossed and self-fertilised seeds, seedlings, or plants; these terms implying that they are the product of crossed or self-fertilised flowers. Cross-fertilisation always means a cross between distinct plants which were raised from seeds and not from cuttings or buds. Self-fertilisation always implies that the flowers in question were impregnated with their own pollen.

My experiments were tried in the following manner. A single plant, if it produced a sufficiency of flowers, or two or three plants were placed mider a net stretched on a frame, and large enough to cover the plant (together with the pot, when one was used) without touching it. 'This latter point is important, for if 
the flowers touch the net they may be cross-fertilised by bees, as I have known to happen; and when the net is wet the pollen may be injured. I used at first "white cotton net," with very fine meshes, but afterwards a kind of net with meshes onc-tenth of an inch in diameter; and this I found by expericnce effectnally excluded all insects excepting Thrips, which no net will cxclude. On the plants thus protected several flowers were marked, and were fertiliserl with their own pollen; and an equal number on the same plants, marked in a different manner, were at the same time crossed with pollen from a distinct plant. The crossed flowers werc never castrated, in order to make the experiments as like as possible to what occurs under nature with plants fertilised by the aid of inscets. Thercforc, somc of the flowers which werc crossed may have failed to be thus fcrtilised, and afterwards have been sclf-fertiliser. But this and some other sources of error will presently be discussed. In some few cascs of spontancously sclf-fcrtile spccies, the flowers werc allowed to fcrtilise themselves under the net; and in still fewer cases uncovered plants were allowed to be freely crossed by the insects which incessantly visited them. There are some great advantages and some disadrantages in my having occasionally varied my method of procceding; but when there was any difference in the trcatment, it is always so stated under the head of each species.

Care was taken that the seeds were thoroughly ripened before being gathered. Aftcrwards the crossed and self-fertilised seeds were in most cases placed on damp sand on opposite sides of.a glass tumbler covered by a glass plate, with a partition between the two lots; and the glass was placed on the chimney-piece in a warm room. I could thus obscrve the germination of 
the seeds. Sometimes a fer would germinate on one side before any on the other, and these were thrown away. But as often as a pair germinated at the same time, they were planted on opposite sides of a pot, with a superfieial partition between the two; and I thus proeeeded until from half-a-dozen to a score or more seedlings of exaetly the same age were planted on the opposite sides of several pots. If one of the young seedlings beeame sickly or was in any way injured, it was pulled up and thrown away, as rell as its antagonist on the opposite side of the same pot.

As a large number of seeds were plaeed on the sand to germinate, many remained after the pairs had been seleeted, some of whieh were in a state of germination and others not so; and these were sown erowded together on the opposite sides of one or two rather larger pots, or sometimes in two long rows out of doors. In these cases there was the most severe struggle for life amoug the erossed seedlings on one side of the pot, and the self-fertilised seedlings on the other side, and between the two lots whieh grew in competition in the same pot. A vast number soon perished, and the tallest of the survivors on both sides when fully grown were measured. Plants treated in this manner, were subjected to nearly the same conditions as those growing in a state of nature, whieh hare to struggle to maturity in the midst of a host of competitors.

On other oceasions, from the want of time, the seeds, instead of being allower to germinate on damp sand, were sown on the opposite sides of pots, and the fully grown plants measured. But this plan is less accurate, as the seeds sonetimes germinated more quiekly on one side than on the other. It was howerer necessary to art in this mamner with sone few speeies, as eertain 
kinds of seeds would not germinate well when exposed to the light; though the glasses containing them were kept on the chimney-piece on one side of a room, and some way from the two windows which faced the N.E.**

The soil in the pots in which the seedlings were planted, or the seeds sown, was well mixed, so as to be uniform in composition. The plants on the two sides were always watered at the same time and as equally as possible; and even if this had not been done, the water would have spread almost equally to both sides, as the pots were not large. The crossed and self-fertilised plants were separated by a superficial partition, which was always kept directed towards the chief source of the light, so that the plants on both sides were equally illuminated. I do not believe it possible that two sets of plants could have been subjected to more closely similar conditions, than were my crossed and self-fertilised seedlings, as grown in the above described manner.

In comparing the two sets, the eye alone was never trusted. Generally the height of every plant on both sides was carefully measured, often more than once, viz., whilst young, sometimes again when older, and finally when fully or almost fully grown. But in some cases, which are always specified, owing to the want of time, only one or two of the tallest plants on each side were measured. This plan, which is not a good one, was never followed (except with the crowded

* This occurred in the plainest manner with the seeds of I'apaver vagum and Delphinium consolida, and less plainly with those of Adonis iestivalis and Ononis minutissima. Iiarely more than one or two of the sceds of these four species geminated on the bare sand, thrugh left there for some weeks; but when these same seeds were placed on enth in pots, and covered with a thin layer of sand, they germinated immediately in large numbers. 
plants raised from the seeds remaining alter the pairs had been planted) unless the tallest plants on eaeh side seemed fairly to represent the average difference between those on both sides. It has, however, some great advantages, as sickly or accidentally injured plants, or the offspring of ill-ripened seeds, are thus eliminated. When the tallest plants alone on each side were measured, their average height of course exceeds that of all the plants on the same side taken together. But in the ease of the mueh erowded plants raised from the remaining seeds, the average height of the tallest plants was less than that of the plants in pairs, owing to the unfavourable conditions to which they were subjeeted from being greatly erowded. For our purpose, however, of the eomparison of the crossed and self-fertilised plants, their absolute height signifies little.

As the plants were measured by an ordinary English standard divided into inches and eighths of an inch, I have not thought it worth while to ehange the fractions into deeimals. The average or mean heights were caleulated in the ordinary rough method by adding up the measurements of all, and diriding the produet by the number of plants measured; the result. being here given in inches and deeimals. Is the different speeies grow to various heights, I have always for the sake of easy comparison given in addition the average height of the erossed plants of each species taken as 100, and have ealculated the arerage height. of the self-fertilised plant in relation to this standard. With respeet to the crowded plants raised from the seeds remaining after the pairs had been planted, and of whieh only some of the tallest on each side were measured, I have not thought it worth while to complieate the results by giring separate arerages 
for them and for the pairs, but have added up all their heights, and thus obtained a single average.

I long doubted whether it was worth while to give the measurements of each separate plant, but have decided to do so, in order that it may be seen that the superiority of the crossed plants over the self-fertilised, does not commonly depend on the presence of two or three extra fine plants on the one side, or of a few very poor plants on the other side. Although several observers have insisted in general terms on the offspring from intercrossed varieties being superior to either parent-form, no precise measurements have been given; ; and I have met with no observations on the effects of crossing and self-fertilising the individuals of the same variety. Moreover, experiments of this kind require so much time-mine having been continued during eleven years-that they are not likely soon to be repeated.

As only a moderate number of crossed and selffertilised plants were measured, it was of great importance to me to learn how far the averages were trustworthy. I therefore asked Mr. Galton, who has had much experience in statistical researches, to examine some of my tables of measurements, seven in number, namely, those of Ipomon, Digitalis, Reseda Iutea, Viola, Limnanthes, Petunia, and Zea. I may premise that if we took by chance a dozen or score of men belonging to two nations and measured them, it would I presume be very rash to form any judgment from such small numbers on their average heights. But the case is somewhat different with my crossed and self-fertilised plants, as they were of exactly the same

* A surnmary of these statements, with reforences, may be found in ny " Variation of Animals and Plants under Dornestiuntion,' chap. xvii., 2nd edit., 1875, vol. ii. p. 109. 
age, were subjected from first to last to the same conditions, and were descended from the same parents. When only from two to six pairs of plants were measured, the results are manifestly of little or no value, except in so far as they confirm and are confirmed by experiments made on a larger scale with other species. I will now give the report on the seven tables of measurements, which Mr. Galton has had the great kindness to draw up for me.

"I have examined the measurements of the plants with care, and by many statistical methods, to find out how far the means of the several sets represent constant realities, such as would come out the same so long as the general conditions of growth remained unaltered. The principal methods that were adopted are easily explained by selecting one of the shorter series of plants, say of Zea mays, for an example."

Zea mays (young plants).

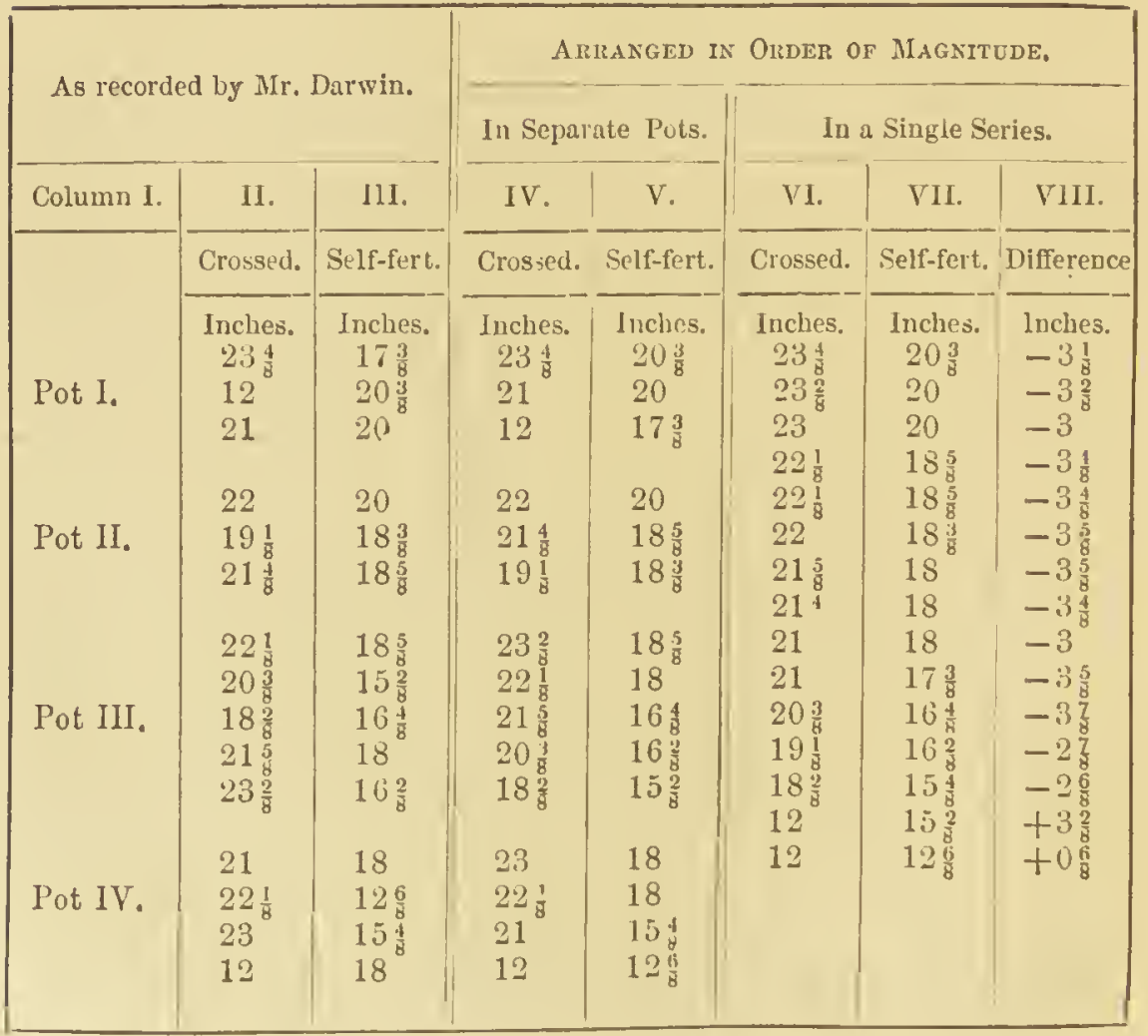


"The observations as I received them are shown in columns II. and III., where they ccrtainly have no primâ fucie appearance of regularity. But as soon as we arrange them in the order of their magnitudes, as in columns IV. and V., the case is matcrially altered. We now see, with few exceptions, that the largest plant on the crossed side in each pot exceeds the largest plant on the self-fertilised side, that the second exceeds the second, the third the third, and so on. Out of the fifteen cases in the table, there are only two exceptions to this rule. We may therefore confidently affirm that a crossed series will always be found to exceed a self-fertilised series, within the range of the conditions under wlich the present experiment has been nuade."

\begin{tabular}{|c|c|c|c|}
\hline Pot. & Crossed. & Self-fert. & nifference. \\
\hline I. & $18 \frac{7}{8}$ & $19 \frac{2}{8}$ & $+0 \frac{3}{8}$ \\
\hline II. & $20 \frac{7}{8}$ & 19 & -17 \\
\hline III. & $21 \frac{1}{8}$ & $16 \frac{7}{8}$ & $-4 \frac{2}{8}$ \\
\hline IV. & $19 \frac{6}{8}$ & 16 & $-3 \frac{6}{8}$ \\
\hline
\end{tabular}

"Next as regards the numerical estimate of this excess. The mean values of the several groups are so discordant, as is shown in the table just given, that a fairly precise numerical estimate seems impossible. But the consicleration arises, whether the difference between pot and pot may not be of much the same order of importance as that of the other conditions upon wlich the growth of the plants has been modified. If so, and only on that condition, it would follow that when all the measurcments, either of the crossed or the self-fertilised plants, were combined into a single series, that series would be statistically regular. The experiment is tried in columns VII. and VIII., where the regularity is abundantly clear, and justifies us in considering its mean as perfectly reliable. I have protracterl those measurements, and revised them in the usual way, by drawing a curve through them with a free hand, but the revision barcly modifies the means derived from the original observations. In the prosent, and in mearly all the othor cases, the difference between the original and revised means is under 2 per cent. of their valuc. It is a very remarkable coincidence 
that in the seven kinds of plants, whose measurements I have examined, the ratio between the heights of the crossed and of the self-fertilised ranges in five cases within very narrow limits. In Zea mays it is as 100 to 84, and in the others it ranges between 100 to 76 and 100 to $86 . "$

"The determination of the variability (measured by what is technically called the "probable error") is a problem of more delicacy than that of determining the means, and I doubt, after making many trials, whether it is possible to derive useful conelusions from these few observations. We onglit to have measurements of at least fifty plants in eaeh ease, in order to be in a position to deduee fair results. One fact, however, bearing on variability, is very evident in most cases, though not in 7ea mays, viz., that the self-fertilised plants inelude the larger number of exeeptionally small specimens, wlile the crossed are more generally full grown."

"Those groups of cases in which neasurements have been made of a few of the tallest plants that grew in rows, eacli of whieh contained a multitude of plants, show very clearly that the crossed plants exceed the self-fertilised in lieight, but they do not tell by inference anything about their respective mean values. If it should happen that a series is known to follow the law of crror or any other law, and if the number of individuals in the series is known, it would be always possible to reconstruct the whole series when a fragment of it has been given. But I find no sueh method to be applienble in the present ease. The doubt as to the number of plants in each row is of minor importance; the real diffeulty lies in our of the precise law followed by the series. The experience of the plants in pots does not help us to determine that la $\%$, becanse the observations of such plants are too few to enable us to lay down more than the middle terms of the series to which they belong with any sort of accuracy, whereas the cases we are now considering refer to one of its extremities. There are other special dificulties whieln need not be gone into, as the one already mentioned is a complete bar."

Mr. Galton. sent me at the same time graphical representations which he had made of the measurements, and they evidently form fairly regular curves. He appends the words "very good" to those of Zea and 
Limnanthes. He also calculated the average height of the crossed and self-fertilised plants in the seven tables by a more correct method than that followed by me, namely; by including the heights, as estimated in accordance with statistical rules, of a few plants which died before they were measured; whereas I merely added up the heights of the survivors, and divided the sum by their number. The difference in our results is in one way highly satisfactory, for the average heights of the self-fertilised plants, as deduced by Mr. Galton, is less than mine in all the cases excepting one, in which our averages are the same; and this shows that I have by no means exaggerated the superiority of the crossed over the self-fertilised plants.

After the heights of the crossed and self-fertilised plants had been taken, they were sometimes cut down close to the ground, and an equal number of both weighed. This method of comparison gives very striking results, and I wish that it had been oftener followed. Finally a record was often kept of any marked difference in the rate of germination of the crossed and self-fertilised seeds, - of the relative periods of flowering of the plants raised from them,--and of their productireness, that is, of the number of seedcapsules which they produced and of the average number of seeds which each capsule contained.

When I began my experiments I did not intend to raise crossed and self-fertilised plants for more than a single generation; but as soon as the plants of the first generation were in flower I thought that I would raise one more generation, and acted in the following manner. Several flowers on one or more of the selffertilised plants were again self-fertilised; and several 
flowers on one or more of the crossed plants were fertilised with pollen from another crossed plant of the same lot. Haring thus once begun, the same method was followed for as many as ten successive generations with some of the species. The seeds and seedlings were always treated in exactly the same manner as already described. The self-fertilised plants, whether originally descended from one or two mother-plants, were thus in each generation as closely interbred as was possible; and I could not have improved on my plan. But instead of crossing one of the crossed plants with another crossed plant, I ought to have crossed the selffertilised plants of each generation with pollen taken from a non-related plant-that is, one belonging to a distinct family or stock of the same species and variety. 'This was done in several cases as an additional experiment, and gave very striking results. But the plan usually followed was to put into competition and compare intercrossed plants, which were almost always the offspring of more or less closely related plants, with the self-fertilised plants of each succeeding generation;--all having been grown under closely similar conditions. I have, however, learnt more by this method of proceeding, which was begun by an oversight and then necessarily followed, than if I had always crossed the self-fertilised plants of each succeeding generation with pollen from a fresh stock.

I have said that the crossed plants of the successive ¿enerations were almost always inter-related. When the flowers on an hermaphrodite plant are crossed with pollen taken from a distinct plant, the seedlings thus raised may be considered as hermaphrodite brothers or sisters; those raised from the same capsule being as close as twins or animals of the same litter. But in one sense the flowers on the same plant are distinct 
individuals, and as several flowers on the mother-plant were crossed by pollen taken from several flowers on the father-plant, such seedlings would be in one sense half-brothers or sisters, but more closely related than are the half-brothers and sisters of ordinary animals. The flowers on the mother-plant were, however, commonly crossed by pollen taken from two or more distinct plants; and in these cases the seedlings might be called with more truth half-brothers or sisters. When two or three mother-plants were crossed, as often happened, by pollen taken from two or three fatherplants (the seeds being all intermingled), some of the seedlings of the first generation would be in no way related, whilst many others would be whole or halfbrothers and sisters. In the second generation a large number of the seedlings would be what may be called whole or half first-cousins, mingled with whole and half-brothers and sisters, and with some plants not at all related. So it would be in the succeeding generations, but there would also be many cousins of the second and more remote degrees. The relationship will thus have become more and more inextricably complex in the later generations; with most of the plants in some degree and many of them closely related.

I have only one other point to notice, but this is one of the highest importance; namely, that the crossed and self-fertilised plants were subjected in the same generation to as nearly similar and uniform conditions as was possible. In the successive generations they were exposed to slightly different conditions as the seasons varied, and they were raised at different periods. But in other respects all were treated alike, being grown in pots in the same artificially prepared soil, being watered at the same time, and kept close together in the same greenhouse or hothouse. They were 
therefore not exposed during successive years to such great vicissitudes of climate as are plants growing out of doors.

On some apparent and real Canses of Error in my Experiments. - It has been objected to such cxperiments as mine, that covering plants with a net, although only for a short time whilst in flower, may affect their health and fertility. I have scen no such effect except in one instance with a Myosotis, and the covering may not then have been the real cause of injury. But eren if the net were slightly injurious, and certainly it was not so in any high degree, as I could judge by the appearance of the plants and by comparing their fertility with that of neighbouring uncovered plants, it would not have vitiated my experiments; for in all the more important cases the flowers were crossed as well as selffertilised under a net, so that they were treated in this respect cxactly alike.

As it is impossible to exclude such minute pollencarrying insects as Thrips, flowers which it was intended to fertilise with their own pollen may sometimes have been afterwards crossed with pollen brought by these insects from another flower on the same plant; but as we shall hereafter see, a cross of this kind does not produce any effect, or at most only a slight one. When two or more plants were placed near one another under the same net, as was often done, there is some real though not great clanger of the flowers which were believed to be self-fertilised being afterwards arossed with pollen brought by Thrips from a distinct plant. I have said that the danger is not great. because I have often found that plants which are self-sterile, unless aided by insects, remained sterile when several plants of the same species rere placed 
under the same net. If, however, the flowers whien had been presumably self-fertilised by me were in any ease afterwards erossed by Thrips with pollen brought from a distinet plant, crossed seedlings would have been ineluded amongst the self-fertilised ; but it should be espeeially observed that this oeeurrenee would tend to diminish and not to inerease any superiority in arerage height, fertility, \&e., of the erossed over the self-fertilised plants.

As the flowers which were erossed were never eastrated, it is probable or even almost eertain that I sometimes failed to eross-fertilise them effeetually, and that they were afterwards spontaneously self-fertilised. This would have been most likely to oeeur with diehogamous speeies, for without mueh eare it is not easy to pereeive whether their stigmas are ready to be fertilised when the anthers open. But in all eases, as the flowers were proteeted from wind, rain, and the access of inseets, any pollen plaeed by me on the stigmatie surfaee whilst it was immature, would generally have remained there until the stigma was mature; and the flowers would then have been erossed as was intended. Nevertheless, it is highly probable that self-fertilised seedlings have sometimes by this means got ineluded amongst the erossed seedlings. The effeet would be, as in the former ease, not to exaggerate but to diminish any average superiority of the erossed over the self-fertilised plants.

Errors arising from the two eauses just named, and from others, - such as some of the seeds not having been thoroughly ripened, though eare was taken to avoid this error-the siekness or unpereeived injury of any of the plants, - will have been to a large extent eliminated, in those eases in whieh many erossed and self-fertilised plants were measured and an average 
struck. Some of these eauses of error will also have been eliminated by the seeds having been allowed to germinate on bare damp sand, and being planted in pairs; for it is not likely that ill-matured and wellmatured, or diseased and healthy seeds, would germinate at exactly the same time. The same result will have been gained in the several eases in which only a few of the tallest, finest, and healthiest plants on each side of the pots were measured.

Kölreuter and Gärtner* have proved that with some plants several, even as many as from fifty to sixty, pollen-grains are neeessary for the fertilisation of all the ovules in the ovarium. Naudin also found in the ease of Mirabilis that if only one or two of its very large pollen-grains were plaeed on the stigma, the plants raised from such seeds were dwarfed. I was therefore eareful to give an amply suffieient supply of pollen, and generally eovered the stigma with it; but I did not take any speeial pains to plaee exaetly the same amount on the stigmas of the selffertilised and crossed flowers. After having aeted in this manner during two seasons, I remembered that Gärtner thought, though without any direct evidence, that an exeess of pollen was perhaps injurious; and it has been proved by Spallanzani, Quatrefages, and Newport, $\uparrow$ that with various animals an excess of the seminal fluid entirely prevents fertilisation. It was therefore neeessary to aseertain whether the fertility of the flowers was affected by applying a rather small and an extremely large quantity of pollen to the stigma. Accordingly a very small mass of pollen-grains was

* 'Iienntniss der Befruehtung,' 1844, 1). 345. Nandin, 'Nouvelles Arehives du Muséum,' tom. i. p. 27.

$\dagger$ 'I'ransactions Philosophical Soe.' 1853 , pp. 253-258. 
placed on one side of the large stigma in sixty-four flowers of Ipomoea purpurea, and a great mass of pollen over the whole surface of the stigma in sixty-four other flowers. In order to vary the experiment, half the flowers of both lots were on plants produced from selffertilised seeds, and the other half on plants from crossed seeds. The sixty-four flowers with an excess of pollen yielded sixty-one capsules; and excluding four capsules, each of which contained only a single poor seed, the remainder contained on an average $5 \cdot 07$ seeds per capsule. The sixty-four flowers with only a little pollen placed on one side of the stigma yielded sixty-three capsules, and excluding one from the same cause as before, the remainder contained on an average $5 \cdot 129$ seeds. So that the flowers fertilised with little pollen yielded rather more capsules and seeds than did those fertilised with an excess; but the difference is too slight to be of any significance. On the other hand, the seeds produced by the flowers with an excess of pollen were a little heavier of the two; for 170 of them weighed $79 \cdot 67$ grains, whilst 170 seeds from the flowers with very little pollen weighed $79 \cdot 20$ grains. Both lots of seeds having been placed on damp sand presented no difference in their rate of germination. We may therefore conclude that my experiments were not affected by any slight difference in the amount of pollen used; a sufficiency having been employed in all cases.

The order in which our subject will be treated in the present volume is as follows. A long series of experiments will first be given in Chapters II. to VI. Tables will afterwards be appended, showing in a condensed form the relative heights, weights, and fertility of the offspring of the various crossed and self-fertilised 
species. Another table exhibits the striking results from fertilising plants, whieh during several generations had either been self-fertilised or had been crossed with plants liept all the time under closely similar conditions, with pollen taken from plants of a distinct stock and which had been exposed to different conditions. In the eoncluding chapters various related points and questions of general interest will be diseussed.

Anyone not specially interested in the subject need not attempt to reard all the details; though they possess, I think, some value, and camnot be all summarised. But I would suggest to the reader to take as an example the experiments on Ipomoea in Chapter II. ; to whieh may be added those on Digitalis, Origanum, Viola, or the eommon eabbage, as in all these eases the erossed plants are superior to the selffertilised in a marked degree, but not in quite the same manner. As instances of self-fertilised plants being equal or superior to the erossed, the experiments on Bartonia, Canna, and the common pea ought to be read; but in the last ease, and probably in that of Canna, the want of any superiority in the crossed plants ean be explained.

Speeies were selected for experiment belonging to widely distinct families, inhabiting various countries. In some few eases several genera belonging to the same family were tried, and these are grouped together; but the families themselves have been arranged not in any natural order, but in that which was the most eonvenient for my purpose. 'The experiments have been fully given, as the resnlts appear to me of suffieient value to justify the details. Plants bearing hermaphrodite flowers can bo interbred more closely than is possible with bisexual animals, and are there- 
fore well-fitted to throw light on the nature and extent of the good effects of crossing, and on the evil effects of close interbreeding or self-fertilisation. The most important conclusion at which I have arrived is that the mere act of crossing by itself does no good. 'The good depends on the individuals which are crossed differing slightly in constitution, owing to their progenitors having been subjected during several generations to slightly different conditions, or to what we call in our ignorance spontaneous variation. This conclusion, as we shall hereafter see, is closely connected with rarious important physiological problems, such as the benefit derived from slight changes in the conditions of life, and this stands in the closest connection with life itself. It throws light on the origin of the two sexes and on their separation or union in the same individual, and lastly on the whole subject of hybridism, which is one of the greatest obstacles to the general acceptance and progress of the great principle of evolution.

In order to avoid misapprehension, I beg leave to repeat that throughout this volume a crossed plant, seedling, or seed, means one of crossed parentage, that is, one derived from a flower fertilised with pollen from a distinct plant of the same species. And that a seiff-fertilised plant, seedling, or seed, means one of self-fertilised parentage, that is, one derived from i flower fertilised with pollen from the same flower, or sometimes, when thus stated, from another flower on the same plant. 


\section{CHAPTER II.}

Convolvelaces.

Ipomoa purpurea, eomparison of the height and fertility of the erossed and self-fertilised plants during ten sueeessive generations -Greater eonstitutional vigour of the erosserl plants-The effeets on the offspring of erossing different flowers on the same plant, instead of erossing distinct individuals - The effects of a eross with a fresh stoek-The descendants of the self-fertilised plant named Hero-Summary on the growth, vigour, and fertility of the suecessive erussed and self-fertilised generations-Small amount of pollen in the antuers of the self-fertilised plants of the later generations, and the sterility of their first-prodneed flowers-Uniform colour of the flowers produeed by the self-fertilised plants-The advantage from a eross between two distinet plants depends on their differing in eonstitution.

A PLANT of Ipomoea purpurea, or as it is often called in England the convolvulus major, a native of South America, grew in my greenhouse. Ten flowers on this plant were fertilised with pollen from the same flower; and ten other flowers on the same plant were crossed with pollen from a distinct plant. The fertilisation of the flowers with their own pollen was superfluous, as this convolvulus is highly self-fertile; but I acted in this manner to make the experiments correspond in all respects. Whilst the flowers are young the stigma projects beyond the anthers; and it might have been thought that it could not be fertilised without the aid of humble-bees, which often visit the flowers; but as the flower grows older the stamens increase in length, and their anthers brush against the stigma, which thus 
receives some pollen. The number of seeds produced by the crossed and self-fertilised flowers differed very little.

Crossed and self-fertilised seeds obtained in the above manner were allowed to germinate on damp sand, and as often as pairs germinated at the same time they were planted in the manner deseribed in the Introduetion, on the opposite sides of two pots. Five pairs were thus planted; and all the remaining seeds, whether or not in a state of germination, were planted on the opposite sides of a third pot, so that the young plants on both sides were here greatly erowded and exposed to very severe eompetition. Rods of iron or wood of equal diameter were given to all the plants to twine up; and as soon as one of each pair reached the summit both were measured. A single rod was placed on each side of the erowded pot, No. III., and only the tallest plant on eaeh side was measured.

TABLE I. (First Generation.)

\begin{tabular}{|c|c|c|}
\hline No. of Pot. & $\begin{array}{l}\text { Seedlings from } \\
\text { Crossed Plants. }\end{array}$ & $\begin{array}{l}\text { Seedlings from } \\
\text { Self-fertilised Plants. }\end{array}$ \\
\hline I. & $\begin{array}{c}\text { Inches. } \\
87 \frac{4}{8} \\
87 \frac{1}{8} \\
89\end{array}$ & $\begin{array}{c}\text { Inches. } \\
69 \\
66 \\
73\end{array}$ \\
\hline II. & $\begin{array}{l}88 \\
87\end{array}$ & $\begin{array}{l}68 \frac{4}{8} \\
60 \frac{4}{8}\end{array}$ \\
\hline $\begin{array}{l}\text { III. } \\
\text { Plants crowded; the } \\
\text { tallest one mea- } \\
\text { sured on each side. }\end{array}$ & 77 & 57 \\
\hline Total in inches. & 516 & 394 \\
\hline
\end{tabular}

The average height of the six erossed plants is here 86 inehes, whilst that of the six self-fertilised plants is only $65 \cdot 66$ inclies, so that the crossed plants are to the self-fertilised in height as 100 to 76 . It should be observed that this difference is not due to a few of the erossed plants being extrcmely tall, or to a few of the self-fertilised being extremely short, but to all the crossed plants attaining a greater height than their antagonists. The three pairs in Pot I. were measured at two earlier periods, and the differcnee was sometimes greater and sometimes less than that 
at the final measuring. But it is an interesting fact, of which I have seen several othel instances, that one of the self-fertilised plants, when nearly a foot in lieight, was half an inch taller than the crossed plant; and again, when two feet higld, it was $1{ }_{5}^{3}$ of an inch taller, but during the ten subsequent days the erossed plant began to gain on its antagonist, and ever afterward asserted its supremacy, until it exceeded its self-fertilised opponent by 16 inches.

The five crossed plants in Pots $I$. and II. were corered with a net, and produced 121 capsules; the fire self-fertilised plants produced eighty-four capsules, so that the numbers of capsules were as 100 to 69 . Of the 121 eapsules on the erossed plants sixty-five were the product of flower's crossed with pollen from a distinct plant, and these contained on an average 5.23 seeds per capsule; the remaining fifty-six capsules rere spontancously self-fertilised. Of the cighty-four capsules on the self-fertilised plants, all the product of renewed self-fertilisation, fifty-fire (which were alone examined) eontained on an arerage 4.85 seeds per capsule. 'I'herefore the cross-fertilised capsules, compared with the self-fertilised capsules, yielded seeds in the proportion of 100 to 93 . The crossed seeds were relatively heavier than the self-fertilised seeds. Combining the above data (i.c., number of eapsules and average number of contained seeds), the crossed plants, compared with the self-fertilised, yielded seeds in the ratio of 100 to 64 .

These crossed plants produced, as already stated, fift-six spontaneously self-fertilised capsules, and the self-fertilised plants produced trenty-nine such eapsules. The former contained on an average, in comparison with the latter, secds in the proportion of 100 to 99.

In Pot III, on the opposite sides of which a large number of crossed and self-fertilised seeds had been sown and the seedlingss allowed to strugghle together, the crosser plants had at first no great arlvantage. At one time the tallest crossert was

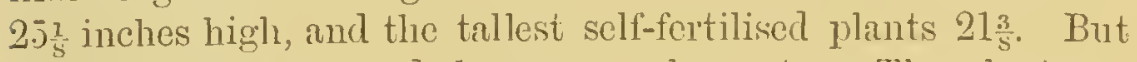
the differenee afterwards became much greater. The plants on both sides, from being so crowded, were poor specimens. The flowers were allowed to fertilise themselres spontanconsly nucler a net; the crossed plants produced thirty-seren capsules, the self-fertilised plants only eighteen, or as 100 to 47 . The former contained on an average $3 \cdot 62$ seeds per capsule; and the latter $3 \cdot 38$ seeds, or as 100 to 93 . Combining these data (i.e., nnmber 
of capsules and average number of seeds), the erowded erossed plants produeed seeds eompared with the self-fertilised as 100 to 45 . These latter seeds, however, were deeidedly heavier, a hundred weighing $41 \cdot 64$ grains, than those from the eapsules on the erossed plants, of which a hundred weighed $36 \cdot 79$ grains; and this probably was due to the fewer eapsules borne by the self-fertilised plants having been better nourished. We thus see that the erossed plants in this the first generation, when grown under favourable eonditions, and when grown under unfavourable eonditions from being mueh erowded, greatly exeeeded in height, and in the number of eapsules produced, and slightly in the number of seeds per eapsule, the self-fertilised plants.

Crossed and sulf-fertilised. Plants of the Second Generation.Flowers on the erossed plants of the last generation (Table I.) were erossed by pollen from distinet plants of the same generation; and flowers on the self-fertilised plants were fertilised by pollen from the same flower. The seeds thus produeed were treated in every respeet as before, and we have in Table II. the result.

TABLE II. (Second Generation.)

\begin{tabular}{|c|c|c|}
\hline No. of Pot. & Crossed Plants. & Self-fertilised Plants. \\
\cline { 1 - 3 } & Inches. & Inches. \\
I. & 87 & $67 \frac{4}{8}$ \\
& 83 & $\frac{4}{8}$ \\
& 83 & $80 \frac{4}{8}$ \\
\hline II. & $85 \frac{4}{8}$ & $61 \frac{4}{8}$ \\
& 89 & 79 \\
& $77 \frac{4}{8}$ & 41 \\
\hline Total inches. & 50.5 & 398 \\
\hline
\end{tabular}

Here again every single erossed plant is taller than its antagonist. The self-fertilised plant in Pot I., whieh ultimately reaehed the unusual height of $80 \frac{4}{5}$ inehes, was for a long time taller than the opposed erossed plant, though at last beaten by it. The average height of the six erossed plants is $84 \cdot 16$ inehes, whilst that of the six self-fertilised plants is 66.33 inehes, or as 100 to 79 .

Crossed and self-fertilisell Plants of the Third. Generation.-Seeds from the erosserl plants of the last generation (Table II.) again 
crossed, and from the self-fertilised plants again self-fertilised, were treated in all respects exactly as before, with the following result :-

TABLE III. (Third Generation.)

\begin{tabular}{|c|c|c|}
\hline No. of Pot. & Crossed Plants. & Self-fertilised Plants. \\
\cline { 2 - 3 } & $\begin{array}{c}\text { Inches. } \\
74\end{array}$ \\
72 & Inches. \\
$56 \frac{4}{8}$ \\
$51 \frac{4}{8}$ \\
$53 \frac{4}{8}$ & 54 \\
\hline II. & 82 & 59 \\
& 81 & 30 \\
& 82 & 66 \\
\hline Total inches. & $464 \cdot 5$ & $317 \cdot 0$ \\
\hline
\end{tabular}

Again all the crossed plants are higher than their antagonists: their average heiglt is $77 \cdot 41$ inches, whereas that of the selffertilised is $52 \cdot 83$ inches, or as 100 to 68 .

I attended closely to the fertility of the plants of this third generation. Thirty flowers on the crossed plants were crossed with pollen from other crossed plants of the same generation, and the twenty-six capsules thus produced contained, on an average, 4.73 seeds; whilst thirty flowers on the self-fertilised plants, fertilised with the pollen from the same flower, produced twenty-three capsules, each containing $4 \cdot 43$ seeds. Thus the average number of seeds in the crossed capsules was to that in the self-fertilised capsules as 100 to 94 . A hundred of the crossed seeds weighed $43 \cdot 27$ grains, whilst a hundred of the selffertilised seeds weighed only $37 \cdot 63$ grains. Many of these lighter self-fertilised seeds placed on damp sand germinated before the crossed; thus thirty-six of the former germinated whilst only thirtecn of the latter or crossed seeds germinated. In Pot I. the three crossed plants produced spontaneously under the net (besides the twenty-six artificially cross-fertilised capsules) seventy-seven self-fertilised capsules containiug on an arernge 1.41 seeds; whilst the three self-fertilised plants prodnced spontaneously (besides the twenty-three artificially self-fertilised capsules) only twenty-nine self-fertilised capsules, containing on an average $4 \cdot 14$ seeds. Therefore the average number of seeds in the two lots of spontaneously self-fertilised capsules was as 
100 to 94 . Taking into eonsideration the number of eapsules together with the average number of seeds, the erossed plants (spontaneously self-fertilised) produeed seeds in eomparison with the self-fertilised plants (spontaneously self-fertilised) in the proportion of 100 to 35 . By whatever method the fertility of these plants is eompared, the crossed are more fertile than the self-fertilised plants.

I tried in several ways the eomparative vigour and power's of growth of the erossed and self-fertilised plants of this third generation. Thus, four self-fertilised seeds whieh had just germinated were planted on one side of a pot, and after an interval of forty-eight hours, four crossed seeds in the same state of germination were planted on the opposite side; and the pot was kept in the hothouse. I thought that the advantage thus given to the self-fertilised seedlings would have been so great that they would never have been beaten by the erossed ones. They were not beaten until all had grown to a height of 18 inehes; and the degree to whieh they were finally beaten is shown in the following table (No. IV.). We here see that the average height of the four erossed plants is 76.62 , and of the four self-fertilised plants $65 \cdot 87$ inehes, or as 100 to 86 ; therefore less than when both sides started fair.

TABLe IV. (Third Generation, the self-fertilised Plants having had a start of forty-eight hours.)

\begin{tabular}{|c|c|c|}
\hline No. of Pôे. & Crossed Plants. & Self-fertilised Plunts. \\
\cline { 2 - 3 } & Inches. & Inches. \\
III. & $78 \frac{4}{8}$ & $73 \frac{4}{8}$ \\
& $77 \frac{4}{8}$ & 53 \\
& 73 & $61 \frac{4}{8}$ \\
& $77 \frac{4}{8}$ & $75 \frac{4}{8}$ \\
\hline Total inches. & $306 \cdot 5$ & $263 \cdot 5$ \\
\hline
\end{tabular}

Crossed and self-fertilised seeds of the third generation were also sown out of doors late in the summer, and therefore under unfavourable eonditions, and a single stick was given to eaeh lot of plants to twine up. The two lots were suffieiently separate so as not to interfere with eaeh other's growth, and the ground was clear of weeds. As soon as they were killed by tho first frost (and there wns no differenee in their hardiness), the two tallest crossed plants were found to be $24 \cdot 5$ and $22 \cdot 5$ inches, 
whilst the two tallest self-fertilised plants were ouly 15 and $12 \cdot 5$ inches in leeight, or as 100 to 59 .

I likewise sowed at the same time two lots of the same seeds in a part of the garden which was shady and covered with weeds. 'The crossed seedlings from the first looked the most 1: ualthy, but they twined up a stick only to a height of $7 \frac{1}{4}$ inehes; whilst the self-fertilised were not able to twine at all; and the tallest of them was only $3 \frac{1}{2}$ inehes in height.

Lastly, two lots of the same seeds were sown in the midst of a bed of candy-tuft (Iberis) growing vigorously. The secdlings came rip, but all the self-fertilised ones soon died excepting one, which never twined and grew to a height of only 4 inches. Many of the crossed seedlings, on the other hand, survived; and some twined mp the stems of the Iberis to the height of 11 inches. These cases prove that the crossed seedlings: liave an immense advantage over the self-fertilised, both when growing isolated under very unfavourable conditions, and when put into eompetition with each other or with other plants, as would happen in a state of nature.

Crossed and self-fertilised Plunts of the Fourth Cenerution.- Seedlings raised as before from the erossed and self-fertilised plants of the third generation in Table III., gave results as follows:-

TABLe V. (Fourth (ieneration.)

\begin{tabular}{|c|c|c|}
\hline No. of Put. & Crossed Plants. & Self-fertilised Plants. \\
\hline I. & $\begin{array}{c}\text { Inches. } \\
8 \pm \\
47\end{array}$ & $\begin{array}{c}\text { Inclues. } \\
80 \\
\pm+\frac{1}{2}\end{array}$ \\
\hline II. & $\begin{array}{l}83 \\
59\end{array}$ & $\begin{array}{l}73 \frac{1}{2} \\
51 \frac{1}{2}\end{array}$ \\
\hline $1 \mathrm{II}$. & $\begin{array}{l}82 \\
65 \frac{1}{2} \\
68\end{array}$ & $\begin{array}{l}56 \frac{1}{2} \\
63 \\
52\end{array}$ \\
\hline Total inches. & $488 \cdot 5$ & $+21 \cdot 0$ \\
\hline
\end{tabular}

Here the average height of the scven crossed plants is $69 \cdot 7 \mathrm{~S}$ inches, and that of the seven self-fertilised plants $60 \cdot 14$; or as 100 to 86 . 'This smaller difference relatively to that in the former generations, may be attributed to the plants having becu raised during the depth of winter, and consequently to their not 
having grown vigorously, as was shown by their general appearmee and from several of them never reaching the summits of the rods. In Pot II., one of the self-fertilised plants was for a long time taller by two inehes than its opponent, but was ultimately beaten by it, so that all the erossed plants exeeeded their opponents in height. Of twenty-eight capsules produced by the crossed plants fertilised by pollen from a distinet plant, each contained on an average 4.75 seeds; of twenty-seven selffertilised capsules on the self-fertilised plants, each eontained on an average 4.47 seeds; so that the proportion of seeds in the crossed and self-fertilised capsules was as 100 to 94 .

Some of the same seeds, from which the plants in the last Table V. had been raised, were planted, after they had germinated on damp sand, in a square tub, in which a large Brugmansia had long been growing. 'The soil was extremely poor' and full of roots; six crossed seeds were planted in one corner', and six self-fertilised seeds in the opposite corner. All the seedlings from the latter soon died excepting one, and this grew to the height of only $I_{2} \frac{1}{2}$ inehes. Of the crossed plants three survived, and they grew to the height of $2 \frac{1}{2}$ inches, but were not able to twine round a stick; nevertheless, to my surprise, they produced some small miserable flower's. The crossed plants thus had a deeided advantage over the self-fertilised plants nuder this extremity of bad conditions.

Crossed und self-fertilised Plurts of the Fifth Generution.-These were raised in the same manner as before, and when measured gave the following results:-

TABLE VI. (Fifth Generation.)

\begin{tabular}{|c|c|c|}
\hline No. of Pot. & Crussed Plants. & Self-fertilised Plants. \\
\hline l. & $\begin{array}{c}\text { Inches. } \\
96 \\
86 \\
69\end{array}$ & $\begin{array}{c}\text { Inches } \\
73 \\
78 \\
29\end{array}$ \\
\hline II. & $\begin{array}{l}84 \\
84 \\
76 \frac{1}{4}\end{array}$ & $\begin{array}{l}51 \\
8 \cdot 4 \\
59\end{array}$ \\
\hline Total inches. & $495 \cdot 13$ & $374 \cdot 00$ \\
\hline
\end{tabular}

The average height of the six crossed plants is $82 \cdot 54$ inches, 
and that of the six self-fertilised plants $62 \cdot 33$ inclies, or as 100 to 75. Every crossed plant exeeeded its antagonist in height. In Pot I. the middle plant on the crossed side was slightly injured whilst young by a blow, and was for a time beaten by its opponent, but ultimately reeoverer the usual superiority. The erossed plants produeed spontaneously a rast munluer more ciapsules than did the self-fertilised plants; and the eapsules of the former contained on an average 3.37 seeds, whilst those of the latter eontained only, $3 \cdot 0$ per eapsule, or as 100 to 89 . But looking only to the artificially fertilised eapsules, those on the crossed plants again erossed contained on an average $4 \cdot 46$ seeds, whilst those on the self-fertilised plants again selffurtilised eontained 4.77 seeds; so that the self-fertilised capsules were the more fertile of the two, and of this unusual fact I can offer no explanation.

Crossed and self-fertilised Plants of the Sixth Geveration.'T'lese were raised in the usual manner, with the following result. I should state that there were originally eight plants on eaeh side; but as two of the self-fertilised became extremely unhealthy and never grew to near their full height, these as mell us their opponents have been struck out of the list. If they had been retained, they would have made the average height of the crossed plants unfairly greater than that of the self-fertilised. I have aeted in the same manner in a few other instanees, when one of a pair plainly beeame very unhealthy.

\section{TABLE VII. (Sixth Generation.)}

\begin{tabular}{|c|c|c|}
\hline No. of Pot. & Crossed Plants. & Self-fertilised Plants. \\
\cline { 1 - 2 } & $\begin{array}{c}\text { Inches. } \\
93\end{array}$ & $\begin{array}{c}\text { Inches. } \\
50 \frac{1}{2} \\
65\end{array}$ \\
\hline I. & 91 & 50 \\
\hline II. & 79 & 87 \\
& $86 \frac{1}{2}$ & 62 \\
\hline III. & 88 & $61 \frac{1}{2}$ \\
\hline Total inches. & $87 \frac{1}{2}$ & 379 \\
\hline
\end{tabular}

The average height of the six crossed plants is here $87 \cdot 5$, and of the six self-fertilised plants $63 \cdot 16$, or as 100 to 72 . This large differenee was ehiefly dne to most of the plants, cspeeially the 
self-fertilised ones, having beeome unhealthy towards the close of their growth, and they were severely attacked by aphicles. From this cause nothing ean be inferred with respect to their relative fertility. In this generation we have the first instance of a self-fertilised plant in Pot II. exeeeding (thongh only by half an inch) its erossed opponent. This vietory was fairly won after a long struggle. At first the self-fertilised plant was several inehes taller than its opponent, but when the latter was $4 \frac{1}{2}$ feet high it had grown equal; it then grew a little taller than the self-fertilised plant, but was ultimately beaten by it to the extent of half an inch, as shown in the table. I was so mueh surprised at this case that I saved the self-fertilised seeds of this plant, which I will call the "Hero," and experimented on its descenclants, as will hereafter be described.

Besicles the plants included in Table VII., nine erossed and nine self-fertilised plants of the same lot were raised in two other pots, IV. and V. These pots had been kept in the hothouse, but from want of room were, whilst the plants were young, suddenly moved during very cold weather into the eoldest part of the greenhouse. They all suffered greatly, and never quite recovered. After a fortnight only two of the nine self-fertilised seedlings were alive, whilst seven of the erossed survived. The tallest of these latter plants when measured was 47 inches in height, whilst the tallest of the two surviving selffertilised plants was only 32 inches. Here again we see how mueh more vigorous the crossed plants are than the self-fertilised.

Crossed and self-fertilised Plants of the Seventh Generation.These were raised as heretofore with the following result:-

TABle VIII. (Seventh Generation.)

\begin{tabular}{|c|c|c|}
\hline No. of Pot. & Crossed Plants. & Self-fertilised Plants. \\
\cline { 1 - 3 } & Inches. & Inches. \\
$84 \frac{4}{8}$ & $74 \frac{6}{8}$ \\
$84 \frac{6}{8}$ & 84 \\
& $76 \frac{2}{8}$ & $55 \frac{4}{8}$ \\
\hline I. & $84 \frac{4}{8}$ & 65 \\
& 90 & $51 \frac{2}{8}$ \\
& $82 \frac{2}{8}$ & $80 \frac{4}{8}$ \\
\hline III. & 83 & $67 \frac{6}{8}$ \\
& 86 & $60 \frac{2}{8}$ \\
\hline IV. & $84 \frac{2}{8}$ & $75 \frac{2}{8}$ \\
\hline Total inches. & $755 \cdot 50$ & $614 \cdot 25$ \\
\hline
\end{tabular}


Each of these nine crossed plants is higher than its opponent, though in one case only by three-quarters of an incl.. Their average height is 83.94 inches, and that of the self-fertilised plants $68 \cdot 2 \tilde{5}$, or as 100 to 81 . These plant, after growingr to their full height, became vely unhealthy and infested with aphides, just when the sceds were setting, so that many of the capsules failed, and nothing can be said on their relative fertility.

Chossed and self-fertilised I'lants of the Eighth Generation.-As just stated, the plants of the last gencration, from which the present ones were raised, were very unhealthy and their seeds of unusually small size; and this probably accounts for the two lots behaving differently to what they did in any of the previous or succeeding generations. Many of the self-fertilised sceds germinated before the crossed ones, and these were of course rejected. When the crossed seedlings in Table IX. had glown to a height of between 1 and 2 fect, they were all, or almost all, shorter than their self-fertilised opponents, but rere not then measured. When they had acquired an average height of 32.28 inches, that of the self-fertilised plants was 40.68 , or as 100 to 122. Moreover, every one of the self-fertilised plants, with a single exception, exceeded its crossed opponent. When, howerer, the crossed plants had grown to an average height of $77 \cdot 56$ inches, they just excceded (viz., by $\cdot 7$ of an inch) the average height of the self-fertilised plants; but two of the latter were still taller than their crossed opponents. I was so much astonished at this whole case, that I tied string to the summits of the rods; the plants bcing thus allowed to continuc climbing upwards. When their growth was complete they wore untwined, stretcher straight, and measured. Tlie crossed plants lad now almost regained their accustomed superiority, as may be secn in Table IX.

The average height of the eight crossed plants is here 113.25 inches, and that of the self-fertilised plints $96 \cdot 65$, or as 100 to 85. Nevertheless two of the self-fertilisc d plants, as may be seen in the table, were still bigher than their crossed opponents. The latter manifestly had much thickel stcms and many more lateral branches, and looked altogether more vigorous than the self-fertilised plants, and gencrally flowered before them. The earlier flower's produced ly these self-fertilised plants did not set any capsules, and their authers contained only a small amount of pollen; but to this sulject I shall returu. Nererthe- 
less capsules prodnced by two other self-fertilised plants of the same lot, not ineluded in Table IX., whieh had been highly favoured by being grown in separate pots, contained the large average number of $5 \cdot 1$ seeds per capsule.

TABLE IX. (Eighth Generation.)

\begin{tabular}{|c|c|c|}
\hline No. of Pot. & Crosscd Plants. & Self-fertilised Plants. \\
\cline { 2 - 3 } & Inches. & Inches. \\
$111 \frac{6}{8}$ & 96 \\
127 & 54 \\
& $130 \frac{6}{8}$ & $93 \frac{4}{8}$ \\
\hline I. & $97 \frac{\frac{2}{8}}{8}$ & 94 \\
& $89 \frac{\frac{1}{8}}{8}$ & $125 \frac{6}{8}$ \\
\hline III. & $103 \frac{6}{8}$ & $115 \frac{4}{8}$ \\
& $100 \frac{6}{8}$ & $84 \frac{6}{8}$ \\
& $147 \frac{\frac{4}{8}}{8}$ & $109 \frac{6}{8}$ \\
\hline Total inches. & $908 \cdot 25$ & $773 \cdot 25$ \\
\hline
\end{tabular}

Crossed and self-fertiliscd Plants of the Ninth Geveration.The plants of this generation were raised in the same manner as before, with the result shown in Table $\mathrm{X}$. :-

The fourteen erossed plants average in height $81 \cdot 39$ inches and the fourteen self-fertilised plants $64^{\circ} 07$, or as 100 to 79 . One self-fertilised plant in Pot III. exeeeded, and one in Pot IV. equalled in height, its opponent. The self-fertilised plants showed no sign of inheriting the preeoeious growth of their parents; this having been clue, as it would appear, to the abnormal state of the seeds from the unhealthiness of their parents. 'The fourteen self-fertilised plants yielded only forty spontaneously self-fertilised eapsules, to which must be added seven, the product of ten flowers artifieially self-fertilised. On the other hand, the fourteen crossed plants yielded 152 spontaneously self-fertilised eapsules; but thirty-six flower's on these plants were erossed (yielding thirty-three eapsules), and these flowers would probably have produced about thirty spontaneously self-fertilised eapsules. Therefore an equal number of the erossed and self-fertilised plants would have produeed capsules in the proportion of abont 182 to 47 , or as 100 to 26 . Another phenomenon was well pronounced in this generation, but I believe had occurred previously to a slight extent; 
namely, that most of the flower's on the self-fertilised plants were somewhat monstrons. The monstrosity consisted in the corolla being irregularly split so that it did not open properly, with one or two of the stamens slightly foliaceous, coloured, and firmly coherent to the corolla. I observed this monstrosity in only one flower on the crossed plants. The self-fertilised plants, if well nourished, would almost certainly, in a fow more gencrations, have produced double flowcrs, for they had alleady become in some degree sterile.*

TABLE X. (Ninth Generation.)

\begin{tabular}{|c|c|c|}
\hline No. of Pot. & Crossed Plants. & Self-fertilised Plants. \\
\cline { 2 - 3 } & Inches. & Inches. \\
\hline I. & $83 \frac{1}{8}$ & 57 \\
& $85 \frac{4}{8}$ & 71 \\
& $83 \frac{4}{8}$ & $48 \frac{3}{8}$ \\
\hline II. & $83 \frac{2}{8}$ & 45 \\
& $64 \frac{2}{8}$ & $43 \frac{6}{8}$ \\
\hline III. & $64 \frac{3}{8}$ & $38 \frac{4}{8}$ \\
\hline & 79 & 63 \\
IV. & $88 \frac{1}{8}$ & 71 \\
& 61 & $89 \frac{4}{8}$ \\
\hline V. & $82 \frac{4}{8}$ & $82 \frac{4}{8}$ \\
Crowded plants. & 90 & $76 \frac{1}{8}$ \\
& $89 \frac{4}{8}$ & 67 \\
\hline Total inches. & $92 \frac{4}{8}$ & $74 \frac{2}{8}$ \\
\hline
\end{tabular}

Crossed and self-fertilised Plants of the Tenth Generation.-Six plants were raised in the ustual manner from the crossed plants of the last generation (Table X.) again intercrossed, and from the self-fertilised again self-fertilised. As one of the crossed plants in Pot I. in the following table became much diseased, having erumpled leaves, and produeing hardly any capsules, it and its opponent have been struck out of the table.

* Scc on this subject ' Variation of Animals and Plants under
Domestication,' ehap. xviii. 2nd edit. vol. ii. p. 152 . 
Chap. II. FLOWERS ON SAME PIANT CROSSED.

Table XI. (Tenth Generation.)

\begin{tabular}{|c|c|c|}
\hline \multirow{2}{*}{ No. of Pot. } & Crossed Plants. & Self-fertllised Plants. \\
\cline { 2 - 3 } & Inches. & Inches. \\
$92 \frac{3}{8}$ & $47 \frac{2}{8}$ \\
& 94 & $34 \frac{4}{8}$ \\
\hline II. & 87 & $54 \frac{4}{8}$ \\
& 895 & $49 \frac{2}{8}$ \\
& 105 & $66 \frac{2}{8}$ \\
\hline Total inches. & $468 \cdot 5$ & $252 \cdot 0$ \\
\hline
\end{tabular}

The five crossed plants arerage $93 \cdot 7$ inches, and the five selffertilised only $50 \cdot 4$, or as 100 to 54 . This difference, however, is so great that it must be looked at as in part accidental. The six crossed plants (the diseased one here included) yielded spontaneously 101 capsules, and the six self-fertilised plants 88, the latter being chiefly produced by one of the plants. But as the diseased plant, which yielded hardly any seed, is here included, the ratio of 101 to 88 does not fairly give the relative fertility of the two lots. The stems of the six crossed plants looked so much finer than those of the six self-fertilised plants, that after the capsules had been gathered and most of the leaves had fallen off, they were weighed. Those of the crossed plants weighed 2,693 grains, whilst those of the self-fertilised plants weighed only 1,173 grains, or as 100 to 44 ; but as the diseased and dwarfed crossed plant is here included, the superiority of the former in weight was really greater.

The Effects on the Offspring of crossing different Flowers on the same Plant, instead of crossing distinct Individuals. -In all the foregoing experiments, seedlings from flowers crossed by pollen from a distinct plant (though in the later generations more or less closely related) were put into competition with, and almost invariably proved markedly superior in height to the offspring from self-fertilised flowers. I wished, therefore, to ascertain whether a cross between two flowers on the same plant would give to the offspring any superiority 
over the offspring from flowers fertilised with their own pollen. I proenred some fresh seed and raised two plants, whieh were covered with a net; and several of their flowers were crossed with pollen from a distinct flower on the same plant. Twenty-nine eapsules thus produeed eontained on an average $4 \cdot 86$ seeds per capsule; and 100 of these seeds weighed $36 \cdot 77$ grains. Several other flowers were fertilised with their own pollen, and twenty-six eapsules thus produced eontained on an average 4.42 seeds per eapsule; 100 of which weighed $42 \cdot 61$ grains. So that a eruss of this kind appears to have increased slightly the number of seeds per eapsule, in the ratio of 100 to 91 ; but these erossed seeds were lighter than the self-fertiliser in the ratio of 86 to 100 . I doubt, however, from other observations, whether these results are fully trustworthy. The two lots of seeds, after germinating on sand, were planted in pairs on the opposite sides of nine pots, and were treated in every respect like the plants in the previous experiments. The remaining seeds, some in a state of germination and some not so, were sown on the opposite sides of a large pot (No. X.); and the four tallest plants on eaeh side of this pot were measured. The result is shown in the following table:-

The average height of the thirty-one erossed plants is 73.23 inehes, and that of the thirty-one self-fertilised plants $77 \cdot 41$ inehes; or as 100 to 106 . Looking to each pair, it may be seen that only thirteen of the erossed plants, whilst eighteen of the self-fertilised plants exeeed their opponents. A record was kept with respeet to the plant whieh flowered first in each pot; and only two of the erossed flowered before one of the self-fertilised in the same pot; whilst eight of the selffertilised flowered first. It thus appears that the 
Chap. II. FLOWERS ON SAME PLANT CROSSED.

TABle XII.

\begin{tabular}{|c|c|c|}
\hline No. of Pot. & Crosed Plants. & Self-fertilised Plants. \\
\hline I. & $\begin{array}{c}\text { Inches. } \\
82 \\
75 \\
65 \\
76\end{array}$ & $\begin{array}{c}\text { Inches. } \\
77 \frac{1}{8} \\
87^{\frac{1}{8}} \\
64 \\
87^{\frac{2}{5}}\end{array}$ \\
\hline II. & $\begin{array}{l}78 \frac{1}{8} \\
43 \\
65 \frac{1}{8}\end{array}$ & $\begin{array}{l}84 \\
86 \frac{1}{6} \\
90 \frac{4}{8}\end{array}$ \\
\hline III. & $\begin{array}{l}61 \frac{2}{8} \\
85 \\
89\end{array}$ & $\begin{array}{l}86 \\
69 \frac{1}{8} \\
87 \frac{4}{8}\end{array}$ \\
\hline IV. & $\begin{array}{l}83 \\
73 \frac{4}{8} \\
67\end{array}$ & $\begin{array}{l}80 \frac{1}{8} \\
88 \frac{4}{8} \\
8+\frac{4}{8}\end{array}$ \\
\hline V. & $\begin{array}{l}78 \\
76 \frac{6}{8} \\
57\end{array}$ & $\begin{array}{l}66 \frac{1}{8} \\
77 \frac{4}{8} \\
81 \frac{4}{8}\end{array}$ \\
\hline VI. & $\begin{array}{l}704 \\
79 \\
796\end{array}$ & $\begin{array}{l}80 \\
82 \frac{1}{8} \\
55 \frac{4}{8}\end{array}$ \\
\hline VII. & $\begin{array}{l}76 \\
844^{4} \\
79\end{array}$ & $\begin{array}{l}77 \\
83 \frac{4}{8} \\
73 \frac{4}{8}\end{array}$ \\
\hline VIII. & $\begin{array}{l}73 \\
67 \\
83\end{array}$ & $\begin{array}{l}76 \frac{4}{8} \\
82 \\
80 \frac{4}{8}\end{array}$ \\
\hline IX. & $\begin{array}{l}73 \frac{2}{8} \\
78\end{array}$ & $\begin{array}{l}78 \frac{4}{8} \\
67 \frac{4}{8}\end{array}$ \\
\hline $\begin{array}{c}\text { X. } \\
\text { Crowded plants. }\end{array}$ & $\begin{array}{l}34 \\
82 \\
84^{6} \\
71^{6}\end{array}$ & $\begin{array}{l}82 \frac{4}{8} \\
36 \frac{6}{8} \\
694 \\
75 \frac{4}{8}\end{array}$ \\
\hline Total inches. & $2270 \cdot 25$ & $2399 \cdot 75$ \\
\hline
\end{tabular}


crossed plants are slightly inferior in height and in earliness of flowering to the self-fertiliserl. But the inferiority in height is so small, namely as 100 to 106 , that I should have felt very doubtful on this head, had I not cut down all the plants except those in the crowded pot No. X.) close to the ground and weighed them. The twenty-seven crossed plants weighed $16 \frac{1}{2}$ ounces, and the twenty-seven self-fertilised plants $20 \frac{1}{2}$ ounces; and this gives a ratio of 100 to 124 .

A self-fertilised plant of the same parentage as those in Table XII. had been raised in a separate pot for a distinct purpose; and it proved partially sterile, the anthers containing very little pollen. Several flowers on this plant were crossed with the little pollen which could be obtained from the other flowers on the same plant; and other flowers were self-fertilised. From the seeds thus produced four crossed and four self-fertilised plants were raised, which were planted in the usual manner on the opposite sides of two pots. All these four crossed plants were inferior in height to their opponents; they averaged $78 \cdot 18$ inches, whilst the four self fertilised plants averaged 84.8 inches; or as 100 to $108{ }^{*}$ This case, therefore, confirms the last. Taking all the evidence together, we must conclude that these strictly self-fertilised plants grew a little taller, were heavier, and generally flowered before those derived from a cross between two flowers on the same plant. These latter plants thus present a wonderful contrast with those derived from a cross between two distinct individuals.

* From one of these self-fertilised plants, spontaneously selffertilised, I gathered twenty-four copsules, and they contained on an avernge only $3 \cdot 2$ seeds per capsule; so that this plant liad apparently inherited some of the sturility of its parent. 
The Effects on the Offspring of a Cross with a distinct or fresh Stock belonging to the same Variety.-From the two foregoing series of experiments we see, firstly, the good effects during several successive generations of a cross between distinct plants, although these were in some degree inter-related and had been grown under nearly the same conditions; and, secondly, the absence of all such gool effects from a cross between flowers on the same plant; the comparison in both cases being made with the offspring of flowers fertilised with their own pollen. The experiments now to be given show how powerfully and beneficially plants, which have been intercrossed during many successive generations, having been kept all the time under nearly uniform conditions, are affected by a cross with another plant belonging to the same variety, but to a distinct family or stock, which had grown under different conditions.

Several flowers on the erossed plants of the ninth generation in Table X., were erossed with pollen from another erossed plant of the same lot. The seedlings thus raised formed the tenth intererossed generation, and I will eall them the "intercrossed plants." Several other flowers on the same erossed plants of the ninth generation were fertilised (not having been eastrated) with pollen taken from plants of the same variety, but belonging to a distinet family, whieh had been grown in a distant garden at Colehester, and therefore under somewhat different eonditions. The eapsules produeed by this eross eontained, to my surprise, fewer and lighter seeds than did the eapsules of the intererossed plants; but this, I think, must have been aeeidental. The seedlings raised from them I will eall the "Colchester-ciossed." The two lots of seeds, after germinating on sand, were planted in the ustual manner on the opposite sides of five pots, and the remaining seeds, whether or not in a state of germination, were thiekly sown on the opposite sides of a very large pot, No. VI., in Table XIII. In three of the six pots, after the young plants had twined a short way up their stieks, one of the 
Colchester-crossed plants was much taller than any one of the intercrossed plants on the opposite side of the same pot; and in the three other pots somewhat taller. I slould state that two of the Colehester-crossed plants in Pot IV., when about two-thirds grown, became much diseased, and wore, together with their intcrerossed opponents, rejected. The remaining nineteen plants, when almost fully grown, were measured, with the following result:-

TABLE YIIl.

\begin{tabular}{|c|c|c|}
\hline No. of Pot. & $\begin{array}{l}\text { Colchester-crossed } \\
\text { Plants. }\end{array}$ & $\begin{array}{l}\text { Intercrossed Plants of } \\
\text { the Tenth Generition. }\end{array}$ \\
\hline 1. & $\begin{array}{c}\text { Inclees. } \\
87 \\
87 \frac{4}{8} \\
85 \frac{1}{8}\end{array}$ & $\begin{array}{c}\text { Inches. } \\
78 \\
68 \frac{4}{8} \\
94 \frac{4}{8}\end{array}$ \\
\hline II. & $\begin{array}{l}936 \\
85 \frac{1}{8} \\
90 \frac{5}{8}\end{array}$ & $\begin{array}{l}60 \\
87 \frac{2}{8} \\
45 \frac{4}{5}\end{array}$ \\
\hline III. & $\begin{array}{l}84 \frac{2}{8} \\
92 \frac{4}{8} \\
85\end{array}$ & $\begin{array}{l}70 \frac{1}{8} \\
81 \frac{6}{8} \\
86 \frac{2}{8}\end{array}$ \\
\hline IT. & $95 \frac{6}{8}$ & $65 \frac{1}{8}$ \\
\hline V. & $\begin{array}{l}90 \frac{4}{8} \\
86^{6} \\
84^{8}\end{array}$ & $\begin{array}{l}85 \frac{6}{8} \\
63 \\
62 \frac{6}{8}\end{array}$ \\
\hline $\begin{array}{l}\text { VI. } \\
\text { Crowded plants it it } \\
\text { very large pot. }\end{array}$ & $\begin{array}{l}90 \frac{4}{8} \\
75 \\
71 \\
83 \frac{6}{5} \\
63 \\
65\end{array}$ & $\begin{array}{l}43 \frac{1}{8} \\
39 \frac{6}{8} \\
30 \frac{2}{8} \\
86 \\
53 \\
48 \frac{6}{8}\end{array}$ \\
\hline Tutal inches. & $1556 \cdot 50$ & $1249 \cdot 75$ \\
\hline
\end{tabular}

In sixteen out of these nineteen pairs, the Colchester-crossed plant execeded in height its intererossed opponent. The arerage lieight of the Colchester-crossed is 84.03 inches, and that of the intererossed 65.78 inches; or as 100 to 78 . With respect 
to the fertility of the two lots, it was too troublesome to eolleet aud eount the eapsules on ail the plants; so I seleeted two of the best pots, V. and VI., and in these the Colehester-erossed produeed 269 mature and lialf-mature eapsules, whilst an equal number of the intererossed plants prodneed only 154 eapsules; $01^{\circ}$ as 100 to 57. By weight the eapsules from the Colehestererossed plants were to those from the intererossed plants as 100 to 51 ; so that the former probably eontained a somewhat larger average number of seects.

We learn from this important experiment that plants in some degree related, which had been intercrossed during the nine previous generations, when they were fertilised with pollen from a fresh stock, yielded seedlings as superior to the seedlings of the tenth intercrossed generation, as these latter were to the selffertilised plants of the corresponding generation. For if we look to the plants of the ninth generation in Table $\mathrm{X}$. (and these offer in most respects the fairest standard of comparison) we find that the intercrossed plants were in lieight to the self-fertilised as 100 to 79 , and in fertility as 100 to 26 ; whilst the Colchestercrossed plants are in height to the intercrossed as 100 to 78 , and in fertility as 100 to 51 .

The Descendants of the self-fertilised 1'lunt, named Her'o, which appeared in the Sixth self-fertitised Generation.-In the five generations before the sixth, the erossed plant of eaeh pair was taller than its self-fertilised opponent; but in the sixth generation (Table VII., Pot II.) the Hero appeared, whieh after a long and dubious struggle conquered its erossed opponent, though by only half an inch. I was so mueh surprised at this faet, that I resolved to aseertain whether this plant would transmit its power's of growth to its seedlings. Several flowers on Hero were therefore fertilised with their own pollen, and the seedlings thus raised were put into eompetition witl self-fertilised and intercrossed plants of the eorresponding generation. 'I'he three lots of seedlings thus all belong to the seventh genera- 
tion. Their relative heights are shown in the two following tables :-

TABLE XIV.

\begin{tabular}{|c|c|c|}
\hline No. of Pot. & $\begin{array}{l}\text { Self-fertilised Plants } \\
\text { of the Seventh Gene- } \\
\text { ration, Children of } \\
\text { Hero. }\end{array}$ & $\begin{array}{l}\text { Self-fertilised Plants } \\
\text { of the Seventh Gene- } \\
\text { ration. }\end{array}$ \\
\hline I. & $\begin{array}{c}\text { Inches. } \\
74 \\
60 \\
55 \frac{2}{8}\end{array}$ & $\begin{array}{c}\text { Inches. } \\
89 \frac{4}{8} \\
61 \\
49\end{array}$ \\
\hline II. & $\begin{array}{l}92 \\
91 \frac{6}{8} \\
74 \frac{2}{8}\end{array}$ & $\begin{array}{l}82 \\
56 \\
38\end{array}$ \\
\hline Total inches. & $447 \cdot 25$ & $375 \cdot 50$ \\
\hline
\end{tabular}

'The avcrage lieight of the six self-fertilised children of Hero is 74.54 inches, whilst that of the ordinary self-fertilised plants of the corresponding generation is only 62.58 inches, or as 100 to 84 .

'JABLE XV.

\begin{tabular}{|c|c|c|}
\hline No. of Pot. & $\begin{array}{c}\text { Self-furtilised Plants } \\
\text { of the Seventh Gene- } \\
\text { raion, Children of } \\
\text { IIero. }\end{array}$ & $\begin{array}{c}\text { Int rerossed Plants of } \\
\text { the Seventh Gene- } \\
\text { ration. }\end{array}$ \\
\hline III. & $\begin{array}{c}\text { Inches. } \\
92\end{array}$ & $\begin{array}{c}\text { Inches. } \\
76 \frac{6}{8}\end{array}$ \\
\hline IV. & 87 & 89 \\
\hline Total inches. & $266 \cdot 75$ & $86 \frac{6}{8}$ \\
\hline
\end{tabular}

Here the average height of the three self-fertilised cliildren of Hero is 88.91 inches, whilst that of the intercrossed plants is $84 \cdot 16$; or as 100 to 95 . We thus see that the self-fertilised children of Hero certainly inherit the powers of growth of their parents; for they greatly exceed in height the self-fertilised offspring of the other self-fertilised plants, and even exceed by a trifle the intercrossed plants, -all of the corresponding gencration. 
Several flowers on the self-fertilised ehildren of Hero in Table XIV. wcre fertilised with pollen from the same flower; and from the seeds thus produeed, self-fertilised plants of the eightli generation (grand-ehildren of Hero) were raised. Several other flower's on the same plants were crossed with pollen from the other ehildren of Hero. The seedling raised from this eross may bc considered as the offspring of the union of brothers and sisters. The result of the competition between these two sets of secdlings (namely self-fertilised and the offspring of brothers and sisters) is given in the following table:-

TABLE XVI.

\begin{tabular}{|c|c|c|}
\hline No. of Pot. & $\begin{array}{c}\text { Self-fertilised Grund-. } \\
\text { children of Hero, } \\
\text { from the Self-fertilised } \\
\text { Children. Eighth } \\
\text { Generation. }\end{array}$ & $\begin{array}{l}\text { Grandchildren frow a } \\
\text { cruss between the self } \\
\text { fertilised Children of } \\
\text { Hero. Eighth Gent- } \\
\text { ration. }\end{array}$ \\
\hline I. & $\begin{array}{c}\text { 1nches. } \\
86 \frac{6}{8} \\
90 \frac{3}{8}\end{array}$ & $\begin{array}{r}\text { Inches. } \\
95 \frac{6}{8} \\
95 \frac{3}{8}\end{array}$ \\
\hline II. & $\begin{array}{l}96 \\
77 \frac{2}{8}\end{array}$ & $\begin{array}{l}85 \\
93\end{array}$ \\
\hline III. & $\begin{array}{l}73 \\
66 \\
8 \pm \frac{1}{8}\end{array}$ & $\begin{array}{l}86 \frac{2}{8} \\
82 \frac{2}{8} \\
70 \frac{6}{8}\end{array}$ \\
\hline IV. & $\begin{array}{l}88 \frac{1}{8} \\
84 \\
36 \frac{2}{8} \\
74\end{array}$ & $\begin{array}{l}66 \frac{3}{8} \\
15 \frac{4}{8} \\
38 \\
78 \frac{3}{8}\end{array}$ \\
\hline V. & $\begin{array}{l}90 \frac{1}{8} \\
90 \frac{5}{8}\end{array}$ & $\begin{array}{l}82 \frac{6}{8} \\
83 \frac{6}{8}\end{array}$ \\
\hline Total inches. & $1037 \cdot 00$ & $973 \cdot 16$ \\
\hline
\end{tabular}

The average height of the thirteen self-fertilised grandchildren of Hero is $79 \cdot 76$ inches, and that of the grandehildren from a eross between the sclf-fertilised children is $74 \cdot 85$; or as 100 to 94 . But in Pot IV. one of the erossed plants grew only to a hcight of $15 \frac{1}{2}$ inehes; and if this plant and its opponent are struek out, as would be the fairest plan, the average height of the erossed plants exeeeds only by a fraction of an ineli that of the self-ferti- 
lised plants. It is therefore elenr that a eross betreen the selffertilised children of Hero did not produee any beneficial effeet worth notiec; and it is very doubtfinl whether this negative result can be attributed merely to the faet of brothers and sisters having been united, for the ordinary intererossed plants of the several snceessive generations must often have been derived from the union of brothers and sisters (as shown in Chap. I.), and yet all of them were greatly superior to the self-fertilised plants. We are therefore driven to the suspieion, whieh we shall soon see strengthened, that Hero transmitted to its offspring a peculiar constitntion adapted for self-fertilisation.

It wonld appear that the sclf-fertilised deseendants of Hero have not only inherited from Hero a power of growth equal to that of the ordinary intererossed plants, but hare beeome more fertile when self-fertilised than is usmal with the plants of the present speeies. The flowers on the self-fertilised grandehildren of Hero in Table XVI. (the eighth generation of self-fertilised plants) were fertilised with their own pollen and prodneed plenty of eapsules, ten of whieh (though this is too few a number for a safe average) eontained $5 \cdot 2$ sceds per eapsule,- a higher average than was observed in any other ease with the self-fertilised plants. 'The anthers produeed by these self-fertilised grandehildren were also as well developed and contained as mueh pollen as those on the intererossed plants of the eorresponding generation; whereas this was not the ease with the ordinary self-fertilised plants of the later generations. Nevertheless some few of the flowers produeed by the grandehildren of Hero rere slightly monstrous, like those of the ordinary self-fertilised plants of the later generations. In order not to reeur to the subjeet of fertility, I may add that twenty-one self-fertilised eapsules, spontaneously produeed by the great-grandehildren of Hero (forming the nintl generation of self-fertilised plants), contained on an average 4.47 sceds; and this is as high an average as the self-fertilised flowers of any gencration usually yielded.

Several flowers on the self-fertilised grandehildren of Hero in Table XVI. were fertilised with pollen from the same flower; and the seedlings raised from them (great-grandelildreu of Hero) formed the ninth self-fertilised generation. Scveral other florrers were erossed with pollen from another grandehild, so that they may be considered as the offspring of brothers and sisters, and the seedlings thus raised may be ealled the intercrossed great-grandehildren. And lastly, other flowers were fertilised with pollen 
from a distinct stock, and the seedlings thus raised may bo called the Colchester-crossed great-grandchildren. In my anxiety to see what the result would be, I unfortunately planted the three lots of seeds (after they had germinated on sand) in the hothouse in the middle of winter, and in consequence of this the seedlings (twenty in number of each kind) became very unhealthy, some growing only a few inches in height, and very few to their proper height. The result, therefore, camnot be fully.trusted; and it would be useless to give the measurements in detail. In order to strike as fair an average as possible, I first excluded all the plants under 50 inches in height, thus rejecting all the most unhealthy plants. The six self-fertilised thus left were on an average 66.86 inches high; the eight intercrossed plants $63 \cdot 2$ high; and the seren Colchester-crossed $65 \cdot 37$ high; so that there was not much difference between the three sets, the selffertilised plants having a slight advantage. Nor was there any great difference when only the plants under 36 inches in height were excluded. Nor again when all the plants, however much dwarfed and unhealthy, were included. In this latter case the Colchester-crossed gave the lowest average of all; and if these plants had been in any marked manner superior to the other two lots, as from my former experience I fully expected they would have been, I cannot but think that some restige of such superiority would have been evident, notwithstanding the very unhealthy condition of most of the plants. No advantage, as far as we can judge, was derived from intercrossing two of the grandchildren of Hero, any more than when two of the children were crossed. It appears therefore that Hero and its descendants have varied from the common type, not only in acquiring great power of growth, and increased fertility when subjected to selffertilisation, but in not profiting from a cross with a distinct stock; and this latter fact, if trustworthy, is a unique case, as far as I have observed in all my experiments.

Summary on the Grouth, Vigour, and Fertility of the successive Generations of the crossed and self-fertulised Plants of Ipomoea purpurea, together with some niiscelTaneous Observations.

In the following table, No. XVII, we see the average or mean heights of the ten successive generations of the intercrussed and self-fertilised plants, grown in 
competition with each other; and in the right-hand column we have the ratios of the one to the other, the height of the intercrossed plants beirg taken at 100 . In the bottom line the mean height of the seventythree intercrossed plants is shown to be $85 \cdot 84$ inches, and that of the seventy-three self-fertilised plants $66 \cdot 02$ inches, or as 100 to 77 .

\section{TABLE XVII.}

Ipomoxa purpurea. Summary of Measurements (in Inches) of the Ten Generations.

\begin{tabular}{|c|c|c|c|c|c|}
\hline Sumber of the Generation. & $\mid \begin{array}{c}\text { Number } \\
\text { of } \\
\text { Crossed } \\
\text { l'lants. }\end{array}$ & $\begin{array}{l}\text { A verage } \\
\text { II cigbt } \\
\text { of Crossed } \\
\text { Plants. }\end{array}$ & $\begin{array}{l}\text { Number } \\
\text { of Self- } \\
\text { forti- } \\
\text { lised } \\
\text { Plants. }\end{array}$ & $\begin{array}{c}\text { Average } \\
\text { Height of } \\
\text { Self-ferti- } \\
\text { lised } \\
\text { Plants. }\end{array}$ & $\begin{array}{l}\text { Ratio herween } \\
\text { A verage } \\
\text { Heights of } \\
\text { Crossed and } \\
\text { Self-tertilised } \\
\text { Plants. }\end{array}$ \\
\hline $\begin{array}{c}\text { First generation } \\
\text { Table } \mathrm{I} \text {. }\end{array}$ & 6 & $86 \cdot 00$ & 6 & $65 \cdot 66$ & as 100 to 76 \\
\hline $\begin{array}{c}\text { second generation } \\
\text { rable II. }\end{array}$ & 6 & $84 \cdot 16$ & 6 & $66 \cdot 33$ & as 100 to 79 \\
\hline $\begin{array}{l}\text { Third generation. } \\
\text { Table III. }\end{array}$ & 6 & $77 \cdot 41$ & 6 & $52 \cdot 83$ & as 100 to 68 \\
\hline $\begin{array}{l}\text { Fourth generation } \\
\text { T'able } T^{T} \text {. }\end{array}$ & 7 & $69 \cdot 78$ & 7 & $60 \cdot 14$ & as 100 to 86 \\
\hline $\begin{array}{c}\text { Fifth generation } \\
\text { Table Vi. }\end{array}$ & 6 & $82 \cdot 54$ & 6 & $62 \cdot 33$ & as 100 to 75 \\
\hline $\begin{array}{l}\text { Sixth generation. } \\
\text { Table VlI. }\end{array}$ & 6 & $87 \cdot 50$ & 6 & $63 \cdot 16$ & as 100 to 72 \\
\hline $\begin{array}{c}\text { Seveuth generation. } \\
\text { l'able VIIL. }\end{array}$ & 9 & $83 \cdot 94$ & 9 & $68 \cdot 25$ & as 100 to 81 \\
\hline $\begin{array}{l}\text { lighth generation } \\
\text { Table IX. }\end{array}$ & 8 & $113 \cdot 25$ & $S$ & $96 \cdot 65$ & as 100 to 85 \\
\hline $\begin{array}{l}\text { Ninth generation } \\
\text { Table } \mathrm{X} .\end{array}$ & 14 & $81 \cdot 39$ & 14 & $6 \pm \cdot 0 \overline{7}$ & as 100 to 73 \\
\hline $\begin{array}{l}\text { Tenth generation } \\
\text { Table Xl. }\end{array}$ & 5 & $93 \cdot 70$ & 5 & $50 \cdot 40$ & as 100 to $5 \frac{1}{4}$ \\
\hline $\left.\begin{array}{c}\text { All the ten generatious } \\
\text { talien together. }\end{array}\right\}$ & 73 & $85 \cdot 84$ & 73 & $6 t \cdot 02$ & as 100 10 7 \\
\hline
\end{tabular}


The mean height of the self-fertilised plants in each of the ten generations is also shown in the accompanying diagram, that of the intercrossed plants being taken at 100; and on the right side we see the relative heights of the seventy-three intercrossed plants, and of the seventy-three self-fertilised plants. The difference in height between the crossed and

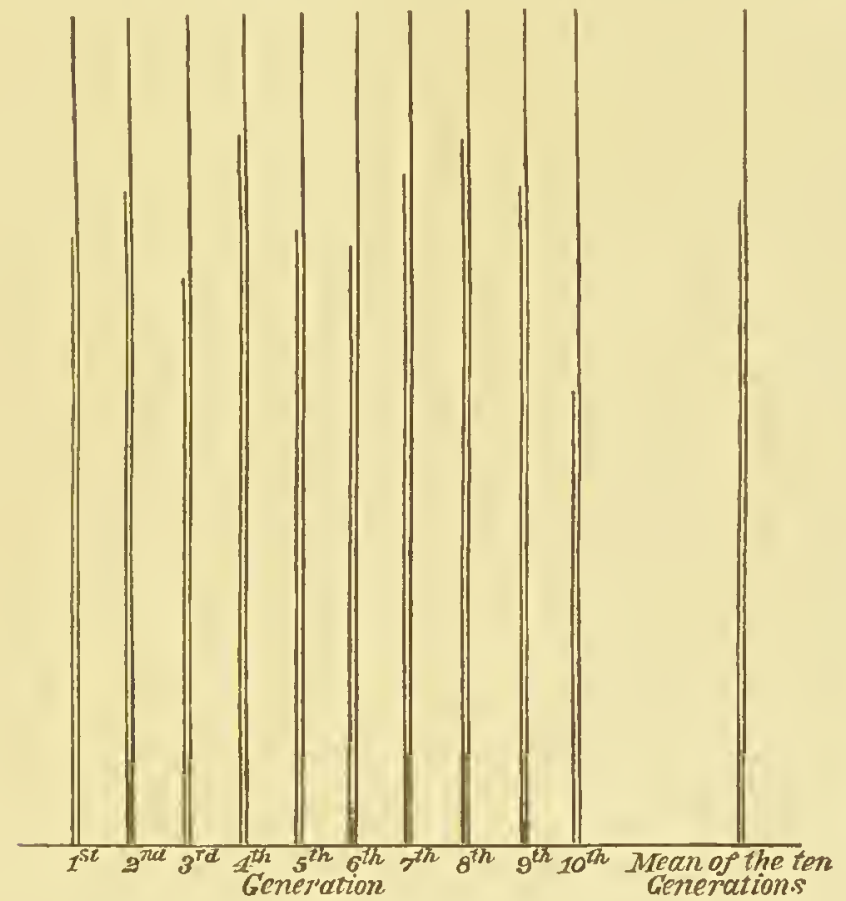

Diagram showing the mean heights of the crossed and self-fertiiised plants of Ipomcea purpurea in the ten generations; the mean height of thr crossed plants being taken as 100 . On the right hand, the mean heights of the crossed and self-fertilised plants of all the generations taken together are shown.

self-fertilised plants will perhaps be best appreciater by an illustration: If all the men in a country were on an average 6 feet high, and there were some families which had been long and closely interbred, these would be almost dwarfs, their average height during ten generations being only 4 feet $8 \frac{1}{4}$ inches. 
It should be especially observed that the average difference between the crossed and self-fertilised plants is not due to a few of the former having grown to an extraordinary height, or to a few of the self-fertilised being extremely short, but to all the crossed plants having surpassed their self-fertilised opponents, with the few following exceptions. The first occurred in the sixth generation, in which the plant named "Hero" appeared; two in the eighth generation, but the selffertilised plants in this generation were in an anomalous condition, as they grew at first at an unusual rate and conquered for a time the opposed crossed plants ; and two exceptions in the ninth generation, though one of these plants only equalled its crossed opponent. 'Therefore, of the seventy-three crossed plants, sixtyeight grew to a greater height than the self-fertilised plants, to which they were opposed.

In the right-hand column of figures, the difference in height between the crossed and self-fertilised plants in the successive generations is seen to fluctuate much, as might indeed have been expected from the small number of plants measured in each generation being insufficient to give a fair average. It should be remembered that the absolute height of the plants goes for nothing, as each pair was measured as soon as one of them had twined up to the summit of its rod. The great difference in the tenth generation, viz., 100 to 54, no doubt was partly accidental, though, when these plants were weighed, the difference was even greater, viz., 100 to 44 . The smallest amount of difference occurred in the fourth and the eighth generations, and this was apparently due to both the crossed and self-fertilised plants haring become unhealthy, which prevented the former attaining their usual degree of superiority. This was an 
unfortunate eireumstanee, but my experiments were not thus vitiated, as both lots of plants were exposed to the sime conditions, whether favourable or unfavourable.

'There is reason to believe that the flowers of this Ipomcea, when growing out of cloors, are habitually crossed by inseets, so that the first seedlings whieh I raised from purehased seeds were probably the offspring of a cross. I infer that this is the ease, firstly from humble-bees often visiting the flowers, and from the quantity of pollen left by them on the stigmas of sueh fiowers; and, seeondly, from the plants raised from the same lot of seed varying greatly in the colour of their flower's, for as we shall hereafter see, this indicates mueh intercrossing. " It is, therefore, remarkable that the plants raised by me from flowers whieh were, in all probability, self-fertilised for the first time after many generations of crossing, should have been so markedly inferior in height to the intercrossed plants as they were, namely, as 76 to 100 . As the plants whieh were self-fertilised in eaeh sueceeding generation neeessarily became mueh more closely interbred in the later than in the earlier generations, it might have been expeeted that the differenee in height between them and the erossed plants would have gone on increasing; but, so far is this from being the ease, that the difference between the two sets of plants in the seventh, eighth, and ninth generations taken together is less than in the first and seeond generations together. When, however, we remember that the self-fertilised and crossed plants are all descended from the same

* Verlot says ("Sur la Production des Var,cétés, 1865̄, p. 66) that certain varicties of in closely allied plant, the Convolvulus Lri- color, cannot be kept pure unless glown at a distance from all other varioties. 
mother-plant, that many of the crossed plants in each generation were related, often elosely related, and that all were exposed to the same eonditious, whieh, as we shall hereafter find, is a very important eireumstanee, it is not at all surprising that the difference between them should have somewhat decreased in the later generations. It is, on the contrary, an astonishing faet, that the erossed plants should have been rietorious, even to a slight degree, over the self-fertilised plants of the later generations.

The mueh greater eonstitutional vigour of the crossed than of the self-fertilised plants, was prored on five oeeasions in various ways; namely, by exposing them, while young, to a low temperature or to a sudden ehange of temperature, or by growing them, under very unfavourable eonditions, in competition with full-grown plants of other kinds.

With respeet to the produetiveness of the erossed and self-fertilised plants of the successive generations, nly observations unfortunately were not made on any uniform plan, partly from the want of time, and partly from not having at first intended to observe more than a single generation, A summary of the results is here given in a tabulated form, the fertility of the erossed plants being taken as 100 .

First Generation of crossed and self-fertilised Plarits yrowing in competition with one another.-Sixty-five eapsules produced from flowers on five erossed plants fertilised by pollen from a distinet plant, and fifty-fire eapsules produeed from flowers on five self-fertilised plants fertilised by their own pollen, eontained seeds in the proportion of . $\cdot$.

Fifty-six spontaneously self-fortilised capsules on the above five erossed plants, and trenty-five spontaneously self-fertilised eapsules on the above five selffertilised plants, yielded seeds in the proportion of . 
Combining the total number of capsules produced by thesc plants, and the average number of seeds in each, the above crosscd and self-fertilised plants yielded seeds in the proportion of . . •
Other plants of this first generation grown mnder mnfavourable conditions and spontancously self-fertilised, yielded seeds in the proportion of .

100 to 64

Third Generation of crossed and self-fertilised Plants. - Crossed capsules compared with self-fertilised capsules contained seeds in the ratio of

An equal number of crossed and self-fertilised plants, both spontaneously self-fertilised, produced capsules in the ratio of .

And these capsulcs contained seeds in the ratio of .

Combining these data, the productiveness of the crossed to the self-fertilised plants, both spontaneously sclf-fertilised, was as

Fourth Generation of crossed and self-fertilised Plants. -Capsules from flower's on the crossed plants fertilised by pollen from another plant, and capsules from flowers on the self-fertilised plants fertilised with their own pollen, contained seeds in the proportion of .

Fifth Generation of crossed and self-fertilised Plants. - The crossed plants produced spontaneously a vast number more pods (not actually counted) than the self-fertilised, and these contained seeds in the proportion of

Nirth Generation of crossed and self-fertilised Plarts. -Fourteen crossed plants, spontaneously self-fertilised, and fourteen self-fertiliscd plants spontaneously self-fertilised, yielded capsulcs (the average number of seeds per capsule not having been ascertaincd) in the proportion of .

Plants derived from a cross with a fresh Stock compared with irtercrossed Plants. - The offspring of intercrossed plants of the ninth generation, crossed by a fresh stock, compared with plants of the samc stock intercrossed during ten generations, both sets of plants left uncovered and naturally fertilised, produced capsules by weight as

100 to 51

We see in this table that the crossed plants are 
always in some degree more productive than the selffertilised plants, by whatever standard they are eompared. The degree differs greatly; but this depends ehiefly on whether an average was taken of the seeds alone, or of the eapsules alone, or of both eombined. The relative superiority of the erossed plants is chiefly due to their producing a much greater number of eapsules, and not to eaeh eapsule containing a larger average number of seeds. For instance, in the third generation the crossed and self-fertilised plants produced eapsules in the ratio of 100 to 38 , whilst the seeds in the eapsules on the erossed plants were to those on the self-fertilised plants only as 100 to 94 . In the eighth generation the eapsules on two selffertilised plants (not ineluded in the above table), grown in separate pots and thus not subjected to any eompetition, yielded the large average of $5 \cdot 1$ seeds. The smaller number of capsules produeed by the selffertilised plants may be in part, but not altogether, attributed to their lessened size or height; this being ehiefly due to their lessened constitutional vigour, so that they were not able to eompete with the crossed plants growing in the same pots. The seeds produced by the erossed flowers on the erossed plants were not always heavier than the self-fertilised seeds on the self-fertilised plants. The lighter seeds, whether produeed from erossed or self-fertilised flower's, generally germinated before the heavier seels. I may add that the erossed plants, with very few exceptions, flowered before their self-fertilised opponents, as might hare been expeeted from their greater height and vigour.

The impaired fertility of the self-fertilised plants was shown in another way, namely, by their anthers being smaller than those in the flowers on the erossed plants. 'This was first observed in the seventh generation, but 
may have oceurred earlier. Several anthers from flowers on the crossed and self-fertilised plants of the eighth generation were eompared under the mieroseope; and those from the former were generally longer and plainly broader than the anthers of the self-fertilised plants. The quantity of pollen eontained in one of the latter was, as far as eould be judged by the eye, about half of that contained in one from a erossed plant. The impaired fertility of the self-fertilised plants of the eighth generation was also shown in another manner, whieh may often be observed in hybrids-namely, by the first-formed flower's being sterile. For instance, the fifteen first flowers on a self-fertilised plant of one of the later generations were carefully fertilised with their own pollen, and eight of them dropped off; at the same time fifteen flowers on a crossed plant growing in the same pot were self-fertilised, and only one dropped off. On two other crossed plants of the same generation, sereral of the earliest flower's were observed to fertilise themselves and to produee eapsules. In the plants of the ninth, and I believe of some previous generations, very many of the flowers, as already stated, were slightly monstrous; and this probably was conneeted with their lessened fertility.

All the self-fertilised plants of the seventh generation, and I believe of one or two previous generations, produced flowers of exaetly the same tint, namely, of a rich dark purple. So did all the plants, without any exception, in the three suceeeding generations of selffertilised plants; and very many were raised on account of other experiments in progress not here reeorded. My attention was first ealled to this fact by $m y$ gardener remarking that there was no oceasion to label the self-fertilised plants, as they could always be known by their colour. The flowers were as uniform in tint 
as those of a wild species growing in a state of nature; whether the same tint occurred, as is probable, in the earlier generations, neither my gardener nor self could recollect. The flowers on the plants which were first raised from purchased seed, as well as during the first few generations, varied mueh in the depth of the purple tint; many were more or less pink, and occasionally a white variety appeared. The erossed plants eontinued to the tenth generation to vary in the same manner as before, but to a much less degree, owing, probably, to their having become more or less closely inter-related. We must therefore attribute the extraordinary uniformity of eolour in the flowers on the plants of the seventh and sueeeeding self-fertilised generations, to inheritance not having been interfered with by crosses during several preceding generations, in combination with the eonditions of life having been very uniform.

A plant appeared in the sixth self-fertilised generation, named the Hero, which exceeded by a little in height its crossed antagonist, and whieh transmitted its powers of growth and inereased self-fertility to its ehildren and grandehildren. A eross between the children of Hero did not give to the grandchildren any advantage over the self-fertilised grandchildren raised from the self-fertilised children. And as far as my observations ean be trusted, whieh were made on very unhealthy plants, the great-grandchildren raised from intererossing the grandehildren had no adrantage over the seedlings from the grandehildren the product of eontinued self-fertilisation; and what is far more remarkable, the great-grandehildren raised by erossing the grandehildren with a fresh stock, had 110 adrantage over either the intercrossed or self-fertilised greatgrandehildren. It thus appears that Hero and its 
descendants differed in constitution in an extraordinary manner from ordinary plants of the present species.

Although the plants raised during ten successive generations from crosses between distinct yet interrelated plants almost invariably exceeded in height, constitutional vigour, and fertility their self-fertilised opponents, it has been proved that seedlings raised by intercrossing flowers on the same plant are by no means superior, on the contrary are somewhat inferior in height and weight, to seedlings raised from flowers fertilised with their own pollen. This is a remarkable fact, which seems to indicate that self-fertilisation is in some manner more advantageous than crossing, unless the cross brings with it, as is generally the case, some decided and preponderant advantage; but to this subject I shall recur in a future chapter.

The benefits which so generally follow from a cross between two plants apparently depend on the two differing somewhat in constitution or character. This is shown by the seedlings from the intercrossed plants of the ninth generation, when crossed with pollen from a fresh stock, being as superior in height and almost as superior in fertility to the again intercrossed plants, as these latter were to seedling's from self-fertilised plants of the corresponding generation. We thus learn the important fact that the mere act of crossing two distinct plants, which are in some degree inter-related and which have been long subjected to nearly the same conditions, does little good as conipared with that from a cross between plants belonging to different stocks or families, and which have been subjected to somewhat different couditions. We may attribute the good derived from the crossing of the intercrossed plants during the ten successive generations to their still differing some- 
what in constitution or character, as was indeed proved by their flowers still differing somewhat in colour. But the several conclusions which may be rleduced from the experiments on Ipomoa will be more fully considered in the final chapters, after all my other observations have been given. 


\section{CHAPTER III.}

Surophulariaced, Gesperiacede, Labiata, etc.

Mimulus luteus; height, vigour, and fertility of the erossed and selffertilised plants of the first four generations-Appearanec of a new, till, and highly self-fertile variety-Offspring from a cross between self-fertilised plants-Effects of a cross with a fresh stock - Effeets of erossing fluwers on the same plant-Summary on Mimulus luteus-Digitalis purpuren, superiority of the crosserl plants-Effects of crossing fluwcrs on the same plant-Caleeolaria - Linaria vulgaris - Verbaseum thapsus - Vandellia nummularifolia-Cleistogene flowers-Gesneria pendulina-Salvia coceineaOrig.ınum vulgare, great inerease of the crossed plants by stolons - Thunbergia alata.

In the family of the Scrophulariaceæ I experimented on species in the six following genera: Mimulus, Digitalis, Calceolaria, Linaria, Verbascum, and Vandellia.

\section{SCROPHULARIACEAE-MIMULUS LUTECS.}

The plants whieh I raised from purehased seed varied greatly in the eolour of their flowers, so that hardly two individuals were quite alike; the corolla being of all shades of yellow, with the most diversified blotches of purple, erimson, orange, and coppery brown. But these plants differed in no other respect.* The flowers are evidently well adapted for fertilisation by the ageney of insects; and in the ease of a closely allied species, $M$. rosea, I have watched bees entering the flowers, thus getting their backs well dusted with pollen; and when they entered another flower the pollen was lieked off their backs by

* I sent severnl spccimens with verionsly coloured flowers to Kow, and Dr. Hooker informs me that they all consisted of $M$. luteus.
The flowers with mueh rerl have been named by horticulturists as var. Youngiana. 
the two-lipped stigma, the lips of which are irritable and close like a forceps on the pollen-grains. If no pollen is enclosed between the lips, these open again after a time. Mrr. Kitcherrer has ingeniously explained * the use of these movements, namely, to prevent the self-fertilisation of the flower. If a bee with no pollen on its back enters a flower it touches the stigma, which quickly closes, and when the bee retires dusted with pollen, it can leave none on the stigma of the same flower. But as soon as it enters any other flower, plenty of pollen is left on the stigma, which will be thus cross-fertilised. Nevertheless, if insects are excluded, the flowers fertilise themselves perfectly and produce plenty of seed; but I did not ascertain whether this is effected by the stamens increasing in length with advancing age, or by the bending down of the pistil. The chief interest in my experiments on the present species, lies in the appearance in the fourth self-fertilised generation of a viliety which bore large peculiarly-coloured flowers, and grew to a greater height than the other varieties; it likewise became wore lighly self-fertile, so that this variety resembles the plant named Hero, which appeared in the sixth self-fertilised greneration of Ipomoa.

Some flower's on one of the plants raised from the purchased seeds were fertilised with their own pollen; and others on the same plant were crossed with pollen from a distinct plant. The sceds from twelve capsinles thus produced were placed in separate watch-glasses for comparison; and those from the six crossed capsules appeared to the eye hardly more numerous than those from the six self-fertilised capsules. But when the sceds were weighed, those from the crossed capsules amomnted to 1.02 grain, whilst those from the self-fertilised capsules were only ' 81 grain; so that the former' were either heavier or more numerous than the latter, in the ratio of 100 to 79.

Crossed and self-fertilised 1 lants of the First (ienerution.-Having ascertained, by leaving crossed and self-fertilised sced on damp sind, that they germinated simultaneously, both kinds were thickly sown on opposite sides of a broad and rather shallow pan ; so that the two sets of scedlings, which came up at the same time, were subjected to the same unfarourable conditions. This was in bad method of treatment, but this species was one of the first on which I experimented. When the crossed seedlings

* 'A Year's Botany,' 18it, p. 11S. 
were on an average half an inch high, the self-fertilised ones were only a quarter of an inch high. When grown to thcir full height under the above unfavonrable conditions, the four tallest crossed plants averaged $7 \cdot 62$, and the four tallest self-fertilised 5.87 inches in height; or as 100 to 77 . Ten flowers on the crossed plants were fully expanded before one on the self-fertilised plants. A few of these plants of both lots werc transplanted into a large pot with plenty of good carth, and the self-fertilised plants, not now being subjected to severe competition, grew during the following ycar as tall as the crossed plants; but from a case which follows it is doubtful whether they would have long continued cqual. Some flowers on the crossed plants were crossed with pollen from another plant, and the capsules thus produced contained a rather greater weight of seed than those on the self-fertilised plants again self-fertilised.

Crossed and self-fertilised Plants of the Second Generation.-Beeds from the foregoing plants, fertilised in the manner just stated, were sown on the opposite sides of a small pot ( $\left.I_{0}\right)$ and came up crowded. The four tallest crossed seedlings, at the time of flowering, averaged 8 inches in height, whilst the four tallest self-fertilised plants averaged only 4 inches. Crossed sceds were sown by themselves in a second small pot, and selffertilised seeds were sown by themselves in a third small pot; so that there was no competition whatever between these two lots. Nevertheless the crossed plants grew from 1 to 2 inches higher on an average than the self-fertilised. Both lots looked equally vigorous, but the crossed plants flowered earlier and more profusely than the self-fertilised. In Pot I., in which the two lots competed with each other, the crossed plants flowered first and produced a large number of capsules, whilst the self-fertilised produced only nineteen. The contents of twelve capsules from the crossed flower's on the crossed plants, and of twclve capsules from self-fertilised flowers on the self-fertilised plants, were placed in separate watch-glasses for comparison; and the crossed seeds scemed more numerous by half than the self-fertilised.

The plants on both sides of Pot I., aftcr they had seeded, were cut down and transplanted into a large pot with plenty of good earth, and on the following spring, when they had grown to a height of between 5 and 6 inches, the two lots werc equal, as occurred in a similar experiment in the last gcneration. But after some wceks the crossed plants cxeceded the self- 
fertilised ones on the opposite side of the same pot, though not nearly to so great a degree as before, when they were suljected to very severe eompetition.

Crossed and self-fertilised Plants of the Third Generation.Crossed seeds from the crossed plants, and self-fertilised seeds from the self-fertilised plants of the last generation, were sown thiekly on opposite sides of a small pot, No. I. The two tallest plants on eaeh side were measured after they had flowered, and the two erossed ones were 12 and $7 \frac{1}{2}$ inches, and the two selffertilised ones 8 and $5 \frac{1}{2}$ inches in height; that is, in the ratio of 100 to 69 . Twenty flower's on. the erossed plants rere again crossed and produeed twenty capsules; ten of whieh contained 1.33 grain weight of seeds. Thirty flowers on the self-fertilised plants were again self-fertilised and produeed twenty-six capsules; ten of the best of whieh (many being very poor) eontained only 87 grain weight of seeds; that is, in the ratio of 100 to 65 by weight.

The superiority of the erossed over the self-fertilised plants was proved in various ways. Self-fertilised seeds were som on one side of a pot, and two days afterwards crossed sceds on the opposite side. The two lots of seedlings were equal until they were above half an ineh ligh; but when fully grom the two tallest crossed plants attained a height of $12 \frac{1}{2}$ and $S_{4}^{3}$ inches, whilst the two tallest self-fertilised plants were only 8 and $5 \frac{1}{2}$ inelies high.

In a third pot, erossed seeds were sown fom days after the self-fertilised, and the seedlings from the latter had at first, as might have been expected, an advantage; but when the two lots were between 5 and 6 inches in height, they mere equal, and ultimately the three tallest crossed plants were 11.10, and 8 inehes, whilst the three tallest self-fertilised were $12,8_{2}^{1}$, and $7 \frac{1}{2}$ inches in height. So that there was not much differenee between them, the erossed plants having an average adrantage of only the third of an inch. The plants were ent down, and without being disturbed were transplanted into a larger pot. Thus the two lots starterl fair on the following splring, and now the erossed plants showed their inherent superiority, for the two tallest were 13 inches, whilst the two tallest self-fertilised plants were only 11 and $8:$ inelies in height; or as 100 to 75 . The two lots were allowed to fertilise themselves spontaneously : the crosser plants produced a large number of capsules, whilst the self-fertilised produced very few and poor ones. The seeds 
from eight of the eapsules on the crossed plants weighed 65 grain, whilst those from cight of the eapsules on the self-fertilised plants weighed only -2:3 grain; or as 100 to 34 .

The crossed plants in the above three pots, as in almost all the previous experiments, flowered before the self-fertilised. This oecurred even in the third pot in whieh the crossed seeds were sown four days after the self-fertilised seeds.

Lastly, seeds of both lots were sown on opposite sicles of a large pot in whieh a Fuchsia had long been growing, so that the earth was full of roots. Both lots grew miserably; but the erossed seedlings had an advantage at all times, and ultimately attained to a height of $3 \frac{1}{2}$ inches, whilst the self-fertilised seedlings never exceeded 1 inch. The several foregoing experiments prove in a decisive manner the superiority in constitutional vigour of the erossed over the self-fertilised plants.

In the three generations now described and taken together, the average height of the ten tallest crossed plants was 8.19 inches, and that of the ten tallest self-fertilised plants 5.29 inches (the plants having been grown in small pots), or as 100 to 65 .

In the next or fourth self-fertilised generation, several plants of a new and tall variety appeared, which inereased in the later self-fertilised generations, owing to its great self-fertility, to the eomplete exclusion of the original kinds. The same variety also appeared amongst the erossed plants, but as it was not at first regarded with any partieular attention, I know not how far it was used for raising the intererossed plants; and in the later crossed generations it was rarely present. Owing to the appearance of this tall variety, the eomparison of the crossed and self-fertilised plants of the fifth and sueeeding generations was rendered unfair, as all the self-fertilised and only a few or none of the crosscd plants consisted of it. Nevertheless, the results of the later experiments are in some respects well worth giving.

Crossed and self-ferlilised Plants of the Fourth Generation.-Seeds of the two kinds, produced in the usual way from the two sets of plants of the third generation, were sown on opposite sides of two pots (I. and II.); but the seodlings were not thinnerl enough and did not grow well. Many of the self-fertilised plants, especially in one of the pots, consisted of the new and tall variety above referred to, which bore large and almost white flower's marked with crimson blotehes. I will call it the White variety. I believe that it first appeared amongst both the 
crossed and self-fertilised plants of the last generation; but neither my gardener nor myself eould remember any sueh variety. in the seedlings raised from the purehased seed. It must therefore lave arisen either through ordinary variation, or, judging from its appearanee amongst both the crossed and self-fertilised plants, more probably through reversion to a formerly existing variety.

In Pot I. the tallest erossed plant was $8 \frac{1}{2}$ inehes, and the tallest self-fertilised 5 inehes in height. In Pot II. the tallest erossed plant was $6 \frac{1}{2}$ inches, and the tallest self-fertilised plant, which eonsisted of the white variety, 7 inches in height; and this was the first instance in my experiments on Mimulus in whieh the tallest self-fertilised plant exeeeded the tallest erossed. Nevertheless, the two tallest crossed plants taken together were to the two tallest self-fertilised plants in height as 100 to 80 . As yet the erossed plants rere superior to the self-fertilised in fertility; for twelve flowers on the crossed plants were erossed and yielded ten eapsules, the seeds of which weighed 1.71 grain. Twenty flomers on the self-fertilised plants were self-fertilised, and produeed fiftecn capsules, all appearing poor; and the seeds from ten of them weighed only 68 grain, so that from an equal number of capsules the crossed seeds were to the selffertilised in weight as 100 to 40 .

Crossed and self-fertilised Plants of the Fifth Generation.-Seeds from both lots of the fourth generation, fertilised in the usual manner, were sown on opposite sides of three pots. When the seedlings flowered, most of the self-fertilised plants were found to eonsist of the tall white rariety. Sereral of the erossed plants in Pot I. likewise belonged to this variety, as did a rery few in Pots II. and III. The tallest crossed plant in Pot I. was 7 inches, and the tallest self-fertilised plant on the opposite side 8 inches: in Pots II. and III. the tallest erossed were $4 \frac{1}{2}$ and $5_{2}^{\frac{2}{2}}$, and the tallest self-fertilised 7 and $6 \frac{1}{2}$ inehes in height; so that the average height of the tallest plants in the two lots was as 100 for the erossed to 126 for the self-fcrtilised; and thus we have a eomplete reversal of what oeeurred in the four previous gencrations. Nevertheless, in all three pots the crossed plants retained their habit of flowering before the self-fertilised. The plants were mhealthy from being erowled and from the extreme heat of the season, and were in consequenee more or less sterile; but the erossed plants were somewhat less sterile than the self-fertilised plants. 
Crossed and self-fertilised Plants of the Sixth Generation.-Seeds from plants of the fifth generation crossed and self-fertilised in the usual manner were sown on opposite sides of several pots. On the self-fertilised side every single plant belonged to the tall white variety. On the crossed side some plants belonged to this variety, but the greater number approached in character to the old and shorter kinds with smaller yellowish flowers blotched with coppery brown. When the plants on both sides were from 2 to 3 inches in height they were equal, but when fully grown the self-fertilised were decidedly the tallest and finest plants, but, from want of time, they were not actually measured. In half the pots the first plant which flowered was a self-fertilised one, and in the other half a crossed one. And now another remarkable change was clearly perceived, namely, that the self-fertilised plants had become more self-fertile than the crossed. The pots were all put under a net to exclude insects, and the crossed plants produced spontaneously only fifty-five capsules, whilst the self-fertilised plants produced eighty-one capsules, or as 100 to 147 . The seeds from nine capsules of both lots were placed in separate watch-glasses for comparison, and the self-fertilised appeared rather the more numerous. Besides these spontaneously self-fertilised capsules, twenty flowers on the crossed plants again crossed yielded sixteen capsules; twenty-five flowers on the self-fertilised plants again self-fertilised yielded seventeen capsules, and this is a larger proportional number of capsules than was produced by the self-fertilised flowers on the self-fertilised plants in the previous generations. The contents of ten capsules of both these lots were compared in separate watch-glasses, and the seeds from the self-fertilised appeared decidedly more numerous than those from the crossed plants.

Crossed and self-fertilised Plants of the Seventh Generation.Crossed and self-fertilised seeds from the crossed and self-fertilised plants of the sixth generation were sown in the usual manner on opposite sides of thrce pots, and the seedlings were well and equally thinned. Evcry one of the self-fertilised plants (and many were raised) in this, as well as in the eighth and ninth generations, belonged to the tall white variety. 'Their uniformity of character, in comparison with the scedlings first raised from the purchased seed, was quitc remarkable. On the other hand, the crossed plants differed much in the tints of their flowers, but not, I think, to so great a degrce as those first raised. I detcrmined this time to measure the plants on both sides 
carefully. The self-fertilised seedlings came up rather before the crossed, but both lots were for a time of equal height. When first measured, the average heiglit of the six tallest crossed plants in the three pots was $7 \cdot 02$, and that of the six tallest solf-tertilised plants 8.97 inches, or as 100 to 128 . When fully grown the same plants were again measured, with the result shown in the following table:-

Table XVIII. (Seventh Generation.)

\begin{tabular}{|c|c|c|}
\hline No. of Pot. & Crossed l'lants. & Self-fertilised Plants. \\
\hline I. & $\begin{array}{c}\text { Inches. } \\
11 \frac{2}{8} \\
11 \frac{7}{8}\end{array}$ & $\begin{array}{l}\text { Inches. } \\
19 \frac{1}{8} \\
1 S^{-1}\end{array}$ \\
\hline II. & $\begin{array}{l}12 \frac{7}{8} \\
11 \frac{2}{8}\end{array}$ & $\begin{array}{l}18 \frac{2}{8} \\
14 \frac{6}{8}\end{array}$ \\
\hline III. & $\begin{array}{r}9 \frac{9}{8} \\
11 \frac{11}{8}\end{array}$ & $12 \frac{6}{8}$ \\
\hline Total inches. & $63 \cdot 63$ & $93 \cdot 88$ \\
\hline
\end{tabular}

The average height of the six crossed is here $11 \cdot 43$, and that of the six self-fertilised $15^{\cdot} 64$, or as 100 to 137 .

As it was now evident that the tall white variety transmitted its characters faitlifully, and as the self-fertilised plants consisted cxclusively of this variety, it was manifest that they would always exceed in height the crossed plants which belonged chiefly to the original shorter varieties. This line of experiment was therefore discontinued, and I tried whether intererossing two self-fertilised plants of the sixth generation, growing in distinct pots, would give their offspring any adrantage over the offspring of flowers on one of the same plants fertilised with their own pollen. These latter seedlings formed the serenth generation of selt-fertilised plants, like those in the right-hand column in Table XVIII.; the crossed plants were the product of six previons self-fertilised generations with an intercross in the last generation. The seeds were allowed to germinate on sand, and were planted in pairs on opposite sides of four pots, all the remaining seeds being sown crowded on opposite sides of Pot Y.in Table XIX.; the thrce tallest on each sicle in this latter pot. heing alone measured. All the plants rere twice measured-the first time whilst young, and the average height of the crossed plants 
CHAP. III. CROSSED AND SELF-FERTILISED PLANTS. 71

to that of the self-fertilised was then as 100 to 122 . When fully glown they were again measured, as in the following table :-

TABLE XIX.

\begin{tabular}{|c|c|c|}
\hline No. of Pot. & $\begin{array}{c}\text { Intercrossed Plants } \\
\text { from Self-fertilised } \\
\text { Plants of the Sixth } \\
\text { Generation. }\end{array}$ & $\begin{array}{l}\text { Self-fertilised Plants } \\
\text { of the Seventh } \\
\text { Generition. }\end{array}$ \\
\hline I. & $\begin{array}{c}\text { Irches. } \\
12 \frac{6}{8} \\
10 \frac{4}{8} \\
10 \\
14 \frac{5}{8}\end{array}$ & $\begin{array}{c}\text { Inches. } \\
15 \frac{2}{8} \\
11 \frac{5}{8} \\
11 \\
11\end{array}$ \\
\hline II. & $\begin{array}{r}10 \frac{2}{8} \\
7 \frac{6}{8} \\
12 \frac{1}{8} \\
7\end{array}$ & $\begin{array}{r}11 \frac{3}{8} \\
11 \frac{4}{8} \\
8 \frac{5}{8} \\
1 \pm \frac{3}{8}\end{array}$ \\
\hline III. & $\begin{array}{l}13 \frac{5}{8} \\
12 \frac{2}{8}\end{array}$ & $\begin{array}{l}10 \frac{3}{8} \\
11 \frac{6}{8}\end{array}$ \\
\hline IV. & $\begin{array}{l}7 \frac{1}{8} \\
8 \frac{2}{8} \\
7 \frac{2}{8}\end{array}$ & $\begin{array}{c}14 \frac{6}{8} \\
7 \\
8\end{array}$ \\
\hline $\begin{array}{c}\text { V. } \\
\text { Crowded. }\end{array}$ & $\begin{array}{l}8 \frac{5}{8} \\
9 \\
8 \frac{2}{8}\end{array}$ & $\begin{array}{r}10 \frac{2}{6} \\
9 \frac{3}{8} \\
9 \frac{2}{8}\end{array}$ \\
\hline Total in inches. & $159 \cdot 38$ & $175 \cdot 50$ \\
\hline
\end{tabular}

The average height of the sixteen intercrossed plants is here $9 \cdot 96$ inches, and that of the sixteen self-fertilised plants $10 \cdot 96$, or as 100 to 110 ; so that the intercrossed plants, the progenitors of which had been self-fertilised for the six previous generations, and had been exposed during the whole time to remarkably uniform conditions, were somewhat inferior in height to the plants of the seventh self-fertilised generation. But as we. shall presently see that a similar experiment made after two additional generations of self-fertilisation gave a different result, I know not how far to trust the present one. In three of the five pots in Table XIX. a self-fertilised plant flowered first, and in the other two a crossed plant. These self-fertilised plants were remarkably fortile, for twenty flower's fertilised with their own pollen produced no less than nineteen very fine capsules! 
The effects of a C'ross with a distinct Stock.-Some flowers on the self-fertilised plants in Pot IV, in Table XIX. were fertilised with their own pollen, and plants of the eightl self-fertilised generation were thus raised, merely to serve as parents in the following experiment. Several flowers on these plants were allowed to fertilise themselves spontaneously (insects being of eourse exeluded), and the plants raised from these seeds formed the ninth self-fertilised generation; they eonsisted wlolly of the tall white variety with erimson blotehes. Other flowers on the same plants of the eightl self-fertilised generation were erossed with pollen taken from another plant of the same lot; so that the seedlings thus raised were the offspring of eight previous generations of self-fertilisation with an intereross in the last generation; these I will eall the intercrossed plunts. Lastly, other flowers on the same plants of the eighth self-fertilised generation were erossed with pollen taken from plants whieh had been raised from seed proeured from a garden at Chelsea. The Chelsea plants bore yellow flowers blotehed with red, but differed in no other respeet. They had been grown out of doors, whilst mine had been eultivated in pots in the greenhouse for the last eight generations, and in a different kind of soil. The seedlings raised from this eross with a wholly different stoek may be ealled the "Chetsea-crossed." The three lots of seeds thus obtained were allowed to germinate on bare sand; and whenever a seed in all three lots, or in only two, germinated at the same time, they were planted in pots superfieially divided into three or two eompartments. The remaining seeds, whether or not in a state of germination, were thiekly sown in three divisions in a large pot, X., in Table XX. When the plants had grown to their full height they were measured, as shown in the following table; but only the three tallest plants in each of the three divisions in Pot $\mathrm{X}$. were measured.

In this table the average height of the twenty-eight Chelseacrossed plants is 21.62 inehes; that of the twenty-seren intererossed plants $12 \cdot 2$; and that of the nineteen self-fertilised $10 \cdot 44$. But with respeet to the latter it will be the fairest plan to strike out two dwarfed ones (only 4 inelies in height), so as not to exaggerate the inferiority of the self-fertilised plants; and this will raise the average height of the seventeen remaining self-fertilised plants to $11 \cdot 2$ inehes. Therefore tlie Chelsea-erossed are to the intercrossed in height as 100 to 56 ; the Chelsea-erossed to the selffertilised as 100 to 52 ; and tho intererossed to the self-fertilised 
TABLE XX.

\begin{tabular}{|c|c|c|c|}
\hline No. of Pot. & $\begin{array}{l}\text { Plants from Self- } \\
\text { fertilised Plaits of } \\
\text { the Eighth Genera- } \\
\text { tion erossed by } \\
\text { Chelsea Plunts. }\end{array}$ & $\begin{array}{l}\text { Plants from an in- } \\
\text { tereross between } \\
\text { the Plants of the } \\
\text { Fighth Self-ferti- } \\
\text { lised Generation. }\end{array}$ & $\begin{array}{l}\text { Self-fertilised } \\
\text { Plants of the Ninth } \\
\text { Generation from } \\
\text { Plants of the } \\
\text { Eighth Self-ferti- } \\
\text { lised Generation. }\end{array}$ \\
\hline I. & $\begin{array}{c}\text { Inclies. } \\
307 \\
28 \frac{7}{8} \\
\ldots\end{array}$ & $\begin{array}{c}\text { Inehes. } \\
14 \\
13 \frac{6}{8} \\
13 \frac{7}{8}\end{array}$ & $\begin{array}{l}\text { Inehes. } \\
9 \frac{4}{8} \\
10 \frac{7}{8} \\
10\end{array}$ \\
\hline II. & $\begin{array}{l}20 \frac{6}{8} \\
22 \frac{2}{8} \\
\cdots\end{array}$ & $\begin{array}{l}11 \frac{4}{8} \\
12 \\
9 \frac{1}{8}\end{array}$ & $\begin{array}{l}11 \frac{6}{8} \\
12 \frac{3}{8} \\
\cdots\end{array}$ \\
\hline III. & $\begin{array}{l}23 \frac{6}{8} \\
24 \frac{1}{8} \\
25 \frac{6}{8}\end{array}$ & $\begin{array}{l}12 \frac{2}{8} \\
\cdots \\
\cdots\end{array}$ & $\begin{array}{r}8 \frac{5}{6} \\
11 \frac{1}{8} \\
6 \frac{7}{8}\end{array}$ \\
\hline IV. & $\begin{array}{l}22 \frac{5}{8} \\
22 \\
17\end{array}$ & $\begin{array}{l}9 \frac{2}{8} \\
8 \frac{1}{8} \\
\cdots\end{array}$ & $\begin{array}{c}4 \\
13 \frac{3}{8} \\
11\end{array}$ \\
\hline V. & $\begin{array}{l}22 \frac{3}{8} \\
19 \frac{5}{8} \\
23 \frac{4}{8}\end{array}$ & $\begin{array}{r}9 \\
11 \\
\cdots\end{array}$ & $\begin{array}{l}4 \frac{4}{8} \\
13 \\
13 \frac{4}{8}\end{array}$ \\
\hline VI. & $\begin{array}{l}28 \frac{2}{8} \\
22 \\
\cdots\end{array}$ & $\begin{array}{c}18 \frac{6}{8} \\
7 \\
12 \frac{4}{8}\end{array}$ & $\begin{array}{l}12 \\
16 \frac{1}{8} \\
\cdots\end{array}$ \\
\hline VII. & $\begin{array}{l}12 \frac{4}{8} \\
24 \frac{3}{8} \\
20 \frac{4}{8} \\
26 \frac{4}{8}\end{array}$ & $\begin{array}{l}15 \\
12 \frac{3}{8} \\
11 \frac{2}{8} \\
15 \frac{2}{8}\end{array}$ & $\begin{array}{l}\cdots \\
\cdots \\
\cdots\end{array}$ \\
\hline VIII. . & $\begin{array}{l}17 \frac{2}{8} \\
22 \frac{6}{8} \\
27\end{array}$ & $\begin{array}{l}13 \frac{3}{8} \\
14 \frac{5}{8} \\
14 \frac{3}{8}\end{array}$ & $\begin{array}{l}\cdots \\
\cdots \\
\cdots\end{array}$ \\
\hline IX. & $\begin{array}{c}22 \frac{6}{8} \\
6 \\
20 \frac{2}{8}\end{array}$ & $\begin{array}{l}11 \frac{6}{8} \\
17 \\
147\end{array}$ & $\begin{array}{l}\cdots \\
\cdots\end{array}$ \\
\hline$\frac{\mathrm{X}}{\text { Crowded Plants. }}$ & $\begin{array}{l}18 \frac{1}{8} \\
16 \frac{5}{8} \\
17 \frac{4}{8}\end{array}$ & $\begin{array}{r}9 \frac{2}{8} \\
8 \frac{2}{8} \\
10\end{array}$ & $\begin{array}{r}10 \frac{3}{8} \\
8 \frac{1}{8} \\
11 \frac{2}{8}\end{array}$ \\
\hline Total inches. & $605 \cdot 38$ & $329 \cdot 50$ & $198 \cdot 50$ \\
\hline
\end{tabular}


as 100 to 92 . We thus see how immensely superior in height the Chelsea-crossed are to the intercrossed and to the selffertilised plants. They began to show their superiority when only one inch high. They were also, when fully grown, much more branched with larger leaves and somewhat larger flowers than the plants of the other two lots, so that if they had been weighed, the ratio would certainly have been much higher than that of 100 to 56 and 52 .

The intercrossed plants are here to the self-fertilised in height as 100 to 92 ; whereas in the analogous experiment given in Table XIX. the intercrossed plants from the selffertilised plants of the sixth generation rere inferior in height to the self-fertilised plants in the ratio of 100 to 110 . I doubt whether this discordance in the resints of the two experiments can be explained by the self-fertilised plants in the present case having been raised from spontaneously selffertilised seeds, whereas in the former case they were raised from artificially self-fertilised seeds; nor by the present plants having been self-fertilised during two additional generations, though this is a more probable explanation.

With respect to fertility, the twenty-eight Chelsea-crossed plants prodnced 272 capsules; the twenty-seven intercrossed plants produced 24; and the seventeen self-fertilised plants 17 capsules. All the plants were left uncovered so as to be naturally fertilised, and empty capsules were rejected.

Capsules.

Therefore 20 Chelsea-crossed plants would have produced $194 \cdot 29$

$\begin{array}{llll}\prime 20 \text { Tutercrossed plants } & , & , & 17 \cdot 77 \\ \text { " } 20 \text { Self-fertilised plants } & , & , & 20 \cdot 00\end{array}$

,20 Self-fertilised plants

Grains.

The seeds contained in 8 capsules from the Chelsen- $1 \cdot 1$ crossed plants weighed .

The steds contained in 8 capsules from the Intercrossed $\} 0.51$ plants weighed

The seeds contained in 8 capsules from the Self-fertilised plants weighed

If we combine the number of capsules produced together with the average weight of contained seeds, we get the following cxtraordinary ratios:

Weight of seed produced by the same number of Chelsea-crossed and intercrossed plants. 
Weight of seed prodneed by the same number of Chelsea-crossed and sclf-fcrtilised plants $\}$ as 1 C0 to 3 Weight of secls produect by the same number of intererossed and self-fcrtilised plants . .

It is also a remarkable faet that the Chelsea-erossed plants exeeeded the two other lots in hardiness, as greatly as they did in height, luxuriance, and fertility. In the early autumn most of the pots were bedded out in the open ground; and this always injures plants whieh have been long kcpt in a warm greenhouse. All three lots eonsequently suffcred greatly, but the Chelseacrossed plants much less than the other two lots. On the 3rd of October the Chelsea-crossed plants began to flower again, and continued to do so for somc time; whilst not a single flower was produeed by the plants of the other two lots, the stems of which wcre cut almost down to the ground and seemed half dead. Early in December there was a sharp frost, and the stems of Chelsea-crossed were now cut down; but on the 23rd of December they began to shoot np again from the roots, whilst all the plants of the other two lots were quite clead.

Although several of the self-fertilised seeds, from which the plants in the right-hand column in Table XX. were raised, germimated (and were of eourse rejected) before any of thosc of the other two lots, yet in only one of the ten pots did a selffertilised plant flower before the Chelser-crossed or the intercrossed plants growing in the same pots. The plants of these two lattcr lots flowered at the same time, though the Chelseacrossed grew so mueh taller and more vigorously than the intererosscd.

As already stated, the flowers of the plants originally raised from the Chelsea sceds werc yellow; and it deserves notiee that crery one of the twenty-eight seedlings raised from the tall white variety fertilised, without bcing eastratcd, with pollen from the Chelsea plants, produeed yellow flowers; and this shows how prepotent this eolour, which is the natural one of the species, is over the white colour.

The liffects on the Offspring of intercrossing Flower's on the same Plant, instead of crossing distinct Individuals.-In all the foregoing cxperiments the crossed plants were the product of a cross betwcen rlistinct plants. I now scleeted a very vigorous plant in 'Table XX., raised by fertilising a plant of the cighth self-fertilised generation with pollen from tho Chelsea stock. 
Several flowers on this plant were erossed with pollen from otlee flower's on the same plant, and several other flowers were fertilised with their own pollen. The seed thus produced was allowed to germinate on bare sand; and the seedlings were planted in the usual manner on the opposite sides of six pots. All the remaining seeds, whether or not in a state of germination, were sown thickly in Pot VII.; the three tallest plants on each side of this latter pot being alone measured. As I was in a hurry to learn the result, some of these seeds were sown late in the autumn, but the plants grew so irregularly during the winter, that one erossed plant was $28 \frac{1}{2}$ inehes, and two others only 4 , or less than 4 inehes in height, as may be seen in Table XXI. Under sueh eircumstances, as I have observed in many other cases, the result is not in the least trustworthy; nevertheless I feel bound to gire the measurements.

TABLE XXI.

\begin{tabular}{|c|c|c|}
\hline No. of Pot. & $\begin{array}{l}\text { Plants raised from a } \\
\text { Cross between dif- } \\
\text { ferent Flowers ou the } \\
\text { same Plant. }\end{array}$ & $\begin{array}{l}\text { Plauts raised from } \\
\text { Flowers fertilised } \\
\text { with their own } \\
\text { Pullen. }\end{array}$ \\
\hline I. & $\begin{array}{c}\text { Inches. } \\
17 \\
9\end{array}$ & $\begin{array}{c}\text { Inches. } \\
17 \\
3 \frac{1}{8}\end{array}$ \\
\hline II. & $\begin{array}{l}28 \frac{2}{8} \\
16 \frac{4}{8} \\
13 \frac{5}{8}\end{array}$ & $\begin{array}{c}19 \frac{1}{8} \\
6 \\
2\end{array}$ \\
\hline III. & $\begin{array}{l}4 \\
2 \frac{2}{8}\end{array}$ & $\begin{array}{l}15 \frac{6}{8} \\
10\end{array}$ \\
\hline IV. & $\begin{array}{l}23 \frac{4}{8} \\
15 \frac{4}{8}\end{array}$ & $\begin{array}{l}6 \frac{2}{8} \\
7 \frac{1}{8}\end{array}$ \\
\hline$V$ & 7 & $13 \frac{4}{8}$ \\
\hline VI. & $\begin{array}{l}18 \frac{3}{8} \\
11\end{array}$ & $\begin{array}{l}1 \frac{1}{8} \\
2\end{array}$ \\
\hline $\begin{array}{c}\text { VII, } \\
\text { Clowded. }\end{array}$ & $\begin{array}{l}21 \\
11 \frac{6}{8} \\
12 \frac{1}{8}\end{array}$ & $\begin{array}{l}15 \frac{1}{8} \\
11 \\
11 \frac{2}{8}\end{array}$ \\
\hline Total inches. & $\begin{array}{c}210 \cdot 88 \\
.\end{array}$ & $1+0 \cdot 73$ \\
\hline
\end{tabular}


The fifteen crossed plants here average $14 \cdot 05$, and the fifteen self-fertilised plants $9 \cdot 38$ in height, or as 100 to 67 . But if all the plants under ten inches in hoight are struck out, the ratio of the eleven crossed plants to the eight self-fertilised plants is as 100 to 82 .

On the following spring, some remaining seeds of the two lots were treated in exactly the same manner; and the measurements of the seedlings are given in the following table:-

\section{TABLE XXII.}

\begin{tabular}{|c|c|c|}
\hline No. of Pot. & $\begin{array}{l}\text { Plants raised fiom a } \\
\text { Cross between diffe- } \\
\text { rent Flowers on the } \\
\text { same Plant. }\end{array}$ & $\begin{array}{l}\text { Plants raised from } \\
\text { Hlowers fertilised } \\
\text { with their own Pollen. }\end{array}$ \\
\hline 1. & $\begin{array}{l}\text { Inehes. } \\
15 \frac{1}{8} \\
12 \\
10 \frac{1}{8}\end{array}$ & $\begin{array}{c}\text { Inches. } \\
19 \frac{1}{8} \\
20 \frac{5}{8} \\
12 \frac{6}{8}\end{array}$ \\
\hline II. & $\begin{array}{l}16 \frac{2}{8} \\
13 \frac{5}{8} \\
20 \frac{1}{8}\end{array}$ & $\begin{array}{l}11 \frac{2}{8} \\
19 \frac{3}{8} \\
17 \frac{4}{8}\end{array}$ \\
\hline III. & $\begin{array}{l}187 \\
15 \\
13 \frac{7}{8}\end{array}$ & $\begin{array}{l}12 \frac{6}{8} \\
15 \frac{7}{8} \\
17\end{array}$ \\
\hline IV. & $\begin{array}{l}19 \frac{2}{8} \\
19 \frac{6}{8}\end{array}$ & $\begin{array}{l}16 \frac{2}{8} \\
21 \frac{5}{8}\end{array}$ \\
\hline $\mathrm{T}$ & $25 \frac{3}{8}$ & $22 \frac{5}{8}$ \\
\hline VI. & $\begin{array}{l}15 \\
20 \frac{2}{8} \\
27 \frac{2}{8}\end{array}$ & $\begin{array}{l}19 \frac{5}{8} \\
16 \frac{2}{8} \\
19 \frac{5}{8}\end{array}$ \\
\hline VII. & $\begin{array}{l}7 \frac{6}{8} \\
14^{7 \frac{4}{8}}\end{array}$ & $\begin{array}{l}7 \frac{6}{8} \\
8 \\
7\end{array}$ \\
\hline $\begin{array}{l}\text { VIII. } \\
\text { Crowded. }\end{array}$ & $\begin{array}{l}18 \frac{2}{8} \\
18 \frac{6}{8} \\
18 \frac{3}{8} \\
18 \frac{3}{8}\end{array}$ & $\begin{array}{l}20 \frac{3}{8} \\
17 \frac{6}{8} \\
15 \frac{1}{8} \\
15 \frac{1}{8}\end{array}$ \\
\hline Total in inches. & $370 \cdot 88$ & $353 \cdot 63$ \\
\hline
\end{tabular}


Here the avernge height of the twenty-two erossed plants is $16 \cdot 85$, and that of the trwenty-two self-fertilised plants $16 \cdot 07$; or as 100 to 95. But if fom of the plants in Pot VII., whieh are mueh shorter than any of the others, are struek out (and this would be the fairest plan), the twenty-one erosser are to the nineteen self-fertilised plants in leeight as 100 to $100 \cdot 6$--that is, are equal. All the plants, exeept the erowded ones in Pot VIII., after being measured were eut down, and the eighteen crossed plants weighed 10 oz., whilst the same munber of self-fertilised plants weighed $10 \frac{1}{4}$ oz., or as 100 to 102.5 ; but if the drarfed plants in Pot VII. had been exeluded, the self-fertilised rould have exeeeded the erossed in weight in a higher ratio. In all the previous experiments in whieh seedlings were raised from a eross between distinet plants, and were put into eompetition with self-fertilised plants, the former generally flowered first; but in the present ease, in seven out of the eight pots a self-fertilised plant flowered before a erossed one on the opposite side. Considering all the evidence with respeet to the plants in Table XXII., a eross between two flowers on the same plant seems to give no advantage to the offspring thus produeed, the self-fertilised plants being in weight superior. But this eonelusion enmot be absolutely trusted, owing to the measurements given in Table XXI, thougl these latter, from the eause alveady assigned, are rery mueh less trustwortlyy than the present ones.

Summary of Observations on Mimulus Tuteus.-In the three first generations of crossed and self-fertilised plants, the tallest plants alone on each side of the several pots were measured; and the arerage height of the ten crossed to that of the ten self-fertilised plants was as 100 to 64 . The crossed were also much more fertile than the self-fertilised, and so much more vigorous that they exceeded them in height, eren when sown on the opposite side of the same pot after an interval of four days. The same superiority was likewise shown in a remarkable manner when both kinds of seeds were sown on the opposite sides of a pot with very poor earth full of the roots of another plant. 
In one instanee crossed and self-fertilised seedlings, grown in rich soil and not put into eompetition with eaeh other, attained to an equal height. When we come to the fourth generation the two tallest erossed plants taken together exeeeded by only a little the two tallest self-fertilised plants, and one of the latter beat its crossed opponent, - a circumstance which had not oceurred in the previous generations. 'This vietorious self-fertilised plant consisted of a new white-flowered variety, whieh grew taller than the old yellowish varieties. From the first it seemed to be rather more fertile, when self-fertilised, than the old varieties, and in the sueeeeding self-fertilised generations beeame more and more self-fertile. In the sixth generation the self-fertilised plants of this variety eompared with the crossed plants produeed eapsules in the proportion of 147 to 100, both lots being allowed to fertilise themselves spontaneously. In the seventh generation twenty flowers on one of these plants artificially self-fertilised yielded no less than nineteen rery fine capsules!

This rariety transmitted its eharaeters so faithfully to all the sueceeding self-fertilised generations, up to the last or ninth, that all the many plants which were raised presented a complete uniformity of eharaeter; thus offering a remarkable eontrast with the seedlings raised from the purchased seeds. Yet this variety retained to the last a latent tendency to produee yellow flowers; for when a plant of the eighth selffertilised generation was erossed with pollen from a yellow-flowered plant of the Chelsea stock, every single seedling bore yellow flowers. A similar variety, at least in the colour of its flowers, also appeared amongst the crossed plants of the third generation. No attention was at first paid to it, and I know not 
how far it was at first used either for crossing or selffertilisation. In the fifth generation most of the self-fertilised plants, and in the sixth and all the succeeding generations every single plant consisted of this variety; and this no doubt was partly due to its great and increasing self-fertility. On the other hand, it disappeared from amongst the crossed plants in the later generations; and this was probably due to the continued intercrossing of the several plants. From the tallness of this variety, the selffertilised plants exceeded the crossed plants in height in all the generations from the fifth to the seventh inclusive; and no doubt would have done so in the later generations, had they been grown in competition with one another. In the fifth generation the crossed plants were in height to the self-fertilised, as 100 to 126 ; in the sixth, as 100 to 147 ; and in the serenth generation, as 100 to 137. This excess of height may be attributed not only to this variety naturally growing taller than the other plants, but to its possessing a peculiar constitution, so that it did not suffer from continued self-fertilisation.

This variety presents a strikingly analogous case to that of the plant called the Hero, which appeared in the sixth self-fertilised generation of Ipomcea. If the seeds produced by Hero had been as greatly in excess of those produced by the other plants, as was the case with Mimulus, and if all the seeds had been mingled together, the offspring of Hero would hare increased to the entire exclusion of the ordinary plants in the later self-fertilised generations, and from naturally growing taller would have exceeded the crossed plants in height in each succeeding generation.

Some of the self-fertilised plants of the sixth generation were intercrossed, as were some in the eighth 
greneration; and the seedlings from these crosses were grown in competition with self-fertilised plants of the two corresponding generations. In the first trial the intercrossed plants were less fertile than the selffertilised, and less tall in the ratio of 100 to 110 . In the second trial, the intercrossed plants were more fertile than the self-fertilised in the ratio of 100 to 73, and taller in the ratio of 100 to 92 . Notwithstanding that the self-fertilised plants in the second trial were the product of two additional generations of self-fertilisation, I cannot understand this discordance in the results of the two analogous experiments.

The most important of all the experiments on Mimulus are those in which flowers on plants of the eighth self-fertilised generation were again self-fertilised; other flowers on distinct plants of the same lot were intercrossed; and others were crossed with a new stock of plants from Chelsea. The Chelsea-crossed seedlings were to the intercrossed in height as 100 to 56 , and in fertility as 100 to 4 ; and they were to the self-fertilised plants, in height as 100 to 52, and in fertility as 100 to 3 . 'These Chelsea-crossed plants were also much more hardy than the plants of the other two lots; so that altogether the gain from the cross with a fresh stock was wonderfully great.

Lastly, seedlings raised from a cross between flowel's on the same plant were not superior to those from flowers fertilised with their own pollen; but this result cannot be absolutely trusted, owing to some previous observations, which, however, were made under very unfavourable circumstances.

\section{Digitalis pURPUREA.}

The flowers of the common Foxglove are proteranclrous; that is, the pollen is mature and mostly shed before the stigma of the same flower is ready for fertilisation. 'L'his is effected by 
the larger humble-bees, which, whilst in seruleh of ncetar, carry pollen fiom flower to flower. 'The two upjer and longere stamens shed their pollen before the two lower and shorter ones. The meaning of this fact probably is, as Dr. Ogle lecmarks, ${ }^{*}$ that the anthers of the longer stamcus stand near to the stigma, so that they would be the most likely to fertilise it: and as it is an advantage to avoirl self-fertilisation, they sherl their pollen first, thus lessening the elimee. There is, however; but little danger of self-fertilisation until the bifid stigna opens; for Hildebrand $\dagger$ found that pollen placed on the stigma before it had opened jrodueed no effect. 'The anthers, which aro large, stand at first tramsrelsely with respeet to the tubular corolla, and if they were to dehisee in this position ther would, is Dr. Ogle also remarks, smear' with pollen the whole back and sides of an entering humble-bee in a useless manner; but the inthers twist round and place themselves longitudinally before they dehisce. The lower and imner side of the month of the corolla is thickly elothed with hairs, and these collect so much of the fallen pollen that I have seen the under surface of a linmble-bee thickly dusted with it; but this ean never be applied to the stigma, as the bees in retreating do not turn their under surfices upwards. I was therefore purzled whether these hails mere of any use; but Mr. Belt has, I think, cxplained their use: the smaller kinds of bees are not fitted to fertilise the flowers, and if they were allowed to enter easily they would steal mueh nectar, and fewer large hees would haunt the flowers. IImble-bees can eranl into the dependent flower's with the greatest ease, using the "hair's as footholds while sucling the honcy; hut the smaller hecs are impeded by them, and when, having at length struggled through them, they reach the slippery precipice above, they are completely baftled." Mrr. Belt says that he watehed many flowers during a whole season in North Wrales, and "only once saw a small bee reach the nectary, though many were seen trying in vain to dro so." \#

1 covered a plant growing in its native soil in North Wales with a net, and fertilised six flowers each with its own pollen.

* Popular Science Reriew; Jitn. 1870, p. 50.

+ - Geschlechter - Vertheilung bei den Pflanzen.' 1867, 1., 20.

*'The Naturalist in Nicara- gun,' 1S7t, p. 132. But it appens: from II. Miille r ${ }^{\circ}$ Die Jefrnclit ung der Blumen, 1873, p. 285. that small insects sometimes succed in entering the flowis. 
and six other's with pollen from a distinct plant groming within the distance of a few feet. The covered plant was occasionally shaken with violence, so as to imitate the effects of a gale of wind, and thus to facilitate as ar as possible self-fertilisation. It bore ninety-two flowers (besides the dozen artificially fertilised), and of these only twenty-four produced capsules; whereas almost all the flowers on the surrounding uncovered plants were fruitful. Of the twenty-four spontaneonsly self-fertilised capsules, only two contained their full complement of seed; six contained a moderate supply; and the remaining sixteen cxtremely few seeds. A little pollen adhering to the anthers after they had dehisced, and accidentally falling on the stigma when mature, must have been the means by which the above twentyfour flowers mere partially self-fertilised; for the margins of the corolla in withering do not curl inwards, nor do the flowérs in dropping off turn round on their axes, so as to bring the pollencovered hairs, with which the lower surface is clothed, into contact with the stigma-by either of which means self-fertilisation might be effected.

Seeds from the abovo crossed and self-fertilised capsules, after germinating on bare sand, were planted in pairs on the opposite sides of firc moderately-sized pots, which were kept in the greenhouse. The plants after a timo appeared starred, and were therefore, without being disturbed, turned out of their pots, and planted in the open ground in two close parallel rows. They were thus subjected to tolerably severe competition with one another; but not nearly so severe as if they had bcen lett in the pots. At the time when they were turned out, their leaves were between 5 and 8 inches in length, and the longest leat on the finest plaut on each side of each pot was measured, with the result that the leares of the crossed plants cxceeded, on all a verage, those of the self-fertilised plants by ' 4 of an inch.

In the folluwing summer the tallest flower-stenı on each plant, when fully grown, was measured. Therc were seventeen crossed plants; but one did not produce a flower-stem. There were also, originally, seventeen self-fertilised plants, but these had stch poor constitutions that no less than nine died in the course of the winter and spring, leaving only eight to be measured, as in the fullowing table:- 


\section{TABLE XXIII.}

The tallest Flower-stem on each Plant measured: 0 means that the Plant died before a Flower-stem was producer.

\begin{tabular}{|c|c|c|}
\hline No. of Pot. & Crossed Plants. & Self-fertilised Plants. \\
\hline I. & $\begin{array}{l}\text { Inches. } \\
53 \frac{6}{6} \\
57 \frac{4}{8} \\
57 \frac{6}{8} \\
65\end{array}$ & $\begin{array}{c}\text { Inches. } \\
27 \\
55 \\
58 \\
0 \\
0\end{array}$ \\
\hline II. & $\begin{array}{l}3 \pm \frac{4}{8} \\
52 \frac{4}{5} \\
63 \frac{6}{8}\end{array}$ & $\begin{array}{l}39 \\
32 \\
21\end{array}$ \\
\hline III. & $\begin{array}{l}57 \frac{4}{8} \\
53 \frac{4}{8} \\
50 \frac{6}{8} \\
37 \frac{2}{8}\end{array}$ & $\begin{array}{c}53 \frac{4}{8} \\
0 \\
0 \\
0\end{array}$ \\
\hline IV. & $\begin{array}{l}64 \frac{4}{8} \\
37 \frac{1}{8} \\
\ldots\end{array}$ & $\begin{array}{c}34 \frac{4}{8} \\
23 \frac{6}{8} \\
0\end{array}$ \\
\hline $\mathrm{T}$. & $\begin{array}{l}53 \\
478 \\
3 \pm \frac{6}{8}\end{array}$ & $\begin{array}{l}0 \\
0 \\
0\end{array}$ \\
\hline Total in inches. & $821 \cdot 25$ & $287 \cdot 00$ \\
\hline
\end{tabular}

The average height of the flower-stems of the sixteen crossed plants is here 51.33 inches; and that of the eight self-fertilised plants, $3 \check{5} \cdot 87$; or as 100 to 70 . But tlis difference in height does not give at all a fair idca of the vast superiority of the crossed plants. These latter produced al together sixty-four flower-stems, each plant producing, on an average, exactly four fluwer-stems; whereas the eight self-fertilised plants produced only fifteen flower-stems, each producing an average only of 1.87 stems, and these had a less luxuriant appearance. We may put the result in another way: the number of flower-stems on the crossed plants was to those on an equal number of self-fertilised plants as 100 to 48 .

Three crossed seeds in a state of germination were also planted in three separate pots; and three self-fertilised seeds in the same state in three other pots. These plants were therefore at first exposed to no competition with one nother, and when 
turued out of their pots into the open ground they were planted at a moderate distance apart, so that they wcre exposed to much less severe competition than in the last case. The longest leaves on the three crossed plants, when turned out, excecded those on the self-fertilised plants by a mere trifle, viz., on an average by - 17 of an inch. When fully grown the three crossed plants produced twenty-six flower-stems; the two tallest of which on each plant were on an average 54.04 inches in height. The three self-fertilised plants produced twenty-three flower-stcms, the two tallest of which on each plant had an average height of $46 \cdot 18$ inches. So that the difference between these two lots, which hardly competed together, is much less than in the last case when there was moderately severe competition, namely, as 100 to 85 , instead of as 100 to 70 .

The Effects on the Offspring of intercrossing different Flowers on the same Plant, instead of crossing distinct Individuals.-A fine plant growing in my garden (one of the foregoing seedlings) was covered with a net, and six flowers were crossed with pollen from another flower on the same plant, and six others were fertilised with their own pollen. All produced good capsules. The seeds from each were placed in separate watch-glasses, and no difference could be perceived by the eye between the two lots of seeds; and when they wcre weighed there was no difference of any significance, as the seeds from the self-fertilised capsules weighed 7.65 grains, whilst those from the crossed capsules weighed $7 \cdot 7$ grains. Therefore the sterility of the present species, when insects are excluded, is not due to the impotence of pollen on the stigma of the same flower. Both lots of seeds and seedlings were treated in exactly the same manner as in the previous table (XXIII.), excepting that after the pair's of germinating seeds had been planted on the opposite sides of eight pots, all the remaining seeds wcre thickly sown on the oppositc sicles of Pots IX. and $\mathrm{X}$, in Table XXIV. The young plants during the following spring were turned out of their pots, without being disturbed, and planted in the open ground in two rows, not very close togethcr, so that they were subjected to only moderately severe competition with one another. Very differently to what occurred in the first expcriment, when the plants wcre subjected to somewhat severe mutnal competition, an equal number on cach side either dicd or did not produce flower-stems. The tallest flower-stems on the surviving plants were measured, as shown in the following table :- 
TABLE XXIV.

N.B. O signifies that the Plant died, or did, not produce a Flowerstem.

\begin{tabular}{|c|c|c|}
\hline No. of Pot. & $\begin{array}{l}\text { Plants raised from a } \\
\text { Cross between dif. } \\
\text { ferent Flowers on the } \\
\text { same Plant. }\end{array}$ & $\begin{array}{c}\text { Tlants raised from } \\
\text { Fluwers fertilised } \\
\text { with the ir own Pollen }\end{array}$ \\
\hline I. & $\begin{array}{c}\text { Inches. } \\
49 \frac{4}{6} \\
46 \frac{7}{8} \\
43 \frac{6}{8}\end{array}$ & $\begin{array}{c}\text { Inches. } \\
45 \frac{5}{8} \\
52 \\
0\end{array}$ \\
\hline II. & $\begin{array}{c}38 \frac{4}{8} \\
47 \frac{4}{8} \\
0\end{array}$ & $\begin{array}{l}54 \frac{4}{8} \\
47 \frac{4}{8} \\
32 \frac{5}{6}\end{array}$ \\
\hline III. & 547 & $46 \frac{5}{8}$ \\
\hline IV. & $\begin{array}{c}32 \frac{1}{8} \\
0 \\
437 \frac{7}{8}\end{array}$ & $\begin{array}{l}41 \frac{3}{8} \\
297 \\
37 \frac{7}{8}\end{array}$ \\
\hline $\mathrm{V}$. & $\begin{array}{l}46 \frac{6}{8} \\
40 \frac{4}{8} \\
43\end{array}$ & $\begin{array}{c}42 \frac{1}{8} \\
42 \frac{1}{8} \\
\end{array}$ \\
\hline VI. & $\begin{array}{l}48 \frac{2}{6} \\
46 \frac{2}{6}\end{array}$ & $\begin{array}{l}47 \frac{7}{8} \\
48 \frac{3}{8}\end{array}$ \\
\hline VII. & $\begin{array}{l}48 \frac{5}{8} \\
42\end{array}$ & $\begin{array}{l}25 \\
40 \frac{5}{8}\end{array}$ \\
\hline VIII. & $46 \frac{7}{8}$ & $39 \frac{1}{8}$ \\
\hline $\begin{array}{l}\text { IX. } \\
\text { Crowded Plants. }\end{array}$ & $\begin{array}{l}49 \\
50 \frac{3}{8} \\
+6 \frac{3}{8} \\
47 \frac{6}{8} \\
0\end{array}$ & $\begin{array}{l}30 \frac{3}{8} \\
15 \\
36 \frac{7}{8} \\
44 \frac{1}{8} \\
31 \frac{6}{8}\end{array}$ \\
\hline $\begin{array}{c}\mathrm{X} . \\
\text { Crowded Plants. }\end{array}$ & $\begin{array}{l}46 \frac{4}{8} \\
35 \frac{2}{8} \\
24 \frac{5}{8} \\
41 \frac{4}{8} \\
17 \frac{3}{8}\end{array}$ & $\begin{array}{c}47 \frac{7}{8} \\
0 \\
3+\frac{2}{6} \\
40 \frac{7}{8} \\
41 \frac{1}{8}\end{array}$ \\
\hline 'Total iuches. & $1078 \cdot 00$ & $995 \cdot 38$ \\
\hline
\end{tabular}


The average, height of the flower-stems on the trventy-five crossed plants in all the pots taken together is $43 \cdot 12$ inehes, and that of the trenty-five self-fertilised plants $39 \cdot 82$, or as 100 to 92. In order to test this result, the plants planted in pairs in Pots I. to VIII. were eonsidered by themselves, and the average height of the sixteen erosed plants is here 44.9 , and that of the sixteen self-fertilised plants $42 \cdot 03$, or as 100 to 94 . A gain, the plants raised from the thiekly sown seed in Pots IX. and X., winieh were suljeeter to very severe mutual eompetition, rere taken by themselves, and the arerage height of the nine erossed plants is $39 \cdot 86$, and that of the nine self-fertilised plants $35 \cdot 88$, or as 100 to 90 . The plants in these two latter pots (IX. and X.), after being measured, were eut down elose to the ground and reighed: the nine crossed plants weighed $57 \cdot 66$ ommees, and the rine self-fertilised plants $45 \cdot 25$ ounees, or as 100 to 78 . On the whole we may eonelude, espeeially from the evidenee of weight, that seedlings from a eross between flowers on the same plant have a deeided, though not great, advantage over those from flowers fertilised with their own pollen, more espeeially in the ease of the plants subjeeted to serere mutual eompetition. But the adrantage is mueh less than that exhibited by the erossed offspring of distinet plants, for these exeeeded the selffertilised plants in buight as 100 to 70 , and in the number of flower-stems as 100 to 48. Digitalis thus differs from Ipomcea, and almost eertainly from Mimulus, as with these two speeies a eross between flowers on the same plant did no good.

\section{Calceolaria.}

A bushy greenhouse variety, with yellow flowers blotched with purple.

The flowers in this genus are eonstrueted so as to favour or almost ensure eross-fertilisation; ${ }^{*}$ and Mr. Anderson remarlzs $†$ that extreme eare is neeessary to exelude insects in order to preserve any kind true. He adds the interesting statement, that when the eorolla is eut quite away, inseets, as far as he has seen, never diseover or visit the flowers. This plant is, however, selffertile if inseets are exeluded. So few experiments were made by me, that they are hardly worth giving. Crossed and self-fertilised seeds were sown on opposite sides of a pot, and

* Hildebrand, as quoted by H. Niiller, "Die Befruchtung der Blumen,' 1873, p. 277.
† 'Gardeners' Chronicle:' 1853 , p. 531 . 
after a time the crossed seedlings slightly exceeded the selffertilised in height. When a little further grown, the longest leaves on the former were very nearly 3 inches in length, whilst those on the self-fertilised plants were only 2 inches. Owing to an accident, and to the pot being too small, only one plant on each side grew up and flowered; the crossed plant was $19 \frac{1}{2}$ inches in height, and the self-fertilised one 15 inches; or as 100 to 77 .

\section{LiNARIA VULGaRis.}

It has been mentioned in the introductory chapter that two large beds of this plant were raised by me many years ago from crossed and self-fertilised seeds, and that there was a conspicuous difference in height and general appearance between the two lots. The trial was afterwards repeated with more care; but as this was one of the first plants experimented on, my usnal method was not followed. Seeds were taken from wild plants growing in this neighbourhood and sown in poor soil in my garden. Five plants were covered with a net, the others being left exposed to the bees, which incessantly risit the flowers of this species, and which, according to $H$. Miüller, are the exclusive fertilisers. This excellent observer remarks * that, as the stigma lies between the anthers and is mature at the same time with them, self-fertilisation is possible. But so few seeds are produced by protected plants, that the pollen and stigma of the same flower seem to have little power of mutual interaction. The exposed plants bore numerous capsules forming solid spikes. Five of these capsules were examined and appeared to contrin an equal number of seeds; and these being counted in one capsule, were found to be 166 . The five protected plants produced altogether only twenty-five capsules, of which five were much finer than all the others, and these contained an average of $23 \cdot 6$ seeds, with a maximmm in one capsule of fifty-five. So that the number of seeds in the capsules on the exprosed plants to the average number in the finest capsules on the protected plants was as 100 to 14 .

Some of the spontaneously self-fertilised seeds from under the net, and some seeds from the uncovered plants naturally fertilised and almost certainly intercrossed by the bees, were somn separately in two large pots of the same size; so that the

* 'Dic Befruchtung,' \&ic. 1'. 279 . 
two lots of seedlings were not subjeeted to any mutual eompetition. Three of the erossed plants when in full-flower were measured, but no care was taken to seleet the tallest plants; their heights were $7 \frac{\mathrm{k}}{\mathrm{s}}, 7 \frac{\mathrm{g}}{\mathrm{s}}$, and $6 \frac{\mathrm{t}}{\mathrm{S}}$ inehes; averaging 7.08 in height. The three tallest of all the self-fertilised plants were then carefully selected, and their lieights were $6 \frac{3}{8}, 5 \frac{5}{5}$, and $5 \frac{2}{8}$, averaging $5 \cdot 75 \mathrm{in}$ height. So that the naturally erossed plants were to the spontaneously self-fertilised plants in height, at least as mueh as 100 to 81 .

\section{VERBASCUM THAPSUS.}

The flowers of this plant are frequented by various insects, ehiefly by bees, for the salie of the pollen. H. Miiller, however, has shown ('Die Befrnehtung;' \&e. p. 277) that $V$. nigrum seeretes minute drops of neetar. The arrangement of the reprodnetive organs, though not at all complex, favour's cross-fertilisation; and even distinct species are often erossed, for a greater number of naturally produced hybrids liave been observed in this genus than in almost any other.* Nevertheless the present species is perfeetly self-fertile, if insects are excluded; for a plant protected by a net was as thiekly loaded with fine eapsules as the surrounding uneovered plants. Verbascum lychuitis is rather less self-fertile, for some protected plants did not yield quite so many eapsules as the adjoining uncovered plants.

Plants of $V$. thapsus had been raised for a distinct purpose from self-fertilised seeds ; and some flowers on these plants were again self-fertilised, yielding seed of the second self-fertilised generation; and other flower's were crossed with pollen from a distinet plant. The seeds thus produced were sown on the opposite sides of four large pots. They germinated, however, so irregularly (the erossed seedlings generally coming up first) that I was able to save only six pairs of equal age. These when in full flower were measured, as in the following table (XXV.).

We here see that two of the self-fertilised plants exeeed in height their crossed opponents. Nevertheless the average height of the six erossed plants is 65.34 inches, and that of the six self-fertilised plants $56 \cdot 5$ inches; or as 100 to 86 .

* I have given a striking case of a lalrge number of sueh liybriils betwecn $V$. thapsus and lychnitis found growing wild: "Journal of Linn. Soc. Bot.' vol. x. p. 451. 
TABLE XXY.

\begin{tabular}{|c|c|c|}
\hline No. of Pot. & Crossed Plants. & $\begin{array}{c}\text { Self-fertilised Plants } \\
\text { of the Second Gene- } \\
\text { ration. }\end{array}$ \\
\cline { 1 - 2 } & $\begin{array}{c}\text { Inches. } \\
76\end{array}$ & $\begin{array}{c}\text { Inches. } \\
5: 3 \frac{4}{8}\end{array}$ \\
\hline I. & 54 & 66 \\
\hline II. & 62 & 75 \\
\hline III. & $60 \frac{5}{8}$ & $30 \frac{4}{5}$ \\
\hline IY. & 73 & 62 \\
\hline Total in inches. & $66 \frac{4}{8}$ & 332 \\
\hline
\end{tabular}

VANDELIIA NUMNULARIFOLIA.

Seeds were sent to me by Mr. J. Scott from Calcutta of this small Indian weed, which bears perfect and cleistogenc ${ }^{*}$ flowers. The latter are extremely small, imperfectly devcloped, and nerer cxpand, yet yicld plenty of seeds. The perfect and open flower's are also small, of a white colour with purple marks; they grenerally produce seed, although the contrary has been asserted; and they do so even if protected from insects. They have a rather complicated structure, and appear to be adapted for cross-fertilisation, but were not earefully examined by me. They are not easy to fertilise artificially, and it is possible that some of the flowers which I thought that I liad succeded in crossing were afterwards spontancously self-fcrtilised under the net. Sixteen capsules from the crossed perfect flowers contained on an average ninety-three seeds (with a maximum in one capsule of 137), and thirteen capsulcs from the self-fertilised perfect flowers contained sixty-two seeds (with a maximum in one calsule of 135 ); ol as 100 to 67 . But I suspect that this considerable excoss was accidental, as on one occasion nine crossed capsules wero comprared with seven self-fertilised capsules (both inclucled in the ahove number), and they contained almost exactly the samo average number of seed. I may add

* The convenient term of cleistogene was proposed by líuhn in an urticle on the present genus in 'Bot. 'Zcitung,' 1867, p. li5. 
that fifteen eapsules from self-fertilised eleistogene flowers eontained on an average sixty-foru seeds, with a maximum in one of eighty-seven.

Crossed and self-fertilised seeds from the perfeet flowers, and other' seeds from the self-fertilised eleistogene flower's, were sown in five pots, eaeh divided supcrficially into three eompartments. The seedling's were thinmed at an early age, so that trenty plants were left in each of the three divisions. The erossed plants when in full flower averaged 4.3 inehes, and the self-fertilised plants from the perfeet flower's 4.27 inehes in height; or as 100 to 99 . The selt-fertilised plants from the eleistogene flower's averaged 4.06 inehes in height; so that the erossed were in height to these latter plants as 100 to 94.

I determined to compare again the growth of plants raised from erossed and self-fertilised perfeet flowers, and obtained two fresh lots of seeds. These were sown on opposite sides of fire pots, but they were not suffieiently thinned, so that they grew rather erowded. When fully grown, all those above 2 inehes in height were seleeted, all below this standard being rejeeted; the former eonsisted of forty-seven erossed and forty-one selffertilised plants; thus a greater number of the erossed than of the self-fertilised plants grew to a height of above 2 inehes. Of the erossed plants, the twenty-four tallest were on an average 3.6 inehes in height; whilst the twenty-four tallest selffertilised plants were $3 \cdot 38$ inehes in average height; or as 100 to 94. All these plants were then eut down elose to the ground, and the forty-seven erossed plants weighed $1090 \cdot 3$ grains, and the forty-one self-fertilised plants weighed $887 \cdot 4$ grains. Therefore an equal number of erossed and self-fertilised rould have been to each other in weight as 100 to 97 . From these several faets we may eonelude that the erossed plants had some real, though very slight, advantage in height and weight over the self-fertilised plants, when grown in eompetition with one another.

The erossed plants were, however, inferior in fertility to the self-fertilised. Six of the finest plants were seleeted out of the forty-seven crossed plants, and six out of the forty-one selffertilised plants; and the former produeed 598 erpsules, whilst the latter or self-fertilised plants produeed 752 capsules. All these eapsules wero the produet of eleistogene flowers, for the plants did not bear during the whole of this season any perfeet flowers. The secds wero eounted in ten eleistogene eapsules 
produecd by the crossed plants, and their average number was 46.4 por eapsule; whilst the number in ten cleistogene capsules produced by the self-fertilised plants was $49 \cdot 4$; or as 100 to 106.

\section{GESNERIACEA.-GESNERIA PENDULINA.}

In Gesneria the several parts of the flower are arranged on nearly the same plan as in Digitalis, and most or all of the species are dichogamous. Plants were raised from seed sent me by Fritz Müller from South Brazil. Seven flower's were crossed with pollen from a distinct plant, and produced seren capsules containing by weight 3.01 grains of seeds. Seven flowers on the same plants wore fertilised with their own pollen, and their scren capsules contained exactly the same weight of seeds. Germinating seeds were planted on opposite sides of four pots, and when fully grown moasured to the tips of their leares.

\section{TABLE XXVI.}

\begin{tabular}{|c|c|c|}
\hline No. of I'ot. & Crossed Plants. & Self-fertilised Plants. \\
\cline { 2 - 3 } & Inches. & Inches. \\
& $42 \frac{2}{8}$ & 39 \\
I. & $24 \frac{4}{8}$ & $27 \frac{3}{8}$ \\
\hline II. & 33 & $30 \frac{6}{8}$ \\
& 27 & $19 \frac{2}{6}$ \\
\hline III. & $33 \frac{4}{8}$ & $31 \frac{7}{8}$ \\
& $29 \frac{4}{8}$ & $28 \frac{6}{8}$ \\
\hline IV. & $30 \frac{6}{8}$ & $29 \frac{6}{8}$ \\
& 36 & $26 \frac{3}{8}$ \\
\hline Total inches. & $256 \cdot 50$ & $233 \cdot 13$ \\
\hline
\end{tabular}

The average height of the eight crossed plants is 32.06 inches, and that of the cight self-fertilised plants $29 \cdot 14$; or as 100 to 90 .

* Lr. Ogle, 'Popular Science Review,' Jan, 1870, p, 51. 


\section{LABIATE.-SALVIA COCOINEA.*}

This species, unlike most of the others in the same genus, yields a good many seeds when insects are excluded. I gathered ninety-eight capsules produced by flowers spontaneously selffertilised under a net, and they contained on an average $1 \cdot 45$ seeds, whilst flowers artificially fertilised with their own pollen, in which case the stigma will have received plenty of pollen, yielded on an average $3 \cdot 3$ seeds, or more than trice as many. Twenty flowers were crossed with pollen from a distinct plant, and twenty-six were self-fertilised. There was no great difference in the proportional number of flowers which produced capsules by these two processes, or in the number of the contained seeds, or in the weight of an equal number of seeds.

Seeds of both kinds were sown rather thickly on opposite sides of three pots. When the seedlings were about 3 inches in height, the crossed showed a slight advantage over the selffertilised. When two-thirds grown, the two tallest plants on each side of each pot were mcasured; the crossed averaged $16 \cdot 37$ inches, and the self-fertilised 11.75 in height; or as 100 to 71 . When the pliants were fully grown and had done flowering, the two tallest plants on each side were again measured, with the results shown in the following table:-

\section{TABLE XXVII.}

\begin{tabular}{|c|c|c|}
\hline No. of Pot. & Crossed Plunts. & Self-fertilised Planis. \\
\hline I. & Inches, & Inches. \\
$32 \frac{6}{8}$ & 25 \\
& 20 & $18 \frac{6}{8}$ \\
\hline II. & $32 \frac{3}{8}$ & $20 \frac{6}{8}$ \\
& $24^{\frac{4}{8}}$ & $19 \frac{4}{8}$ \\
\hline III. & $29 \frac{4}{8}$ & 25 \\
& 28 & 18 \\
\hline Total inches. & $167 \cdot 13$ & $127 \cdot 00$ \\
\hline
\end{tabular}

* The admirable meehanical idaptations in this genus for favouring or ensuring eross-fertilisation, have been fully deseribed by Sprengel, Hildehrand, Delpino, H. Müller, Ogle, and others, in their soveral worlss. 
It may be here seen that cach of the six tallest erossed plants exceeds in height its self-fertilised opponent; the former averaged $27 \cdot 85$ inches, whilst the six tallest self-fertilised plant: averaged $21 \cdot 16$ inehes; or as 100 to 76 . In all three pots the first plant which flowered was a crossed one. All the crossed plants together produeed 409 flowers, whilst all the self-fertilised together produced only 232 flowers; or as 100 to 57 . So that the erossed plants in this respeet were far more productive than the self-fertilised.

\section{OIIIGANUM VULGARE.}

This plant exists, aceording to H. Miiller, under two folms ; one hermaphrodite and strongly proterandrous, so that it is almost eertain to be fertilised by pollen from another flomer; the other form is exelusirely female, has a smaller corolla, and must of eourse be fertilised by pollen from a distinct plaut in order to yield any seeds. The plants on which I experimented were hermaphrodites; they had been eultivated for a long period as a pot-herb in my kitchen garden, and were, like so many long-cultivated plants, extremely sterile. As I felt doubtful ahout the speeifie name I sent specimens to Kew, and was assured that the species was $O$. vulyure. My plants formed one great clump, and had evidently spread from a single root by stolons. In a strict sense, therefore, they all belonged to the same individual. My object in experimenting on them was, firstly, to ascertain whether erossing flowers borne by plants having distinct roots, but all derived asexually from the same individual, would be in any respect more adrantageous than self-fertilisation ; and, secondly, to raise for future trial seedlings which would constitute really distinct individuals. Serelal plants in the above elump were eovered by a net, and about two dozen seeds (many of which, however, were small and withered) were obtained from the flowers thus spontaneously self-fertilised. The remainder of the plants were left uncovered and were incessintly visited by bees, so that they were doubtless crossed by them. These exposed plants yielded rather more and fincr seed (but still very fer) than did the covered plants. The two lots of seeds thus olstrined were sown on opposite sides of two pots; the seedlings were carefully olsscrved from their first growth to maturity, but they did not differ at any period in height or in vigour, the importance of which latter observation we shall presently sce. Thluen fully grown, the tallest erosscd 
plant in one pot mas a very little taller than the tallest selffertilised plant on the opposite side, and in the other pot exactly the reverse oecurred. So that the two lots were in fact equal; and a eross of this kind did no more good than erossing two flowers on the same plant of Ipomœer or Mimulus.

The plants were turned out of the two pots rithout being distmibed and planted in the open ground, in order that they unight grow more vigoronsly. In the following summer all the self-fertilised and some of the cluasi-crossed plants were eovered by a net. Many flower's on the latter were erossed by me with pollen from a distinct plant, and others were left to be crossed by the bees. These quasi-crossed plants produced rather more seed than did the original ones in the great clump when left to the aetion of the bees. Many flowers on the self-fertilised plants were artifieially self-fertilised, and others were allowed to fertilise themselves spontaneously under the net, but ther yielded altogether very few seeds. These two lots of seedsthe product of a cross between distinct seedlings, instead of as in the last case between plants multiplied by stolons, and the product of self-fertilised flowers - were allowed to germinate on bare sand, and several equal pairs were planted on opposite sides of two large pots. At a very early age the crosscd plants showed some smperiority over the self-fertilised, which was ever afterwards retained. When the plants were fully gromm, the two tallest crossed and the two tallest self-fertilised plants in each pot were measured, as shown in the following tahle. I regret that from want of time I did not measure all the pairs; but the tallest on each side seemed fairly to represent the average difference between the two lots.

TABLE XYYIII.

\begin{tabular}{|c|c|c|}
\hline No. of l'ot. & $\begin{array}{l}\text { Crossed Plants (two } \\
\text { tallest in each pot). }\end{array}$ & $\begin{array}{c}\text { Silf-f-rtilised Plants } \\
\text { (two tallest in each } \\
\text { pot). }\end{array}$ \\
\hline 1. & $\begin{array}{c}\text { Inches. } \\
26 \\
21\end{array}$ & $\begin{array}{c}\text { Inches. } \\
24 \\
21\end{array}$ \\
\hline II. & $\begin{array}{l}17 \\
16\end{array}$ & $\begin{array}{l}12 \\
11 \frac{4}{8}\end{array}$ \\
\hline Tntal inches. & $80 \cdot 0$ & $68 \cdot 5$ \\
\hline
\end{tabular}


The average height of the erossed plants is here 20 inehes, and that of the self-fer'tilised $17 \cdot 12$; or as 100 to 86 . Jut this excess of height by no means gives a fair idea of the vast superiority in vigour of the crossed over the self-fertilised plants. The crossed flowered first and produced thirty flower-stems, whilst the selffertilised produced only fifteen, or half the number. The pots were then bedded out, and the roots probably came out of the holes at the bottom and thus aided their growth. Early in the following summer the superiority of the crossed plants, owing to their increase by stolons, over the self-fertilised plants was truly wonderful. In Pot I., and it should be remembered that very large pots had been used, the oval clump of crossed plants was 10 by $4 \frac{1}{2}$ inches across, with the tallest stem, as yet young, $5 \frac{1}{2}$ inches in height; whilst the clump of self-fertilised plants, on the opposite side of the same pot, was only $3 \frac{1}{2}$ by $2 \frac{1}{2}$ inches across, with the tallest young stem 4 inches in height. In Pot II., the clump of crossed plants was 18 by 9 inches across, with the tallest young stem $8 \frac{1}{2}$ inches in height; whilst the clump of self-fertilised plants on the opposite side of the same pot was 12 by $4 \frac{1}{2}$ inches across, with the tallest young stem 6 inches in height. 'The crossed plants during this season, as during the last, flowered first. Both the crossed and self-fertilised plants being left freely exposed to the visits of bees, manifestly produced much more seed than their grand-parents, - the plants of the original clump still growing close by in the same garden, and equally left to the action of the bees.

\section{ACANTHACE 伥.-Thunbergia ALATA.}

It appears from Hildebrand's description ('Bot. Zeitung;' 1S67, p. 285 ) that the conspicuous flowers of this plant are adapted for cross-fertilisation. Seedlings were twice raised from purchased seed; but during the early summer, when first experimented on, they were extremely sterile, many of the anthers containing hardly any pollen. Nevertheless, during the autumn these same plants spontaneously produced a good many seeds. Twenty-six flowers during the two years were crossed with pollen from a distinct plant, but they yielded only eleren capsules; and these contained very few seeds! Twenty-eight flowers were fertilised with pollen from the same flower, and these yielded only ten capsules, which, howerer, contained rather more seed than the crossed capsules. Eight pairs of 
germinating seeds were planted on opposite sides of five pots; and exactly half the erossed and half the self-fertilised plants exeeeded their opponents in height. 'Two of the self-fertilised plants died young, before they were measured, and their crossed opponents were thrown away. The six remaining pairs grew very unequally, some, both of the crossed and self-fertilised plants, being more than twiee as tall as the others. The average lieight of the crossed plants was 60 inelies, and that of the selffertilised plants 65 inches, or as 100 to 108 . A eross, therefore, between distinet individuals here appear's to do no good; but this result dedueed from so few plants in a very sterile condition and growing very unequally, obviously eannot be trusted. 


\section{CHAPTER IT.}

Circieera, Payareracex, Resedacex; etc.

I3rassica olerncca, crossed and self-fertilised plants-Great effect of a closs with a fresh stock on the weight of the offispring-Iberis mmbellatn-Papaver vagum - Eschscholtzin californica, seedlings from a cross with a fresh stock not more rigrorous, but more fertile than the self-fertilised seedlings - Reseda lutea and odorata, many individuals sterile with their own pollen-Tiola tricolos. wonderful effects of a cross-A donis estivalis-Delplinimu consolida - Viscaria oculata, crossed plants hardly taller, but more fertile than the self-fertilised-Dianthus caryophyllus, crossed and self-fertilised plants compared for four generations-Great effects of a cross with a fresh stock-Uniform colour of the flowers on the self-fertilised plants-Hibiscus africanus.

\section{TI. CRUCIFER AE.-Brassica oleracea.}

Tar. Cattell's Early Barres Cablage.

THe flower's of the eommon cabbage are adapted, as show by H. Miiller, ${ }^{*}$ for eross-fertilisation, and should this fuil, for selffertilisation. It is well known that the rarieties are erossed so largely by insects, that it is impossible to raise pure linds in the same garden, if more than one kind is in flower at the same time. Cabbages, in one respeet, were not trell fitted for my experiments, as, after they had formed heads, they were often difficult to measure. The flower-stems also differ muel in height; and a poor plant will sometimes throw up a higher stem than that of a fine plant. In the later experiments, the fully-gromullants were ent down and weiglied, and then the immense adrantage from a cross beeame manifest.

A single plant of the abore variety was covered with a net just before flowering, and was erossed with pollen from another plant of the same rariety growing cluse by ; and the seren eapsules thus produced contained on an arerage $16 \cdot 3$ seeds, witl a

* 'Die Befruclitung,' \&c. p. 139. 
maximum of twenty in one capsule. Some flowers were artificially self-fertilised, but their capsules did not contain so many seeds as those from flowers spontaneously self-fertilised under the net, of which a considerable number were produccd. Fourteen of these latter capsules containcd on an average $4 \cdot 1$ seeds, with a maximum in one of ten seeds; so that the seeds in the crossed capsules were in number to those in the self-fertilised capsulcs as 100 to 25. The self-fertilised seeds, fifty-eight of which weighed 3.88 grains, were, however, a little finer than those from the crossed capsules, fifty-eight of which weighed $3 \cdot 76$ grains. When ferr seeds are produced, these seem often to be better nourished and to be heavier than when many arc prodnced.

The two lots of sceds in an equal state of germination were planted, some on opposite sides of a singlc pot, and some in the opcn ground. The young crossed plants in the pot at first exceeded by a little in height the self-fertilised; then equalled them; wcre then beaten; and lastly were again victorions. The plants, without being clisturbed, wcre turned out of the pot, and planted in the open ground; and after growing for some time, the crossed plants, which were all of nearly the same height, exceeded the self-fertilised ones by 2 inches. When they flowered, the flower-stems of the tallest crossed plant exceeded that of the tallest self-fertilised plant by 6 inches. The other scedlings which were planted in the open ground stood separate, so that thcy did not compete with one another; nevertheless the crossed plants certainly grew to a rather greater height than the sclf-fertilised; but no measurements were made. The crossed plants which had been raised in the pot, and those planted in the opcn ground, all flowered a littlc before the self-fertilised plants.

Crossed and self-fertilised Plants of the Second Generation.-Dome flowers on the crossed plants of the last generation were again crosscd with pollen from another crossed plant, and produced finc capsules. "Ihe flowers on the self-fcrtilised plants of the last generation were allowed to fertilise themselves spontaneously under a net, and they produced some remarkably fine capsules. The two lots of seeds thus produced germinated on sand, and eight pairs were planted on opposite sides of four pots. These plants were measured to the tips of their leaves on the 20th of October of the same ycar, and the cight crossed plants averaged in height 8.4 inches, whilst the self-fertilised averaged 8.53 inches, so that the crossed were a little inferior in height, as 100 to $101 \cdot 5$. By the 5 th of June of the following year these 
plants had grown mueh bulkier, and had begun to form heads. The crossed had now acquired a marked superiority in general appearance, and averaged 8.02 inches in height, whilst the self-fertilised averaged 7.31 inehes; or as 100 to 91 . The plants were then turned out of their pots and planted undisturped in the open ground. By the 5th of August their heads were fully formed, but several had grown so erooked that their heights eould hardly be measured with aecuraey. The crossed plants, however, were on the whole eonsiderably taller than the self-fertilised. In the following year they flowered; the erossed plants flowering before the self-fertilised in three of the pots, and at the same time in Pot II. The flower-stems rere now measured, as shown in Table XXIX.

\section{TABLE XXIX.}

Measured to tops of Flower-stems; 0 signifies that a Flower-stem was not formed.

\begin{tabular}{|c|c|c|}
\hline No. of Pot. & Crossed Plants. & Self-fertilised Plants. \\
\hline & Inches. & Inches. \\
$49 \frac{2}{8}$ & 44 \\
& $39 \frac{4}{8}$ & 41 \\
& $37 \frac{4}{8}$ & 38 \\
& $33 \frac{4}{8}$ & $35 \frac{4}{8}$ \\
\hline II. & 47 & $51 \frac{1}{8}$ \\
& 40 & $41 \frac{2}{6}$ \\
& 42 & $46 \frac{4}{8}$ \\
\hline III. & $43 \frac{6}{8}$ & $20 \frac{2}{8}$ \\
& $37 \frac{2}{6}$ & $33 \frac{3}{8}$ \\
& 0 & 0 \\
\hline IV. & $369 \cdot 75$ & $351 \cdot 00$ \\
\hline
\end{tabular}

The nine flower-stems on the erossed plants here arerage $41 \cdot 08$ inehes, and the nine on the self-fertilised plants 39 inehes in height, or as 100 to 95. But this small differenee, which, moreover, depended almost wholly on one of the self-fertilised plants being only 20 inehes high, does not in the least show the rast superiority of the erossed over the self-fertilised plants. Both lots, including the two plants in Pot IV., whiel did not flower, were now ent down elose to the ground and weighed, but 
those in Pot II. were excluded, for they had been accidentally injured by a fall during transplantation, and one was almost killed. The eight crossed plants weighed 219 ounces, whilst the eight self-fertilised plants weighed only 82 ounces, or as 100 to 37 ; so that the superiority of the former over the latter in weight was great.

The Effects of a C'ross with a fresh Stock.-Some flower's on a crossed plant of the last or second generation were fertilised, without being castrated, by pollen taken from a plant of the same variety, but not related to my plants, and brought from a nursery garden (whence my seeds originally came) having a different soil and aspect. The flower's on the self-fertilised plants of the last or second generation (Table XXIX.) were allowed to fertilise themselves spontaneously under a net, and yielded plenty of seeds. These latter and the crossed seeds, after germinating on sand, were planted in pairs on the opposite sides of six large pots, which were kept at first in a cool greenhouse. Early in January their leights were measured to the tips of their leaves. The thirteen crossed plants averaged $13 \cdot 16$ inches in lieight, and the twelve (for one had died) self-fertilised plants averaged $13 \cdot 7$ inches, or as 100 to 104 ; so that the self-fertilised plants exceeded by a little the crossed plants.

\section{TABLE XXX.}

Weight of Plants after they had formerl Heads.

\begin{tabular}{|c|c|c|}
\hline No. of Pot. & $\begin{array}{c}\text { Crossed Plints from } \\
\text { Pollen of fresh Stock. }\end{array}$ & $\begin{array}{c}\text { Self-fertilised Plants } \\
\text { of the 'Third Gene- } \\
\text { ration. }\end{array}$ \\
\hline I. & $\begin{array}{c}\text { Ounces. } \\
130\end{array}$ & $\begin{array}{c}\text { Ounces. } \\
18 \frac{2}{4}\end{array}$ \\
\hline II. & 74 & $34 \frac{3}{4}$ \\
\hline III. & 121 & $17 \frac{2}{4}$ \\
\hline IV. & 1272 & 14 \\
\hline V. & 90 & $11 \frac{2}{4}$ \\
\hline VI. & $106 \%$ \\
\hline Total in ounces. & $649 \cdot 00$ & $142 \cdot 25$ \\
\hline
\end{tabular}


Early in the spring the plants were gradually hardened, and turned out of their pots into the open ground without being disturbed. By the end of August the greater number had formed fine heads, but several grew extremely crooked, from having been drawn up to the light whilst in the greenhouse. As it was scarcely possible to measure their heights, the finest plant on each side of each pot was cut down close to the ground and weighed. In the preceding table we have the result.

The six finest crossed plants average $108 \cdot 16$ ounces, whilst the six finest self-fertilised plants average only $23 \cdot 7$ ounces, or as 100 to 22. This difference shows in the clearest manner the enormous benefit which these plants derived from a cross with another plant belonging to the same sub-variety, but to a fresh stoek, and grown during at least the three previous generations under somewhat different conditions.

The Offspring from a cut-leaved, curled, and variegated whitegreen Cabbage crossed uith a cut-leaved, curled, and varieguted crimson-green Cabbage, compared with the self-fertili:ed Offspring from the two Varieties.-These trials were made, not for the sake of comparing the growth of the crossed and self-fertilised seedlings, but because $I$ had seen it stated that these varieties would not naturally intercross when growing uncorered and near one another. This statement proved quite crroneons; but the white-green variety was in some degree sterile in my garden, producing little pollen and few seeds. It was therefore no wonder that scedlings raised from the self-fertilised flowers of this varicty were greatly exceeded in lieight by seedlings from a cross between it and the more vigorous crimson-green variety; and nothing more need be said about this experiment.

The seedlings from the reciprocal cross, that is, from the crimson-green variety fertilised with pollen from the whitc-green variety, offer a somewhat more curious case. A few of these crossed seedlings reverted to a pure green variety with their leares less cut and curled, so that they were altogether in a mucl more natural state, and these plants grew more vigorously and taller than any of the others. Now it is a strange fact that a much larger number of the self-fertilised seedlings from the erimson-green variety than of the crossed seedlings thus reverted ; and as a consequence the self-fertilised scedlings grew taller by $2 \frac{1}{2}$ inches on an average than the crossed seedlings, with which they were put into eompetition. At first, however, the crossed seedlings exeeeded the self-fertilised by an average of a quarter 
of an inch. We thus see that reversion to a more natural condition aeted more powcrfully in favouring the ultimate growth of these plants than did a erosss; but it should be remembered that the cross was with a semi-sterile variety having a feeble constitution.

\section{IBERIS UIBELLATA.}

Tar. Kermesianct.

This variety produecd plenty of spontaneously self-fertilised seed under a net. Other plants in pots in the greenhouse were left uncovered, and as I saw small flics visiting the flowers, it seemed probable that they would be intercrossed. Consequently seeds supposed to have been thus erossed and spontaneously selffertilised seeds were sown on opposite sides of a pot. The self-fertilised seedlings grew from the first quieker than the supposed crossed scedlings, and when both lots were in full flower the former were from 5 to 6 inches higher than the erossed! I reeord in my notes that the self-fertilised seeds from which these self-fertilised plants were raised were not so well ripened as the crossed; and this may possibly have eaused the g'reat differenee in their growth, in a somewhat analogous manner as oecurred with the self-fertilised plants of the eighth generation of Ipomcer raised from unhealthy parents. It is a curions cireumstanee, that two other lots of the above seeds were sown in pure sand nixed with burnt earth, and therefore without any organie matter; and here the supposed crossed seedlings grew to double the height of the self-fertilised, before both lots died, as necessarily oecurred at an early period. TVe shall hereafter meet with another ease apparently analogons to this of Iberis in the third generation of Petunia.

The above self-fertilised plants were allowed to fertilise themselves again under a net, yielding self-fertilised plants of the seeond generation, and the supposed crossed plants werc erossed by pollen of a distinet plant; but from want of time this was done in a earcless manner, namcly, by smearing one head of expanded flowers over another. I should have thought that this would have succecded, and perhaps it did so; but the faet of 108 of the self-fertilised sceds weighing 4.87 grains, whilst the same number of the supposed crossed seeds weighed only $3 \cdot 57$ grains, does not look like it. Five sccdlings from each lot of seeds wcre raised, and the self-fertilised plants, when fully grown, exeeeded 
in average height by a trifle (viz. '4. of an inch) the five probably crossed plants. I have thought it right to give this casc and the last, because had the supposed crossed plants proved superior to the self-fertilised in height, I should have assumed without doubt that the former had really been crossed. As it is, I do not know what to conclude.

Being much surprised at the two foregoing trials, I determined to make another, in which there should be no doubt about the crossing. I therefore fertilised with great care (but as usual without castration) twenty-four flowers on the supposed crossed plants of the last generation with pollen from distinct plants, and thus obtained twenty-one capsules. The self-fertilised plants of the last generation were allowed to fertilise themselves again under a net, and the seedlings reared from these seeds formed the third self-fertilised generation. Both lots of seeds, after germinating on bare sand, werc planted in pairs on the opposite sides of two pots. All the remaining sceds were sown crowded on opposite sides of a third pot; but as all the self-fertilised seedlings in this latter pot died bcfore they grew to any considerablc height, they were not measurcd. The plants in Pots I. and II. were measured when betwcen 7 and 8 inches in height, and the crossed exceeded the self-fertilised in average height by 1.57 inches. When fully grown they werc again measured to the summits of their flower-heads, with the following result:-

\section{TABLE XXXI.}

\begin{tabular}{|c|c|c|}
\hline No. of Pot. & Crossed Plants. & $\begin{array}{c}\text { Self-fertilised Plants } \\
\text { of the Third Gene- } \\
\text { ration. }\end{array}$ \\
\cline { 2 - 3 } I. & $\begin{array}{c}\text { Inches. } \\
18\end{array}$ & $\begin{array}{c}\text { Inches. } \\
19 \\
21\end{array}$ \\
$18 \frac{2}{8}$ & 21 \\
& $19 \frac{4}{8}$ \\
\hline II. & 19 & $16 \frac{6}{8}$ \\
& $17 \frac{6}{8}$ & $7 \frac{1}{8}$ \\
& $21 \frac{3}{8}$ & $16 \frac{4}{8}$ \\
\hline Total in inches. & $133 \cdot 88$ & $11 \pm \cdot 75$ \\
\hline
\end{tabular}

The average height of the seven crossed plants is lere $19 \cdot 12$ 
inelies, and that of the seven self-fertilised plants $16 \cdot 39$, or as 100 to 86 . But as the plants on the self-fertilised side grew very unequally, this ratio eannot be fully trusted, and is probably too liigh. In both pots a crossed plant flowered before any one of the self-fertilised. These plants were left uneovered in the greenhouse; but from being too much crowded they were not very produetive. The seeds from all seven plants of both lots were counted; the erossed produeed 206, and the self-fertilised 154 ; or as 100 to 75 .

Cross by a fresh Stock. - From the doubts eaused by the two first trials, in whieh it was not known with eertainty that the plants had been crossed; and from the crossed plants in the last experiment having been put into competition with plants self-fertilised for three generations, which moreover grew very unequally, I resolved to repeat the trial on a larger seale, and in a rather different manner. I obtained seeds of the same erimson variety of $I$. umbellata from another nursery garden, and raised plants from them. Some of these plants were allowed to fertilise themselves spontaneously under a net; others were erossed by pollen taken from plants raised from seed sent me by Dr. Durando from Algiers, where the parent-plants had been cultivated for some generations. These latter plants differed in having pale pink instead of erimson flowers, but in no other respeet. That the eross had been effective (though the flowers on the crimson mother-plant had not been castrated) was well shown when the thirty erossed seedlings flowered, for twenty-four of them produeed pale pink flowers, exactly like those of their father; the six others having crimson flowers exaetly like those of their mother and like those of all the self-fertilised seedlings. This ease offers a good instanee of a result whieh not rarely follows from erossing varieties having differently eoloured flowers; namely, that the colours do not blend, but resemble perfectly those either of the father or mother plant. The seeds of both lots, after germinating on sand, were planted on opposite sides of eight pots. When fully grown, the plants were measured to the summits of the flower-heads, as shown in the following table :- 


\section{TABLE XXXIT.}

Iberis umbellata: 0 signifies that the Plant died.

\begin{tabular}{|c|c|c|}
\hline No. of Put. & $\begin{array}{l}\text { Plants from a Cruss } \\
\text { with a trese Stocks. }\end{array}$ & $\begin{array}{l}\text { Plants from Spon- } \\
\text { taneously selff-ferti- } \\
\text { lised Seeds. }\end{array}$ \\
\hline I. & $\begin{array}{r}\text { Inches. } \\
18 \frac{6}{6} \\
17.0 \\
17 \frac{6}{6} \\
20 \frac{1}{8}\end{array}$ & $\begin{array}{c}\text { Inclies. } \\
17 \\
16 \frac{3}{8} \\
13 \frac{1}{8} \\
15 \frac{3}{8}\end{array}$ \\
\hline II. & $\begin{array}{l}20 \frac{2}{8} \\
158 \\
17^{2}\end{array}$ & $\begin{array}{c}0 \\
16 \frac{5}{5} \\
15 \frac{5}{8}\end{array}$ \\
\hline III. & $\begin{array}{l}19 \frac{2}{6} \\
18 \frac{1}{8} \\
15 \frac{2}{5}\end{array}$ & $\begin{array}{l}13 \frac{6}{8} \\
14 \frac{2}{8} \\
13 \frac{7}{8}\end{array}$ \\
\hline IV. & $\begin{array}{l}17 \frac{1}{8} \\
18 \frac{7}{8} \\
17 \frac{5}{8} \\
15 \frac{1}{8} \\
14 \frac{4}{8}\end{array}$ & $\begin{array}{l}16 \frac{1}{3} \\
1+\frac{1}{8} \\
16 \\
15 \frac{3}{8} \\
1+\frac{7}{8}\end{array}$ \\
\hline V. & $\begin{array}{l}18 \frac{1}{8} \\
14 \frac{7}{8} \\
16 \frac{2}{5} \\
15 \frac{3}{8} \\
12 \frac{1}{8}\end{array}$ & $\begin{array}{l}16 \frac{1}{5} \\
16 \frac{2}{8} \\
14 \frac{2}{5} \\
14 \frac{2}{8} \\
16 \frac{1}{8}\end{array}$ \\
\hline VI. & $\begin{array}{l}18 \frac{6}{8} \\
18 \frac{6}{8} \\
17 \frac{3}{8}\end{array}$ & $\begin{array}{l}16 \frac{1}{8} \\
15 \\
15 \frac{2}{8}\end{array}$ \\
\hline VII. & $\begin{array}{l}18 \\
16 \frac{1}{5} \\
18 \frac{2}{\frac{5}{3}}\end{array}$ & $\begin{array}{l}16 \frac{3}{2} \\
14 \frac{1}{6} \\
13 \frac{5}{5}\end{array}$ \\
\hline VIII. & $\begin{array}{l}20 \frac{6}{6} \\
17 \frac{8}{8} \\
13 \frac{5}{5} \\
19 \frac{2}{8}\end{array}$ & $\begin{array}{l}15 \frac{6}{8} \\
16 \frac{3}{8} \\
20 \frac{2}{8} \\
15 \frac{6}{8}\end{array}$ \\
\hline otal in inches. & $520 \cdot 38$ & $449 \cdot 88$ \\
\hline
\end{tabular}

The average height of the thirty crossed plants is here $17 \cdot 34$, and that of the twonty-nine self-fertilised plants (one 
having died) $15 \cdot 51$, or as 100 to 89 . I am surprised that the difference did not prove somewhat greater, considering that in the last experiment it was as 100 to 86 ; but this latter ratio, as before explained, was probably too great. In should, however, be observed that in the last experiment (Table XXXI.), the crossed plants competed with plants of the third self-fertilised generation; whilst in the present case, plants derived from a cross with a fresh stock competed with self-fertilised plants of the first generation.

The crossed plants in the present case, as in the last, were more fertile than the self-fertilised, both lots being left uncovered in the grcenhouse. The thirty crossed plants produced 103 seed-bearing flower-heads, as well as some heads which yielded no seeds; whereas the twenty-nine self-fertilised plants produced only 81 seed-bearing heads; therefore thirty such plants would have produced 83.7 heads. We thus get the ratio of 100 to 81 , for the number of seed-bearing flower-heads produced by the crossed and self-fertilised plants. Moreover, a number of sced-bcaring heads from the crossed plants, compared with the same number from the self-fcrtilised, yielded seeds by weight, in the ratio of 100 to 92 . Combining theso two elements, viz., the number of seecl-bearing heads and the weight of seeds in each head, the productiveness of the crossed to the self-fertilised plants was as 100 to 75 .

The crossed and self-fertilised seeds, which remained aftor the above pairs had been planted, (some in a state of germination and some not so), were sown early in the year out of doors in two rows. Many of the self-fertilised seedlings suffered greatly, and a much larger number of them perished than of the crossed. In the autumn the surviving self-fertilised plants werc plainly less well-grown than the crossed plants.

\section{PAPAVERACE五.-PAPaver vagun.}

$A$ sub-species of P. dubium, from the south of France.

The poppy does not secrete nectar, but the flowers are highly conspicuous and are visited by many pollen-collecting becs, flies and beetles. The anthers shed their pollen very early, and in the case of $P$. rhoeas, it falls on the circumference of the radiating stigmas, so that this species must often be self-fertilised; but with 1 . dubium the same result does not follow (according to H. Müller, 'Die Befruchtung,' p. 128), owing to 
the shortness of the stamens, unless the flower happens to stand inclined. The present species, therefore, does not seem so rell fitted for self-fertilisation as most of the others. Nevertheless $P$. vayum produced plenty of capsules in my garden when insects were exeluded, but only late in the season. I may here add that $P$. somniferum produees an abundance of spontaneously selffertilised capsules, as Professor H. Hoffmann likewise found to be the case.* Some species of Papaver cross freely when growing in the same garden, as I have known to be the ease with $P$. bracteatum and orientale.

Plants of Papaver vagum were raised from seeds sent me from Antibes through the kindness of Dr. Bornet. Some little time after the flowers had expanded, several were fertilised with their own pollen, and others (not eastrated) with pollen from a distinet individual; but I have reason to believe, from observations subsequently made, that these flower's had been already fertilised by their own pollen, as this process seems to take place soon after their expansion. $\dagger$ I raised, however, a few seedlings of both lots, and the self-fertilised rather exeeeded the crossed plants in height.

Early in the following year I acted differently, and fertilised seven flower's, very soon after their expansion, with pollen from another plant, and obtained six capsules. From eounting the seeds in a medium-sized one, I estimated that the average number in each was at least 120 . Four out of twelve capsules, spontaneously self-fertilised at the same time, were found to eontain no good seeds; and the remaining eight eontained on an average $6 \cdot 6$ seeds per eapsule. But it should be observed that later in the season the same plants produeed under a net plenty of very fine spontaneously self-fertilised eapsules.

The above two lots of seeds, after germinating on sand, were planted in pairs on opposite sides of five pots. The two lots of seedlings, when half an inch in height, and again when 6 inehes high, were measured to the tips of their leaves, but presented

* 'Zur Speciesfrage,' 1875, p. 53.

+ Mr. J. Scott found (" Report on the Experimental Culture of the Opium Poppy :' Calcutta, 1874, p. 47), in the case of Papaver somniferum, that if he cut away the stigmatic surface before the flower lind expunded, no seerls were produced; but if this was done "on the second dny, or even n few liours after the expansion of the flower on the first day, a partial fertilisation had already been effected, and a few good seeds were almost invariably procluced." This proves at how early a period iertilisation talies place. 
no difference. When fully grown, the flower-stalks were measured to the summits of the seed capsules, with the following result :-

\section{TABLE XXXIII.}

Papaver vagum.

\begin{tabular}{|c|c|c|}
\hline No. of Pot. & Crossed Plants. & Self-fertilised Plants. \\
\cline { 1 - 3 } & Inches. & Inches. \\
& $24 . \frac{2}{8}$ & 21 \\
& 30 & $26 \frac{5}{8}$ \\
& $18 \frac{1}{8}$ & 16 \\
\hline II. & $14 \frac{4}{8}$ & $15 \frac{3}{8}$ \\
& 22 & $20 \frac{1}{8}$ \\
& $19 \frac{5}{8}$ & $14 \frac{1}{8}$ \\
& $21 \frac{3}{8}$ & $16 \frac{4}{8}$ \\
\hline III. & $20 \frac{6}{8}$ & $19 \frac{2}{8}$ \\
& $20 \frac{8}{8}$ & $13 \frac{2}{8}$ \\
\hline IV. & $20 \frac{8}{8}$ & 18 \\
\hline V. & $25 \frac{3}{8}$ & $23 \frac{2}{8}$ \\
\hline & $24 \frac{2}{8}$ & 23 \\
\hline Total in inches. & 20 & $18 \frac{3}{8}$ \\
\hline
\end{tabular}

The fifteen crossed plants here average 21.91 inches, and the fifteen self-fertilised plants $19 \cdot 54$ inches in height, or as 100 to 89. These plants did not differ in fertility, as far as could be judged by the number of capsules produced, for there were seventy-five on the crossed side and seventy-four on the selffertilised sidc.

\section{ESCHSCHOLTZIA CALIFORNICA.}

This plant is remarkable from the crossed scedlings not cxceeding in height or vigour the self-fertilised. On the other hand, a cross greatly increases the productiveness of the flowers on the parent-plant, and is indeed sometimes necessary in order that they should produce any sced; moreover, plants thus derived are themselves much more fertile than those raised from 
self-fertilised flowers; so that the whole advantage of a cross is confined to the reproductive system. It will be necessary for me to give this singular case in considerable detril.

Twelve flowers on some plants in my flower-garden were fertilised with pollen from distinct plants, and produced twelre capsules; but one of these contained no good seed. The seeds of the eleven good capsules weighed $17 \cdot 4$ grains. Eighteen flowers on the same plants were fertilised with their own pollen and produced twelve good capsules, which contained 13.61 grains weight of seed. Therefore an equal number of crossed and self-fertilised capsules would have yielded seed by weight as 100 to 71 .* If we take into account the fact that a much greater proportion of flowers produced capsules when crossed than when self-fertilised, the relative fertility of the crosserl to the self-fertilised flowers was as 100 to 52 . Nevertheless these plants, whilst still protected by the net, spontaneousiy produced a consiclerable number of self-fertilised capsules.

The seeds of the two lots after germinating on sand were planted in pairs on the opposite sides of four large pots. At first there was no difference in their growth, but ultimately the crossed sendlings exceeded the self-fertilised considerably in height, as shown in the following Table. But I believe from

TABdE XXXIV.

Eschscholtzia californica.

\begin{tabular}{|c|c|c|}
\hline No. of Pot. & Crossed Plants. & Self-fertilised Plants. \\
\hline I. & $\begin{array}{c}\text { Inches. } \\
33 \frac{\mathrm{s}}{\mathrm{g}}\end{array}$ & $\begin{array}{c}\text { Inches. } \\
25\end{array}$ \\
\hline II. & $34 \frac{3}{8}$ & $3 j$ \\
\hline III. & 29 & $27 \frac{2}{8}$ \\
\hline IV. & 22 & $1 j$ \\
\hline Tutal in inches. & $118 \cdot 75$ & $102 \cdot 25$ \\
\hline
\end{tabular}

* Prof, Hildelurand experimented on plants in Germany on a larger scale than I disl, and found them inuch more self-sterile. lighteen cujsules, produced by cross-fertilisation, contrincl on an aremęc cighty-five seeds, whilst fouteen cillsules from self-fertilised flowers eontained on an averige only nine seeds; that is. as 100 to 11: 'Jahrb. fiir I'isec(ll. Butanili:' B. rii. 1. $46 \%$. 
the cases which follow that this result was acciclental, owing to only a few plants laving been measured, and to one of the self-fertilised plants having grown only to a height of 15 inches. The plants had been kept in the greenhouse, and from being drawn up to the light had to be tied to sticks in this and the following trials. They were measured to the summits of their flomer-stems.

The four crossed plants here average 29.68 inches, and the four self-fertilised $25 \cdot 56$ in lreight; or as 100 to 86 . The remaining seeds werc sown in a large pot in which a Cineraria lad long been growing; and in this case again the two crossed plants on the one side greatly exceeded in height the two selffertilised plants on the opposite side. The plants in the above four pots from having been kept in the greenhouse did not produce on this or any other similar occusion many capsules; but the flower's on the crossed plants when again crossed were much more productive than the flowers on the self-fertilised plants when again self-fertilised. These plants after seeding were cut down and kept in the grcenhouse; and in the following year, when grown again, their relative heights were reversed, as the self-fertiliser plants in three out of the four pots were now taller than and flowered before the crossed plants.

Crossed and self-fertilis d Plants of the Second Generation.-The fact just given with respect to the growth of the cut-down plants made me doubtful about my first trial, so I determined to make another on a larger scale with crossed and self-fertilised seerllings raised from the crossed and self-fertilised plants of the last generation. Eleven pairs were raised and grown in competition in the usual manner; and now the result was different, for the two lots were nearly equal during their whole growth. It would therefore be superfluous to give a table of their heights. When fully grown and measured, the crossed averaged $32 \cdot 47$, and the self-fertilised 32.81 inches in height; or as 100 to 101. There was no great difference in the number' of flowers and capsules produced by the two lots, when both were left freely exposed to the visits of insects.

Plrents raised from Brazilian Secd.-Fritz Müller sent me from South Brazil seeds of plants which were there absolutely stcrile when fertilised with pollen from the same plant, but werc perfectly fertile when fertilised with pollen from any other plant. The plants raised by me in England from these 
seeds were examined by Professor Asa Gray, and pronounced to belong to $E$. culiforrica, with which they were identical in general appearance. Two of these plants were covered by a net, and were found not to be so completely self-sterile as in Brazil. But I shall recur to this subject in another part of this work. Here it will suffice to state that eight flowers on these two plants, fertilised with pollen from another plant under the net, produced eiglit fine capsules, each containing on an average about eighty seeds. Eight flowers on these same plants, fertilised with their own pollen, produced seven capsules, which contained on an average only twclve seeds, with a maximum in one of sixteen seeds. Therefore the cross-fertilised capsules, compared with the self-fertilised, yielded seeds in the ratio of about 100 to 15 . These plants of Brazilian parentage differed also in a marked manner from the English plants in producing extremely few spontaneously self-fertilised capsules under a net.

Crossed and self-fertilised seeds from the above plants, after germinating on bare sand, were planted in pairs on the opposite sides of five large pots. The seedlings thus raised were the grandchildren of the plants which grew in Brazil; the parents having been grown in England. As the grandparents in Brazil absolutely require cross-fertilisation in order to yield any seeds, I expected that self-fertilisation would have proved very injurious to these seedlings, and that the crossed ones would lave been greatly superior in height and vigour to those raised from self-fertilised flower's. But the result showed that my anticipation was erroneous; for as in the last experiment with plants of the English stock, so in the present one, the self-fertilised plants exceeded the crossed by a little in height. It will be sufficient to state that the fourteen crossed plants averaged $44 \cdot 64$, and the fourteen self-fertilised $45 \cdot 12$ inches in lieight; or as 100 to 101.

The Effects of a Cross with a fresh Stock.-I now tried a different experiment. Eight flowers on the self-fertilised plants of the last experiment (i.e., grandchildren of the plants which grew in Brazil) were again fertilised with pollen from the same plant, and produced five capsules, containing on an arerage $27 \cdot 4$ seeds, with a maximum in one of forty-two seeds. The seedlings raised from these seeds formed the second self-fertilised greueration of the Brazilian stock.

Eight flowers on one of the crossed plants of the last experi- 
ment were crossed with pollen from another grandchild, and prodnced five capsules. These contained on an average $31 \cdot 6$ seeds, with a maximum in one of forty-nine seeds. The seedlings raised from these seeds may be called the Intercrossed.

Lastly, eight other flowers on the crossed plants of the last experiment were fertilised with pollen from a plant of the English stock, growing in my garden, and which must have been exposed during many previous generations to ver'y different conditions from those to which the Brazilian progenitors of the mother-plant had been subjected. These eight flower's produced only four capsules, containing on an average $63 \cdot 2$ seeds, with a ıaximum in one of ninety. The plants raised from these seeds 111ay be called the English-crossed. As far as the above averages can be trusted from so few capsules, the English-crossed capsules contained trrice as many seeds as the intercrossed, and rather more than twice as many as the sclf-fertilised capsules. The plants which yielded these capsules were grown in pots in the greenhouse, so that their absolute productireness must not be compared with that of plants growing out of doors.

The above three lots of secds, viz., the self fertilised, intercrossed, and English-crossed, were planted in an equal state of germination (having been as usual sown on bare sand) in nine large pots, each divided into three parts by superficial partitions. Wany of the self-fertilised seeds germinated before those of the tro crossed lots, and these were of course rejected. The seedlings thus raised are the great-grandchildren of the plants which grew in Brazil. When they were from 2 to 4 inches in height, the three lots were equal. They were measured when four-fifths grown, and again when fully grown, and as their relative heights were almost exactly the same at these two ages, I will give only the last measurements. The average height of the nineteen English-crossed plants was $45 \cdot 92$ inches; that of the eighteen intercrossed plants (for one died), 43.38; and that of the nineteen self-fertilised plants, $50 \cdot 3$ inches. So that we have the following ratios in height:-

The English-crossed to the self-fertilised plants, as 100 to 109 The English-crossed to the intercrossed plants, as 100 to 94 The intercrossed to the sclf-fertilised plants, as 100 to 116

After the seed-capsules had bcen gathered, all these plants were cut down close to the ground and weighed. The nineteen English crossed plants weighed $18 \cdot 2.5$ ounces; the intercrossed 
plants (with thcir weight ealeulated as if therc had been nineteen) weighed 18.2 ounees; and the nineteen sclf-fertilised plants, 21.5 ounees. We have therefore for the weights of the threc lots of plants the following ratios:-

The English-crossed to the self-fertilised plants, as 100 to 118

The English-erossed to the intererossed plants, as 100 to 100

The intererossed to the self-fertilised plants, as 100 to 118

We thus see that in weight, as in height, the self-fertiliscd plants had a deeided advantage over the English-erossed and intererossed plants.

The remaining seeds of the three kinds, whether or not in a state of germination, werc sown in tbree long parallel rows in the open ground; and here again the self-fcrtilised seedlings excceded in height by between 2 and 3 inches the seedlings in the two other rows, which werc of nearly equal heights. The three lows were left unproteeted throughout the winter, and all the plants were killed, with the exeeption of two of the selffertilised; so that as far as this little bit of evidence goes, some of the self-fertilised plants were more liardy than any of the crossed plants of either lot.

We thus see that the self-fertilised plants whieh were grown in the nine pots were superior in height (as 116 to 100), and in weight (as 118 to 100), and apparently in hardiness, to the intererossed plants derived from a eross between the grandehildren of the Brazilian stoek. The superiority is here much moro strongly marked than in the seeond trial with the plants of the English stoek, in which the self-fertilised were to the crossed in height as 101 to 100 . It is a far more remarkable fact-if we bear in mind the effects of erossing plants with pollen from a fresh stock in the eases of Ipomøa, Mimulus, Brassica, and Iberis-that the self-fertilised plants exeeeded in height (as 109 to 100), and in weight (as 118 to 100), the offspring of the Brazilian stock crossed by the English stoek; the two stoeks having bcen long subjeeted to widely different conditions.

If we now turn to the fertility of the three lots of plants we find a very different result. I may promise that in fire out of the nine pots the first plant which flowered was one of the Englislicrossed; in four of the pots it was a self-fertilised plant; and in not one did an intercrossed plant flower first; so that these latter plants were beatcn in this respect, as in so many other ways. The thr'ce closcly adjoining rows of plants growing in 
the open ground flowered profusely, and the flowers were incessantly visited by bces, and certainly thus intercrossed. The manner in which several plants in the previous experiments continued to be almost sterile as long as they were covered by a net, but set a multitude of capsules immediately that they were uncovered, proves how effectually the bees carry pollen from plant to plant. My gardener gathered, at three successive times, an equal number of ripe capsules from the plants of the three lots, until he had collected forty-five from each lot. It is not possible to judge from external appearance whether or not a capsule contains any good seeds; so that I opened all the capsules. Of the forty-fire from the English-crossed plants, four were empty; of those from the intercrossed, five were empty; and of those from the self-fertilised, nine were empty. The : seeds were counted in twenty-one capsules taken by chance out i of each lot, and the average number of seeds in the capsules from the English-crossed plants was 67 ; from the intercrossed, 56 ; and from the self-fertilised, $48 \cdot 52$. It therefore follows that

Seeds.

The forty-five capsules (the four empty ones included) from the English-crossed plants contained 2747

The forty-five capsules (the five empty ones included) from the intercrossed plants contained . 2240 The forty-five capsules (the nine empty ones included) from the self-fertilised plants contained . $1746 \cdot 7$

The reacler should remember that these capsules are the pro(duct of cross-fertilisation, effected by the bees; and that the clifference in the number of the contained sceds must depend on the constitution of the plants; - that is, on whether they were clerived from a cross with a distinct stock, or from a cross lbetween plants of the same stock, or from self-fertilisation. From the above facts we obtain the following ratios:-

Number of seeds contained in an equal number of naturally fertilised capsules produced-

By the English-crossed and self-fertilised plants, as 100 to 63 By the English-crossed and intercrossed plants, as 100 to 81 By the intercrossed and self-fertilised plants, as 100 to 78

But to have ascertained the productireness of the three lots of plants, it would have been necessary to know how many capsules were produced by the same number of plants. Tho 
three long rows, however, were not of quite erfual lengths, and the plants were much erowded, so that it would have been extremely difficult to have ascertained low many capsules were produeed by them, even if I had been willing to undertalie so laborious a task as to collect and count all the capsules. But this was feasible with the plants grown in pots in the grecnhouse; and although these were much less fertile than those growing out of doors, their relative fertility appeared, after earefully observing them, to be the same. The nineteen plants of the English-crossed stock in the pots produced altogether 210 eapsules; the intercrossed plants (caleulated as nineteen) produced $137 \cdot 22$ capsules; and the nineteen self-fertilised plants, 152 capsules. Now, knowing the number of seeds coutained in forty-five eapsules of each lot, it is easy to calculate the relative numbers of seeds prodnced by an equal number of the plants of the three lots.

Number of sceds prodnced by an equal number of naturallyfertilised plants.

Plants of English-crossed and self-fertilised parcutige.

Plants of the English-crossed and intercrossed parentagee.

Plants of the intercrossed and self-fertilised parentage.

Seeds. as 100 to 45 as 100 to 89

The superiority in produetiveness of the intercrossed plants (that is, the produet of a eross between the grandchildren of the plauts which grew in Brazil) over the self-fertiliserf, small as it is, is wholly due to the larger average number of seeds containcd in the eapsules; for the intererossed plants produced fewer eapsules in the greenhonse than did the self-fertilised plants. The great superiority in productiveness of the English-crossed orer the self-fertilised plants is shown by the linger number of capsules produced, the larger avernge number of contained seeds, and the smaller number of empty eapsules. As the Englishcrossed and intercrossed plants were the offspring of crosses in every previons generation (as must liave heen the case from the flowers being sterile with their own polleu), we may conelude that the great superiority in produetiveness of the Englisll-crossed aver the intercrossed plants is due to the two parents of the for'mer having been long subjected to diflurent conditions. 
The English-crossed plants, though so superior in produetiveness, were, as we have seen, decidedly inferior in height and weight to the self-fertilised, and only equal to, or hardly superior to, the intererossed plants. Therefore, the whole advantage of a eross with a distinet stoek is here confined to productiveness, and I bare met with no similar casc.

\section{TIII, RESEDACEZE-RESEDA IUTEA.}

Seeds colleeted from wild plants growing in this neighbourhood were sown in the kitehen-garden; and several of the seedlings thus raised were covered with a net. Of these, some were found (as will hereafter be morc fully described) to be absolutely sterile when left to fertilise themselves spontaneously, although plenty of pollen fell on their stigmas; and they wcre equally sterile when artifieially and repeatedly fertilised with their own pollen; whilst other plants produeed a fow spontaneously self-fertiliscd capsules. The remaining plants were left uncovered, and as pollen was earried from plant to plant by the hive and humble-bets which incessantly visit the flowers, they produced an abundance of capsules. Of the neecssity of pollen being carried from one plant to another, I had ample revidenee in the case of this spceies and of $l$. orlorata; for those iplants, which set no seeds or very few as loug as they were iprotected from insects, beeame loaded with capsules immediately that they were uneovered.

Seeds from the flower's spontaneously self-fertilised under the inet, and from flowers naturally erossed by the bees, were sown on copposite sides of five large pots. The seedlings were thinned as soon as they appeared above ground, so that an equal nuwber rwere left on the two sidcs. After a time the pots were plunged into the open ground. The same number of plants of crossed and sclf-fertilised parcntagc wcre measurcd up to the summits of their flower-stems, with the result given in the following table (XXXV.). Those which did not produee flower-stems were not incasured.

The average height of the twenty-four crossed plants is here $17 \cdot 17$ inelies, and that of the same number of self-fertiliscd plants 14.61 ; or as 100 to 85 . Of the erossed plants all but five flowered, whilst several of the sclf-fertilised did not do so. The above pairs, whilst still in flowcr, but with some eapsules already formed, werc afterwards cut down and weighed. The crossed 
weighed $90 \cdot 5$ ounces; and an equal number of the self-fertilised ouly 19 ounces, or as 100 to 21; and this is an astonishing difference.

\section{TABLE XXXV.}

Resecla lutea, in pots.

\begin{tabular}{|c|c|c|}
\hline No. of Pot. & Crossed Plants. & Self-fertilised Plants. \\
\hline I. & $\begin{array}{c}\text { Inches. } \\
21 \\
14 \frac{2}{8} \\
19 \frac{1}{8} \\
7 \\
15 \frac{1}{8}\end{array}$ & $\begin{array}{c}\text { Inches. } \\
127 \\
16 \\
11 \frac{7}{8} \\
15 \frac{2}{8} \\
19 \frac{1}{8}\end{array}$ \\
\hline II. & $\begin{array}{l}20 \frac{4}{8} \\
17 \frac{3}{8} \\
23 \frac{7}{8} \\
17 \frac{1}{8} \\
20 \frac{6}{8}\end{array}$ & $\begin{array}{l}12 \frac{4}{8} \\
16 \frac{2}{8} \\
16 \frac{2}{6} \\
13 \frac{3}{8} \\
13 \frac{5}{8}\end{array}$ \\
\hline III. & $\begin{array}{l}16 \frac{1}{8} \\
17 \frac{6}{8} \\
16 \frac{2}{8} \\
10 \\
10\end{array}$ & $\begin{array}{r}14 \frac{4}{8} \\
19 \frac{1}{8} \\
20 \frac{7}{8} \\
7 \frac{7}{8} \\
17 \frac{10}{8}\end{array}$ \\
\hline IV. & $\begin{array}{l}22 \frac{1}{8} \\
19 \\
18 \frac{7}{8} \\
16 \frac{4}{8} \\
19 \frac{2}{8}\end{array}$ & $\begin{array}{l}9 \\
11 \frac{4}{8} \\
11 \\
16 \\
16 \frac{3}{8}\end{array}$ \\
\hline V. & $\begin{array}{r}25 \frac{2}{8} \\
22 \\
8 \frac{6}{8} \\
14 \frac{8}{8}\end{array}$ & $\begin{array}{l}14 \frac{6}{6} \\
16 \\
14 \frac{3}{8} \\
14 \frac{2}{8}\end{array}$ \\
\hline Total in inches. & $412 \cdot 25$ & $350 \cdot 86$ \\
\hline
\end{tabular}

Seeds of the same two lots were also sown in two adjoining rows in the open ground. There were twenty crossed plants in the one row and thirty-two self-fertilised plants in the other row, so that the experiment was not quite fair; but not so unfair as it at first appears, for the plants in the same row were not crowded so much as seriously to interfere with each other's growth, and the ground was bare on the outside of botli rows. 
These plants were better nourished than those in the pots and grew to a greater height. 'The eight tallest plants in each row were measured in the same manner as before, with the following result:-

\section{TABLE XXXVI.}

Reseda lutea, growing in the open ground.

\begin{tabular}{|c|c|}
\hline Crossed Plants. & Self-fertiliser Plants. \\
\cline { 2 - 3 } Inches. & Inches. \\
28 & $33 \frac{2}{8}$ \\
$27 \frac{3}{6}$ & 23 \\
$27 \frac{5}{8}$ & $21 \frac{5}{8}$ \\
$28 \frac{6}{8}$ & $20 \frac{1}{8}$ \\
$29 \frac{7}{8}$ & $21 \frac{5}{8}$ \\
$26 \frac{6}{8}$ & 22 \\
$26 \frac{2}{8}$ & $21 \frac{2}{8}$ \\
$30 \frac{1}{8}$ & $21 \frac{7}{8}$ \\
\hline $224 \cdot 75$ & $185 \cdot 13$ \\
\hline
\end{tabular}

The average height of the crossed plants, whilst in full flower, was here $28 \cdot 09$, and that of the self-fertilised $23 \cdot 14$ inclies; or as 100 to 82. It is a singular fact that the tallest plant in the two rows, was one of the self-fertilised. The self-fertilised plants had smaller and paler green leaves than the crossed. All the plants in the two rows were afterwards cut down and weighed. The twenty crossed plants weighed 65 ounces, and twenty self-fertilised (by calculation from the actual weight of the thirty-two selffertilised plants) weighed $26 \cdot 25$ ounces; or as 100 to 40 . Thereforc the crossed plants did not exceed in weight the self-fertilised plants in nearly so great a degree as those growing in the pots, owing probably to the latter having been subjected to more severe mutual competition. On the other hand, they exceeded the sclf-fertilised in height in a slightly greater degree.

\section{RESEDA ODORATA.}

Plants of the common mignonette were raised from purcliased secd, and several of them were placed under separate nets. Of these some became loadcd with spontaneously self-fertilised capsules; othcrs produced a few, and others not a single one. It must not be supposed that these latter plants produced no seed 
beeause their stignas did not receive any pollen, fur they were repeatedly fertilised with pollen from the same plant with to effect; but they were perfeetly fertile with pollen from any other plant. Spontaneously self-fertilised seeds were saved from one of the highly self-fertile plants, and other seeds were collected from the plants growing outside the nets, whieh had been crossed by the bees. These seeds after germinating on sand were planted in pairs on the opposite sides of fire pots. The plants wcre trained up stieks, and measured to the summits of their leafy stems - the flower-stems not being inclucled. Tre here have the result :-

\section{TABLE XXXVIT.}

Reseda odorata (seculings from a Thighty Self-fertile Plant).

\begin{tabular}{|c|c|c|}
\hline No. of Pot. & Crossed Plants. & Self-fertilised Plants. \\
\hline I. & $\begin{array}{c}\text { Inches. } \\
20 \frac{7}{8} \\
34 \frac{7}{8} \\
26 \frac{6}{8} \\
32 \frac{1}{8}\end{array}$ & $\begin{array}{l}\text { Inches. } \\
22 \frac{4}{8} \\
28 \frac{5}{8} \\
23 \frac{2}{8} \\
30 \frac{4}{8}\end{array}$ \\
\hline II. & $\begin{array}{l}34 \frac{3}{8} \\
34 \frac{5}{8} \\
11 \frac{5}{8} \\
33 \frac{3}{8}\end{array}$ & $\begin{array}{l}28 \frac{5}{8} \\
30 \frac{5}{8} \\
23 \\
30 \frac{1}{8}\end{array}$ \\
\hline III. , & $\begin{array}{l}17 \frac{7}{8} \\
27 \\
39 \frac{1}{6} \\
30 \frac{2}{8}\end{array}$ & $\begin{array}{l}4 \frac{4}{8} \\
25 \\
26 \frac{3}{5} \\
25 \frac{1}{5}\end{array}$ \\
\hline$I V$. & $\begin{array}{l}21 \frac{5}{8} \\
28 \\
32 \frac{5}{8} \\
32 \frac{3}{8}\end{array}$ & $\begin{array}{l}22 \frac{6}{8} \\
25 \frac{1}{8} \\
15 \frac{1}{8} \\
24 \frac{6}{8}\end{array}$ \\
\hline$r$. & $\begin{array}{l}21 \\
25 \frac{2}{8} \\
26 \frac{5}{8}\end{array}$ & $\begin{array}{l}11 \frac{6}{8} \\
19 \frac{7}{8} \\
10 \frac{4}{8}\end{array}$ \\
\hline Tot 1 in inches. & $522 \cdot 25$ & $428 \cdot 50$ \\
\hline
\end{tabular}

The avcrage height of the nineteen crossed plants is here $27 \cdot 48$, and that of the ninetcen self-fertilised $22 \cdot 55$ inches; or' as 100 to 82 . All these plants were cut down in the early antumn 
and reighed: the erossed weighed $11 \cdot 5$ ounces, and the selffertilised $7 \cdot 75$ ounees, or as 100 to 67 . These two lots having been left freely exposed to the visits of inseets, did not present any differenee to the eye in the number of seed-eapsules whieh they produced.

The remainder of the same two lots of seeds were sown in two adjoining rows in the open ground; so that the plants were exposed to only moderate eompetition. The eight tallest on eaeh side were measured, as shown in the following table:-

TABLE XXXVIII.

Resedu odorata, growing in the open ground.

\begin{tabular}{|c|c|}
\hline Crosserl Plants. & Self-fertilised Plants. \\
\hline Incles. & Inches. \\
$24 \frac{4}{8}$ & $26 \frac{5}{8}$ \\
$27 \frac{2}{8}$ & $25 \frac{7}{8}$ \\
24 & 25 \\
$26 \frac{6}{8}$ & $28 \frac{3}{8}$ \\
25 & $29 \frac{7}{8}$ \\
$26 \frac{2}{8}$ & $25 \frac{7}{8}$ \\
$27 \frac{2}{8}$ & $26 \frac{7}{8}$ \\
$25 \frac{1}{8}$ & $28 \frac{2}{8}$ \\
\hline Total in $\} 206 \cdot 13$ & $216 \cdot 75$ \\
\hline inches. & \\
\hline
\end{tabular}

The average height of the eight erossed plants is $25 \cdot 76$, and that of the eight fertilised $27 \cdot 09$; or as 100 to 105.

We here have the anomalous result of the self-fertilised plants being a little taller than the erossed; of whieh faet I ean offer no. explanation. It is of eourse possible, but not probable, that the labels may have been interehanged by aeeident.

Anothcr experiment was now tried: all the self-fertilised eapsules, though very few in number, were gathered from one of the semi-self-sterile plants under a net; and as several flowers on this same plant had been fertilised with pollen from a distinet individual, erossed seeds were thus obtained. I expeeted that the secdlings from this semi-self-sterile plant would have profited in a higher degree from a eross, than did the seedlings from the fully self-fertile plants. But my antieipation was quite wrong, for they profited in a less degree. An analogous result followed in the case of Essehseholtzia, in whieh the offspring of the plants of Prazilian parentage (wlieh were partially self-sterile) did not 
profit more from a cross, than did the plants of the far more self-fertile English stock. The above two lots of crossed and self-fertilised seeds from the same plant of Reseda odorata, after germinating on sand, were planted on opposite sides of five pots, and measured as in the last case, with the following result:-

\section{TABLE XXXIX.}

Reseda odorata (seedlings from a semi-self-sterite Plant).

\begin{tabular}{|c|c|c|}
\hline No. of Pot. & Crossed Plants. & Self-fertilised Plants. \\
\hline I. & $\begin{array}{c}\text { Incles. } \\
33 \frac{4}{8} \\
30 \frac{6}{8} \\
29 \frac{6}{8} \\
20\end{array}$ & $\begin{array}{c}\text { Inches. } \\
31 \\
28 \\
13 \frac{2}{8} \\
32\end{array}$ \\
\hline II. & $\begin{array}{l}22 \\
33 \frac{4}{8} \\
31 \frac{2}{8} \\
32 \frac{4}{8}\end{array}$ & $\begin{array}{l}21 \frac{6}{8} \\
26 \frac{6}{8} \\
25 \frac{2}{8} \\
30 \frac{4}{8}\end{array}$ \\
\hline III. & $\begin{array}{l}30 \frac{1}{8} \\
32 \frac{1}{8} \\
31 \frac{4}{8} \\
32 \frac{2}{8}\end{array}$ & $\begin{array}{l}17 \frac{2}{8} \\
29 \frac{6}{8} \\
24 \frac{6}{8} \\
34 \frac{2}{8}\end{array}$ \\
\hline IV. & $\begin{array}{l}19 \frac{1}{8} \\
30 \frac{1}{8} \\
24 \frac{3}{8} \\
30 \frac{6}{8}\end{array}$ & $\begin{array}{l}20 \frac{6}{8} \\
32 \frac{6}{8} \\
31 \frac{4}{8} \\
36 \frac{6}{8}\end{array}$ \\
\hline V. & $\begin{array}{l}34 \frac{6}{8} \\
37 \frac{1}{8} \\
31 \frac{2}{8} \\
33\end{array}$ & $\begin{array}{l}24 \frac{5}{8} \\
34 \\
22 \frac{2}{8} \\
38 \frac{1}{8}\end{array}$ \\
\hline Total in inches. & $599 \cdot 75$ & $554 \cdot 25$ \\
\hline
\end{tabular}

The avcrage height of the twenty crossed plants is here 29.98 , and that of the twenty self-fertilised $27 \cdot 71$ inches; or as 100 to 92. These plants were then cut down and woighed; and the erossed in this case exceeded the self-fertilised in weight by a mere trifle, viz., in the ratio of 100 to 99 . The two lots, left freely exposed to insects, seemed to be equally fertile.

'The remainder of the seed was sown in two adjoining rows in 
the open ground; and the eight tallest plants in each row were measured, with the following result:-

TABLE XL.

Reseda odorata (seedlings from a semi-self-sterile Plant, planted in the open ground).

\begin{tabular}{|c|c|}
\hline Crossed Plants. & Self-fertilised Plants. \\
\cline { 1 - 2 } Inclies. & Inches. \\
$28 \frac{2}{8}$ & $22 \frac{3}{8}$ \\
$22 \frac{4}{8}$ & $24 \frac{3}{8}$ \\
$25 \frac{7}{8}$ & $23 \frac{1}{8}$ \\
$25 \frac{3}{8}$ & $21 \frac{1}{8}$ \\
$29 \frac{1}{8}$ & $22 \frac{3}{8}$ \\
$27 \frac{1}{8}$ & $27 \frac{3}{8}$ \\
$22 \frac{4}{8}$ & $27 \frac{3}{8}$ \\
$26 \frac{2}{8}$ & $19 \frac{2}{8}$ \\
\hline Total in $3207 \cdot 38$ & $188 \cdot 38$ \\
inches. & \\
\hline
\end{tabular}

The average height of the eight crossed plants is here $25 \cdot 92$, and that of the eight self-fertilised plants $23 \cdot 54$ inches; or as 100 to 90 .

\section{VIOLACE无.-VIOLA TRICOLOR.}

Whilst the flowers of the common cultivated heartsease are young, the anthers shed their pollen into a little semi-cylindrical passage, formed by the basal portion of the lower petal, and surrounded by papillæ. The pollen thus collected lies close beneath the stigma, but can seldom gain access into its cavity, exeept by the aid of insects, which pass their proboscides down this passage into the nectary.* Consequently when I eovered up a large plant of a eultivated variety, it set only cighteen capsules, and most of these eontained very few good seeds-several from only one to three; whereas an cqually fine

* The flowers of this plant have been fully deseribed by Sprengel, Hildelirand, Delpino, and $H$. Miuller. 'The latter author sums up all the previous observations in his 'Befruehtung der Blumen,' and in 'Nature,' Nov. 20, 1873, p. 44. See also Mr. A. IV.
Bennett, in 'Nature,' May 15, 1873 , p. 50 ; and some remarks by Mr. Kitehener, ibid. 1) 143. The faets which follow on the eflects of eovering up a plant of $V$. tiricolor have been quoted by Sir J. Lubbock in lis ' Jritish Wild Flowers,' de. p. 62. 
uncovered plant of the same variety, growing close by, produced 105 fine capsules. The few flowers which produce capsules when insects are excluded, are perlaps fertilised by the curling inwards of the petals as they wither, for by this means pollen-grains adhering to the papillæ might be inserted into the cavity of the stigma. But it is more probable that their fertilisation is effected, as Mr. Bemett suggests, by Thrips and certain minute beetles which haunt the flowers, and which cammot be excluded ly any net. Humble-bees are the usual fertilisers; but I have than once seen flies (Rhinyiu rostratu) at work, with the under sides of their bodies, heads and legs dusted with pollen; and having marked the flowers which they risited, I found them after a few days fertilised.* It is curious for how long a time the flowers of the heartscase and of some other plants may be watched without an insect being seen to visit them. During the summer of 1811 , I observed many times daily for more than a fortnight some large clumps of heartsease growing in my garden, before I saw a single humble-bee at work. During another summer I did the same, but at last saw some dark-coloured humble-bees visiting on three snccessive days almost every flower in several clumps; and almost all these flowers quickly withered and produced fine capsules. I presume that a certain state of the atmosplere is necessary for the secretion of nectrr, and that as soon as this occurs the insects discover the fact by the odour emitted, and immediately frequent the flowers.

As the flowers require the aid of insects for their complete

* I should add that this fly apparently did not suck the nectar, but was attracted by the pilpillæe which surround the stigma. H. Müiller also saw a small bee, an Andrena, which could not reach the nectar, repeatedly inserting its proboscis bencath the stigma, where the papillw are situnted; so that these papillae must be in sume way attrnetive to insects. $\Lambda$ writer asserts (' '/nologist,' vol. iii.-iv. p. 1225) that a moth (Plusin) frecuuently visits the Howers of the pansy. Hive-bees do not ordinilrly visit them, but "1 case lins been reeorded ("Galdeners' Chroniele,' 1844, 1).374) of these bees doing so. H. Miiller has also seen the hive-bee at work, but only on the wild smallflowered form. He gives a list ('Nature,' $1873, p$ 45) of all the insects which he has seen visiting both the large and small-flowered forms. From his necomnt, I suspeet that the flowers of plants in a state of nature are visited more frequently by inseets than those of the cultivated varicties. He las seen several butterflies sneking the flowers of wild plants, and this I hare nerer observed in gurdens, though I have watelied the flowers during many rears. 
fertilisation, and as they are not visited by inseets nearly so often as most other neetar-secreting flower's, we can understand the remarkable fact discovered by H. Miiller and described by him in 'Nature,' namely, that this species exists under two forms. One of these bcar's conspicuous flowers, whieh, as we have seen, requirc the aid of insects, and are adapted to be eross-fertilised by them; whilst the other form has much smaller and less eonspicuously coloured flowers, which are eonstrueted on a slightly different plan, favouring self-fertilisation, and are thus adapted to ensure the propagation of the species. The selffertile form, however, is oceasionally visited, and may be crossed by inseets, thongh this is rather doubtful.

In my first experiments on Violu tricolor I was unsuccessful in raising seedlings, and obtained only one full-grown crossed and self-fertilised plant. The former was $12 \frac{1}{2}$ inches and the latter $\mathrm{S}$ inehes in height. On the following year several flower's on a fresh plant were erossed with pollen from another plant, which was known to be a distinct seedling; and to this point it is important to attend. Several other flowers on the same plant were fertilised with their own pollen. The average number of seeds in the ten erossed capsules was 18.7, and in the twelve self-fertilised eapsules 12.83 ; or as 100 to 69 . These seeds, after germinating on bare sand, were planted in pairs on the opposite sides of five pots. They were first measured when about a third of their full size, and the erossed plants then averaged $3 \cdot 87$ inches, and the self-fertilised only $2 \cdot 00$ inehes in height; or as 100 to 52 . They were kept in the greenhouse, and did not grow vigorously. Whilst in flower they were again measured to the summits of their stems (see Table XLI.), with the following result:-

The average height of the fourteen crossed plants is here 5.58 inehes, and that of the fourteen self-fortilised $2 \cdot 37$; or as 100 to 42. In four out of the five pots, a erossed plant flowered before any one of the self-fertilised; as likewise oecur'ed with the pair raised during the previous ycar. These plants without being disturbed were now turned out of their pots and planted in the open ground, so as to form five scparate elumps. Early in the following summer (1869) they flowered profusely, and being visited by humble-bees set many eapsules, whieh were carefully eollected from all the plants on both sides. The crossed plints produced 167 eapsulcs, and the self-fertilised only 17; or as 100 to 10 . So that the crossed plants were more than twice the 
height of the self-fertilised, generally flowered first, and produeed ten times as many naturally fertilised eapsules.

TABle XLI.

Viola triculor.

\begin{tabular}{|c|c|c|}
\hline No. of Pot. & Crossed Plants. & Self-fertilised Plants. \\
\hline I. & $\begin{array}{c}\text { Inches. } \\
8 \frac{2}{8} \\
7 \frac{4}{8} \\
5\end{array}$ & $\begin{array}{c}\text { Iuches, } \\
0 \frac{2}{8} \\
2 \frac{4}{8} \\
1 \frac{2}{8}\end{array}$ \\
\hline II. & $\begin{array}{l}5 \\
4 \\
4^{4}\end{array}$ & $\begin{array}{l}6 \\
4 \\
3 \frac{1}{8}\end{array}$ \\
\hline III. & $\begin{array}{l}9 \frac{1}{8} \\
3 \frac{3}{8} \\
8 \frac{4}{8}\end{array}$ & $\begin{array}{l}3 \frac{1}{8} \\
1 \frac{7}{8} \\
0 \frac{5}{8}\end{array}$ \\
\hline IV. & $\begin{array}{l}47 \\
4 \frac{2}{8} \\
4\end{array}$ & $\begin{array}{l}2 \frac{1}{8} \\
1 \frac{6}{8} \\
2 \frac{1}{8}\end{array}$ \\
\hline V. & $\begin{array}{l}6 \\
3 \frac{3}{8}\end{array}$ & $\begin{array}{l}3 \\
1 \frac{4}{8}\end{array}$ \\
\hline Total in inches. & $78 \cdot 13$ & $33 \cdot 25$ \\
\hline
\end{tabular}

By the early part of the summer of 1870 the erossed plants in all the five elumps had grown and spread so mueh more than the self-fertilised, that any eomparison between them was superfluous. The erossed plants were eovered with a sheet of bloom, whilst only a single self-fertilised plant, whieh was muel finer than any of its brethren, flowered. The crossed and selffertilised plants had now grown all matted together on the respeetive sides of the superfieial partitions still separnting them; and in the clump whieh ineluded the finest self-fertilised plant, I estimated that the surfaee eovered by the erossed plants was about nine times as large as that eovered by the self-fertilised plants. The extraordinary superiority of the crossed orer the self-fertilised plants in all five elumps, wns no doubt due to the erossed plants at first having had a decided adrantage orer the self-fertilised, and then robbing them more and more of their food during the sneeeeding seasons, But we should remember 
that the same result would follow in a state of nature even to a greater degree; for my plants grew in ground kept clear of weeds, so that the self-fertilised had to compete only with the crossed plants; whereas the whole surface of the ground is naturally covered with various kinds of plants, all of which have to struggle together for existence.

The ensuing wintcr was very severe, and in the following spring (1871) the plants were again examined. All the selffertilised were now dead, with the exccption of a singlc branch on one plant, which bore on its summit a minute rosette of leaves about as large as a pea. On the other hand, all the crossed plants without exception were growing vigorously. So that the self-fertilised plants, besides their inferiority in other respects, were more tender.

Another experiment was now tried for the sakc of ascertaining how far the superiority of the crossed plants, or to speak more correctly, the inferiority of the sclf-fertilised plants, would be transmitted to their offspring. The one crossed and onc selffertilised plant, whicl were first raised, had been turned out of their pot and planted in the open ground. Both produced an abundance of very fine capsules, from which fact we may safely conclude that they had been cross-fertilised by insects. Seeds from both, after germinating on sand, were planted in pairs on the opposite sidcs of three pots. The naturally crossed seedlings

\section{TABLE XLII.}

Viola tricolor: seedlings from crosstd and self-fertilised Plants, the parents of both sets having been left to be naturally fertilised.

\begin{tabular}{|c|c|c|}
\hline No. of Pot. & $\begin{array}{c}\text { Naturally crossed } \\
\text { Plants from artifi- } \\
\text { cially crossed Plints. }\end{array}$ & $\begin{array}{c}\text { Naturally crossed } \\
\text { Plants from self- } \\
\text { fertilised Plants. }\end{array}$ \\
\hline I. & $\begin{array}{c}\text { Inches. } \\
12 \frac{1}{8}\end{array}$ & $\begin{array}{r}\text { Inches. } \\
9 \frac{6}{8} \\
8 \frac{3}{8}\end{array}$ \\
\hline II. & $11 \frac{6}{8}$ & $9 \frac{6}{8}$ \\
& $13 \frac{2}{8}$ & $11 \frac{4}{8}$ \\
\hline III. & 10 & $11 \frac{1}{8}$ \\
\hline Total in inches. & $14 \frac{4}{8}$ & $11 \frac{3}{8}$ \\
\hline
\end{tabular}


derived from the erossed plants flowered in all three pots bufore the natur:rly erossed seedlings derived from the self-fertilised plants. When both lots were in full flower, the two tallest plants on each side of each pot were measured, and the "result is shown in the preceding table.

'I'he average height of the six tallest plants derived from the erossed plants is $12 \cdot 56$ inehes; and that of the six tallest plants derived fiom the self-fertilised plants is 10.31 inches; or as 100 to 82 . We here see a eonsiderable difference in height between the two sets, though very far from equalling that in the previous trials between the offspring from erossed and selffertilised flowers. This differenee must be attributed to the latter set of plants having inherited a weak eonstitution from their parents, the offspring of self-fertilised flowers ; notwithstanding that the parents themselves had been freely intercrossed with other plants by the aid of inseets.

\section{RANUNCULACE E.-ADONIS esTIVALIS.}

The results of my experiments on this plant are hardly worth giving, as I remark in my notes made at the time, "scedlings, from some unknown eause, all miserably unhealthy." Nor did they ever beeome healtly ; yet I feel bound to give the present ease, as it is opposed to the general results at which I hare arrived. Fifteen flower's were crossed and all produeed fruit, containing on an average $32 \cdot 5$ seeds; nineteen flower's were fertilised with their own pollen, and they likewise all yielded fruit, containing a rather larger average of 34.5 seeds; or as 100 to 106 . Seedlings were raised from these seeds. In one of the pots all the selffertilised plants died whilst quite young; in the two others, the meas'irements were as follows:

\section{TABLE XLIII.}

Aclonis astivali.

\begin{tabular}{|c|c|c|}
\hline No. of Pot. & Crosscd l'Iants. & Sclf-fertilised Plants. \\
\hline I. & $\begin{array}{c}\text { Inches. } \\
14 \\
13\end{array}$ & $\begin{array}{r}\text { Inches. } \\
13 \frac{4}{6} \\
13 \frac{1}{6}\end{array}$ \\
\hline II. & $\begin{array}{l}16 \% \\
13 \frac{2}{15}\end{array}$ & $\begin{array}{l}15 \frac{2}{8} \\
15\end{array}$ \\
\hline Total in incles. & $57 \cdot 00$ & $i 7 \cdot 25$ \\
\hline
\end{tabular}


The average height of the four crossed plants is $14 \cdot 25$, and that of the four self-fertilised plants $14 \cdot 31$; or as 100 to $100 \cdot 4$; so that they were in faet of equal height. A ecording to Professor H. Hoffmann, ${ }^{*}$ this plant is proterandrons; nevertheless it yields plenty of seeds when protected from insects.

\section{Delphinium CONSOLIDA.}

It has been said in the case of this plant, as of so many others, that the flowers are fertilised in the bud, and that distinct plants or varieties ean never naturally intereross. $\dagger$ But this is an error, as we may infer, firstly from the flowers being proterandrous, - the mature stamens bending up, one after the other, into the passage which leads to the nectary, and afterwards the mature pistils bending in the same direction; secondly, from the number of humble-bees which visit the flowers $\ddagger$; and thirdly, from the greater fertility of the flowers when crossed with pollen from a distinct plant than when spontaneously solf-fertilistd. In the year $1863 \mathrm{I}$ enelosed a large braneh in a net, and crossed five flower's with pollen from a distinet plant; these yielded eapsules containing on an average $35 \cdot 2$ very fine seeds, with a maximum of forty-two in one capsule. Thirty-two other flowers on the same branch produeed twenty-eight spontaneously self-fertilised eapsules, containing on an average $17 \cdot 2$ seeds, with a maximum in one of thirty-six seeds. But six of these eapsules were very poor, yielding only from one to five seeds; if these are exeluded, the remaining twenty-two eapsules give an average of 20.9 seeds, though many of these seeds were small. The fairest ratio, therefore, for the number of seeds produeed by a cross and by spontaneous self-fertilisation is as 100 to 59. These seeds were not sown, as I had too many other experiments in progress.

In the summer of 1867 , whieh was a very unfavourable one, I again erossed several flower's under a net with pollen from a distinct plant, and fertilised other flowers on the same plant with their own pollen. The former yiclded a much larger proportion of capsules than the latter' and many of the seeds in the selffertilised eapsules, though numerous, were so poor that an equal number of seeds from the erossed and self-fertilised capsules

\section{* 'Zur Speciesfrage,' 187j,}

p. 11.

† Deeaisne, 'Comptes-Iiendus, July, 1863, p. 5. t Their strueture is described by H. Müller, 'Befruchtung,' \&e., 1). 122 
were in weight as 100 to 45 . The two lots were allowed to germinate on sand, and pairs were planted on the opposite sides of four pots. When nearly two-tliirds grown they were measured, as shown in the following table:-

TABLe XLIV.

Delphinium consolida.

\begin{tabular}{|c|c|c|}
\hline No. of Pot. & Crossed Plants. & Self-fertilised Plants. \\
\hline I. & $\begin{array}{c}\text { Inches. } \\
11\end{array}$ & $\begin{array}{c}\text { Inches. } \\
11\end{array}$ \\
\hline II. & $\begin{array}{l}19 \\
16 \frac{2}{8}\end{array}$ & $\begin{array}{l}16 \frac{2}{8} \\
11 \frac{4}{8}\end{array}$ \\
\hline III. & 26 & 22 \\
\hline IV. & $\begin{array}{l}\frac{9}{8} \\
8\end{array}$ & $\begin{array}{l}8 \frac{2}{8} \\
6 \frac{1}{6}\end{array}$ \\
\hline Total in inches. & $89 \cdot 75$ & $75 \cdot 50$ \\
\hline
\end{tabular}

The six crossed plants here average $14 \cdot 95$, and the six selffertilised $12 \cdot 50$ inches in height; or as 100 to 84 . When fully grown they were again measured, but from want of time only a single plant on each side was measured; so that I have thought it best to give the earlier measurements. At the later period the three tallest crossed plants still exceeded considerably in height the three tallest selffertilised, but not in quite so great a degree as before. The pots were left uncovered in the greenhouse, but whether the flowers were intercrossed by bees or selffertilised I do not know. The six crossed plants produced 282 mature and immature capsules, whilst the six self-fertilised plants produced only 159 ; or as 100 to 56 . So that the crossed j)lants were very much more productive than the self-fertilised.

\section{CARYOPHYLILACEA.-T'iscaRia OCUlata.}

T'welve flowers were crossed with pollen from another plant. and yielded ten capsules, containing by weight 5.77 grains of sceds. Eighteen flowers wcre fertilised witl their own pollcn and yielded twelve capsules, containing by weight $2 \cdot 63$ grains. Therefore the seeds from an rqual number of crossed and solf 
fertilised flower's would have been in wcight as 100 to 38 . I had previously selectcd a medium-sized eapsule from eaeh lot, and counted the seeds in botlı; the crossed onc contained 284, and the self-fertilised one 126 seeds; or as 100 to 44 . These seeds were sown on opposite sides of thrce pots, and several seedlings raised; but only the tallest flower-stem of one plant on eaeh side was mcasured. The three on the erossed side areraged $32 \cdot 5$ inches, and the three on the self-fertilised side 34 inehes in lıcight; or as 100 to 104 . But this trial was on mueh too small a scale to be trustcd; the plants also grew so uncqually that one of the three flower-stems on the crossed plants was very nearly twice as tall as that on one of the others; and one of the three flower-stems on the self-fertilised plants exeeeded in an equal degree one of the others.

In the following year the experiment was repcalcd on a larger scale: ten flowers were crossed on a new set of plants and yielded ten capsules contrining by wcight $6 \cdot 54$ g'rains of seed. Eighteen spontaneously self-fertilised capsules were gathered, of whieh two contained no seed ; the other sixteen contained by weight 6.07 grains of seed. Therefore the weight of seed from an equal number of crossed and spontaneously self-fertilised flowers (instead of artificially fertilised as in the previous case) was as 100 to $5 \mathrm{~S}$.

The sceds after germinating on sand were planted in pairs on the opposite sides of four pots, with all the rcmaining seeds sown crowded in the opposite sides of a fifth pot; in this latter pot only the tallest plant on cach side was measured. Until the seedlings had grown about 5 inches in height no differenee could be perceived in the two lots. Both lots flowered at nearly the same time. When they had almost done flowering, the tallest flower-stem on eaeh plant was measured, as shown in the following table (XLV.).

The fifteen crossed plants here average $34 \cdot 5$, and the fifteen self-fertilised $33 \cdot 55$ inches in height; or as 100 to 97 . So that the exeess of height of the crossed plants is quite insignificant. In productiveness, however, the difference was mueh more plainly marked. All the capsules werc gathered from both lots of plauts (except from the erowded and unproductive ones in Pot V.), and at the elose of the scason the fow remaining flowers werc arkled in. The fourteen crossed plants produced 381, whilst the lourteen self-fertilised plants produced only 293 capsules and flowcrs; II: 1 ? 101 to 77. 
TABLE XIV.

Viscaria oculata.

\begin{tabular}{|c|c|c|}
\hline No. of Pot. & Crossed Plants. & Self-fertilised Plants. \\
\cline { 1 - 2 } I. & Inches, & Inches. \\
19 & $32 \frac{3}{8}$ \\
& 33 & 38 \\
41 & 38 \\
41 & $28 \frac{7}{8}$ \\
\hline II. & $37 \frac{4}{6}$ & 36 \\
& $36 \frac{1}{8}$ & $32 \frac{3}{8}$ \\
& 38 & $35 \frac{6}{8}$ \\
\hline III. & $44 \frac{4}{8}$ & 36 \\
& $39 \frac{4}{6}$ & $20 \frac{7}{8}$ \\
& 39 & $30 \frac{5}{8}$ \\
\hline IV. & $30 \frac{2}{8}$ & 36 \\
& 31 & 39 \\
& $33 \frac{1}{8}$ & 29 \\
\hline V. & 24 & $38 \frac{4}{8}$ \\
\hline Crowded. & $30 \frac{2}{8}$ & 32 \\
\hline Total in inches. & $517 \cdot 63$ & \\
\hline
\end{tabular}

\section{DiANTHUS CARTOPHYLLES.}

The eommon carnation is strongly proterandrous, and therefore depends to a large extent upon insects for fertilisation. I have seen only humble-bees visiting the flowers, but I dare say other inseets likewise do so. It is notorious that if pure seed is desired, the greatest eare is necessary * to prevent the varieties whiel grow in the same garden from intercrossing. The pollen is generally shed and lost before the two stigmas in the same flower diverge and are ready to be fertilised. I was therefore often forced to use for self-fertilisation pollen from the same plant instead of from the same flower, But on two oeeasions, when I attended to this point, I was not able to detect any marked difference in the number of seeds produeed by these two forms of self-fertilisation.

* 'Cardeners' Chronicle,' 18t7, p. 268. 
Several single-flowered carnations were planted in good soil, and were all covered with a net. Eight flowers werc crossed with pollen from a distinct plant and yielded six capsules, containing on an average $88^{\circ} 6$ seeds, with a maximum in one of 112 seeds. Eight other flowers were self-fertilised in the manner ahove described, and yielded seven capsules containing on an average 82 seeds, witl a maximum in one of 112 seeds. So that there was very little difference in the number of seeds produced by cross-fertilisation and self-fertilisation, viz., as 100 to 92 . As these plants were covered by a net, they produced spontaneously only a few capsules containing any seeds, and these few may perhaps be attributed to the action of Thrips and other minute insects which haunt the flowers. A large majority of the spontancously self-fertilised capsules produced by scveral plants contained no seeds, or only a single one. Excluding thesc latter: capsules, I counted the seeds in eighteen of the finest ones, and these contained on an arerage 18 seeds. One of the plants was spontaneously self-fertile in a higher degrec than any of the others. On another occasion a single covercd-np plant produced spontaneously eighteen capsules, but only two of these contained any seed, namely 10 and 15.

Crossed and self-fertilised Plants of the First Generation.-The many seeds obtained from the above crossed and artificially self-fertilised flowers were sown out of doors, and two large beds of seedlings, closely adjoining one another, thus raised. This was the first plant on which I experimented, and I had not then formed any regular scheme of operation. When the two lots were in full flower, I measured roughly a large number of plants but record only that the crossed were on an average fully 4 inches taller than the self-fertilised. Judging from subsequent measurements, we may assume that the crossed plants, were about 28 inches, and the self-fertilised about 21 inches in height; and this will give uls a ratio of 100 to 86. Out of a large number of plants, four of the crossed ones flowered before any ono of the sclf-fertilised plants.

Thirty flowers on these crossed plants of the first generation were again crossed with pollen from a distinct plant of the same lot, and yiclded twenty-nine capsules, containing on an average $55 \cdot 62$ seeds, with a maximum in one of 110 seeds.

Thirty flowers on the sclf-fertilised plants were again sclffertilised; eight of them with pollen from the same flower, and the remainder with pollen from another flower on the samc 
plant; and these produeed twenty-two eapsules, eontaining on an average 35.95 seeds, with a maximum in one of 61 seeds. We thus see, judging by the number of seeds per crpsule, that the erossed plants again crossed were more produetive than the self-fertilised again self-fertilised, in the ratio of 100 to 65 . Both the erossed and self-fertilised plants, from liaving grown mueh erowded in the two beds, prodneed less fine eapsules and fewer seeds than did their parents.

Crossed and self-fertilised Plunts of the Second Generation.-The crossed and self-fertilised seeds from the erossed and self-fertilised plants of the last generation were sown on opposite sides of two pots; but the seedlings were not thinned enough, so that both lots grew very irregularly, and most of the self-fertilised plants after a time died from being smothered. My measurements rere, therefore, very ineomplete. From the first the erossed seedlings appeared the finest, and when they were on an average, by estimation, 5 inehes high, the self-fertilised plants were only 4 inehes. In both pots the crossed plants flowered first. The two tallest flower-stems on the erossed plants in the two pots were 17 and $16 \frac{1}{2}$ inehes in height; and the two tallest flower-stems on the self-fertilised plants $10 \frac{1}{2}$ and 9 inehes; so that their heights were as 100 to 58. But this ratio, dedueed from only two pairs, obviously is not in the least trustworthy, and would not have been given had it not been otherwise supported. I state in my notes that the erossed plants were very mueh more luxuriant than their opponents, and seemed to be twiee as bulky. This latter estimate may be beliered from the ascertained weights of the two lots in the next generation. Some flowers on these erossed plants were again erossed with pollen from another plant of the same lot, and some flowers on the selffertilised plants again self-fertilised; and from the seeds thus obtained the plants of the next genelation were raised.

Crossed and st 7 -fertilised Plants of the Third Generation.-The seeds just alluded to were ailowed to germinate on bare sand, and were planted in pairs on the opposite sides of four pots. When the scedlings were in full flower, the tallest stem on eaeh plant was measnred to the base of the calyx. The measurements are given in the following table (XLVI.). In Pot I. the erossed and self-fertilised plants flowered at the same time; but in the other three pots the erossed flowered first. These latter plants also eontinued floworing muels later in the autumm than the self-fertilised. 
Chap. IV. CROSSED AND SEtF-FERTILISED PLANTS. 135

TABLE XLVI.

Dianthus caryophyllus (Thind Generation).

\begin{tabular}{|c|c|c|}
\hline No. of Pot. & Crossed Plants. & Self-fertilised Plants. \\
\hline I. & $\begin{array}{r}\text { Inches. } \\
28 \frac{6}{8} \\
27 \frac{3}{5}\end{array}$ & $\begin{array}{c}\text { Inches. } \\
30 \\
26\end{array}$ \\
\hline II. & $\begin{array}{l}29 \\
29 \frac{4}{8}\end{array}$ & $\begin{array}{l}30 \frac{7}{8} \\
27 \frac{1}{8}\end{array}$ \\
\hline III. & $\begin{array}{l}28 \frac{4}{8} \\
23 \frac{1}{8}\end{array}$ & $\begin{array}{l}31 \frac{6}{8} \\
24 \frac{5}{8}\end{array}$ \\
\hline IV. & $\begin{array}{l}27 \\
33 \frac{4}{8}\end{array}$ & $\begin{array}{l}30 \\
25\end{array}$ \\
\hline Total in inches. & $227 \cdot 13$ & $225 \cdot 75$ \\
\hline
\end{tabular}

The average height of the eight crossed plants is here 28.39 inches, and of the eight self-fertilised 28.21 ; or as 100 to 99. So that there was no difference in height worth speaking of; but in general vigour and luxuriance there was an astonishing diffcrence, as shown by their weights. After the seed-capsules had been gathered, the eight crossed and the eight self-fertilised plants were cut down and weighed; the former weighed 43 ounces, and the latter only 21 ounces; or as 100 to 49.

These plants were all kept under a net, so that the capsules which they produced must have been all spontaneously selffertilised. The eight crossed plants produced twenty-one such capsules, of which only twelve contained any sced, averaging 8.5 per capsule. On the other hand, the eight self-fertilised plants produced no less than thirty-six capsules, of which I examined twenty-five, and, with the exception of three, all contained sceds, avcraging 10.63 seeds per capsule. Thus the proportional number of seeds per capsule produced by the plants of crossed origin to those prodnced by the plants of self-fertilised origin (both lots being spontanconsly sclf-fertilised) was as 100 to 125. This anomalous result is probably due to some of the self-fertilised plants having varied so as to mature their pollen and stigmas more nearly at the same time than is proper to the species; and we have already secn that some plants in the 
first experiment differed from the others in being slightly more self-fertile.

The Lffects of a C'ross with a fresh Stock. - Twenty flowers on the self-fertilised plants of the last or third generation, in Table XLVI., were fertilised with their own pollen, but taken from other flower's on the same plants. These produced fifteen capsules, which contained (omitting two with only three and six seeds) on an average $47 \cdot 23$ seeds, with a maximum of serenty in one. The self-fertilised capsules from the self-fertilised plants of the first generation vielded the much lower arelage of $35 \cdot 95$ seeds; but as these latter plants grew extremely erowded, nothing can be inferred with respect to this difference in their self-fertility. The seedlings raised from the above seeds constitute the plants of the fourth self-fertilised generation in the following table (XLVII.).

'I'welve flowers on the same plants of the third self-fertilised generation, in Table XLVI., were crossed with pollen from the erossed plants in the same table. These crossed plants had been intererossed for the three previous generations; and many of them, no doubt, were more or less closely inter-related, but not so elosely as in some of the experiments with other species; for several carnation plants had been raised and crossed in the earlier generations. They were not related, or only in a distant degree, to the self-fertilised plants. The parents of both the self-fertilised and crossed plants had been subjected to as nearly as possible the same conditions during the three previous generations. The above twelve flower's produced ten capsules, containing on an average 48.66 sceds, with a maximum in one of seventy-two seeds. The plants raised from these seeds may be called the intercrossed.

Lastly, twelve flowers on the same self-fertilised plants of the third generation were erossed witl pollen from plants which had been raised from seeds purchased in London. It is almost eertain that the plants which produced these seeds had gromm under very different conditions to those to which my selffertilised and erossed plants had been subjected; and they were in no degree related. The above twelve flowers thus crossed all produeed eapsules, but these contained the low arerage of 37.41 seeds per capsule, with a maximum in one of sixty-four seeds. It is surprising that this cross with a fresh stock did not give a much higher arerage number of seeds; for, as we shall inmediately see, the plants raised from these seeds, whieh ma: 
Chap. IV.

be called the London-crossel, benefited greatly by the cross, both in growth and fertility.

The above three lots of seeds were allowed to germinate on bare sand. Many of the London-crossed germinated before the others, and were rejected; and many of the intercrossed later than those of the other two lots. The seeds after thus germinating were planted in ten pots, made tripartite by superficial

TABLE XLVII.

Dianthus suryophyllus.

\begin{tabular}{|c|c|c|c|}
\hline No. of Pot. & $\begin{array}{l}\text { London-crossfd } \\
\text { Plants. }\end{array}$ & Intercrossed Plants. & $\begin{array}{l}\text { Self-fertilised } \\
\text { Plunts. }\end{array}$ \\
\hline I. & $\begin{array}{c}\text { Inches. } \\
39 \frac{5}{8} \\
30 \frac{7}{8}\end{array}$ & $\begin{array}{c}\text { Inches. } \\
25 \frac{1}{8} \\
21 \frac{6}{8}\end{array}$ & $\begin{array}{c}\text { Inches. } \\
29 \frac{2}{8} \\
+\end{array}$ \\
\hline II. & $\begin{array}{c}36 \frac{2}{8} \\
0\end{array}$ & & $\begin{array}{l}22 \frac{3}{8} \\
+\quad\end{array}$ \\
\hline III. & $\begin{array}{l}28 \frac{5}{8} \\
+\end{array}$ & $\begin{array}{l}30 \frac{2}{8} \\
23 \frac{1}{8}\end{array}$ & \\
\hline IV. & $\begin{array}{l}33 \frac{4}{8} \\
28 \frac{7}{8}\end{array}$ & $\begin{array}{l}35 \frac{5}{8} \\
32\end{array}$ & $\begin{array}{l}30 \\
24 \frac{4}{8}\end{array}$ \\
\hline V. & $\begin{array}{r}28 \\
0\end{array}$ & $\begin{array}{l}34 \frac{4}{8} \\
24 \frac{2}{8}\end{array}$ & + \\
\hline VI. & $\begin{array}{l}325 \\
31\end{array}$ & $\begin{array}{l}247 \\
26\end{array}$ & $\begin{array}{l}30 \frac{3}{8} \\
24 \frac{4}{8}\end{array}$ \\
\hline VII. & $\begin{array}{l}41 \frac{7}{8} \\
34 \frac{7}{8}\end{array}$ & $\begin{array}{l}297 \\
26 \frac{7}{8}\end{array}$ & $\begin{array}{l}27 \frac{7}{8} \\
27^{2}\end{array}$ \\
\hline VIII. & $\begin{array}{r}345 \\
285\end{array}$ & $\begin{array}{r}29 \\
0\end{array}$ & $\begin{array}{l}26 \frac{6}{8} \\
+\end{array}$ \\
\hline IX. & $\begin{array}{c}25 \frac{5}{8} \\
0\end{array}$ & $\begin{array}{l}28 \frac{5}{8} \\
+\end{array}$ & $\stackrel{+}{0}$ \\
\hline $\mathrm{x}$ & $\begin{array}{l}38 \\
32 \frac{1}{8}\end{array}$ & $\begin{array}{l}284 \\
+\end{array}$ & $\begin{array}{c}22 \frac{7}{8} \\
0\end{array}$ \\
\hline Total in inches. & $525 \cdot 13$ & $420 \cdot 00$ & $265 \cdot 50$ \\
\hline
\end{tabular}


divisions; but when only two kinds of seeds germinated at the same time, they were planted on the opposite sides of other pots; and this is indieated by blank spaces in one of the three eolumns in Table XLVI. An 0 in the table signifies that the seedling died before it was measured; and a + signifies that the plant dicl not produee a flower-stem, and therefore was not measured. It deserves notiee that no less than eight out of the eighteen selffertilised plants either died or did not flower; whereas only three out of the eighteen intererossed, and four out of the twenty London-erossed plants, were in this predicament. The selffertilised plants had a decidedly less vigorous appearance than the plants of the otler two lots, their leaves being smaller and narrower. In only one pot did a self-fertilised plant flower before one of the two kinds of crossed plants, between which there was no marked differenee in the period of flowering. The plants were measured to the base of the ealyx, after they hac completed their growtl, late in the autumn.

The average height of the sixteen London-erossed plants in the preeeding tablc is 32.82 inehes; that of the fifteen intercrossed plants, 28 inehes; and that of the ten self-fertilised plants, $26 \cdot 55$.

So that in height we have the following ratios:-

The London-erossed to the self-fertilised as 100 to S1

The London-erossed to the intererossed as 100 to 85

The intererossed to the self-fertilised as 100 to 95

These three lots of plants, whiell it should be remembered were all derived on the mother-side from plants of the third self-fertilised generation, fertilised in three different ways, were left exposed to the visits of inseets, and their flowers were freely crossed by them. As the capsules of eaeh lot beeame ripe they were gathered and kept separate, the empty or bad ones being thrown away. But towards the middle of Oetober, when the capsules eould no longer ripen, all were gathered and rere eounted, whether good or bad. The eapsules were then erushed, and the seed cleaned by sieves and weighed. For the sake of uniformity the results are given from ealeulation, as if there liad been twenty plants in eneh lot.

'The sixteen London-erossed plants aetually produeed 286 capsules; therefore twenty sueh plants would have produeed $357 \cdot 5$ eapsules; and from the actual weight of the sceds, the twenty plants would have yielded 462 grains weiglit of seeds. 
The fifteen intererossed plants aetually produeed 157 eapsules; therefore twenty of them would have produeed $209 \cdot 3$ eapsules, and the seeds would have weighed $208 \cdot 48$ grains.

The ten self-fertilised plants aetually produeed 70 capsules; therefore twenty of them would have produeed 140 capsules; and the seeds would have weighed $153 \cdot 2$ grains.

From these data we get the following ratios:-

Number of capsules producel by an equal number of plants of the three lots.

Number of Capsules.

The London-erossed to the self-fertilised, as 100 to 39

The London-erossed to the intererossed, as 100 to 45

The intererossed to the self-fertilised, as 100 to 67

Weight of seeds produced by an equal number of plants of the three lots.

Weight of Seed.

The London-erossed to the self-fertilised, as 100 to 33 The London-erossed to the intererossed, as 100 to 45 The intererossed to the self-fertilised, as 100 to 73

We thus see how greatly the offspring from the self-fertilised plants of the third generation erossed by a fresh stock, had their fertility inereased, whether tested by the number of eapsules produeed or by the weight of the eontained seeds; this latter being the more trustworthy method. Even the offspring from the self-fertilised plants erossed by one of the erossed plants of the same stoek, notwithstanding that both lots had been long subjeeted to the same eonditions, had their fertility eonsiderably inereased, as tested by the same two methods.

In eonelusion it may be well to repeat in referenee to the fertility of these three lots of plants, that their flowers were left freely exposed to the visits of inseets and were undoubtedly erossed by them, as may be inferred from the large number of good eapsules produeed. T'hese plants were all the offspring of the same mother-plants, and the strongly marked differenee in their fertility must be attributed to the nature of the pollen employed in fertilising their parents; and the differenee in the nature of the pollen must be attributed to the different treatment to whieh the pollen-bearing parents liad been subjeeted during several previous generations.

Colour of the H'lowers. - The flowers produeed by the self-fertilised 
plants of the last or fourth generation were as uniform in tint as those of a wild spccies, being of a pale pink or rose colour. Analogous eases with Mimulus and Ipomœe, after several generations of self-fertilisation, lave been already given. The flowers of the intererossed plants of the fourth generation were likewise nearly uniform in eolour. On the other hand, the flowers of the London-erossed plants, or those raised from a cross with the fresh stoek whieh bore dark erimson flowers, varied extremely in eolour, as might have been expeeted, and as is the general rule with seedling carnations. It deserves notice that only two or three of the London-crossed plants produeed dark erimson flowers like those of their fathers, and only a very few of a pale pink like those of their mothers. The great majority had their petals longitudinally and variously striped with the two eolours, - the groundwork tint being, however, in some eases darker than that of the mother-plants.

\section{MALVACEZE.-HIBISCUS AFriOANUS.}

Many flowers on this Hibiseus were erossed with pollen from a distinct plant, and many others were self-fertilised. A rather larger proportional number of the erossed than of the selffertilised flowers yielded eapsules, and the erossed capsules eontained rather more seeds. The self-fertilised seeds were a little heavier tlan an equal number of the crossed seeds, but they germinated badly, and I raised only four plants of eaeh lot. In three out of the four pots, the crossed plants flowered first.

\section{TABLE XLVIII. \\ llibiscus africanus.}

\begin{tabular}{|c|c|c|}
\hline No. of Put. & $\begin{array}{c}\text { Crossed Plants. } \\
\text { I. }\end{array}$ & $\begin{array}{c}\text { Self-fertilised Plants. } \\
\text { Inches. } \\
13 \frac{4}{8}\end{array}$ \\
\hline II. & $\begin{array}{c}\text { Inches. } \\
16 \frac{2}{8}\end{array}$ \\
\hline III. & 14 & 14 \\
\hline IV. & 8 & 7 \\
\hline Total in inches. & $17 \frac{4}{8}$ & $20 \frac{4}{8}$ \\
\hline
\end{tabular}


The four crossed plants avcrage $13 \cdot 25$, and the four self-fertilised 14.43 inches in height; or as 100 to 109 . Here we have the unusual case of self-fertilised plants exceeding the crossed in height; but only four pairs were measured, and these did not grow well or equally. I did not compare the fertility of the two lots. 


\section{CHAPTER V.}

Geraniacex, Legchinose, Onagrace

Pelargonium zonale, a eross between plants propagated by euttings does no good-Tropæolum minus-Linnanthes douglasii-Lupinus luteus and pilosus-Phaseolus multiflorus and vulgaris-Lathyrus odoratus, varicties of, never naturnlly intereross in England-Pisum sativum, varicties of, rarely intercross, but a cross between them highly benefieial-Sarothamnus scoparius, wonderful effects of a cross-Ononis minutissima, eleistogene flowers of-Summary on the Leguminosa-Clirkia elegans-Bartonia aurea-Passiflora graeilis-Apium petroselinum - Scabiusa atropurpurea-Laetuca sativa-Specularia speeulum-Lobelia ramosa, advantages of a eross during two generations-Lobel ia fulgens-Nemophila insignis, great adrantages of a cross-Borago officinalis-Nolana prostrata.

\section{GERANIACEAE.-PELARgonium 7onale.}

THIs plant, as a general rule, is strougly proterandrous, ${ }^{*}$ and is therefore adapted for cross-fertilisation by the aid of insects. Some flower's on a common scarlet variety were self-fertilised, and other flower's rere crossed with pollen from another plant; but no sooner had I done so, than I remembered that these plants had been propagated by cuttings from the same stock, and were therefore parts in a strict sense of the same individual. Nevertheless, having made the cross I resolved to save the seeds, which, after germinating on sand, were planted on the opposite

* Mr. J. Denuy, a great raiser of new varieties of pelargoniums, after stating that this sjecies is proterandrous, adds ("The Flosist and Pomologist,' Jan. 1572, p. 11) "there are some varieties, especially those with petuls of a piuk colour, or whieh possess a wcakly constitution, where the pistil exyands as soom as on reven before the lollen-luis husts, and in whieh also the pistil is frequently short, so when it expands it is smothered as it werc by the bursting anthers; these varicties are grcat seeders, each pip bciug fertilised by its own pollen. I would instance Christino as an example of this fact." We lave here an interestiug calse of valiability in an inuportant inuctiumal juint. 
sides of three pots. In one pot the curasi-erossed plant was very soon and ever afterwards taller and finer than the self-fertilised. In the two other pots the seedlings on both sides were for a time exactly equal; but when the self-fertilised plants were about 10 inehes in height, they surpassed their antagonists by a little, and ever afterwards showed a more decided and inereasing: advantage; so that the self-fertilised plants, taken altogether, were somewhat superior to the quasi-erossed plants. In this ease, as in that of the Origanum, if individuals whieh have been asexually propagated from the same stoek, and whieh have been long subjected to the same eonditions, are erossed, no advantage whatever is gained.

Several flowers on another plant of the same variety were fertilised with pollen from the younger flowers on the same plant, so as to aroid using the old and long-shed pollen from the same flower, as I thought that this latter might be less effieient than fresh poilen. Other flowers on the same plant were erossed with fresh pollen from a plant which, although elosely similar, was known to hare arisen as a distinet seeciling. The self-fertilised seeds germinated rather before the otlers; but as soon as I got equal pairs they were planted on the opposite sides of fuur pots.

Table XLIX.

Pelurgonium zonale.

\begin{tabular}{|c|c|c|}
\hline No. of Pot. & Crossed Plints. & Self-fertilised Plants. \\
\cline { 1 - 3 } I. & $\begin{array}{c}\text { Inches. } \\
22 \frac{3}{8} \\
19 \frac{6}{8}\end{array}$ & $\begin{array}{r}\text { Inches. } \\
25 \frac{5}{8} \\
12 \frac{1}{8}\end{array}$ \\
\hline II. & 15 & $19 \frac{6}{8}$ \\
& $12 \frac{2}{8}$ & $19 \frac{3}{8}$ \\
\hline III. & $30 \frac{5}{8}$ & $7 \frac{4}{8}$ \\
\hline IV. & $18 \frac{1}{8}$ & $9 \frac{1}{8}$ \\
\hline Total in inches. & 38 & $116 \cdot 38$ \\
\hline
\end{tabular}

When the two lots of seedlings were between 4 and 5 inehes in height they were equal, exeepting in Pot IV., in whieh the erossed plant was inueh the tallest. When between 11 and 14 inches

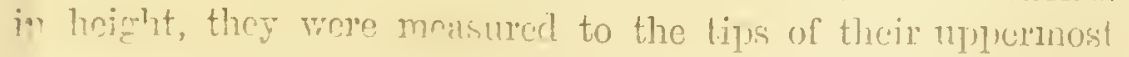


leaves; the erossed averaged $13 \cdot 46$, and the self-fertilised 11.07 inches in height, or as 100 to 82 . Five months later they were again measured in the same manner, and the results are given in the preceding table.

The seven crossed plants now averaged $22 \cdot 35$, and the seren self-fertilised $16 \cdot 62$ inches in height, or as 100 to 74 . But from the great inequality of the several plants, the result is less trustworthy than in most other cases. In Pot II. the two selffertilised plants always had an advantage, except whilst quite young over the two crossed plants.

As I wished to ascertain how these plants would behave during a second growth, they were eut down close to the ground whilst growing freely. The crossed plants now showed their superiority in another way, for only one out of the seven was killed by the operation, whilst three of the self-fertilised plants never recovered. There was, therefore, no use in keeping any of the plants excepting those in Pots I. and III.; and in the following year the crossed plants in these two pots showed during their seeond growth nearly the same relative superiority over the self-fertilised plants as before.

\section{Tropelolum MinUs.}

The flower's are proterandrous, and are manifestly adapted for cross-fertilisation by insects, as shown by Sprengel and Delpino. Twelve flowers on some plants growing out of doors were crossed with pollen from a distinct plant and produced eleven capsules, eontaining altogether twenty-four good seeds. Eighteen flowers were fertilised with their own pollen and produced only eleven capsules, containing twenty-two good seeds; so that a much larger proportion of the crossed than of the self-fertilised flowers produced capsules, and the crossed capsules eontained rather more seed than the self-fertilised in the ratio of 100 to 92 . The seeds from the self-fertilised capsules were however the heavier of the two, in the ratio of 100 to 87.

Seeds in an equal state of germination were planted on the opposite sides of four pots, but only the two tallest plants on each side of each pot were measured to the tops of their stems. The pots were plaeed in the greenhouse, and the plants trained up sticks, so that they aseended to an unusual height. In three of the pots the erossed plants flowered first, but in the fourtl at the same time witl the self-fertilised. When the seedlings were between 6 and 7 inehes in height, the crossed began to 
show a slight advantage over their opponents. When grown to a cousiderable height the eight tallest crossed plauts averaged $44 \cdot 43$, and the eight tallest self-fertilised plants $37 \cdot 34$ inches, or as 100 to 84 . When their growth was eompleted they were again measured, as shown in the following table:-

TABLE L.

Tropaeolum minus.

\begin{tabular}{|c|c|c|}
\hline No. of Pot. & Crossed Plants. & Self-fertilised Plants. \\
\hline I. & $\begin{array}{c}\text { Inches. } \\
65 \\
50\end{array}$ & $\begin{array}{c}\text { Inches. } \\
31 \\
45\end{array}$ \\
\hline II. & $\begin{array}{l}69 \\
35\end{array}$ & $\begin{array}{l}42 \\
45\end{array}$ \\
\hline III. & $\begin{array}{l}70 \\
5 y_{\frac{1}{8}}\end{array}$ & $\begin{array}{l}50 \frac{1}{8} \\
55 \frac{1}{8}\end{array}$ \\
\hline IV. & $\begin{array}{l}61 \frac{1}{8} \\
57 \frac{4}{8}\end{array}$ & $\begin{array}{l}37 \frac{1}{8} \\
61 \frac{1}{8}\end{array}$ \\
\hline Total in inches. & $467 \cdot 5$ & $368 \cdot 0$ \\
\hline
\end{tabular}

The eight tallest erossed plants now averaged $55 \cdot 43$, and the eight tallest self-fertilised plants 46 inehes in height, or as 100 to 79 .

There was also a great difference in the fertility of the two lots which were left incovered in the greenhouse. On the 17 th of September the eapsules from all the plants were gathered, and the seeds counted. The crossed plants yielded 243, whilst the same number of self-fertilised plants yielded only 155 seeds, or as 100 to 64.

\section{LinNANTHES DOUGLASII.}

Several flowers were crossed and self-fertilised in the usual : manner, but there was no marked differenee in the number of seeds which they yielded. A vast number of spontaneously selfffertilised capsules were also produced under the net. Seedlings rwere raised in five pots from the above seeds, and when the crossed were about 3 inehes in height they showed a slight advantage over the self-fertilised. When double this height, the 
sixteen crossed and sixteen self-fertilised plants were measured to the tips of their leaves; the former averaged $7 \cdot 3$ inches, and the self-fertilised 6.07 inches in height, or as 100 to 83 . In all the pots, exccpting IV., a crossed plant flowered before any one of the self-fertilised plants. The plants, when fully grown, were again measured to the summits of their ripe capsules, with the following result:-

TABLE LI.

Limnanthes douglusii.

\begin{tabular}{|c|c|c|}
\hline No. of Pot. & Crossed Plants. & Self-fertilised Plants. \\
\hline I. & $\begin{array}{c}\text { Inches. } \\
17 \frac{7}{8} \\
17 \frac{6}{8} \\
13\end{array}$ & $\begin{array}{c}\text { Inches. } \\
15 \frac{1}{8} \\
16 \frac{1}{8} \\
11\end{array}$ \\
\hline II. & $\begin{array}{l}20 \\
22 \\
21 \\
18 \frac{4}{5}\end{array}$ & $\begin{array}{l}14 \frac{1}{8} \\
15 \frac{6}{8} \\
16 \frac{1}{8} \\
17\end{array}$ \\
\hline III. & $\begin{array}{l}15 \frac{6}{8} \\
17 \frac{2}{8} \\
14^{8}\end{array}$ & $\begin{array}{c}11 \frac{4}{6} \\
10 \frac{1}{8} \\
0\end{array}$ \\
\hline IV. & $\begin{array}{l}20 \frac{4}{6} \\
14 \\
18\end{array}$ & $\begin{array}{l}13 \frac{4}{8} \\
13 \\
12 \frac{2}{6}\end{array}$ \\
\hline V. & $\begin{array}{l}17 \\
185 \\
14 \frac{5}{8}\end{array}$ & $\begin{array}{l}14 \frac{2}{8} \\
14 \frac{1}{8} \\
12 \frac{5}{8}\end{array}$ \\
\hline Total in inches. & $279 \cdot 50$ & $207 \cdot 75$ \\
\hline
\end{tabular}

The sixteen crossed plants now areraged $17 \cdot 46$, and the fifteen (for one had died) self-fertilised plants $13 \cdot 55$ inches in height, or as 100 to 79 . Mr. Galton considers that a ligher ratio would be fairer', viz., 100 to 76 . He made a graphieal representation of the ahove measurements, and adds the words "very good" to the curvature thus formed. Both lots of plants produced an abundance of seed-eapsules, and, as far as conld be judged by the eye, there was no differenee in their fertility. 


\section{LEGUMINOSA.}

In this family I experimented on the following six genera, Lupinus, Phaseolus, Lathyrus, Pisum, Sarothamnus, and Ononis.

\section{LUPINUS LUTEUS.*}

A few flowers were erossed with pollen from a distinet plant, but owing to the unfavourable season only two erossed seeds were produeed. Nine sceds were saved from flowers spontaneously self-fertilised under a net, on the same plant whieh yielded the two erossed seeds. One of these erossed seeds was sown in a pot with two self-fertilised seeds on the opposite side; the latter eame up between two and tluee days before the erossed seed. The seeond erossed seed was sown in like manner with two self-fertilised seeds on the opposite side; these latter also eame up about a day before the erossed one. In both pots, therefore, the erossed seedlings from germinating later, were at first eompletely beaten by the self-fertilised; nevertheless, this state of things was afterwards eompletely reversed. The seeds were sown late in the autumn, and the pots, whieh were mueh too small, were kept in the greenhouse. The plants in eonsequenee grew badly, and the self-fertilised suffered most in both pots. The two erossed plants when in flower during the following spring were 9 inehes in height; one of the self-fertilised plants was 8 , and the three others only 3 inches in height, being thus mere dwarfs. The two erossed plants produeed thirteen pods, whilst the four self-fertilised plants produced only a single one. Some other self-fertilised plants whieh had been raised separately in larger pots produeed several spontaneously selffertilised pods under a net, and seeds from these were used in the following experiment.

Crossed and self-fertiliserl Plants of the Second Generation.-The

* The structure of the flower's of this plant, and their manner of fertilisation, have been duselibed by H. Mïller', 'Befruclitung,' Ste. p. 24:. The flowers do not secrete frec nectir, and beas generally visit them for their pollen. Mr. larrer, however, remarkis
('Nature,' 1872, p. 499) that "there is a cavity at the back and base of the vexillum, in which 1 have not been able to find neetur. But the bees, which constantly visit these flowers, certainly go to this eavity for what they rant, and not to the staminal tubc."

I. 2 
spontaneously self-fertilised sceds just mentioned, and crossed seeds obtained by intererossing the two crossed plants of the last generation, after germinating on sand, werc planted in pairs on the opposite sides of tlurec large pots. When the seedlings were only 4 inches in height, the crossed had a slight advantage over their opponents. When grown to their full height, every one of the erossed plants excecded its opponent in height. Nevertheless the self-fertilised plants in all three pots flowered beforc the crossed! The measurements are given in the following table :-

\section{TABLE LII.}

Lupinus luteus.

\begin{tabular}{|c|c|c|}
\hline No. of Pot. & Crossed I'lants. & Self-fertılised Plants. \\
\hline I. & $\begin{array}{c}\text { Inches. } \\
33 \frac{2}{8} \\
30 \frac{1}{8} \\
30\end{array}$ & $\begin{array}{c}\text { Inches. } \\
24 \frac{4}{6} \\
18 \frac{1}{8} \\
28\end{array}$ \\
\hline II. & $\begin{array}{l}29+\frac{1}{8} \\
30^{8}\end{array}$ & $\begin{array}{l}26 \\
25\end{array}$ \\
\hline III. & $\begin{array}{l}30 \frac{4}{8} \\
31 \\
31 \frac{4}{8}\end{array}$ & $\begin{array}{l}28 \\
27 \frac{2}{8} \\
24 \frac{4}{8}\end{array}$ \\
\hline Total in inches. & $246 \cdot 2 j$ & $201 \cdot 75$ \\
\hline
\end{tabular}

The eight crossed plants here average $30 \cdot 78$, and the cight self-fertilised $25^{2} 21$ incles in height; or as 100 to 82 . These plants were left uncovered in the grecnhouse to set their pods, but they prodnced very few good ones, perhaps in part owing to few becs visiting them. The crossed plants produced nine pods, eontaining on an average 3.4 sceds, and the sclf-fertilised plants seven pods, eontaining on an average 3 sceds, so that the secds from an equal number of plants were as 100 to $S 8$.

'I'wo other crossed secllings, each with two sclf-fertilised scedlings on the opposite sides of the same large pot, were turned out of their pots carly in the scason, witlont being disturbed, into open ground of good quality. They were thus subjected to but little competition with onc another, in comparison with the plants in the above tliree pots. In the autumu 
the two crossed plants were about 3 inches taller than the four self-fertilised plants; they looked also more vigorous and produced many more pods.

Two otlicr crossed and self-fertilised seeds of the same lot, after germinating on sand, wcre planted on the opposite sides of a large pot, in which a Calceolaria had long been growing, and were therefore exposed to unfavourable conditions: the two crossed plants ultimately attained a height of $20 \frac{1}{2}$ and 20 inches, whilst the two self-fertilised were only 18 and $9 \frac{1}{2}$ inches high.

\section{LUPINUS PILOSUS.}

From a series of accidents I was again unfortumate in obtaining a sufficient number of crossed seedlings; and the following results would not be worth giving, did they not strictly accord with those just given with respect to L. luteus. I raised at first only a single crossed seedling, which was placed in competition with two self-fertilised ones on the opposite side of the same pot. These plants, without being disturbed, were soon afterwards turned into the open ground. By the autumn the crossed plant had grown to so large a size that it almost smothered the two self-fertilised plants, which were mere dwarfs; and the latter died without maturing a single pod. Several selffertilised seeds had been planted at the same time separately in the open ground; and the two tallest of these wore 33 and 32 inches, whereas the one crossed plant was 38 inches in height. This latter plant also produced many more pods than did any one of the self-fertilised plants, although growing separately. A few flowers on the one crossed plant were crossed with pollen from one of the self-fcrtilised plants, for I had no other crossed plant from which to obtain pollen. One of the self-fertilised plants having becn covered by a net produced plenty of spontaneously sclf-fertilised pods.

Crossed and self-fertilised Plants of the Second Generation.-From crossed and self-fertilised seeds obtained in the manner just described, I succeeded in raising to maturity only a pair of plants, which were kept in a pot in the greenhouse. The crossed plant grew to a height of 33 inches, and the self-fertilised to that of $26 \frac{1}{2}$ inches. 'The former produced, whilst still kept in the grcenhouse, eight pods, containing on an average $2 \cdot 77$ seeds; and the latter only two pods, containing on all average $2 \cdot 5$ seeds. The average height of the two crossed plants of the two 
generations taken together was $35 \cdot 5$, and that of the three selffertilised plants of the same two generations 30.5 ; or as 100 to $86 .^{*}$

\section{Phaseolus multiflorus.}

This plant, the scarlet-runner of English gardener's and the $P$. cocineus of Lamarck, originally came from Mexico, as I am informed by Mr. Bentham. The flowers are so constructed that hive and humble-bees, which visit them incessantly, almost always alight on the left wing-petal, as they can best suck the nectar from this side. Their weight and movements depress the petal, and this causes the stigma to protrude from the spirally-round keel, and a brush of hairs round the stigma pushes ont the pollen before it. The pollen adheres to the head or proboscis of the bee which is at work, and is thus placed either on the stigma of the same flower, or is carried to another flower.t Several years ago I covered some plants under a large net, and these produced on one occasion about one-third, and on another occasion about one-cighth, of the number of pods which the same number of uncovered plants growing close alongside produced.f This lessened fertility was not caused by auy injury from the net, as I moved the wing-petals of several protected flowers, in the same manner as bees do, and these produced remarkably

* We here see that both r.upinus luteus and pilosus secd freely whon insects are exeluded; but Mr. Swale, of Christchureh, in New Zealand, informs me (seo 'Gardeners' Chronicle,' 1858, p. 828) that the garden varicties of the lupine are not there visited lyy any bees, and that they seed less freely than any other introduced leguminuus plant, with the exception of rel clover. He adds, "I have, for amuscment, during the summer, released the stamens with a pin, and a porl of secd has always rewarded me for my trouble, the adjoining fluwers lot so served hiving all proved blincl." I do not know to what speeies this statement refers.

$t$ The flowers have been deseribed by Delpino, and in $\mathrm{an}$ arlmirable manuer by Mr. Farrer in the 'Annals and Mag. of Nat. Hist.' vol. ii. (4th serics) Oet. IS68, p. 256. MIy son Franeis has explained ('Nuture,' Jan. 8, I87t, p. 189) the use of onc peculiarity in their structure, numely, a little vertical projection on the single free stamen near its base, which seems placed as if to guard the entrance into the two nectarholes in the staminal sheath. He shows that this projection prerents the bees reaehing the nectar, unle'ss they go to the left side of the flower, and it is absolutely nceessary for eross-f rertilisation that they should alight on the left wing-petal.

‡ 'Gardeners' Chronicle,' 1857; p. 725 , and more esplecially ibid, 1858, p. 828. Al:o 'Ammals and May. of Nit. Hist.' :Hrd series, vol. ii. I858, p. 462 . 
fine pods. When the net was taken off, the flowers were immediately visited by bees, and it was interesting to observe how quickly the plants became covered with young pods. As the flowers are much frequented by Thrips, the self-fertilisation of most of the flowers under the net may have bcen clue to the action of these minute insects. Dr. Ogle likewise covered up a large portion of a plant, and "out of a vast number of blossoms thus protected not a single one produced a pod, while the unprotected blussoms were for the most part fruitful." Mr. Belt gives a more curious case; this plant grows well and flowers in Nicaragua; but as none of the native bees visit the flowers, not a single pod is ever produced.*

From the facts now given we may feel nearly sure that individuals of the same variety or of diffcrent varieties, if growing near each other and in flower at the same time, would intercross; but I cannot myself advance any direct evidence of such an occurrence, as only a single variety is commonly cultivated in England. I have, however, reccived an account from the Rev.' W. A. Leighton, that plants raised by him from ordinar'y seed produced seeds differing in an extraordinary manner in colour and shape, leading to the bclief that their parents must have been crossed. In France MI. Fermond more than once planted close together varieties which ordinarily come true and which bear differently coloured flowers and seeds; and the offspring thus raised varied so greatly that there could hardly be a cloubt that they had intercrossed. $\dagger$ On the other hand, Professor $\mathrm{H}$. Hoffmann $\neq$ does not believe in the natural crossing of the varieties; for although seedlings raised from two varieties growing close together produced plants which yielded seeds of a mixed character, he found that this likewise occurred with plants separated by a space of from 40 to 150 paces from any other variety; he therefore attributes the mixed character of the seed to sponta-

* Dr. ()gle, 'Pop. Science Review, 1870, p. 168. Mr. Belt, 'The Naturalist in Nicaragu,' 1874, p. 70. The latter author gives a case ('Nature,' 1875, j. 26) of a late crop of $P$. multiflorus near London, which "was rendered barren" by the humblebees cutting, as they froquently do, holes at the bases of the fluwers instead of entering them in the proper manner.

† 'Fécondation elıcz les Végétatux, 1859, pp. 3t-40. He alds that M. Villiers has described a spontaneous hybrid, which he calls $P$. coccineus hybridus, in the - Annales de la Sos. R. de Hortieulture,' June 184t.

f 'Bestimmung des Werthes von Species und Varietiit,' 1869, pp. 47-72. 
neous variability. But the above distance would be very far from sufficient to prevent intercrossing: cabbages have bcen known to cross at several times this distance; and the carcful Gärtncr* gives many instances of plants growing at from 600 to 800 sards apart fertilising one another. Professor Hoffmann even maintains that the flowers of the kidney-bean are specially adapted for self-fertilisation. He enclosed several flowers in bags; and as the buds often dropped off, he attributcs the partial sterility of these flowers to the injurious effects of the bags, and not to the exclusion of insects. But the only safe method of experimenting is to cover up a whole plant, which then never suffers.

Self-fertilised seeds were obtained by moving up and down in the same manner as bces do the wing-petals of flowers protected by a net; and crossed seeds were obtained by crossing two of the plants undcr the same net. The seeds after germinating on sand were planted on the oppositc sidcs of two large pots, and equalsized sticks were given them to twine up. When 8 inches in height, the plants on the two sides were equal. The crossed plants flowered bcfore the self-fertilised in both pots. As soon as one of each pair had grown to the summit of its stick botly were measured.

TABLE LIIT.

Phaseolus multiforus.

\begin{tabular}{|c|c|c|}
\hline No. of Pot. & Crossed Plants. & Self-fertilised Plant8. \\
\cline { 1 - 3 } \cline { 3 - 3 } & Inches. & Inches. \\
& 87 & $84 \frac{6}{8}$ \\
& 88 & 86 \\
& $82 \frac{4}{8}$ & 76 \\
\hline II. & 90 & $86 \frac{4}{8}$ \\
& $82 \frac{4}{8}$ & $87 \frac{4}{8}$ \\
\hline Total in inches. & $430 \cdot 00$ & $411 \cdot 75$ \\
\hline
\end{tabular}

The average height of the five crossed plants is 86 inches, and that of the five self-fertilised plants $82 \cdot 35$; or as 100 to 96 . The pots were kept in the grcenhouse, and there was little or no difference in the fertility of the two lots. Therefore as far as these few observations serve, the advantagc gained by a cross is very small.

* 'Kenntniss der Befruchtung,' 184t, pp. 573, 577. 


\section{Phaseolus vulgaris.}

With respect to this species, I merely ascertained that the flowers were highly fertile when insects were cxcluded, as indeed must be the case, for the plants are often forced during the winter when no insects are present. Some plants of two varieties (viz., Canterbury and Fulmer's Forcing Bean) were covered with a net, and they seemed to produce as many pods, containing as many beans, as some uncovered plants growing alongside; but neither the pods nor the beans were actually counted. This difference in self-fertility between $P$. vulgaris and multiflorus is remarkable, as these two species are so closely related that Linnæus thought that they formed one. When the varieties of $P$. vulgaris grow near one another in the open ground, they sometimes cross largely, notwithstanding their capacity for selffertilisation. Mr. Coe has given me a remarkable instance of this fact with respect to the negro and a white-seeded and a brown-seeded variety, which were all grown together. The diversity of character in the seedlings of the second generation raised by me from his plants was wonderful. I could add other analogous cases, and the fact is well known to gardeners.*

\section{LATHYRUS ODORATUS.}

Almost everyone who has studied the structure of papilionaceous flowers has been convinced that they are specially adapted for cross-fertilisation, although many of the species are likewise capable of self-fertilisation. The case therefore of Lathyrus odoratus or the sweet-pea is curious, for in this country it seems invariably to fertilise itself. I conclude that this is so, as five varieties, differing greatly in the colour of their flowers but in no other respect, are commonly sold and come true; yet on inquiry from two great raisers of seed for sale, I find that they take no prccautions to insure purity-the five varietics being habitually grown close together. $\dagger$ I have myself purposely made similar trials with the same result. Althongh the varietics alway's come true, yet, as we shall presently sce, one

* I have given Mr. Coe's ease in the 'Gardener's' Chronicle, 1858 , p. 829 . Sce also for anotluer case, ibid. p. 845.

† Sce Mr. W. Earley in ' $\mathrm{Na}$ - ture,' 1872, p. 242. to the rame eftect. He once, however, saw bees visiting the flowers, and supposed thut on this oecasion they would have been intercrossed. 
of the five well-known varieties oecasionally gives birth to another, which exhibits all its usual characters. Owing to this curious faet, and to the darker-coloured varieties being the most productive, thesc increase, to the exclusion of the others, as I was informed by the late Mr. Masters, if there be no seleetion.

In order to ascertain what would be the effect of crossing two varieties, some flowers on the Purple sweet-pen, whicls has a dark reddish-purple standard-petal with violet-coloured wingpctals and lieel, were castrated whilst vcry young, and were fertilised with pollen of the Painted Lady. This latter variety has a pale cherry-coloured standard, with almost white wings and keel. On two oceasions I raised from a flowcr thus crossed plants perfectly resembling both parent-forms; but the greater number resembled the paternal variety. So perfect was the resemblance, that $I$ should have suspected some mistake in the label, had not the plants, which were at first identieal in appearance with the father or l'ainted Lady, later in the season produced flowers blotched and streaked with dark purple. This is an interesting example of partial reversion in the same individual plant as it grows older. The purple-flowered plants were throrm away, as they might possibly have been the product of the accidental self-fertilisation of the mother-plant, owing to the castration not having been effectual. But the plants which resembled in the colour of their flowers the paternal variety or Painted Lady were preserved, and their seeds sared. Next summer many plants were raised from these seeds, and they generally resembled their grandfather the Painted Lady, but most of them had their wing-petals streaked and staincd with dark pink; and a few had pale purple wings with the standard of a darker erimson than is natural to the Painted Lady, so that they formed a new sub-variety. Amongst these plants a single one appeared having purple flowers like those of the grandmother, but with the petals slightly streaked with a paler tint: this was thrown away. Seeds were again saved from the foregoing plants, and the seedlings tlius raised still resembled the Painted Lady, or great-grandfather; but they now raried much, the standard petal varying from pale to dark red, in a few instanees with blotches of white; and the wing-petals raried from nearly white to purple, the licel being in all nearly white.

As no variability of this kind can be detected in plants raised from seeds, the parents of which have grown during many successive generations in elose proximity, we may infer that they 
cannot have intcrerossed. That does oceasionally oeeur is that in a row of plants raised from seeds of one variety, another variety true of its kind appears; for instance, in a long row of Searlets (the seeds of which had been carcfully gathered from Searlets for the sake of this experiment) two Purples and one Painted Lady appcared. Seeds from these three aberrant plants were saved and sown in separate beds. The seedlings from both the Purples werc ehicfly Purples, but with some Painted Ladies and some Scarlets. The seedlings from the aberrant Painted Lady were ehiefly Painted Ladies with some Searlets. Each variety, whatevcr its parentage may have been, retained all its eharaeters perfcct, and there was no streaking or blotching of the colours, as in the foregoing plants of erossed origin. Another variety, however, is often sold, which is striped and blotehed with dark purple; and this is probably of crossed origin, for I found, as well as Mr. Masters, that it did not transmit its characters at all truly.

From the evidence now given, we may eonelude that the varieties of the sweet-pea rarely or never intereross in this eountry; and this is a highly remarkable fact, considering, firstly, the gencral structure of the flowers; sceondly, the large quantity of pollen produeed, far more than is requisite for self-fertilisation; and thirdly, the occasional visits of inscets. That inseets should sometimes fail to cross-fertilise the flowers is intelligible, for I have thriee seen humble-bees of two kinds, as well as hive-bces, sucking the neetar, and they did not depress the keel-pctals so as to cxpose the anthers and stigma; thcy werc therefore quite inefficient for fcrtilising the flowers. One of these bees, namely, Bombus lapidarius, stood on onc side at the base of the standard and inserted its proboseis beneath the single separate stamen, as I aftcrwards aseertained by opening the flower and finding this stamen prised up. Bees are foreed to act in this manner from the slit in the staminal tube bcing closely covcred by the broad membranous margin of the single stamen, and from the tube not bcing perforated by nectar-passages. On the other hand, in the threc British speeies of Lathyrus whieh I have examined, and in the allied genus Vieia, two ncetar-passages are prescnt. 'Therefore British bees might well be puzzled how to act in the easc of the sweet-pca. I may add that the staminal tube of another exotic speeics, Lathyrus grandifloru", is not perforated by nectar-passages, and this speeies has rarcly set any pods in my garden, unless the wing-petals were moved up and 
down, in the same manner as bees ought to do; and then pods were generally formed; but from some cause often dropped off afterwards. One of my sons eaught an elephant sphinx-moth whilst visiting the flowers of the sweet-pea, but this insect wonld not depress the wing-petals and keel. On the other hand, I have seen on one occasion hive-bees, and two or three oecasions the Megachile willughbiella in the act of depressing the keel; and these bees had the under sides of their bodies thiekly covered with pollen, and could not thus fuil to carry pollen from one flower to the stigma of another. Why then do not the varieties oeeasionally intercross, though this would not often happen, as insects so rarely act in an efficient manner? The fact cannot, as it appears, be explained by the flowers being self-fertilised at a very early age; for although neetar is sometimes secreted and pollen adheres to the viseid stigma before the flowers are fully expanded, yet in five young flowers which were examined by me the pollen-tubes were not exserted. Whatever the cause may be, we may eonclude, that in England the varieties never or very rarely intereross. But it does not follow from this, that they would not be crossed by the aid of other and larger insects in their native country, which in botanieal works is said to be the south of Enrope and the East Indies. Accordingly I wrote to Professor Delpino, in Florenee, and he informs me "that it is the fixed opinion of gardeners there that the varieties do intercross, and that they eamnot be preserved pure unless they are sown separately."

It follows also from the foregoing facts that the several varieties of the sweet-pea must have jropagated themselves in England by self-fertilisation for very many generations, since the time when each new variety first appeared. From the analogy of the plants of Mimulus and Ipomoea, which had been self-fertilised for several generations, and from trials previously made with the common pea, which is in nearly the same state as the sweetper, it appeared to me very improbable that a cross between the individuals of the same variety would benefit the offspring. A eross of this kind was therefore not tried, which I now regret. But some flowers of the Painted Lady, castrated at an early age, were fertilised with pollen from the Purple sweet-pea; and it should be remembered that these varieties differ in nothing except in the colour of their flowers. The cross was manifestly effectual (though only two seeds mere obtained), as was shown by the two seedlings, when they flowered, closely resembling 
their father, the Purple pea, exeepting that they were a little lightel coloured, with their keels slightly streaked with pale purple. Seeds from flower's spontaneously self-fertilised under a net were at the same time saved from the samt mother-plant, the Painted Lady. These seeds unfortunately did not germinate on sand at the same time with the erossed seeds, so that they eould not be planted simultaneously. One of the two erossed seeds in a state of germination was planted in a pot (No. I.) in which a self-fertilised seed in the sawe state had been planted four days befure, so that this latter seedling had a great advantage over the erossed one. In Pot II. the other erossed seed was planted two dajs before a self-fertilised one; so that here the erossed seedling had a eonsiderable advantage over the self-fertilised one. But this erossed seedling had its summit gnawed off by a slug, and was in eonsequenee for a time quite beaten by the selffertilised plant. Nevertheless I allowed it to remain, and so great was its eonstitutional vigour that it ultimately beat its uninjured self-fertilised rival. When all four plants were almost fully grown they were measured, as here shown :-

TABLE LIV.

Lathyrus odoratus.

\begin{tabular}{|c|c|c|}
\hline No. of Pot. & Crossed Plants. & Self-fertilised Plants. \\
\hline I. & $\begin{array}{c}\text { Inches. } \\
\text { So }\end{array}$ & $\begin{array}{c}\text { Inches. } \\
64 \frac{3}{8}\end{array}$ \\
\hline II. & $78_{8}^{4}$ & 63 \\
\hline Total in inches. & $158 \cdot 5$ & $127 \cdot 5$ \\
\hline
\end{tabular}

The two crossed plants here average $79 \cdot 25$, and the two selffertilised $63 \cdot 75$ inehes in height, or as 100 to 80 . Six flowers on these two erossed plants were reeiproeally erossed with pollen from the other plant, and the six pods thus produeed eontained on an average six peas, with a maximum in one of seven. Eighteen spontaneously self-fertilised pods from the Painted Lady, whieh, as already stated, had no doubt been self-fertilised for many previous generations, eontained on an average only 3.93 peas, with a maximum in one of five peas; so that the number of peas in the erossed and self-fertilised pods was as 100 to 65. 
The self-fertilised peas were, however, quite as heavy as those from the erossed pods. From these two lots of seeds, the plants of the next generation were raised.

Plants of the Second Generution.-Many of the self-fertilised peas just referred to germinated on sand before any of the erossed ones, and were rejeeted. As soon as I got equal pairs, they were planted on the opposite sides of two large pots, whieh were kept in the greenhouse. The seedlings thus raised were the grandehildren of the Painted Lady, whieh was first crossed by the Purple variety. When the two lots were from 4 to 6 inehes in height there was no differenee between them. Nor was there any marked difference in the period of their flowering. When fully grown they were measured, as follows :-

TABLE LV.

Luthyrus odoratus (Second Generation).

\begin{tabular}{|c|c|c|}
\hline No. of Put. & $\begin{array}{c}\text { Seedlings from Plints } \\
\text { crossed during the } \\
\text { two previous Genera- } \\
\text { tions. }\end{array}$ & $\begin{array}{c}\text { Seedings from Plants } \\
\text { selfertilised during } \\
\text { many previuus } \\
\text { Generations. }\end{array}$ \\
\hline I. & $\begin{array}{c}\text { Inches. } \\
72 \frac{4}{8}\end{array}$ & $\begin{array}{c}\text { Inches. } \\
57 \frac{4}{8} \\
71\end{array}$ \\
& $52 \frac{2}{8}$ & $56 \frac{2}{8}$ \\
\hline II. & $81 \frac{4}{8}$ & $66 \frac{2}{8}$ \\
& $45 \frac{2}{8}$ & 38 \\
\hline Total in inches. & 55 & 46 \\
\hline
\end{tabular}

The average height of the six erossed plants is here 62.91 , and that of the six self-fertilised 55.31 inches; or as 100 to 88. There was not mueh differenee in the fertility of the two lots; the erossed plants having produced in the greenhouse thirty-fire pods, and the self-fertilised thirty-two pods.

Seeds were saved from the self-fertilised flowers on these two lots of plants, for the sake of ascertaining whether the seedlings thus raised would inherit any differenee in growth or vigour. It must therefore be understood that both lots in the following trial are plants of self-fertilised parentage; but that in the one lot the plants were the ehildren of plants whieh had been erossed during two previous generations, having been before that self- 
fertilised for many generations; and that in the other lot they were the children of plants which had not been crossed for very many previous generations. The seeds germinated on sand and were planted in pairs on the opposite sides of fom pots. They wcre measured, when fully grown, with the following result:-

TABLE LVI.

Lathyrus odoratus.

\begin{tabular}{|c|c|c|}
\hline No. of Pot. & $\begin{array}{c}\text { Self-fertilised Plants } \\
\text { from Crossed Plunts. }\end{array}$ & $\begin{array}{c}\text { Self-fertilised Plunts } \\
\text { foum Self-fertilised } \\
\text { Plants. }\end{array}$ \\
\hline I. & $\begin{array}{c}\text { Inches. } \\
72\end{array}$ & $\begin{array}{c}\text { Inches. } \\
65 \\
62\end{array}$ \\
\hline II. & $61 \frac{4}{8}$ \\
\hline & 58 & 64 \\
& 68 & $68 \frac{2}{8}$ \\
III. & $72 \frac{1}{8}$ & $60 \frac{2}{8}$ \\
\hline IV. & 81 & $76 \frac{1}{8}$ \\
\hline Total in inches. & $77 \frac{1}{8}$ & 452 \\
\hline
\end{tabular}

The average height of the seven self-fertilised plants, the offspring of crossed plants, is $71 \cdot 57$, and that of the seven self-fertilised plants, the offspring of self-fertilised plants, is 64.57 ; or as 100 to 90 . The self-fertilised plants from the self-fertilised produced rather more pods-viz., thirty-six-than the self-fertilised plants from the crossed, for these prodnced only thirty-one pods.

A few sceds of the same two lots were sown in the opposite cormers of a large box in which a Brugmansia had long been growing, and in which the soil was so exhansted that seeds of Ipomoea purpurea would hardly vegetate; yet the two plants of the swcet-pea which were raised flourished well. For a long time the self-fertilised plaut from the self-fertilised beat the selffertiliscd plant from the crossed plant; the former flowered first, and was at one time $77 \frac{1}{2}$ inches, whilst the latter was only $68 \frac{1}{2}$ in height; but ultimately the plant from the previous cross showed its superiority and attained a height of $108 \frac{1}{2}$ inches, whilst the other was only 95 .inches. I also sowed some of the same two 
lots of seeds in poor soil in a shady place in a shrubbery. Here again the self-fertilised plants from the self-fertilised for a long time exeeeded eonsiderably in height those from the previously erossed plants; and this may probably be attributed, in the present as in the last ease, to these seeds having germinated rather sooner than those from the crossed plants; hut at the close of the season the tallest of the self-fertilised plants from the erossed plants was 30 inehes, whilst the tallest of the selffertilised from the self-fertilised was $29 \frac{3}{8}$ inehes in height.

From the various faets now given we see that plants derived from a eross between two varieties of the sweet-pea, which differ in no respeet exeept in the eolour of their flowers, exeeed eonsiderably in height the offspring from self-fertilised plants, both in the first and seeond generations. The erossed plants also transmit their superiority in height and vigour to their self-fertilised offspring.

\section{Pisum sativum.}

The common pea is perfeetly fertile when its flowers are protected from the visits of inseets; I aseertained this with two or three different varieties, as did Dr. Ogle with another. But the flowers are likewise adapted for eross-fertilisation; Mr. Farrel" speeifies * the following points, namely: "The open blossom displaying itself in the most attraetive and eonvenient position for inseets; the eonspienous vexillum; the wings formiug an alighting plaee; the attaehment of the wings to the keel, by whieh any body pressing on the former must press down the latter; the staminal tube enelosing neetar, and affording by means of its partially free stamen with apertures on eaeh side of its base an open passage to an inseet seeking the neetar; the moist and stieky pollen plaeed just where it will be swept out of the apex of the keel against the entering inseet; the stiff elastie style so placed that on a pressure being applied to the keel it will be pushed upwards out of the keel; the hairs on the style plaeed on that side of the style only on which there is spaee for the pollen, aud in sueh a direetion as to sweep it out; and the stigma so plaeed as to meet an entering inseet, - all these beeome correlated parts of one elaborate meehanism, if we

* 'Nature, Uct. 10, 157:2, p. 479. H. Miiller gives an Mlibnrate description of the Hlowers, 'Be. fruchtung, sc. p. 247. 
suppose that the fertilisation of these flowers is effeeted by the earriage of pollen from one to the other." Notwithstanding these manifest provisions for eross-fertilisation, varicties whieh have been eultivated for very many sueeessive generations in elose proximity, although flowering at the same time, remain pure. I have elsewhere* given evidence on this head, and if required eould give more. There ean hardly be a doubt that some of Knight's varieties, whieh were originally produeed by an artifieial eross and were very vigorous, lasted for at least sixty years, and during all these years were self-fertilised; for had it been otherwise, they would not have kept true, as the several varieties are generally grown near together. Most of the varieties, however, endure for a shorter period; and this may be in part due to their weakness of eonstitution from long-eontinued selffertilisation.

It is remarkable, eonsidering that the flowers seerete muel neetar and afford mueh pollen, how seldorn they are visited by inseets either in England or, as H. Mïller remarks, in North Germany. I have observed the flowers for the last thirty years, and in all this time have only thriee seen bees of the proper kind at work (one of them being Bombus muscorum), snell as were suffieiently porrerful to depress the keel, so as to get the rundersides of their bodies dnsted with pollen. These bees visited several flower's, and eould hardly have failed to eross-fertilise them. Hive-bees and other small kinds sometimes eolleet pollen from old and already fertilised flowers, but this is of no aecount. The rarity of the visits of effieient bees to this exotie plant is, I believe, the ehief eause of the varieties so seldom intererossing. That a eross does oeeasionally take place, as might be expeeted from what has just been stated, is eertain, from the reeorded eases of the direet aetion of the pollen of one variety on the seed-eoats of another. $\dagger$ The late Mr. Masters, who partieularly attended to the raising of new varieties of peas, was convinced that some of them had originated from aceidental erosses. But as sueh erosses are rare, the old varieties would not often be thus deteriorated, more espeeially as plants departing from the proper type are generally rejeeted by those who eolleet seed for sale. There is another eanse which probably tends to render eross-fertilisation rare,

* "Variation of Animuls and Plants under Domestication, chap. ix. 2nd clit. vol, i. 1, 348.
† 'Var. under Domestication,' cha1. xi. 2nd edit. vol. i. p. 428. 
namely, the early age at whieh the pollen-tubes are exserted; cight flowers not fully expanded were examined, and in seven of these the pollen-tubes were in this state; but they liad not as yet penetrated the stigma. Although so few inseets visit the flowers of the pea in this eountry or in North Germany, and although the anther's seem here to open abnormally soon, it does not follow that the species in its native country would be thus eireumstanced.

Owing to the varieties having been self-fertilised for many generations, and to their having been subjeeted in each generation to nearly the same conditions (as will be explained in a future chapter), I did not expeet that a eross between two sueh plants would benefit the offspring; and so it proverl on trial. In 1867 I covered up several plants of the Early Emperor pea, which was not then a very new varicty, so that it must already have been propagated by self-fertilisation for at least a dozen generations. Some flowers were erossed with pollen from a distinet plant growing in the same row, and others were allowed to fertilise themselves under a net. The two lots of sceds thus obtained were sown on opposite sides of two large pots, but only four pair's eame up at the same time. The pots rere kept in the greenhouse. The seedlings of both lots when between 6 and 7 inehes in height were equal. When nearly full-grown they were measured, as in the following table:-

TABLE LVII.

Pisum sutivum.

\begin{tabular}{|c|c|c|}
\hline No. of Pot. & Crossed Plants. & Self-fertilised Plants. \\
\cline { 1 - 2 } & $\begin{array}{c}\text { Inches. } \\
35\end{array}$ & $\begin{array}{c}\text { Inches. } \\
29 \frac{6}{8}\end{array}$ \\
\hline I. & $31 \frac{1}{8}$ & 51 \\
& 35 & 45 \\
& 37 & 33 \\
\hline Total in inches. & $135 \cdot 50$ & $158 \cdot 76$ \\
\hline
\end{tabular}

The average height of the four crossed plints is here $3 \pm \cdot 62$, and that of the four self-fertilised plants $39 \cdot 68$, or as 100 to 115 . So that the erossed plants, far from beating the self-fertilised, were eompletely beaten by them. 
There can be no doubt that the result would have beer. widely different, if any two varieties out of the numbcrless ones which exist had been crossed. Notwithstanding that both had been self-fertilised for many previous geuerations, each would almost certainly have possessed its own peculiar constitution; and this degrce of differentiation would have been sufticient to make a cross highly beneficial. I have spoken thus confidently of the benefit which would have been derived from crossing any two varieties of the pca from the following facts: Andrew Knight in speaking of the results of crossing reciprocally very tall and short varieties, says," "I had in this experiment a striking instance of the stimulative effects of crossing the breeds ; for the smallcst variety, whose height rarely exceeded 2 feet, was increased to 6 feet; whilst the height of the large and luxuriant kind was very little diminished." Reccntly Mr. Laxton las made numerons crosses, and everyone has been astonished at the vigour and luxuriance of the new varieties which he has thus raised and afterwards fixed by selection. He gave me seed-peas produced from crosses between four distinct kinds; and the plants thus raised were extraordinarily vigorous, being in each case from 1 to 2 or even 3 feet taller than the parent-forms, which were raised at the same time close alongside. But as I did not measurc their actual height I cannot give the exact ratio, but it must have been at lcast as 100 to 75 . A similar trial was subscquently made with two othcr pcas from a different cross, and the result was nearly the samc. For instance, a crossed seedling between the Maple and Purple-podded pea was planted in poor soil and grew to the extraordinary height of 116 inches ; whereas the tallest plant of either parent variety, namely, a Purple-podded pea, was only 70 inches in height; or as 100 to 60.

\section{SarothaynUS SCOPARIUS.}

Bees incessantly visit the flowcrs of the common Broom, and these arc adapted by a curious mcchanism for cross-fertilisation. When a bee alights on the wing-petals of a young flower, the keel is slightly opencd and the short stamens spring out, which rub their pollen against the abdomen of the bce. If a rather older flower is visited for the first time (or if the bee exerts great force on a younger flower), the keel opeus along its wholc length, and the longer as well as the shorter stamens, together 
with the much elongated curved pistil, spring forth with violence. 'The flattened, spoon-like extremity of the pistil rests for' a time on the back of the bee, and leaves on it the load of pollen with which it is charged. As soon as the bee flies away, the pistil instantly curls round, so that the stigmatic surface is now upturned and occmpies a position, in which it would be rubbed against the abdomen of another bee risiting the same flower. Thus, when the pistil first escapes from the keel, the stigma is rubbed against the back of the bee, dusted with pollen from the longer stamens, either of the same or another flower; and afterwards against the lower surface of the bee dusted with pollen from the shorter stamens, which is often shed a day or two hefore that from the longer stamens. * By this mechanism cross-fertilisation is rendered almost inevitable, and we shall immediately see that pollen from a distinct plant is more effective than that from the same flower. I need only aild that, according to H. Miüller, the flowers do not secrete nectar, and he thinks that bees insert their proboscides only in the hope of finding nectar; but they act in this manner so frequently and for so long a time that I cannot aroid the belief that they obtain something palatable within the flowers.

If the visits of bees are prevented, and if the flowers are not dashed by the wind against any ohject, the lieel never opens, so that the stamens and pistil remain enclosed. Plants thus protected yicld very few pods in comparison with those prodncer by neighbouring uncorered bushes, and sometimes none at all. I fertilised a few flowers on a plant growing almost in a state of nature with pollen from another plant close alongside, and the four crossed capsules contained on an average 9.2 sechs. This large number no donbt was dne to the busl being covered $m p$, and thus not exhansted lyy producing many pods; for fifty pods gathered from an aljoining plant, the flowers of which had been fertilised by the hees, contained an average of only $7 \cdot 14$ seeds. Nincty-tlurce lods spontanconsly self-fertilised on a large bush which harl becn covered up, hut had been much agitated ly the wind, confained an average of 2.93 seeds. Ten of the finest of these ninety-

* These obsrrivations have been quoted in ast ablineviated linm by the liev. C. Henslow, in the 'Journal of limn. soc. Bot.' rol. ix. IS66, p. 3.is. M. Müller las since publisted a full and exeellent aceount of the flower in his -Befiruclitulyg; dic. 1). 210. 
three capsules yielded an arerage of $4 \cdot 30$ seeds, that is less than lialf the arerage number in the four artificially crossed capsules. The ratio of $7 \cdot 14$ to $2 \cdot 93$, or as 100 to 41 , is probably the fairest for the number of seeds per pod, yielded by naturallycrossed and spontmeously self-fertilised flowers. The crossed sceds compared with an equal number of the spontaneously selffertilisen seeds were heavier, in the ratio of 100 to 88 . We thus see that besides the mechanical adaptations for cross-fertilisation, the flowers are much more productire with pollen from a distinct plant than with their own pollen.

Eight pairs of the above crossed and self-fertilised seeds, after they had germinated on sand, were planted (1867) on the opposite sides of two large pots. When several of the seedlings were an inch and a half in height, there was no marked difference between the two lots. But even at this early age the leaves of the self-fertilised seedlings were smaller and of not so bright a green as those of the crossed seedlings. The pots were kept in the greenlouse, and as the plants on the following spring (1868) looked mhealthy and had grown but little, they were plunged, still in their pots, into the open ground. The plants all suffered much from the sudden change, especially the self-fertilised, and two of the latter died. The remainder were measured, and I give the measurements in the following table, because I have not seen in any other species so great a difference between the crosserl and self-fertilised seedlings at so early an age.

\section{TABLE LVIII.}

Surothamnus scoparius (very young plunts).

\begin{tabular}{|c|c|c|}
\hline \multirow{2}{*}{ To. of Pot. } & Crossed Plants. & Self-fertilised Plants. \\
\cline { 1 - 3 } & Inches. & Inches. \\
& $4 \frac{1}{8}$ & $2 \frac{4}{8}$ \\
& 6 & $1 \frac{4}{8}$ \\
& 2 & 1 \\
\hline I. & 2 & $1 \frac{4}{5}$ \\
\cline { 1 - 3 } & $2 \frac{4}{8}$ & 1 \\
\hline Total in inches. & $0 \frac{\frac{1}{8}}{8}$ & $8 \cdot 0$ \\
\hline
\end{tabular}

The six crossed plants here average $2 \cdot 91$, and the six self- 
fertilised 1.33 inches in height; so that the former were more than twice as high as the latter, or as 100 to 46 .

In the spring of the sueeeding year (1869) the three crossed plants in Pot I. had all grown to nearly a foot in height, and they lad smothered the three little self-fertilised plants so eompletely that two were dead; and the third, only an ineh and a half in height, was dying. It should be remembered that these plants had been bedded out in their pots, so that they were subjeeted to very severe competition. This pot was now thrown away.

The six plants in Pot II. were all alive. One of the selffertilised was an inch and a quarter taller than any owe of the crossed plants; but the other two self-fertilised plants were in a very poor condition. I therefore resolved to leave these plants to struggle together for some rears. By the autumn of the same year (1869) the self-fertilised plant whieh had been victorious was now beaten. The measurements are shown in the following table :- .

TABLE IIIX.

Pot II.-Sarothamnus scoparizes.

\begin{tabular}{|c|c|}
\hline Crossed Flants. & Self-fertilised Plants. \\
\cline { 2 - 2 } Inches. & Inches. \\
$15 \frac{6}{8}$ & $13 \frac{1}{8}$ \\
$9 \frac{6}{8}$ & 3 \\
$8 \frac{2}{8}$ & $2 \frac{4}{8}$ \\
\hline
\end{tabular}

The same plants were again measured in the autumn of the following year, 1870 .

TABLE LX.

Pot II.-Surothamnus scoparius.

\begin{tabular}{|c|c|}
\hline Crossed Plants. & Self-fertilised Plants. \\
\cline { 2 - 2 } Inches. & Inches. \\
$26 \frac{2}{8}$ & $14 \frac{2}{8}$ \\
$16 \frac{4}{8}$ & $11 \frac{4}{8}$ \\
14 & $9 \frac{6}{8}$ \\
\hline $56 \cdot 75$ & $35 \cdot 50$ \\
\hline
\end{tabular}


The three erossed plants now averaged $18 \cdot 91$, and the three self-fertilised $11 \cdot 83$ inches in height; or' as 100 to 63 . 'The three crossed plants in Pot I., as already shown, had beaten the three self-fertilised plants so eompletely, that any eomparison between them was superfluous.

The winter of 1870-1871 was severe. In the spring the three crossci plants in Pot II. had not even the tips of their shoots in the least injured, whereas all three self-fertilised piants were killed half-way down to the ground; and this shows how much mole tcnder they were. In consequenee not one of these latter plants bore a single flower dmring the ensuing summer of 1871, whilst all three crossed plants flowered.

\section{ONONIS MINUTISSIMA.}

This plant, of which seeds were sent me from North Italy, produees, besides the ordinary papilionaccous flower's, minute, imperfect, closed or cleistogene flowers, which can never be cross-fertilised, but are highly self-fertile. Some of the perfect flower's were crossed with pollen from a distinet plant, and six eapsules thus prodnced yielded on an average 3.66 seeds, with a maximum of five in one. Twelve perfect flowers were marked and allowed to fertilise themselves spontaneously under a net, and they yielded eight eapsules, eontaining on an average $2 \cdot 38$ seeds, with a maximum of three seeds in one. So that the crossed and selffertilised capsules from the perfeet flowers yielded seeds in the proportion of 100 to 65 . Fifty-three capsules produeed by the eleistogene flower's contained on an average $4 \cdot 1$ seeds, so that these were the most productive of all; and the seeds themselves looked finer even than those from the crossed perfeet flowcr's.

The secds from the erossed perfect flowers and from the selffcrtilised clcistogene flowers were allowed to germinate on sand; but unfortunately only two pairs germinated at the same time. These wcre planted on the opposite sides of the same pot, which was kept in the grecnhouse. In the summer of the same year, when the scedlings were about $4 \frac{1}{2}$ inches in height, the two lots werc equal. In the autumn of the following year (1868) the two crossed plants werc of exactly the same height, viz., 114 inches, and the two self-fertilised plarts $12 \frac{6}{8}$ and $7 \frac{2}{8}$ inches; so that me of the self-fertilised exceeded considcrably in height all the other's. By the autunn of 1869 the two erossed plants had required the 
supremacy ; their height being $10_{s}^{4}$ and $15 \%$, whilst that of the tro self-fertilised plants was $14_{s}^{5}$ and $11 \frac{4}{6}$ inches.

By the autumn of 1870, the heights were as follows:-

TABLI: LXI.

Ononis minutisima.

\begin{tabular}{|c|c|}
\hline Crossed Plints. & Self-fertilised Plants. \\
\hdashline Inches. & lnches. \\
$20, \frac{3}{8}$ & $17 \frac{4}{8}$ \\
$19 \frac{2}{8}$ & $17 \frac{2}{5}$ \\
\hline $39 \cdot 63$ & $34 \cdot 75$ \\
\hline
\end{tabular}

So that the mean height of the two crossed plants was $19 \cdot 81$, and that of the two self-fertilised $17 \cdot 37$ inches; or as 100 to 88. It should be remembered that the two lots were at first equal in height; that one of the self-fertilised plants then had the advantage, the two crossed plants being at last victorious.

Summary on the Lequminosr.-Six gellera in this family were experimented on, and the results are in some respects remarkable. l'he crosscd plants of the two specics of Lupinus were conspicuously smperior to the self-fertilised plants in height and fertility; and when grown under very unfarourable conditions, in vigonr. 'The scarlet-rnnner (Phaseolus multiflorus) is partially sterile if the visits of bees arc prevented, and there is reason to belicre that rarietics growing near onc another intercross. 'The fire crossed plants, howercr, excceded in height the fire self-fertilised only by a little. Phaseolus vulgaris is perfectly self-fcrtilc; nevertheless, varieties growing in the same garden sometines intercross largely. The varieties of Lathyras odoratus, on the other hand, appear nerer to intereross in this comutry; and though the flowers are not often risited by efficicnt inscets, I cannot accomnt for this fact, more especially as the varicties are bclieved to 
intercross in North Italy. Plants raised from a cross between two varicties, differing only in the eolour of their flowers, grew much taller and were under unfirvourable conditions more vigorous than the self-fertilised plants; they also transmitted, when self-fertilised, their supcriority to their offspring. The many varieties of the eommon Pea (Pisum sativum), though growing in close proximity, very seldom intercross; and this scems due to the rarity in this country of the visits of bees suffieicntly powcrful to effcet eross-fertilisation. A cross between the self-fertilised individuals of the same variety does $n$ good whatever to the offspring; whilst a eross betwcen distinct varietics, though elosely allied, does great good, of whieh we have exeellent evidenee. The flowers of the Broom (Sarothamnus) are almost sterile if they arc not disturbed and if inseets are $\mathrm{cx}$ eluded. The pollen from a distinet plant is more effective than that from the same flower in producing seeds. The erossed seedlings have an enormous advantage orcr the self-fertilised when grown together in close eompctition. Lastly, only four plants of the Ononis minutissina were raised; but as these werc observed during their whole growth, the advantage of the erossed over the self-fertilised plants may, I think, be fully trusted.

\section{ONAGRACEA.-CLARKIA ELEgans.}

Owing to the season being very unfavourable (1867), few of the flowers which I fertilised formed capsules; twelve erossed flowers produced only four, and eighteen self-fertilised flowers yielded only one capsule. The seeds after germinating on sand were planted in tbree pots, but all the self-fertilised plants dicd in one of them. When the two lots were betwcen 4 and 5 inchos in height, the crossed began to show a slight superiority over the self-fertilised. When in full flower they were measured, with the following result:- 
TABLE LXII.

Clarkia elegans.

\begin{tabular}{|c|c|c|}
\hline No. of Pot. & Crossed Plants. & Self-fertili.cod Plants. \\
\hline & Inches. & Inches. \\
I. & $40 \frac{1}{6}$ & 33 \\
& 35 & 24 \\
& 25 & 23 \\
\hline II. & $33 \frac{4}{8}$ & $30 \frac{4}{8}$ \\
\hline Total in inches. & $\mathbf{1 3 4 \cdot 0}$ & $110 \cdot 5$ \\
\hline
\end{tabular}

The average height of the four crossed plants is $33 \cdot 5$, and that of the four self-fertilised plants $27 \cdot 62$ inches, or as 100 to 82. The erossed plants altogetber produced 105 and the selffortilised plants 63 eapsules; or as 100 to 60 . In both pots a self-fertilised plaut flowered before any one of the crossed plants.

XVI. LOASACEA:-BARTONIA AUREA.

Some flowers were erossed and self-fertilised in the usual manner during two seasons; but as I reared on the first occasion

\section{TABLE LXIII.}

Burtonia anrea.

\begin{tabular}{|c|c|c|}
\hline No. of Pot. & Crossed Plants. & Self-fertilised Plants. \\
\hline I. & $\begin{array}{c}\text { Iuches. } \\
31\end{array}$ & $\begin{array}{c}\text { Incbes. } \\
37\end{array}$ \\
\hline II. & $18 \frac{4}{8}$ & $20 \frac{4}{8}$ \\
\hline III. & $19 \frac{4}{8}$ & $40 \frac{4}{5}$ \\
\hline IV. & $\begin{array}{l}25 \\
36\end{array}$ & $\begin{array}{l}35 \\
15 \frac{4}{8}\end{array}$ \\
\hline $\mathrm{V}$ & $\begin{array}{l}31 \\
16\end{array}$ & $\begin{array}{l}18 \\
11 \frac{4}{8}\end{array}$ \\
\hline YI. & 20 & $32 \frac{4}{8}$ \\
\hline Total in inches. & $197 \cdot 0$ & $210 \cdot 5$ \\
\hline
\end{tabular}


only two pairs, the results are given together. On both oeeasions the crossed capsules eontained slightly more seeds than the selffertilised. During the first year, when the plants were about 7 inebes in height, the self-fertilised were the tallest, and in the second year the erossed were the tallest. When the two lots were in full flower they were measured, as in the preeeding table.

The average height of the eight crossed plants is $24 \cdot 62$, and that of the eight self-fertilised $26 \cdot 31$ inehes; or as 100 to 107 . So that the self-fertilised had a deeided advantage over the erossed. But the plants from some cause never grew well, and finally beeame so unhealthy that only three crossed and three self-fertilised plants survived to set any eapsules, and these were few in number. The two lots secmed to be about equally unproduetive.

\section{PASSIFLORACEA.-PASSIFLORA GRACILIS.}

This annual species produces spontaneously numerous fruits when inseets are excluded, and behaves in this respeet very differently from most of the other speeies in the genus, which are extremely sterile unless fertilised with pollen from a distinct plant.* Fourteen fruits from erossed flowers eontained on an average 24.14 seeds. Fourteen fruits (two poor ones being rejected), spontaneously self-fertilised under a net, eontained on an average 20.58 seeds per fruit; or as 100 to 85 . These seeds were sown on the opposite sides of three pots, but only two pair's came up at the same time; and therefore a fair judgment eannot be formed.

TABLE LXIV.

Passiflora gracilis.

\begin{tabular}{|c|c|c|}
\hline No. of Pot. & Crossed Plants. & Self-fertilised Plants. \\
\hline I. & $\begin{array}{c}\text { Inches. } \\
56\end{array}$ & $\begin{array}{c}\text { Inches. } \\
38\end{array}$ \\
\hline II. & 42 & 64 \\
\hline Total in inches. & 98 & 102 \\
\hline
\end{tabular}

The mean of the two erossed is 49 inches, and that of the two self-fertilised 5.1 inches; or as 100 to 104.

* "Variation of Animals and Plants under Domestication, 118. 
XVIII. UMBELLIFER AE.-A PIUM PETROSELINUM.

The Umbelliferæ are proterandrous, and ean hardly fail to be eross-fertilised by the many flies and small Hymenoptera which visit the flowers.* A plant of the eommon parsley was corered by a net, and it appareutly produeed as many and as fine spontaneously solf-fertilisod fruits or sceds as the adjoining nneovered plants. The flowers on tho latter were visited by so many insects that they must haro received pollen from one another. Some of these two lots of seeds were left on sand, but nearly all the self-fertilisod sceds germinated before the others, so that I was forced to throw all away. Tho remaining seeds were then sown on the opposito sides of four pots. At first the self-fertilised scedlings were a littlo taller in most of the pots than the naturally crossod seedlings, and this no donbt was dne to the self-fertilised seeds having germinatod first. But in the autumn all the plants wero so oqual that it clid not seem wortl while to moasure thom. In two of the pots they were absolutely oqual; in a third, if there was any differenee, it was in farour of the crossod plants, and in a somewhat plainer mamner in the fourth pot. But neither side liad any substantial advantage over the other; so that in height they may be said to be as 100 to 100 .

\section{DIPSACEE.-SOABIOSA ATRO-PURPUREA.}

The flowers, whieh are proterandrous, were fertilised during TABLE LXV.

Scubiosa atro-purpurea.

\begin{tabular}{|c|c|c|}
\hline No. of Pot. & Croswed Plants. & Self fertillsed Plants. \\
\hline I. & $\begin{array}{c}\text { Inches. } \\
1+\end{array}$ & $\begin{array}{c}\text { Inches. } \\
20\end{array}$ \\
\hline II. & 15 & $14 \frac{4}{8}$ \\
\hline III. & $\begin{array}{l}21 \\
18 \frac{4}{8}\end{array}$ & $\begin{array}{l}14 \\
13\end{array}$ \\
\hline Total in inches. & $68 \cdot 5$ & $61 \cdot 5$ \\
\hline
\end{tabular}

* II. Mülller, 'Befruchtung,' \&er. p. 96 . Aceording to M. Mrustel (as stated by Godron, 'De l'Fs- pice,' tom. ii.p. 58, 1859), varieties of the carrot growing near each other rendily intercross. 
the unfavourable season of 1867 , so that I got fow seeds, especially from the self-fertilised heads, which were extremely sterile. The crossed and self-fertilised plants raised from these seeds were measured before they were in full-flower, as in the preceding table.

The four crossed plants avernged $17 \cdot 12$, and the four self-fertilised 15.37 inches in height; or as 100 to 90 . One of the selffertilised plants in Pot III. was killed by an accident, and its fellow pulled up; so that when they were again mensured to the summits of their flowers, there were only three on each side; the crossed now avernged in height 32.83 , and the self-fertilised $30 \cdot 16$ inches; or as 100 to 92.

\section{CONPOSITE.-IActuda sativa.}

- Three plants of Lettuce* (Great London Cos var.) grew close together in my garden; one was covered by a net, and produced self-fertilised seeds, the other two were allowed to be naturally crossed by insects; but the season (1867) was unfavourable, and I did not obtain many seeds. Only one crossed and one selftertilised plant were raised in Pot I., and their mensurements ar' given in the following table (LXVI.). The flowers on this one self-fertilised plant were again self-fertilised under a net, not with pollen from the same floret, but from other florets on the same head. The flower's on the two crossed plants were left to be crossed by insects, but the process was aided by some pollen being occasionally transported by me from plant to plant. These two lots of seeds, after germinating on sand, were planted in pairs on the opposite sides of Pots II. and III., which were at first kept in the greenhouse and then turned out of doors. The plants were measured when in full flower. The following table, therefore, includes plants belonging to two generations. When the seedlings of the two lots were only 5 or 6 inches in height they were equal. In Pot III. one of the self-fertilised plants died before flowering, as has occrured in so many other cases.

* The Composito are welladapted for eross-fortilisation, but a unseryuan on whorn I can rely, tolil we that he had been in the hatsit of sowing several kinds of lettuee near together for the salic of secd, and heul never olserved that they became crossed.
It is very improbable that all the varieties which were thus enltivated near together flowered at different times; but two which I selected by hazared and sowed near each other did not Hower at the same time; and my trial failcd. 


\section{TABLE LXVI.}

Lactuca sativa.

\begin{tabular}{|c|c|c|}
\hline No. of Pot. & Crossed Plants. & Self-fertilised Plants. \\
\hline $\begin{array}{l}\text { I. } \\
\text { First generation, } \\
\text { planted in open } \\
\text { ground. }\end{array}$ & $\begin{array}{c}\text { Inches. } \\
27 \\
25\end{array}$ & $\begin{array}{l}\text { Inches. } \\
21 \frac{1}{6} \\
20^{\frac{1}{3}}\end{array}$ \\
\hline $\begin{array}{l}\text { II. } \\
\text { Second generation, } \\
\text { planted in open } \\
\text { ground. }\end{array}$ & $\begin{array}{l}29 \frac{4}{5} \\
17 \frac{4}{8} \\
12 \frac{4}{8}\end{array}$ & $\begin{array}{l}24 \\
10 \\
11\end{array}$ \\
\hline $\begin{array}{l}\text { III. } \\
\text { Second generation, } \\
\text { kept in the pot. }\end{array}$ & $\begin{array}{l}17 \\
10 \frac{4}{8}\end{array}$ & $\begin{array}{l}9 \frac{4}{8} \\
0\end{array}$ \\
\hline Total in inches. & 136 & 96 \\
\hline
\end{tabular}

The average height of the seven crossed plants is $19 \cdot 43$, and that of the six self-fertilised plants 16 inclies; or as 100 to 82.

\section{CAMPANULACEA.-SPECULARIA SPECULUN.}

In the closely allied genus, Campanula, in which Specularia was formerly included, the anthers shed at an early period their pollen, and this adheres to the collecting hairs which surround the pistil beneath the stigma; so that without some mechanical aid the flowers cannot be fertilised. For instance, I covered up a plant of Campanula carpathica, and it did not produce a single capsule, whilst the surrounding uncovered plants seeded profusely. On the other hand, the prescnt species of Specularia appears to set almost as many capsules whcu corered up, as when left to the visits of the Diptera, which, as far as I have seen, are the only inseets that frequent the flowers.* I did not aseertain whether the naturally crossed and spontaneously selffertilised eapsules contained an equal number of seeds, but a comparison of artificially crossed and self-fertilised flowers,

* It has long been known that another species of the genus, specularia perfoliata, produces eleistogene as well as perfeet flowers, and the formor are of course self-fertile. 
showed that the former were probably the most productive. It appears that this plant is capable of producing a large number of self-fertilised capsules owing to the petals closing at night, as well as during cold weather. In the act of closing; the margins of the petals become reflexed, and their inwardly projecting midribs then pass between the clefts of the stigma, and in doing so push the pollen from the outside of the pistil on to the stigmatic surfaces. ${ }^{*}$

Twenty flowers were fertilised by me with their own pollen, but owing to the bad season, only six capsules were produced; they contained on an a verage 21.7 seeds, with a maximum of forty-eight in one. Fourteen flowers were crossed with pollen from another plant, and these produced twelve capsules, containing on an average 30 seeds, with a maximum in one of fiftyseren seeds; so that the crossed seeds were to the self-fertilised from an equal number of capsules as 100 to 72 . The former wcre also heavier than an equal number of self-fertilised seeds, in the ratio of 100 to 86 . 'Thus, whether we judge by the number' of capsules produced from an equal number of flower's, or by the average number of the contained seeds, or the maximum number in any one capsule, or by their weight, crossing does great good in comparison with self-fertilisation. The two lots of seeds were

TABLe LXVII.

Speculuria speculum.

\begin{tabular}{|c|c|c|}
\hline No. of Pot. & $\begin{array}{c}\text { Tallest Crossed Plant } \\
\text { in each Pot. }\end{array}$ & $\begin{array}{c}\text { Tallest Self-fertilised } \\
\text { Plant in each Pot. }\end{array}$ \\
\cline { 2 - 3 } & $\begin{array}{c}\text { Inches. } \\
1 \mathrm{~S}\end{array}$ & $\begin{array}{c}\text { Inches. } \\
15 \frac{6}{8}\end{array}$ \\
\hline I. & 17 & 19 \\
\hline II. & $22 \frac{1}{8}$ & 18 \\
\hline III. & 20 & 23 \\
\hline IV. & $77 \cdot 13$ & $75 \cdot 75$ \\
\hline Total in inches. & & \\
\hline
\end{tabular}

* Mr. Mcehan bas lately shown ('I'roc. Acrd. Nat. Sc. Philadelphia, May 16, 1876, p. S.1) that the closing of the flowers of clay- tonia virginica and Ranunculus bulbosus cluring the night causes their self-fertilisution. 
sown on the opposite sides of fom pots; but the seccllings were not suffieiently thinned. Only the tallest plaut on each sicle was measured, when fully grown. 'The measurcments are given in the preceding table. In all four pots the erossed plants flowered first. When the seedlings were vnly abuut an inch aud a half in height both lots were equal.

The form tallest erossed plants averaged $19 \cdot 28$, and the four tallest self-fertilised 18.93 inches in height; or as 100 to 98 . So that there was no differenee worth sjeaking of between the two lots in height; thougl other great advantuges are derired, as we have seen, from eross-fertilisation. From being grown in pots and kept in the greenhouse, none of the plants produced any capsules.

\section{Lobelia Ramosa.*}

Var. Suou-flalie.

The well-adapted means by whieh eross-fertilisation is ensured in this genus have been deseribed by several authors. $\dagger$ The pistil as it slowly inereases in length pushes the pollen out of the eonjoined anther's, by the aid of a ring of bristles; the two lobes of the stigma being at this time elosed and ineapable of fertilisation. The extrusion of the pollen is also aided by inseets, whieh rub against the little bristles that projeet from the anthers. The pollen thus pushed out is earried by inseets to the older flowers, in which the stigma of the now frecly projeeting pistil is open and ready to be fertilised. I proved the importance of the gaily-eoloured eorolla, by eutting off the large lower petal of several flowers of Lobetia crims; and these flowers were negleeted by the hive-bees whieh were ineessantly visiting the other flowers.

A eapsule was obtained by erossing a flower of $L$. ramosa

* I have adopted the name given to this plant in the "Gardeners' Chronicle, 1866. Prof. T. Dyer, however, informs me that it probably is a white variety of $L$. tenuior of R. Brown, from W. Austrulia.

+ See the works of Hildebrand and Delpino. ILr. Farrer also has given a remarkably elear description of the mechaniom by which uross-fertili-ation iseflecte d in this genus, in the 'Anmals and
Mag. of Nat. IIist,' rol. ii. (tth series) 1S6S, p. 2tio. In the allied geuts Isotuma, the curious spike whieh projects rectangularly from the anthers, and which when slinken causes the pollen to fall ont the back of an enteriug insect. secuns to linve buen developed fiom a bristle, like one of those which spuing fom the anthers in some of or all the speeies of Lobeliu, as described by Mlo. lianer. 
with pollen from another plant, and two other capsules from artificially self-fertilised flowers. The contained seeds were sown on the opposite sides of four pots. Some of the crossed seedlings which came up before the other's had to be pulled up and thrown away. Whilst the plants were very small there was not much difference in height between the two lots; but in Pot III. the self-fertilised were for a time the tallest. When in full flower the tallest plant on each side of each pot was measured, and the result is shown in the following table. In all four pots a crossed plant flowered before any one of its opponents.

TABLE LXVIII.

Lobelia ramosa (First Generation).

\begin{tabular}{|c|c|c|}
\hline No. of Pot. & $\begin{array}{c}\text { Tallest Crossed Plant } \\
\text { in each Pot. }\end{array}$ & $\begin{array}{c}\text { Tallest Self-fertilised } \\
\text { Plant in each Pot. }\end{array}$ \\
\cline { 1 - 1 } I. & $\begin{array}{c}\text { Inches. } \\
22 \frac{4}{8}\end{array}$ & $\begin{array}{c}\text { Inches. } \\
17 \frac{4}{8}\end{array}$ \\
\hline II. & $27 \frac{4}{8}$ & 24 \\
\hline III. & $16 \frac{4}{8}$ & 15 \\
\hline IV. & $22 \frac{4}{8}$ & 17 \\
\hline Total in inches. & $59 \cdot 0$ & $73 \cdot 5$ \\
\hline
\end{tabular}

The four tallest crossed plants areraged $22 \cdot 25$, and the four tallest self-fertilised 18.37 inches in height; or as 100 to 82 . I was surprised to find that the anther's of a good many of these self-fertilised plants did not cohere and did not contain any pollen; and the anthers even of a very few of the crossed plants were in the same condition. Some flowers on the crossed plants were again crossed, four capsules being thus obtained; and some flowers on the self-fertilised plants were again self-fertilised, seven capsules being thus obtained. The seeds from both lots were weighed, and it was calculated that an equal number of capsules would have yielded seed in the proportion by weight of 100 for the crossed to 60 for the self-fertilised capsules. So that the flowers on the crossed plants again crossed were mitch more fertile than those on the self-fertilised plants again sellfertilised. 
Plants of the Second Ceneration.-The above two lots of seeds were placed on damp sand, and many of the erossed seeds germinated, as on the last oeeasion, before the self-fertilised, and were rejeeted. Three or four pairs in the same state of germination were planted on the opposite sides of two pots; a single pair in a third pot; and all the remaining seeds were sown erowded in a fourth pot. When the seedlings were about oue and a half inches in height, they were equal on both sides of the three first pots; but in Pot IV., in which they grew erowded and were thus exposed to severe eompetition, the erossed were about a third taller than the self-fertilised. In this latter pot, when the erossed averaged 5 inehes in height, the self-fertilised were about 4 inches; nor did they look nearly sueh fine plants. In all four pots the erossed plants flowered some days before the self-fertilised. When in full flower the tallest plant on each side was measured; but before this time the single erossed plant in Pot III., whieh was taller than its antagonist, had died and was not measured. So that only the tallest plant on each side of three pots was measured, as in the following table:-

\section{TABLe LXIX.}

Lobetia ramosa (Second Generation).

\begin{tabular}{|c|c|c|}
\hline No. of Pot, $\cdots$ & $\begin{array}{c}\text { Tallest"Crossed Plant } \\
\text { in each Pot. }\end{array}$ & $\begin{array}{c}\text { Tallest Self-fertilised } \\
\text { Plant in each Pot. }\end{array}$ \\
\hline I. & $\begin{array}{c}\text { Inches. } \\
27 \frac{4}{8}\end{array}$ & $\begin{array}{c}\text { Inches. } \\
18 \frac{1}{8}\end{array}$ \\
\hline II. & 21 & $19 \frac{4}{6}$ \\
\hline $\begin{array}{c}\text { IV. } \\
\text { Crowded. }\end{array}$ & $21 \frac{4}{8}$ & 19 \\
\hline Total in inches. & 70 & 57 \\
\hline
\end{tabular}

The average height of the three tallest erossed plants is herc $23 \cdot 33$, and that of the three tallest self-fertilised 19 inehes; or as 100 to 81 . Besides this differenee in height, the erossed plants were muel more vigorous and more branehed than the selffertilised plants, and it is unfortunate that they were not weighed. 


\section{LOBELIA FULGENS.}

This species offers a somcwhat perplexing case. In the first generation the self-fertilised plauts, though few in number, greatly exceeded the erossed in hcight; whilst in the second generation, when the trial was made on a much larger scale, the crossed beat the self-fertilised plants. As this speeies is generally propagated by off-sets, somc scedlings werc first raised, in order to have distinct plants. On one of these plants several flowers were fertilised with their own pollen; and as the pollen is mature and shed long before the stigma of the same flower is ready for fertilisation, it was necessary to number each flower and keep its pollen in paper with a corresponding number. By this menns well-matured pollen was used for self-fertilisation. Several flowers on the same plant were crossed with pollen from a distinet individual, and to obtain this the conjoined anthers of young flowers were roughly squeezed, and as it is naturally protruded very slowly by the growth of the pistil, it is probable that the pollen used by me was hardly maturc, certainly less mature than that employed for self-fertilisation. I did not at the time think of this source of error, but I now suspeet that the growth of the crossed plants was thus injured. Anyhow the trial was not perfeetly fair. Opposed to the belief that the i pollen used in erossing was not in so good a state as that used ifor self-fertilisation, is the faet that a greater proportional number of the crossed than of the self-fertilised flowers produced caps sules; but there was no marked difference in the amount of secd ceontained in the eapsules of the two lots.*

As the seeds obtained by the above two metbods would not germinate when left on bare sand, they were sown on the opposite sides of four pots; but I succeedcd in raising only a single pair of seedlings of the same age in each pot. The selffertilised secdlings, when only a few inehes in height, were in most of the pots taller than their opponents; and they flowered so mueh earlier in all the pots, that the height of the floweristcms could be fairly eompared only in Pots I. and II.

* Gärtner has shown that certain plants of Lobelic fulgens are quite sterile with pollen from the same plant, though this pollen is sfficient on any uther individual; but none of the plants on which I experimented, which were kept in the greenhouse, were in this peculiur condition. 
TABLE LXX.

Lobelia fulgens (First Generation).

\begin{tabular}{|c|c|c|}
\hline No. of Pot. & $\begin{array}{c}\text { Height of Flower- } \\
\text { stems un the Crossed } \\
\text { Plants. }\end{array}$ & $\begin{array}{c}\text { Height of lilower- } \\
\text { stems on the Self-fer- } \\
\text { tilised Plants. }\end{array}$ \\
\hline I. & $\begin{array}{c}\text { Inches. } \\
33\end{array}$ & $\begin{array}{c}\text { Inches. } \\
50\end{array}$ \\
\hline II. & $36 \frac{1}{8}$ & $38 \frac{1}{8}$ \\
\hline III. & $\begin{array}{c}21 \\
\text { Not in full flower. }\end{array}$ \\
\hline IV. & $\begin{array}{c}12 \\
\text { Not in full flower. }\end{array}$ \\
\hline
\end{tabular}

The mean height of the flower-stems of the two crosscd plants in Pots $\mathrm{I}$. and II. is herc 34.75 inches, and that of the tro sclffertilised plants in the same pots $44 \cdot 25$ inches; or as 100 to 127 . The self-fertilised plants in Pots III. and IV. were in everY respect very much finer than the crossed plants.

I was so much surprised at this great superiority of the sclffertilised over the crossed plants, that I determined to try how they would behave in one of the pots during a sccond gromtli. The two plants, thercfore, in Pot I. werc cut down, and repotted without being disturbed in a much larger pot. In the following year the self-fertilised plant showed even a greater superiority than before; for the two tallest flower-stems produced by the one crosscil plant were only $29 \frac{1}{5}$ and $30 \frac{1}{5}$ inches in height, whereas the two tallest stems on the one sclf-fertilised plant. were $49 \frac{4}{8}$ and $49 \frac{6}{5}$ inches; and this gives a latio of 100 to 167 . Considering all the evidence, there can be no doubt that thesc self-fertilised plants liad a great supcriority orer the crossed plants.

Crossed and self-fertilised Plants of the Second Gencration.-I determined on this occasion to avoid the crror of using pollcn of not quite cqual maturity for crossing and sclf-fertilisation; so that I squeczed pollen out of the coujoined anther's of roung flower's for both operations. Screral flower's on the crossed plant in Pot I. in Table LXX. Tere again crossed with pollen from $\Omega$ ristinct plant. Several other flowers on the self-fertilised plant 
TABLe LXXI.

Lobeliu fulgens (S'econd Generation).

\begin{tabular}{|c|c|c|}
\hline No. of Pot. & $\begin{array}{l}\text { Crossed Plants. } \\
\text { Height of Flower- } \\
\text { stems. }\end{array}$ & $\begin{array}{l}\text { Self-fertilised Plants. } \\
\text { Height of Flower- } \\
\text { stems. }\end{array}$ \\
\hline I. & $\begin{array}{c}\text { Inches. } \\
27 \frac{3}{8} \\
26 \\
24 \frac{3}{8} \\
24 \frac{4}{8}\end{array}$ & $\begin{array}{r}\text { Inches. } \\
32 \frac{3}{8} \\
26 \frac{3}{8} \\
25 \frac{1}{8} \\
26 \frac{2}{8}\end{array}$ \\
\hline II. & $\begin{array}{l}34 \\
26 \frac{6}{8} \\
25 \frac{1}{8} \\
26\end{array}$ & $\begin{array}{l}36 \frac{2}{8} \\
28 \frac{6}{8} \\
30 \frac{1}{8} \\
32 \frac{2}{8}\end{array}$ \\
\hline III. & $\begin{array}{l}40 \frac{4}{8} \\
37 \frac{5}{8} \\
32 \frac{1}{8}\end{array}$ & $\begin{array}{l}30 \frac{4}{8} \\
28 \frac{2}{8} \\
23\end{array}$ \\
\hline IV. & $\begin{array}{l}34 \frac{5}{8} \\
32 \frac{2}{8} \\
29 \frac{3}{8} \\
27 \frac{1}{8}\end{array}$ & $\begin{array}{l}29 \frac{4}{8} \\
28 \frac{3}{8} \\
26 \\
25 \frac{2}{8}\end{array}$ \\
\hline V. & $\begin{array}{l}28 \frac{1}{8} \\
27 \\
25 \frac{3}{8} \\
24 \frac{3}{8}\end{array}$ & $\begin{array}{l}29 \\
24 \frac{6}{8} \\
23 \frac{2}{8} \\
24\end{array}$ \\
\hline VI. & $\begin{array}{l}33 \frac{5}{8} \\
32 \\
26 \frac{1}{8} \\
25\end{array}$ & $\begin{array}{l}44 \frac{2}{8} \\
37 \frac{6}{8} \\
37 \\
35\end{array}$ \\
\hline VII. & $\begin{array}{l}30 \frac{5}{8} \\
30 \frac{3}{8} \\
29 \frac{2}{8}\end{array}$ & $\begin{array}{l}27 \frac{2}{8} \\
19 \frac{2}{8} \\
21\end{array}$ \\
\hline VIII. & $\begin{array}{l}39 \frac{3}{8} \\
37 \frac{2}{8} \\
36 \\
36\end{array}$ & $\begin{array}{l}23 \frac{1}{8} \\
23 \frac{4}{8} \\
25 \frac{4}{8} \\
25 \frac{1}{8}\end{array}$ \\
\hline IX. & $\begin{array}{l}33 \frac{3}{8} \\
25 \\
25 \frac{3}{8} \\
21 \frac{7}{8}\end{array}$ & $\begin{array}{l}19 \frac{3}{8} \\
16 \frac{3}{8} \\
19 \\
18 \frac{6}{8}\end{array}$ \\
\hline Total in inches. & $1014 \cdot 00$ & $921 \cdot 63$ \\
\hline
\end{tabular}


in the same pot were again self-fertilised with pollen from the anther's of other flower's on the same plant. Therefore the degree of self-fertilisation was not quite so close as in the last generation, in which pollen from the same flower, kept in paper, was used. These two lots of seeds were thinly sown on opposite sides of nine pots; and the young seedlings were thinned, an equal number of nearly as possible the same age being left on the two sides. In the spring of the following year (1870), when the seedlings had grown to a considerable size, they were measured to the tips of their leaves; and the twenty-three crossed plants avcraged $14 \cdot 04$ inches in height, whilst the twentythree self-fertilised seedlings were $13 \cdot 51$ inches; or as 100 to 96 .

In the summer of the same year sereral of these plants flowered, the crossed and self-fertilised plants flowering almost simultaneously, and all the flower-stems were measured. Those produced by eleven of the erossed plants averaged $30 \cdot 71$ inches, and those by nine of the self-fertilised plants 29.43 inches in height; or as 100 to 96.

The plants in these nine pots, after they had flowered, were repotted without being disturbed in much larger pots; and in the following year, 1871, all flowered freely; but they had grown into such an entangled mass, that the separate plants on eacl side could 110 longer be distinguished. Accordingly three or four of the tallest flower-stems on each side of each pot were measured; and the measurements in the prececling table are, I think, more trustworthy than the previous ones, from being more numcrous, and from the plants being well established and growing vigorously.

The average height of the thirty-four tallest flower-stems on the trenty-three crossed plants is 29.82 inches, and that of the same number of flower-stems on the same number of selffertilised plants is $27 \cdot 10$ inches; or as 100 to 91 . So that the crossed plants now showed a decided advantage over their selffertilised opponents.

\section{POLEMIONIACE无.-NEMOPHILA INSIGNIS.}

Twolve flower's were erossed witl pollen from a distinct plant, but produeed only six capsules, eontaining on an arerage $15 \cdot 3$ seeds. Eighteen flowers were fertilised with their own pollen and produeed ten eapsules, containing on an average $12 \cdot 7$ 
seeds; so that the seeds per capsule were as 100 to 69 ** The $^{*}$ The crossed seeds weighed a little less than an equal number of selffertilised seeds, in the proportion of 100 to 105 ; but this was clearly due to some of the self-fertilised capsules containing very few seeds, and these were much bulkier than the others, from having been better nourished. A subsequent comparison of the number of seeds in a fer crapsules did not show so great a superiority on the side of the crossed capsules as in the present case.

The seeds were placed on aand, and after germinating were planted in pairs on the opposite sides of five pots, which were kept in the greenhouse. When the seedlings were from 2 to 3 inches in height, most of the crossed had a slight advantage over the self-fertilised. The plants were trained up sticks, and thus grew to a considerable height. In four out of the five pots a crossed plant flowered before any one of the self-fertiliserl.

TABLE LXXII.

Nemophila insignis; 0 means that the plant died.

\begin{tabular}{|c|c|c|}
\hline No. of Pot. & Crossed Plants. & Self-fertilised Plants. \\
\hline I. & $\begin{array}{c}\text { Inches. } \\
32 \frac{4}{8}\end{array}$ & $\begin{array}{r}\text { Inches. } \\
21 \frac{2}{8}\end{array}$ \\
\hline II. & $34 \frac{4}{8}$ & $23 \frac{5}{8}$ \\
\hline III. & $\begin{array}{l}33 \frac{1}{8} \\
22 \frac{2}{8} \\
29\end{array}$ & $\begin{array}{c}19 \\
7 \frac{2}{8} \\
17 \frac{1}{8}\end{array}$ \\
\hline IV. & $\begin{array}{l}35 \frac{4}{8} \\
33 \frac{4}{8}\end{array}$ & $\begin{array}{l}10 \frac{1}{8} \\
27\end{array}$ \\
\hline V. & $\begin{array}{l}35 \\
38 \\
36 \\
37 \frac{4}{8} \\
32 \frac{4}{8}\end{array}$ & $\begin{array}{c}0 \\
18 \frac{3}{8} \\
20 \frac{4}{8} \\
34 \\
0\end{array}$ \\
\hline Total in inches. & $399 \cdot 38$ & $199 \cdot 00$ \\
\hline
\end{tabular}

* Several species of Polemoniace» are known to be proterandrous, but I did not attend to this point in Nemophila. Verlot says ('Des Variétés,' 1865, p. 66) that varieties growing near one another spontaneously intercross. 
The plants were first measured to the tips of their leaves, before they had flowered and when the crossed were under a foot in height. The twelve crossed plants averaged $11 \cdot 1$ inches in height, whilst the twelve self-fertilised were less than half of this height, viz., $5 \cdot 45$; or as 100 to 49 . Before the plants had gromn to their full height, two of the self-fertilised died, and as I feared that this might happen with others, they were again measured to the tops of their stems, as shown in the preceding table.

The twelve crossed plants now averaged $33 \cdot 28$, and the ten selffertilised 19.9 inches in height, or as 100 to 60 ; so that they differed somewhat less than before.

The plants in Pots III. and V. were placed under a net in the greenhonse, two of the crossed plants in the latter pot being pulled up on account of the death of two of the self-fertilised; so that altogether six crossed and six self-fertilised plants were left to fertilise themselves spontaneously. The pots were rather small, and the plants did not produce many capsules. The small size of the self-fertilised plants will largely account for the fewness of the capszzles which they prodnced. The six crossed plants bore 105, and the six self-fertilised only 30 capsules; or as 100 to 29.

The self-fertilised seeds thus obtained from the crossed and self-fertilised plauts, after germinating ou sand, were planted

\section{TABre LXXIII.}

Nemophila insignis.

\begin{tabular}{|c|c|c|}
\hline No. of Put. & $\begin{array}{l}\text { Self-fertilised Plants } \\
\text { from Crossed Plants. }\end{array}$ & $\begin{array}{l}\text { Self-fertilised Plants } \\
\text { from Self-fertlised } \\
\text { Plants. }\end{array}$ \\
\hline I. & $\begin{array}{l}\text { Inches. } \\
27 \\
11\end{array}$ & $\begin{array}{l}\text { Inches. } \\
27 \frac{1}{8} \\
3 \pm \frac{2}{8}\end{array}$ \\
\hline II. & $\begin{array}{l}17 \frac{6}{8} \\
2 \pm \frac{1}{8}\end{array}$ & $\begin{array}{l}23 \\
32\end{array}$ \\
\hline III. & 16 & 7 \\
\hline IT. & $\begin{array}{l}5 \frac{3}{8} \\
5 \frac{4}{8}\end{array}$ & $16^{7 \frac{9}{5}}$ \\
\hline Total in inches. & $110 \cdot 13$ & $147 \cdot 00$ \\
\hline
\end{tabular}


on the opposite sides of four small pots, and treated as before. But many of the plants wcre unhealthy, and their heights were so unequal-some on both sides being five times as tall as the others - that the averages deduced from the measurements in the preceding table arc not in the least trustworthy. Nevertheless I have felt bound to givo them, as they are opposed to my general conclusions.

The seven self-fertilised plants from the crossed plants here average $15 \cdot 73$, and the seven self-fertilised from the self-fertilised 21 inches in height; or as 100 to 133 . Strictly analogous experiments with Viola tricolor and Lathyrus odoratus gave a very different result.

\section{BORAGINACE E.-BoRAGo OFFICINALIS.}

This plant is frequented by a greater number of bees than almost any other one which I have observed. It is strongly proterandrous (H. Miiller, 'Befruchtung,' \&c., p. 267), and the flowers can hardly fail to be cross-fertilised; but should this not occur, they are capable of self-fertilisation to a limited extent, as some pollen lony remains within the anthers, and is apt to fall on the mature stigma. In the year $1863 \mathrm{I}$ covered up a plant, and examined thirty-five flowers, of which only twelve yielded any seeds; whereas of thirty-five flowers on an exposed plant growing close by, all with the exception of two yielded seeds. The covered-up plant, however, produced altogether twenty-five spontaneously sclf-fertilised seeds; the exposed plant producing fifty-five seeds, the product, no doubt, of crossfertilisation.

In the year 1868 eighteen flowers on a protected plant were crossed with pollen from a distinct plant, but only seven of these produced fruit; and I suspect that I applied pollen to many of the stigmas before they were mature. These fruits contained on an average 2 secds, with a maximum in one of three seeds. Twenty-four spontancously self-fertilised fruits wcre produced by the same plant, and these contained on an average $1 \cdot 2$ seeds, with a maximum of two in one fruit. So that the fruits from the artificially crossed flowers yiclded seeds compared with those from the spontancously self-fertilised flowers, in the ratio of 100 to 60. But the sclf-fertiliscd seeds, as ofton occurs when few are produced, wcre heavier than the crossed secds in the ratio of 100 to 99. 
These two lots of seeds were sown on opposite sicles of two large pots; but I succeeded in raising only four pairs of equal age. When the seedlings on both sicles werc about 8 inches in height they were equal. When in full flower they were measured, as follows:-

TABLE LXXIV.

Borago officinalis.

\begin{tabular}{|c|c|c|}
\hline No. of Pot. & Crossed Plants. & Self-rertillsed Plants. \\
\cline { 1 - 2 } & Inches. & Inclues. \\
13 & $13 \frac{4}{8}$ \\
& 21 & $18 \frac{6}{8}$ \\
& $16 \frac{1}{8}$ & $20 \frac{2}{8}$ \\
\hline II. & $26 \frac{2}{8}$ & $32 \frac{2}{8}$ \\
\hline Total in inches. & $82 \cdot 75$ & $84 \cdot 75$ \\
\hline
\end{tabular}

The average height of the four erossed plants is here $20 \cdot 68$, and that of the four self-fertilised 21.18 inches; or as 100 to 102. The self-fertilised plants thus exceeded the crossed in height by a little; but this was entirely due to the tallness of one of the self-fertilised. The crossed plants in both pots flowered before the self-fertiliscd. Thercfore I believe if more plants had been raiscd, the result would have been different. I regret that I did not attend to the fertility of the two lots.

\section{NOLANACEZ.-Nolana prostrata.}

In some of the flowers the stamens are considerably shorter than the pistil, in others equal to it in length. I suspected, therefore, but emoneously as it proved, that this plant was dimorphic, like Primula, Linum, \&e., and in the year 1862 trrelre plants, covered by a net in the greenhouse, were subjected to trial. The spontaneously self-fertilised flower's yielded 64 grains weight of seeds, but the product of fourteen artificially crossed flowers is here included, which falsely increases the weight of the self-fertilised seeds. Nine uncovered plants, the flowers of which were eagerly visited by bees for their pollen and were 110 doubt intercrossed by them, produeed 79 grains weight of seeds: therefore twolve plants thus treated would have yielded 105 
grains, Thus the seeds produced by the florrers on an equal number of plants, when crossed by bees, and spontaneously selffertilised (the product of fourteen artificially crossed flowers being, however, included in the latter) were in weight as 100 to 61 .

In the summer of 1867 the trial was repeated; thirty flowers were crossed with pollen from a distinct plant and produced trenty-seven capsules, each containing fire seeds. Thirty-two flowers were fertilised with their own pollen, and produced only six capsules, each with five seeds. So that the crossed and selffertilised capsules contained the same number of sceds, though many more capsules were produced by the cross-fertilised than by the self-fertilised flowers, in the ratio of 100 to 21 .

An equal number of seeds of both lots were weighed, and the crossed seeds were to the self-fertilised in weight as 100 to 82 . Therefore a cross increases the number of capsules produced and the weight of the seeds, but not the number of seeds in each capsule.

These two lots of seeds, after germinating on sand, were planted on the opposite sides of three pots. The seedlings when from 6 to 7 inches in height were equal. The plants were measured when fully grown, but their hcights were so unequal in the several pots, that the result cannot be fully trusted.

TABLE LXXV.

Nolana prostrata.

\begin{tabular}{|c|c|c|}
\hline No. of Pot. & Crossed Plants. & Self-fertilised Plants. \\
\hline I. & $\begin{array}{c}\text { Inches. } \\
8 \frac{4}{8} \\
6 \frac{4}{8}\end{array}$ & $\begin{array}{c}\text { Inches. } \\
4 \frac{2}{8} \\
7 \frac{1}{8}\end{array}$ \\
\hline II. & $\begin{array}{l}10 \frac{4}{8} \\
18\end{array}$ & $\begin{array}{l}14 \frac{4}{8} \\
18\end{array}$ \\
\hline III. & $20 \frac{2}{8}$ & $22 \frac{6}{8}$ \\
\hline Total in inches, & $63 \cdot 75$ & $67 \cdot 00$ \\
\hline
\end{tabular}

The fivo crossed plants average $12 \cdot 75$, and the five selffertilised $13 \cdot 4$ inches in height; or as 100 to 105 . 


\section{CHAPTER TI.}

Solanaceze, Primulacede, Polygonee, etc.

Petunia violacea, crossed and self-fertilised plants eompared for four generations-Effects of a cross with a fresh stock-Uniform colour of tho flowers on the self-fertilised plants of the fourth generation - Nicotiana tabacum, crossed and self-fertilised plants of equal height-Great effects of a cross with a distinct sub-variety on the height, but not on the fertility, of the offspring-Cyclamen persicum, crossed seedlings greatly superior to the self-fcrtilisedAnngallis collina-Primula veris-Equal-styled variety of Primula veris, fertility of, greatly increased by a cross with a fresh stockFagopyrum esculentum-Beta vulgaris-Canna warseewiczi, crossed and self-fertilised plants of equal height-Zca mays-Phalaris canariensis.

XXV. SOLANACE RE.-Petunia violacea.

\section{Dingy purple variety.}

THE flowers of this plant are so seldom visited during the day by inseets in this country, that I have never seen an instance; but my gardener, on whom I can rely, once saw some humblebees at work. Mr. Meehan says, ${ }^{*}$ that in the United States bees bore through the corolla for the nectar, and adds that their "fertilisation is carried on by night-moths."

In France M. Naudin, after castrating a large number of flowers whilst in bud, left them exposed to the visits of insects, and about a quarter produced capsules; $\uparrow$ but I am convinced that a much larger proportion of flowers in my garden are crossfertilised by insects, for protectod flower's with their own pollen placed on the stigma never sielded nearly a full complement of seed; whilst those left uneorered produced fine capsules, showing that pollen from other plants must have been bronght to them, probably by moths. Plants growing vigorously and flowering in pots in the grecn-liouse, never yielded a singlo capsule; and

* 'Proc. Acad. Nat. Sc. of Philadelphia,' Aug. 2nd, 1870, 1. 90.
+ 'Annales des Sc. Nat.' 4th series, Bot. tom. ix. enl. 5. 
this may be attributed, at least in chief part, to the exclusion of moths.

Six flowers on a plant covered by a net were crossed with pollen from a distinct plant and produced six capsules, containing by weight 4.44 grains of sced. Six other flowers were fertilised with their own pollen and produced only thrce capsulcs, containing only 1.49 grains weight of seed. From this it follows that an equal number of crossed and sclf-fertilised capsules would have contained seeds by weight as 100 to 67 . I should not have thought the proportional contents of so few capsules worth giving, had not nearly the same result been confirmed by several subsequent trials.

Seeds of the two lots were placed on sand, and many of the self-fcrtilised seeds germinated before the crosscd, and were rejected. Several pairs in an equal state of germination were planted on the opposite sides of Pots I. and II.; but only the tallest plant on each side was measured. Seeds were also sown thickly on the two sides of a large pot (III.), the seedlings being afterwards thiuncd, so that an equal number was left on each side; the three tallest on each side being mcasured. The pots were kept in the greenhouse, and the plants were trained up sticks. For some time the young crossed plants had no advantage in height over the self-fertilised; but their leaves were larger. When fully grown and in flower the plants wcre measured, as follows :-

\section{TABLe LXXVI.}

Petunia violacea (First Generation).

\begin{tabular}{|c|c|c|}
\hline No. of Pot. & Crossed Plants. & Self-fertilised Plants. \\
\hline I. & $\begin{array}{c}\text { Inches. } \\
30\end{array}$ & $\begin{array}{c}\text { Inches. } \\
20 \frac{4}{8}\end{array}$ \\
\hline II. & $3+\frac{4}{8}$ & $27 \frac{4}{8}$ \\
\hline III. & $\begin{array}{l}34 \\
30 \frac{1}{8} \\
25\end{array}$ & $\begin{array}{l}28 \frac{1}{8} \\
27 \frac{4}{8} \\
26\end{array}$ \\
\hline Total in inches. & 154 & 130 \\
\hline
\end{tabular}

The five tallest crossed plants here average $30 \cdot 8$, and the five tallest self-fertilised 26 inclies in height, or as 100 to 84. 
Three eapsules were obtained by crossing flowers on the above crossed plants, and three other capsules by again selffertilising flowers on the self-fertilised plants. One of the latter capsules appeared as fine as any one of the crossed capsules; but the other two contained many imperfect seeds. From these two lots of seeds the plants of the following generation were l'aised.

Cirossed and self-fertilised Plants of the Second Generution.-As in the last generation, many of the self-fertilised seeds germinated before the crossed.

Seeds in an equal state of germination were planted on the opposite sides of three pots. The crossed seedlings soon greatly exceeded in height the self-fertilised. In Pot I., when the tallest crossed plant was $10 \frac{1}{2}$ inches high, the tallest self-fertilised was only $3 \frac{1}{2}$ inches ; in Pot II. the excess in height of the crossed was not quite so great. The plants were treated as in the last generation, and when fully grown measured as before. In Pot III. both the crossed plants were killed at an early age by some animal, so that the self-fertilised had no competitor's. Nevertheless these two self-fertilised plants were measured, and are inclucled in the following table. The crossed plants flowered long before their self-fertilised opponents in Pots I. and II., and before those growing separately in Pot III.

\section{TABLE LXXVII. \\ Petunia violacea (Second Generution).}

\begin{tabular}{|c|c|c|}
\hline Noo. of Pot. & Crossed Plants. & Self-fertilised Plants. \\
\hline I. & $\begin{array}{l}\text { Inches. } \\
57 \frac{2}{8} \\
36 \frac{3}{8}\end{array}$ & $\begin{array}{c}\text { Inches. } \\
13 \frac{4}{8} \\
8\end{array}$ \\
\hline II. & $\begin{array}{l}4 \pm \frac{4}{8} \\
24\end{array}$ & $\begin{array}{l}332 \\
28\end{array}$ \\
\hline III. & $\begin{array}{l}0 \\
0\end{array}$ & $\begin{array}{l}46 \frac{2}{5} \\
28 \frac{1}{5}\end{array}$ \\
\hline Total in inches. & $162 \cdot 0$ & $157 \cdot 5$ \\
\hline
\end{tabular}

The four crossed plants avernge $40 \cdot 5$, and the six self-fertilised $26 \cdot 25$ inches in licight; or as 100 to 65 . But this great inequality is in part accidental, owing to some of the self- 
fertilised plants being very short, and to one of the crossed being very tall.

Twelve flowers on these crossed plants were agrin crossed, and eleven capsules were produced; of these, five were poor and six good; the latter contained by weight $3 \cdot 75$ grains of seeds. Trelve flower's on the self-fertilised plants were again fertilised with their own pollen and produced no less than twelve capsules, and the six finest of these contained by weight 2.57 grains of seeds. It should however be observed that these latter capsules were produced by the plants in Pot III., which were not exposed to any competition. The seeds in the six fine crossed capsules to those in the six finest self-fertilised capsules rere in weight as 100 to 68 . From these seeds the plants of the next generation were raised.

Crossed and self-fertilised Plunts of the Third Generation.-The above seeds were placed on sand, and after germinating were planted in pairs on the opposite sides of four pots; and all the remaining seeds were thickly sown on the two sides of a fifth large pot. The result was surprising, for the self-fertilised seedlings very early in life beat the crossed, and at one time were nearly double their height. At first the case appeared like that of Mimulus, in which after the third generation a tall and highly self-fertile variety appeared. But as in the two succeeding generations the crossed plants resumed their former superiority orer the self-fertilised, the case must be looked at as an anomaly. The sole conjecture which I can form is that the crossed seeds

TABLE IXXVIII.

Petunia violacea (Third Generation; plants very young).

\begin{tabular}{|c|c|c|}
\hline No. of Pot. & Crossed Plants. & Self-fertilised Plants. \\
\hline I. & Inches. \\
$1 \frac{4}{8}$ & $\begin{array}{c}\text { Inches. } \\
5 \frac{6}{8} \\
4 \frac{4}{8}\end{array}$ \\
\hline II. & $5 \frac{7}{8}$ & $8 \frac{3}{8}$ \\
& $5 \frac{7}{8}$ \\
\hline III. & 4 & $5 \frac{5}{8}$ \\
\hline IV. & $1 \frac{4}{8}$ & $5 \frac{3}{8}$ \\
\hline Total in inches. & $19 \cdot 63$ & $36 \cdot 50$ \\
\hline
\end{tabular}


had not been suffieiently ripened, and thus produeed weakly plants, as oceurred with Tberis. When the erossed plants were between 3 and 4 inehes in height, the six finest in four of the pots were measured to the summits of their stems, and at the same time the six fiuest of the self-fertilised plants. The measurements are given in the preceding table (LXXIIII.), and it may be here seen that all the self-fertilised plants exeeed their opponents in lieight, whereas when subsequently measured the exeess of the self-fertilised depended ehiefly on the unusual tallness of two of the plants in Pot II. The erossed plants here average $3 \cdot 27$, and the self-fertilised 6.08 inehes in height; or as 100 to 186 .

When fully grown they were again measured, as follows:-

TABLE LXXIX.

Petunia violacea (Third Generation; plants fully grown).

\begin{tabular}{|c|c|c|}
\hline \multirow{2}{*}{ No. of Pot. } & Crossed Plants. & Self-fertilised Plants. \\
\cline { 2 - 3 } & Inches. & $\begin{array}{c}\text { Inches. } \\
40 \frac{6}{8} \\
\text { I. }\end{array}$ \\
& $41 \frac{4}{8}$ & 39 \\
& 36 & 48 \\
\hline II. & 36 & 47 \\
& 21 & $80 \frac{2}{8}$ \\
& $36 \frac{2}{8}$ & $86 \frac{2}{8}$ \\
\hline III. & 52 & 46 \\
\hline IV. & 57 & $43 \frac{6}{8}$ \\
\hline Total in inches. & $327 \cdot 75$ & $431 \cdot 00$ \\
\hline
\end{tabular}

The eight erossed plants now averaged $40 \cdot 96$, and the eight self-fertilised plants 53.87 inches in height, or as 100 to 131 ; and this exeess ehiefly depended, as already stated, nn the unusnal tallness of two of the scif-fertilised plants in Pot II. The selffertilised had therefore lost some of their former great superiority over the crossed plants. In three of the pots the self-fertilised plants flowered first; but in Pot III. at the same time with the erossed.

The case is rendered the more strange, beeause the erossed plants in the fifth pot (not ineluded in the two last tables), in 
which all the remaining secls had been thickly sown, werc from the first fincr plants than the self-fertilised, and had larger leaves. At the period when the two tallest crossed plants in this pot were $6 \frac{\mathrm{s}}{\mathrm{s}}$ and $4 \frac{5}{\mathrm{~s}}$ inches high, the two tallest self-fertilised were only 4 inches. When the two crossed plants wcre 12 and 10 inches high, the two sclf-fcrtilised werc only 8 inches. These latter plants, as well as many others on the same side of this pot never grew any higher, whereas several of the crossed plants grew to the height of two feet! On account of this grent superiority of the crossed plants, the plants on neither sidc of this pot have been included in the two last tables.

Thirty flowers on the crossed plants in Pots I. and IV. (Table LXXIX.) were again crossed, and produced serentecn capsules. Thirty flowers on the self-fertilised plants in the same two pots were again self-fertilised, but produced only scven capsules. The contents of cach capsule of both. lots wcre placed in separate watch-glasses, and the sceds from the crossed appeared to the eye to be at lcast double the number of those from the sclffertilised capsules.

In order to ascertain whether the fertility of the self-fertilised plants had been lessened by the plants having been self-fertilised for the three previous gcnerations, thirty flowers on the crossed plants were fertiliscd with their own pollen. These yielded only five capsules, and their seeds being placed in separate watch-glasses did not seem more numerous than those from the capsules on the self-fertilised plants self-fertilised for the fourth time. So that as far as can be judged from so few capsules, the self-fertility of the self-fertilised plants had not decreased in comparison with that of the plants which liad been intercrossed during the thrce previous generations. It should, however, be remembered that hoth lots of plants had becn subjected in each gencration to almost exactly similar conditions.

Secds from the crossed plants again crosscd, and from the sclffertilised again self-fertilised, produced by the plants in Pot I. (Table LXXIX.), in which the three sclf-fertilised plants wer'c on an average only a little taller than the crossed, were used in the following cxpcriment. They werc kept scparate from two similar lots of seeds produced by the two plants in Pot IV. in the same table, in which the crossed plant was much taller than its sclf-fertilised opponent.

Crossed and self-fertilised Plants of the Fourth Generation 
(raised from the Plants in Pot I., Table LXXIX.).-Crossed and self-fertilised sceds from plants of the last generation in Pot I., in Table LXXIX., were placed on sand, and after germinating, were planted in pairs on the opposite sides of fomr pots. 'The seedlings when in full flower were measured to the base of the calyx. The remaining seeds were sown crowded on the two sides of Pot V.; and the four tallest plants on each side of this pot were measured in the same manner.

\section{TABLE LXXX.}

Petunia violacea (Fourth Generation; raised from Plants of the Third Generation in Pot I., Table LXXIX.).

\begin{tabular}{|c|c|c|}
\hline No. of Pot. & Crossed Plants. & Self-fertilised Plants. \\
\hline I. & $\begin{array}{c}\text { Inches. } \\
29 \frac{2}{8} \\
36 \frac{2}{8} \\
49\end{array}$ & $\begin{array}{c}\text { Inches. } \\
30 \frac{2}{6} \\
34 \frac{6}{8} \\
31 \frac{3}{8}\end{array}$ \\
\hline II. & $\begin{array}{l}33 \frac{3}{8} \\
37 \frac{3}{8} \\
56 \frac{4}{8}\end{array}$ & $\begin{array}{l}31 \frac{5}{8} \\
38 \frac{2}{8} \\
38 \frac{4}{8}\end{array}$ \\
\hline III. & $\begin{array}{l}46 \\
67 \frac{2}{8} \\
54 \frac{3}{8}\end{array}$ & $\begin{array}{l}45 \frac{1}{8} \\
45 \\
23 \frac{2}{8}\end{array}$ \\
\hline IV. & $\begin{array}{l}51 \frac{6}{5} \\
51 \frac{7}{8}\end{array}$ & $\begin{array}{r}34 \\
0\end{array}$ \\
\hline $\begin{array}{c}\text { V. } \\
\text { Crowded plants. }\end{array}$ & $\begin{array}{l}49 \frac{1}{8} \\
46 \frac{3}{8} \\
40 \\
53\end{array}$ & $\begin{array}{l}22 \frac{3}{8} \\
24 \frac{2}{5} \\
24 \frac{6}{8} \\
30\end{array}$ \\
\hline Total in inches. & $701 \cdot 88$ & $453 \cdot 50$ \\
\hline
\end{tabular}

The fifteen crossed plants average $46 \cdot 79$, and the fourteen (one having died) self-fertilised plants $32 \cdot 39$ inches in height; or' as 100 to 69 . So that the crossed plants in this gencration had recovered their wonted superiority over the self-fertilised plants; though the parents of tle latter in Pot I., Table LXXIX., were a little taller than their crossed opponents.

Crossed and self-fertilised Plants of the Fourth Generution 
(raised from the Plants in Pot $T V$., in Table LXXIX.).-Two similar lots of seeds, obtained from the plants in Pot IV. in Table LXXIX., in whieh the single crossed plant was at first shorter, but ultimately much taller than its self-fertilised opponent, were treated in every way like their brethren of the same generation in the last experiment. We have in the following Table LXXXI. the measurements of the present plants. Although the crossed plants greatly exceeded in height the selffertilised; yet in three out of the five pots a self-fertilised plant flowered before any one of the erossed; in a fourth pot simultaneously; and in a fifth (viz., Pot II.) a erossed plant flowered first.

\section{TABLE LXXXI.}

Petunia violacea (Fourth Generation; raised from Plunts of the Third Generation in Pot IV., Table IXIIX.).

\begin{tabular}{|c|c|c|}
\hline No. of Pot. & Crossed Plants. & Self-fertilised Plants. \\
\hline & Inches. & Inches. \\
I. & 46 & $30 \frac{2}{8}$ \\
& 46 & 28 \\
\hline II. & $50 \frac{6}{8}$ & 25 \\
& $40 \frac{2}{8}$ & $31 \frac{3}{8}$ \\
& $37 \frac{3}{8}$ & $22 \frac{4}{8}$ \\
\hline III. & $54 \frac{2}{6}$ & $22 \frac{5}{8}$ \\
& $61 \frac{1}{8}$ & $26 \frac{5}{8}$ \\
\hline IV. & 45 & 32 \\
\hline V. & 30 & $28 \frac{4}{8}$ \\
\hline Crowded plants. & $29 \frac{1}{8}$ & 26 \\
\hline & $37 \frac{4}{8}$ & $40 \frac{2}{8}$ \\
\hline Total in inches. & 63 & $18 \frac{5}{8}$ \\
& $41 \frac{2}{8}$ & $17 \frac{4}{8}$ \\
\hline
\end{tabular}

The thirteen crossed plants here average $44 \cdot 74$, and the thirtcen self-fertiliscd plants 26.87 inehes in height; or as 100 to 60 . The crossed parents of thesc plants were inucl tallc1, relatively to the self-fertilised parents, than in the last case ; and apparently they transmitted some of this superiority to their 
erossed offspring. It is unfortunate that I did not turn these plants out of doors, so as to observe their relative fertility, for I eompared the pollen from some of the erossed and self-fertilised plants in Pot I., Table LXXXI., and there was a marked differenee in its state; that of the erossed plants eontained hardly any bad and empty grains, whilst sueh abounded in the pollen of the self-fertilised plants.

The Liffects of a C'ross with a fresh Stock. - I proeured from a garden in Westerham, whenee my plants originally eame, a fresh plant differing in no respeet from mine except in the eolour of the flowers, which was a fine purple. But this plant must have been exposed during at least four generations to very different eonditions from those to whieh my plants had been subjeeted, as these had been grown in pots in the greenhouse. Eight flowers on the self-fertilised plants in Table LXXXI., of the last or fourth self-fertilised generation, were fertilised with pollen from this fresh stoek; all eight produced eapsules eontaining together by weight 5.01 grains of seeds. The plants raised from these seeds may be ealled the Hesterhumcrossed.

Eight flowers on the erossed plants of the last or fourth generation in Table LXXXI. were again erossed with pollen from one of the other erossed plants, and produeed five capsules, containing by weight 2.07 grains of seeds. The plants raised from these seeds may be ealled the intercrossed; and these form the fiftl intererossed generation.

Eight flowers on the self-fertilised plants of the same generation in Table LXXXI. were again self-fertilised, and produeed seven capsules, eontaining by weight $2 \cdot 1$ grains of seeds. The self-fertilised plants raised from these seeds form the fifth selffertilised generation. These latter plants and the intercrossed are comparable in all respeets with the erossed and self-fertilised plants of the four previous generations.

From the foregoing data it is easy to ealeulate that,

Gr. Weight of Seed.

Ten Westerham-erossed eapsules would have eontained $6 \cdot 26$ Ten intererossed eapsules would have eontained . . $4 \cdot 14$ Ten self-fertilised eapsules would hare eontained . $3 \cdot 00$ 
Seeds from the Westerham-erossed eapsules to those from the capsules of the fifth self-fertilised generation, in weight,

Seeds from the Westerham-erossed capsules to those from the eapsules of the fifth intererossed generation,

Seeds from the intererossed to those from the self-fertilised eapsules, as 100 to $66^{\circ}$

So that a eross with pollen from a fresh stock greatly increased the produetiveness of the flowers on plants whieh had been selffertilised for the four previous generations, in comparison not only with the flowers on the same plants self-fertilised for the fifth time, but with the flowers on the erossed plants crossed with pollen from another plant of the same old stoek for the fifth time.

These three lots of seeds were plaeed on sand, and were planted in an equal state of germination in seven pots, each made tripartite by three superficial partitions. Some of the remaining seeds, whether or not in a state of gcrmination, were thickly sown in an eighth pot. The pots were kept in the grcenhouse, and the plants trained up sticks. They were first measured to the tops of their stems when eoming into flower ; and the twentytwo Westerham-erossed plants then averaged $25 \cdot 51$ inehes; the twenty-three intercrossed plants 30.38 ; and the twenty-three self-fertilised plants $23 \cdot 40$ inches in height. We thus get the following ratios :-

The Westerham-erossed plants in height to the self-fertilised

The Westerham-erossed plants in height to the intercrossed The intercrossed plants in height to the selffertilised as 100 to 91

These plants were again measured when their growth appeared on a easual inspection to be eomplete. But in this I was mistaken, for after eutting them down, I found that the summits of the stems of the Westerhana-crossed plants were still growing vigorously; whilst the intererossed had almost, and the selffertiliscd had quite eompleted their growth. Thereforc I do not doubt, if the three lots had been left to grow for another month, that the ratios would have been somewhat different 
from those dedued from the measurements in the following table :-

\section{TABLE LXXXII. \\ Petunia violacea.}

\begin{tabular}{|c|c|c|c|}
\hline No. of Pot. & $\begin{array}{l}\text { Westerham-crossed } \\
\text { Plants (from Self- } \\
\text { fertilised Plants of } \\
\text { Fourth Generation } \\
\text { crossed hy a fresh } \\
\text { Stock). }\end{array}$ & $\begin{array}{l}\text { Intercrossed Plants } \\
\text { (Plants of one and } \\
\text { the same Stock } \\
\text { intercrossed for } \\
\text { Five Generations). }\end{array}$ & $\begin{array}{l}\text { Self-fertilised Plants } \\
\text { (self-fertilised for } \\
\text { Five Generations). }\end{array}$ \\
\hline I. & $\begin{array}{l}\text { Inches. } \\
64 \frac{5}{8} \\
24 \\
51 \frac{4}{8}\end{array}$ & $\begin{array}{c}\text { Inches. } \\
57 \frac{2}{8} \\
64 \\
58 \frac{6}{8}\end{array}$ & $\begin{array}{c}\text { Inches. } \\
43 \frac{6}{8} \\
56 \frac{3}{8} \\
31 \frac{5}{8}\end{array}$ \\
\hline II. & $\begin{array}{l}48 \frac{7}{8} \\
54 \frac{4}{8} \\
58 \frac{1}{8}\end{array}$ & $\begin{array}{l}597 \\
58 \frac{7}{8} \\
53\end{array}$ & $\begin{array}{l}41 \frac{5}{8} \\
41 \frac{2}{8} \\
18 \frac{2}{8}\end{array}$ \\
\hline III. & $\begin{array}{l}62 \\
53 \frac{2}{8} \\
627\end{array}$ & $\begin{array}{l}52 \frac{2}{8} \\
54 \frac{6}{8} \\
61 \frac{6}{8}\end{array}$ & $\begin{array}{l}46 \frac{6}{8} \\
45 \\
19 \frac{4}{5}\end{array}$ \\
\hline IV. & $\begin{array}{l}44 \frac{4}{8} \\
49 \frac{2}{8} \\
. .\end{array}$ & $\begin{array}{l}587 \\
65 \frac{2}{8} \\
59 \frac{6}{8}\end{array}$ & $\begin{array}{l}37 \frac{5}{8} \\
33 \frac{2}{8} \\
32 \frac{2}{8}\end{array}$ \\
\hline V. & $\begin{array}{l}43 \frac{1}{8} \\
53 \frac{7}{8} \\
53 \frac{2}{8}\end{array}$ & $\begin{array}{l}35 \frac{6}{8} \\
3+\frac{6}{8} \\
5+\frac{6}{8}\end{array}$ & $\begin{array}{c}41 \frac{6}{6} \\
26 \frac{4}{8} \\
0\end{array}$ \\
\hline VI. & $\begin{array}{c}37 \frac{4}{8} \\
61^{8} \\
0\end{array}$ & $\begin{array}{l}56 \\
63 \frac{5}{8} \\
57 \frac{7}{8}\end{array}$ & $\begin{array}{l}46 \frac{4}{5} \\
29 \frac{6}{5} \\
14 \frac{4}{8}\end{array}$ \\
\hline VII. & $\begin{array}{l}59 \frac{6}{8} \\
43 \frac{4}{8} \\
50 \frac{5}{8}\end{array}$ & $\begin{array}{c}51 \\
49 \frac{6}{8} \\
0\end{array}$ & $\begin{array}{c}43 \\
12 \frac{2}{8} \\
0\end{array}$ \\
\hline $\begin{array}{l}\text { VIII. } \\
\text { Crowded. }\end{array}$ & $\begin{array}{l}37 \frac{7}{8} \\
37 \frac{2}{8}\end{array}$ & $\begin{array}{l}38 \frac{5}{8} \\
44 \frac{5}{8}\end{array}$ & $\begin{array}{l}21 \frac{6}{8} \\
14 \frac{5}{8}\end{array}$ \\
\hline Total in inches. & $1051 \cdot 25$ & $1190 \cdot 50$ & $697 \cdot 88$ \\
\hline
\end{tabular}

The twenty-one Westerhau-crossed plants now areraged $50 \cdot 05$ inches; the twenty-two intercrossed plants, $54 \cdot 11$ inches; and the twenty-one self-fertilised plants, $33 \cdot 23$ inches in leight. TVe thus get the following ratios:- 
The Testerham-erossed plants in height to the self-fertilised

The Westerham-erossed plants in height to the intercrossed

The intercrossed plants in height to the selffertilised - as 100 to 61

We here see that the Westerham-crossed (the offspring of plants self-fertilised for four generations and then erossed with a fresh stoek) have gained greatly in height, sinee they were first measured, relatively to the plants self-fertilised for five generations. They were then as 100 to 91 , and now as 100 to 66 in height. The intercrossed plants (i.e., those which had been intercrossed for the last five generations) likewise exceed in lreight the self-fertilised plants, as oceured in all the previons generations with the exception of the abnormal plants of the third generation. On the other hand, the Westerham-crossed plants are exceeded in height by the intererossed; and this is a surprising fact, judging from most of the other strictly analogous cases. But as the Westerham-erossed plants were still growing vigorously, while the intercrossed had almost eeased to grow, there can hardly be a doubt that if left to grow for another month they would have beaten the intercrossed in height. That they were gaining on them is elear, as when measured before they were as 100 to 119 , and now as only 100 to 108 in height. The Westerham-crossed plants had also leaves of a darker green, and looked altogether more vigorous than the intererossed; and what is mueh more important, they produced, as we shall presently see, much heavier sced-capsules. So that in fact the offspring from the self-fertilised plants of the fourth generation crossed by a fresh stock were superior to the intererossed, as well as to the self-fertilised plants of the fifth generation--of which latter fact there could not be the lcast doubt.

These three lots of plants were eut down close to the sround and weighed. The twenty-one Westerham-crossed plants weighed 32 ounees; the twenty-two intererossed plants, 34 ounces, and the twenty-one self-fertilised plants $7:$ ounces. The following ratios are ealculated for an equal number of plants of each kind. But as the self-fertilised plants were just beginning to wither, their relative weight is here slightly too small; and as the Westcrhamcrossed were still growing vigorously, their relative weight with time allowed would no doubt have greatly inereased. 
The Tresterbam-erossed plants in weight to the self-fertilised . . . . . as 100 to 22

The Westerham-erossed plants in weight to the intererossed . . . . as 100 to 101 The intererossed plants in weight to the selffertilised - as 100 to $22 \cdot 3$

We here see, judging by weight instead of as before by height, that the Westerham-crossed and the intererossed have an immense advantage over the self-fertilised. The Westerhamcrossed are inferior to the intererossed by a mere trifle; but it is almost eertain that if they had been allowed to go on growing for another month, the former would have eompletely beaten the latter.

As I had an abundanee of seeds of the same three lots, from whieh the foregoing plants had been raised, these were sown in three long parallel and adjoining rows in the open ground, so as to aseertain whether under these eireumstanees the results would be nearly the same as before. Late in the autumn (Nov. 13) the ten tallest plants were earefully seleeted out of eacli row, and their heights measured, with the following result:-

\section{TABLE LXXXIII.}

P'etunia violacea (plants growing in the open ground).

\begin{tabular}{|c|c|c|}
\hline $\begin{array}{l}\text { Westerham-crossed } \\
\text { Plants (frum Self- } \\
\text { fertilis d Plants of the } \\
\text { Fourth Genelation } \\
\text { crossed by a fiesh } \\
\text { Stock). }\end{array}$ & $\begin{array}{l}\text { Intercrossed Plants } \\
\text { (Plants of one and the } \\
\text { same Stock inter- } \\
\text { crossed for Five } \\
\text { Generations). }\end{array}$ & $\begin{array}{l}\text { Self-fertilised Plants } \\
\text { (Self-fertilised fur } \\
\text { Iive Generatious). }\end{array}$ \\
\hline $\begin{array}{c}\text { Inches. } \\
34 \frac{2}{8} \\
36 \frac{2}{8} \\
35 \frac{2}{8} \\
32 \frac{4}{8} \\
37 \\
36 \frac{4}{8} \\
40 \frac{7}{8} \\
37 \frac{2}{8} \\
38 \frac{2}{8} \\
38 \frac{5}{8}\end{array}$ & $\begin{array}{l}\text { Inches. } \\
38 \\
36 \frac{2}{5} \\
39 \frac{5}{8} \\
37 \\
36 \\
41 \frac{3}{3} \\
37 \frac{2}{8} \\
40 \\
41 \frac{2}{5} \\
36\end{array}$ & $\begin{array}{l}\text { Inches. } \\
27 \frac{3}{8} \\
23 \\
25 \\
24 \frac{1}{8} \\
22 \frac{1}{8} \\
23 \frac{3}{8} \\
21 \frac{5}{8} \\
23 \frac{1}{8} \\
21 \frac{3}{8} \\
21 \frac{2}{8}\end{array}$ \\
\hline $366 \cdot 76$ & $382 \cdot 76$ & $233 \cdot 13$ \\
\hline
\end{tabular}


The ten Westerham-crossed plants here average $36 \cdot 67$ inches in height; the ten intercrossed plants, 38.27 inches; and the ten self-fortilised, $23 \cdot 31$ inches. These three lots of plants wcre also weighed; the Westcrham-crossed plants weighed 28 ounces; the intercrossed, 41 ounces; and the self-fertilised, 14.75 ounces. We thus get the following ratios :-

The Westerham-crossed plants in height to the self-fertilised . $\cdot$.

The Westerham-crossed plants in weight to the

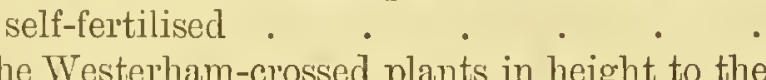

The Westerham-crossed plants in height to the intercrossed

as 100 to 63

The Westerham-crossed plants in weight to the intercrossed . . . . as 100 to 146

- The intercrossed plants in height to the selffertilised. . . . . . as 100 to 61 The intererossed plants in weight to the selffertilised. . . . . as 100 to 36

Here the relative heights of the three lots are nearly the same (within three or four per cent.) as with the plants in the pots. In weight there is a much greater difference : the Westerhamcrossed excecd the self-fertilised by much less than they did before; but the self-fertilised plants in the pots had become slightly withered, as before stated, and werc in consequence unfairly light. The Westerham-crossed plants are here inferior in wcight to the intercrossed plants in a much higher degree than in the pots; and this appcared due to their being much less branched, owing to their having germinated in greater numbers and conscquently being much crowded. Their leaves were of a brighter green than those of the intercrossed and self-fertilised plants.

Pielative Fertility of the Three Lots of Plants, -None of the plants in pots in the grcenhouse ever produced a capsule; and this may be attributed in chief part to the exclusion of moths. Therefore the fertility of the threc lots could be judged of only by that of the plants growing out of doors, wlich from bcing left uncovered werc probably cross-fertilised. The plants in the threc rows were exact]y of the same age and had been subjected to closely similar conditions, so that any difference in their fortility must be attributed to their different origin; namely, to the 
one lot being derived from plants self-fertilised for four generations and then crossed with a fresh stock; to the second lot bcing derived from plants of the same old stock intercrossed for five generations; and to the third lot being derived from plants selffertilised for five generations. All the capsules, some nearly mature and some only half-grown, were gathered, counted, and weighed from the ten finest plants in each of the three rows, of which the measurements and weights have already been given. The intercrossed plants, as we have seen, were taller and considerably heavier than the plants of the other two lots, and they produced a greater number of capsules than did even the Westerham-crossed plants; and this may be attributed to the latter having grown more crowded and being in consequence less branched. Therefore the average weight of an equal number of capsules from each lot of plants seems to be the fairest standard of comparison, as their weights will have been determined chiefly by the number of the included seeds. As the intercrossed plants were taller and heavier than the plants of the other two lots, it might have been expected that they would have produced the finest or heaviest capsules; but this was very far from being the case.

The ten tallest Westerham-crossed plants produced 111 ripe and unripe capsules, weighing $121 \cdot 2$ grains. Therefore 100 of such capsules would have weighed $109 \cdot 18$ grains.

The ten tallest intercrossed plants produced 129 copsules, weighing $76 \cdot 45$ grains. Therefore 100 of these capsules wonld have weighed $59 \cdot 26$ grains.

The ten tallest self-fertilised plants produced only 44 capsules, weighing $22 \cdot 35$ grains. Therefore 100 of these capsules would have weighed $50 \cdot 79$ grains.

From these data we get the following ratios for the fertility of the three lots, as deduced from the relative weights of an equal number of capsules from the finest plants in each lot:-

\section{Westerham-crossed plants to self-fertilised} plants

Westerham-crossed plants to intercrossed plants Intercrossed plants to self-fertilised plants

as 100 to 46 as 100 to 54 as 100 to $S 6$

We here see how potent the influence of a cross with pollen from a fresh stock has been on the fertility of plants self-fertilised for four generations, in comparison with plants of the old stock when either intercrossed or self-fertilised for five generations; the 
flotrers on all these plants laving been left to be frecly crossed liy inscets or to fertilise themselves. The Westcrham-crossed plants were also much taller and heavier plants than the selffertilised, both in the pots and open ground; but they were less tall and heary than the intercrossed plants. This latter result, however, would almost certainly have been reversed, if the plants had been allowed to grow for another month, as the Westerham-crossed were still growing vigorously, whilst the intercrossed had almost ceased to grow. This case reminds us of the somewhat analogous one of Eschscholtzia, in which plants raised from a cross with a frcsh stock did not grow higher than the sclf-fertilised or intercrossed plants, but produced a greater number of seed-capsules, which contained a far larger average number of sceds.

Colour of the Flowers on the above Thee Lots of Plants.-The original mother-plant, from which the five successive self-fertilised generations wcre raised, bore dingy purple flowers. At no time was any selection practised, and the plants were subjected in each generation to cxtremely uniform conditions. The result was, as in some previous cascs, that the flowers on all the selffertilised plants, both in the pots and open ground, were absolutely uniform in tint; this being a dull, rather peculiar flesh colour. This uniformity was very striking in the long row of plants growing in the open ground, and thesc first attracted my attention. I did not notice in which generation the original colomr began to cirange and to become uniform, but I have every l'eason to believe that the change was gradual. The flowers on the intcrerossed plants were mostly of the same tint, but not nearly so unifor'm as thosc on the self-fertilised plants, and many of them were pale, approaching almost to white. The flowers on the plants from the cross with the purple-flowered Westerham stock wcre, as might have becn expected, much more purple and not nearly so uniform in tint. The self-fertilised plants wore also remarkably uniform in height, as judged by the eye; the intercrossed less so, whilst the Westcrham-crosscd plants varied much in height.

\section{Nicotiana tabadum.}

'This plant offers a curious case. Out of six trials with crossed and self-fertilised plants, belonging to three suecessive generations, in one alone did the erossed show any marked supcriority in height over the sclf-fertilised; in four of the trials they werc 
approximatcly equal; and in one (i.c., in the first generation) the self-fertilised plants were greatly superior to the crosscd. In no case did the capsules from flowers fcrtilised with pollen from a distinct plant yield many more, and sometimes they yiclded much fewer seeds than the capsules from self-fertilised flowcr's. But when the flowers of one variety were crossed witl pollen from a slightly different variety, which had grown under somervat different conditions, - that is, by a fresh stock, - the seedlings derived from this cross exceeded in height and weight those from the self-fertilised flowers in an extraordinary degrec.

Twelve flowers on some plants of the common tobacco, raised from purchased seeds, were crossed with pollen from a distinct plant of the same lot, and these produced ten capsules. Twelve flowers on the same plants were fertilised with their own pollen, and produced eleven capsules. The sceds in the ten crossed capsules weighed 31.7 grains, whilst those in ten of the selffertilised capsules weighed $47 \cdot 67$ grains; or as 100 to 150 . The much greater productivencss of the self-fertilised than of the crossed capsules can hardly be attributed to chance, as all the capsules of both lots were very fine and healthy ones.

The seeds werc placed on sand, and several pairs in an equal statc of germination were planted on the opposite sides of three pots. The remaining seeds were thickly sown on the tro sides of Pot IV., so that the plants in this pot were much crowded. The tallest plant on each side of each pot was measured. Whilst the plants wcre quite young the four tallest crossed plants averaged 7.87 inches, and the four tallest self-fcrtilised 14.87 inches in height; or as 100 to 189. The heights at this age arc given in the two left colnmms of the following table.

When in full flower the tallest plants on each side were again measured (sec the two right-hand columns), with the following result. But I should state that the pots were not large enough, and the plants nevcr grew to their proper height. The four tallest crossed plants now areraged $18 \cdot 5$, and the four tallest self-fertilised plants $32 \cdot 75$ inches in height; or as 100 to 178 . In all four pots a self-fertilised plant flowered bcforc any one of the crossed.

In Pot IV., in which the plants were extremcly crowded, the two lots were at first equal; and ultimately the tallest crossed plant cxceeded by a trifle the tallest sclf-fertilised plant. This recalled to my mind an analogous caso in the one generation of Petunia, in which the self-fertilised plants were throughout 


\section{TABLe LXXXIV.}

Nicotiana tabacum (First Generation).

\begin{tabular}{|c|c|c|c|c|}
\hline \multirow{2}{*}{ No. of Put. } & \multicolumn{2}{|c|}{ May 20, 1868.} & \multicolumn{2}{|c|}{ December 6, Is68. } \\
\hline & $\begin{array}{l}\text { Crossed } \\
\text { Plants. }\end{array}$ & $\begin{array}{c}\text { Self-fertilised } \\
\text { Plunts. }\end{array}$ & $\begin{array}{l}\text { Crossed } \\
\text { Plants. }\end{array}$ & $\begin{array}{l}\text { Self-fertilised } \\
\text { Plints. }\end{array}$ \\
\hline I. & $\begin{array}{c}\text { Inches. } \\
15 \frac{4}{8}\end{array}$ & $\begin{array}{l}\text { Inches. } \\
26\end{array}$ & $\begin{array}{c}\text { Inches. } \\
40\end{array}$ & $\begin{array}{c}\text { Inches. } \\
44\end{array}$ \\
\hline II. & 3 & 15 & $6 \frac{1}{8}$ & 43 \\
\hline III. & 8 & $13 \frac{4}{8}$ & 16 & 33 \\
\hline $\begin{array}{c}\text { IV. } \\
\text { Crowded. }\end{array}$ & 5 & 5 & $11 \frac{4}{6}$ & 11 \\
\hline $\begin{array}{l}\text { Total in } \\
\text { inches. }\end{array}$ & $31 \cdot 5$ & $59 \cdot 5$ & $.74 \cdot 0$ & $131 \cdot 0$ \\
\hline
\end{tabular}

their growth taller than the erossed', in all the pots except in the erowded one. Accordingly another trial was made, and some of the same erossed and self-fertilised seeds of tobacco were sown thickly on opposite sides of two additional pots; the plants being left to grow up mueh crowded. When they were between 13 and 14 inches in height there was no difference between the two sides, nor was there any marked difference when the plants had grown as tall as they could; for in one pot the tallest crossed plant was $26 \frac{1}{2}$ inches in height, and exceeded by 2 inehes the tallest self-fertilised plant, whilst in the other pot, the tallest crossed plant was shorter by $3 \frac{1}{2}$ inches than the tallest self-fertilised plant, whieh was 22 inches in height.

As the plants did not grow to their proper height in the above small pots in Table LXXXIV., four crossed and four self-fertilised plants were raised from the same seed, and were planted in pairs on the opposite sides of four very large pots containing rich soil ; so that they were not exposed to at all severe mutual eompetition. When these plants were in flower I neglected to measure them, but reeord in my notes that all four self-fertilised plants exceeded in height the four crossed plants by 2 or 3 inehes. We have seen that the flowers on the original or parent-plants which were erossed with pollen from a distinet plant yielded much fewer seeds than those fertilised with their own pollen; and the trial just given, as well as that in Table LXXXIV., show us clearly 
that the plants raised from the crossed seeds were inferior in height to those from the self-fertilised seeds; but only when not greatly crowded. When erowded and thus subjected to very serere eompetition, the crossed and self-fertilised plants were nearly equal in height.

Crossed and self-fertilised Plants of the Second Generation.Twelve flowers on the crossed plants of the last generation growing in the four large pots just mentioned, were crossed with pollen from a crossed plant growing in one of the other pots; and twelve flowers on the self-fertilised plants were fertilised with their own pollen. All these flowers of both lots produced fine capsules. Ten of the crossed capsules contained by weight 38.92 grains of seeds, and ten of the self-fertilised capsules $37 \cdot 74$ grains; or as 100 to 97 . Some of these seeds in an equal state of germination were planted in pairs on the opposite sides of five large pots. A good many of the crossed seeds germinated before the self-fertilised, and were of course rejected. The plants thus raised were measured when several of them were in full flower.

TABLE LXXXV.

Nicotiana tabacum (Second Generation).

\begin{tabular}{|c|c|c|}
\hline No. of Pot. & Crossed Plants. & Self-fertilised Plants. \\
\hline I. & $\begin{array}{c}\text { Inches. } \\
14 \frac{4}{8} \\
78 \frac{4}{8} \\
9\end{array}$ & $\begin{array}{c}\text { Inches. } \\
27 \frac{6}{8} \\
8 \frac{6}{8} \\
56\end{array}$ \\
\hline II. & $\begin{array}{l}60 \frac{4}{8} \\
44 \frac{6}{5} \\
10\end{array}$ & $\begin{array}{c}16 \frac{6}{8} \\
7 \\
50 \frac{4}{8}\end{array}$ \\
\hline III. & $\begin{array}{r}57 \frac{1}{8} \\
1 \frac{2}{8}\end{array}$ & $\begin{array}{l}87 \text { (A) } \\
81 \frac{2}{8}(\mathrm{~B})\end{array}$ \\
\hline IV. & $\begin{array}{r}6 \frac{6}{5} \\
31 \\
694 \frac{4}{8}\end{array}$ & $\begin{array}{c}19 \\
43 \frac{2}{5} \\
4\end{array}$ \\
\hline V. & $\begin{array}{l}99 \frac{4}{6} \\
29 \frac{2}{8}\end{array}$ & $\begin{array}{l}9 \frac{4}{8} \\
3\end{array}$ \\
\hline Total in inches. & $511 \cdot 63$ & $413 \cdot 75$ \\
\hline
\end{tabular}


The thirteen crossed plants here average $39 \cdot 35$, and the thirteen self-fertilised plants 31 .82 inches in height; or as 100 to 81. But it would be a very much fairer plan to exclude all the starved plants of only 10 inches and under in height; and in this case the nine remaining crossed plants avernge $53 \cdot 84$, and the seven remaining self-fertilised plants 51.78 inches in height, or as 100 to 96 ; and this difference is so small that the crossed and self-fertilised plants may be considered as of equal heights.

In addition to these plants, three crossed plants were planted separately in three large pots, and three self-fertilised plants in three other large pots, so that they were not exposed to any competition; and now the self-fertilised plants exceeded the crossed in height by a little, for the three crossed areraged 55.91 , and the three self-fertilised $59 \cdot 16$ inches; or as 100 to 106.

Crossed and self-fertilised Plants of the Third Generation.-As I wished to ascertain, firstly, whether those self-fertilised plants of the last generation, which greatly exceeded in height their crossed opponents, would transmit the same tendency to their offspring, and secondly, whether they possessed the same sexual constitution, I selected for experiment the two self-fertilised plants marked $A$ and $B$ in Pot III. in Table LXXXV., as these two

\section{TABLE LXXXVI.}

Nicotiana tabacum (Third Generation). Seedlings from the Self-fertitised Plant $A$ in Pot III., Table $L X X X V$., of the last or Second Generation.

\begin{tabular}{|c|c|c|}
\hline \multirow{2}{*}{ No. of Pot. } & $\begin{array}{c}\text { From Self-fertilised } \\
\text { Plant, crossed by a } \\
\text { Crossed Plant. }\end{array}$ & $\begin{array}{c}\text { From Self-fertilised } \\
\text { Plant again self-ferti- } \\
\text { lised, forming the } \\
\text { Third Self-fertilised } \\
\text { Generation. }\end{array}$ \\
\cline { 2 - 3 } & $\begin{array}{c}\text { Inches. } \\
100 \frac{2}{8}\end{array}$ & $\begin{array}{c}\text { Inches. } \\
98 \\
79\end{array}$ \\
\hline I. & 91 & 79 \\
\hline II. & $110 \frac{2}{8}$ & $59 \frac{1}{8}$ \\
& $100 \frac{4}{8}$ & $66 \frac{6}{8}$ \\
\hline III. & 104 & $79 \frac{6}{8}$ \\
\hline IV. & $84 \frac{2}{8}$ & $110 \frac{4}{8}$ \\
& $76 \frac{7}{8}$ & $64 \frac{1}{8}$ \\
\hline
\end{tabular}


were of nearly equal hejght, and were greatly superior to their crossed opponents. Fonr flowers on each plant were fertilised with their own pullen, and fonr others on the same plants mere crossed with pollen from one of the crossed plants growing in another pot. This plan differs from that before followed, in which seedlings from crossed plants again crossed, have been compared with seedlings from self-fertilised plants again selffertilised. The seeds from the crossed and self-fertilised capsules of the above two plants were placed in separate watch-glasses and compared, but were not weighed; and in both cases those from the crossed capsules seemed to bo rather less numerous than those from the self-fertilised capsnles. These seeds were planted in the usnal manner, and the beights of the crossed and selffertilised seedlings, when fully grown, are given in the preceding and following table, LXXXVI. and LXXXVIT.

The seven crossed plants in the first of these two tables average $95 \cdot 25$, and the seven self-fertilised $79 \cdot 6$ inches in beight; or as 100 to 83 . In half the pots a crossed plant, and in the other half a self-fertilised plant flowered first.

We now come to the seedlings raised from the other parentplant $\mathrm{B}$.

\section{TABLE LXXYVII.}

Nicotiana tubacum (Third Generation). Seedlings from the Self-fertiliserl Plant B in Pot III., Table LXXXV., of the last or Second Generation.

\begin{tabular}{|c|c|c|}
\hline No. of Pot. & $\begin{array}{c}\text { From Self-fertilised } \\
\text { Plant, crossed by a } \\
\text { Crossed Plant. }\end{array}$ & $\begin{array}{c}\text { From Self-fertilised } \\
\text { Plant again self-ferti- } \\
\text { lised, furming ibe } \\
\text { Third Sulf-fertilised } \\
\text { Generation. }\end{array}$ \\
\hline I. & $\begin{array}{c}\text { Inches. } \\
87 \frac{2}{8} \\
49\end{array}$ & $\begin{array}{c}\text { Inches. } \\
72 \frac{4}{8} \\
14 \frac{2}{8}\end{array}$ \\
\hline II. & $98 \frac{4}{8}$ & 73 \\
\hline III. & 0 & $110 \frac{4}{8}$ \\
\hline IV. & 99 & $106 \frac{4}{8}$ \\
\hline V. & $97 \frac{6}{8}$ \\
\hline Total in inches. & $48 \frac{6}{8}$ & $48 \frac{6}{8}$ \\
\hline
\end{tabular}


The scren crossed plants (for two of them died) hcre avcrage $70 \cdot 78$ inches, and the nine self-fertilised plants 71.3 inches in height; or as 100 to barcly 101 . In four out of these five pots, a self-fertiliscd plant flowercd before any one of the crossed plants. So that, differently from the last case, the sclf-fertilised plants are in some respects slightly supcrior to the crossed.

If we now consider the crossed and self-fertilised plants of the three generations, we find an extraordinary diversity in their relative heights. In the first generation, the crossed plants were inferior to the self-fcrtilised as 100 to 178; and the flower's on the original parent-plants which wcre crossed with pollen from a distinct plant yielded much fewer seeds than the self-fertilised flowers, in the proportion of 100 to 150 . But it is a strange fact that the self-fertilised plants, which were subjected to vcry severc competition with the crossed, had on two occasions no advantage orer them. The inferiority of the crossed plants of this first gencration cannot be attributed to the immaturity of the seeds, for I carcfully examined them; nor to the seeds bcing diseascd or in any way injured in some one capsule, for the contents of the ton crosscd capsules were mingled together and a few taken by chance for sowing. In the second gencration the crossed and self-fertilised plants wer'c ncarly equal in hcight. In the third generation, crossed and self-fertilised seeds wcre obtained from two plants of the previous gencration, and the seedlings raised from them differed rewarkably in constitution; the crossed in the one casc excecded the sclf-fertilised in height in the ratio of 100 to 83 , and in the othcr case were almost cqual. This difference bctween the two lots, raiscd at the same time from two plants growing in the same pot, and treated in evcry respect alikc, as well as the cxtraordinary supcriority of the self-fertilised over the crossed plants in the first gcncration, considered together, make me believe that some individuals of the present species differ to a certain extent from others in their scxual affinities (to use the term employed by Gärtncr), like closely allied species of the same genus. Conscquently if two plants which thus differ are crosscd, the seedlings suffer and are beaten by those from the self-fertilised flowers, in which the sexual clemerts are of the same nature. It is known* that with our domestic animals

* I have given evidence on this head in my "Variation of Animals and Plants under Do- mestication' chap. xviri. 2nd edit. vol. ii. p. 146. 
certain individuals are sexually ineompatible, and will not produee offspring, although fertile with other individuals. But Kölreuter has reeorded a ease* whieh bears more closely on our present one, as it shows that in the genus Nieotiana the rarieties differ in their scxual affinitios. $\mathrm{He}$ experimented on five varicties of the eommon tobaeeo, and proved that they were varieties by showing that they were perfeetly fertile when reciproeally erossed; but one of these varieties, if used either as the father or the mother, was more fertile than any of the others when erossed with a widely distinet speeies, $N$. glutinosa. As the different varieties thus differ in their sexual affinities, there is nothing surprising in the individuals of the same rariety differing in a like manner to a slight degree.

Taking the plants of the three generations altogether, the crossed show no superiority over the self-fertilised, and I call aecount for this faet only by supposing that with this species, which is perfeetly self-fertile without inseet aid, most of the individuals are in the same condition, as those of the same rariety of the eommon per and of a few otler exotie plants, which have been self-fertilised for many generations. In sueh eases a cross between two individuals does no good; nor does it in any case, unless the individuals differ in general constitution, either from so-ealled spontaneous variation, or from their progenitors having been subjeeted to different eonditions. I beliere that this is the true explanation in the present instanee, because, as we shall immediately see, the offspring of plants, whieh did not profit at all by being crossed with a plant of the same stock, profited to an cxtraordinary degree by a cross with a slightly different sub-variety.

The Effects of a Cross with a ficsh Stoch:-I proeured some seed of $N$. tubocum from Kew and raised some plants, whieh formed a slightly different sub-variety from my former plants: as the flowers were a shade pinker, the leaves a little more pointed, and the plants not quite so tall. Therefore the adrantage in height which the seedlings gained by this cross eannot be attributed to direct inheritanee. 'Two of the plants of the third self-fertilised generation, growing in Pots II. and V. in Table LXXXYII., which exeeeded in lheight their erossed opponents (as dicl their parents in a still higlier degree) rere fertilised witl pollen from the Kew plants, that is, by a fresh stoek. The seedlings

* 'Das Geschlecht ler Pflanzen, Zweite Fortsetzung,' 176t, p. 55-60. 
thus raised may be called the Tew-crossed. Some other flower's on the same two plants were fertilised with their own pollen, and the secdlings thus raised form the fourth self-fertilised generation. The erossed eapsules produeed by the plant in Pot II., Table LXXXVII., were plainly less fine than the selffertilised eapsules on the same plant. In Pot V. the one finest capsule was also a self-fertilised onc; but the seeds produced by the two crossed eapsules together exceeded in number those produced by the two self-fertilised eapsules on the same plant. Therefore as far as the flower's on the parent-plants are concerned, a eross with pollen from a fresh stoek did little or no good; and I did not expeet that the offspring would have reeeired any benefit, but in this I was completcly mistaken.

The crossed and self-fcrtilised seeds from the two plants were plaeed on bare sand, and very many of the crossed seeds of both sets germinated before the self-fertilised seeds, and protruded their radicles at a quicker rate. Hence many of the crossed seeds had to be rejected, before pairs in an equal state of germination were obtained for planting on the opposite sides of sixteen large pots. The two series of seedlings raised from the parentplants in the two Pots II. and V. were kept separate, and when fully grown were measured to the tips of their highest leaves, as shown in the following double table. But as there was no uniform differenee in height between the crossed and self-fertilised secdlings raised from the two plants, thcir heights have been added together in calenlating the averages. I should state that by the accidental fall of a large bush in the greenhouse, several plants in both the series were much injured. These were at once measured together with their opponents and afterwards thrown amay. The others werc left to grow to their full height, and were measured when in flower. This accident accounts for the small beight of some of the pairs; but as all the pairs, whether ouly partly or fully grown, were measured at the same time, the measurements are fair.

The average height of the twenty-six erossed plants in the sixtcen pots of the two series is $63 \cdot 29$, and that of the twentysix self-fertilised plants is $41 \cdot 67$ inches; or as 100 to 66 . The superiority of the erossed plants was shown in another way, for in every one of the sixtecn pots a crossed plant flowered bcfore a self-fertilised one, with the exception of Pot VI. of the seeond series, in which the plants on the two sides flowered simultancously. 


\section{TABLE LXXXYIII.}

\section{Nicotiana tubacum.}

Plants raised from two Plants of the Third Self-fertitised Generation in Pots II. and V., in Table LXXXVII.

\begin{tabular}{|c|c|c|c|c|c|}
\hline \multicolumn{3}{|c|}{ From Pot IY., Table LXXXVII. } & \multicolumn{3}{|c|}{ From Pot V., Table LXXXVII. } \\
\hline No. of Pot. & $\begin{array}{l}\text { IJew-crossed } \\
\text { Plants. }\end{array}$ & $\begin{array}{l}\text { Plants of the } \\
\text { Fourth Self- } \\
\text { fertilised Gen- } \\
\text { eration. }\end{array}$ & No. of Pot. & $\begin{array}{l}\text { Kew-crossed } \\
\text { I'lants. }\end{array}$ & $\begin{array}{l}\text { Plants of the } \\
\text { Funrth Self- } \\
\text { fertilistd Gen- } \\
\text { eration. }\end{array}$ \\
\hline I. & $\begin{array}{l}\text { Inches. } \\
8+\frac{6}{8} \\
31\end{array}$ & $\begin{array}{c}\text { Inclies. } \\
68 \frac{4}{8} \\
5\end{array}$ & I. & $\begin{array}{c}\text { Inches. } \\
77 \frac{6}{8} \\
7 \frac{2}{5}\end{array}$ & $\begin{array}{l}\text { Inches. } \\
56 \\
5 \frac{3}{5}\end{array}$ \\
\hline II. & $\begin{array}{l}78 \frac{4}{8} \\
48\end{array}$ & $\begin{array}{l}51 \frac{4}{8} \\
70\end{array}$ & İI. & $\begin{array}{l}55 \frac{4}{8} \\
18\end{array}$ & $\frac{27 \frac{6}{6}}{7}$ \\
\hline III. & $\begin{array}{l}77 \frac{3}{5} \\
77 \frac{1}{8}\end{array}$ & $\begin{array}{r}12 \frac{6}{8} \\
6 \frac{6}{8}\end{array}$ & III. & $76 \frac{2}{8}$ & $60 \frac{6}{8}$ \\
\hline IV. & $\begin{array}{l}49 \frac{2}{8} \\
15 \frac{6}{8}\end{array}$ & $\begin{array}{l}29+\frac{4}{8} \\
32\end{array}$ & IV. & $\begin{array}{l}90 \frac{1}{5} \\
22 \frac{2}{8}\end{array}$ & $\begin{array}{r}11 \frac{6}{6} \\
4 \frac{1}{8}\end{array}$ \\
\hline 1. & $\begin{array}{l}89 \\
17\end{array}$ & $\begin{array}{l}85 \\
5 \frac{3}{8}\end{array}$ & $\mathrm{~T}$. & $9+\frac{2}{8}$ & $28 \frac{4}{8}$ \\
\hline VI. & 90 & 80 & VI. & 78 & $78 \frac{6}{8}$ \\
\hline VII. & $\begin{array}{l}8+\frac{4}{8} \\
76 \frac{4}{8}\end{array}$ & $\begin{array}{l}48 \frac{6}{8} \\
56 \frac{4}{8}\end{array}$ & VII. & $85 \frac{4}{8}$ & $61 \frac{1}{8}$ \\
\hline VIII. & $83 \frac{4}{8}$ & $8+\frac{1}{8}$ & VIII. & $\begin{array}{l}65 \frac{5}{8} \\
72 \frac{2}{5}\end{array}$ & $\begin{array}{l}78 \frac{3}{5} \\
27 \frac{4}{8}\end{array}$ \\
\hline $\left.\begin{array}{c}\text { Total in } \\
\text { inches. }\end{array}\right\}$ & $902 \cdot 63$ & $636 \cdot 13$ & $\left.\begin{array}{r}\text { Total in } \\
\text { inches. }\end{array}\right\}$ & $743 \cdot 13$ & $4+7 \cdot 38$ \\
\hline
\end{tabular}

Some of the remaining seeds of both series, whether or not in a state of germination, were thickly sown on the opposite sides of two very large pots; and the six highest plants on each side of each pot were measured after they had grom to mearly their full height. But their heights were much less than in the former trials, owing to their extremely erowded condition. Even whilst quite young, the erossed scedlings manifestly had much broader and finer leaves than the self-fertilised seedlings. 


\section{TABLE LXXXIX.}

\section{Nicotiana tabacum.}

Plants of the same parentage as those in Table LXXXVIII., but grown extremely crowded in two large pots.

\begin{tabular}{|c|c|c|c|}
\hline \multicolumn{2}{|c|}{ From Pot II., Table LIXXVIr. } & \multicolumn{2}{|c|}{ From Pot V., Table LXXXVII. } \\
\hline $\begin{array}{l}\text { Kew-crossed : } \\
\text { Plants. }\end{array}$ & $\begin{array}{l}\text { Plants of the } \\
\text { Fourth Self-ferti- } \\
\text { lised Generation. }\end{array}$ & $\begin{array}{l}\text { Kew-crossed } \\
\text { Plants. }\end{array}$ & $\begin{array}{l}\text { Plants of the } \\
\text { Fourth Self-ferti- } \\
\text { lised Generation. }\end{array}$ \\
\hline $\begin{array}{c}\text { Inches. } \\
42 \frac{4}{8} \\
34 \\
30 \frac{4}{8} \\
23 \frac{4}{8} \\
26 \frac{6}{8} \\
18 \frac{3}{8}\end{array}$ & $\begin{array}{l}\text { Iuches. } \\
22 \frac{4}{8} \\
19 \frac{2}{8} \\
14 \frac{2}{8} \\
16 \\
13 \frac{4}{8} \\
16\end{array}$ & $\begin{array}{c}\text { Inches. } \\
44 \frac{6}{8} \\
42 \frac{4}{8} \\
27 \frac{4}{8} \\
31 \frac{2}{8} \\
32 \\
24 \frac{6}{8}\end{array}$ & $\begin{array}{c}\text { Inches. } \\
22 \frac{1}{8} \\
21 \\
18 \\
15 \frac{2}{8} \\
13 \frac{3}{8} \\
14 \frac{7}{8}\end{array}$ \\
\hline $175 \cdot 63$ & $101 \cdot 50$ & $202 \cdot 75$ & $105 \cdot 13$ \\
\hline
\end{tabular}

The trielve tallest crossed plants in the two pots belonging to the two series average here $31 \cdot 53$, and the twelve tallest self-fertilised plants $17 \cdot 21$ inches in height; or as 100 to 54 . The plants on both sides, when fully grown, some time after they had been measured, were cut down close to the ground and weighed. The twelve crossed plants weighed $21 \cdot 25$ ounces; and the twelve self-fertilised plants only 7.83 ounces; or in weight as 100 to 37 .

The rest of the crossed and self-fertilised seeds from the two parent-plants (the same as in the last experiment) was sown on the lst of July in four long parallel and separate rows in good soil in the open ground; so that the seedlings were not subjected to any mutual competition. The summer was wet and unfavourable for their growtl. Whilst the seedlings were very small the two crossed rows had a clear advantage over the two self-fertilised rows. When fully grown the twenty tallest crossed plants and the twenty tallest self-fertilised plants were selected and measured on the 11th of November to the extremities of their leaves, as shown in the following table (XC.). Of the twenty crossed plants, twelve had flowered; whilst of the twenty self-fertilised plants one alone had flowered. 


\section{Table XC. \\ Nicotiana tabacum.}

I'lants raised from the same seeds as in the last two experiments, but sown separately in the open ground, so as not to compute together.

\begin{tabular}{|c|c|c|c|}
\hline \multicolumn{2}{|c|}{ From Pot II., Table LXXXVII. } & \multicolumn{2}{|c|}{ From Pot V., Table IXXXVII. } \\
\hline $\begin{array}{l}\text { Kew-crossed } \\
\text { Plauts. }\end{array}$ & $\begin{array}{l}\text { Plants of the } \\
\text { Fourth Self-ferti- } \\
\text { lised Generation. }\end{array}$ & $\begin{array}{c}\text { Kew-crossed } \\
\text { Plants. }\end{array}$ & $\begin{array}{l}\text { I'lants of the } \\
\text { Fourth Self-ferti- } \\
\text { lised Generation. }\end{array}$ \\
\hline $\begin{array}{c}\text { Inches. } \\
42 \frac{2}{8} \\
54 \frac{5}{8} \\
39 \frac{3}{8} \\
53 \frac{2}{8} \\
49 \frac{3}{8} \\
50 \frac{3}{8} \\
47 \frac{1}{8} \\
57 \frac{3}{8} \\
37 \\
48\end{array}$ & $\begin{array}{c}\text { Inches. } \\
22 \frac{6}{8} \\
37 \frac{1}{8} \\
34 \frac{1}{8} \\
30 \\
28 \frac{6}{8} \\
31 \frac{2}{8} \\
25 \frac{1}{8} \\
26 \frac{2}{8} \\
22 \frac{3}{8} \\
28\end{array}$ & $\begin{array}{l}\text { Inches. } \\
54 \frac{1}{5} \\
51 \frac{4}{8} \\
45 \\
43 \\
43 \\
48 \frac{6}{8} \\
44 \\
48 \frac{2}{8} \\
55 \frac{1}{8} \\
63\end{array}$ & $\begin{array}{c}\text { Inches. } \\
34 \frac{4}{8} \\
38 \frac{5}{8} \\
40 \frac{6}{8} \\
43 \frac{2}{8} \\
40 \\
38 \frac{2}{6} \\
35 \frac{6}{8} \\
39 \frac{6}{8} \\
47 \frac{6}{8} \\
58 \frac{5}{8}\end{array}$ \\
\hline $478 \cdot 75$ & $286 \cdot 86$ & $496 \cdot 13$ & $417 \cdot 25$ \\
\hline
\end{tabular}

The twenty tallest erossed plants here average $48 \cdot 74$, and the twenty tallest self-fertilised 35.2 inches in height; or as 100 to 72. These plants after being mensured were ent down elose to the ground, and the twenty erossed plants weighed $19.5 \cdot 75$ ounees, and the twenty self-fertiliced plants 123.25 ounees; or as 100 to 63 .

In the three preceding tables, LXXXVIII., LXXXIX., and $\mathrm{XC}$., we have the measurements of fifty-six plants dericed from two plants of the third self-fertiliscd generation crossed with pollen from a fresh stock, and of fifty-six plants of the fomrth selffertilised generation deriver from the same tro plants. These crossed and self-fertilised plants were treated in three different ways, having been put, firstly, into moderately close eompetition. with one another in pots; secondly, haring been subjected to unfavourable eonditious and to rery severe eompetition from being greatly erowded in two large pots; and thirdly, having being sown separately in open and good ground, so as not to suffer from any mutual competition. In all these eases the crossed plants in each lot were greatly superior to the self- 
fertilised. This was shown in several ways, - by the earlier germination of the crossed seeds, by the more rapid growth of the seedlings whilst quitc young, by the earlier flowering of the mature plants, as well as by the greater height which they ultimately attained. The superiority of the crossed plants was shown still more plainly when the two lots were weighed; the weight of the crossed plants to that of the self-fertilised in the two crowcled pots being as 100 to 37. Better evidence could hardly be desired of the immense advantage derived from a cross with a fresh stock.

\section{PRIMULACE $\mathbb{E}$.-CyClayen PERSICUM.*}

Ten flowers crossed with pollen from plants known to be distinct seedlings, yielded nine capsules, containing on an arcrage 84.2 sceds, with a maximum of seventy-seven in one. Tcn flowers self-fcrtilised yielded cight capsules, containing on an average only $13 \cdot 1$ seeds, with a maximum of twenty-five in one. This gires a ratio of 100 to 38 for the average number of seeds per capsule for the crossed and self-fertilised flowers. The flowers hang downwards, and as the stigmas stand close beneath the anthers, it might have been expected that pollen would have fallen on them, and that they would have been spontaneously self-fertilised; but these covered-up plants did not produce a single capsule. On some other occasions uncovered plants in the same greenhouse produced plenty of capsules, and I suppose that the flowers had been visited by bees, which could hardly fail to carry pollen from plant to plant.

The seeds obtained in the manner just described were placed on sand, and after germinating were planted in pairs, - three crossed and three self-fcrtilised plants on the opposite sides of four pots. When the leaves were 2 or 3 inches in length, including the foot-stalks, the seedlings on both sicles were crual. In the course of a month or two the crossed plants began to show a slight superiority ovcr the self-fertilised, which steadily increased; and the crossed flowered in all four pots some weeks beforc, and much more profuscly than the self-fertilised. The two tallest flower-stcms on the crossed plants in each pot wcre now moasured, and the avcragc hcight of the eight stems

* Cyclamen repandum, necording to Lecong ( Génerriplic Botanique de l'Jiurnpe,' tom, viii. 1858, n. 150), is proternandrous, and this I believe to be the case with $C$. persicum. 
was $9 \cdot 49$ inehes. After a considerable interval of time the self-fertilised plants flowered, and several of their flower-stems (but I forgot to record how many) were roughly measured, and theil average height was a little under $7 \cdot 5$ inches; so that the flower-stems on the crossed plants to those on the self-fertilised were at least as 100 to 79. The reason why I did not make more careful measurements of the self-fertilised plants was, that they looked such poor specimens that I determined to have them re-potted in larger pots and in the following year to measure them carefully; but we shall see that this was partly frustrated by so few flower-stems being then produced.

These plants were left uncovered in the greenhouse; and the twelve crossed plants produced forty capsules, whilst the twelve self-fertilised plants produced only five; or as 100 to 12. But this difference does not give a just idea of the relative fertility of the two lots. I counted the seeds in one of the finest eapsules on the crossed plants, and it contained seventy-three; whilst the finest of the five capsules produced by the selffertilised plants contained only thirty-five good seeds. In the other four capsules most of the seeds were barely half as large as those in the crossed capsules.

\section{TABLE XCI.}

Cyclamen persicum: 0 implies that no flower-stem was produced.

\begin{tabular}{|c|c|c|}
\hline No. of Pot. & Crossed Plauts. & Self-fertilised Plants. \\
\hline I. & $\begin{array}{c}\text { Inches. } \\
10 \\
9 \frac{2}{8} \\
10 \frac{2}{8}\end{array}$ & $\begin{array}{c}\text { Inches. } \\
0 \\
0 \\
0\end{array}$ \\
\hline II. & $\begin{array}{l}9 \frac{2}{8} \\
10^{2} \\
10 \frac{2}{8}\end{array}$ & $\begin{array}{l}0 \\
0 \\
0\end{array}$ \\
\hline III. & $\begin{array}{l}9 \frac{1}{8} \\
9 \frac{5}{8} \\
9 \frac{5}{5}\end{array}$ & $\begin{array}{l}8 \\
67 \\
6 \frac{7}{8}\end{array}$ \\
\hline IV. & $\begin{array}{l}11 \frac{1}{8} \\
10 \frac{5}{8} \\
10 \frac{6}{8}\end{array}$ & $\begin{array}{l}0 \\
77 \frac{7}{8} \\
0\end{array}$ \\
\hline Total in inches. & $119 \cdot 88$ & $29 \cdot 50$ \\
\hline
\end{tabular}


In the following year the crossed plants again bore many flowers before the self-fertilised bore a single one. The three tallest flower-stems on the crossed plants in each of the pots were measured, as shown in Table XCI. In Pots I. and II. the self-fertilised plants did not produce a single flower-stem; in Pot IV. only one; and in Pot III. six, of which the three tallest wcre measured.

The average height of the twelve flower-stems on the crossed plants is $9 \cdot 99$, and that of the four flower-stems on the selffertilised plants $7 \cdot 37$ inches; or as 100 to 74 . The self-fertilised plants were miserable specimens, whilst the crossed ones looked very vigorous.

\section{ANagallis.}

Anagallis collina, var. grandiflora (pale red and blue-flowered sub-varieties).

Firstly, twenty-five flowers on some plants of the red variety were crossed with pollen from a distinct plant of the same variety, and produced tcn capsules; thirty-one flowers were fertilised with their own pollen, and produced eighteon capsules. These plants, which were grown in pots in the greenhouse, were evidently in a very sterile condition, and the seeds in both sets of capsules, especially in the self-fertilised, although numerous, were of so poor a quality that it was very difficult to determine which were good and which bad. But as far as I could judge, the crossed capsules contained on an average $6 \cdot 3$ good seeds, with a maximum in one of thirteen; whilst the self-fertilised contained 6.05 such seeds, witl a maximum in one of fourteen.

Secondly, eleven flowers on the red variety were castrated whilst young and fertilised with pollen from the blue variety, and this cross cvidently much increased their fertility; for the eleven flowers yiclded seven capsules, which contained on an average twicc as many good sceds as before, viz., $12 \cdot 7$; with a maximum in two of the capsules of seventcen seeds. Therefore thesc crosscd capsules yiclded secds compared with those in tho foregoing self-fertiliscd capsules, as 100 to 48 . Thesc secds were also conspicuously larger than those from the cross between two individuals of the same red variety, and germinated much more frecly. 'The flowcrs on most of the plants produced by the cross betwcen the two-coloured varicties (of which several were raised), 
took after their mother, and were red-coloured. But on two of the plants the flowers were plainly stained witl blue, and to such a degree in one case as to be almost intermediate in tint.

The crossed seeds of the two foregoing kinds and the selffertilised were sown on the opposite sides of two large pots, and the secdlings were measured when fully grown, as shown in the two following tables:-

\section{TABLE XCII.}

Anagullis collina.

\begin{tabular}{|c|c|c|}
\hline \multicolumn{3}{|c|}{$\begin{array}{c}\text { Red Variety crossed by a distinct Plant of the Red Variety, } \\
\text { and Red Variety Self-fertilised. }\end{array}$} \\
\hline No. of Pot. & Crussed Plints. & Self-fertilised Plants. \\
\hline I. & $\begin{array}{l}\text { Inches. } \\
23 \frac{1}{8} \\
21 \\
17 \frac{2}{8}\end{array}$ & $\begin{array}{c}\text { Inches. } \\
15 \frac{4}{8} \\
15 \frac{4}{8} \\
14\end{array}$ \\
\hline Total in inches. & $61 \cdot 75$ & $45 \cdot 00$ \\
\hline \multicolumn{3}{|c|}{$\begin{array}{l}\text { Red Variety crossed by Blue Variety, and Red Variety } \\
\text { Self-fertilised. }\end{array}$} \\
\hline No. of l'ot. & Crossed Plants. & Self-fertilised l'lants. \\
\hline 11. & $\begin{array}{c}\text { Inches. } \\
30 \frac{4}{8} \\
27 \frac{3}{8} \\
25\end{array}$ & $\begin{array}{c}\text { Inches. } \\
24 \frac{1}{8} \\
18 \frac{4}{8} \\
11 \frac{1}{8}\end{array}$ \\
\hline Total in inches. & $82 \cdot 88$ & $5 \div \cdot 75$ \\
\hline Total of both lots. & $14 \pm \cdot 63$ & $99 \cdot 75$ \\
\hline
\end{tabular}

As the plants of the two lots are few in number, they may be run together for the general arerage; but I may first state that the height of the seedlings from the cross between two individuals of the red varicty is to that of the self-fertilised plants of the red variety as 100 to 73 ; whereas the height of the crossed offspring from the two varictios to the self-fertilised plants of the red variety is as 100 to 66 . So that the cross between the tro varicties is here seen to be the most adrantagcous. 'Ihe arerage height of all six crossed plants in the two lots taken togetlicr is 
$48 \cdot 20$, and that of the six self-fertilised plants $33 \cdot 25$; or as 100 to 69 .

These six crossed plants produeed spontaneously twenty-six capsules, whilst the six self-fertilised plants produced only two, or as 100 to $\mathrm{S}$. There is therefore the same extraordinary differenee in fertility between the crossed and self-fertilised plants as in the last genus, Cyclamen, whieh belongs to the same family of the Primulacce.

Primula veris. Brit. Flora.

(Var. officinalis, Linn.). The Cowslip.

Most of the speeies in this genus arc heterostyled or' dimorphie ; that is, they present two forms,-one long-styled with short stamens, and the other short-styled with long stamens.* For eomplete fertilisation it is neeessary that pollen from the one form should be applied to the stigma of the other form; and this is effeeted under nature by inseets. Sueh unions, and the seedlings raised from them, I have ealled legitimate. If one form is fertilised with pollen from the same form, the full complement of seed is not produced; and in the ease of some heterostyled generr no seed at all is produeed. Such unions, and the seedlings raised from them, I have called illegitimate. These seedlings are often dwarfed and more or less sterile, like hybrids. I possessed some long-styled plants of $P$. veris, which during four sueeessive generations had been produeed from illegitimate unions between long-styled plants ; they were, moreover, in some degree inter-related, and had been subjeeted all the time to similar conditions in pots in the greenhouse. As long as they were eultivated in this manner, they grew well and were healthy and fertile. Their fertility even inereased in the later generations, as if they were becoming habituated to illegitimate fertilisation. Plants of the first illegitimate generation when taken from the greenhouse and planted in moderately good soil out of doors grew well and were healthy; but when those of the two last illegitimate generations were thus treated thcy became exces-

* See my paper 'On the 'Two Forms or Dimorphic Condition in the Species of Primula,' in 'Joul'nal of Proc. Linn. Soc.' vol. vi. 1862, n. 77. A sceond priper, to which I presently refer, ' On tho Hybrid- like Nature of the Offspring from the Illegitimate Unions of Dimorphic and 'I'rimorphic Plants,' was publisherl in vol. x. 1867, p. 393, of the same journal. 
sively sterile and dwarfed, and remained so during the following year, by whieh time they ought to have become aceustomed to growing out of doors, so that they must have possessed a weak eonstitution.

Under these eireumstances, it seemed advisable to aseertain what would be the effeet of legitimately erossing long-styled plants of the fourth illegitimate generation with pollen taken from non-related short-styled plants, growing under different conditions. Aceordingly several flowers on plants of the fourth illegitimate generation (i.e., great-great-grandehildren of plants which had been legitimately fertilised), growing vigorously in pots in the greenhouse, were legitimately fertilised with pollen from an almost wild short-styled eowslip, and these flowers yielded some fine eapsules. Thirty other flowers on the same illegitimate plants were fertilised with their own pollen, and these yielded seventeen eapsules, containing on an average thirty-two seeds. This is a high degree of fertility; higher, I believe, than that whieh generally obtains with illegitimately fertilised longstyled plants growing out of doors, and higher than that of the previous illegitimate generations, although their flowers mere fertilised with pollen taken from a distinct plant of the same form.

These two lots of seeds were sown (for they will not germinate well when placed on bare sand) on the opposite sides of four pots, and the seedlings were thinned, so that an equal number were left on the two sides. For some time there was no marked differenee in height between the two lots; and in Pot III., Table XCIII, the self-fertilised plants were rather the tallest. But by the time that they had thrown up young flower-stems, the legitimately erossed plants appeared mueh the finest, and had greener and larger leaves. The breadth of the largest leaf on eaeh plant was measured, and those on the erossed plants were on an average a quarter of an inch (exactly $2 S$ of an inch) broader than those on the self-fertilised plants. 'The plants, from being too mueh crowded, produeed poor and short flower-stems. The two finest on each side were measured; the eight on the legitimately crossed plants averaged $4 \cdot 08$, and the eight on the illegitimately self-fertilised plants averaged 2.93 inehes in height; or as 100 to 72.

These plants after they had flowered were turned out of their pots, and planted in fairly good soil in the open ground. In the following year (1870), when in full flower, the two tallest 
flower-stems on each side were again measured, as shown in the following table, which likewise gives the number of flower-stems produced on both sides of all the pots.

TABLE TCIII,

Primula veris.

\begin{tabular}{|c|c|c|c|c|}
\hline \multirow{2}{*}{ No. of Pot. } & \multicolumn{2}{|c|}{ LegitimatelJ crossed Flants. } & \multicolumn{2}{|c|}{$\begin{array}{l}\text { Illegitimately self-fertilised } \\
\text { Plants. }\end{array}$} \\
\hline & $\begin{array}{l}\text { Height in } \\
\text { inches. }\end{array}$ & $\begin{array}{l}\text { No. of Flower- } \\
\text { stems pro- } \\
\text { duced. }\end{array}$ & $\begin{array}{l}\text { Height in } \\
\text { inches. }\end{array}$ & $\begin{array}{l}\text { No. of Flower- } \\
\text { stems pro- } \\
\text { duced. }\end{array}$ \\
\hline I. & $\begin{array}{l}9 \\
8\end{array}$ & 16 & $\begin{array}{l}2 \frac{1}{8} \\
3 \frac{4}{8}\end{array}$ & 3 \\
\hline II. & $\begin{array}{l}7 \\
6 \frac{4}{6}\end{array}$ & 16 & $\begin{array}{l}6 \\
5 \frac{4}{8}\end{array}$ & 3 \\
\hline III. & $\begin{array}{l}6 \\
6 \frac{2}{8}\end{array}$ & 16 & $\begin{array}{l}3 \\
0 \frac{4}{8}\end{array}$ & 4 \\
\hline IV. & $\begin{array}{l}7 \frac{3}{8} \\
6 \frac{1}{8}\end{array}$ & 14 & $\begin{array}{l}2 \frac{5}{8} \\
2 \frac{4}{8}\end{array}$ & 5 \\
\hline Total. & $56 \cdot 26$ & 62 & $25 \cdot 75$ & 15 \\
\hline
\end{tabular}

The average height of the eight tallest flower-stems on the erossed plants is here 7.03 inehes, and that of the eight tallest flower-stems on the self-fertilised plants $3 \cdot 21$ inches; or as 100 to 46 . We see, also, that the erossed plants bore sixty-two flowerstcms; that is, above four times as many as those (viz., fifteen) borne by the self-fertilised plants. The flower's were left exposed to the visits of inseets, and as many plants of both forms grew closc by, they must have been legitimately and naturally fertilised. Under thesc cireumstances the erossed plants produeed $32 t$ eapsules, whilst the self-fertilised produced only 16 ; and these were all produeed by a single plant in Pot II., which was muel finer than any other self-fertilised plant. Judging by the number of capsules produced, the fertility of an equal number of crossed and self-fertilised plants was as 100 to 5 .

In the sueceeding year (1871) I did not count all the flowerstems on these plants, but only those whieh produced capsules containing good seeds. The season was unfavourable, and the crossed plants produeed only forty stuch flower-stems, bearing 
168 good capsules, whilst the self-fertilised plants produced only two sueh flower-stems, bearing only 6 eapsules, half of whieh were very poor ones. So that the fertility of the two lots, judging by the number of eapsules, was as 100 to $3 \cdot 5$.

In considering the great differenee in height and the wonderful difference in fertility between the two sets of plants, we should bear in mind that this is the result of two distinct ageneies. The self-fertilised plants were the produet of illegitimate fertilisation during five suecessire generations, in all of whieh, exeepting the last, the plants had been fertilised with pollen taken from a distinet individnal belonging to the same form, but which was more or less elosely related. The plants had also been subjeeted in each generation to elosely similar eonditions. This treatment alone, as I know from other observations, would have greatly redueed the size and fertility of the offspring. On the other hand, the erossed plants were the offspring of long-styled plants of the fourth illegitimate generation legitimately erossed with pollen from a short-styled plant, whieh, as well as its progenitors, had been exposed to very different eonditions; and this latter eireumstance alone would have given great vigour to the offspring, as we may infer from the several analogous eases already given. How numeh proportional weight ought to be attributed to these two ageneies, - the one tending to injure the self-fertilised offspring, and the other to benefit the erossed offspring,-eannot be determined. But we shall immediately see that the greater part of the benefit, as far as inereased fertility is eoncerned, must be attributed to the eross haring been made with a frosh stoek.

\section{Primula veris.}

Equal-styled and red-flowered var.

I have deseribed in my paper 'On the Illegitimate Unions of Dimorphie and Trimorphie Plants' this remarkable variety, which was sent to me from Edinburgh by Mr. J. Seott. It possessed a pistil proper to the long-styled form, and stamens proper to the short-styled form; so that it had lost the heterostyled or dimorphie eharaeter eommon to most of the speeies of the genus, and may be compared with an hermaphrodite form of a bisexual animal. Consequently the pollen and stigma of the same flower are adapted for eomplete mutnal fertilisation, instead of its being necessary that pollen should be brought from one 
form to another, as in the common cowslip. From the stigma and anther's standing nearly on the same level, the flowers are perfeetly self-fertile when insects are excluded. Owing to the fortunate existence of this variety, it is possible to fertilise its flowers in a legitimate manner with their own pollen, and to eross other flowers in a legitimate manner with pollen from another rariety or fresh stock. Thus the offspring from both unions can be compared quite fairly, free from any doubt from the injurious effeets of an illegitimate union.

The plants on which I experimented had been raised during two sueeessive generations from spontaneously. self-fertilised seeds produced by plants under a net; and as the variety is highly self-fertile, its progenitors in Edinburgh may have been self-fertilised during some previous generations. Several flower's on two of my plants were legitimately erossed with pollen from a short-styled eommon cowslip growing almost wild in my orchard; so that the eross was between plants which had been subjeeted to eonsiderably different conditions. Several other flowers cn the same two plants were allowed to fertilise themselves under a net; and this union, as already explained, is a legitimate one.

The crossed and self-fertilised seeds thus obtained were sown thickly on the opposite sides of three pots, and the seedlings thinned, so that an equal number were left on the two sides. The seedlings during the first year were nearly equal in height, exceptiug in Pot III., Table XCIV., in which the selffertilised plants had a deeided advantage. In the autumn the plants were bedded out, in their pots; owing to this cireumstance, and to many plants growing in each pot, they did not flourish, and none were very productive in seeds. But the eonditions were perfeetly equal and fair for both sides. In the following spring I record in my notes that in two of the pots the erossed plants are "incomparably the finest in general apperranee," and in all three pots they flowered before the selffertilised. When in full flower the tallest flower-stem on eaeh. side of each pot was measured, and the number of the flowerstems on both sides eounted, as shown in the following table. 'The plants were left uneovered, and as other plants were growing close by, the flowers no doubt were crossed by inseets. When the eapsules were ripe they were gathered and eounted, and the result is likewise shown in the following table:- 
TABLE XCTV.

Primula veris (equal-styled, red-flowered variety).

\begin{tabular}{|c|c|c|c|c|c|c|}
\hline \multirow[b]{2}{*}{ No. of Put. } & \multicolumn{3}{|c|}{ Crossed Plants. } & \multicolumn{3}{|c|}{ Self-fertilised l'lants. } \\
\hline & $\begin{array}{l}\text { Height of } \\
\text { tallest } \\
\text { Flower-stem } \\
\text { in inches. }\end{array}$ & $\begin{array}{l}\text { No. of } \\
\text { Flower- } \\
\text { stems. }\end{array}$ & $\begin{array}{l}\text { No. of good } \\
\text { Capsules. }\end{array}$ & $\begin{array}{c}\text { Height of } \\
\text { tallest } \\
\text { Flower-stem } \\
\text { in inclies. }\end{array}$ & $\begin{array}{l}\text { No. of } \\
\text { Flower- } \\
\text { stems. }\end{array}$ & $\begin{array}{l}\text { No. of gond } \\
\text { Capsules. }\end{array}$ \\
\hline I. & 10 & 14 & 163 & $6 \frac{4}{8}$ & 6 & 6 \\
\hline II. & $8 \frac{4}{8}$ & 12 & $\begin{array}{c}\text { Several, } \\
\text { not } \\
\text { counted. }\end{array}$ & 5 & 2 & 0 \\
\hline III. & $7 \frac{4}{8}$ & 7 & 43 & $10 \frac{4}{8}$ & 5 & 26 \\
\hline Totals. & $26 \cdot 0$ & 33 & 206 & $22 \cdot 0$ & 13 & 32 \\
\hline
\end{tabular}

ע

The average lieight of the three tallest flower-stems on the crossed plants is 8.66 inehes, and that of the three on the self-fertilised plants $7 \cdot 33$ inehes; or as 100 to 85 .

All the erossed plants together prodneed thirty-three flowerstems, whilst the self-fertilised bore only thirteen. The number of the eapsules were counted only on the plants in Pots I. and III., for the self-fertilised plants in Pot II. produeed none; therefore those on the erossed plants on the opposite side were not counted. Capsules not eontaining any good seeds were rejeeted. The erossed plants in the above two pots produeed 206, and the self-fertilised in the same pots only 32 capsules; or as 100 to 15. Judging from the previous generations, the extreme unproduetiveness of the self-fertilised plants in this experiment was wholly due to their having been subjected to $m$ nfarourable conditions, and to severe competition with the erossed plants; for had they grown separately in good soil, it is almost eertain that they would hare produeed a large number of enpsnles. The seeds were eounted in twenty eapsules from the crossed plants, and they areraged 24.75; whilst in twenty eapsules from the self-fertilised plants the average was $17 \cdot 6.5$; or as 100 to 71 . Moreover, the seeds from the self-fertilised plants were not nearly so fine as those from the crossed plants. If we consider together the number of eapsules produced and the averago number of contained seeds, the fertility of the crossed plants to the self-fertilised plants was as 100 to 11 . 
We thus see what a great effect, as far as fertility is concerned, was produced by a cross between the two varietics, which had been long exposed to different eonditions, in comparison with self-fertilisation; the fertilisation having been in both eases of the legitimate order.

\section{Primula sinensis.}

As the Chinesc primrose is a heterostyled or dimorphic plant, like the common cowslip, it might have been expected that the flower's of both forms when illegitimately fertilised with their own pollen or with that from flowers on another plant of the same form, would have yielded less seed than the legitimately crossed flowers; and that the seedlings raised from illegitimately self-fertilised seeds would have been somewhat dwarfed and less fertile, in comparison with the seedlings from legitimately crossed seeds. This holds good in relation to the feltility of the flowers; but to my surprise there was no difference in growtl between the offspring from a legitimate union between tro distinct plants, and from an illegitimate union whether between the flowers on the same plant, or between distinet plants of the same form. But I have shown, in the paper before referred to, that in England this plant is in an abnormal condition, such as, judging from analogous cases, would tend to render a cross between two individuals of no benefit to the offspring. Our plants have been commonly raised from self-fertilised seeds; and the seedlings have gencrally been subjected to nearly uniform conditions in pots in greenhouses. Moreover, many of the plants are now varying and changing their charaeter', so as to become in a greater or less degree equal-styled, and in eonsequence highly self-fertile. From the analogy of $P$. veris there can hardly be a doubt that if a plant of $P$. sinensis could have been procured direet from China, and if it had been crossed with one of our English varieties, the offspring would have shown wonderful superiority in height and fertility (though probably not in the beauty of their flowers) over our ordinary plants.

My first experiment consisted in fertilising many flowers on long-styled and short-styled plants with their own pollen, and other flowers on the same plants with pollen taken from distinet plants belonging to the same form; so that all the unions were illegitimate. 'There was no uniform and marked difference in 
the number of seeds obtained from these two modes of self-fertilisation, both of which were illegitimate. The two lots of seeds from both forms were sown thickly on opposite sides of four pots, and numervus plants thus raised. But there was no difference in their growth, excepting in one pot, in which the offspring from the illegitimate union of two long-styled plants exceeded in a decided manner in height the offspring of flowers on the same plants fertilised with their own pollen. But in all four pots the plants raised from the union of distinct plants belonging to the same form, flowered before the offspring from the selffertilised flowers.

Some long-styled and short-styled plants were now raised from purchased seeds, and flowers on both forms were legitimately crossed with pollen from a distinct plant; and other flowers on both forms were illegitimately fertilised with pollen from the flowers on the same plant. The seeds were sown on opposite sides of Pots I. to IV. in the following table (XCV.); a single plant being left on each side. Several flowers on the illegitimate longstyled and short-styled plants describod in the last paragraph, were also legitimately and illegitimately fertilised in the manner just described, and their seeds were sown in Pots V. to VIII. in the same table. As the two sets of seedlings did not differ in any essential manner, their measurements are giren in a single table. I should add that the legitimate unions in both eases yiclded, as might have been expected, many more seeds than the illegitimate unions. The seedlings whilst half-grown presented no difference in height on the two siles of the several pots. When fully grown they were measured to the tips of their longest leaves, and the result is given in Table XCV.

In six out of the eight pots the legitimately crossed plants exceeded in height by a trifie the illegitimately self-fertilised plants; but the latter exceeded the former in tro of the pots in a more strongly marked manner. The average height of the eight legitimately crossed plants is $9 \cdot 01$, and that of the eight illegitimately self-fertilised 9.03 inches; or as 100 to 100.2 . The plants on the opposite sides produced, as tiar as could be judged by the eyc, an equal number of flowers. I did not count the capsules or the seeds produced by them; but undonbtedly, judging from many previons observations, the plants derived from the legitimately crossed seeds would have been considerably more fertile than those from the illegitinately self-fertilised seeds. The crossed plants, as in the previous case, flowered before the 


\section{Table XCV. \\ Primula sinensis.}

\begin{tabular}{|c|c|c|}
\hline No. of Pot. & $\begin{array}{l}\text { Plants from legiti- } \\
\text { mately crossed Seeds. }\end{array}$ & $\begin{array}{l}\text { Plants from illegiti- } \\
\text { mately self-fertilised } \\
\text { Seeds. }\end{array}$ \\
\hline $\begin{array}{c}\text { I. } \\
\text { From short-styled } \\
\text { mother. }\end{array}$ & $\begin{array}{l}\text { Inches. } \\
8 \frac{2}{8}\end{array}$ & $\begin{array}{c}\text { Inches. } \\
8\end{array}$ \\
\hline $\begin{array}{l}\text { II. } \\
\text { From short-styled } \\
\text { mother. }\end{array}$ & $7 \frac{4}{8}$ & $8 \frac{5}{8}$ \\
\hline $\begin{array}{l}\text { III. } \\
\text { From long-styled } \\
\text { mother: }\end{array}$ & $9 \frac{5}{8}$ & $9 \frac{3}{8}$ \\
\hline $\begin{array}{l}\text { IV. } \\
\text { From long-styled } \\
\text { mother. }\end{array}$ & $8 \frac{4}{8}$ & $8 \frac{2}{8}$ \\
\hline $\begin{array}{c}\mathrm{V} . \\
\text { From illegitimate } \\
\text { short-styled } \\
\text { mother. }\end{array}$ & $9 \frac{3}{3}$ & 9 \\
\hline $\begin{array}{c}\text { VI. } \\
\text { From illegitimate } \\
\text { short-styled } \\
\text { mother. }\end{array}$ & $9 \frac{7}{8}$ & $9 \frac{4}{8}$ \\
\hline $\begin{array}{l}\text { VII. } \\
\text { From illegitimate } \\
\text { long-styled mother. }\end{array}$ & $8 \frac{4}{8}$ & $9 \frac{1}{8}$ \\
\hline $\begin{array}{l}\text { VIII. } \\
\text { From illegitimate } \\
\text { long-styled mother. }\end{array}$ & $10 \frac{4}{8}$ & 10 \\
\hline Total in inches. & $72 \cdot 13$ & $72 \cdot 25$ \\
\hline
\end{tabular}

self-fertilised plants in all the pots exeept in Pot II., in whieh the two sides flowered simultaneonsly; and this early flowering may, perhaps, be considered as an advantage. 


\section{POLTGONEA.-FAGOPYRUM ESCULENTUM.}

This plant was discovered by Hildebrand to be leterostyled, that is, to present, like the species of Primula, a long-styled and a short-styled form, which are adapted for reciprocal fertilisation. Therefore the following comparison of the growth of the erossed and self-fertilised seedlings is not fair, for we do not know whether the difference in their heights may not be wholly due to the illegitimate fertilisation of the self-fertilised flowers.

I obtained seeds by legitimately crossing flowers on long-styled and short-styled plants, and by fertilising other flowers on both forms with pollen from the same plant. Rather more seeds were obtained by the former than by the latter process; and the legitimately crossed seeds were heavier than an equal number of the illegitimately self-fertilised seeds, in the ratio of 100 to 82 . Crossed and self-fertilised seeds from the short-styled parents, after germinating on sand, were planted in pairs on the opposite sides of a large pot; and two similar lots of seeds from longstyled parents were planted in a like manner on the opposite sides of two other pots. In all three pots the legitimately crossed seedlings, when a few inches in height, were taller than the selffertilised; and in all three pots they flowered before them by one or two days. When fully grown they were all eut down close to the ground, and as I was pressed for time, they were placed in a long row, the eut end of one plant touehing the tip of another, and the total length of the legitimately erossed plants was $47 \mathrm{ft} .7 \mathrm{in}$., and of the illegitimately self-fertilised plants $32 \mathrm{ft} .8 \mathrm{in}$. Therefore the average height of the fifteen crossed plants in all three pots was 38.06 inches, and that of the fifteen self-fertilised plants $26 \cdot 13$ inches; or as 100 to $6 \%$.

\section{XXV1II. CHENOPODIACEZE-BETA VULGARIS.}

A single plant, no others growing in the same garden, was left to fertilise itself, and the self-fertilised seeds were eollected. Seeds were also collected from a plant growing in the midst of a lirge bed in another garden; and as the incoherent pollen is aluundant, the seeds of this plant will almost certainly liave been the product of a cross between distinct plants by means of the wind. Some of the two lots of seeds were somn on the opposite sides of two very large pots; and the young seedlings were thinned, so that an equal but considerable number was left on the two sides. These plants were thus subjected to rery severe 
competition, as well as to poor conditions. The remaining seeds were sown out of doors in good soil in two long and not elosely adjoining rows, so that these seedlings were plaeed under favourable eonditions, and were not subjeeted to any mutual competition. The self-fertilised seeds in the open ground came up rery badly; and on removing the soil in two or three places, it was found that many had sprouted under ground and had then dier. No sueh ease had been observed before. Owing to the large number of seedlings which thus perished, the surviving self-fertilised plants grew thinly in the row, and thus had an advantage over the crossed plants, whieh grew very thickly in the other row. The young plants in the two rows were proteeted by a little straw during the winter, and those in the two large pots were placed in the greenhouse.

There was no difference between the two lots in the pots until the ensuing spring, when they had grown a little, and then some of the crossed plants were finer and taller than any of the selffertilised. When in full flower their stems were measured, and the measurements are given in the following table:-

TABLE XCVI.

Beta vulgaris.

\begin{tabular}{|c|c|c|}
\hline No. of Pot. & Crossed Plants. & Self-fertilised Plants. \\
\cline { 1 - 3 } I. & Inches. & Inches. \\
& $34 \frac{6}{8}$ & 36 \\
& 30 & $20 \frac{1}{8}$ \\
& $33 \frac{6}{8}$ & 32 \\
& $34 \frac{4}{8}$ & 32 \\
\hline II. & $42 \frac{3}{8}$ & $42 \frac{1}{8}$ \\
& $33 \frac{1}{8}$ & $26 \frac{4}{8}$ \\
& $31 \frac{2}{8}$ & $29 \frac{2}{8}$ \\
& 33 & $20 \frac{2}{8}$ \\
\hline Total in inches. & $272 \cdot 75$ & $338 \cdot 50$ \\
\hline
\end{tabular}

The average height of the eight erossed plants is here $34^{\circ} 09$, and that of the eight self-fertilised plants $29 \cdot 81$; or as 100 to 87.

With respeet to the plants in the open ground, eaeh long rorv was divided into half, so as to diminish the chanee of any accidental advantage in one part of either row; and the four tallest plants in the two halves of the two rows wore earefully 
selected and measured. The eight tallest crossed plants averaged 30.92 , and the eight tallest self-fertilised 30.7 inches in height, or as 100 to 99 ; so that they were practically equal. But we should bear in mind that the trial was not quite fair, as the self-fertilised plants had a great advantage over the crossed in being much less crowded in their own row, owing to the large number of seeds which had perished under ground after spronting. Nor were the lots in the two rows subjected to any mutual competition.

\section{CANNACEZE,CANNA WARSCEWICZI.}

In most or all the species belonging to this genus, the pollen is shed before the flower expands, and adheres in a mass to the foliaceous pistil close beneath the stigmatic surface. As the edge of this mass generally touches the edge of the stigma, and as it was ascertained by trials purposely made that a very few pollen-grains suffice for fertilisation, the present species and probably all the others of the genus are highly self-fertile. Exceptions occasionally occur in which, from the stamen being slightly shorter than usual, the pollen is deposited a little bencath the stigmatic surface, and such flowers drop off unimpregnated unless they are artificially fertilised. Sometimes, thougl rarely, the stamen is a little longer than usual, and then the whole stigmatic surface gets thickly covered with pollen. As some pollen is generally deposited in contact with the edge of the stigma, certain authors have concluded that the flower's are invariably self-fertilised. This is an extraordinary conclusion, for it implies that a great amount of pollen is produced for no purpose. On this view, also, the large size of the stigmatic surface is an unintelligible feature in the structure of the flower, as well as the relative position of all the parts, which is such that when insects visit the flowers to suck the copious nectar, they cannot fail to carry pollen from one flower to another.*

* Delpino lias described ('Bot. Zeitung,' 1S67, p. 277, and 'Sciontific Opinion,' 1870 , p. $13 \pi$ ) the structure of the flowers in this genus, but he was mistaken in thinking that selt-fertilisation is impossible, at lenst in the cuse of the present species. Dr. Dickie and Prof: Faive state that the fluwers are fertilised in the bud, and that self-fertilisation is incritable. I presume that they wero misled by the pollen buing depositer at a very early perind on the pistil : see 'Journal of Linn. Soe. Bot.' vol. x. p. 55, and 'Variabilité des Especees;' 1868 , p. 158. 
According to Delpino, becs eagerly visit the flowers in North Italy, but I have never seen any inseet visiting the flowers of the present speeies in my hothouse, although many plants gicw there during scveral years. Nevcrtheless these plants produced plenty of seed, as they likervise did when covcred by a net; they are therefore fully eapable of self-fertilisation, and have probably been self-fertilised in this country for many generations. As they are eultivated in pots, and are not exposed to competition with surrounding plants, they have also been subjeeted for a eonsiderable time to somewhat uniform eonditions. This, therefore, is a ease exaetly parallel with that of the eommon pea, in whieh we have no right to expect mueh or any good from intercrossing plants thus deseended and thus treated; and no good did follow, cxeepting that the eross-fertilised flowers yielded rather more seeds than the self-fertilised. This species was one of the earlier ones on whieh I expcrimented, and as I had not then raised any self-fertilised plants for scveral sueessive generations under uniform conditions, I did not know or even suspeet that such treatment would interfere with the adrantages to be gained from a eross. I was thereforc mueh surprised at the crossed plants not growing more vigorously than the selffcrtilised, and a large number of plants were raiscd, notwithstanding that the present speeies is an extremely troublesome one to experiment on. The sceds, cven those which have becn long soaked in water, will not germinate well on bare sand; and those that were sown in pots (whieh plan I was foreed to follow) germinated at very unequal intervals of time; so that it was diffieult to get pairs of the same exact age, and many scedlings had to be pulled up and thrown away. My experiments werc continued during threc sueeessive generations; and in each generation the self-fertilised plants werc again self-fcrtilised, their early progenitors in this eountry having probably been selffertilised for many previous generations. In each generation, also, the erossed plants werc fertilised with pollen from another crossed plant.

Of the flowers whieh were crossed in the three generations, taken together, a rather larger proportion yielded capsules than did those whieh were self-fertilised. The secds were counted in forty-seven eapsules from the crossed flowcrs, and they eontained on an avernge $9 \cdot 95$ seeds; whereas forty-eight eapsules from the sclf-fertilised flowcrs eontained on an average 8.45 seeds; or as 100 to 85. Tho seeds from the crosscd flower's werc 
not heavier, on the eontrary a little lighter, than those from the self-fertilised flowers, as was thriee aseertained. On one oeeasion I weighed 200 of the erossed and 106 of the self-fertilised seeds, and the relative reight of an equal number was as 100 for the erossed to $101 \cdot 5$ for the self-fertilised. With other plants, when the seeds from the self-fertilised flowers were heavier than those from the erossed flowers, this appeared to be due generally to fewer having been produeed by the self-fertilised flowers, and to their having been in eonsequenee botter nourished. But in the present instanee the seeds from tlie erossed eapsules were separated into two lots,-namely, those from the eapsnles eontaining over fourteen seeds, and those from expsules eontaining minder fomrteen seeds, and the seeds from the more prodnetive eapsules were the heavier of the two; so that the above explanation here fails.

As pollen is deposited at a very early age on the pistil, generally in eontaet with the stigma, some flowers whilst still in bud were eastrated for my first experiment, and were aftermards fertilised with pollen from a distinet plant. Other flowers were fertilised with their own pollen. From the seeds thus obtained, I sueeeded in rearing only three pairs of plants of equal age. The three erossed plants averaged 32.79 inehes, and the three self-fertilised 32.08 inehes in height; so that they were nearly equal, the erossed having a slight advantage. As the same result followed in all three generations, it would be superfluous to give the heights of all the plants, and I will gire only the averages.

In order to raise erossed and self-fertilised plants of the second generation, some flower's on the above erossed plints were crossed within twenty-four hours after they had expanded with pollen from a distinet plant; and this interval would probably not be too great to allow of eross-fertilisation being effeetual. Some flowers on the self-fertilised plants of the last generation were also selffertilised. From these two lots of seeds, ten erossed and trelre self-fertilised plants of equal ages were raised; and these were measured when fully grown. The erossed arernged $36^{\circ} \cdot 98$, and the self-fertilised averaged $37 \cdot 42$ inehes in height; so that here again the two lots were nearly equal; but the self-fertilised had a slight advantage.

In order to raise plants of the third generation, a better plan was followed, and flowers on the erossed plants of the seeond generation were selected in whieh the stamens were foo slort to 
reach the stigmas, so that they could not possibly lave been self-fertilised. These flowers were crossed with pollcn from a distinct plant. Flower's on the self-fertilised plants of the second generation rere again self-fertilised. From the two lots of seeds thus obtained, twenty-one crossed and nincteen self-fertilised plants of equal age, and forming the third generation, were raised in fourtecu large pots. They were measured when fully grown, and by an odd chance the average height of the two lots was exactly the same, namely, 35.96 inches; so that neither side had the least adrantage over the other. To test this result, all the plants on both sides in ten out of the above fourteen pots were cut down after they had flowered, and in the ensuing year the stems were again measured; and now the crossed plants exceeded by a little (viz., 1·7 inches) the self-fertilised. They were again cut down, and on their flowering for the third time, the self-fertilised plants had a slight advantago (viz., 1.54 inches) over the crossed. Hence the result arrived at with these plants during the previons trials was confirmed, namcly, that neither lot had any decided advantage over the other. It may, however, bc worth mentioning that the self-fertilised plants showed some tendency to flowcr before the crossed plants: this occurred with all three pairs of the first generation; and with the cut down plants of the third generation, a self-fertilised plant flowered first in nine out of the twelve pots, whilst in the remaining three pots a crossed plant flowered first.

If we consider all the plants of the three generations taken together, the thirty-four crossed plants average $35 \cdot 98$, and the thirty-four self-fertilised plants 36.39 inches in height: or as 100 to 101 . Te may therefore conclude that the two lots possessed equal powers of growth; and this I believe to be the result of long-continued self-fertilisation, together with exposure to similar conditions in each generation, so that all the indivicluals had acquired a closely similar constitution.

\section{GRAMINACEA.ZZEA MAYS.}

This plant is monocious, and was selected for trial on this account, no other such plant having been experimented on.* It is

* Hildebrand remarlis that this specius seems at first sight adapted to be fertilised by pollen from the same plant, owing to the male flower's stanling above the fernale llowers; but practically it inust generilly be fertilised by pollen from another plant, as tho 
also anemophilous, or is fertilised by the wind; and of such plants only the common beet hal been tried. Some plants were laised in the greenhouse, and were crossed with pollen taken ${ }^{f}$ rom a distinet plant; and a single plant, growing quite separately in a different part of the house, was allowed to fertilise itsolf spontaneously. The seeds thus obtained were placed on damp sand, and as they germinuted in pairs of equal age were plauted on the opposite siles of fonl very large pots; nevertheless they wore cousiderably erowded. The pots were kept in the hothouse. The plants were first measured to the tips of their leares when only between 1 and 2 feet in height, as shown in the following table:-

\section{TABLE XCVII.}

Zect muy:s:

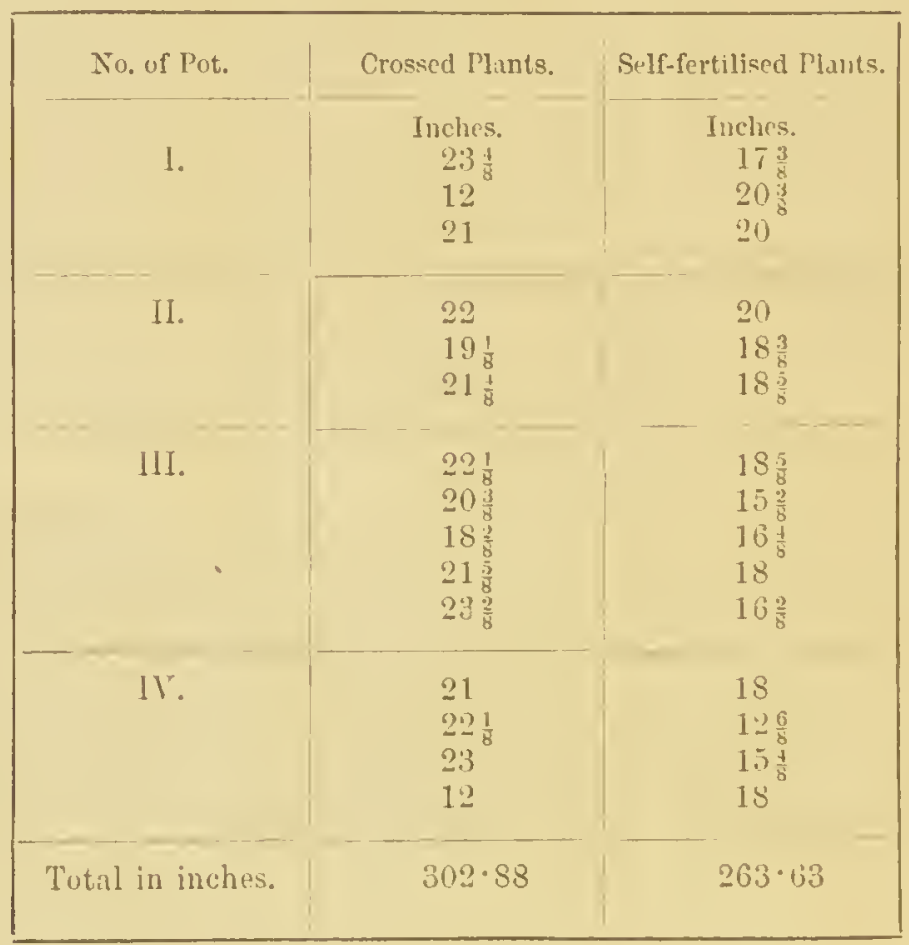

The fiftecn crosserl plants here average $20 \cdot 19$, and the fifteen self-fertiliser plants $17 \cdot 57$ inches in height; or as 100 to 57 . Mrr. Gaiton made a graplicen rejrescntation, in accordance with the method described in the introdnetory ehapter, of the abore

male flowers ustually sher their pollen before the female flowers are mature: "Mlonatsbericht der' h. Akad. Berlin, Oct. 1\$72, 1. $7 \pm 3$. 
measurements, and adds the words "very good" to the curves thus formed.

Shortly aftcrwards one of the crossed plants in Pot I. dicd; another became much discased and stunted; and the third never grew to its full hcight. They seemed to have been all injured, probably by some larva gnawing their roots. Therefore all the plints on both sides of this pot were rejected in the subsequent measurements. When the plants were fully grown they were again measured to the tips of the highest leares, and the eleven crossed plants now avcraged $68^{\circ} 1$, and the eleven selffertilised plants $62 \cdot 34$ inches in height; or as 100 to 91 . In all four pots a crossed plant flowcred beforc any one of the self-fertilised; but three of the plants did not flower at all. Those that flowered were also measured to the summits of the male flowers: the ten crossed plants averaged $66 \cdot 51$, and the nine self-fertilised plants $61 \cdot 59$ inches in hcight; or as 100 to 93.

A large number of the same crossed and self-fertilised scerls were sown in the middle of the summer in the open ground in two long rows. Very much ferrer of the self-fertilised than of the crosscd plants produced flowers; but those that did flower, flowered almost simultaneously. When fully grown the ten tallest plants in each row were selected and measured to the tips of their highest leaves, as well as to the summits of their male flowers. The crossed avcraged to the tips of their leaves 54 inches in height, and the self-fertilised $44^{\circ} 65$, or as 100 to $\mathrm{S} 3$; and to the summits of their male flowers, 53.96 and $43 \cdot 45$ inches; or as 100 to 80.

\section{Phalaris canariensis.}

Hildebrand has shown in the paper referred to under the last species, that this hermaphrodite grass is better adapted for cross-fertilisation than for self-fertilisation. Several plants were raised in the greenhousc close together, and their flowcrs were mutually intercrossed. Pollen from a single plant growing quitc separatcly was collected and placed on the stigmas of the same plant. The secds thus produced were self-fertilised, for they were furtilised with pollen from the same plant, but it will have been a merc chance whether with pollen from the samc flowers. Both lots of sccds, after germinating on sand, were planted in pair's on the opposite sides of four pots, which were kept in the greenhouse. When the plants were a little over a 
foot in height they were measured, and the erossed plants averaged $13 \cdot 38$, and the self-fertilised $12 \cdot 29$ inehes in height; or as 100 to 92.

When in full flower they were again measured to the extremities of their eulms, as shown in the following table:-

\section{Table XCVIII.}

Phataris canariensis.

\begin{tabular}{|c|c|c|}
\hline No. of Pot. & Crossed Plants. & Self-fertilised Plants. \\
\cline { 1 - 2 } & Inches. & Inches. \\
& $42 \frac{2}{8}$ & $41 \frac{2}{8}$ \\
& $39 \frac{6}{8}$ & $45 \frac{4}{8}$ \\
\hline II. & 37 & $31 \frac{6}{8}$ \\
& $49 \frac{4}{8}$ & $37 \frac{2}{8}$ \\
& 29 & $42 \frac{3}{8}$ \\
& 37 & $34 \frac{7}{8}$ \\
\hline III. & $37 \frac{6}{8}$ & 28 \\
& $35 \frac{4}{8}$ & 28 \\
& 43 & 34 \\
\hline IV. & $40 \frac{2}{8}$ & $35 \frac{1}{8}$ \\
\hline & 37 & $34 \frac{4}{8}$ \\
\hline Total in inches. & $428 \cdot 00$ & $392 \cdot 63$ \\
\hline
\end{tabular}

The eleven crossed plants now averaged $39 \cdot 9$, and the eleren self-fertilised plants $35 \cdot 69$ jnehes in height; or as 100 to 92 , whieh is the same ratio as before. Differently to what occurred with the maize, the crossed plants did not flower before the selffertilised; and though both lots flowered very poorly from having been kept in pots in the greenhouse, yet the self-fertilised plants produced twenty-eight flower-heads, whilst the erossed produced only twenty!

Two long rows of the same seeds were somn out of doors, and care was taken that they were sown in nearly equal number; but a far greater number of the erossed than of the self-fertilised seeds yielded plants. The self-fertilised plants were in eonsequenee not so mueh crowded as the crossed, and thus had an advantage over them. When in full flower, the twelve tallest plants were earefully seleeted from both rows and measured, as shown in the following table:- 


\section{TABLE XCTX.}

Phalaris canariensis (growing in the open ground).

\begin{tabular}{|c|c|}
\hline $\begin{array}{c}\text { Crossed Plants, twelve } \\
\text { tallest. }\end{array}$ & $\begin{array}{l}\text { Self-fertilised Plants, } \\
\text { twelve tallest. }\end{array}$ \\
\hline $\begin{array}{c}\text { Inches. } \\
34 \frac{1}{8} \\
35 \frac{7}{8} \\
36 \\
35 \frac{5}{8} \\
35 \frac{5}{8} \\
36 \frac{1}{8} \\
36 \frac{6}{8} \\
38 \frac{6}{8} \\
36 \frac{2}{8} \\
35 \frac{5}{8} \\
34 \frac{1}{8} \\
34 \frac{5}{8}\end{array}$ & $\begin{array}{c}\text { Inches. } \\
35 \frac{2}{8} \\
31 \frac{1}{8} \\
33 \\
32 \\
31 \frac{5}{8} \\
36 \\
33 \\
32 \\
35 \frac{1}{8} \\
33 \frac{5}{8} \\
34 \frac{2}{8} \\
35\end{array}$ \\
\hline $\left.\begin{array}{l}\text { Total in } \\
\text { inches. }\end{array}\right\} 429 \cdot 5$ & $402 \cdot 0$ \\
\hline
\end{tabular}

The twelve crossed plants here average $35 \cdot 78$, and the twelve self-fertilised 33.5 inches in height; or as 100 to 93 . In this case the crossed plants flowered rather before the self-fertilised, and thus differed from those growing in the pots. 


\section{CHAPTER YII.}

Sumiary of the Heights and Weichts of the Crossed and Self-Fentilised Playts.

Number of species and plints measured-Tables given-Preliminary remarks on the oft'spring of plants crossed by a fresh stock-Thirteen cuses specially considererl--The effects of crossing a self-fertilised plant either by another self-fertilised plant or by an intercrossed plant of the old stock-Summary of the results-Preliminary remarks on the crossed and self-fertilised plants of the same stock-The twentysix exceptional cases considered, in which the crussed plants did not exceed greatly in height the self-fertilised-Most of these cases shown not to be real exccptions to the rule that cross-fertilisation is beneficial-Summary of results-Relative weights of the crossed and self-fertilised plants.

T'ne details which have been given under the head of each species are so numerous and so intricate, that it is necessary to tabulate the results. In Table $A$, the number of plants of each kind which were raised from a cross between two individuals of the same stock and from self-fertilised seeds, together with their mean or average heights, are given. In the right-hand column, the mean lieight of the crossed to that of the seif-fertilised plants, the former being taken as 100 , is shown. To make this clear, it may be advisable to give an eximple. In the first generation of Ipomoea, six plants derived from a cross between two plants were measured, and their mean height is $\$ 6 \cdot 00$ inches; six plants derived from flowers on the same parent-plant fertilised with their own pollen were measured, and their mean height is 65.66 inches. 
From this it follows, as shown in the right-hand column, that if the mean height of the crossed plants be taken as 100 , that of the self-fertilised plants is 76 . The same plin is followed with all the other species.

The erossed and self-fertilised plants were generally grown in pots in competition with one another, and always under as closely similar eonditions as eould be attained. They were, however, sometimes grown in separate rows in the open ground. With several of the species, the crossed plints were again erossed, and the self-fertilised plants again self-fertilised, and thus sueeessive generations were raised and measured, as may be seen in Table A. Owing to this manner of proeeeding, the crossed plants beeame in the later generations more or less closely inter-related.

In t'able B the relative weights of the crossed and self-fertilised plants, after they had flowered and had been cut down, are given in the few cases in which they were aseertained. 'The results are, I think, more striking and of greater value as evidence of eonstitutional vigour than those dedueed from the relative heights of the plants.

'The most important table is that of $\mathrm{C}$, as it ineludes the relative heights, weights, and fertility of plants raised from parents crossed by a fresh stock (that is, by non-related plants grown under different conditions), or by a distinct sub-variety, in comparison with selffertilised plants, or in a few cases with plants of the same old stock intercrossed during several generations. The relative fertility of the plants in this and the other tables will be more fully considered in a future chapter. 


\section{TABLE A.-Relative Meights of Plants from Parents crnssed with Pollen from other Plunts of the sume Stock, and self-fertitised.}

\begin{tabular}{|c|c|c|c|c|c|c|c|}
\hline NAMES OF PLANTS. & 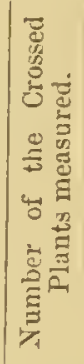 & 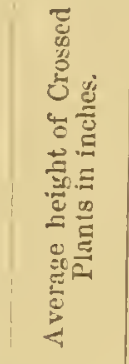 & 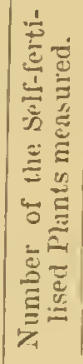 & 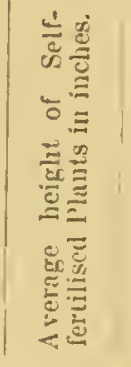 & \multicolumn{3}{|c|}{ 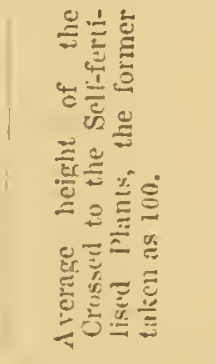 } \\
\hline Ipomœa purpurea-1st generation & 6 & $86 \cdot 00$ & 6 & $65 \cdot 66$ & as 100 & to & $7 i$ \\
\hline a - 2nd gen & 6 & $84 \cdot 16$ & 6 & $66 \cdot 33$ & , & & 79 \\
\hline a-3rd generation & 6 & $77 \cdot 41$ & 6 & $52 \cdot 83$ & $"$ & & 68 \\
\hline Ipomoea purpurea-4th generation & 7 & $69 \cdot 78$ & 7 & $60 \cdot 14$ & 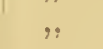 & & 86 \\
\hline Ipomøa jurpurea-5th generat & 6 & $82 \cdot 54$ & 6 & $62 \cdot 33$ & $"$, & & 75 \\
\hline Iponwa purpuren-6th generat & 6 & $87 \cdot 50$ & 6 & $63 \cdot 16$ & , & & 72 \\
\hline urea-7th generation & 9 & $83 \cdot 94$ & 9 & $68 \cdot 25$ & , & & 81 \\
\hline ulea-8th generation & 8 & $113 \cdot 25$ & 8 & $96 \cdot 65$ & $\because$ & " & 85 \\
\hline Ipomoa purpureit-9th generat & 14 & $81 \cdot 39$ & 14 & $6+\cdot 07$ & ," & & 79 \\
\hline $\begin{array}{l}\text { Ipomor purpurea-10th generation } \\
\text { Number and average height of all }\end{array}$ & 5 & $93 \cdot 70$ & 5 & $50 \cdot 40$ & $"$ & $"$ & 54 \\
\hline $\begin{array}{l}\text { the plants of the ten genera- } \\
\text { tions }\end{array}$ & 73 & $85 \cdot 84$ & 73 & $66 \cdot 02$ & , & , & 77 \\
\hline $\left.\begin{array}{l}\text { Mimulus luteus-three first gene- } \\
\text { rations, before the new and taller } \\
\text { self-fertilised variety appeared }\end{array}\right\}$ & 10 & $8 \cdot 19$ & 10 & $5 \cdot 29$ & " & : & 65 \\
\hline Digitalis purpurea . . • • . & 16 & $51 \cdot 35$ & 8 & $35 \cdot 87$ & $"$ & $\because$ & 70 \\
\hline $\left.\begin{array}{l}\text { Calceolaria-(common greenhouse } \\
\text { variety }) \cdot \cdot \cdot \cdot \cdot \cdot \cdot \cdot\end{array}\right\}$ & 1 & $19 \cdot 50$ & 1 & $15 \cdot 00$ & $"$ & $"$ & 77 \\
\hline Linaria vulgaris $\quad . \quad . \quad . \quad . \quad$. & 3 & $7 \cdot 08$ & 3 & $5 \cdot 75$ & " & ," & 81 \\
\hline $\begin{array}{l}\text { Verbascum thapsus } \\
\text { Vandellia nummularifolia-crossed }\end{array}$ & 6 & $65 \cdot 34$ & 6 & 5650 & $"$, & . & 86 \\
\hline $\begin{array}{l}\text { and self-fertilised plants, raised } \\
\text { from perfect flower's. }\end{array}$ & 20 & $4 \cdot 30$ & 20 & $4 \cdot 27$ & $"$ & $"$ & 99 \\
\hline $\begin{array}{l}\text { andellia numinularifolia-crossed } \\
\text { and self-fertilised plants, raised } \\
\text { from perfect flowers: second } \\
\text { trial, plants crowded . . . }\end{array}$ & 24 & $3 \cdot 60$ & $2 \cdot 4$ & $3 \cdot 38$ & , & " & 94 \\
\hline $\begin{array}{l}\text { andellia nummularifolia-crossel } \\
\text { plants raised fiom perfect flowers, } \\
\text { and self-fertilised plants from } \\
\text { cleistogene flowers } . . \\
\text {. }\end{array}$ & 20 & $4 \cdot 30$ & 20 & $4 \cdot 06$ & $\because$ & $\because$ & 94 \\
\hline esneria pendulina. . & 8 & $32 \cdot 06$ & 8 & $29 \cdot 14$ & " & " & 90 \\
\hline Alvia coccinea. & 6 & $7 \cdot 85$ & 6 & $1 \cdot 16$ & $"$ & $\because$ & 76 \\
\hline Origanum vulgare . & 4 & & 4 & $17 \cdot 12$ & " & . & S6 \\
\hline Thunbergia alata & 6 & $60 \cdot 00$ & 6 & $65 \cdot 00$ & $\because$ & $\because$ & 105 \\
\hline Brassical oleracear a & 9 & $41 \cdot 08$ & 9 & $39 \cdot 00$ & $"$ & ", & $9 . i$ \\
\hline $\left.\begin{array}{c}\text { peris umbellata-the self-fertilised } \\
\text { plants of the } 3 \mathrm{r} d \text { generation }\end{array}\right\}$ & 7 & $19 \cdot 12$ & $\bar{t}$ & $16 \cdot 39$ & $\because$ & $\because$ & 86 \\
\hline
\end{tabular}


TABLE A-continued.

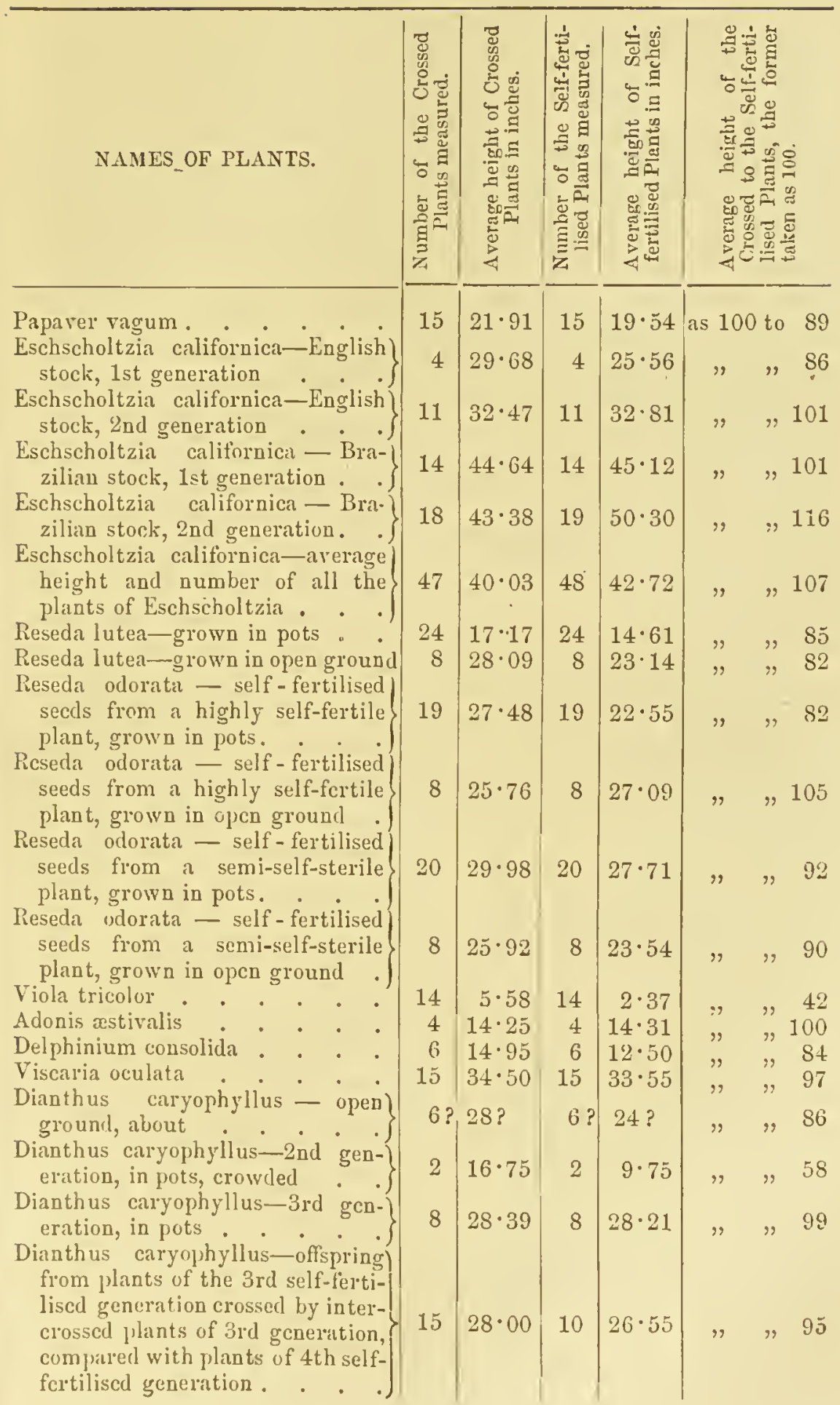


Table A-continued.

Dianthus caryophyllus - number and arerage height of all the plants of Diauthus

Hibiscus africanns

Pelargonium zoule $\bullet^{\circ} \cdot{ }^{\circ} \cdot$

Tropxolum minus

Limmanthes douglasii • • •

Lupinus luteus-2nd generation .

Lupinus pilosus - plants of two generations . . . . . .

Phaseolus multiflorus . . . .

Jisum sativum . •
Sarothamnus scoparius - smali seedlings . . . . . .

Sarothamnus scoparius-the three survivors on each side after three years' growth

Ononis minutissima

Clarkia elegaus.

Bartonia aurea.

Prssiflora gracilis

Apium petroselinum

Scabiosa atro-purpurea .

Lactuca sativa-plants of two gen-) erations

Specularia speculum

Lobelia ramosa-1st generation .

Lolelia ramosi-and generation .

Lobelia fulgens-1st generation .

Lobelia fulgens-2nd generation.

Nemophila insignis-half-grown.

Nemophila iusignis - the same fully) grown

Bolago officiualis

Nolana prostratia

Petunia violacea-1st generation.

Petunia violacea-2nd generation .

Petunia violacea-3rd generation.

Petunia violacea -4th generation

\begin{tabular}{|c|c|c|c|c|c|c|}
\hline 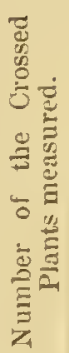 & 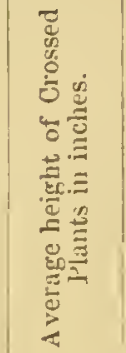 & 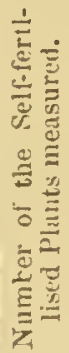 & 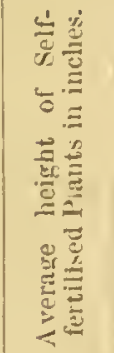 & \multicolumn{3}{|c|}{ 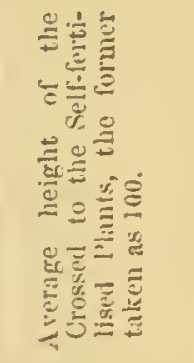 } \\
\hline 31 & $27 \cdot 37$ & 26 & $25 \cdot 18$ & \multicolumn{3}{|c|}{ as 100 to 92} \\
\hline 4 & $13 \cdot 25$ & 4 & $14 \cdot 43$ & & , & 109 \\
\hline 7 & $22 \cdot 35$ & 7 & $16 \cdot 62$ & , & $"$ & 74 \\
\hline 8 & $58 \cdot 43$ & 8 & $46 \cdot 00$ &, & , & 74 \\
\hline 16 & $17 \cdot 46$ & 16 & $13 \cdot 85$ & $\because$ & $"$ & 79 \\
\hline 8 & $30 \cdot 78$ & 8 & $25 \cdot 21$ & $"$ & $\because$ & 82 \\
\hline 2 & $35 \cdot 50$ & 3 & $30 \cdot 50$ & , & ", & 86 \\
\hline 5 & $86 \cdot 00$ & 5 & $82 \cdot 35$ & $"$ & & 96 \\
\hline 4 & $34 \cdot 62$ & 4 & $39 \cdot 68$ & , & " & 115 \\
\hline 6 & $2 \cdot 91$ & 6 & $1 \cdot 33$ & , & $"$ & 46 \\
\hline & $18 \cdot 91$ & & $11 \cdot 83$ & & $"$ & 63 \\
\hline 2 & $19 \cdot 81$ & 2 & $17 \cdot 37$ & ", & & 88 \\
\hline 4 & $33 \cdot 50$ & 4 & $27 \cdot 62$ & $"$ & & 82 \\
\hline 8 & $24 \cdot 62$ & 8 & $26 \cdot 31$ & " & $\eta$ & 107 \\
\hline 2 & $49 \cdot 00$ & 2 & $51 \cdot 00$ & , & $\because$ & 104 \\
\hline ? & $\begin{array}{c}\text { not } \\
\text { measured, }\end{array}$ & ? & $\begin{array}{l}\text { not } \\
\text { meas ured. }\end{array}$ & $"$ & $"$ & 100 \\
\hline 4 & $17 \cdot 12$ & 4 & $15 \cdot 37$ & :" & $"$ & 90 \\
\hline 7 & $19 \cdot 43$ & 6 & $16 \cdot 00$ & " & & $8: 2$ \\
\hline 4 & $19 \cdot 28$ & 4 & $18 \cdot 9.3$ & " & & 98 \\
\hline 4 & $22 \cdot 25$ & 4 & $18 \cdot 37$ & " & & $8: 2$ \\
\hline 3 & $23 \cdot 33$ & 3 & $19 \cdot 00$ & 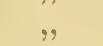 & & 81 \\
\hline 2 & $34 \cdot 75$ & 2 & $44 \cdot 25$ & $\because$ & ., & 127 \\
\hline 23 & $29 \cdot 82$ & 23 & $27 \cdot 10$ & , & , & 91 \\
\hline 12 & $11 \cdot 10$ & 12 & $5 \cdot 45$ & , & " & 49 \\
\hline & $33 \cdot 28$ & & $19 \cdot 90$ & :" & & 60 \\
\hline 4 & $20 \cdot 68$ & 4 & $21 \cdot 18$ & , & & 102 \\
\hline 5 & $12 \cdot 75$ & 5 & $13 \cdot 40$ & " & ", & $10 i$ \\
\hline 5 & $30 \cdot 80$ & 5 & $26 \cdot 00$ & , & & 84 \\
\hline 4 & $40 \cdot 50$ & 6 & $26 \cdot 25$ & & & 65 \\
\hline 8 & $40 \cdot 9 i$ & 8 & $53 \cdot 87$ & $"$ & : & $1: 31$ \\
\hline 15 & $46 \cdot 79$ & 14 & $32 \cdot 39$ & $"$ & : & 69 \\
\hline
\end{tabular}


TABLE A-continued.

INATES OF PLANTS.

Petunia violacea-4th generation, from a distinct parent . . .

Petunia violacea -5 th generation.

Petunia violacea-5th generation, ) in open ground . . . . .

Petunia violacen - Number and average height of all the plants in pots of Petunia . . . .

Nicotiana tabacum-1st generation

Nicotiana tabacum-2nd generation

Nicotiana tabacum-3rd generation

Nicotiana tabacum-3rd generation) but raised from a distinct plant

Nicotiana tabacum-number and average height of all the plauts of Nicotiana

Crclamen persicum

Anagallis collina $\cdot \bullet^{-} \cdot \bullet^{-} \cdot$

Primula sinensis - a dimorphic species . . . . . . . $\}$

Fagopyruin esculentum-a dimorphic species. . . . .

Beta vulgaris -in pots.

Beta vulgaris-in open ground

Canna wal'scewiczi-plants of three generations

Zea mays-in pots, whilst young, measured to tips of leaves .

Zea mays-when full grown, after the death of some, measured to tips of leaves.

Kea inays - when full grown, after the death of some, measured to tips of flower:

Zeat inays-grown in open ground, measured to tips of leares . .

7ea mays-grown in open ground, measured to tips of Howers . .

Phalaris cunariensis-in pots. .

Phalaris canariensis-in open ground

\begin{tabular}{|c|c|c|c|c|c|c|}
\hline 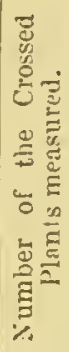 & 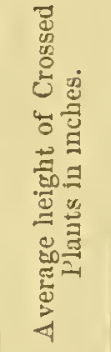 & 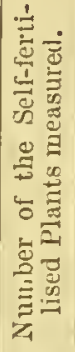 & 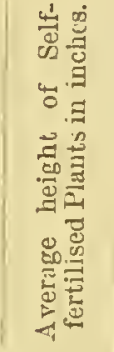 & \multicolumn{3}{|c|}{ 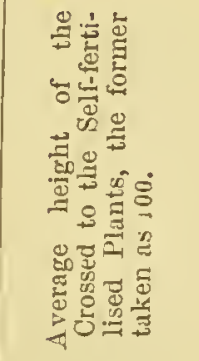 } \\
\hline 13 & $44 \cdot 74$ & 13 & $26 \cdot 87$ & as 100 & to & 60 \\
\hline 22 & $54 \cdot 11$ & 21 & $33 \cdot 23$ & $\eta$ & 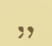 & 61 \\
\hline 10 & $38 \cdot 27$ & 10 & $23 \cdot 31$ & , & $"$ & 61 \\
\hline 67 & $46 \cdot 53$ & 67 & $33 \cdot 12$ & " & " & 71 \\
\hline 4 & $18 \cdot 50$ & 4 & $32 \cdot 75$ & , & , & 178 \\
\hline 9 & $53 \cdot 84$ & 7 & $51 \cdot 78$ & $"$ & $\eta$ & 96 \\
\hline 7 & $95 \cdot 25$ & 7 & $79 \cdot 60$ & $"$ & ," & 83 \\
\hline 7 & $70 \cdot 78$ & 9 & $71 \cdot 30$ & $"$ & " & 101 \\
\hline 27 & $63 \cdot 73$ & 27 & $61 \cdot 31$ & $"$ & $"$ & 96 \\
\hline 8 & $9 \cdot 49$ & 8? & $7 \cdot 50$ & $"$ & $"$ & 79 \\
\hline (i & $42 \cdot 20$ & 6 & $33 \cdot 35$ & , & ", & 69 \\
\hline 8 & $9 \cdot 01$ & 8 & $9 \cdot 03$ & $"$ & ", & 100 \\
\hline 15 & $38 \cdot 06$ & 15 & $26 \cdot 13$ & ", & , & 69 \\
\hline 8 & $34 \cdot 09$ & 8 & $29 \cdot 81$ & ,• & ", & 87 \\
\hline 8 & $30 \cdot 92$ & 8 & $30 \cdot 70$ & $"$ & " & 99 \\
\hline 34 & $35 \cdot 98$ & 34 & $36 \cdot 39$ & $"$ & , & 101 \\
\hline 15 & $20 \cdot 19$ & 15 & $17 \cdot 57$ & $"$ & $"$ & 87 \\
\hline & $68 \cdot 10$ & & $62 \cdot 34$ & $"$ & $"$ & 91 \\
\hline & $60 \cdot 51$ & & $61 \cdot 59$ & " & " & 93 \\
\hline 10 & $54 \cdot 00$ & 10 & $44 \cdot 55$ & " & " & 83 \\
\hline & $53 \cdot 96$ & & $43 \cdot 45$ & $"$ & $"$ & 80 \\
\hline 11 & $38 \cdot 90$ & 11 & $85 \cdot 69$ & $n$ & $"$ & 92 \\
\hline 12 & $35 \cdot 78$ & 12 & $33 \cdot 50$ & $"$ & $"$ & 93 \\
\hline
\end{tabular}


TABLE B.-Relative Weights of Plants from Parents crossed with Pollen from ristinct Plants of the same Stock, and Self-fertilised.

\section{NAMES OF PLANTS.}

Number Number of Crossed of Self-

Plants. fertilised Plants.
Weight of the Crossed Plants taken as 100.

Ipomoa purpurea-plants of the 10th) generation. . . . . . . . Vindellia nummularifolia-1st generation . . . . . . .

Brassiea oleracea-1st generation . . lischseholtzia ealiforniea-plants of the znd generation . . . . . .

lieseda lutea-1st generation, grown in pots . . . . . . . .

Reseda lutea-1st generation, grown in open ground . . . . . . .

lieseda odorata-1st generation, deseended from a lighly self-fertile plant, grown in pots . . . . . lieseda odorata-1st generation, deseended from a semi-self-sterile plant, grown in pots. . . . . .

Dianthus earyophyllus-plants of the 3 rd generation.

Petunia violacea-plants of the 5 th generation, in pots . . . . .

Petunia violacea-plants of the 5 th generation, in open ground . . .

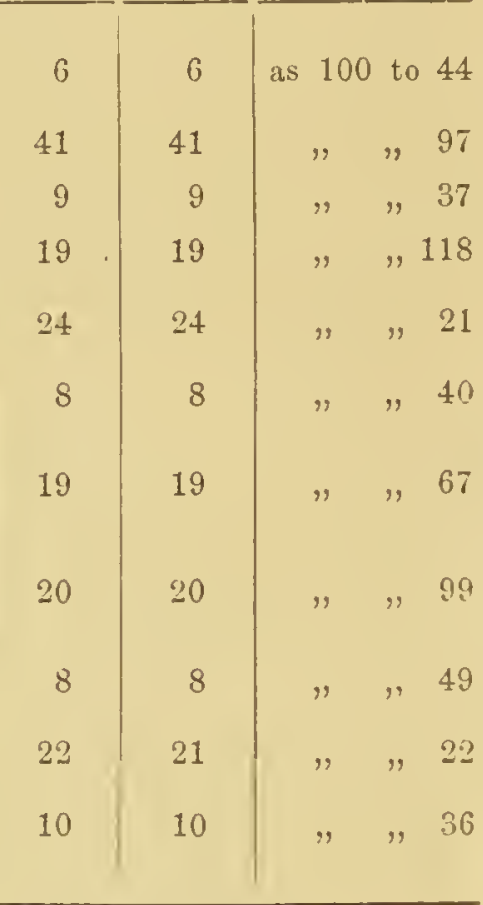


TABLe C. - Relative Heights, Weights, and Fertility of Plants from Parents crossed by a fresh Stock, and from Parents either selffertilised or intercrossed with Plants of the same Stock.

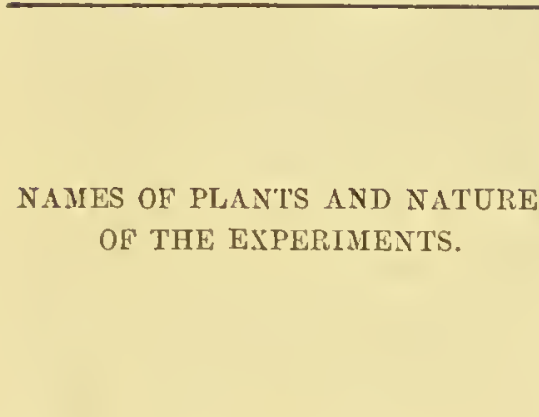

Ipomœa purpurea - offspring of plants intercrossed for nine generations and then crossed by a fresh stock, compared with plants of the 10th intercrossed generatio

Ipomøa purpurea - offspring of plants intercrossed for nine generations and then crossed by a fresh stock, compared with plants of the 10th intercrossed generation, in fertility . . .

Mimulus luteus-offspring of plants self-fertilised for eight generations and then crossed by a fresh stock, compared with plants of the 9 th self-fertilised generation

Mimulus luteus-offspring of plants self-fertilised for eight generations and then crossed by a fresh stock, compared with plants of the 9 th self-fertilised generation, in fertility . . . . . .

Minulus luteus -offspring of plants self-fertilised for eight generations and then crossed by a fresh stock, compared with the offspring of a plant self-fertilised for eight generations, and then intercrossed with another selffertilised plant of the same generation

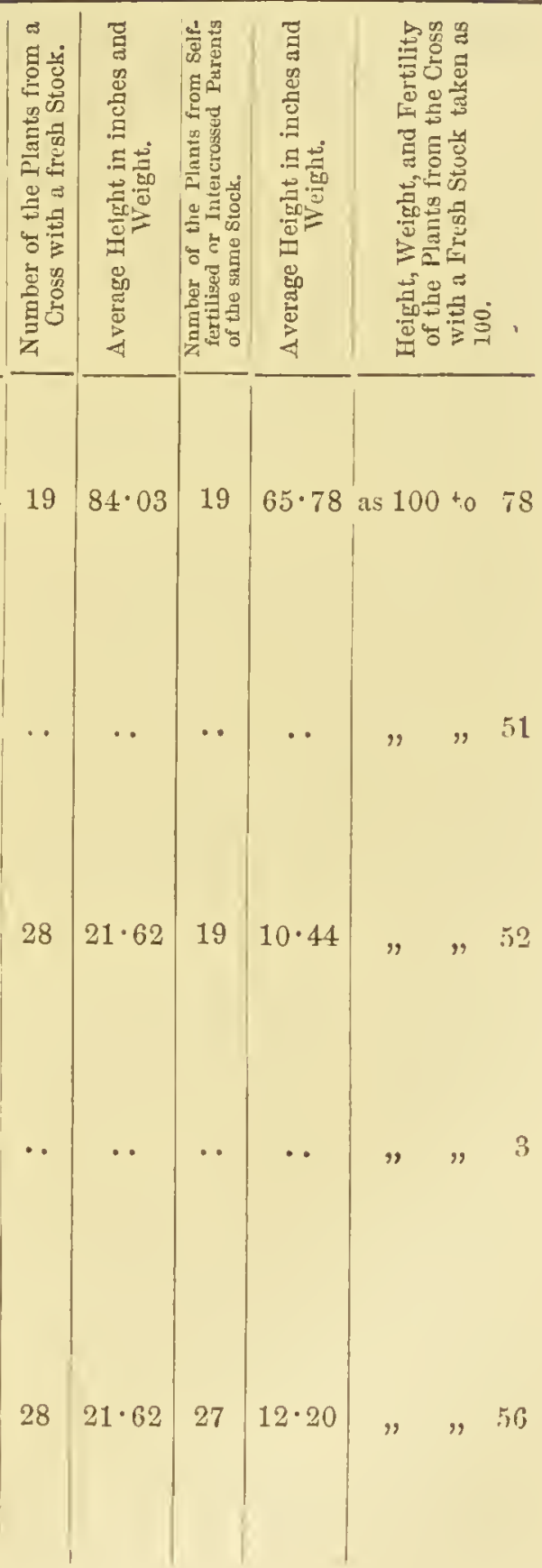


TABLE C-continued.

NAMES OF PLANTS AND NATURE OF THE IXPERIMENTS.

Mimulus luteus-offspring of plants self-fertilised for eight generations and then crossed by a fiesh stock, complared with the offspring of a plant self-fertilised for eight generations, and then intercrossed with another selffertilised plant of the sime gencration, in fertility . . . .

Brassica oleracea - offspring of plants self-fertilised for two generations and then crossed by a fresh stock, compared with plants of the 3rol self-fertilised generation, by weight . . .)

Iberis umbellata-offspring from English variety crossed by slightly different Algerine variety, compared with the selffertilised oft'spring of the English variety

lberis umbellata-offspring from English variety, crossed by slightly different Algerine variety, compared with the selffertilised offspring of the English variety, in fertility . . . .

Eschscholtzia cali fornica-offspring) of a Brazilian stock crossed by an linglish stock, compared with plants of the Brazilian stock of the 2 nd self-fertilised generation

Eschscholtzia californica-oftspring of a Brazilian stock crossed by an English stock, compared with plants of the Brazilian stock of the 2 nd self-fertilised generation, in weight

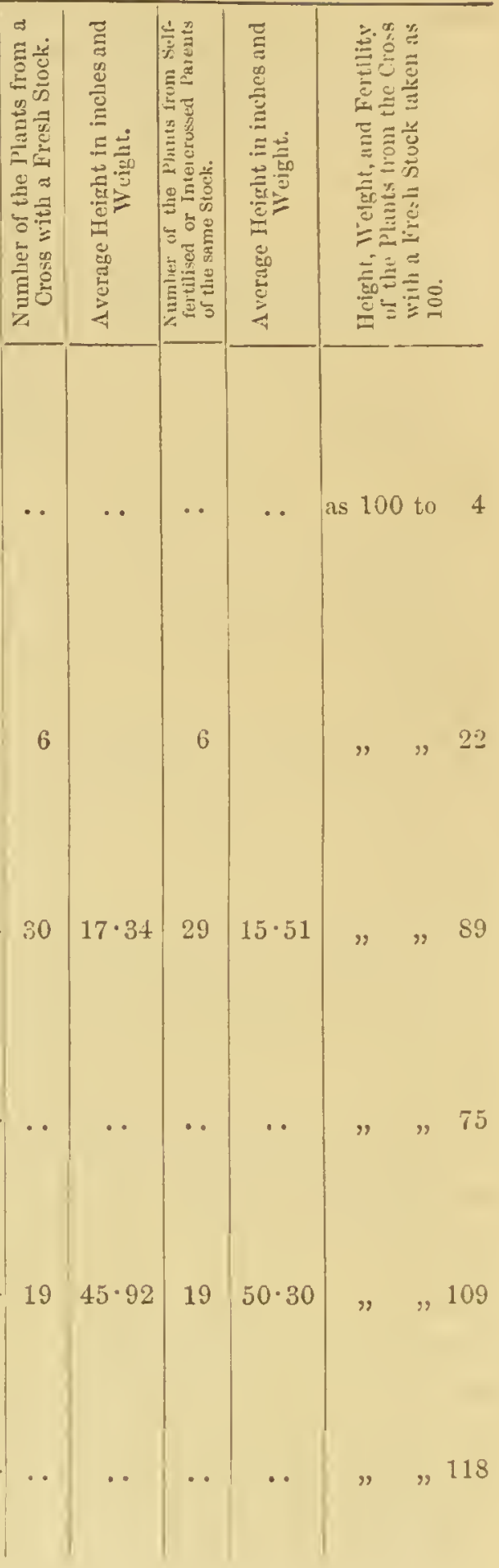


Tabie C-continued.

YAIES OF PLANTS AND NATURE
OF THE EXPERIMENTS.

Eschscholtria californica-offspring) of a Braziliau stock crossed by an English stock, compared with plants of the Brazilian stock of the 2nd self-fertilised generation, in fertility

Eschscholtzia californica-offspriug) of a Brazilian stock crossed by an English stock, compared with plants of the Brarilian stock of the 2nd intercrossed gencration, in height.

Eschscholtzia californica-offspring of a Brazilian stock erossed by an English stock, compared with plants of the Brizilian stock of the 2 ar intercrossed generation, in weight

Eschscholtzia californica-offspring) of a Brazilian stock crossed by an English stock, compared with plants of the Brazilian stock of the 2nd intercrossed generation, in fertility

Dianthus caryophyllus-offspring of plants sclf-fertilised for threc generations and then crossed by a fresh stock, compared with plants of the 4 th sclf-fertilised generation

Dianthus caryolnyllus-offspring of plants self-iertilised for thrce generations and then erossed by a fresh stock, compared with plants of the 4 th self-fertilised generation, in fertility ...

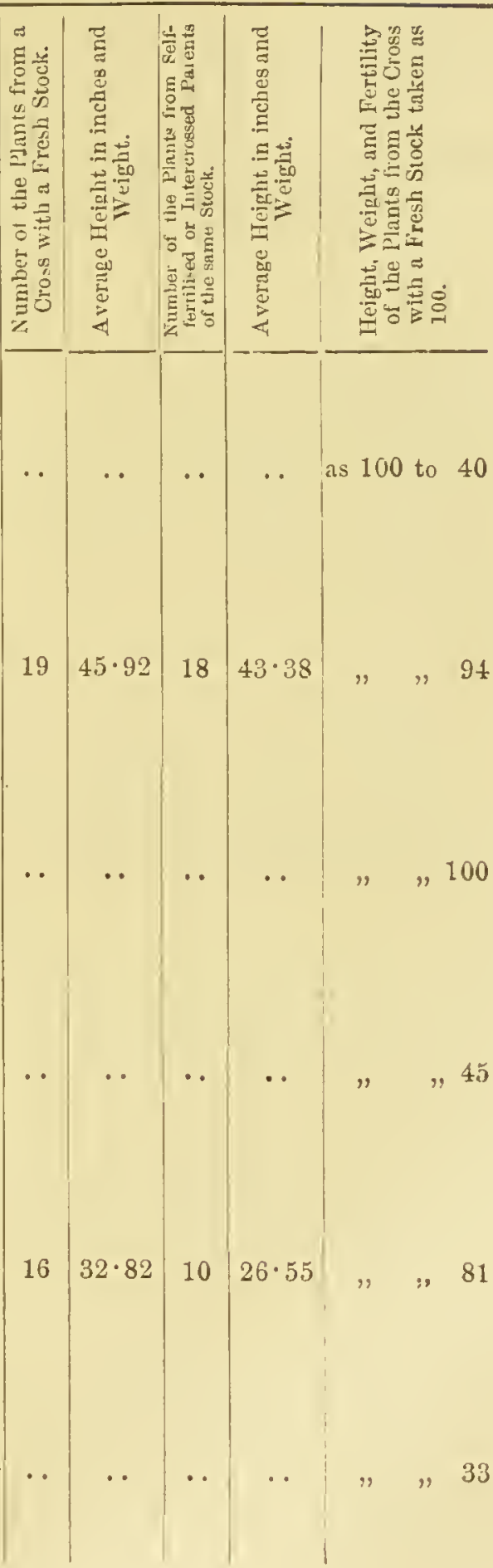


TABLE C-continued.

NAMES OF PLANTS AND NATURE OF THE EXPERIMENTS.
Dianthus caryophyllus-offspring) of plants self-fertilised for three generations and then crossed by a fiesh stock, compared with the offspring of plants self-fertilised for three generations and then crossed by plants of the 3rd intercrossed generation . . .)

Dianthus caryophyllus-offspring) of plants self-fertilised for three generations and then crossed by a fresh stock, compared with the offspring of plants self-fertilised for three generations and then crossed by plants of the 3rd intercrossed generation, in fertility

Pisum sativum-offspring from a) cross between two closely allied varieties, compared with the selffertilised ofispring of one of the varieties, or with intercrossed plants of the same stock . .

Lathyrus odoratus - offspring from two varieties, differing only in colour of their flowers, compared with the self-fertilised offspring of one of the varieties: in 1 st generation

Lathyrus odoratus-offspring from two varieties, differing only in colour of their flowers, compared with the self-fertilised off'spring of one of the rarieties: in 2 ud generation . . . . .

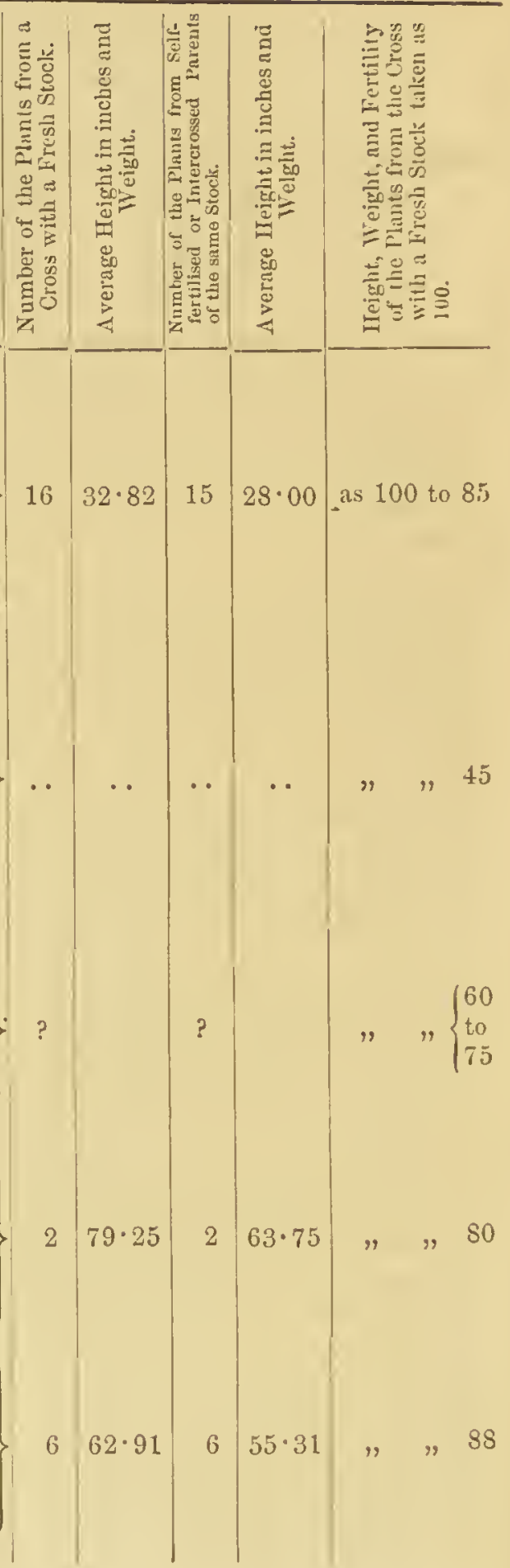


TABLE C-continued.

NAMES OF PLANTS AND NATURE OF 'THE EXPERIMENTS.

\begin{tabular}{|c|}
\hline 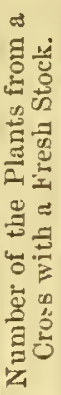 \\
\hline
\end{tabular}

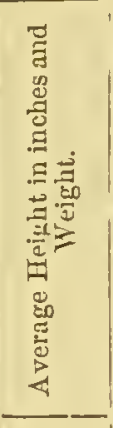

Petunia violacea - offspring of plants self-fertilised for four generations and then crossed by a fresh stock, eompared with plants of the 5 th self-fertilised generation, in height . . .

Petunia violacea-offspring of plants self-fertilised for four generations and then erossed by a fresh stock, eompared with plants of the 5 th self-fertilised generation, in weight . . .

Petunia violacea - offspring of plants self-fertilised for four generations and then erossed by a fresh stock, compared with plants of the 5 th self-fertilised generation, grown in open ground, in height .

Petunia violacea - offspring of plants self-fertilised for four generations ind then erossed by a fresh stock, compared with plants of the 5 th self-fertilised generation, grown in open ground, in weight

Petunia violacea - offspring of plants self-fertilised for four generations and then erossed by a fresh stock, compared with plants of the 5th self-fertilised generation, grown in open ground, in fertility

Petunia violacea - offspring of plants self-fertilised for four generations and then erossed by a fresh stoek, compared with plants of the 5 th intercrossed generation, in height . . .

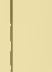

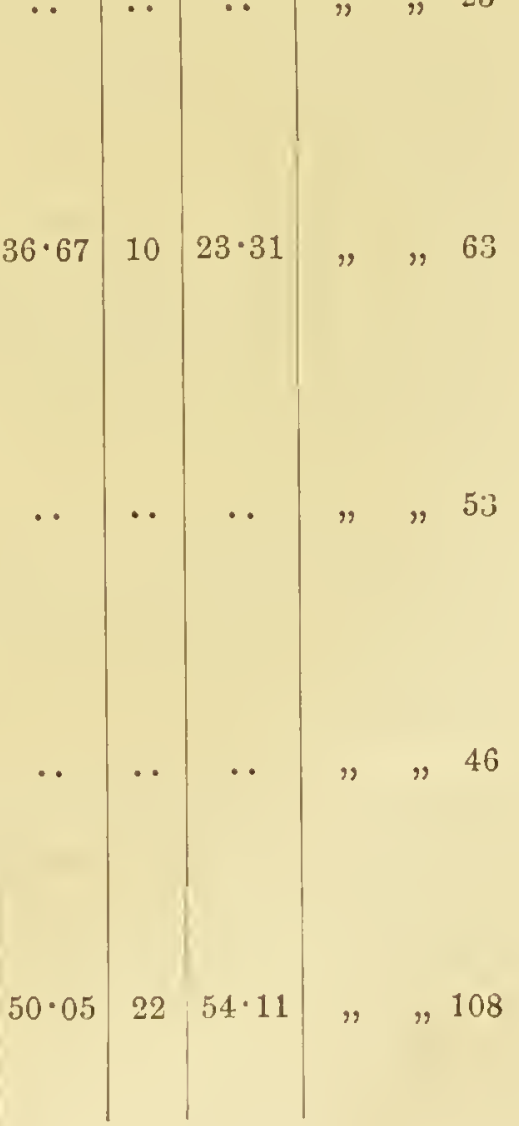


TABLE C-continued.

NAMES OF PLANTS AND NATURE OF THE EXPERIMENTS.

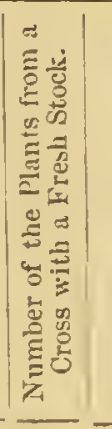

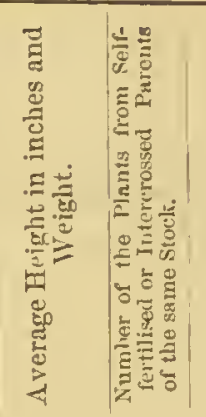

Petunia violacea - offspring of plants self-fertilised for four generations and then erossed by a fresh stoek, compared with plants of the 5 th intererossed generation, in weight . . .

Petunia violacea - offspring of plants selffertilised for four generations and then erossed by a fresh stoek, eompared with plants of the 5th intercrossed generation, grown in openground, in height

Petunia violacea - offspring of plants self-f'ertilised for four generations and then erossed by a fresh stoek, eompared with plants of the 5 th intererossed generation, grown in open ground, in weight.

Petunia violacea - offspring of plants self-tertilised for fou1 generations and then erossed by a fresh stoek, eompared with plants of the 5 th intererossed generation, grown in open ground, in fertility . . . .

Nieotiana tabncum-offspring of plants self-fertilised fur three generations and then erossed by a slightly different variety, eompared with plants of the 4th self-fertilised generation, grown not much crowded in pots, in lieight

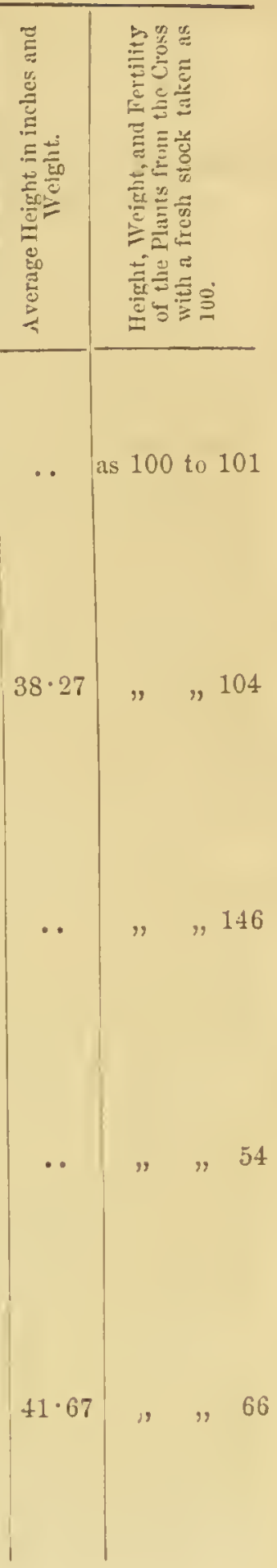


TABuE C-continued.

NAMES OF PLAN'S AND NATURE OF 'THE EXPERIMENTS.

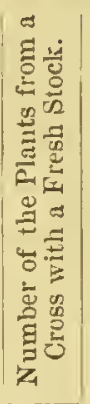

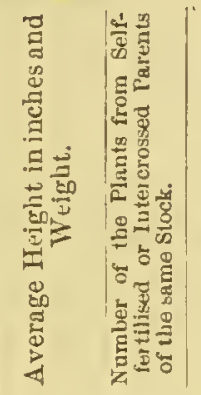

18 क क

릴

a

छ छ

ट

$\pm \infty$

만 $\frac{\infty}{5} \div$

$\geqslant \frac{C_{1}}{I_{1}}$

t5요

$\frac{\pi}{4}=\frac{1}{2} 8$
Nicotiana tabacum-offspring of plants self-fertilised for three generations and then crossed by a slightly difierent variety, compared with plants of the 4 th self-fertilised generation, grown much crowded in pots, in height)

Nicotiana tabacum-nffspring of plants self-fertilised for three generations and then crossed by a slightly different variety, compared with plants of the 4 th self-fertilised generation, grown much crowded in pots, in weight)

Nicotiana tabacum-offspring of plants self-fertilised for three generations and then crossed by a slightly different variety, compared with plants of the 4 th self-fertilised generation, grown in open ground, in height . .)

Nicotiana tabacum-offspring of plants self-fertilised for three generations and then crossed by a slightly different variety, compared with plants of the 4 th self-fertilised generation, grown in open ground, in weight . .)

Anagallis collina-offspring from a red variety crossed by a blue variety, compared with the selffertilised offspring of the red variety as 100 to 54 
TABLE C-continuer.

Anagallis collina-offspring from a) red variety crossed by a blue variety, compared with the selffertilised oftspring of the red variety, in fertility . . . .)

Primula veris-offspring from long-) styled plants of the 3rd illegitimate generation, crossed by a fresh stock, compared with plants of the 4th illegitimate and self-fertilised generation .J

Primula veris-offspring from longstyled plants of the ard illegitimate generation, crossed by a fresh stock, compared with plants of the 4th illegitimate and self-fertilised generation: in fertility . . . . . .

Primula veris-offspring from long-) styled plants of the 3rd illegitimate generation, crossed by a fresh stock, compared with plants of the 4th illegitimate and self-fertilised generation, in fertility in following year . .)

Primula veris (equal-styled, red-) flowered variety) - offspring from plants self-fertilised for two generations and then crossed by a different variety, compared with plants of the 3rd self-fertilised generation

Primula veris (equal-styled, redfowered variety) - offs pring from plants self-fertilised for two generations and then crossed by a different variety, compared witl plants of the 3rel self-fertilised generation, in fertility . . .

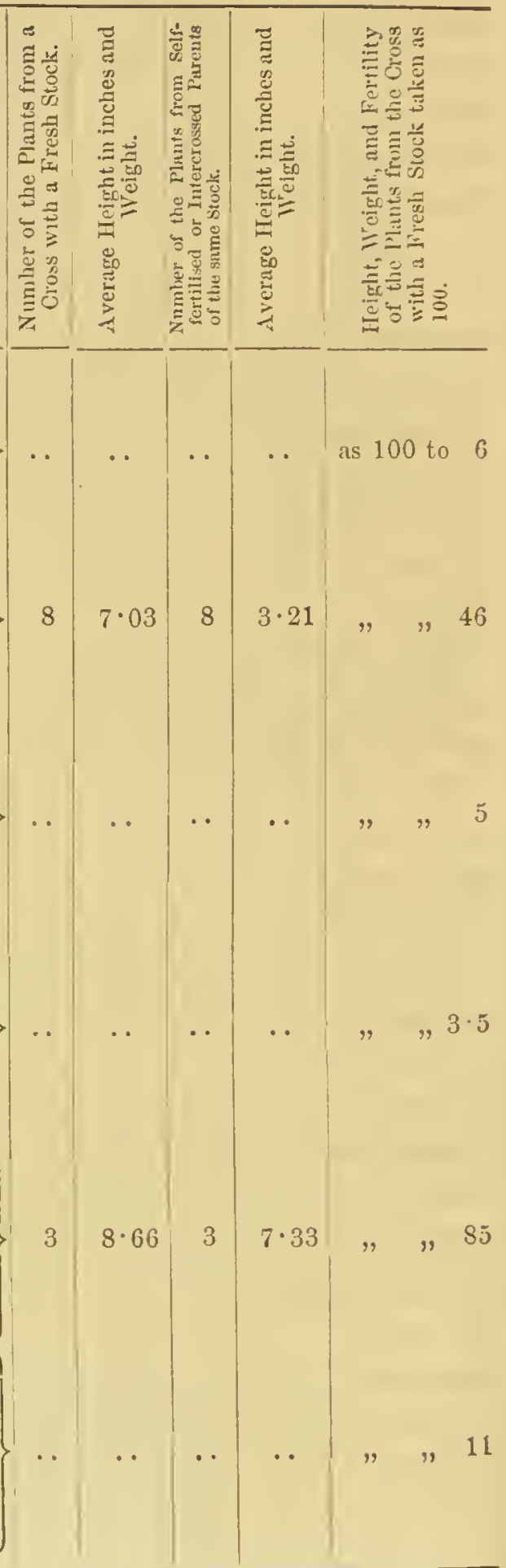


In these three tables the measurements of fifty-seven speeies, belonging to fifty-two genera and to thirty great natural families, are given. The speeies are natives of various parts of the world. The number of erossed plants, ineluding those derived from a eross between plants of the same stock and of two different stocks, amounts to 1,101; and the number of self-fertilised plants (ineluding a few in Table $\mathrm{C}$ derived from a cross between plants of the same old stoek) is 1,076 . Their growth was observed from the germination of the seeds to maturity; and most of them were measured twiee and some thriee. The various precautions taken to prevent either lot being unduly favoured, have been described in the introductory ehapter. Bearing all these eireunstances in mind, it may be admitted that we have a fair basis for judging of the eomparative effeets of eross-fertilisation and of self-fertilisation on the growth of the offspring.

It will be the most eonvenient plan first to eonsider the results given in Table $\mathrm{C}$, as an opportunity will thus be afforded of ineidentally diseussing some important points. If the reader will look down the right-hand eolumn of this table, he will see at a glanee what an extraordinary advantage in height, weight, and fertility the plants derived from a eross with a fresh stock or with another sub-variety have over the self-fertilised plants, as well as over the intercrossed plants of the same old stock. There are only two exeeptions to this rule, and these are hardly real ones. In the ease of Esehseholtzia, the advantage is eonfined to fertility. In that of Petunia, though the plants derived from a eross with a fresh stock had an immense superiority in height, weight, and fertility over the self-fertilised plants, they were eonquered by the intercrossed plants of the same old stoek in height and weight, but not 
in fertility. It has, however, been shown that the superiority of these intererossed plants in height and weight was in all probability not real; for if the two sets had been allowed to grow for another month, it is almost eertain that those from a eross with the fresh stoek would have been vietorious in every way orer the intererossed plants.

Before we eonsider in detail the several eases given in Table $\mathrm{C}$, some preliminary remarks must be made. There is the elearest evidenee, as we sball presently see, that the advantage of a cross depends wholly on the plants differing somewhat in eonstitution; and that the disadvantages of self-fertilisation depend on the two parents, which are eombined in the same hermaphrodite flower, having a elosely similar eonstitution. A certain amount of differentiation in the sexual elements seems indispensable for the full fertility of the parents, and for the full vigour of the offspring. All the individuals of the same speeies, even those produced in a state of nature, differ somewhat, though often very slightly, from one another in external eharaeters and probably in eonstitution. This obviously holds good between the varieties of the same species, as far as external eharaeters are eoncerned; and mueh evidenee eould be adraneed with respect to their generally differing somewhat in eonstitution. There ean hardly be a doubt that the differenees of all kinds between the individuals and varieties of the same species depend largely, and as I believe exelusively, on their progenitors having been subjeeted to different eonditions; though the eonditions to whieh the individuals of the same speeies are exposed in a state of nature often falsely appear to us the same. For instanee, the individuals growing together are neeessarily exposed to the same elimate, and they seem to us at first sight to be subjeeted to identically 
the same eonditions; but this ean hardly be the ease, except under the musual eontingeney of each individual being surrounded by other kinds of plants in exactly the same proportional numbers. For the surrounding plants absorb different amounts of various substances from the soil, and thus greatly affeet the nourishment and even the life of the individuals of any particular speeies. These will also be shaded and otherwise affected by the nature of the surrounding plants. Moreover, seeds often lie dormant in the ground, and those which germinate during any one year will often have been matured during very different seasons. Seeds are widely dispersed by various means, and some will oceasionally be brought from distant stations, where their parents have grown under somewhat different eonditions, and the plants produeed from sueh seeds will intercross with the old residents, thus mingling their eonstitutional peculiarities in all sorts of proportions.

Plants when first subjeeted to enlture, even in their native country, eannot fail to be exposed to greatly changed conditions of life, more espeeially from growing in eleared ground, and from not having to compete with many or any surrounding plants. They are thus enabled to absorb whatever they require whieh the soil may contain. Fresh seeds are often brought from distant gardens, where the parentplants have been subjeeted to different conditions. Cultivated plants like those in a state of nature frequently intercross, and will thus mingle their constitutional peculiarities. On the other hand, as long as the individuals of any speeies are cultivated in the same garden, they will apparently be subjected to more uniform eonditions than plants in a state of nature, as the individuals have not to compete 
with various surrounding speeies. The seeds sown at the same time in a garden have generally been matured during the same season and in the same plaee; and in this respeet they differ much from the seeds sown by the hand of nature. Some exotie plants are not frequented by the native inseets in their new home, and therefore are not intererossed; and this appears to be a highly important faetor in the individuals aequiring uniformity of eonstitution.

In my experiments the greatest eare was taken that in each generation all the erossed and self-fertilised plants should be subjected to the same conditions. Not that the conditions were absolutely the same, for the more vigorous individuals will have robbed the weaker ones of nutriment, and likewise of water when the soil in the pots was beeoming dry; and both lots at one end of the pot will have reeeived a little more light than those at the other end. In the sueeessive generations, the plants were subjeeted to somewhat different conditions, for the seasons neeessarily varied, and they were sometimes raised at different periods of the year. But as they were all kept under glass, they were exposed to far less abrupt and great ehanges of temperature and moisture than are plants growing out of doors. With respect to the intererossed plants, their first parents, whieh were not related, would almost eertainly have differed somewhat in constitution; and such eonstitutional peeuliarities would be variously mingled in eaeh sueeeeding intererossed generation, being sometimes augmented, but more eommonly neutralised in a greater or less degree, and sometimes revived through reversion; just as we know to be the case with the external charneters of crossed speeies and varieties. With the plants whieh were self-fertilised during the successive generations, this latter important 
source of some diversity of constitution will have been wholly eliminated; and the sexual elements produced by the same flower must have been developed under as nearly the same conditions as it is possible to conccive.

In T'Table $\mathrm{C}$ the crossed plants are the offspring of a cross with a fresh stock, or with a distinct variety; and they were put into competition either with self-fertilised plants, or with intercrossed plants of the same old stock. By the term fresh stock I mean a non-related plant, the progenitors of which have been raised during some generations in another garden, and have consequently been exposed to somewhat different conditions. In the case of Nicotiana, Iberis, the red variety of Primula, the common Pea, and perhaps Anagallis, the plants which were crossed may be ranked as distinct varieties or sub-varieties of the same species; but with Ipomoea, Mimulus, Dianthus, and Petunia, the plants which were crossed differed exclusively in the tint of their flowers; and as a large proportion of the plants raised from the same lot of purchased seeds thus varied, the differences may be estimated as mercly individual. Haring made these prelimiuary remarks, we will now consider in detail the several cases given in Table $\mathrm{C}$. and they are well worthy of full consideration.

(1.) Ipomoa purpurea.-Plants growing in the same puts, and subjected in each generation to the same conditions, were intercrossed for nine consecutive generations. 'T'hese intercrossed plants thus became in the later generations more or less closely inter-related. Flowers on the plants of the ninth intercrossed generation were fertilised with pollen taken from a fresh stock, and seedlings thus raised. Other flowers on the same intercrossed plants were fertiliscd with pollen from another intercrossed plant, producing seedlings of the tcnth intercrossed generation. These two sets of 
seedlings were grown in competition with one another, and differed greatly in height and fertility. For the offspring from the cross with a fresh stock exceeled in height the intercrossed plants in the ratio of 100 to is; and this is nearly the same excess which the intercrossed had over the self-fertilised plants in all ten generations taken together, namely, as 100 to 77 . The plants raised from the cross with a fresh stock were also greatly superior in fertility to the intercrossed, namely, in the ratio of 100 to 51 , as judger by the relative weight of the seed-capsules produced by an equal number of plants of the two sets, both having been left to be naturally fertilised. It should be especially observed that none of the plants of either lot were the product of self-fertilisation. On the contrary, the intercrossed plants had certainly been crossed for the last ten generations, and probably, during all previous generations, as we may infer from the structure of the flowers and from the frequency of the visits of humblebees. And so it will have been with the parent-plants of the fresh stock. The whole great difference in height and fertility between the two lots must be attributed to the one being the prodnct of a cross with pollen from a fresh stock, and the other of a cross betwcen plants of the same old stock.

This species offer's another interesting case. In the five first generations in which intercrossed and selffertilised plants were put into competition with one mother, every single intercrossed plant beat its selffertiliser antagonist, except in one instance, in which they were equal in height. But in the sixth generation a plant appeared, named by me the Hero, remarkable for its tallness and increased self-fortility, and which transmitted its characters to the next three generations. The children of Hero were again self- 
fertilised, forming the eighth self-fertilised generation, and were likewise intercrossed one with another; but this cross between plants which had bcen subjected to the same conditions and had bcen sclf-fertilised during the seven previous gencrations, did not effect the least good ; for the intercrossed grandchildren were actually shorter than the self-fertilised grandchildren, in the ratio of 100 to 107 . We here see that the mere act of crossing two distinct plants does not by itself benefit the offspring. This case is almost the converse of that in the last paragraph, in which the offspring profited so greatly by a cross with a fresh stock. A similar trial was made with the descendants of Hero in the following generation, and with the same result. But the trial cannot be fully trusted, owing to the extremely unhealthy condition of the plants. Subject to this same serious cause of doubt, even a cross with a fresh stock dicl not benefit the greatgrandchildren of Hero; and if this were really the case, it is the greatest anomaly observed by me in all my experiments.

(․) Mimulus luteus.-During the three first generations the intercrossed plants taken together exceeded in height the self-fertilised taken together, in the ratio of 100 to 65 , and in fertility in a still higher degrec. In the fourth generation a new variety, which grew taller and had whiter and larger flowers than the old varicties, began to prevail, especially amongst the selffertilised plants. This variety transmitted its characters with remarkable fidelity, so that all the plants in the later self-fertilised generations belonged to it. These consequently cxeceded the intercrossed plants considerably in height. 'Thus in the seventh generation the intercrosserl plants were to the self-fertilised in height as 100 to 137. It is a more remirkible fitct that the 
self-fertilised plants of the sixth generation had become much more fertile than the intercrossed plants, jurlging by the number of capsules spontaneously produced, in the ratio of 147 to 100 . This variety, which as we liave seen appeared amongst the plints of the fourth self-fertilised generation, resembles in almost all its constitutional peculiarities the variety called Hero which appeared in the sixth self-fertiliser generation of Ipomoea. No other such case, with the partial exception of that of Nicotiana, occurred in my experiments, carried on during eleven years.

Two plants of this variety of Dimulus, belonging to the sixth self-fertilised generation, and growing in separate pots, were intercrossed; and some flowers on the same plants were again self-fertilised. From the seeds thus obtained, plants derived from a cross between the self-fertilised plarits, and others of the seventh self-fertilised generation, were raised. But this cross did not do the least good, the intercrossed plants being inferior in height to the self-fertilised, in the ratio of 100 to 110 . This case is exactly parallel with that giren under Ipomoea, of the grandchildren of Hero, and apparently of its great-grandchildren; for the seedlings raised by intercrossing these plants were not in any way superior to those of the corresponding generation raised from the self-fertilised flowers. Therefore in these several cases the crossing of plants, which had been self-fertilised for several generations and which had been cultivated all the time nunder as nearly as possible the same conditions, was not in the least beneficial.

Auotler experiment was now tried. Firstly, plants of the eighth self-fortilised generation were again scliffertilised, producing plints of the ninth selffertilised generation. Secondly, two of the plants of the 
eighth self-fertilised generation were intererossed one with another, as in the experiment above referred to; but this was now effeeted on plants whieh had bren subjected to two additional generations of self-fertilisation. Thirdly, the same plants of the eighth selffertilised generation were crossed with pollen from plants of a fresh stock brought from a distant garden. Numerous plants were raised from these three sets of seeds, and grown in competition with one another. The plants derived from a cross between the self-fertilised plants exeeeded in height by a little the selffertilised, viz., as 100 to 92 ; and in fertility in a greater degree, viz., as 100 to 73 . I do not know whether this difference in the result, compared with that in the previous case, can be aceomnted for by the increased deterioration of the self-fertilised plants from two additional generations of self-fertilisation, and the consequent advantage of any eross whatever, although merely between the self-fertilised plants. But lowever this may be, the effeets of crossing the self-fertilised plants of the eighth generation with a fresh stock were extremely striking; for the seedlings thus raised were to the self-fertilised of the vinth generation as 100 to 52 in height, and as 100 to 3 in fertility! They were also to the intererossed plants (derived from erossing two of the self-fertilised plants of the eighth generation) in height as 100 to 56 , and in fertility as 100 to 4 . Better evidenee could hardly be desired of the potent influence of a eross with a fresh stoek on plants which harl been self-fertilised for eight generations, and had been cultivated all the time under nearly uniform conditions, in eomparison with plants self-fertiliserl for nine generations continuously, or then once intercrossed, namely in the last generation.

(3.) Brassica oleracea.-Some flowers on eabbage 
plants of the second self-fertilised generation were crossed with pollen from a plant of the same variety brought from a distant garden, and other flowers were again self-fertilised. Plants derived from a cross with a fresh stock and plants of the third self-fertilised generation were thus raised. The former wore to the self-fertilised in weight as 100 to 22 ; and this enormons difference must be attributed in part to the beneficial effects of a eross with a fresh stock, and in part to the deteriorating effects of self-fertilisation eontinued during three generations.

(4.) Iberis umbellata. - Seedlings from a erimson English variety erosser by a pale-eoloured rariety whieh had been grown for some generations in Algiers, were to the self-fertilised seedlings from the crimson variety in height as 100 to 89 , and as 100 to 75 in fertility. I am surprised that this eross with another variety did not produee a still more strongly marked benefieial effect; for some intercrossed plants of the erimson English variety, put into eompetition with plants of the same variety self-fertilised during three generations, were in height as 100 to 86 , and in tertility as 100 to 75 . The slightly greater differenee in height in this latter case, may possibly be attributed to the deteriorating effeets of self-fertilisation carried on for two additional generations.

(5.) Eschscholtzia californica.-This plant offers an almost unique case, inasmuch as the good effects of a eloss are confined to the reproductive system. Intercrossed and self-fertilised plants of the English stoek did not differ in height (nor in weight, as far as was ascertained,) in any constant mamner; the selffertilised plants usually laving the advantage. So it was with the offspring of plants of the Brazilian stock, tried in the same mamner. 'The parent-plants, howerer, 
of the English stock produced many more seeds when fertilised with pollen from another plant than when self-fertilised; and in Brazil the parent-plants were absolutely sterile unless they were fertilised with pollen from another plant. Intercrosser seedlings, raised in England from the Brazilian stock, compared with self-fertilised seedlings of the corresponding second generation, yielded seeds in number as 100 to 89 ; both lots of plants being left freely exposed to the visits of insects. If we now turn to the effects of crossing plants of the Brazilian stock with pollen from the English stock, - so that plants which had been long. exposed to rery different conditions were intercrossecl, - we find that the offspring were, as before, inferior in height and weight to the plants of the Brazilian stock after two generations of self-fertilisation, but were superior to them in the most marked manner in the number of seeds produced, namely, as 100 to 40 ; both lots of plants being left freely exposed to the risits of insects.

In the case of Ipomøa, we have seen that the plants derived from a cross with a fresh stock were superior in height as 100 to 78 , and in fertility as 100 to 51 , to the plants of the old stock, although these had been intercrossed during the last ten generations. With Eschscholtzia we have a nearly parallel case, but only as far as fertility is concerned, for the plants derived from a cross with a fresh stock were superior in fertility in the ratio of 100 to 45 to the Brazilian plants, which had been artificially intercrossed in England for the two last generations, and which must have becu naturally intercrossed by insects during all previous generations in Brazil, where otherwise they are quite sterile.

(6.) Dianthus caryophyllus.-Dlants self-fertilised 
for three generations were erossed with pollen from a fresh stock, and their offspring were grown in competition with plants of the fourth self-fertilised generation. The erossed plants thus obtained were to the self-fertilised in height as 100 to 81 , and in fertility (both lots being left to be naturally fertilised by inseets) as 100 to 33.

These same erossed plants were also to the offspring from the plants of the third self-fertilised generation erossed by the intererossed plants of the corresponding generation, in height as 100 to 85 , and in fertility as 100 to 45 .

We thus see what a great advantage the offspring: from a eross with a fresh stoek had, not only over the self-fertilised plants of the fourth generation, but over the offspring from the self-fertilised plants of the third generation, when erossed by the intercrossed plants of the old stoek.

(7.) Pisum satium.-It has been shorn under the head of this species, that the several varieties in this eountry almost invariably fertilise themselves, owing: to insects rarely visiting the flowers; and as the plants have been long cultivated under nearly similar eonditions, we ean understand why a cross between two individuals of the same variety does not do the least good to the offspring either in height or fertility. This case is almost exactly parallel with that of Mimulus, or that of the Ipomoea named Hero; for in these two instances, erossing plants whieh had been self-fertilised for seven generations dirl not at all benefit the offspring. On the other hand, a cross between two rarieties of the pea causes a marked superiority in the growth and vigour of the offspring, over the self-fertilised plants of the same rarieties, as shown by two exeellent observers. From my own 
observations (not made with great care) the offspring from crossed varieties were to self-fertilised plants in height, in one casc as 100 to about 75 , and in a second case as 100 to 60 .

(8.) Lathyrus odoratus.- The swect-pea is in the same statc in regard to sclf-fertilisation as the common pea; and we have seen that secdlings from a cross between two varieties, which differed in no respect except in the colour of their flowers, wcre to the self-fertilised seedlings from the samc mother-plant in height as 100 to 80 ; and in the sccond gencration as 100 to 88 . Unfortunatcly I did not ascertain whether crossing two plants of the same varicty failed to producc any beneficial effect, but I venturc to predict such would be the result.

(9.) Petunia violacea.-The intercrossed plants of the same stock in four out of the five successive generations plainly excecded in height the self-fertilised plants. The latter in the fourth gencration were crossed by a fresh stock, and the secdlings thus obtained were put into competition with the self-fertilised plants of the fifth generation. The crossed plants cxcecded the sclf-fertilised in height in the ratio of 100 to 66 , and in weight as 100 to 23; but this difference, though so great, is not much greater than that between the intercrossed plants of the same stock in comparison with the self-fertilised plants of the corresponding generation. 'I'his casc, therefore, scems at first sight opposed to the rule that a cross with a fresh stock is much more beneficial than a cross between individuals of the same stock. But as with Eschscholtzia, the reprodnctive system was here chiefly benefiterl; for the plants raised from the cross with the fresh stock were to the self-fertilised plants in fertility, both lots boing naturally fertilised, as 100 to 46 , whereas the 
intererossed plants of the same stock were to the selffertilised plants of the corresponding fifth generation in fertility only as 100 to 86 .

Although at the time of measurement the plants raised from the eross with the fresh stork did not exeeed in height or weight the intercrossed plants of the old stoek (owing to the growth of the former not having been eompleted, as explained under the head of this species), yet they exeeeded the intercrossed plants in fertility in the ratio of 100 to $5 t$. This fact is interesting, as it shows that plants self-fertilised for four generations and then erossed by a fresh stock, yielded seedlings whieh were nearly twiee as fertile as those from plants of the same stoek which had been intercrossed for the five previous generations. We here see, as with Esehscholtzia and Dianthus, that the mere act of erossing, independently of the state of the crossed plants, has little effieney in giving increased fertility to the offspring. The same conelusion holds good, as we have already seen, in the analogous eases of Ipomœa, Mimulus, and Dianthus, with respeet to height.

(10.) Nicotiana tabacum.--My plants were remarkably self-fertile, and the eapsules from the self-fertilised flowers apparently yielded more seeds than those whieh were eross-fertilised. No insects were seen to visit the flowers in the hothouse, and I suspeet that the stock on whieh I experimented had been raised under glass. and had been self-fertilised during several previous generations; if so, we can understand why, in the course of three generations, the crossed seedlings of the same stoek did not uniformly exeeed in height the self-fertilised seedlings. But the case is complieated by individual plantshaving different eonstitutions, so that some of the crossed and self-fertilised seedlings raiser at the same time from the same parents behaved differently. 
However this may be, plants raised from self-fertilised plants of the third generation erossed by a slightly different sub-variety, exeeeded greatly in height and weight the self-fertilised plants of the fourth generation; and the trial was made on a large seale. They exceeded them in height when grown in pots, and not mueh erowded, in the ratio of 100 to 66 ; and when mueh erowded, as 100 to 54. These erossed plants, when thus subjeeted to severe eompetition, also exeeeded the self-fertilised in weight in the ratio of 100 to 37. So it was, but in a less degree (as may be seen in Table (), when the two lots were grown out of doors and not subjeeted to any mutual competition. Nevertheless, strange as is the faet, the flowers on the mother-plants of the third self-fertilised generation did not yield more seed when they were erossed with pollen from plants of the fresh stoek than when they were self-fertilised.

(11.) Anugallis collina.-Plants raised from a red variety erossed by another plant of the same variety were in height to the self-fertilised plants from the red variety as 100 to 73 . When the flowers on the red variety were fertilised with pollen from a elosely similar blue-flowered variety, they yielded double the number of seeds to what they did when erossed by pollen from another individual of the same red variety, and the seeds were mueh finer. The plants raised from this eross between the two varieties were to the self-fertilised seedlings from the red variety, in height as 100 to 66 , and in fertility as 100 to 6 .

(12.) Primula veris.-Some flowers on long-styled plants of the third illegitimate generation were legitimately crossed with pollen from a fresh stoek, and others wore fertilised with their own pollen. From the seeds thus produced crossed plants, and self- 
fertilised plants of the fourth illegitimate generution, were raised. The former were to the latter in height as 100 to 46 , and in fertility during one year as 100 to 5 , and as 100 to 3.5 during the next year. In this case, however, we have no means of distinguishing between the evil effects of illegitimate fertilisation continued during four generations (that is, by pollen of the same form, but taken from a distinct plant) and strict self-fertilisation. But it is probable that these two processes do not differ so essentially as at first appears to be the case. In the following experiment any doubt arising from illegitimate fertilisation was completely eliminated.

(13.) Primula veris. (Equal-styled, red-flowered variety).-Flowers on plants of the second self-fertilised generation were crossed with pollen from a ristinct variety or fresh stock, and others were again selffertilised. Crossed plants and plants of the third selffertilised generation, all of legitimate origin, were thus raised; and the former was to the latter in height as 100 to 85 , and in fertility (as judged by the number of capsules produced, together with the average number of seeds) as 100 to 11 .

Summary of the Measurements in Table C.--This table includes the heights and often the reights of 292 plants derived from a cross with a fresh stock; and of 305 plants, either of self-fertilised origin, or derived from an intercross between plants of the same stock. These 597 plants belong to thirteen species and twelve genera. The various precantions which were taken to ensure a fair comparison have already been staterl. If we now look down the right-hand column, in which the mean height, weight, and fertility of the plants derived from a cross mith a fresh stock are represented by 100 , we shall see 
by the other figures how wonderfully superior they are both to the self-fertilised and to the intercrossed plants of the same stock. With respect to height and weight, there are only two exceptions to the rule, namely, with Eschscholtzia and Petunia, and the latter is probably no real exception. Nor do these two species offer an exception in regard to fertility, for the plants derived from the cross with a fresh stock were much more fertile than the self-fertilised plants. The difference between the two sets of plants in the table is generally much greater in fertility than in height or weight. On the other hand, with some of the species, as with Nicotiana, there was no difference in fertility between the two sets, although a great difference in height and weight. Considering all the cases in this table, there can be no doubt that plants profit immensely; though in different ways, by a cross with a fresh stock or with a distinct sub-variety. It cannot be maintained that the benefit thus derived is due merely to the plants of the freslı stock being perfectly healthy, whilst those which had been long intercrossed or selt-fertilised had become unhealthy ; for in most cases there was no appearance of such unhealthiness, and we shall see under Table A that the intercrossed plants of the same stock are generally superior to a certain extent to the self-fertilised,--both lots having been subjected to exactly the same conditions and being equally healthy or unhealthy.

We further learn from Table $C$, that a cross between plants that have been self-fertilised during several successive generations and kept all the time under nearly uniform conditions, does not benefit the offspring in the least or only in a very slight degree. Mimulus and the descendants of Ipomoea named Hero offer instunces of this rule. Again, plants self-fertilised 
during several generations profit only to a small extent by a cross witll intererossed plants of the same stoek (as in the ease of Dianthus), in comparison with the effeets of a cross by a fresh stoek. Plauts of the same stoek intererossed during sereral generations (as with Petunia) were inferior in a marked manner in fertility to those derived from the eorresponding self-fertilised plants erossed by a fresh stoek. Lastly, certain plants whieh are regularly intererossed by inseets in a state of nature, and whieh were artifieially crossed in eaeh sueeeeding generation in the eourse of my experiments, so that they ean never or most rarely have suffered any evil from self-fertilisation (as with Eschscholtzia and Ipomoa), nevertheless profited greatly by a eross with a fresh stoek. These several cases taken together show us in the elearest manner that it is not the mere erossing of any two individuals whieh is benefieial to the offspring. The benefit thus derived depends on the plants whieh are nnited differing in some manner, and there can hardly be a doubt that it is in the eonstitution or nature of the sexual elements. Anyhow, it is certain that the differences are not of an external nature, for two plants which resemble each other as elosely as the individuals of the same species ever do, profit in the plainest mamner when intererossed, if their progenitors have been exposed during several generations to different eonditions. But to this latter subjeet I shall have to reeur in a future chapter.

\section{TABLE A.}

We will now turn to our first table, which relates to crossed and self-fertilised plants of tile sime stock. 'These eonsist of fifty-four species belonging to thirty natural orders. 'I'he total number of erossed plants of which measurements are given is 796, and 
of self-fertilised plants 809 ; that is altogether 1,605 plants. Some of the species were experimented on during several successive generations; and it should be borne in mind that in such cases the crossed plants in each generation were crossed with pollen from another crossed plant, and the flowers on the selffertilised plants were almost always fertilised with their own pollen, though sometimes with pollen from other flowers on the same plant. The crossed plants thus became more or less closely inter-related in the later generations; and both lots were subjected in each generation to almost absolutely the same conditions, and to nearly the same conditions in the successive generations. It would have been a better plan in some respects if I had always crossed some flowers either on the self-fertilised or intercrossed plants of each generation with pollen from a non-related plant, grown under different conditions, as was done with the plants in Table $\mathrm{C}$; for by this procedure I should have learnt how much the offspring became deteriorated through continued self-fertilisation in the successive generations. As the case stands, the self-fertilised plants of the successive generations in Table A were put into competition with and compared with intercrossed plants, which were probably deteriorated in some degree by being more or less inter-related and grown under similar conditions. Nevertheless, had I always followed the plan in Table C, I should not have discovered the important finct that, although a cross between plants which are rather closely related and which had been subjected to closely similar conditions, gives during several generations some advantage to the offspring, yet that after a time they may be intercrossed with no advantage whatever: to the offspring. Nor should I have learnt that the sclf-fortilised plants of the later generations might 
be crossed with intercrossed plants of the same stock with little or 110 alvantage, although they profited to an extraordinary degree by a cross with i fresh stock.

With respect to the greater number of the plants in Table $\mathrm{A}$, nothing speeial need here be said; full partieulars may be formd under the head of each species by the aid of the Index. The figures in the right-hand column show the mean height of the selffertilised plants, that of the crossed plants with which they competed being represented by 100. No notice is here taken of the few cases in which crossed and self-fertilised plants were grown in the open ground, so as not to compete together. The table inelndes, as we have seen, plants belonging to fifty-four species, but as some of these were measurerl during sereral suecessive generations, there are eighty-three cases in which crossed and self-fertilised plants were compared. As in each generation the number of plants which were measured (given in the table) was never very large and sometimes small, whenerer in the right-hand column the mean height of the erossed and self-fertilised plants is the same within five per cent., their heights may be considered as practically equal. Of sueh cases, that is, of self-fertilised plants of which the mean height is expressed by figures between 95 and 105 , there are eighteen, either in some one or all the generations. There are eight cases in which the selffertilised plants exceed the crossed by abore fire per cent., as shown by the figures in the right-hand column being above 105. Iastly, there are fifty-seren cases in which the crossed plants exceed the self-fertilised in a ratio of at least 100 to 95 , and generally in a much higher degree.

If the relative heights of the crossed and self-fertiliserl plants had been due to mere chance, there rould have 
been about as many cases of self-fertilised plants exceeding the crossed in height by above five per cent. as of the crossed thus exceeding the self-fertilised; but we see that of the latter there are fifty-seven cases, and of the former only eight cases; so that the cases in which the crossed plants exceed in height the selffertilised in the above proportion are more than seven times as numerous as those in which the self-fertilised exceed the crossed in the same proportion. For our special purpose of comparing the powers of growth of crossed and self-fertilised plants, it may be said that in fifty-seven cases the crossed plants exceeded the self-fertilised by more than five per cent., and that in twenty-six cases $(18+8)$ they did not thus exceed them. But we shall now show that in several of these twenty-six cases the crossed plants had a decided advantage over the self-fertilised in other respects, though not in height; that in other cases the mean heights are not trustworthy, owing to too few plants having been measured, or to their having grown unequally from being unhealthy, or to both causes combined. Nevertheless, as these cases are opposed to my general conclusion I have felt bound to give them. Lastly, the cause of the crossed plants having no advantage over the self-fertilised can be explained in some other cases. Thus a very small residue is left in which the selffertilised plants appear, as far as my experiments serve, to be really equal or superior to the crossed plants.

We will now consider in some little detail the eigllteen cases in which the self-fertilised plants equalled in average height the crossed plants within five per cent.; and the eight cases in which the self-fertilised plants exceeded in average height the crossed plants by above five per cent.; making altogether twenty-six 
cases in which the crossed plants were not taller than the self-fertilised plants in any marked degree.

(1.) Dianthus caryophyllus (third generation).--This plant was experimented on during fonr generations, in three of which the crossed plants exeeeded in height the self-fertilised generally by much more than five per cent.; and we have seen under Table $\mathrm{C}$ that the offspring from the plants of the third self-fertilised generation crossed by a fresh stock profited in height and fertility to an extraordinary degree. But in this third gencration the crossed plants of the same stoek were in height to the selffertilised only as 100 to 99 , that is, they were practically equal. Nevertheless, when the eight crossed and eight self-fertilised p'ants were cut down and weighed, the former were to the latter in weight as 100 to 49 ! 'There can therefore be not the least doubt that the erossed plants of this species are greatly superior in vigour and luxuriance to the self-fcrtilised; and what was the catise of the self-fertilised plants of the third generation, though so light and thin, growing up so as almost to equal the crossed in height, I eannot explain.

(2.) Lobelin fulgens (first generation).--The crossed plants of this generation were much inferior in lueight to the self-fertilised, in the proportion of 100 to 127: Althongh only two pairs were measured, which is obviously much too few to be trusted, yet from other evidence given under the head of this species, it is eertain that the sclf-fertilised plants were rery much more rigorous than the crossed. As I nsed pollen of unequal maturity for erossing and self-fertilising the parent-plants, it is possible that the great differenee in the growth of their offspring may have been due to this cause. In the next scneration this source of error was avoided, and many more plants were raised, and now the arerage leight of the twenty-thrce crossed plants was to that of the twenty-three self-fertilised plants as 100 to 91 . Wc can therefore hardly clonbt that a cross is benefieial to this species.

(3.) Petunia violucea (third generation).--Eight crossed plants were to eight self-fertilised of the third generation in arcragc height as 100 to 131 ; and at all early age the crossed wcre inferior even in a still higher degree. But it is a remarkable fact that in one pot in whieh plants of both lots grew extremely crowded, the crossed were thrice as tall as the self-fertilised. As in the two preceding and two succeding generations, as well as 
with plants raised by a eross with a fresh stoek, the crossed greatly exceeded the self-fertilised in height, weight, and fertility (when these two latter points were attended to), the present ease must be looked at as an anomaly not affecting the general rule. The most probable explanation is that the seeds from whieh the self-fertilised plants of the third generation were raised were not wcll ripened; for I have observed an analogous ease with Iberis. Self-fertilised seedlings of this latter plant, which were lnown to have been produeed from seeds not well matured, grew from the first much more quiekly than the crossed plants, whieh wcre raised from better maturcd seeds; so that having thus once got a great start thcy were enabled ever afterwards to retain their advantage. Some of these same seeds of the Theris were sown on the oppositc sides of pots filled with burnt earth and purc sand, not eontaining any organie mattcr; and now the young crossed seedlings grew during their short life to double the heiglit of the self-fertilised, in the same manner as oecurred with the above two sets of seedlings of Petminia which were much crowded and thus exposed to very unfavourable conditions. TVe have seen also in the eighth generation of Ipomoea that selffertilised scedlings raised from unhealthy parents grew at first very mueh more quickly than the erossed scedlings, so that they were for a long time much taller, though ultimately beaten by them.

(4, 5, 6.) Eschscholtzia californica.-Four sets of measurements are given in Table $A$. In one of these the crossed plants exeeed the self-fertilised in average height, so that this is not one of the cxceptions here to be considered. In two other cases the erossed equalled the self-fcrtilised in height within five per ecnt. ; and in the fourth ease the self-fertilised excecded the crossed by above this limit. We have seen in Table $\mathrm{C}$ that the whole advantage of a cross by a fresh stock is eonfined to fertility, and so it was with the intererossed plants of the same stoek eompared with the self-fertilised, for the former were in fertility to the latter as 100 to 89. The intererossed plants thus have at least one important advantage over the self-fertilised. Moreover, the flowers on the parent-plants when fertilised witl pollen from another individual of the same stock yicld far more sceds than when sclf-fertilised; the flowers in this latter case being often quite stcrile. We may thercfore conclude that a cross does some grood, though it does not give to the erossed secdlings inereased powers of growtll. 
(7.) Viscaria sculata.-The average height of the fifteen intercrossed plants to that of the fifteen self-fertilised plants was only as 100 to 97 ; but the former produced many more cajsulus than the latter, in the ratio of 100 to 77 . Moreover, the flowers on the parent-plants which were crossed and self-fertilised, yielded seeds on one occasion in the proportion of 100 to 38 , and on a second occasion in the proportion of 100 to 58 . So that there can be no doubt about the beneficial effects of a cross, although the mean height of the crossed plants was only three per cent. abore that of the self-fertilised plants.

(8.) Speculuria speculum.--Only the four tallest of the crossed aud the four tallest of the self-fertilised plants, growing in four pots, were measured ; and the former were to the latter in height as 100 to 98 . In all four pots a crossed plant flotrered before any one of the self-fertilised plants, and this is usually a safe indication of some real superiority in the crossed plants. The flowers on the parent-plants which were crossed with pollen from another plant yielded seeds compared with the self-fertilised flower's in the ratio of 100 to 72 . We may therefore draw the same conclusion as in the last ease with respect to a cross being decidedly beneficial.

(9.) Borago officinatis.-Only four crossed and four selffertilised plants were raised and measured, and the former were to the latter in height as 100 to 102 . So small a number of measurements ought never to be trusted; and in the prescnt instance the advantage of the self-fertilised over the crossed plants depended almost entirely on one of the self-fertilised plants having grown to an umusual height. All four crossed plants flowered before their self-fertilised opponents. The crossfurtilised flowers on the parent-plants in comparison with the self-fertilised flowers yielded seeds.in the proportion of 100 to 60 . so that here again we may draw the same conclusion as in the two last cases.

(10.) Passiflora gracitis.-Only tro crossed and two selffertilised plants were raised; and the former rere to the latter in height as 100 to 104 . On the otlier hand, fruits from the crossfurtilised flower's on the parent-plauts coutained seeds in number, compared with those from the self-fertilised flowers, in the proportion of 100 to 85 .

(11.) Hhaseolus multiflorus.-The five crossed plants were to the five self-fertilised in height as 100 to 96 . Although the crossed plants were thus only four per cent. taller than the 
self-fertilised, they flowered in both pots before them. It is therefore probable that they had some real advantage over the self-fertilised plants.

(12.) Adonis costivalis,-The four crossed plants were almost exactly equal in height to the four self-fertilised plants, but as so few plants were measured, and as these were all " miserably unhealthy," nothing can be inferred with safety with respect to their relative heights.

(13.) Bartonia aurea.-The eight crossed plants were to the eight self-fertilised in height as 100 to 107 . This number of plants, considering the care with which they were raised and compared, ought to have given a trustworthy result. But from some unknown cause they grew very rnequally, and they became so unhealthy that only three of the crossed and three of the self-fertilised plants set any seeds, and these few in number: Under these circumstances the mean height of neither lot can be trusted, and the experiment is valueless. The crossfertilised flowers on the parent-plants yielded rather more seeds than the self-fertilised flowers.

(14.) Thumbergia alata.-The six crossed plants were to the six self-fertilised in height as 100 to 108 . Here the self-fertilised plants seem to have a decided advantage; but both lots grew unequally, some of the plants in both being more than twice as tall as others. The parent-plants also were in an odd semisterile condition. Under these circumstances the superiority of the self-fertilised plants cannot be fully trusted.

(15.) Nolana prostrata.- The five crossed plants were to the five self-fertilised in height as 100 to 105 ; so that the latter seem here to have a small but decided advantage. On the other hand, the flowers on the parent-plants which were cross-fertilised produced very many more capsules than the self-fertilised flower's, in the ratio of 100 to 21 ; and the seeds which the former coutained were heavier than an equal number from the self-fertilised capsules in the ratio of 100 to 82 .

(16.) Hibiscus aficanus.-Only four pairs were raised, and the crossed were to the self-fertilised in height as 100 to 109. Excepting that too few plants were measured, I know of nothing else to cause distrust in the result. The cross-fertilised flowers on the parent-plants were, on the other hand, rather more productive than the self-fertilised flowers.

(17.) Apium petroselinum.-A few plants (number not recorderl) derived from flowers believed to have been crossed by 
inseets and a few self-fertilised plants were grown on the opposite sides of four pots. They attained to a nearly equal height, the erossed having a very slight adrantage.

(18) Vandellia nummularifolia.-Twenty crossed plants raised from the seeds of perfeet flower's were to twenty self-fertilised plants, likewise raised from the seeds of perfeet flowers, in height as 100 to 99. The experiment was repented, with the sole differenee that the plants were allowed to grow more erowded; and now the twenty-fom tallest of the crossed plants were to the twenty-four tallest self-fertilised plants in height as 100 to 91, and in weight as 100 to 97. Moreover, a larger number of the erossed than of the self-fertilised plants grew to a moderate height. The above-mentioned twenty erossed plants were also grown in eornpetition with trenty self-fertilised plants raised from the elosed or cleistogene flowers, and their heights were as 100 to 94 . Therefore had it not been for the first trial, in whieh the crossed plants were to the self-fertilised in lieight only as 100 to 99 , this speeies might have been elassed with those in whieh the crossed plants exeeci the self-fertilised by above fire per eent. On the other hand, the erossed plants in the second trial bore fewer eapsules, and these eontrined fewer seeds, than did the self-fertilised plants, all the eapsules having been produeed by eleistogene flowers. The whole case therefore must be left doubtful.

(19.) Pisum sativum (eommon pea).-Four plants derived from a eross between individuals of the same rariety were in lieight to four self-fertilised plants belonging to the same rariety as 100 to 115. Although this eross did no good, we have seen under Table $\mathrm{C}$ that a eross between distinet varieties adds greatly to the height and vigour of the offspring; and it was there explained that the fact of a eross between the individuals of the same rariety not-being benefieial, is almost eertainly due to their having been self-fertilised for many generations, and in each generation grown under nearly similar eonditions.

(20, 21, 22.) Cunna warscewiczi.-Plants belonging to three generations. were observed, and in all of three the crossed rere approximately equal to the self-fertilised; the arerage height of the thirty-fomr erossed plants being to that of the same number of self-fertilised plants as 100 to 101 . Therefore the erossed plants had no advantage orer the self-fertilised; and it is probable that the same explanation here holds good as in the case of Pisum sativum; for the flowers of this Camma are perfoctly 
self-fertile, and were never seen to be visited by insects in the hothouse, so as to be crossed by them. This plant, moreover, has been cultivated under glass for several generations in pots, and therefore under nearly uniform conditions. The capsules produced by the cross-fertilised flowers on the above thirty-four crossed plants contained more seeds than did the capsules produced by the self-fertilised flowers on the self-fertilised plants, in the proportion of 100 to $85 ;$; so that in this respect crossing was beneficial.

(23.) Primula sinensis.-The offspring of plants, some of which were legitimately and other's illegitimately fertilised with pollen from a distinct plant, wcre almost exactly of the same height as the offspring of self-fertilised plants; but the former with rare exceptions flowered before the latter. I have shown in my paper on dimorphic plants that this species is commonly raised in England from self-fertilised seed, and the plants from having been cultivated in pots have been subjected to nerrly uniform conditions. Moreover, many of them are now varying and changing their character, so as to become in a greater or less degree equal-styled, and in consequence highly self-fertile. Therefore I believe that the canse of the crossed plants not exceeding in height the self-fertilised is the same as in the two previous cases of Pisum sutivum and Canna.

$(24,25,26$.) Nicotiana tabacum.-Four sets of measurements were made; in one, the self-fertilised plants grcatly exceeded in height the crossed, in two others they were approximately equal to the crossed, and in the fourth were beaten by them; but this latter case does not here concern us. The individual plants differ in constitution, so that the descendants of some profit by their parents having been intercrossed, whilst others do not. Taking all three generations together, the twenty-seven crossed plants were in height to the twenty-seven self-fertilised plants as 100 to 96. This excess of hejght in the crossed plants, is so small compared with that displayed by the offspring from the same mother-plants when crossed by a slightly different variety, that we may suspect (as explained under Table C) that most of the individuals belonging to the variety which served as the mother-plants in my experiments, had acquired a nearly similar constitution, so as not to profit by being mutually intercrossed.

Reviewing these twenty-six eases, in which the crossed plants either do not exceed the self-fertilised 
by above five per cent. in height, or are inferior to them, we may conclude that much the greatcr number of the cases do not form real exceptions to the rule, -that a cross between two plants, unless these have been self-fertilised and exposed to nearly the same conditions for many generations, gives a great. adrantage of some kind to the offspring. Of the twenty-six cases, at least two, namely, those of $\mathbf{A}$ donis and Bartonia, may be wholly excluded, as the trials werc worthless from the extreme unhealthiness of the plants. In twelve other cases (three trials with Eschsclooltzia here included) the crossed plants either were superior in height to the self-fertilised in all the other generations excepting the one in question, or they slowed their superiority in some different manner, as in weight, fertility, or in flowering first; or again, the cross-fertilised flowers on the mother-plant were much more productive of seed than the self-fertilised.

Deducting these fourteen cases, there remain twelve in which the crossed plants show no well-marked advantage over the self-fertilised. On the other hand, we have seen that there are fifty-seren cases in which the crossed plants exceed the self-fertilised in height by at least five per cent., and generally in a much higher degree. But even in the twelve cases just referred to, the want of any adrantage on the crossed side is far from certain: with Thunbergia the parcutplants were in an odd semi-sterile condition, and the offspring grew very unequally; with Hibiscus and Apium much too few plants were raised for the measurements to be trusted, and the cross-fertilised flowers of Hibiscus prodnced rather more seed than did the selffertilised; with Tandellin the crossed plants were a little taller and heavier than the self-fertilised, but as they were less fertile the case must be left doubtful. 
Lastly, with Pisum, Primula, the threc gencrations of Canna, and the three of Nicotiana (which together complete the twelve cascs), a cross between two plants certainly did no good or very little good to the offspring; but we have reason to believe that this is the result of these plants having been self-fertilised and cultivated under nearly uniform conditions for sevcral generations. The same result followed with the experimental plants of Ipomœa and Mimnlus, and to a certain extent with somc other species, which had been intentionally treated by me in this manner; yet we know that these spccics in their normal condition profit greatly by being intercrossed. There is, therefore, not a singlc case in Tablc A which affords decisirc evidence against the rule that a cross between plants, the progenitors of which have been subjected to somewhat diversified conditions, is beneficial to the offspring. This is a surprising conclusion, for from the analogy of domesticated animals it could not have been anticipated, that the good effects of crossing or the evil effects of selffertilisation would have been perceptible until the plants had been thus treaterl for several generations.

The results given in Tablc A may be looked at under another point of view. Hitherto each generation has been considered as a separatc casc, of which therc are eighty-three; and this no doubt is the more corrcet method of comparing the crosscd and selffertilised plants.

But in those cascs in which plants of the same species were observed during several generations, a general average of their heights in all the gencrations together may be made; and such averages arc given in 'Table $A$; for instance, under Ipomoea the general average for the plants of all ten gencrations is as 100 for the crossed, to 77 for the self-fertiliser 
plants. This having been done in each case in which more than one generation was raised, it is easy to calculate the average of the average heights of the crossed and self-fertilised plants of all the species included in Table A. It should however be observed that as only a few plants of some species, whilst a considerable number of others, were measured, the value of the mcan or average heights of the several species is very different. Subject to this source of error, it may be worth while to give the mean of the mean heights of the fifty-four species in Table $A$; and the result is, calling the mean of the mean heights of the crossed plants 100, that of the self-fertilised plants is 87. But it is a better plan to divide the fifty-four species into three groups, as was done with the previously given eighty-three cases. The first gromp consists of species of which the mean heights of the self-fertilised plants are within five per cent. of 100 ; so that the crossed and self-fertilised plants are approximately equal; and of such species there are twelve about which nothing need be said, the mean of the mean heights of the self-fertilised being of course very nearly 100 , or exactly $99 \cdot 58$. The second group consists of the species, thirty-seven in number, of which the mean heights of the crossed plants exceed that of the self-fertilised plants by more than five per cent.; and the mean of their mean heights is to that of the self-fertilised plants as 100 to 78. The third group consists of the species, only five in number, of which the mean heights of the self-fertilised plants exceed that of the crossed by more than five per cent.; and here the mean of the mean heights of the crossed plants is to that of the self-fertilised as 100 to 109 . Therefore if we exclucle the species which are approximately equal, there are 
thirty-scren spccies in which the mean of the mcan heights of the crossed plants exceeds that of the selffertilised by twcnty-two per cent.; whereas thcre are only five species in which the mean of the mcan heights of the sclf-fertilised plants exceeds that of the crossed, and this only by nine por cent.

The truth of the conclusion-that the good effects of a cross depend on the plants having bcen subjected to different conditions or to their belonging to different varieties, in both of which cascs they would almost certainly differ somewhat in constitution-is supported by a comparison of the Tables $\mathrm{A}$ and $\mathrm{C}$. The latter table gires the results of crossing plants with a fresh stock or with a distinct variety; and the superiority of the crossed offspring ovcr the sclf-fertilised is here much more gencral and much more strongly marked than in Table A, in which plants of the same stock were crossed. We have just seen that the mean of the mcan heights of the crossed plants of the whole fiftyfour species in Tablc $\mathrm{A}$ is to that of the sclf-fertilised plants as 100 to 87 ; whereas the mean of the mean heights of the plants crossed by a fresh stock is to that of the self-fertiliscel in Table $\mathrm{C}$ as 100 to 74 . So that the crossed plants bcat the sclf-fertilised plants by thirtecn per cent. in Table A, and by twenty-six per cent., or double as much, in Table $C$, which includes the results of a cross by a fresh stock.

\section{Table B.}

A few words must be added on the weights of the crossed plants of the same stock, in comparison with the self-fertilised. Elcven cases are given in Table $B$, relating to cight species. The number of plants which were wcighed is shown in the two left columns, and their relative weights in the right 
column, that of the crossed plants being taken as 100. A few other cases have already been reeorder in Table $\mathrm{C}$ in reference to plants erossed by a fresh stock. I regret that more trials of this kind were not marle, as the evidence of the superiority of the erossed over the self-fertilised plants is thus shown in a more conelusive manner than by their relative heights. But this plan was not thought of until a rather late period, and there were diffieulties in the way, as the seeds had to be eolleeted when ripe, by which time the plants had often begun to wither. In only one ont of the eleven eases in Table B, that of Eschseholtzia, do the self-fertilised plants exceed the erossed in weight; and we have already seen they are likewise superior to them in height, though inferior in fertility, the whole advantage of a eross being here confined to the reproduetive system. With Vandellia the erossed plants were a little heavier, as they were also a little taller than the self-fertilised; but as a greater number of more produetive capsules, were produced by the cleistogene flowers on the self-fertilised plants than by those on the erossed plants, the ease must be left, as remarked under Table A, altogether doubtful. The crossed and self-fertilised offspring from a partially self-sterile plant of Reseda odorata were almost equal in weight, though not in height. In the remaining eight cases, the erossed plants show a wonderful superiority over the self-fertilised, being more than louble their weight, exeept in one case, and here the ratio is as high as 100 to 67 . The results thus deduced from the weights of the plants confirm in a striking manner the former evidenee of the heneficial effects of a cross between two plants of the same stock; and in the few eases in which plants deriverl from a cross with a fresh stock were weighed, the results are similns: or even more striking. 


\section{CHAFTER VIII.}

Differefice Between Crossed and Self-fiertilised Plants in CONSTITUTIONAL Vigour aND IN OTHER RESPECTS.

Greater eonstitutional vigour of crossed plants-The effects of great crowdiug-Competition with other kinds of plants-Self-fertilised plants more liuble to premature death-Crossed plants generally flower before the self-fertilised-Negative effeets of intererossing flowers on the same plant-Cases deseribed-Transmission of the good effects of a cross to later generations-Effects of crossing plants of elosely related parentage-Uniform eolour of the flowers on plants self-fertilised during several generations and cullivated under similar conditions.

Greater constitutional Vigour of crossed Plants.-As in almost all my experiments an equal number of crossed and self-fertilised seeds, or more commonly seedlings just beginning to sprout, were planted on the opposite sides of the same pots, they had to compete with one another; and the greater height, weight, and fertility of the crossed plants may be attributed to their possessing greater innate constitutional vigour. Generally the plants of the two lots whilst very young were of equal height; but afterwards the crossed gained insensibly on their opponents, and this shows that they possessed some inherent superiority, though not displayed at a very early period of life. There were, however, some conspicuous exceptions to the rule of the two lots being at first equal in height; thus the crossed scedlings of the broom (Sarothamnus scoparius) when under three inches in height were more than twice as tall as the self-fertilised plants. 
After the erossed or the self-fertilised plants had once grown deciledly taller than their opponents, a still increasing advantage would tend to follow from the stronger plants robbing the wcaker ones of nourishment and orershadowing them. This was evidently the ease with the crossed plants of Viola tricolor, which ultimately quite orerwhelmed the selffertilised. But that the erossed plants have an inherent superiority, independently of eompetition, was sometimes well shown when both lots were planted separately, not far distant from one another, in good soil in the open ground. This was likewise shown in sereral eases, even with plants growing in close competition with one another, by one of the self-fertilised plants exeeeding for a time its erossed opponent, which had been injured by some aeeident or was at first sickly, but being ultimately eonquered by it. The plants of the eighth generation of Ipomøa were raised from small seeds prorluced by unhealthy parents, and the self-fertilised plants grew at first rery rapidly, so that when the plants of both lots were about three feet in height, the mean height of the crossed to that of the self-fertilised was as 100 to 122 ; when they were about six feet high the two lots were rery nearly equal, but ultimately when bctween eight and nine feet in height, the crossed plants asserted their usual superiority, and were to the self-fertilised in height as 100 to 85 .

The constitutional superiority of the erossed orer the self-fertilised plants was proved in another way in the third generation of Mimulus, by self-fertilised seeds being sown on one side of a pot, and after a certain interval of time crossed seeds on the opposite side. The self-fertilised seedlings thus had (for I ascertained that the seeds germinated simultaneously) a clear adrantage 
over the crossed in the start for the race. Nevertheless they were easily beaten (as may be seen under the head of Mimulus) when the crossed seeds were sown two whole days after the self-fertilised. But when the interval was four days, the two lots were nearly equal throughout life. Even in this latter case the crossed plants still possessed an inherent advantage, for after both lots had grown to their full height they were cut down, and without being disturbed were transferred to a larger pot, and when in the ensuing year they had again grown to their full height they were measured; and now the tallest crossed plants were to the tallest self-fertilised plants in height as 100 to 75 , and in fertility (i.e., by weight of seeds produced by an equal number of capsules from both lots) as 100 to 34 .

My usual method of proceeding, namely, to plant several pairs of crossed and self-fertilised seeds in an equal state of germination on the opposite sides of the same pots, so that the plants were subjected to moderately severe mutual competition, was I think the best that could have been followed, and was a fair test of what occurs in a state of nature. For plants sown by nature generally come up crowded, and are almnst always exposed to very severe competition with one another and with other kinds of plants. This latter consideration led me to make some trials, chiefly but not exclusively with Ipomoea and Mimulus, by sowing crossed and self-fertilised seeds on the opposite sides of large pots in which other plants had long been growing, or in the midst of other plants out of doors. The seedlings were thus subjected to very severe competition with plants of other kinds; and in all such cases, the crossed seedlings exhibited a great superiority in their power of growth over the selffertilised. 
After the germinating seedlings had been planted in pairs on the opposite sides of several pots, the remaining seeds, whether or not in a state of germination, were in most cases sown very thickly on the two sides of an additional large pot; so that the seedlings came up extremely crowded, and were subjected to extremely severe competition and unfarourable conditions. In such cases the crossed plants almost invariably showed a greater superiority over the self-fertilised, than did the plants which grew in pairs in the pots.

Sometimes crossed and self-fertilised seeds were sown in separate rows in the open ground, which was kept clear of weeds; so that the seedlings were not subjected to any competition with other kinds of plants. Those however in each row had to struggle with the adjoining ones in the same row. When fully grown, several of the tallest plants in each row were selected, measured, and compared. The result was in several cases (but not so invariably as might have been expected) that the crossed plants did not exceed in height the self-fertilised in nearly so great a degree as when grown in pairs in the pots. Thus with the plants of Digitalis, which competed together in pots, the crossed were to the self-fertilised in height as 100 to 70 ; whilst those which were grown separately were unly as 100 to 85 . Nearly the same result was observed with Brassica. With Nicotiana the crossed were to the self-fertilised plants in height, when grown extremely crowded together in pots, as 100 to 5t; when grown much less crowded in pots as 100 to 66, and when grown in the open ground, so as to be subjected to but little competition, as 100 to 72 . On the other hand with Ker, there was a greater difference in height between the crossed and self-fertilised plants growing out of doors, than between the pairs which 
grew in pots in the hothouse; but this may be attributed to the self-fertilised plants being more tender, so that they suffered more than the erossed, when both lots were exposed to a eold and wet summer. Lastly, with one out of two series of Reseda odorata, grown out of doors in rows, as well as with Beta vulgaris, the erossed plants did not at all exeeed the selffertilised in height, or exceeded them by a mere trifle.

'The innate power of the erossed plants to resist unfavourable conditions far better than did the selffertinised plants, was shown on two oeeasions in a curious manner, namely, with Iberis and in the third generation of Petunia, by the great superiority in height of the erossed over the self-fertilised seedlings, when both sets were grown under extremely unfavourable conditions; whereas owing to special circumstances exactly the reverse oeemrred with the plants raised from the same seeds and grown in pairs in pots. A nearly analogous case was observed on two other oeeasions with plants of the first generation of Nicotiana.

The erossed plants always withstood the injurious effects of being suddenly removed into the open air after having been kept in the greenhouse better than did the self-fertilised. On several oeeasions they also resisted mueh better eold and intemperate weather. This was manifestly the ease with some erossed and self-fertilised plants of Ipomoca, whieh were suddenly moved from the hothouse to the eoldest part of a eool greenhouse. The offspring of plants of the eighth self-fertilised generation of Mimulus crossed by a fresh stock, survived a frost which killed every single selffertilised and intererossed plant of the same old stock. Nearly the same result followed with some erossed and self-fertilised plants of Viola tricolor. Even the tips of the shoots of the crossed plants of Sarothamnus 
scoparius were not tonehed by a very screre winter; whereas all the self-fertilised plants were killerl halfway down to the ground, so that they were not able to flower during the next summer. Young crossed seedlings of Nieotiana withstood a eold and wet summer mueh better than the self-fertilised seerlings. I have met with only one exception to the rule of crossed plants being hardier thin the self-fertilised: three long rows of Esehscholtzia plants, consisting of crossed seedlings from a fresh stock, of intercrossed seedlings of the same stuek, and of self-fertilised ones, were left mprotected during a severe winter, and all perished exeept two of the self-fertilised. But this ease is not so anomalous as it at first appears, for it should be remembered that the self-fertilised plants of Esehscholtzia always grow taller and are hearier than the crossed; the whole benefit of a eross with this speeies being eonfined to increased fertility.

Independently of any external cause whieh eould be detected, the self-fertiliser plants were more liable to premature leath than were the crosserl; and this seems to me a eurious faet. Whilst the seerlings were very young, if one died its antagonist was pulled up and thrown away, and I believe that many more of the self-fertilised died at this early age than of the crossed; but I negleeted to keep any record. With Beta vulgaris, howerer, it is certain that a large number of the self-fertilised secds perisher after geminating beneath the ground, whereas the crossed seeds sown at the same time did not thus suffer. When a plant died at a somewhat more arlvanced age the fact was recorded; and I find in my notes that ont of several hundred plints, only seren of the erossed died, whilst of the self-fertilised at least twenty-nine were thus lost, that is more than four times as many. Mr. Galton, 
after examining some of my tables, remarks: "It is very evident that the columns with the self-fertilised plants include the larger number of exceptionally small plants ; " and the frequent presence of such puny plants no doubt stands in elose relation with their liability to premature death. The self-fertilised plants of Petunia eompleted their growth and began to wither sooner than did the intererossed plants; and these latter eonsiderably before the offspring from a cross with a fresh stock.

Period of Flowering.-In some cases, as with Digitalis, Dianthus, and Reseda, a larger number of the erossed than of the self-fertilised plants threw up flower-stems; but this probably was merely the result of their greater power of growth ; for in the first generation of Lobelia fulgens, in whieh the self-fertilised plants greatly exceeded in height the erossed plants, some of the latter failed to throw up flower-stems. With a large number of species, the crossed plants exhibited a well-marked tendency to flower before the self-fertilised ones growing in the same pots. It should however be remarked that no reeord was kept of the flowering of many of the speeies; and when a record was kept, the flowering of the first plant in each pot was alone observed, although two or more pair's grew in the same pot. I will now give three lists,- - one of the speeies in which the first plant that flowered was a erossed one,-a second in which the first that flowered was a self-fertilised plant,--and a third of those which flowered at the same time.

Species, of which the first Plants that flowered were of Crossed Parentage.

Ipomoa purpurea.-J. record in my notes that in all ten generations many of the crossed plants flowered before the selffertilised; but no details were kept. 
Mimulus luteus (Finst Generation).-Ten flowers on the crossed plants were fully expanded before one on the self-fertilised. Mimulus luteus (Seeond and Third Generation).-In both these generations a erossed plant flowered before one of the selffertilised in all tliree pots.

Mimulus luteus (Fifth Generation).- - In all three pots a erossed plant flowered first; yet the self-fertilised plants, which belonged to the new tall valriety, were in height to the crossed as 126 to 100 .

Mlimulus luteus.-Plants derived from a eross with a fresh stoek, as well as the intererossed plants of the old stoek, flowered before the self-fertilised plants in nine out of the ten pots. Sulvia coccined.-A erossed plant flowered before any one of the self-fertilised in all three pots.

Uigganum vulyure.-Durming two sueessive seasons several erossed plants flowered before the self-fertilised.

Licussica olerucer (First Generation).-All the erossed plants growing in pots and in the opell ground flowered first.

Brassica olerecea (Seeond Generation).-A erossed plant in three out of the four pots flowered bafore any one of the self-fertilised.

lberis umbelluta. - In both pots a erossed plant flowered first.

Eischscholtzin californica.-Plants derired from the Brazilian stoek erossed by the English stoek flowered in five out of the nine pots first; in four of them a self-fertilised plant flowered first; and not in one pot did an intererossed plant of the old stoek flower first.

liola tricolur.-A erossed plant in five out of the six pots flowered before any one of the self-fertilised.

Jianthus caryopleyllus (First Generation). - In two large beds of plants, four of the erossed plants flowered before any one of the self-fertilised.

Jiunthus curyophyllas (Seeond Generation). - In both pots a crossed plant flowered first.

Jiuntlus ccryophyllus (Thind Generation).-In tince out of the four pots a erossed plant flowered first; yet the erossed were to the self-fertilised in height only as 100 to 99 , but in weight as 100 to 49 .

Jianthus caryophyllus. - Plants derived from a eross witl a frosl stoek, and the intererossed plants of the old stoek, botl flowered before the self-fertilised in nine out of the ten pots. Ilibiscus africunus.-In three out of the four pots a crossed 
plant flowered before any one of the self-fertilised; yet the lattcr were to the crossed in height as 109 to 100.

Troparolum minus.-A crossed plant flowered before any one of the self-fertilised in three out of the four pots, and simultaneously in the fourth pot.

Limnanthes donglasii.-A crossed plant flowered before any one of the self-fertilised in four out of the firc pots.

Phasentus multiflorus.-In both pots a crossed plant flowered first.

Specularia speculum.-In all four pots a crossed plant flowered first.

Lobeliu ramosa (First Generation).-In all four pots a crossed plant flowercd before any one of the self-fertilised.

Lobelia ramosa (Second Generation).-In all four pots a crosser plant flowered some days before any one of the selffertilised

Nemophila insignis.-In four out of the five pots a crossed plant flowered first.

Borago officinalis, - In both pots a crossed plant flowered first. Petunia violacea (Second Generation).-In all three pots a crossed plant flowered first.

Nicatiana tabacum.-A plant derived from a cross with a fresh stock flowered before any one of the self-fertilised plants of the fourth generation, in fiftecn out of the sixteen pots.

Cyclamen persirum.-During two successive scasons a crossed

plant flowered some weeks before any one of the self-fertilised in all four pots.

Primula veris (equal-styled var.). - In all three pots a crossed plant flowered first.

I'rimula sinensis. - In all four pots plants derived from an

illcgitimate cross between distinct plants flowered before any one of the self-fertilised plants.

Irimutu sinensis.-A legitimately crossed plant flowered before any one of the self-fertilised plants in seven out of the eight pots.

Fagopyrum esculentum.-A legitimately crossed plant flowered from one to two days before any one of the self-fertilised plants in all three pots.

Zere mays. - In all four pots a crossed plant flowered first.

Plutaris canariensis. - The crossed plants flowered before the self-fertilised in the open ground, but simultaneously in the pots. 
S'pecies, of which the first Plants that flowered were of Self-fertilised Parentuge.

Eschscholtzia californica (First Gencration).-The crossed plants were at first taller than the self-fertilised, but on their second growth during the following year the self-fortilised exceeded the erossed in height, and now they flowered first in three out of the four pots.

Lupinus luteus. - Although the erossed plants were to the selffertilised in height as 100 to 82 ; yet in all three pots the self-fertilised plants flowered first.

Clarkin eleguns.-Althongh the crossed plants were, as in the last ease, to the self-fertilised in height as 100 to 82 , yettim the two pots the self-fertilised flowered first.

Lobelin fulgens (First Gencration).- The crossed plants were to the self-fertilised in height only as 100 to 127 , and the latter flowered mueh before the crossed.

I'etunia violucea (Third Generation).-The crossed plants were to the self-fertilised in height as 100 to 131 , and in three ont of the forr pots a self-fertilised plant flowered first; in the fourth pot simultaneously.

l'etunir violucere (Fourth Generation).-Although the crossed plants were to the self-fertilised in lheight as 100 to 69 , ret in three ont of the five pots a self-fertilised plant flowered first; in the fourth pot simnltaneonly, and only in the fifth did a erossed plant flower first.

Nicotiuna tabacum (First Generation).-The crossed plants were to the self-fortilised in height only as 100 to 178 , and a self-fertilised plant flowered first in all four pots.

Nicrtiunu tabucum (Third Generation).-The crossed plants were to the self-fertilised in height as 100 to 101, and in four out of the five pots a self-fertilised plaut flowered first. Canna varsceviczi.-In the three gencrations taken together the crossed were to the self-fertilised in height as 100 to 101 ; in the first generation the self-fertilised plants slowed some tendoney to flower first, and in the third generation they flowered first in nine out of the twelve pots.

Species in which the Crossed and Self-fertitised Plants flowered atmost simultaneously.

Mimulus luteus (Sixth Generation).-The crossed plants were inferior in height and vigour to the self-fertilised plants, 
whieh all belonged to the new white-flowered tall variety, yet in only half the pots did the self-fertilised plants flower first, and in the other hall: the erossed plants.

Viscaria oculate. -The erossed plants were only a little taller than the self-fertilised (viz., as 100 to 97), but eonsiderably more fertile, yet both lots flowered almost simultaneously.

I.athyrus odoratus (Seeond Generation).-Although the erossed plants were to the self-fertilised in height as 100 to 88, yet there was no marked difference in their period of flowering. Iobrtic futgens (Seeond Generation).--Although the erossed plants were to the self-fertilised in height as 100 to 91 , yet they flowered simultaneously.

Nicotiunu tabacum (Third Generation).-Although the erossed plants were to the self-fertilised in height as 100 to 83 , yet in half the pots a self-fertilised plant flowered first, and in the other half a erossed plant.

These three lists inelude fifty-eight cases, in whieh the period of flowering of the crossed and self-fertilised plants was recorded. Tn forty-four of them a erossed plant flowered first either in a majority of the pots or in all; in mine instanees a self-fertilised plant flowered first, and in five the two lots flowered simultaneously. One of the most striking eases is that of Cyelamen, in which the crossed plants flowered some weeks before the self-fertilised in all four pots during two seasons. In the second generation of Lobelia ramosa, a erossed plant flowered in all four pots some days before any one of the self-fertilised. Plants derived from a cross with a fresh stoek generally showed a very strongly marked tendency to flower before the selffertilised and the intercrossed plants of the old stock ; all three lots growing in the same pots. Thus with Jimulus and Dianthus, in only one pot out of ten, and in Nicotiana in only one pot ont of sixteen, did a selffortilised plant flower before the plants of the two crossed linels, - these latter flowering almost simultancously. 
A consideration of the two first lists, especially of the second one, shows that a tendency to flower first is generally connected with greater power of growth, that is, with greater height. But there are some remarkable exceptions to this rule, proving that some other canse comes into play. Thus the crossed plants both of Lupinus Tuteus and Clartia elegans were to the selffertilised plants in height as 100 to 82 , and yet the latter flowered first. In the third generation of Nicotiana, and in all three generations of Canna, the crossed and self-fertilised plants were of nearly equal height, yet the self-fertilised tended to flower first. On the other hand, with Primula sinensis, plants raised from a cross betwcen two distinct individuals, whether these were legitimately or illegitimately crossed, flowered before the illegitimately self-fertilised plants, although all the plants were of nearly equal height in both cases. So it was with respect to height and flowering with Phaseolus, Specularia, and Borago. The crossed plants of Hibiscus were inferior in height to the self-fertilised, in the ratio of 100 to 109 , and ret they flowered before the self-fertilised in three out of the four pots. On the whole, there can be no doubt that the crossed plants exhibit a tendency to flower before the self-fertilised, almost though not quite so strongly marked as to grow to a greater height, to weigh more, and to be more fertile.

A few other cases not included in the above three lists deserve notice. In all three pots of Viola tricolor, naturally crossed plants the offspring of crossed plants flowered before naturally crossed plants the offspring of self-fertilised plants. Flowers on two plints, both of self-fertilised parentage, of the sixth generation of Mimulus Tuteus were intercrossed, and other flowers on the same plants were fertilised with their own pollen; 
intercrossed seedlings and secdlings of the seventh self-fertilised generation wcre thus raiscd, and the latter flowered before the intercrossed in threc out of the five pots. Flowers on a plant both of Mimulus luteus and of Ipomoea purpurea were crossed with pollen from other flowers on the same plant, and other flower's werc fertilised with their own pollen; intercrossed seedlings of this peculiar kind, and other's strictly selffertilised being thus raised. In the case of the Mimulus the self-fertilised plants flowered first in seven out of the eight pots, and in the case of the Ipomoa in eight out of the ten pots; so that an intercross between the flowers on the same plant was very far from giving to the offspring thus raised, any advantagc over the strictly self-fertilised plants in their pcriod of flowering.

\section{The Effects of crossing Flowers on the same Plant.}

In the discussion on the results of a cross with a fresh stock, given under Table $\mathrm{C}$ in the last chapter, it was shown that the merc act of crossing by itsclf does no good; but that the advantages thus derived depend on the plants which arc crossed, either consisting of distinct varietics which will almost certainly differ somewhat in constitution, or on the progenitors of the plants which arc crossed, though identical in every external character, having been subjected to somewhat different conditions and having thus acquired some slight difference in constitution. All the flowers produced by the same plant have becn developed from the same sced; those which expand at the samc time have been exposed to cxactly the same climatic influences; and the stems have all been nourished by the same roots. Therefore in accordance with the conclusion just referred to, no good ought to result from 
crossing flowers on the same plant.* In opposition to this eonelusion is the faet that a bud is in one sense a distinct individual, and is eapable of occasionally or even not rarely assuming new external characters, as well as new eonstitutional peeuliarities. Plants raised from buds whieh have thus varied may be propagated for a great length of time by grafts, euttings, dc., and sometimes even by seminal generation. $\dagger$ There exist also numerous speeies in whieh the flowers on the same plant differ from one another,-as in the sexual organs of monocious and polygamous plants,--in the structure of the eirenmferential flowers in many Compositx, Umbelliferæ, \&e.,-in the strueture of the central flower in some plants, - in the two kinds of flowers produeed by cleistogene species, - and in several other sueh cases. These instances clearly prove that the flowers on the same plant have often varied independently of one another in many important respeets, such variations having been fixed,

* It is, however, possible that the stamerss which differ in length or eonstruetion in the same flower mny produce pollen differing in nature, aud in this manner a eross inight be made effective between the sereral flowels on the same plant. Mr: Mraenitb states (in a communication to MI. Verlot, "La Production des Variétés,' 1865, p. 42) that seedlings raised from the shorter and longer stamens of rhododendron difter in chanacter; but the sloriel stamens apparently are becoming rulimentary, and the seedlings are dwarfs, so that the result may lie simply due to a want of fortilising power in the pollen, as in the cuse of the dwarfed plants of Mirabilis linisul by Naurlin by the use of too few pollen-grains. $\quad \Lambda$ ualogous state- ments have been made with respect to the stamens of Yelargonium. With some of the Melastumacer, seedlings raised by me from flowers fertilised by pollen from the shorter stamens, certrinly differed in appearance from those raised from the longer stamens, with differently coloured anthers; but here, again, there is some reason for believing that the shorter stamens are tending towards aljortion. In the very different ease of trimorphic licterostyled plants, the two sets of stainculs in the sime flower have widely different fertilising powers.

+ I have given numerous cases of such bud-variations in my' $\mathrm{Ta}$ riation of Anima!s and Plunts under Domestiention,' chnp. xi, 2ul edit. rol. i. p. $4+8$. 
like those on distinct plants during the development of speeics.

It was therefore nccessnry to ascertain by experiment what would be the effect of intererossing flowers on the same plant, in comparison with fertilising them with their own pollen or crossing them with pollen from a distinct plant. Trials were earefully made on fire genera belonging to four families; and in only one case, namely, Digitalis, did the offspring from a cross between the flowers on the same plant reeeive any benefit, and the benefit hcre was small compared with that derived from a eross between distinct plants. In the chapter on Fertility, when we consider the cffeets of cross-fertilisation and self-fertilisation on the produetiveness of the parent-plants we shall arrive at ncarly the same result, namcly, that a cross between the flowers on the same plant does not at all inerease the number of the seeds, or only oeeasionally and to a slight degrec. I will now give an abstract of the results of the fire trials which were made.

(1.) Digitalis purpurea.- Seedlings raised from intercrossed flowers on the same plant, and others from flowers fertilised with their own pollen, were grown in the usual manncr in competition with one another on the opposite sides of ten pots. In this and the four following cases, the details may be found under the head of cach specics. In eight pots, in whieh the plants did not grow much crowded, the flower-stems on sixteen intercrossed plimts were in height to those on sixteen self-fertilised plants, as 100 to 94 . In the two other pots in which the plants grew much crowled, the flower-stems on nine intererossed plants were in height to those on nine self-fertilised plants, as 100 to 90. That the intercrosserl plants in these two latter pots had a real artrantage over their self-fertilised 
opponents, was well shown hy theip redutive weights

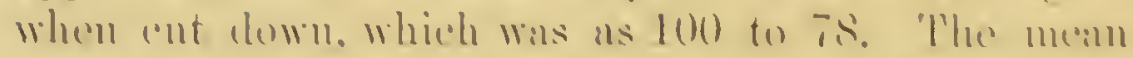
heright of the thewerpstents on the twenty-live inter-

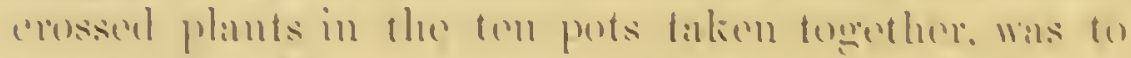
that of the therrer-stems om the twenty-tive self-ferti-

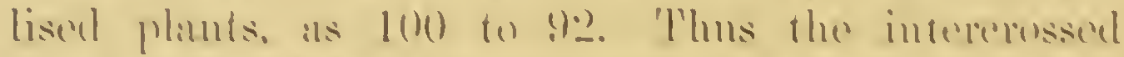
plants were certamly superiod to the solf-tidtilised in

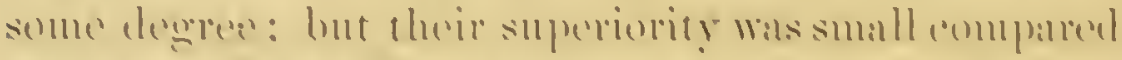

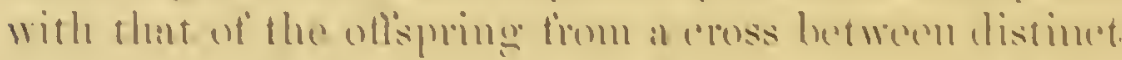
plants over the solfferetilised. this herieg in the ratio

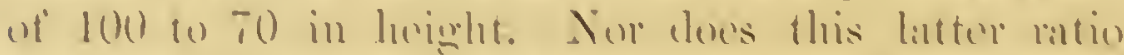

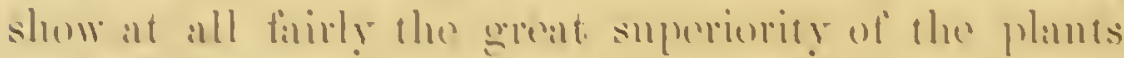

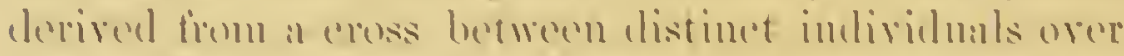
the self-fertilised. als the former produced mone tham twier as many thewer-stems as the litter. and were much less lialibe te promiture death.

(․) Ipomeen purpurer.-'Thirty-ome interemensed plants riased from al aress between thewers on the sime plants were erewn in toul pots in empertition with the silme momber of self-firtilised plants, and the former were to the lattere in height as 100 to tode. So that the self-fertilised plants were a little tallere than the inter-

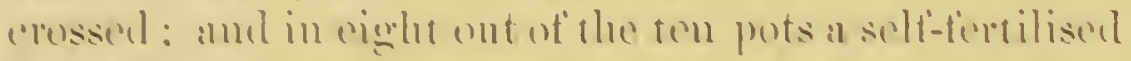
plant thesered before any one of the eressed plants in the sime pets. 'The plimts which wew met ereatly

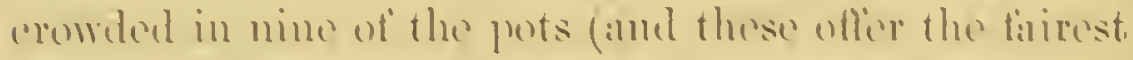

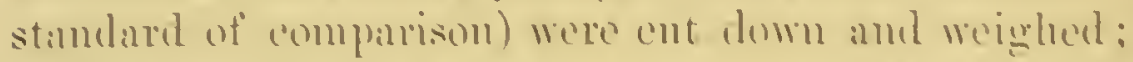
and the weight of the twenty-seren interemesed plants was to that of the twenty-soren self-tertilisol as $1(0)$ to 12-4: so that ly this test the suprerientity of the solf-fertilised was stromely marked. To this subjeret of the superiority of the self-fertilised plants in erertin

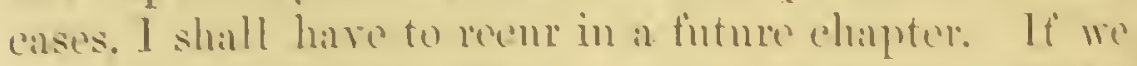
now toln to the oftspring from a cross hetween distinet plants when put into eomperition with self- 
fertilised plants, we find that the mean height of seventy-three such erossed plants, in the eourse of ten generations, was to that of the same number of self-fertilised plants as 100 to 77 ; and in the case of the plants of the tenth generation in weight as 100 to 44. Thus the contrast between the effeets of erossing flowers on the same plant, and of erossing flowers on distinet plants, is wonderfully great.

(3.) Mimulus luteus.-Twenty-two plants raised by crossing flowers on the same plant were grown in eompetition with the same number of self-fertilised plants; and the former were to the latter in height as 100 to 105 , and in weight as 100 to 103 . Moreover, in seven out of the eight pots a self-fertilised plant flowered before any of the intercrossed plants. So that here again the self-fertilised exhibit a slight superiority over the intercrossed plants. For the sake of comparison, I may add that seedlings raised during three generations from a eross between distinet plants were to the self-fertilised plants in height as 100 to 65 .

(4.) Pelargonium zonale.-Two plants growing in separate pots, which had been propagated by euttings from the same plant, and therefore formed in faet parts of the same individual, were intererossed, and other flowers on one of these plants were self-fertilised; but the seedlings obtained by the two proeesses did not differ in height. When, on the other hand, flowers on one of the above plants were crossed with pollen taken from a distinct seedling, and other flowers were self-fertilised, the crossed off'spring thus obtained were to the self-fertilised in height as 100 to 74 .

(5.) Origanum vulgare.-A plant which had been long cultivated in my kitchen garden, had spread by stolons so as to form a large bed or elump. Seedlings raised by intercrossing flowers on these plants, whieh 
strict]y consisted of the same plant, and other scerllings raised from self-fertilised flowers, were carefinlly compared from their earliest youth to maturity; and they did not differ at all in height or in constitutional vigour. Some flowers on these seerllings were then crossed with pollen taken from a distinct seedling, and other Howers were self-fertilised; two fresh lots of seedlings being thus raised, which were the grandchildren of the plant that had spread by stolons and formed a large clump in my garlen. These diftered much in height, the crossed plants being to tho self-fertilised as 100 to $\mathrm{S6}$. They differed. also, to a wonderful degree in constitutional vigour. The crossed plants flowered first, and prodnced exactly twice as many flower-stems; and they afterwards increased by stolons to such an extent as almost to overwholm the self-fertilised plants.

Reviewing these five cases, we see that in four of them, the effect of a cross between flowers on the same plant (even on offsets of the same plant growing on separate roots, as with the Pelargonium and Origanum) does not differ from that of the strictest selffertilisation. Indeerl, in two of the cases the self-fertilised plants were superior to such intercrossed plants. With Digitalis a cross between the flowers on the same plant certainly did do some good, yet rery slight compared with that fiom a cross between distinct plants. On the whole the results here arrired at, if we bear in mind that the flower-buds are to a rertain extent distinct individuals and occasionally vary independently of one another, agree well with our gencral conclusion, that the advantages of a cross depend on the progenitors of the crossed plants posscssing somewhat different constitutions, either from liaving been exposed to different conditions, or to their having 
varied from unknown causes in a manner which we in our ignolance are forced to speak of as spontaneous. Hereafter I shall hare to recur to this subject of the inefficiency of a cross between the flowers on the same plant, when we consider the part which insects play in the eross-fertilisation of flowers.

On the Transmission of the good Effects from a Cross and of the evil Effects from Self-fertilisation.-We have seen that seedlings from a cross between distinct plants almost always exceed their self-fertilised opponents in height, weight, and constitutional rigour, and, as will hereafter be shown, often in fertility. To ascertain whether this superiority would be transmitted beyond the first generation, seedlings were raised on three occasions from crossed and self-fertilised plants, both sets being fertilised in the same manner, and therefore not as in the many cases given in Tables A, B, and $\mathrm{C}$, in which the crossed plants were again crossed and the self-fertilised agaiu self-fertilised.

Firstly, seedlings were raised from self-fertilised seeds produced under a net by crossed and self-fertilised plants of Nemophita insignis; and the latter were to the former in height as 133 to 100. But these seedlings became very unhealthy early in life, and grew so unequally that some of them in both lots were five times as tall as the others. Therefore this experiment was quite worthless; but I have felt bound to give it, as opposed to my general conclusion. I should state that in this and the two following trials, both sets of plants were grown on the opposite sides of the same pots, and treated in all respects alike. The details of the exporiments may be found under the head of each species.

Secondly, a crosserl and a self-fertilised plant of Heartsease (Viola tricolor) grew near together in the 
open ground and near to other plants of heartsease; and as both produeed an abundance of very fine capsules, the flowers on both were eertainly cross-fertilised by inseets. Seeds were eolleeted from both plants, and seedlings raised from them. Those from the erossed plants flowered in all three pots before those from the self-fertilised plants; and when fully grown the former were to the latter in height as 100 to 82. As both sets of plants were the produet of eross-fertilisation, the difference in their growth and period of flowering was clearly due to their parents having been of erossed and self-fertilised parentage; and it is equally elear that they transmitted different eonstitutional powers to their offspring, the grandehildren of the plants whieh were originally erossed and self-fertilised.

'I'hirdly, the Sweet Pea (Lathyrus odoratus) habitually fertilises itself in this eountry. As I possessed plants, the parents and grandparents of which had been artificially erossed and other plants deseended from the same parents which had been self-fertilised for many previous generations, these two lots of plants were allowed to fertilise themselves under a net, and their self-fertilised seeds saved. The seedlings thus raised were grown in competition with each other in the usual manner, and differed in their powers of growth. 'l'hose from the self-fertilised plants which had been crossed during the two previous generations were to those from the plants self-fertilised during many previous generations in height as 100 to 90 . These two lots of seeds were likewise tried by being sown under very unfavourable eonditions in poor exhausted soil, and the plants whose grandparents and great-grandparents hat been erossed showed in an ummistakable manner their superior eonstitutional vigomr. In this case. as in that of the heartsease, there eould be no doubt that 
the advantage derived from a cross between two plants was not confined to the offspring of the first generation. That constitutional vigour due to cross-parentage is transmitted for many generations may also be inferred as highly probable, from some of Andrew Knight's rarieties of the common pea, which were raised by crossing distinct varieties, after which time they no doubt fertilised themselves in each succeeding generation. These varieties lasted for upwards of "sixty years, "but their glory is now departed." * On the other hand, most of the varieties of the common pea, which there is no reason to suppose owe their origin to a cross, have had a much shorter existence. Some also of Mr. Laxton's varieties produced by artificial crosses have retained their astonishing vigour and luxuriance for a considerable number of generations; but as Mr. Laxton informs me, his experience does not extend beyond twelve generations, within which period he has never perceived any diminution of vigour in his plants.

An allied point may be here noticed. As the force of inheritance is strong with plants (of which abundant evidence could be given), it is almost certain that seedlings from the same capsule or from the same plant would tend to inherit nearly the same constitution; and as the advantage from a cross depends on the plants which are crossed differing somewhat in constitution, it may be inferred as probable that under similar conditions a cross between the nearest relations would not benefit the offspring so much as one between nonrelated plants. In support of this conclusion we have some evidence, as Fritz Müller has shown by his

* See the evidenco on this hend in my - Variation under Durnes- tieation,' ehap. ix. vol. i. 2nd edit. p. 397. 
valuable experiments on hybrid Abutilons, that the union of brothers and sisters, parents and children, and of other near relations is highly injurious to the fertility of the offspring. In one case, moreover, seedlings from such near relations possessed very weak constitutions. $^{*}$ This same observer also found three plants of a Bignonia growing near together. He fertilised twenty-nine flowers on one of them with their own pollen, and they did not set a single capsule. Thirty flowers were then fertilised with pollen from a distinct plant, one of the three growing together, and they yielded only two capsules. Lastly, fire flowers were fertilised with pollen from a fourth plant growing at a distance, and all five produced capsules. It seems therefore probable, as Fritz Müller suggests, that the three plants growing near together were seedlings from the same parent, and that from being closely related they had little power of fertilising one another. $\neq$

Lastly, the fact of the intercrossed plants in Table A not exceeding in height the self-fertilised plants in a greater and greater degree in the later generations, is probably the result of their having become more and more closely inter-related.

Uniform Colour of the Flowers on Plants, self-fertitised and grown under simitar conditions for several Generations.-At the commencement of my experiments, the parent-plants of Mimulus luteus, Ipomoed purpurea, Dianthus caryophyllus, and Petunia violacea, raised from purchased seeds, varied greatly in the colour

* Jenaische Zeitschrift für Naturw.; B. vii., pp. 22 and 4.5 , 1872 ; mil 187:, l1. $441-450$.

† ' Lot. Zeitmme, 1868, j). 626.

‡ Suno l'mirliable cares ne given in my "Variation un :er
Domesticstion' (chap. xvii. 2nd cdit. vol. 2, p. 1201) of liybrids of Gladiolus and Cistus, any one of which could be fertilised by pollen from any other, but nut liy its own pollen. 
of their flowers. This oceurs with many plants whieh have been long eultivated as an ornament for the flower-garden, and whieh have been propagated by seeds. The eolour of the flowers was a point to which I did not at first in the least attend, and no seleetion whatever was practised. Nevertheless, the flowers produeed by the self-fertilised plants of the above four species became absolutely uniform in tint, or very nearly so, after they had been grown for some generations under elosely similar eonditions. The intererossed plants, whieh were more or less elosely inter-related in the later generations, and whieh had been likewise eultivated all the time under similar eonditions, became more uniform in the colour of their flowers than were the original parent-plants, but much less so than the self-fertilised plants. When self-fertilised plants of one of the later generations were erossed with a fresh stock, and seedlings thus raised, these presented a wonderful eontrast in the diversified tints of their flowers eompared with those of the self-fertilised seedlings. As such cases of flowers becoming uniformly eoloured without any aid from seleetion seem to me eurious, I will give a full abstract of my observations.

Mimulus luteus. - A tall variety, bearing large, almost white flowers blotched with crimson, appeared amongst the intererossed and self-fertilised plants of the third and fourth generations. This variety increased so rapidly, that in the sixth generation of self-fertilised plants every single one eonsisted of it. So it was with all the many plants which were raised, up to tho last or ninth self-fertilised generation. Although this varicty first appeared amongst the intercrossed plants, yet from their offspring being intercrossed in each succecding generation, it never prevailerl amongst 
them; and the flowers on the several intercrossed plants of the winth generation differed eonsiderably in colour. On the other hand, the uniformity in colour of the flowers on the plants of all the later self-fertilised generations was quite surprising; on a casual inspection they might have been said to be quite alike, but the crimson blotches were not of exactly the same shape, or in exactly the same position. Both my gardener and myself believe that this variety did not appear amongst the parent-plants, raised from purchased seeds, but from its appearance amongst both the crossed and self-fertilised plants of the third and fourth generations; and from what I have seen of the variation of this species on other occasions, it is probable that it would occasionally appear under any eireumstances. We learn, however, from the present case that under the peculiar conditions to whieh my plants were subjected, this particular variety, remarkable for its colouring, largeness of the corolla, and increased height of the whole plant, prevailed in the sixth and all the succeeding self-fertilised generations to the complete exclusion of every other variety.

Ipomoea purpurea.- Mly attentiun was first drawn to the present subject by observing that the flowers on all the plants of the seventh self-fertilised generation were of a uniform, remarkably rich, dark purple tint. The many plants whieh were raised during the three succceding generations, up to the last or tenth, all produced flowers coloured in the same mamner. They were absolutely uniform in tint, like those of a constant species living in a state of nature; and the self-fertilised plants might have been distinguished with certainty, as my gardener remarked, witlont the aid of labels, from the intercrossed plants of the later gencrations. 'l'hese, however, had more uniformly coloured flowers 
than those whieh were first raised from the purchased seeds. This dark purple variety did not appear, as far as my gardener and myself eould reeollect, before the fifth or sixth self-fertilised generation. However this may have been, it beeame, through eontinued self-fertilisation and the eultivation of the plants under uniform conditions, perfeetly constant, to the exelusion of every other variety.

Dianthus caryophyllus.--The self-fertilised plants of the third generation all bore flowers of exactly the same pale rose-colour; and in this respect they differed quite remarkably from the plants growing in a large bed close by and raised from seeds purehased from the same nursery garden. In this case it is not improbable that some of the parent plants which were first selffertilised may have borne flowers thus coloured; but as several plants were self-fertilised in the first generation, it is extremely improbable that all bore flowers of exactly the same tint as those of the self-fertilised plants of the third generation. The intererossed plants of the third generation likewise produced flowers almost, though not quite so uniform in tint as those of the self-fertilised plants.

Petunia violacea.-In this ease I happened to reeord in my notes that the flowers on the parent-plant which was first self-fertilised were of a "dingy purple eolour." In the fifth self-fertilised generation, every one of the twenty-one self-fertilised plants growing in pots, and all the many plants in a long row out of doors, produced flowers of absolutely the same tint, namely, of a dull, rather peculiar and ugly flesh colour; therefore, considerably unlike those on the parent-plant. I believe that this ehange of eolour supervened quite gradually; but I kept no record, as the point dirl not interest me until I was struek with the uniform tint 
of the flowers on the self-fertilised plants of the fifth generation. The flowers on the intererossed plants of the corresponding generation were mostly of the same dull flesh colour, but not nearly so uniform as those on the self-fertilised plants, some few being very pale, almost white. The self-fertilised plants which grew in a long row in the open ground were also remarkable for their uniformity in height, as were the intercrossed plants in a less degree, both lots being eompared with a large number of plants raised at the same time under similar eonditions from the self-fertilised plants of the fourth generation erossed by a fresh stoek. I regret that I did not attend to the uniformity in height of the self-fertilised seedlings in the later generations of the other speeies.

These few eases seem to me to possess mueh interest. We learn from them that new and slight shades of eolour may be quiekly and firmly fixed, independently of any seleetion, if the eonditions are kept as nearly uniform as is possible, and no intererossing be permitted. With Mimulus, not only a grotesque style of colouring, but a larger eorolla and inereased height of the whole plant were thus fixed; whereas with most plants whieh have been long eultivated for the flowergarden, no eharaeter is more variable than that of colour, exeepting perhaps that of height. From the eonsideration of these eases we may infer that the variability of cultivated plants in the above respeets is due, firstly, to their being subjeeted to somewhat diversified eonditions, and, seeondly, to their being often inter-erossed, as would follow from the free aecess of inseets. I do not see how this inferenee ean be avoided, as when the above plants were eultivated for several generations under elosely similar conditions, and were intercrossed in each generation, the colomr 
Chap. Vili. ON SELF-FERTILISED PLAN'TS.

of their flowers tended in some degree to change and to become uniform. When no intercrossing with other plants of the same stock was allowed,-that is, when the flowers werc fertilised with their own pollen in each generation-their colour in the later generations became as uniform as that of plants growing in a state of nature, accompanied at least in one instance by much uniformity in the height of the plants. But in saying that the diversified tints of the flowers on cultivated plants treated in the ordinary manner are due to differences in the soil, climate, \&c., to which they are exposed, I do not wish to imply that such variations are caused by thesc agencies in any more direct manner than that in which the most diversified illnesses, as colds, inflammation of the lungs or pleura, rheumatism, \&c., may be said to be caused by exposure to cold. In both cases the constitution of the being which is acted on is of preponderant importance. 


\section{CHAPTER IX.}

Tue Effectí of Cross-fertilisation and Self-fertilisation en the Proncction of Seeds.

Fertility of plints of erossed and self-fertilised parentace, both lots being fertilised in the same manner-Fertility of the parent-plants when first crossed and self-fertilised, and of their crossed and selffertilised ofispring when again erosserl and self-fertilised-Comparison of the fertility of flowers fertilised with their own polle's and with that from other flowers on the same plant-Self-sterile plants-Canses of self-sterility-The appearunre of hirhly selffertile varieties-Self-fertilisation ipparently in some respects beneficial, independently of the assured production of seeds.-Relative weights and rates of germination of seerls from crossed ancl : elffertilised flowers.

THE present chapter is devoted to the Fertility of plants, as influenced by cross-fertilisation and selffertilisation. The subject consists of two distinct branches; firstly, the relative productiveness or fertility of flowers crossed with pollen from a distinct plant and with their own pollen, as shown by the proportional number of capsules which they produce, together with the number of the contained seeds. Secondly, the degree of innate fertility or sterility of the seedlings raised from crossed and self-fertilised seeds; such seedlings being of the same age, grown under the same conditions, and fertilised in the same manner. 'These two branches of the subject correspond with the two which have to be considered by any one treating of hybrid plants; namely, in the first place the comparative prodnctiveness of a species when fertilised with pollen from a distinct species and with its own pollen; and 
in the second place, the fertility of its hybrid offspring. 'These two elasses of cases do not always run parallel; thus some plants, as Gärtner has shown, can be erossed with great ease, but yield excessively sterile hybrids; while others are erossed with extreme difficulty, but yield fairly fertile hybrids.

The natural order to follow in this chapter would have been first to eonsider the effeets on the fertility of the parent-plants of crossing them, and of fertilising them with their own pollen; but as we have discussed in the two last chapters the relative height, weight, and eonstitutional vigour of crossed and self-fertilised plants--that is, of plants raised from erossed and self-fertilised seeds-it will be convenient here first to eonsider their relative fertility. The cases observed by me are given in the following table, $\mathrm{D}$, in which plants of crossed and self-fertilised parentage were left to fertilise themselves, being either erossed by insects or spontaneously self-fertilised. It should be observed that the results cannot be considered as fully trustworthy, for the fertility of a plant is a most variable element, depending on its age, health, nature of the soil, amount of water given, and temperature to which it is exposed. The number of the eapsules produced and the number of the eontained seeds, ought to have been aseertained on a large number of crossed and selffertilised plants of the same age and treated in every respect alike. In these two latter respects my observations may be trusted, but a sufficient number of eapsules were eounted only in a few instances. The fertility, or as it may perhaps better be called the produetiveness, of a plant depends on the number of eapsules produeed, and on the number of seeds which these contain. But from various causes, ehiefly from the want of time, I was often eompelled to rely on the 
number of the capsules alone. Nevertheless, in the more interesting cases, the seeds were also counted or weighed. The average number of seeds per capsule is a more valuable criterion of fertility than the number of capsules produced. This latter circumstance depends partly on the size of the plant; and we know that crossed plants are generally taller and heavier than the self-fertilised; but the difference in this respect is rarely sufficient to account for the difference in the number of the capsules produced. It need hardly be added that in the following table the same number of crossed and self-fertilised plants are always compared. Subject to the foregoing sources of doubt I will now give the table, in which the parentage of the plants experimented on, and the manner of determining their fertility are explained. Fuller details may be found in the previous part of this work, under the head of each species.

TABLE D.-Relative Fertility of Plants of crossed and self-fertilised Purentage, both sets being fertilised in the same manner. Fertility judged of by various Standards. That of the crossed Plants taken as 100.

IPOMGE PURPUREA-first generation: seeds per eapsule ou crossed and self-fertilised plants, not growing much

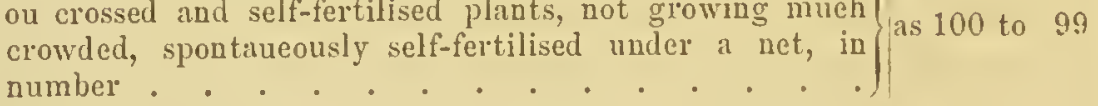

IPOMCE $A$ PURPUREA-seeds per capsule on erossed and self-fertilised plants from the same parents at in the list ease, but growing much crowded, spontaneously selffertilised under a net, in number

IPOMEA PURPUREA-produetiveness of the same plants, as judged by the number of capsules produced, and average number of seeds per capsule

IPOMCA PURPUREA-thurd generation: seeds per capsule/ on clossed and self-fertilised plants, spontancously selffertilised under a uet, in number . . . . . . . .

IPOMGA PURPUREA-productiveness of the same plants, as judged by number of capsules produced, and averige number of seeds per eapsule 


\section{TABLE D-continued.}

IPOIEAA PURPUREA-fifth generation: seeds per capsule) on crossed and self-fertilised plants, left uneovered in the 3 as 100 to 8.9 hothouse, and spontaneously ferilised

IPONEA PURPUREA - ninth generation: number of capsules on crossed plants to those on self-fertilised plants, spon-

taneously self-f'ertilised under a net . . . • • •

Mimulus Luteus-an equal number of capsules on plants descended from self-fertilised plants of the 8th generation crossed by a fresh stock, and on plants of the 9 th self-fertilised generation, both sets having been left uncorered and spontaneously fertilised, contained seeds, by weight

Minulus Luteus-productiveness of the same plants, as) judged by number of capsules produced, and average weight of seeds per capsule.

VANdelia NUMmularifolia-seeds per capsule from/ cleistogene flowers on the crossed and self-fertilised plants, in number . . . . . . . . . . .

SALTIA cocciNeA-crossed plants, compared with self-fer-tilised plants, produced flowers, in number . . . .

IBERIS UMBELLATA-plants left uneovered in greenhouse; intercrossed plants of the $3 \mathrm{rd}$ generation, compared with self-fertilised plants of the 3rd generation, yielded seeds, in number

IBERIS UMBELLATA-plants from a cross between two varieties, compared with self-fertilised plants of the $\left.3 \mathrm{r}^{\circ} \mathrm{d}\right\}$ generation, yielded seeds, by weight . . . . . .)

PAPAVER VAGUM-crossed and self-fertilised plants, left uncovered, produced capsules, in number . • • . . .

FsChSCHOLTZIA CALIFORNICA-Brazilian stoek; plants left uncovered and cross-fertilised by bees; eapsules on intercrossed plants of 2nd generation, compared with capsules on self-fertilised plants of 2 nd generation, contained seeds, in numbcr.

ESCHSCHOLTZIA CALIFORNICA-productiveness of the same) plants, as judged by number of capsules produced, and average number of seeds per capsule . . . . . .

Eschscholtzia CALIFORNICA-plants left uncovered and) cross-fertilised by bees: capsules on plants derived from intererossed plants of 2nd gencration of the Brazilian stock crossed by English stock, compared with capsules on self-fertilised plants of 2nd generation, contained seeds, in number.

ESCHSCHOLTZIA CALIFORNICA-productiveness of the same plants, as jurlged by number of capsules produccd, and average number of seeds per capsule... . . . 


\section{TABLE D-contivuert.}

RESEDA ODORATA-crossed and self-fertilised plants, left uncovered and cross-fertilised by bees, produced capsules as 100 to 100 in number (about)

VIOLA TRICOLOR-crossed and self-fertilised plants, left uncovered and cross-fertilised by bees, produced capsules in number

DelpiINIUN CONSOLIDA-crossed and self-fertilised plants, left uncoverced in the greenhouse, produced capsules in number

Viscaria oculata-crossed and self-fertilised plants, left uncovered in the greenhouse, producc l capsules in number

DiaNTHUS CARYOPHYLLUS-plants spontaneously self-fertilised under a net; capsules on intercrossed and selffertilised plants of the 3rd generation contanned seeds in number

DiANTIUS CARYOPHYLUS-plants left uncovercd and crossfertilised by insects: offspring from plants self-fertilised for three generations and then crossed by an intercrossed plant of the same stock, compared with plants of the 4th self-fertilised generation, produced secds by weight

Dianthus Caryopiyllus-plants left uncovered and crossfertilised by insects : off'spring from plants self-fertilised for three generations and then crossed by a fresh stock, compared with plants of the 4th self-fertilised gencration, produced seeds by weight .

Tropsolum MINUS-crossed and self-fertilised plants, left? uncovered in the greenhouse, produced seeds in number .

LimNANTHES DOUGLaSiI-crossed and self-fertilised plints, left uncovered in greenhouse, produced capsules in number (about) .

LuPINUS LUTEUS-crossed and self-fertilised plants of the 2 nd generation, left uncovered in the greenhouse, produced seeds in number (judged from only a few pods) .

Pinaseolus multiflorus-crossed and self-fertilised plants, left uncovered in the greenhousc, produced seeds in number (about) .

LATHYRUS ODORATUS - crossed and self-fertilised plants of the 2nd generation, lcft uncovered in the greenhouse, but certainly self-fertilised, produced pods in number . .

Clarkia flegans-crossed and self-fertilised plants, left uncovered in the greenhouse, produced capsules in number $\}$

NewOPIILA INSIGNis-crossed and self-fertilised plants, covered by a net and spontaneously self-fertilised in the greenhousc, produced capsules in number . . - .

Petunia violacea-left uncovered and cross-fertilised by
insects: plants of the 5 th intercrossed and self-fertilised generations produced seeds, as judged by the weight of an equal number of capsules 
TABre I)-cimtinuel.

l'LTUNIA VIOLACEA-left uneovered as above: ofispring of plants self-fertilised for four generations and then erossed by a fiesh stoek, compared with plants of the 5 th self- $\}$ as 100 to 46 fertilised generation, produced seeds, as judged by the reight of an equal number of eapsules

CYCLAMEN PERSICUM-erossed and self-fertilised plants, left uncovered in the greenhouse, produeed eapsules in number

ANAGALlis Collixa -rossed and self-fertilised plants, left uneorered in the gi senhouse, produeed eapsules in number

Prinula veris-lefe uneovered in open ground and erossfertilised by inseets: offspring from plants of the 3r.d illegitimate generation erossed by a fresh stoek, emparred with plants of the 4 th illegitimate and selt-fertilised generation, produced capsules in number . . . . . Same plants in the following year . . . . . . . , , 3.5

Primusa rLRis-(equal-styled varietr): left uneorered in) open ground and eross-fertilised by inseets: offspring from plants self-fertilised for two generations and then erossed br another variety, compared with plants of the $3 \mathrm{rd}$ self-fertilised generation, produeed eapsules in number

Primula veris-(equal-stỵled var,) same plants; arerage) number of seeds per eipsule

Primula veris - (equal-styled var.) produetiveness of the same plants, as judged by number of caipsules produeed and arerage number of seeds per capsule.

This table includes thirty-three cases relating to twenty-three species, and shows the degree of innate fertility of plants of crossed parentage in comparison with those of sclf-fertilised parentage; both lots being fertilised in the same manner. With several of the species, as with Esehseholtzia, Reseda, Viola, Dianthus, Petunia, and Primula, both lots were certainly cross-fertilised by inseets, and so it probably was with several of the others; but in some of the species, as with Nemophila, and in some of the trials with I pomoea and Jianthus, the plants were covered up, and both lots were spontaneously self-fertilised. This also was necessarily the case with the eapsules produced by the cleistogene flowers of Vandellia. 
The fertility of the erossed plants is represented in the table by 100 , and that of the self-fertilised by the other figures. There are five cases in whieh the fertility of the self-fertilised plants is approximately equal to that of the erossed; nevertheless, in four of these cases the erossed plants were plainly taller, and in the fifth somewhat taller than the self-fertilised. But I should state that in some of these five eases the fertility of the two lots was not strietly aseertained, as the capsules were not aetually eounted, from appearing equal in number and from all apparently eontaining a full complement of seeds. In only two instanees in the table, viz., with Vandellia and in the third generation of Dianthus, the eapsules on the self-fertilised plants contained more seed than those on the crossed plants. With Dianthus the ratio between the number of seeds contained in the self-fertilised and erossed capsules was as 125 to 100 ; both sets of plants were left to fertilise themselves under a net; and it is almost certain that the greater fertility of the self-fertilised plants was here due merely to their having varied and become less strictly diehogamous, so as to mature their anthers and stigmas more nearly at the same time than is proper to the species. Exeluding the seven eases now referred to, there remain twenty-six in whieh the erossed plants were manifestly mueh more fertile, sometimes to an extraordinary degree, than the self-fertilised with which they grew in competition. The most striking instanees are those in whieh plants lerived from a eross with a fresh stoek are compared with plants of one of the later self-fertilised generations; yet there are some striking eases, as that of Violi, between the intererossed plants of the same stock and the self-fertilised, even in the first generation. The results most to be trusted are those 
in which the productiveness of the plants was ascertained by the number of capsules produced by an equal number of plants, together with the actual or arelage number of seeds in each capsule. Of such cases there are trelve in the table, and the mean of their mean fertility is as 100 for the crossed plants, to 59 for the self-fertilised plants. The Primulacer seem eminently liable to suffer in fertility from selffertilisation.

The following short table, E, includes four cases which have already been partly given in the last table.

TABLE F.- Innate Fertility of Plunts fiom a Cross with a fresh Stock, compared with that of Intercrossed Plants of the sume Stock, and with that of Self-fertilised Plants, all of the corresponding Generation. Fertility judged of by the number or weight of seeds producel by an equul number of Plunts.

\begin{tabular}{|c|c|c|c|}
\hline & 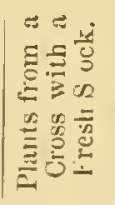 & 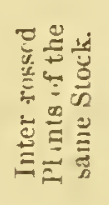 & 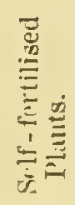 \\
\hline $\begin{array}{l}\text { MryULUS LUTEUS-the intererossed plants are de- } \\
\text { rived from a eross between two plants of the } \\
\text { 8th self-fertilised generation. The self-fertilised } \\
\text { flants belong to the } 9 \text { th generation. . . }\end{array}$ & 100 & 4 & 3 \\
\hline $\left.\begin{array}{l}\text { ESCHSCHOLTZIA CALIFORXICA-the intererossed and } \\
\text { self-fertilised plants belong to the 2nd generation }\end{array}\right\}$ & 100 & 45 & 40 \\
\hline 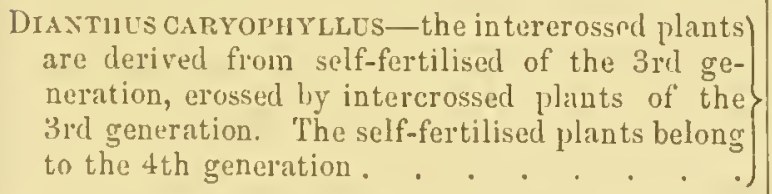 & 100 & 45 & 33 \\
\hline $\begin{array}{l}\text { PETUNia vionaces-the intererossed and self-fer- } \\
\text { tilised plants belong to the 5th generation. }\end{array}$ & 100 & 54 & 46 \\
\hline
\end{tabular}

N.B.- In the above cases, exeepting in that of Eschscholtzia, the plants derived from a eross with a fresh stock belong on the mother-sicle to the same stock with the intererossed and self-fertilised plants, and to the colresponding generution. 
These cases show us how greatly superior in iunate fertility the seedlings from plants self-fertilised or intercrossed for several generations and then crossed by a fresh stock are, in comparison with the seedlings from plants of the old stock, either intercrossed or self-fertilised for the same number of generations. The three lots of plants in each case were left freely exposed to the visits of insects, and their flowers without doubt were cross-fertilised by them.

'This table further shows us that in all four cases the intercrossed plants of the same stock still have a decided though small advantage in fertility orer the self-fertilised plants.

With respect to the state of the reproductive organs in the self-fertilised plants of the two last tables, only a few observations were made. In the serenth and eighth generation of Iponcen, the anthers in the flowers of the self-fertilised plants were plainly smaller than those in the flowers of the intercrossed plants. The tendency to sterility in these sane plants was also shown by the first-formed flowers, after they had been carefully fertilised, often dropping off, in the same numner as frequently occurs with hybrids. The flowers likewise tended to be monstrous. In the fourth generation of Petunia, the pollen produced by the self-fertilised and intercrossed plants was compared, and there were far more empty and shrivelled grains in the former.

Relative Fertility of Flowers crossed with Pollen from a distinct Plant and with their own Pollen. This heading inchudes flowers on the Parent-plants, and on the crossed and self-fertitised Seedtings of the first or a succeeding Generation.-I will first treat of the parent-plants, which 
were raised from seeds purchased from nursery-gardens, or taken from plants growing in my garden, or growing wild, and surrounded in every case by many individuals of the same species. Plants thus circumstanced will commonly have been intercrossed by insects; so that the seedlings which were first experimented on will generally have been the product of a cross. Consequently any difference in the fertility of their flowers, when crossed and self-fertilised, will have been caused by the nature of the pollen employed; that is, whether it was taken from a distinct plant or from the same flower. The degrees of fertility shown in the following table, $\mathrm{F}$, were determined in each case by the average number of seeds per capsule, ascertained either by counting or weighing:

Another element onght properly to have been taken into account, namely, the proportion of flowers which yielded capsules when they were crossed and self-fertilised; and as crossed flowers generally produce a larger proportion of capsules, their superiority in fertility, if this element had been taken into account, would have been much more strongly marked than appears in Table F. Bnt had I thus acted, there would have been greater liability to error, as pollen applied to the stigma at the wrong time fails to produce any effect, independently of its greater or less potency. A good illustration of the great difference in the results which sometimes follows, if the number of capsules produced relatively to the number of flowers fertilised be included in the calculation, was afforded by Nolana prostrata. Thirty flowers on some plants of this species werc crossed and produced twenty-seven capsules, each containing five seeds; thirty-two flowers on the same plants wern self-fertilised and produced 
only six capsules, each eontaining five seeds. As the number of seeds per capsule is here the same, the fertility of the crossed and self-fertilised flowers is given in Table $F$ as equal, or as 100 to 100 . But if the flowers whieh failed to produce eapsules be included, the crossed flowers yielded on an average $4 \cdot 50$ seeds, whilst the self-fertilised flowers yielded only 0.94 seeds, so that their relative fertility would have been as 100 to 21. I should here state that it has been found eonvenient to reserve for separate diseussion the eases of flowers whieh are usually quite sterile with their own pollen.

Table F.- Kielative Fertility of the Flowers on the Parent-plants used in my Experiments, when fertilised with Pollen from a distinct Plant and with their own Pollen. Fertitity judged of by the average Number of Seeds per Capsule. Fertility of Crossed Flouers taken as 100.

IPOAIEA PLRPUREA-erossed and self-fertilised flowers yielded seeds as (abont).

100 to 100

Minulus LUTEUS-erossed and self-fertilised flowers yielded) seeds as (by weight).

IINARTA VULGARIS-erossed and self-fertilised flowers) yielded seeds as

VANDELLIA NUMTIULARIFOLTA-crossed and self-fertilised) flowers yielded seeds as . . . . . . . . . .

Gesneria pexdulna-crossed and self-fertilised flowers yielded seeds as (by weight)

SALVIA COCCINEA-erossed and self-fertilised flowers yielded sceds as (about).

BluASSICA OLERACEA - crossed and self-fertilised flower's yielded seeds as .

Escisciroltzia CALHORxiCA-(kinglish stoek) crossed and) self-fertilised Anwers yielded seeds as (by weight) . . $, \quad, 79$ $, \quad, 14$ England) erossed and self-fertilised flowers yielded seeds (by weight) as (about)

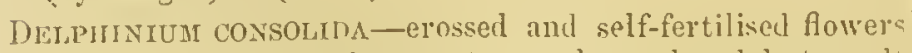
(self-fertilised eapsules spontaneously produced, but result supported by other evidenec) yielded seerls as. 


\section{TABLE F-continued.}

Tiscaria ocolata-erossed and self-fertilised flowers vielued seeds as (by weight) . . . . . . .

Viscaria oculata - erossed and self-fertilised flowers (erossed eapsules compared on following year with spontaneously self-fertilised capsules) yielded seeds as . . .

DIANTHUS UARYOPHYLLUS - erossed and self-fertilised flower's vielded seeds as . . . . . . . . . .

Troptelus IINUS-erossed and self-fertilised flower's) yielded seeds as .

Tropeolun TrICOLORUa* - ejossed and self-fertilised flowers yielded seeds as . . . . . . . . .

LIMNANTHES DOUGLASI-erossed and self-fertilised flowers

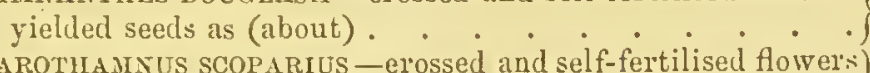

SAROTILAINUS SCOPARIUS - erossed and self-fertilised flower:

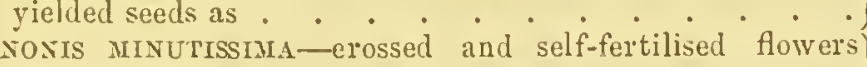
yielded seeds as.

Cuphea purpurea - erossed and self-fertilised flowers

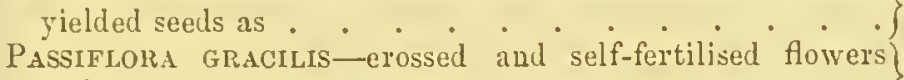

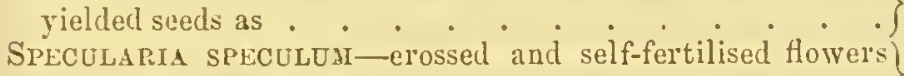

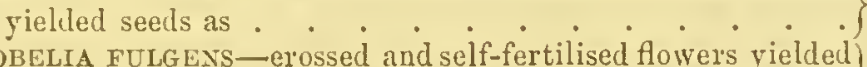

LOBELIA FULGENS-erossed and self-fertilised flower's yielded

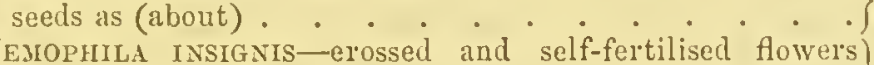

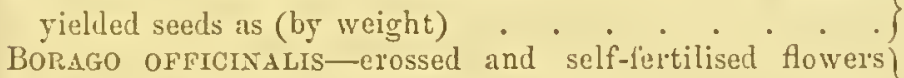
yielded seeds as . . . . . . . . .

Noldsa prostrata - erossed and self-fertilised flowers)

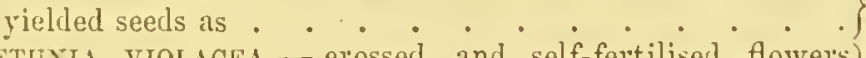

PETUNia violaceA - erossed and self-fertilised flower's? yielded seeds as (by weight) . • . • . . .

Nicotiana TABACum-erossed and self-fertilised flowers) yielded seerls as (by weight)

CrClanen plesicuin - erossed and self-fertilised Howers) yielded seerls as . . . . • . • . .

ArAGALLIS COLLINA - erossed and self-fertilised flower's;

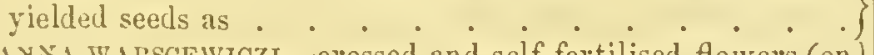

CANNA WARSCEIVICZI-erossed and self-fertilised flowers (on) three generations of erossed and self-fertilised plants taken all together) yielded seeds as

* Tropeolum tricolorum and Cuphea purpurea have been introduced into this table, nlthough seedlings were not rnised from them; but of the Cuphea only six crossed and six self-fertilised capsules, and of the 'I'ropic- olum only six crossed and eleven self-fertilised capsules, were eompared. A lurger proportion of the self-fertilised than of the crossed flower's of the 'Tropinolım produced fruit. 
A second table, $G$, gives the relative fertility of flowers on crossed plants again cross-fertilised, and of flowers on self-fertilised plants again self-fertilised, either in the first or in a later generation. Here two causes combine to diminish the fertility of the selffertilised flowers; namely, the lesser efficacy of pollen from the same flower, and the innate lessened fertility of plants derioved from self-fertilised seeds, which as we have seen in the previous Table D is strongly marked. The fertility was determined in the same manner as in Table $\mathrm{F}$, that is, by the average number of seeds per capsule; and the same remarks as before, with respect to the different proportion of flowers which set capsules when they are cross-fertilised and self-fertilised, are here likewise applicable.

Table G.-Relative Fertility of Flowers on Crossed and Selffertilisen Plants of the First or some suceeeding Generation; the former being again fertilised with Pollen from a distinct 1 lunt, and the latter aguin with their own Pollen. Fertility judged of by the averaye Numler of Seeds per Capsule. Fertility of Crossed Flowers taken as 100.

IrOMAEA PURPUREA-crossed and self-fertilised flowers on the crossed and self-fertilised plants of the 1 st generation yielderl seeds as

lpondea pURPUREA-crossed and self-fertilised flowers on the erossed and self-fertilised plants of the 3rd generation yielded seens as

IPOMOEA PURPURLA-crossed and self-fertilised flowers on the erossed aud self-fertilised plants of the 4 th generation rielderl seeds as

IPOMEA PLRPUREA-crnssed and self-fertilised fowers on the crossed and self-fertilised plants of the oth generation vielded seeds as

Minulus Lureus-crosserl and self-tertilised flowers on the crossed and self-fertilised plants of the 3rd generation yielded seeds as (by weight)

Minulus LuTbus-same jiants ireated in the same manner on following year yielled seeds as (by weight) . . . .

MIMULUS Lerrus-erossed and self-fertilised flowers on the crossed and self-fertilised plants of the 4 th generation vielded seerls as (by weight) 
T.ABLE G-continued.

VIOLA TRICOLOR-erossed and self-fertilised flowers on the crossed and self-fertilised plants of the 1st generation yielled seeds as .

Draythus CARYophyLLUS-erossed and self-fertilised flowers on the crossed and self-fertilised plants of the 1st generation yielded seeds as.

DIANTHUS CARYOPIYLLUS-flowers on self-fertilised plants of the 3rd generation erossed by intererossed plants, and other flowers again self-fertilised yielded seeds as . .

Dianthus Caryophylus-flowers on self-fertilised plants of the 3rd generation erossed by a fresh stuck, and other flowers agrin self-fertilised yielded seeds as . . . .)

LATHIRLS ODORATUS - clossed and self-fertilised flowers on the crossed and self-fertilised plants of the 1st generation yielded seeds as

LOBELIA RANOSA-crossed and self-fertilised flowers on the erossed and self-fertilised plants of the 1 st generation yielded seeds as (by weight)

Petunia violacea-erossed and self-fertilised flowers on the erossed and self-fertilised plants of the 1st generation yielded seeds as (by weight)

PETUNia VIOLACEA-erossed and self-fertilised flowers on the crussed and self-fertilised plants of the 4 th generation yielded seeds as (by weight)

Petuxia riolacea-flowers on self-fertilised plants of the 4th generation erossed by a fresh stock, and other flowers again self-fertilised yielded seeds as (by weight) . . .)

Nicotiana Tabacun-crossed and self-fertilised flowers on the erossed and self-fertilised plants of the 1st generation yielded seeds as (by weight)

Nicotiana TABACUI-flower's on self-fertilised plants of the 2nd generation erossed by intererossed plants, and other flower's again self-fertilised yielded seels as (by estimation).

Sicotixa tabacun - flowers on self-fertilised plants of the $3 r d$ generation erossed by a fresh stock, and other Howers again self-fertilised yielded seeds as (by estimation)

AxAGALLIS COLLINA-flowers on a red variety crossel by a) blue variety, and other flowers on the red variety selffertilised yiclded seeds as . . . . . . . . Axad WarscewiCzI-erossed and self-fertilised flowers on the crossed and self-fertilisel plants of three generations taken together yielded seeds as.

As both these tables relate to the fertility of flowers fertilised by pollen from another plant and by their own pollen, they may be considered together. 'The difference between them consists in the self- 
furtilised flowers in the second table, G, being produced by self-fertilised parents, and the crossed flowers by crossed parents, which in the later generations har become somewhat closely inter-related, and harl been subjected all the time to nearly the same conditions. These two tables include fifty cases relating to thirty-two species. The flowers on many other species were crossed and self-fertilised, but as only a few were thus treated, the results cannot be trusted, as far as fertility is concerned, and are not lere given. Some other cases have been rejected, as the plants were in an mnlealthy condition. If we look to the figures in the two tables expressing the ratios between the mean relative fertility of the crossed and self-fertilised flowers, we see that in a majority of the cases (i.e., in thirty five out of fifty) flowers fertilised by pollen from a distinct plant yield more, sometimes many more, serds than flowers fertilised with their own pollen; and they commonly set a larger proportion of capsules. The degree of infertility of the self-fertilised flowers differs extremely in the different species, and even, as we shall see in the section on self-sterile plants, in the individuals of the same species, as well as under slightly changed conditions of life. Their fertility ranges from zero to fertility equalling that of the crossed flowers; and of this fact no explanation can lo offered. There are fifteen cases in the two tables in which the number of seeds per capsule produced by the self fertilised flowers equals or even exceeds that yiclded by the crossed flowers. Some few of these cuses are, I believe, accidental; that is, would not recur on a second trial. This was apparently the case with the plants of the fifth generation of $\mathrm{I}_{\mathrm{p}}$ omca, and in one of the experiments with Dianthus. Nicotiana offers the most anomalous case of any, 
as the self-fertilised flowers on the parent-plants, and on their descendants of the seeond and third generations, produeed more seeds than did the crossed flowers; but we shall recur to this ease when we treat of highlv self-fertile varieties.

It might have been expeeted that the difference in fertility between the erossed and selffertilised flowers would have been more strongly marked in Table G, in which the plants of one set were derived from selffertilised parents, than in Table F, in which flowers on the parent-plants were self-fertilised for the first time. But this is not the case, as far as my scanty materials allow of any judgment. There is therefore no evidenee at present, that the fertility of plants goes on diminising in sueeessive self-fertilised generations, although there is some rather weak evidenee that this does occur with respeet to their height or growth. But we should bear in mind that in the later generations the erossed plants had beeome more or less elosely inter-related, and had been subjeeted all the time to nearly uniform conditions.

It is remarkable that there is no elose correspondenee, either in the parent-plants or in the sueeessive generations, between the relative number of seeds produced by the crossed and self-fertilised flowers, and the relative powers of growth of the seedlings raised from sueh seeds. Thus, the erossed and self-fertilised flowers on the parent-plants of Ipomøea, Gesneria, Salvia, Limmanthes, Lobelia fulgens, and Nolana produeed a nearly equal number of seeds, yet the plants raised from the erossed seeds exeeeded eonsiderably in height those raised from the self-fertilised seeds. The erossed flowers of Linaria and Viscaria yielded fir more seeds than the self-fertilised flowers; and althongh the plants raised from the former were taller 
than those from the latter, they were not so in any eorresponding degree: With Nicotiana the flowers fertilised with their own pollen were more productive than those erossed with pollen from a slightly different variety; yet the plants raised from the latter seeds were much taller, heavier, and more hardy than those raised from the self-fertilised seeds. On the other hand, the crossed seedlings of Eschscholtzia were neither taller nor hearier thim the self-fertilised, although the crossed flowers were far more producive than the self-fertilised. But the best evidence if il want of eorrespondence between the number of ceeds produced by crossed and self-fertilised flowers, and the vigour of the offspring raised from them, is afforded by the plants of the Brazilian and European stocks of Eschscholtzia, and likewise by certain individual plants of Reseda odorata; for it might have been expeeted that the seedlings from plants, the flowers of whieh were excessively sclf-sterile, would have profited in a greater degree by a cross, than the seedlings from plants which were moderately or fully sclf-fertile, and therefore apparently had no need to be crossed. But no sueh result followed in either case: for instance, the crossed and self-fertilised offspring from a highly self-fertile plant of Reseda odorata were in average height to each other as 100 to 82 ; whereas the similar offspring from an excessively self-sterile plant were as 100 to 92 in arerage height.

With respect to the innate fertility of the plants of crossed and self-fertilised parentage, giren in the previous Table D-that is, the number of seerls prodnced by both lots when their flowers were fertilised in the same manner,-ncarly the same remarlis are applicable, in reference to the absence of any elose correspondenee between their fertility and powers of 
growth, as in the case of the plants in the Tables F and $G$, just considered. Thus the crossed and self-fertilised plants of Ipomoa, Papaver, Reseda odorata, and Limnanthes were almost equally fertile, yet the former exceeded considerably in height the self-fertilised plants. On the other hand, the crossed and self-fertilised plants of Mimulus and Primula differed to an extreme degree in innate fertility, but by no means to a corresponding degree in height or vigour.

In all the cases of self-fertilised flowers included in Tables E, F, and G, these were fertilised with their own pollen ; but there is another form of self-fertilisation, viz., by pollen from other flowers on the same plant; but this latter method made no difference in comparison with the former in the number of seeds produced, or only a slight difference. Neither with Digitalis nor Dianthus were more seeds produced by the one method than by the other, to any trustworthy degree. With Ipomøa rather more seeds, in the proportion of 100 to 91 , were produced from a cross between flowers on the same plant than from strictly self-fertilised flowers; but I have reason to suspect that the result was accidental. With Origunum vulgare, however, a cross between flowers on plants propagated by stolons from the same stock certainly increased slightly their fertility. 'Ihis likewise occurred, as we shall see in the next section, with Eschschultzia, perhaps with Corydalis cava and Oncidium; but not so with Bignonia, Abutilon, Tabernæemontana, Senecio, and apparently Reseda odorata.

\section{Self-sterile Plants.}

'The cases here to be doscribed might have been introduced in Table $\mathbf{H}$, which gives the relative fertility of flowers fertilised with their own pollen, and 
with that from a distinct plant; but it has been found morc convenient to kecp them for scparate discussion. The present cases must not be confounded with those to be given in the next chapter relatively to flowers which are sterile when insects arc excluded; for such stcrility depends not merely on the flowers being incapable of fertilisation with their own pollcn, but on mechanical causes, by which their pollen is prevented from reaching the stigma, or on the pollen and stigma of the same flower bcing matured at different pcriods.

In the screntecnth cliaptcr of my 'Variation of Animals and Plants underDomestication'I had occasion to enter fully on the present subject; and I will thereforc here give only a brief abstract of the cases there described, but others must be added, as they have an important bearing on the present work. Kölreuter long ago described plants of Verbascum phoeniceum which during two ycars were stcrile with their own pollen, but wcre easily fertilised by that of four other specics; these plants however afterwards became more or less sclf-fertilc in a strangcly fluctuating manwer. Mr. Scott also found that this specics, as wcll as two of its varieties, were sclf-stcrilc, as did Gärtner in the case of Verbascum nigrum. So it was, according to this latter author, with two plants of Lobetia fulgens, though the pollen and ovules of both wcre in an efficicnt statc in relation to other species. Five species of Passiflora and certain individuals of a sixth species have becn found stcrile with their own pollen; but slight changes in thcir conditions, such as being grafted on another stock or a change of tcmperature, rendered them self-fertile. Flowers on a completely self-impotent plant of Passiflor a alata fertilised with pollen from its own self-impotent seedlings were quitc fertilc. Mr. Scott, and aftcrwards Mr. Mumro, found that some 
species of Oncidium and of Maxillaria enltivated in a hothouse in Edinburgh were quite sterile with their own pollen; and Fritz Müller found this to be the case with a large number of Orchidaeeous genera growing in their native home of South Brazil.* He also discovered that the pollen-masses of some orehids acted on their own stigmas like a poison; and it appears that Gärtner formerly observed indieations of this extraordinary faet in the ease of some other plants.

Fritz Müller also states that a speeies of Bignonia and Tabernomontana echinata are both sterile with their own pollen in their native eountry of Brazil. $\dagger$ Several Amaryllidaceous and Liliaceous plants are in the same predicament. Hildebrand observed with care Corydalis cava, and found it completely self-sterile; $\ddagger$ but aeeording to Caspary a few self-fertilised seeds are oceasionally produced: Corydatis halleri is only slightly self-sterile, and $C$. intermedia not at all so. $\$$ In another Fumariaeeous genus, Hypeeoum, Hildebrand observed \| that $H$. grandiflorum was highly self-sterile, whilst $H$. procumbens was fairly self-fertile. Thunbergia alata kept by me in a warm greenhouse was self-sterile early in the season, but at a later period produeed many spontaneously self-fertilised fruits. So it was with Papaver vagum: another species, $P$. alpinum, was found by Professor H. Hoffmann to be quite selfsterile excepting on one occasion; 9 whilst P. somniferum has been with me always completely self-fertile.

Eschscholtzia culifornica. - This species deserves a fuller consideration. A plant cultivated by Fritz

* 'Bnt. '/eitung,' 1868, p. 114.

+ Ibid. 1868 , p. 626, and 1870 , 1). 27 t.

$\ddagger$ 'Teport of the International Hort. Congress,' 1866.
§ 'Bot. Yeitung,' June 27, 1873.

H 'Jalirb. füir wiss. Botanik,' B. vii. p. 464 .

If 'Lur Speciesfrage,' 1875, p. 47. 
Mïller in South Brazil happened to flower a month before any of the others, and it did not produee a single capsule. This led him to make further observations during the next six generations, and he found that all his plants were eompletely sterile, unless they were crossed by inseets or were artifieially fertilised with pollen from a distinet plant, in which ease they were completely fertile.* I was mueh surprised at this faet, as I had found that English plants, when eovered by a net, set a eonsiderable number of capsules; and that these eontained seeds by weight, compared with those on plants intercrossed by the bees, as 71 to 100 . Professor Hildebrand, however, found this speeies much more self-sterile in Germany than it was with me in England, for the eapsules produced by selffertilised flowers, eompared with those from intererossed flowers, eontained seeds in the ratio of only 11 to 100 . At my request Fritz Müller sent me from Brazil seeds of his self-sterile plants, from which I raised seedlings. Two of these were eovered with a net, and one produeed spontaneously only a single capsule containing no good seeds, but yet, when artifieially fertilised with its own pollen, produced a few capsules. The other plant prodneed spontaneously under the net eight eapsules, one of which eontained no less than thirty seeds, and on an average about ten seeds per capsule. Eight flowers on these two plants were artifieially self-fertilised, and produeed seven eapsules, containing on an average twelve seeds; eight other flowers were fertilised with pollen from a distinet plant of the Brazilian stock, and produeed eight capsules, containing on an arerage about eighty seeds: this gives a ratio of 15 seeds for the self-fertilised eapsules to 100 for the erossed 
eapsules. Later in the season twelve other flowers on these two plants were artifieially self-fertilised; but they yielded only two eapsules, eontaining three and six seeds. It appears therefore that a lower temperature than that of Brazil favours the self-fertility of this plint, whilst, a still lower temperature lessens it. As soon as the two plants whieh had been eovered by the net were uneovered, they were visited by many bees, and it was interesting to observe how quiekly they became, even the more sterile plant of the two, eorered with young eapsules. On the following year eight flowers on plants of the Brazilian stoek of selffertilisel parentage (i.e., grandehildren of the plants whieh grew in Brazil) were again self-fertilised, and produeed five eapsules, eontaining on an average $27 \cdot 4$ seeds, with a maximum in one of forty-two seeds; so that their self-fertility had evidently inereased greatly by being reared for two generations in England. On the whole we may eonelude that plants of the Brazilian stoek are mueh more self-fertile in this eountry than in Brazil, and less so than plants of the English stoek in England; so that the plants of Brazilian parentage retained by inheritanee some of their former sexual eonstitution. Conversely, seeds from English plants sent by me to Fritz Alüller and grown in Brazil, were mieh more self-fertile than his plants whieh had been eultivated there for several generations; but he informs me that one of the plants of English parentage whieh lid not flower the first year, and was thus exposed for two seasons to the elimate of Brazil, proved quite selfsterile, like a Brazilian plant, showing how quiekly the elimate had aeted on its sexual eonstitution.

Abutiton daruinii.-Seeds of this plant were sent me by Frity Müller, who found it, as well as some other speeies of the sume genus, quite sterile in its 
native home of South Brazil, unless fertilised with pollen from a distinct plant, cither artificially or naturally by humming-birds.* Several plants were raised from these seeds and kept in the hothonse. They produced flowers very early in the spring, and twenty of them were fertilised, some with pollen from the same flower, and some with pollen from other flowers on the same plants; but not a single capsule was thus produced, yet the stigmas twenty-seren hours after the application of the pollen were penetrated by the pollen-tubes. At the same time nineteen fiowers were crossed with pollen from a distinct plant, and these produced thirteen capsules, all abounding with fine seeds. A greater number of capsules would have been produced by the cross, had not some of the nineteen flowers been on a plant which was afterwards proved to be from some unknown cause completely sterile with pollen of any kind. Thus far these plants behaved exactly like those in Brazil ; but later in the season, in the latter part of May and in June, they began to produce under a net a few spontaneously self-fertilised capsules. As soon as this occurred, sixteen flowers were fertilised with their own pollen, and these produced five capsules, containing on an average 3.4 seeds. At the same time I selected by chance four capsules from the uncovered plants groring close by, the flowers of which I had seen risited by humble-bees, and these contained on an arerage $21 \cdot 5$ seeds; so that the seeds in the naturally intercrossed capsules to those in the self-fertilised capsules were as 100 to 16 . The interesting point in this case is that these plants, which were mmaturally treated by being grown in pots in a hothouse, under another

* 'Jenaische Zeitschr. für Naturwiss.' B. vii. 1872, p. 22, and 1873 . p. $4+1$. 
hemisphere, with a complete reversal of the seasons, were thus rendered slightly self-fertile, whereas they seem always to be eompletely self-sterile in their native home.

Senecio cruentus (greenhouse, varieties, commonly called Cinerarias, probably derived from several fruticose or herbaceous species much intercrossed*).-Two purpleflowered varieties were placed under a net in the greenhouse, and four eorymbs on each were repeatedly brushed with flowers from the other plant, so that their stigmas were well eovered with each other's pollen. Two of the eight corymbs thus treated produced very few seeds, but the other six produced on an average $41 \cdot 3$ seeds per corymb, and these germinated well. 'The stigmas on four other corymbs on both plants were well smeared with pollen from the flowers on their own corymbs; these eight corymbs produeed altogether ten extremely poor seeds, which proved ineapable of germinating. I examined many flowers on both plants, and found the stigmas spontaneously eovered with pollen; but they produced not a single sced. 'These plants were afterwards left uncovered in the same house where many other Cinerarias were in flower; and the flowers were frequently visited by bees. They then produeed plenty of seed, but one of the two plants less than the other, as this species shows some tendency to be dioecious.

The trial was repeated on another variety with white petals tipped with red. Many stigmas on two corymbs were eovered with pollen from the foregoing purple variety, and these produced eleven and twenty-

* I am much obliged to $M r$. Moore and to Mr. Thistlton Dyer for giving me information with respect to the varieties on which I experimented. Mr. Moore bu- lieves that Senecio cruentus, tussilaginis, and perhaps heritieri, maderensis and populifolius huve all been more or less blended together in our Cinerarias. 
two seeds, which germinated well. A large number of the stigmas on several of the other corymbs were repeatedly smeared with pollen from their own corymb; but they yielded only five very poor seeds, which were incapable of germination. Therefore the above three plants belonging to two varieties, though growing vigorously and fertile with pollen from either of the other two plants, were utterly sterile with pollen from other flowers on the same plant.

Reseda odorata.-Having observed that certain individuals were self-sterile, I covered during the summer of 1868 seren plants under separate nets, and will call these plants A, B, C, D, E, F, G. They all appeared to be quite sterile with their own pollen, but fertile with that of any other plant.

Fourteen flowers on A were crossed with pollen from $\mathrm{B}$ or $\mathrm{C}$, and produced thirteen fine capsules. Sixteen flowers were fertilised with pollen from other flowers on the same plant, but yielded not a single capsule.

Fourteen flowers on B were crossed with pollen from A, C, or D, and all produced capsules; some of these were not very fine, yet they contained plenty of seeds. Eighteen flowers were fertilised with pollen from other flowers on the same plant, and produced not one capsule.

Ten flowers on $\mathrm{C}$ were crossed with pollen from $\mathrm{A}$, B, D, or E, and produced nine fine capsules. Nineteen flowers were fertilised with pollen from other flowers on the same plant, and produced no capsules.

Ten flowers on D were crossed with pollen from A, B, C, or E, and produced nine fine capsules. Eighteen flowers were fertilised with pollen from other flowers on the sime plant, and produced no capsules.

Seven flowers on $\mathrm{E}$ were crossed with pollen from 
A, C, or D, and all produced fine eapsules. Eight flowers were fertilised with pollen from other flowers on the same plant, and produeed no capsules.

On the plants $\mathrm{F}$ and $\mathrm{G}$ no flowers were crossed, but very many (number not recorded) were fertilised with pollen from other flowers on the same plants, and these did not produce a single capsule.

We thus see that fifty-five flowers on five of the above plants were reciproeally erossed in various ways; several flowers on eaeh of these plants being fertilised with pollen from several of the other plants. These fifty-five flowers produeed fifty-two eapsules, almost all of whieh were of full size and contained an abundanee of seeds. On the other hand, seventynine flowers (besides many other's not recorded) were fertilised with pollen from other flowers on the same plants, and these did not produce a single capsule. In one ease in whieh I examined the stigmas of the flowers fertilised with their own pollen, these were penetrated by the pollen-tubes, although such penetration produced no effeet. Pollen falls generally, and I believe always, from the anthers on the stigmas of the same flower; yet only three out of the above seven protected plints produced spontaneously any copsules, and these it might have been thought must have been self-fertilised. There were altogether seven such eapsules; but as they were all seated elose to the artificially crossed flowers, I can hardly doubt that a few grains of foreign pollen had aeeidentally fallen on their stigmas. Besides the above seven plants, four others were kept covered under the same large net; and some of these produced here and there in the most eapricious manner little groups of capsules; and this makes me believe that a bee, many of which settled on the outside of the net, being 
attraeted by the odour, had on some one oceasion found an entrance, and lad intercrossed a few of the flowers.

In the spring of 1869 four plants raised from fresh seeds were carefully protected under separate nets; and now the result was widely different to what it was before. Three of these protected plants became actually loaded with capsules, especially during the early part of the summer; and this fact indieates that temperature produces some effect, but the experiment given in the following paragraph shows that the innate constitution of the plant is a far morc important clement. The fourth plant produeed only a few capsules, many of them of small size; yet it was far more self-fertile than any of the seven plants tried during the previous year. The flowers on four small branches of this semi-self-sterile plant were smeared with pollen from one of the other plants, and they all produced fine capsules.

As I was much surprised at the difference in the results of the trials made during the two previous years, six fresh plants were protected by separate nets in the year 1870. Two of these proved almost complctcly sclf-sterile, for on carefully searching them I found only three small capsules, each containing either one or two seeds of small size, which, however, germinated. A few flowers on both these plants were reciprocally fertilised with each other's pollen, and a few with pollen from one of the following selffertile plants, and all these flowers produced fine capsules. 'The four other plants whilst still remaining protected beneath the nets presented a wourlerful contrast (though one of them in a somewhat less (legree than the others), for they became aetmally covered with spontaneously self-fertilised capsules, as 
numerous as, or very nearly so, and as fine as those on the unprotected plants growing near.

The above three spontaneously self-fertilised capsules produced by the two almost completely selfsterile plants, contained altogether five seeds; and from these I raised in the following year (1871) five plants, which were kept under separate nets. They grew to an extraordinarily large size, and on August 29th were examined. At first sight they appeared entirely destitute of capsules ; but on carefully search. ing their many branches, two or three capsules were found on three of the plants, half-a-dozen on the fomrth, and about eighteen on the fifth plant. But all these capsules were small, some being empty; the greater number contained only a single seed, and very rarely more than one. After this examination the nets were taken off, and the bees immediately carrierl ipollen from one of these almost self-sterile plants to the other, for no other plants grew near. After a few weeks the ends of the branches on all five plants ibecame covered with capsules, presenting a curious contrast with the lower and naked parts of the same llong branches. These five plants therefore inherited aimost exactly the same sexual constitution as their Iparents; and without doubt a self-sterile race of Mignonette could have been easily established.

Reseda lutea.-Plants of this species were raiserl from seeds gatliered from a group of wild plants growing at no great distance from my garden. After 'asually observing that some of these plants were selfsterile, two plants taken by hazard were protected under separate nets. One of these soon became overed with spontaneously self-fertilised capsules, as numerous as those on the surrounding unprotected slants; so that it was evidently quite self-fertile. 
The other plant was partially self-sterile, producingr very few capsules, many of which were of small size. When, however, this plant had grown tall, the uppermost branches became pressed against the net and grew crooked, and in this position the bees were able to suck the flowers through the meshes, and brought pollen to them from the neighbonring plants. These branches then became loaded with capsules; the other and lower branches remaining almost bare. The sexual constitution of this species is therefore similar to that of Reseda odorata.

\section{Concluding Remartis on self-sterile Plants.}

In order to favour as far as possible the self-fertilisation of some of the foregoing plants, all the flowers on Reseda odorata and some of those on the Abutilon were fertilised with pollen from other flowers on the same plant, instead of with their own pollen, and in the case of the Senecio with pollen from other flowers on the same corymb; but this made no difference in the result. Fritz Müller tried both kinds of self-fertilisation in the case of Bignonia, Tabernamontana and Abutilon, likewise with no difference in the result. With Eschscholtzia, however, he found that pollen from other flowers on the same plant was a little more effective than pollen from the same flower. So did Hildebrand* in Germany; as thirteen out of fourteen flowers of Eschscholtzia thens fertilised set capsules, these containing on an arerage $9 \cdot 5$ seeds ; whereas only fourteen flowers out of twentyone fertilised with their own pollen set capsules: thesc containing on an arerage $9 \cdot 0$ seeds. Hildebrand

* 'Pringshcim's Jahrbuch. für wiss. Botanik,' vii. p. 467. 
found a trace of a similar difference with Corydalis cava, as dicl Fritz Müller with an Oncidium.*

In considering the several cases above given of complete or almost complete self-sterility, we are first strmek with their wide distribntion throughout the regetable kingdom. Their number is not at present large, for they can be discovered only by protecting plants from insects and then fertilising them with pollen from another plant of the same species and with their own pollen; and the latter must be proved to be in an efficient state by other trials. Unless all this be done, it is impossible to know whether their self-sterility may not be due to the male or female reproductive organs, or to both, having been affecterl by changed conditions of life. As in the course of my experiments I have found three new cases, and as Fritr Müller has observed indications of several others, it is probable that they will hereafter be proved to be far from rare. $\dagger$

As with plants of the same species and parentage, some individnals are self-sterile and other's self-fertile, of which fact Reseda odorata offers the most striking instances, it is not at all surprising that species of the same genus differ in this same manner. Thus Verbascum phoeniceum and nigrum are self-sterile, whilst $V$. thapsus and lychnitis are quite self-fertile, as I know by trial. There is the same difference between some of the species of Papaver, Corydalis, and of other genera. Nevertheless, the tendency to self-sterility certainly runs to a certain extent in groups, as we see

* "Variation under Domestication,' chap. xvii. 2nd edit. vol. ii. 11). 113-115.

+ IIr. Willer, the erlitor of $a$ horticultural journal in the United Stutes (yuoted in 'Ciardeners'
Chronicle,' 1868, p. 1286) states that Lilium arbratum, Impatiens pallicla and fulva, anil Forsythia virilissima, cunnot be fertilised with their own pollen. 
in the genus Passiflora, and with the Tandex amongst Orchids.

Self-sterility differs much in degree in different plants. In those extraordinary cases in which pollen from the same flower acts on the stigma like a poison, it is almost certain that the plants would never yield a single self-fertilised seed. Other plants, like Corydalis cava, occasionally, though very rarely, produce a few self-fertilised seeds. A large number of species, as may be seen in Table F, are less fertile with their own pollen than with that from another plant; and lastly, some species are perfectly self-fertile. Even with the inclividuals of the same species, as just remarked, some are utterly self-sterile, others moderately so, and some perfectly self-fertile. The cause, whatever it may be, which renders many plants more or less sterile with their own pollen, that is, when they are selffertilised, must be different, at least to a certain extent, from that which determines the difference in height, vigour, and fertility of the seedlings raised from selffertilised and crossed seeds; for we have already seen that the two classes of cases do not by any meaus run parallel. This want of parallelism would be intelligible, if it could be shown that self-sterility depended solely on the incapacity of the pollen-tubes to penetrate the stigma of the same flower deeply enough to reach the ovules; whilst the greater or less vigorous growth of the seedlings no doubt depends on the nature of the contents of the pollen-grains and ovules. Now it is certain that with some plants the stigmatic secretion does not properly excite the pollenmrains, so that the tubes are not properly dereloped. if the pollen is taken from the same flower. 'This is the case according to Fritz Müller with Eschscholtzia, for he found that the pollen-tubes did not penetrate 
the stigma deeply;* and with the Orchidaeeous genus Notylia they failed altogether to penetrate it.

With dimorphie and trimorphie speeies, an illegitimate union between plants of the same form presents the closest analogy with self-fertilisation, whilst a legitimate union closely resembles cross-fertilisation; and here again the lessened fertility or eomplete sterility of an illegitimate union depends, at least in part, on the incapacity for interaction between the pollen-grains and stigma. Thus with Linum grandiflorum, as I have elsewhere shown, $\uparrow$ not more than two or three out of hundreds of pollen-grains, either of the long-styled or short-styled form, when placed on the stigma of their own form, emit their tubes, and these do not penetrate deeply; nor does the stigma itself change colour, as oceurs when it is legitimately fertilised.

On the other hand the differenee in innate fertility, as well as in growth between plants raised from crossed and self-fertilised seeds, and the differenee in fertility and growth between the legitimate and illegitimate offspring of dimorphic and trimorphie plants, must depend on some ineompatibility between the sexual elements contained within the pollen-grains and ovules, as it is through their union that new organisms are developed.

If we now turn to the more immediate cause of self-sterility, we clearly see that in most cases it is determined by the eonditions to whieh the plants have been subjeeted. Thus Esehscholtzia is eompletely selfsterile in the hot climate of Brazil, but is perfeetly fertile there with the pollen of any other individual. The offspring of Brazilian plants became in England 115.

* 'Lot. '/citung' 1868, pp. 114, + 'Journal of Limn. Snc. Bot.' vol. vii. 1863, pp. $73-75$. 
in a single generation partially self-fertile, and still more so in the second generation. Conversely, the offspring of English plants, after growing for two seasons in Brazil, became in the first generation quite self-sterile. Again, Abutiton darwinii, which is selfsterile in its native home of Brazil, became moderately self-fertile in a single generation in an English hothouse. Some other plants are self-sterile during the early part of the year, and later in the season become self-fertile. I'assiflora alata lost its self-sterility when grafted on another species. With Reseda, however, in which some individuals of the same parentage are self-sterile and others are self-fertile, we are forced in our ignorance to speak of the cause as due to spontaneous variability; but we should remember that the progenitors of these plants, either on the male or female side, may have been exposed to somewhat different conditions. The power of the enviromment thus to affect so readily and in so pecnliar a manner the reproductive organs, is a fact which has many important bearings; and I have therefore thought the foregoing details worth giving. For instance, the sterility of many animals and plants under changed conditions of life, such as confinement, evidently comes within the same general principle of the sexual system being easily affected by the environment. It has already been proved, that a cross between plants which have been self-fertilised or intercrossed during several generations, having been kept all the time under closely similar conditions, does not benefit the offspring; and on the other hand, that a cross between plants that have been subjected to different conditions benefits the offspring to an extraordinary degree. We may therefore conclude that some degree of differentiation in the sexual system is necessary for 
the full fertility of the parent-plants and for the full vigour of their offspring. It seems also probable that with those plants which are capable of complete selffertilisation, the male and female elements and organs already differ to an extent sufficient to excite their mntual interaction; but that when snch plants are taken to another country, and become in consequence self-sterile, their sexual elements and organs are so acted on as to be rendered too uniform for such interaction, like those of a self-fertilised plant long cultivated under the same conditions. Conversely, we may further infer that plants which are self-sterile in their native country, but become self-fertile under changed conditions, have their sexual elements so acterl on, that they become sufficiently differentiated for mutual interaction.

We know that self-fertilised seedlings are inferior in many respects to those from a cross; and as with plants in a state of nature pollen from the same flower can hardly fail to be often left by insects or by the wind on the stigma, it seems at first sight highly probable that self-sterility has been gradually acquired through natural selection in order to prevent selffertilisation. It is no valicl objection to this belief that the structure of some flowers, and the dichogamous condition of many others, suffice to prevent the pollen reaching the stigma of the same flower; for we should remember that with most species many flowers expand at the same time, and that pollen from the same plant is equally injurious or nearly so as that from the same flower. Nevertheless, the belief that self-sterility is a quality which has been gradually acquired for the special purpose of preventing selffertilisation must, I believe, be rejecterl. In the first place, there is no close correspondence in degree 
between the sterility of the parent-plants when selffertilised, and the extent to which thcir offspring suffer in vigour by this process; and some such correspondence might have been expected if self-sterility had been acquired on account of the injury caused by selffertilisation. The fact of individuals of the same parentage differing greatly in their degree of selfsterility is likewise opposed to such a belief; unless, indeed, we suppose that certain individuals hare been rendered self-sterile to favour intercrossing, whilst other individuals have been rendered selffertile to ensure the propagation of the species. The fact of self-sterile individuals appearing only occasionally, as in the case of Lobclia, does not countenance this latter view. But the strongest argument against the belief that sclf-stcrility has been acquired to prevent self-fertilisation, is the immediate and powerful effect of changed conditions in either causing or in removing self-sterility. We are not therefore justified in admitting that this peculiar state of the reproductive system has been gradually acquired throngh natural selection; but we must look at it as an incidental result, dependent on the conditions to which the plants have been subjected, like the ordinary sterility caused in the case of mimals by confincment, and in the case of plants by too much manure, heat, \&c. I do not, however, wish to maintain that self-sterility may not sometimes be of service to a plant in prerenting self-fertilisation; but there are so many other means by which this result might be prevented or rendered difficult, including as we shall see in the next chapter the prepotency of pollen from a distinct individual over a plant's own pollen, that self-sterility seems an almost superfluous acquirement for this purpose.

Finally, the most interesting point in regard to self- 
sterile plants is the evidence which they afford of the advantage, or rather of the necessity, of some degree or kind of differentiation in the sexual elements, in order that they should unite and give birth to a new being. It was ascertained that the five plants of Reseda odorata which were selected by chance, could be perfectly fertilised by pollen taken from any one of them, but not by their own pollen; and a few additional trials were made with some other individuals, which I have not thought worth recording. So again, Hildebrand and Fritz Müller frequently speak of self-sterile plants being fertile with the pollen of any other individual; and if there had been any exceptions to the rule, these could hardly have escaped their observation and my own. We may therefore confidently assert that a self-sterile plant can be fertilised by the pollen of any one out of a thousand or ten thousand individuals of the same species, but not by its orn. Now it is obriously impossible that the sexual organs and elements of every individual can have been specialised with respect to every other individual. But there is no difficulty in believing that the sexual elements of each differ slightly in the same diversified manner as do their external characters; and it has often been remarked that no two individuals are absolutely alike. Therefore we can hardly avoid the conclusion, that differences of an analogous and indefinite nature in the reproductive system are sufficient to excite the mutual action of the sexual elements, and that unless there be such differentiation fertility fails.

\section{The appearance of highly self-fertile Varieties.-We} have just seen that the degree to which flowers are capable of being fertilised with their own pollen differs much, both with the species of the same genus, and 
sometimes with the individuals of the same species. Some allied eases of the appearanee of varieties which, when self-fertilised, yield more seed and produce offspring growing taller than their self-fertilised parents, or than the intercrossed plants of the eorresponding generation, will now be considered.

Firstly, in the third and fourth generations of Mimulus luteus, a tall variety, often allurler to, having large white flowers blotched with crimson, appeared amongst both the intercrossed and selffertilised plants. It prevailed in all the later selffertilised generations to the exclusion of every other variety, and transmitted its eharaeters faithfully, lout disappeared from the intererossed plants, owing no doubt to their eharacters being repeatedly blended by erossing. The self-fertilised plants belonging to this variety were not only taller, but more fertile than the intercrossed plants; though these latter in the earlier generations were mueh taller and more fertile than the self-fertilised plants. Thus in the fifth generation the self-fertilised plants were to the intererossed in height as 126 to 100 . In the sixth generation they were likewise much taller and finer plants, but were not actually measured; they produeed eapsules compared with those on the intererossed plants, in number, as 147 to 100 ; and the self-fertilised eapsules eontained a greater number of seerls. In the seventh generation the self-fertilised plants were to the crossed in height as 137 to 100 ; and twenty flowers on these self-fertilised plants fertilised with their own pollen yielded nineteen very fine capsules, - a degree of self-fertility which I have not seen equalled in any other ease. This rariety seems to have become speeially adapted to profit in every way by self-fertilisation, although this proeess was so injurious to the parent-plants during the first 
four generations. It should however be remembered that seedlings raised from this variety, when crossed by a fresh stock, were wonderfully superior in height and fertility to the self-fertilised plants of the corresponding generation.

Secondly, in the sixth self-fertilised generation of Ipomoea a single plant named the Hero appeared, which exceeded by a little in height its intercrossed opponent, -a case which had not occurred in any previous generation. Hero transmitted the peculiar colour of its flowers, as well as its increased tallness and a high degree of self-fertility, to its children, grandchildren, and great-grandchildren. The self-fertilised children of Hero were in height to other self-fertilised plants of the same stock as 100 to 85 . Ten self-fertilised capsules produced by the grandehildren contained on an average 5.2 seeds; and this is a higher average than was yielded in any other generation by the capsules of self-fertilised flowers. The great-grandchildren of Hero derived from a cross with a fresh stock were so unhealthy, from having been grown at an unfavourable season, that their average height in comparison with that of the self-fertilised plants cannot be judged of with any safety; but it did not appear that they had profited even by a cross of this kind.

Thirdly, the plants of Nicotiana on which I experimented appear to come under the present class of cases; for they varied in their sexual constitution and were more or less highly self-fertile. They were probably the offspring of plants which had been spontaneously self-fertilised under glass for several generations in this country. The flowers on the parent-plants which were first fertilised by me with their own pollen yielded half again as many seeds as did 
those which were crossed; and the scedlings raised from thcse self-fertilised secds excceded in height those raised from the crossed seeds to an cxtraordinary degrec. In the second and third generations, although the self-fertilised plants did not excecd the crossed in height, yet their self-fertilised flowers yielded on two occasions considerably more seeds than the crossed flowers, cren than those which were crossed with pollen from a distinct stock or variety.

Lastly, as certain individual plants of Reseda odorata and lutea are incomparably more self-fertile than other individuals, the former might be included under the present heading of the appearance of new and highly self-fertile varieties. But in this case we should have to look at these two specics as normally self-sterile; and this, judging by my experience, appears to be the correct vicw.

We may thereforc conclude from the facts now given, that varieties somctimes arise which when sclf-fertilised possess an increased power of producing seeds and of growing to a greater height, than the intercrossed or sclf-fertilised plants of the corresponding generation-all the plants being of course subjected to the same conditions. The appearance of such varieties is interesting, as it bear's on the existence under nature of plants which regularly fertilise themselves, such as Ophrys apifera and a few other orchids, or as Leersia oryzoides, which produces an abundance of clcistogene flowers, but most rarcly flowers capable of cross-fertilisation.

Somc observations made on other plants lead me to suspect that self-fertilisation is in some respects beneficial; although the beucfit thus derived is as a rule very small compared with that from a cross with a distinct plant. 'Thus we have seen in the last chapter' 
that seedlings of Ipomoa and Mimulus raised from flowers fertilised with their own pollen, which is the strictest possible form of self-fertilisation, were superior in height, weight, and in early flowering to the seedlings raised from flowers crossed with pollen from other flowers on the same plant; and this superiority apparently was too strongly marked to be accidental. Again, the cultivated varieties of the common pea are highly selffertile, although they have been self-fertilised for many generations; and they exceeded in height seedlings from a cross between two plants belonging to the same variety in the ratio of 115 to 100 ; but then only four pairs of plants were measured and compared. The self-fertility of Primula veris increased after several generations of illegitimate fertilisation, which is a process closely analogous to self-fertilisation, but only as long as the plants were cultivated under the same favourable conditions. I have also elsewhere shown* that with Primula veris and sinensis, equal-styled varieties occasionally appear which possess the sexual organs of the two forms combined in the same flower. Consequently they fertilise themselves in a legitimate manner and are highly self-fertile; but the remarkable fact is that they are rather more fertile than ordinary plants of the same species legitimately fertilised by pollen from a distinct individual. Formerly it appeared to me probable, that the increased fertility of these dimorphic plants might be accounted for by the stigma lying so close to the anthers that it was impregnated at the most favourable age and time of the day; but this explanation is not applicable to the above given cases, in which the flowers were artificially fertilised with their own pollen.

* 'Journal Linn. Soc. Bot.' vol. x. 1867, pp. 417, 419. 
Considering the facts now adduced, inciuding the appearance of those raricties which are more fertile and taller than their parents and than the intercrossed plants of the corresponding generation, it is difficult to aroid the suspicion that self-fertilisation is in some respects advantageous; though if this be really the case, any such advantage is as a rule quite insignificant compared with that from a cross with a distinct plant, and especially with one of a fresh stock. Should this suspicion be hereafter verified, it would throw light, as we shall see in the next chapter, on the existence of plants bearing small and inconspicuous flowers which are rarely visited by insects, and therefore are rarely intercrossed.

\section{Relative Weight and Period of Germination of Seeds} from crossed and self-fertitised Flowers.-An equal number of seeds from flowers fertilised with pollen from another plant, and from flowers fertilised with their ow pollen, were weighed, but only in sixtcen cases. 'Their' relative weights are given in the following list; that of the seeds from the crossed florers being taken as 100 .

I pomœa purpurea (parent plants)

as 100 to 127

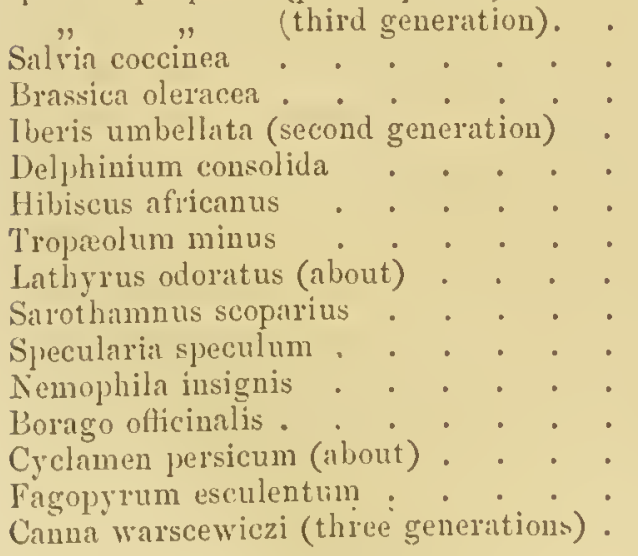

$\begin{array}{rrr}" & , & 87 \\ " & , & 100 \\ " & " & 103 \\ " & " & 136 \\ " & , & 45 \\ " & , & 105 \\ " & , & 115 \\ " & , & 100 \\ " & , & 88 \\ " & , & 86 \\ " & , & 105 \\ " & , & 111 \\ " & , & 50 \\ " & , & 82 \\ " & , & 102\end{array}$

It is remarkable that in ten out of these sixteen 
cases the self-fertilised seeds were either superior or equal to the erossed in weight; nevertheless, in six out of the ten eases (viz., with Ipomoea, Salvia, Brassiea, Tropxolum, Lathyrus, and Nemophila) the plants raised from these self-fertilised seeds were very inferior in height and in other respeets to those raised from the crossed seeds. The superiority in weight of the selffertilised seeds in at least six out of the ten eases, namely, with Brassica, Hibiseus, Tropæolum, Nemophila, Borago, and Canna, may be aecomnted for in part by the self-fertilised eapsules eontaining fewer seeds ; for when a capsule contains only a few seeds, these will be apt to be better nourished, so as to be heavier, than when many are eontained in the same capsule. It should, however, be observed that in some of the above eases, in whieh the crossed seeds were the heaviest, as with Sarothamnus and Cyclamen, the erossed eapsules contained a larger number of seeds. Whatever may be the explanation of the self-fertilised seeds being often the heaviest, it is remarkable in the ease of Brassiea, 'Tropæolum, Nemophila, and of the first generation of Ipomoea, that the seedlings raised from them were inferior in height and in other respeets to the seedlings raised from the crossed seeds. This faet shows how superior in eonstitutional vigour the erossed seedlings must bave been, for it cannot be doubted that heary and fine seeds tend to yield the finest plants. Mr. Galton has shown that this holds good with Lathyrus odoratus; as has Mr. A: J. Wilson with the swedish tminip, Brassica campestris ruta baga. Mr. Wilson separated the largest and smallest seeds of this latter plant, the ratio between the weights of the two lots being as 100 to 59, and he found that the seedlings "from the larger seeds took the lead and maintained their superiority to the last, both in height and thick- 
ness of stem."* Nor can this difference in the growth of the seedling turnips be attributed to the heavier seeds having been of erossed, and the lighter of selffertilised origin, for it is known that plants belonging to this genus are habitually intercrossed by inseets.

With respeet to the relative period of germination of crossed and self-fertilised seeds, a reeord was kept in only twenty-one eases; and the results are rery perplexing. Neglecting one ease in which the tro lots germinated simultaneously, in ten eases or exaetly onehalf many of the self-fertilised seeds germinated before the crossed, and in the other half many of the erossed before the self-fertilised. In four ont of these twenty cases, seeds derived from a eross with a fresh stock were eompared with self-fertilised seeds from one of the later self-fertilised generations; and here again in half the eases the erossed seeds, and in the other half the self-fertilised seeds, germinated first. Yet the seedlings of Mimulus raised from sueh self-fertilised seeds were inferior in all respeets to the erossed seedlings, and in the case of Esehscholtzia they were inferior in fertility. Unfortunately the relative weight of the two lots of seerls was aseertained in only a few instanees in which their germination was observed; but with Ipomoea and I believe with some of the other species, the relative lightness of the self-fertilised seeds apparently deter-

* 'Gardeners' Chronicle,' 1867, p. 107. Loiseleur-Deslongchamp ('Les Cérćales,' 1842, pp. 20S-219) was led by his observations to the extrnordinary conelusion that the smaller grains of ccreals produce as fino plants as the large. This conelnsion is, however, contradicted by Major Hallet's great success in improving wheat by the sclection of the fincst grains. It is possible, however, that man, by long-continued selection. mny liave given to the grains of the cercals a grenter amount of starch or other matter, than the seedlings ean utilise for their growtl. 'Therc can be little dombt, ns Tumboldt long ago remarked, that the grains of cereals liave been rendered attractive to birds in a degree which is highly injurious to the speeies. 
Chap. IX. CROSSED AND SELF-FERTILISED SEEDS. 355

mincd their early germination, probably owing to the smaller mass being favourable to the more rapid completion of the chemical and morphological changes necessary for germination. On the other hand, Mr. Galton gave me seeds (no doubt all self-fertilised) of Lathyrus cdoratus, which were divided into two lots of heavier and lighter seeds; and several of the former rerminated first. It is evident that many more observations arc necessary before anything can be deciderl with respect to the relative period of germination of crossed and self-fertilised seeds. 


\section{CHAPTER X.}

\section{Means of Fertilisation.}

Siterility and fertility of plants when inscets ale exeluded-The means by which flowers are eross-fertilised-Structures favourable to selffertilisation-Relation between the structure and conspienousuess of flowers, the visits of insects, and the alvantages of eross-fertilisation - The meaus by whieh flowers are fertilised witl pollen from a distinct plant-Grenter fertilising power of such pollen -Anemophilous species-Conversion of anemophilous spceies into entomophilous - Origin of rcetar-Anemophilous plants generally liavo their sexes separated - Conversion of dielinous into hermaphrodite flowers-Trees often have their sexes separated.

Is the introductory ehapter I briefly speeified the rarious means by whieh cross-fertilisation is faroured (1) cnsured, namely, the separation of the sexes,--the maturity of the male and female sexual elements at different periods, - the beterostyled or dimorphic and trimorphie condition of eertiin plants, - many mcehanical contrivanees, - the more or less complete ineffieieney of a flower's own pollen on the stigma, - and the prepoteney of pollen from any other indiridual wer that from the same plant. Some of these proints require further consideration; but for full details 1 must refer the reader to the sereral excellent works mentioned in the introduction. I will in the first place grive two lists : the first, of plants which are either quite sturile or produce less than abont half the full complement of seeds, when inseets are excluded: and a second list of plants which, when thus treated, are fully fortile or produee at least half the full complement 
of seeds. These lists have been compiled from the several previous tables, with some additional cases from iny own observations and those of others. The species are arranged nearly in the order followed by Lindley in his 'Vegetable Kingdom.' The reader should observe that the sterility or fertility of the plants in these two lists depends on two wholly distinet eauses; namely, the absence or presenee of the proper means by which pollen is applied to the stigma, and its less or greater efficiency when thus applied. As it is obvious that with plants in whieh the sexes are separate, pollen must be earried by some means from flower to flower, such speeies are excluded from the lists; as are likewise dimorphic and trimorphic plants, in whieh the same necessity oeeurs to a limited extent. Experience has proved to me that, independently of the exclusion of insects, the seerl-bearing power of a plant is not lessened by eovering it while in flower under at thin net supported on a frame; and this might indeed have been inferred from the eonsideration of the two following lists, as they inelude a eonsiderable number of species belonging to the same genera, some of whiel are quite sterile and others quite fertile when protected by a net from the aeeess of inseets.

List of Plants which, when Insects are excluded, are either quite sterite, or produce, as far as I could judge, less than half the number of Seeds produced by unprotected Plants.

Passiforu alutu, racemosa, coerulea, edulis, laurifuliu, and some individuals of $P$. quadrangularis (Passifloracer), are quite sterile under these conditions: see "Variation of Animals and Plants under Domestication,' chap. xvii. 2nd edit. vol. ii. p. 118.

Violu cunina (Violaccæ).-Perfect flowers quite sterile mless fertilised by bees, or artificially fertilised. 
1. tricolor.-Sets very few and poor eapsules.

lieseda odorata (Resedreex).--Some individuals quite sterile.

R. Iutea.-Some individuals produce very few and poor eapsules.

Abutilon durwinii (Malvaceæ).-Quite sterile in Brazil: see previous diseussion on self-sterile plants.

Nymphoca (Nymphæaeeæ).-Professor Caspary informs me that some of the species are quite sterile if inseets are excluded.

Euryale amazonica (Nymphæaeex).-Mr. J. Smith, of Kew, informs me that eapsules from flowers left to themselves, and probably not visited by insects, eontained from eight to fifteen seeds; those from flowers artifieially fertilised with pollen from other flowers on the same plant eontained from fifteen to thirty seeds; and that two flowers fertilised with pollen brought from another plant at Chatsworth eontained respeetively sixty and seventy-five seeds. I have given these statements becanse Professor Caspary advances this plant as a ease opposed to the doetrine of the neeessity or advantage of eross-fertilisation: see Sitzungsberiehte der Phys.-̈̈kon. Gesell. zu Königsberg, B. vi. p. 20.

Detphinium consolida (Ranuneulacea).-Produces many eapsules, lont these eontain only about half the number of seeds eompared with eapsules from flowers naturally fertilised by bees.

Eschscholtzic californica (Papaveracere).-Brazilian plants quite sterile: English plants prodnce a few capsules.

Puprever vagum (Papaveracex).-In the early part of the summer produeed very few eapsules, and these contained rery few seeds.

1'. alpinum.-H. Hoffmann ('Speeiesfrage,' 1875, p. 47) states that this species produced seeds capable of germination only on one oeeasion.

Corydalis cava (Fumariaeer).--Sterile: see the previous discussion on self-sterile plants.

C. sotidn.-I had a single plant in my garden (1863), and saw many hive-bees sueking the flowers, but not a single seed was produced. I was muel surprised at this fact, as Professor Hildebrand's discovery that $C$. cava is sterile with its own pollen had not then been made. He likewise coneludes from the few experiments whieh he made on the present speeies that it is self-sterile. The two foregoing cases are interesting, because botanists formerly thonght (seo, for 
instanee, Lecoq, 'De la Féeondation et de l'Hybridation,' 1845, p. 61, and Lindley, 'Vegetable Kingdom,' 185̃3, p. 436) that all the species of the Fumariaeer were specially adapted for self-fertilisation.

C. lutec.-A eovered-up plant produeed (1861) exaetly half as many capsules as an exposed plant of the same size growing close alongside. When humble-bees visit the flowers (and I repeatedly saw them thus acting) the lower petals suddenly spring downwards and the pistil upwards; this is clue to the elasticity of the parts, which takes effect, as soon as the coherent edges of the hood are separated by the entrance of an insect. Unless insects visit the flower's the parts do not move. Nevertheless, many of the flowers on the plants which I had proteeted prodnced eapsules, notwithstanding that their petals and pistils still retained their original position; and I found to my surprise that these eapsules contained more seeds than those from flowers, the petals of whieh had been artificially separated and allowed to spling apart. Thus, nine eapsules produced by undisturbed flower's eontained fifty-three seeds; whilst nine eapsules from flower's, the petals of whieh had been artificially separated, contained only thirty-two seeds. But we should remember that if bees had been permitted to visit these flowers, they would have visited them at the best time for feltilisation. 'The flowel's, the petals of which had been artifieially separated, set their capsules before those which were left undisturbed under the net. To show with what certainty the flowers are visited by bees, I may add that on one occasion all the flowers on some unprotected plants were examined, and every single one had its petals separated; and, on a seeond oecasion, forty-one out of fortythree flowers werc in this state. Hildebrand states (Pring. Jahr. f. wiss. Botanilk, B. vii., p. 450) that the mechanism of the parts in this species is nearly the same as in $C$. ochroleuca, which he has fully described.

Iypecoum grundiflorum (Fumariaceæ).-Highly self-sterile (Hildebrand, ibid.).

Kalmia latifolia (Ericaeex).-Mr. W. J. Beal says ('American Naturalist,' 1867) that flowers protected from insects wither and drop off, with "most of the anthers still remaining in the poekets."

Peluryonium zonale (Geraniaeca).-Almost sterile; one plant 
produeed two fruits. It is probable that different varieties wonld differ in this respeet, as some are only feebly diehogamous.

Dimithus caryophyllus (Caryophyllaeere).-Produces very few eapsules, which eontain any good seeds.

l'huseolus multiflorus (Leguminosæ). - Plants proteeted from insects produeed on two oeeasions about one-third and oneeighth of the full number of seeds: see my article in 'Gardener's' Chroniele,' 1857, p. 225, and 1858, p. 828; also 'Amnals and Mag. of Natural History,' 3rd series, vol. ii. 1858, p. 462. Dr. Ogle ('Pop. Seienee Review;' 1870, p. 168') found that a plant was quite sterile when eovered up. The flowers are not visited by inseets in Niearagua, and, aeeording to Mr. Belt, the speeies is there quite sterile: "The Naturalist in Niearagua,' p. 70.

I icia faba (Leguminosæ). - Seventeen eovered-up plants rielded 40 beans, whilst seventeen plants left mnproteeted and growing elose alongside produeed 135 beans; these latter plants were, therefore, between three and four times more fertile than the protected plants: see 'Gardencrs' Chroniele ' for fuller details, 1858 , p. 828 .

Eingthrinu (sp. ?) (Leguminosi).--Sir W. MaeArthur informed me that in New South Wales the flowers do not set, unless the petals are moved in the same manner as is done by inseets.

Lathyrus glandiflorus (Leguminosx).--Is in this country more or less sterile. It nerer sets pods unless the flower's arc risited by humble-bees (and this happens only rarely), or unless they are artificially fertilised: see my artiele in 'Gardeners' Chroniele,' 1858, p. 828.

Sirothamrus scoparius (Leguminosa).-Extremely sterile when the flowers are neither visited by bees, nor disturbed by being beaten by the wind against the surrounding net.

Melilotus officinalis (Leguminose). - An unproteeted plant visited by bees produeed at least thirty times more seeds than a proteeted one. On this latter plant many seores of raecmes did not prodnee a single pod; several raeemes produeed each one or two pods; five produeed three; six produeed four; and one produeed six pods. On the mimproteeted plant each of several racemes produced fifteen pods; nine modueed between sixteen and trenty-tro pods, and one produeed thirty pods. 
Lutus corniculatus (Lcguminase),-Several covered-up plants produced only two cmpty pods, and not a single good sced.

Trifoliums repens (Leguminosa). - Several plants were protected from insects, and the sceds from ten flower-heads on thesc plants, and from ten lieads on other plants growing outside the net (which I saw visited by bees), were comnted; and the seeds from the lattcr plants were vcry nearly ten times as numcrous as those from the protccted plants. The experiment was repeated on the following ycar; and twenty protected hoads now yielded only a single aborted sced, whilst twenty heads on the plants outside the net (which I saw visited by bees) yiclded 2290 seeds, as calculated by weighing all the secd, and counting the number in a weight of two grains.

T. pratense.-Onc liundred flowcr-hcads on plants protectcd by a net did not produce a single secd, whilst 100 hoads on plants growing outsidc, which were visited by bees, yielded 68 grains weight of seeds; and as eighty seeds weighed two grains, the 100 heads must have yielded 2,720 seeds. I have often: watched this plant, and have never seen hive-bees sucking the flowers, except from the outside through holes bitten by humble-bees, or deep down between the flowers, as if in search of sume secretion from the calyx, almost in the same manner as described by Mr. Farrer, in the case of Coronilla ('Nature,' 1874, July 2, p. 169). I must, however, except one occasion, when an adjoining field of sainfoin (Hedysarum onobrychis) had just been cut down, and when the bees seemed driven to desperation. On this occasion most of the flowers of the clover were somewhat withered, and contained an extraordinary quantity of nectar, which the bees were able to suck. An experienced apiarian, Mr. Miner, says that in the United States hive-bees never suck the red clover; and Mr. R. Colgate informs me that he bas observed the same fact in New Zealand after the introduction of the hive-bee into that island. On the other laand, H. Miiller ('Befruchtung,' p. 224) has often seen hivebees visiting this plant in Germany, for the salre both of pollen and ncctar, which latter they obtained by breaking apart the petals. It is at least certain that humble-bees are the chief fertilisers of the common red clover.

$T$. incarnatum.-The flower-heads containing ripe seeds, on some covered and uncovered plants, appcared equally fine, but 
this was a false appearance; 60 heads on the latter yielded 349 grains weight of seeds, whereas 60 on the eovered-up plants yielded only 63 grains, and many of the seeds in the latter lot were poor and aborted. Therefore the flowers which were visited by bees produced between five and six times as many seeds as those which were protected. The covered-up plants not having been mueh exhausted by seedbearing, bore a second considerable crop of flower-stems, whilst the exposed plants did not do so.

Cytisus laburnum (Leguminosæ). - Seven flower-racemes ready to expand were enclosed in a large bag made of net, and they did not seem in the least injured by this treatment. Only three of them produced any pods, each a single one; and these three pods contained one, four, and five seeds. So that only a single pod from the seren racemes included a fair complement of seeds.

Cuphea purpurea (Lythraeeæ).-CProduced no seeds. Otber flowers on the same plant artificially fertilised under the net yielded seeds.

Vincu major (Apocynaceæ).-Is generally quite sterile, but sometimes sets secds when artifieially cross-fertilised: see my notice, 'Gardener's' Chronicle,' 1861, p. 552.

$V$. rosec.-Behaves in the same manner as the last species: 'Gardener's' Chroniele,' 1861, pp. 699, 736, 831.

Taberncemontana echinata (A poeynaceæ).-Quite sterile.

P'etunic violacca (Solanaceæ).-Quite sterile, as far as I have observed.

Solauum tuberosum (Solanacex).-Tinzmanu says ('Gardeners' Chronicle,' 1846 , p. 183) that some varieties are quite sterile unless fertilised by pollen from another variety.

Primula scotica (Primulacex).-A nou-dimorphie species, which is fertile with its own pollen, but is extremely sterile if insects are exeluded. J. Sentt, in 'Jourual Linn. Soc. Bot.' vol. viii. 1864, p. 119.

Cortusa matthioli (Primulacex).--Protected plants completely sterile; artificially self-fertilised flowers perfectly fertile. J. Scott, ibid. p. S4.

Cyclumen persicum (Primulacex).-During ono season sereral covercid-up plants did not produce a single seed.

Borago officinalis (Boraginacex).-Clrotected plants produced about half as many seeds as the umprotected.

Salvia tenori (Labiatr).-Quite sterile; but two or three flowers 
on the summits of three of the spikes, which touched the net when the wind blew, produced a few seeds. This sterility was not due to the injurious effects of the net, for I fertilised five flowers with pollen from an adjoining plant, and these all yielded fine seeds. I removed the net, whilst one little branch still bore a fow not completely faded flowers, and these were visitcd by becs and yielded seeds.

S. coccinea.-Some covered-up plants produced a good many fruits, but not, I think, half as many as did the uncovered plants; twenty-eight of the fruits spontaneously prodnced by the protected plant contained on an average only 1.45 seeds, whilst somc artificially self-fertilised fruits on the same plant contained more than twicc as many, viz., $3 \cdot 3$ secds.

Bignonic (umamed spccies) (Bignoniaceæ).-Quite sterile: see my account of self-sterile plants.

Digitulis purpurea (Scrophulariaceæ).-Extremely sterile, only a few poor capsules being produced.

Linaria vulgaris (Scrophulariaceæ).-Extremely sterile.

Antirrtinum majus, red var. (Scrophulariaceæ).-Fifty pods gathered from a large plant under a net contained $9 \cdot 8$ grains weight of seeds; but many (unfortunately not counted) of the fifty pods contained no seeds. Fifty pods on a plant fully exposcd to the visits of humblc-bees contained $23 \cdot 1$ grains weight of seed, that is, more than twice the wcight; but in this case again, several of the fifty pods contained no seeds.

A. majus (white var., with a pink mouth to the corolla).Fifty pods, of which only a vcry few wcre empty, on a covered-up plant containcd 20 grains weight of seed; so that this variety seems to be much more self-fertile than the previous one. With Dr. W. Ugle ("Pop. Science Review,' Jan. 1870, p. 52) a plant of this specics was much more sterile when protected from insects than with me, for it produced only two small capsules. As showing the efficiency of bces, I may add that Mr. Crocker castratcd some young flowers and left them uncovered; and thesc produced as many secds as the unmutilated flowers.

A. majus (peloric var.).-This variety is quite fertile when artificially fortiliscd with its own pollen, but is utterly sterilc when left to itself and uncovered, as humble-bees carnot crawl into the narrow tubular flowers. 
Verbascum phoniceum (Scrophulariacere).-Quite sterile jee my acV. nigrum.-Quite sterile . . . . . S sterile plants. Campanula carpathica (Lobeliaceæ) - Quite sterile.

Lobelia ramosu (Lobeliacere).-Quite sterile.

L. fulgens. - This plant is never visited in my garden by bees, and is quite sterile; but in a nursery-garden at a ferw miles' distance I saw humble-bees visiting the flowers, and they produced some capsules.

Isotomr (a wlite-flowered var.) (Lobeliacer). - Five plants luft unprotected in my greenhouse produced twenty-four fine capsules, containiug altogether $1 \% \cdot 2$ grains weight of seed, and thirtecn other very poor capsules, which were rejected. live plants protected from insects, but otherwise exposed to the same conditions as the above plants, produced sixteen fine capsules, and twenty other very poor and rejected ones. 'The sixteen fine capsules contained seeds by weight in such proportion that twenty-fuur would lave yielded $4 \cdot 66$ grains. So that the umprotected plants produced nearly thrice as many seeds by weight as the protected plants.

Jeschencultia formosr (Goodeniacen).-Quite sterile. My experiments on this plant, showing the necessity of insect aid, are given in the 'Gardeners' Chronicle,' 1871, p. 1166.

Senecio cruentus (Composite).-Quite sterile: sce my account of self-sterile plants.

Heterocentron mexicanum (MIalastomacex).-Quite sterile; but this species and the following members of the group produce plenty of seed when artificially self-fertilised.

Ritheria glandulosa (Melastomacer).- - Set spontaneously only two or three capsules.

Centrudeniu floribundu (Melastomacen).-During some year's produced spontaneously two or three capsules, sometimes none.

Pleromr. (unnamed species from Kew) (Melastomacer).-Duriug some year's produced spontaneously two or three capsules, sometimes none.

Monochcetum ensiferum (Melastomacex).-During some year's produced spontaneously two or three capsules, sometimes none.

Hedychium (unnamed species) (Marantaceæ).-Almost self-sterile without aid.

Orchidew.-An immense proportion of the species sterile, if insects are excluded. 
List of Plants. which when protected from Insects are either quite Fertile, or yield more than half the Number of Seeds produced by unprotected Plants.

Passiflora gracitis (Passifloracer).-Produces many fruits, but these eontain ferver seeds than fruits from intererossed flowers. Brassica oleracea (Crueiferæ). - Produees many eapsules, but - these generally not so rieh in seed as those on uneovered plants.

liaphanus sativus (Crueiferæ).-Half of a large branebing plant was eovered by a net, and nas as thickly covered with eapsules as the other and unproteeted half; but twenty of the eapsules on the latter eontained on an average 3.5 seeds, whilst twenty of the proteeted eapsules eontained only $1 \cdot 85$ seeds, that is, only a little more than half the number. This plant might perhaps have been more properly ineluded in the forwer list.

Iberis umbellata (Crueiferæ).-Highly fertile.

1. umara.-Highly fertile.

Reseda odorata and luteca (Resedaeere).-Certain individuals eompletely self-fertile.

Euryale ferox (Nymphæacer), - Professor Caspary informs me that this plant is highly self-fertile when inseets are exeluded. $\mathrm{He}$ remarks in the paper before referred to, that his plants (as well as those of the Victoria regia) produee only one flower at a time; and that as this speeies is an aunual, and was introdueed in 1809, it must have been self-fertilised for the last fifty-six generations; hut Dr. Hooker assures me that to his knowledge it has been repeatedly introdueed, and that at Kew the same plant both of the Euryale and of the Vietoria produce several flowers at the same time.

Nymphere (Nymphracere), - Some species, as I am informed by Professor Caspary, are quite self-fertile when inseets are exelucled.

Allonis restivalis (Ranuneulaeere).-Prodnees, aeeording to Professor' H. Hoffmann ('Speeiesfrage,' p. 11), plenty of seeds when protected from inseets.

liamunculus acris (Ranuneulacere).-Produees plenty of seeds under a net.

Pupuner sominiferem (Papaveraeese).-Thirty eapsules from uncovered plants yie!ded 15.6 grains weight of seed, and thirty eapsules from eovered-up plants, growing in the same bed, 
yielded $16 \cdot 5$ grains weight; so that the latter plants were more productive than the uncovered. Professor H. Hoffmann ('Speciesfrage,' 1875 , p. 53) also found this species self-fertile when protected from insects.

$P$. vagum.-Produced late in the summer plenty of seeds, which germinated well.

1'argemonoides . . . . According to Hildebrand ("JahrG'aucium luterm (Papaverncea) . buch für w. Bot.' B. vii. p. 466), Argemone ochroleuca (Papaveracea) . S spontuneously self-fertilised flowers Adlumic cirrhosa (Fumariacer). - Sets an abundance of capsules. Iypecoim procumbens (Fumariacer). Hildcbrand says (idem), with respect to protected flowers, that " eine gute Fruchtbildung eintrete."

Fumaria officinalis (Fumariacer).-Covered-up and unprotected plants apparently produced an equal number of capsules, and the seeds of the former seemed to the eye equally good. I have often watched this plant, and so has Hildebrand, and we have never scen an insect visit the flowers. H. Miuller has likewise been struck with the rarity of the visits of insects to it, though he has sometimes seen hive-bees at work. The flowers may perhaps be visited by small moths, as is probably the case with the following species.

F. capreolata.-Several large beds of this plant growing wild were watched by me during many days, but the flowers were never visited by any insects, though a liumble-bee was once seen closely to inspect them. Nevertheless, as the nectary contains much nectar, especially in the evening, I felt convinced that they werc visited, probably by moths. The petals do not naturally separate or open in the least; but thcy had been opened by some means in a certain proportion of the flowers, in the same manncr as follows when a thick bristle is pushed into the nectary; so that in this respect they resemble the flower's of Corydulis luter. Thirtyfour heads, each including many flower's, wcre examined, and twenty of them had from one to four flowers, whilst fourteen had not a single flower this opened. It is therefore clear that some of the flowers had been visited by insects, while the majority had not; yet almost all produced capsules.

Linum usitatissinum (Linacer).-Appears to be quitc fertilc. H. Hoffmann, 'Bot. Zeitung,' 1876, p. 566.

Impatiens barbigerum (Balsaminacer). - The flowers, thongh ex- 
cellently adapted for cross-fertilisation by the bees which freely visit them, sct abundantly under a net.

1. noti-me-tungere (Balsaminacer).- This species produces cleistogene and perfect flowers. A plant was covered with a net, and some perfect flowcrs, marked with threads, produced eleven spontaneously self-fertilised capsules, which contained on an averagc 3.45 sceds. I neglected to ascertain the number of seeds produced by perfect flowers exposed to the visits of insects, but I believe it is not greatly in excess of the above average. Mr. A. W. Bennett has carefully described the structure of the flowers of $I$. fulva in 'Journal Linn. Soc.' sol. xiii. Bot. 1872, p. 147. This latter spccies is said to be sterile with its own pollen ('Gard. Chronicle,' 1868, p. 12S6), and if so, it presents a remarkable contrast with $I$. burbigerum and noli-me-tangere.

Limnanthes douglasii (Geraniaceæ).-Highly fertilc. Viscaria oculuta (Caryophyllacer).-Produces plenty of capsules with good secds.

Stellaria medic (Caryophyllacer).-Covered-up and uncovered plants produced an equal number of capsulcs, and the secds in both appeared equally numerous and good.

Beta vulgaris (Chenupodiaceæ).- - Highly self-fertile.

Vicia sativa (Leguninosæ).-Protected and unprotected plants produced an equal number of pods and equally finc seeds. If therc was any difference between the two lots, the coveredup plants were the most productive.

V. hirsuta. - This species bears the smallest flower's of any

British legtuminous plant. The result of covering up plants

was exactly the same as in the last species.

P'isum sativum (Leguminos $x$ ). - Fully fertile.

Lathyrus odoratıs (Leguminosæ). - Fully fertilc.

L. nissolia.-Fully fertilc.

Lupinus luteus (Leguminosæ),-Fairly productive.

L. pilosus, - Produced plenty of pods.

Ononis minutissima (Leguminosæ). -Twelve perfect flowers on a plant under a net were marked by threads, and produced eight pods, containing on an average 2.38 seeds. Pods produced by flowers visited by insects would probably have contained on an average 3.66 seeds, judging from the effcets of artificial cross-fertilisation.

1'haseolus vulyaris (Leguminosæ).-Quitc fertile. Trifolium arvense (Leguminosx). - The excessivcly small flower's 
are incessantly visited by hive and humble-bees. When insccts were excluded the flower-heads scemed to produce as many and as fine sceds as the cxposed heads.

T. procumbens.-On one occasion covered-up plants seemed to yield as many seeds as the uncovered. On a second occasion sixty uncovered flower-heads yielded $9 \cdot 1$ grnins weight of seeds, whilst sixty heads on protected plants yielded no less than $17 \cdot 7$ grains; so that these latter plants wore much more productive; but this result I supposo was acciclental. I have often watched this plant, and have nerer seen the flowers visited by insects; but I suspect that the flowers of this species, and more especially of Trifolium minus, are frequented by small nocturnal moths which, as I hear from $\mathrm{MI}$. Bond, haunt the smaller clover's.

Medicago lupulina (Leguminosæ).--On account of the danger of losing the seeds, I was forced to gather the pods before they were quite ripe; 150 flower-heads on plants visited by hees yielded pods weighing 101 grains; whilst 150 heads on pro:ceted plants yieldrd pods weighing 77 grains. The inequality would probably have been greater if the mature sceds could have been all safely collected and compared. Ig. Urban (Keimung, Bluthell, \&c., bei Medicago, 1873) has described the means of fertilisation in this genus, as lias the Rev. G. Henslow in the 'Jourual of Linn. Soc. Bot,' rol. ix. 1866, pp. 327 and 355.

Nicotiancu tubacum (Solanaces).-Fully self-fertile. Ipomøu purpurea (Convolvulaccæ).--Highly self-fertile.

Leptosiphon androsaceus (Polemoniacer).-Plants under a net produced a good many capsules.

I'rimule mollis (Primulaccæ). - A non-dimorplic specics, sclf-fertile: J. Scott, in 'Journal Limn. Soc. Bot.' rol, viii. 1864, p. 120. Nolana prostrata (Nolanacer).- - Plants covered up in the greenlouse, yieided sceds by weight compared with uncorered plants, the flowers of which were visited by many bees, in the ratio of 100 to 61 .

Ajugce reptaus (Labiatæ). - Set a good many sceds; but none of the stems under a net produced so many as sereral uncovered stems growiug closely by.

Enpleresice officinulis (Scrophulariacer),-Covered-up plants produced plenty of seed; whether less than the exposed plauts 1 cannot say. I saw two small Dipterous insects (Dolichopos nigripennis and limpis chioptera) repeatedly sucking the 
flowers; as they crawled into them, they rubbed agaimst the bristles which project from the anthers, and became dusted with pollen.

leronica ayrest is (Scrophulariacen), - Covercd-up plants produced an abundance of seeds. I do not know whether any insects visit the flowers; but I have observed Srrphidæ repeatedly covered with pollen visiting the flowers of $V$. hederofolia and chamadrys.

Mimulus luteus (Scrophulariacer).-Highly self-fertile.

Culceolaria (greenhouse variety) (Scrophulariaceæ).-Highly selffertile.

Verbascum thapsus (Scrophulariaceæ).-Highly self-fertile. V. Iychnitis.-Highly self-fertile.

Vandellia nummularifolia (Scrophulariaceæ).-Perfect flowers produce a good many capsulcs.

Bartsia chlontites (Scrophulariacere).-Covered-up plants produced

a good many seeds; but several of these were shrivelled, nor were they so numerous as those produced by unprotected plauts, which were incessantly visited by hive and humblebees.

Speculuria speculum (Lobeliacce). - Covcred plants produced almost as many capsules as the uncovered.

Lactuca sativa (Compositx),- - Covered plants produced some seeds, but the summer was wet and unfavourable.

Galium upurine (Rubiacex).-Covered plants produced quite as many seeds as the uncovered.

Apium petroselinum (Umbelliferæ).-Covered plants apparently were as productive as the uncovered.

Zea mays (Graminex). - A single plant in the greenhouse produced a good many grains.

Canna warscewiczi (Marantaceæ).-Highly self-fertile.

Orchidacece. - In Europe Ophrys apiferce is as regularly selffertilised as is any cleistogene flower. In the United States, Soutb Africa, and Australia there are a few species which are perfectly sclf-fertile. These several cases are given in the 2 nd edit. of my work on the Fertilisation of Orchids.

Allium cepa (blood red var.) (Liliaceæ).-Four flower-hcads were covercd with a net, and they produced somewhat fewer and smaller capsulcs than those on the uncovered hcads. The capsules werc counted on one uncovered head, and wcre 289 in number; whilst those on a finc head from under the net werc only 199. 
Each of these lists contains by a mere accirlent the same number of genera, viz., forty-nine. The genera in the first list include sixty-five species, and those in the second sixty species; the Orchidere in both being excluded. If the genera in this latter order, as well as in the Asclepiadre and Apocynacex, had been included, the number of species which are sterile if insects are excluded would have been greatly increased; but the lists are confined to species which were actually experimented on. The results can be considered as only approximately accurate, for fertility is so variable a character, that each species ought to have been tried many times. The above number of species, namely, 125 , is as nothing to the host of living plants; but the mere fact of more than half of them being sterile within the specified degree, when insects are excluded, is a striking one; for whenever pollen has to be carried from the anthers to the stigma in order to ensure full fertility, there is at least a good chance of cross-fertilisation. I do not, however, believe that if all known plants were tried in the same manner, half would be found to be sterile within the specified limits; for many fiowers were selected for experiment which presented some remarkable structure; and such flowers often require insect-aid. Thus out of the forty-nine genera in the first list, about thirty-two have flowers which are asymmetrical or present some remarkable peculiarity; whilst in the second list, including species which are fully or moderately fertile when insects were excluded, only about twenty-one out of the forty-nine are asymmetrical or present any remarkable peculiarity.

Means of cross-fertitisation.-The most important of all the means by which pollen is carried from the anthers to the stigma of the same flower, or from flower 
to flower, are insects, belonging to the orders of Hymenoptera, Lepidoptera, and Diptera; and in some parts of the world, birds.* Next in importance, but in a quite subordinate degree, is the wind; and with some aquatic plants, according to Delpino, currents of watel. The simple fact of the necessity in many cases of extraneous aid for the transport of the pollen, and the many contrivances for this purpose, render it highly probable that some great benefit is thus gained; and this conclusion has now been firmly established by the proved superiority in growth, vigour, and fertility of plants of crossed parentage over those of self-fertilised parentage. But we should always keep in mind that two somewhat opposed ends have to be gained; the first and more important one being the production

* I will here give all the cases known to ine of birds fertilising flowers. In South Brazil, humming-birds certainly fertilise the various species of $\mathrm{A}$ butilon, which are sterile without their aid: (Fritz Müller, 'Jenaisehe Zeitsehrift f. Naturwiss.' B. vii. 1S72, p. 24.) Long-beaked humming-birds visi: the flowers of Brugmausia, whilst some of the short-benked species often penetrate its large corolla in orcler to obtuin the nectar in an illegitimate manner, in the same manner as do bees in all parts of the world. It appears, indeed, that the beaks of humming-birds are specially adapted to the various kinds of flowers which they visit: on the Cordillera they suck the Snlvix, and lacerate the flowers of the Tacsonix; in Nienragua, Mr. Bclt saw them sucling the flowers of MIarcgravia and Erythrina, and thus they carried pollen from flower to flower. In North America they are said to frequent the flowers of Impatiens: (Gould, 'Introduetion to the 'T'ro- chilidx,' 1S61, pp. 15, 120 ; 'Gard. Chronicle,' 1869, p. 359; 'The Naturalist in Nicaragua,'p. 129 ; 'Journul of Limn. Soe. But.' rol. xiii. 1872, p. 151.) I may add that I often saw in Chile a Mimus with its hend yellow with pollen from, as I believe, a Cassia. I huve been assured that at the Cape of Good Hope, Strelitzia is fertilised by the Nectarinida. There can hardly be a doubt that many Australian flowers are fertilised by the many honey-sucking birds of that country. Mr. Wrallace remarks (address to the B10logical Scetion, Brit. Assoe. 1876; that he has "often obscrved the beaks and faees of the brushtongued lories of the Molucens covered with pollen." In New Zealund, many specimens of the Arthornis melamura liad their hends coloured with pollen from the flowers of an endemic species of Euchsia: (''otts, 'I'ransact. New Kealand Institute,' vol, iii. 1870, p. 72.) 
of sceds by any means, and the second, eross fertilisation.

The advantages derived from eross-fertilisation throw a flood of light on most of the ehief eharacters of flowers. We ean thus understand their large size and bright eolours, and in some cases the bright tints of the adjoining parts, sueh as the peduncles, braetex, \&e. By this means they are rendered conspieuous to inseets, on the same principle that almost erery fruit whieh is devoured by birds presents a strong eontrast in colour with the green foliage, in order that it may be seen, and its seeds freely disseminated. With some flowers eouspieuousness is gained at the expense even of the reproductive organs, as with the ray-florets of many Compositx, the exterior flowers of Hydrangea, and the terminal flowers of the Feather-hyneinth or Muscari. 'I'here is also reason to believe, and this was the opinion of Sprengel, that flowers differ in eolour in aeeordanee with the kinds of inseets which frequent them.

Not only do the bright colours of flower's serve to attraet insects, but dark-eoloured streaks and marks ire often present, which Sprengel long ago maintained served as guides to the nectary. These marks follow the reins in the petals, or lie between them. They may oeeur on only one, or on all exeepting one or more of the upper or lower petals; or they may form a dark ring round the tubular part of the corolla, or be eonfined to the lips of an irregular flower. In the white varieties of many flowers, sueh as of Digitalis purpurea, Antirrhinum majus, several species of Dianthus, Phlox, Myosotis, Rhododendron, Pelargonium, P'rimula and Petunia, the marks generally persist, whilst the rest of the eorolla has beeome of a pure white; but this may be due merely to their colour being more intense and thus less realily obliternted. 
Sprengel's notion of the use of these marks as guides appeared to me for a long time faneiful; for inseets, without sueh aid, readily diseover and bite holes through the neetary from the ontside. They also diseover the minute nectar-seereting glands on the stipules and leaves of eertain plants. Moreover, some few plants, sueh as eertain poppies, whieh are not neetariferous, have guiding marks; but we might perhaps expeet that some few plants would retain traees of a former neetariferous eondition. On the other hand, these marks are mueh more eommon on asymmetrieal flowers, the entrance into whieh would be apt to puzzle inseets, than on regular flowers. Sir J. Lubbock has also proved that bees readily distinguish eolours, and that they lose mueh time if the position of honey whieh they have onee visited be in the least ehanged.* The following ease affords, I think, the best evidenee that these marks have really been developed in eorrelation with the neetary. The two upper petals of the eommon Pelargonium are thus marked near their bases; and I have repeatedly observed that when the flowers vary so as to beeome pelorie or regular, they lose their neetaries and at the same time the dark marks. When the neetary is only partially aborted, only one of the upper petals loses its mark. 'Therefore the neetary and these marks elearly stand in some sort of elose relation to one another; and the simplest view is that they were developed together for a speeial purpose; the only eoneeivable one being that the marks serve as a guicle to the nectary. It is, however, evident from what has been already said, that inseets could diseover the nectar without the aid of guiding marks. 'They are of service to the plant, only by aicling inseets to

* 'British Wild Flowers in rulation to Insects,' 1875, p. 44. 
visit and suek a greater number of flowers within a given time than would otherwise be possible; and thus there will be a better chanee of fertilisation by pollen brought from a distinet plant, and this we know is of paramount importanee.

The odours emitted by flowers attraet insects, as I have observed in the ease of plants covered by a muslin net. Nägeli affixed artifieial flowers to branehes, scenting some with essential oils and leaving others unscented; and inseets were attraeted to the former in an unmistakable manner.* Not a few flowers are both conspieuous and odoriferous. Of all eolours, white is the prevailing one; and of white flowers a eonsiderably larger proportion smell sweetly than of any other colour, namely, $14 \cdot 6$ per eent.; of red, only $\delta \cdot 2$ per cent. are odoriferous. $\dagger^{-}$The fact of a larger proportion of white flowers smelling sweetly may depend in part on those whieh are fertilised by moths requiring the double aid of conspieuousness in the dusk and of odour. So great is the eeonomy of nature, that most flowers whieh are fertilised by crepuseular or noeturnal inseets emit their odour ehiefly or exclusively in the evening. Some flowers, however, whieh are highly odoriferous depend solely on this quality for their fertilisation, sueh as the night-flowering stoek (Hesperis) and some species of Daphne; and these present the rare case of flowers which are fertilised by insects being: obseurely eoloured.

'The storage of a supply of nectar in a protected place is manifestly conneeted with the visits of insects. So is the position whieh the stamens and pistils oceupy,

* 'Jinsteliung, \&c, der Naturlist. Alt.' 1S6:, p. 23.

$\dagger$ 'I'he colour's and odours of the flowel's of 4200 species liare been tabulated by Landgrabe, and by Schiibler and Fibller. I have not secn their original works, but a very full abstract is given in Jourlon's 'Gardener's Mag.' vol. xiii. 1837, 1. 367. 
either permanently or at the proper period through their own morements; for when mature they invariably stand in the pathway leading to the neetary. The shape of the neetary and of the adjoining parts are likewise related to the particular kinds of insects which habitually visit the flowers; this has been well shown by H. Mü̈ller by his eomparison of lowland speeies whieh are chiefly visited by bees, with alpine speeies belonging to the same genera which are visited by butterflies.* Flowers may also be adapted to certain kinds of insects, by seereting nectar partieularly attraetive to them, and unattractive to other kinds; of whieh faet Epipactis latifolia offers the most striking instanee known to me, as it is visited exclusively by wasps. Structures also exist, sueh as the hairs within the eorolla of the foxglove (Digitalis), whieh apparently serve to exelude inseets that are not well fitted to bring pollen from one flower to another. $\dagger$ I need say nothing here of the endless contrivances, sueh as the viseid glands attached to the pollen-masses of the Orchider and Asclepiadr, or the viscid or roughened state of the pollen-grains of many plants, or the irritability of their stamens whieh move when touehed by insects, \&e., -as all these eontrivanees evidently favour or ensure cross-fertilisation.

All ordinary flowers are so far open that inseets can foree an entrance into them, notwithstanding that some, like the Snapdragon (Antirrhinum), various Papilionaeeous and Fumariaeeous flowers, are in appearance elosed. It eannot be maintained that their openness is neeessary for fertility, as eleistogene flowers which are permanently elosed yield a full complement of seeds. Pollen contains mueh nitrogen and phos-

* 'Nature,' 1874, p. 110; 1875 , p. $190 ; 1876$, pl. $210,289$. $\dagger$ Belt, "The Naturalist in Nicaragua,' 1874 , p. 132. 
phorus - the two most preeious of all the elements for the growth of plants-but in the ease of most open flowers, a large quantity of pollen is consumed by pollen-devouring inseets, and a large quantity is destroyed during long-continued rain. With many plants this latter evil is guarded against, as far as is possible, by the anthers opening only during dry weather,* -by the position and form of some or all of the petals, - by the presence of hairs, \&e., and as Kerner has shown in his interesting essay, $\dagger$ by the morements of the petals or of the whole flower during eold and wet weather. In order to compensate the loss of pollen in so many ways, the anthers produce a far larger amount than is neeessary for the fertilisation of the same flower. I know this from my own experiments on Ipomcea, given in the Introduction; and it is still more plainly shown by the astonishingly small quantity produeed by eleistogene flowers, whieh lose none of their pollen, in eomparison with that produced by the open flowers borne by the same plants; and yet this small quantity suffices for the fertilisation of all their numerons seeds. Mr. Hassall took pains in estimating the number of pollen-grains prodneed by a flower of the Dandelion (Leontodon), and found the number to be 243,600, and in a Prony 3,654,000 grains.f The editor of the 'Botanieal Register' eounted the ovules in the flowers of Wistaria sinensis, and earefully estimated

* Mr. Blackley observed that the ripe anthers of rye did not dehisce whilst kept under a bellglass in a damp atmosphere, whilst other anthers cxposed to the same temperature in the open air rlehisced freoly. He also found much more pollen adhering to the sticky slides, which wore attached to kites and sent high up in the atmospherc, during the first fine and dry days after wot weather, than at other times: 'Experimental liestarches on Hay Fever,' 1573, 1. 127.

$\dagger$ 'Die Schutzmittel des Pollens,' 1873.

I'Annals and Mag. of Nat. Hist.' rol. viii. 18t2, p. 108. 
the number of pollen-grains, and he found that for eaeh ovule there were 7,000 grains.* With Mirabilis, three or four of the very large pollen-grains are suffieient to fertilise an ovule; but I do not know how many grains a flower produces. With Hibiscus, Kölreuter found that sixty grains were necessary to fertilise all the ovules of a flower, and he ealculated that 4863 grains were produced by a single flower, or eighty-one times too many. With Geum urbanum, however, aeeording to Gärtner, the pollen is only ten times too much. $\dagger$ As we thus see that the open state of all ordinary flowers, and the eonsequent loss of much pollen, neeessitate the development of so prodigious an excess of this precious substanee, why, it may be asked, are flowers always left open? As many plants exist throughout the vegetable kingdom which bear eleistogene flowers, there ean hardly be a doubt that all open flowers might easily have been converted into closed ones. The graduated steps by whieh this process could have been effected may be seen at the present time in Lathyrus nissolia, Biophytum sensitivum, and several other plants. The answer to the above question obviously is, that with permanently elosed flowers there could be no crossfertilisation.

The frequeney, almost regularity, with which pollen is transported by insects from flower to flower, often from a conșiderable distance, well deserves attention. $\neq$

* Quoted in 'Gard. Chron.' 1846, p. 771 .

+ Kölreuter, 'Vorlänfige Nachricht,' 1761, p. 9. Gärtner, 'Bcitrage zur Kenntniss, \&e. p. 346.

\pm An experiment made by Kölrenter ('Fortsetsung,' \&c. 1763, p. 69) affurils grool evidence on this hend. Iribiscus vesicarius is strongly dichogamous, its pollen buing shed before the stigmas are mature. Kölreuter marked 310 flowers, and put pollen from other flowers on their stigmas every day, so thit they were thoroughly fertilised; and he left the same number of other flowers to the ageney of insects. Afterwarls he eounted the seeds of both lots: the flowers which he had fertilised with such astonishing eare produeed 11,237 seeds, 
'This is best shown by' the impossibility in many cases of raising two varieties of the same speeies pure, if they grow at all near together; but to this subjeet I shall presently return; also by the many eases of hybrids which have appeared spontaneously both in gardens and a state of nature. With respeet to the distance from whieh pollen is often brought, no one who has had any experienee would expeet to obtain pure cabbage-seed, for instanee, if a plant of another variety grew within two or three hundred yards. An aceurate observer, the late Mr. Masters of Canterbury, assured me that he once had his whole stock of seeds "seriously affeeted with purple bastards," by some plants of purple kale which flowered in a eottager's garden at the distance of half a mile; no other plant of this variety growing any nearer.* But the most striking case which has been recorded is that by MI. Godron, + who shows by the nature of the hybrids produced that Primula grandiflora must have been erossed with pollen brought by bees from $P$. officinatis, growing at the distance of above two kilometres, or of about one English mile and a quarter.

All those who have long attended to hybridisation, insist in the strongest terms on the liability of eastrated flowers to be fertilised by pollen brought from distant plants of the same species. $\neq$ The following ease shows

whilst those left to the inseets produeed 10,886 ; that is, a less number by only 351 ; and this small inferiority is fully aecounted for by the insects not having worked during some days, when the weather was eold with continued rain.

* MIr. W. O. Marshall caught no less than seven speeimens of a moth (Cucullia umbratica) with the pollinia of the butterfy-oreh is (Habenaria chlorantha) stieking to their eyes, and, therefore, in the proper position for fertilising the flower's of this speeies, on an island in Derwentwaler, at the distanee of half a mile from any plaee where this plant grew : 'Nature,' 1872, p. 393.

† 'Revue des Sc. Nat.' 1S75, p. 331 .

† See, for instnnee, the remarks by Herbert, 'Amaryllidaecre, 1837, p. 349. Also Gärtner's strong expressions on this subjeet in lis 'Bastarderzeugung,' 1 s 49. p. 670 ; and 'Kenntuiss der Be- 
this in the elearest manner: Gärtner, before he had gained much experienee, castrated and fertilised 520 flowers on various speeies with pollen of other genera or other speeies, but left them unproteeted; for, as he says, he thought it a laughable idea that pollen should be brought fiom flowers of the same speeies, none of whieh grew nearer than between 500 and 600 yards.* The result was that 289 of these 520 flowers yielded no seed, or none that germinated; the seed of 29 flowers produeed hybrids, such as might have been expeeted from the nature of the pollen employed; and lastly, the seed of the remaining 202 flowers produeed perfeetly pure plants, so that these flowers must have been fertilised by pollen brought by inseets from a distanee of between 500 and 600 yards. $\dagger$ It is of course possible that some of these 202 flowers might have been fertilised by pollen left aeeidentally in them when they were castrated; but to show how improbable this is, I may add that Gärtner, during the next eighteen years, eastrated no less than 8042 flowers and hybridised them in a elosed room; and the seeds from only seventy of these, that is considerably less than 1 per eent., produeed pure or unhybridised offspring. $\ddagger$

fruchtung,' 1St4, pp. 510, 573. Also Leeoq, 'De la liécondation,' \&c., 1845, p. 27. Some statements have been published during late years of the extraordinary tenlency of liybrid plants to revert to their parent forms; but as it is not said how the flowers were protected from inseets, it may be suspected that they were often fertilised with pollen brought from a distance from the parentspecies.

* 'Kenntniss der Befruehtung,' pp. 539, 550, 575, 576. $\dagger$ Hensehel's experiments (quoted by Gärtner, 'Kenntniss,' \&e., p. 574), which are worthless in all other respects, likewise show how largely flowers are intererossed by insects. He eastrated many flowers on thirtyseven speeies, belonging to twentytwo genera, and put on their stigmas either uo pollen, ol pollen from distinct genera, yut they all seeded, and all the seedlings raised from them were of eomrse jure.

f 'Kenntniss,' de. p). 555, 576 . 
From the various facts now given, it is evident that most flowers are adapted in an admirable manner for eross-fertilisation. Nevertheless, the greater number likewise present struetures which are manifestly adapted, though not in so striking a manner, for selffertilisation. 'The ehief of these is their hermaphrodite eondition; that is, their including within the same eorolla both the male and female reproduetive organs. These often stand elose together and are mature at the same time; so that pollen from the same flower eamnot fail to be deposited at the proper period on the stigma. There are also various details of strueture adapted for self-fertilisation.* Sueh structures are best shown in those eurious eases diseovered by $\mathrm{H}$. Müller, in whieh a species exists under two forms,one bearing eonspienous flower's fitted for eross-fertilisation, and the other smaller flowers fitted for self-fertilisation, with many parts in the latter slightly modified for this speeial purpose. $t$

As two objeets in most respeets opposed, namely, eross-fertilisation and self-fertilisation, have in many cases to be gained, we can understand the eo-existenee in so many flowers of struetures whieh appear at first sight unneeessarily complex and of an opposed nature. We ean thus understand the great contrast in strueture between cleistogene flowers, which are adapted exclusively for self-fertilisation, and ordinary flowers on the same plant, whieh are adapted so as to allow of at least oecasional eross-fertilisation. $\neq$ The former are always

* H. Miiller, 'Die Befruehtung,' \&.c. p. 448.

†'Nature,' 1873, pp. 4t, 433.

Fritz Miiller has diseovered in the animal kinglom ('Jenaisehe Zeitschr.' B. iv. p. 451) a ease euriously analogous to that of the plants which ben eleistogine and perfect flowers. He finds in the nests of 'Termites, in Brazil, males and females with imperfect wings, which do not lenve the nests and propagate the species in a eleistogene mauner 
mimute, eompletely elosed, with their petals more or less rudimentary and never brightly coloured; they never secrete nectar, never are odoriferous, have very small anthers whieh produce only a few grains of pollen, and their stigmas are but little developed. Bearing in mind that some flowers are cross-fertilised by the wind (called anemophilous by Delpino), and others by insects (ealled entomophilous), we ean further understand, as was pointed out by me several years ago, the great contrast in appearance between these two classes of flowers. Anemophilous flowers resemble. in many respeets cleistogene flowers, but differ widely in not being closed, in produeing an extraordinary amount of pollen which is always incoherent, and in the stigma often boing largely developed or plumose. We eertainly owe the beauty and odour of our flowers and the storage of a large supply of honey to the existenee of inseets.

On the Relation between the Structure and Conspicuousness of Flowers, the Visits of Insects, and the Advantages of Cross-fertilisation.

It has already been shown that there is no elose relation between the number of seeds produeed by flowers when erossed and self-fertilised, and the degree to whieh their offspring are affected by the two processes. I have also given reasons for believing that the inefficiency of a plant's own pollen is in most eases

but only if a fully-developed queen after swarming rloes not enter the old nost. The fully-developed males and fimales are winged, and individuals from distinet nests ean liardly fail often to intercross. In the aet of swarming they are destroyed in almost infinite numbers by a linst of' enemies, so that a queen may often filil to enter an old nest; and then the imperfeetly developed malesanil females propagate and keep up the stoek.

* 'Journal of Linn. Soc.' vol. vii. Bot. 1863, p. 77. 
an incidental result, or has not been specially acquired for the sake of preventing self-fertilisation. On the other hand, there can hardly be a doubt that dichogamy, which prevails according to Hildebrand* in the greater number of species, - that the heterostyled condition of certain plants,-and that many mechanical structures -have all been acquired so as both to check selffertilisation and to favour cross-fertilisation. The means for favouring cross-fertilisation must have been acquired before those which prevent self-fertilisation; as it would manifestly be injurious to a plant that its stigma should fail to receive its own pollen, unless it had already become well adapted for receiring pollen from another individual. It should be observed that many plants still possess a high porrer of self-fertilisation, although their flowers are excellently constructed for cross-fertilisation-for instance, those of many papilionaceous species.

It may be admitted as almost certain that some structures, such as a narrow elongated nectary, or a long tubular corolla, have been developed in order that certain kinds of insects alone should obtain the nectar. These insects would thus find a store of nectar preserved from the attacks of other insects; and they would thus be led to visit frequently such flowers and to carry pollen from one to the other. $\dagger$ It might perhaps have been expected that plants having their flowers thus peculiarly constructed would profit in a greater degree by being crossed, than ordinary or simple flowers; but this does not seem to hold good. Thus Troprolum minus has a long nectary and an irregular corolla, whilst Limnanthes

* 'Die Geschlcchter Vertheilung,' Sc. p. 32.

$f$ 'See the interesting discussion on this subject by H. Mïller,

- Die Befruchtung, 'sc. p. $4: 31$. 
douglasii has a regular flower and no proper nectary, yet the crossed seedlings of both species are to the self-fertilised in height as 100 to 79 . Salvia coccinea has an irregular corolla, with a curious apparatus by which insects depress the stamens, while the flowers of Ipomoea are regular; and the crossed seedlings of the former are in height to the self-fertilised as 100 to 76 , whilst those of the Ipomoea are as 100 to 77. Fagopyrum is dimorphic, and Anagallis collina is non-dimorphic, and the crossed seedlings of both are in height to the self-fertilised as 100 to 69 .

With all European plants, excepting the comparatively rare anemophilous kinds, the possibility of distinct individuals intercrossing depends on the visits of insects; and $H$. Müller has proved by his valuable observations, that large conspicuous flowers are visited much more frequently and by many more kinds of insects, than are small inconspicuous flowers. He further remarks that the flowers which are rarely visited must be capable of self-fertilisation, otherwise they would quickly become extinct. * There is, however, some liability to error in forming a judgment on this head, from the extreme difficulty of ascertaining whether flowers which are rarely or never visited during the clay (as in the above given case of Fumaria capreolata) are not visited by small nocturnal Lepidoptera, which are known to be strongly attracted by sugar. $\dagger$ The two lists given in the early part of this chapter support Müller's conclusion that small and inconspicuous flowers are completely self-fertile;

* 'Befruehtung,' \&e., p. 426. 'Nature,' 1873, p. 433.

+ In answer to a question by me, the editor of an entomological journal writes - "The Depressarix, as is notorious to cvery collector of Noctua, come very freely to sugar, and no doubt naturally visit flowers:" the "Entomologists' Weelily Intelligencer,' 1860, 1. 103. 
for only eight or nine out of the 125 speeies in the two lists come under this head, and all of these were proved to be highly fertile when inseets were excluded. The singularly ineonspieuous flowers of the Fly Ophrys (O. muscifera), as I have elsewhere shown, are rarely visited by insects ; and it is a strange instance of imperfeetion, in eontradietion to the above rule, that these flowers are not self-fertile, so that a large proportion of them do not produee seeds. The eonverse of the rule that plants bearing small and inconspieuous flowers are self-fertile, namely, that plants with large and eonspicuous flowers are self-sterile, is far from true, as may be seen in our seeond list of spontaneously self-fertile species; for this list ineludes sueh species as Ipomœa purpurea, Adonis restivatis, Verbascum thapsus, Pisum sativum, Lathyrus odoratus, some speeies of Paparer and of Nymphra, and others.

The rarity of the visits of inseets to small flowers, does not depend altogether on their ineonspieuousness, but likewise on the absenee of some suffieient attraetion ; for the flowers of Trifolium arvense are extremely small, yet are ineessantly visited by hive and humblebees, as are the small and dingy flowers of the asparagus. The flowers of Linaria cymbalaria are small and not very conspicuous, yet at the proper time they are freely visited by hive-bees. I may add that, aecording to Mr. Bennett, ${ }^{*}$ there is another and quite distinet class of plants which cannot be mueh frequented by inseets, as they flower either exclusively or often during the winter, and these seem adapted for selffertilisation, as they shed their pollen before the flowers expand.

That many flowers have been rendered conspicuous

* 'Nature,' 1869, p. 11. 
for the sake of gruiding insects to them is highly probable or almost certain ; but it may be asked, have other flowers been rendered inconspicuous so that they may not be frequently visited, or have they merely retained a former and primitive condition? If a plant were much reduced in size, so probably would be the flowers through correlated growth, and this may possibly account for some cases; but the size and colour of the corolla are both extremely variable characters, and it can hardly be doubted that if large and brightlycoloured flowers were advantageous to any species, these could be acquired through natural selection within a moderate lapse of time, as indeed we see with most alpine plants. Papilionaceous flowers are manifestly constructed in relation to the visits of insects, and it seems improbable, from the usual character of the group, that the progenitors of the genera Vicia and Trifolium produced such minute and unattractive flowers as those of $V$. hirsuta and $T$. procumbens. We are thus led to infer that some plants either have not had their flowers increased in size, or have actually had them reduced and purposely rendered inconspicuous, so that they are now but little visited by insects. In either case they must also have acquired or retained a high degree of self-fertility.

If it became from any cause advantageous to a species to have its capacity for "self-fertilisation increased, there is little difficulty in believing that this could readily be effected; for three cases of plants varying in such a manner as to be more fertile with their own pollen than they originally were, occurred in the course of my few experiments, namely, with Mimulus, Ipomoa, and Nicotiana. Nor is there any reason to rloubt that many kinds of plants are capable under favourable circumstances of propagating themselves 
for very many generations by self-fertilisation. This is the ease with the varieties of Pisum sativum and of Lathyrus odoratus whieh are eultivated in England, and with Ophrys apifera and some other plants in a state of nature. Nevertheless, most or all of these plants retain structures in an effieient state whieh cannot be of the least use exeepting for erossfertilisation. We have also seen reason to suspeet that self-fertilisation is in some peeuliar manner benefieial to certain plants; but if this be really the ease, the benefit thus derived is far more than eounterbalaneed by a eross with a fresh stoek or with a slightly different variety.

Notwithstanding the several eonsiderations just advaneed, it seems to me highly improbable that plants bearing small and ineonspicuous flowers have been or should eontinue to be subjeeted to selffertilisation for a long series of generations. I think so, not from the eril whieh manifestly follows from self-fertilisation, in many cases even in the first generation, as with Viola tricolor, Sarothamnus, Nemophila, Cyelamen, \&c.; nor from the probability of the evil inereasing after several generations, for on this latter head I have not suffieient evidenee, owing to the manner in whieh my experiments were eondueted. But if plants bearing small and ineonspienous flowers were not oceasionally intererossed, and did not profit by the proeess, all their flowers would probably lave been rendered eleistogene, as they would thus have largely benefited by having to produee only a small quantity of safely-proteeted pollen. In eoming to this eonelusion, I have been guided by the frequeney with whieh plants belonging to distinet orders have been rendered eleistogene. But I ean hear of no instanee of a speeies with all its flowers rendered permanently 
cleistogene. Leersia makes the nearest approach to this state; but as already stated, it has been known to produce perfect flowers in one part of Germany. Some other plants of the cleistogene class, for instance Aspicarpa, have failed to produce perfect flowers during several years in a hothouse; but it does not follow that they would fail to do so in their native country, any more than with Vandellia, which with me producerl only cleistogene flowers during certain years. Plants belonging to this class commonly bear both kinds of flowers every season, and the perfect flowers of Viola canina yield fine capsules, but only when visited by bees. TVe have also seen that the seedlings of Ononis minutissima, raised from the perfect flowers fertilised with pollen from another plant, were finer than those from self-fertilised flowers; and this was likewise the case to a certain extent with Vandellia. As therefore no species which at one time bore small and inconspicuous flowers has had all its flowers rendered cleistogene, I must believe that plants now bearing small and inconspicuous flowers profit by their still remaining open, so as to be occasionally intercrosserl by insects. It has been one of the greatest oversights in my work that I did not experimentise on such flowers, owing to the difficulty of fertilising them, and to my not having seen the importance of the subject.*

* Some of the species of Solanum would be gooil ones for such cxperiments, for they are said by H. Müller ('Befruchtung', p. 431) to be unattractive to insects from not secreting nectar, not producing much pollen, and not being very conspicunns. Hence probably it is thist, according to Verlot ('Production des Variétés,' 1865, p. 72), the varieties of "les aubergines et les tomates" (species of Solit- num) do not intercross when they are cultivated near together; but it should be remembered that these are not enlemic specius. On the other hand, the flowers of the comirion potato (S. tuberosum), though they do not secrete nectar (Kurr', "Bedeutung der" Nekt.rrien,' 1533 , p. 40), yet cammot be ronsidered as inconspicuous. and they are sometimes visited by Diptera (Miiller) and, as I havo 
It should be remembered that in two of the cases in which highly self-fertile varieties appeared amongst my experimental plants, namely, with Mimulus and Nicotiana, such varieties were greatly benefited by a cross with a fresh stock or with a slightly different variety; and this likewise was the case with the cultivated varieties of Pisum sativum and Lathyrus odoratus, which have been long propagated by selffertilisation. Therefore until the contrary is distinctly proved, I must believe that as a general rule small and inconspicuous flowers are occasionally intercrossed by insects; and that after long-continued self-fertilisation, if they are crossed with pollen brought from a plant growing under somewhat different conditions, or descended from one thus growing, their offspring would profit greatly. It cannot be admitted, under our present state of linowledge, that self-fertilisation continued during many successive generations is erer the most beneficial method of reproduction.

The Means which favour or ensure Flouers being fertilised with Pollen from a distinct Plant.- We hare seen in four cases that seedlings raised from a cross between flowers on the same plant, even on plants appearing distinct from having been propagated by stolous or cuttings, were not superior to seedlings from self-fertilised flowers; and in a fifth case (Digitalis) superior only in a slight degree. Therefore we might expect that with plants growing in a state of nature a cross between the flowers on distinct individuals, and not merely letween the flowers on the same plant, would generally

secn, by humble-loces. Tinzmann (as quoted in '(ialdeners' Chronicle; $1816,1 \%, 18: 3$ ) finnd that sume of the varicties did not henr seed when fertilised wilh pullen from the same varicty, but were fertile with that from another varicty. 
or often be effected by some means. The fact of bees and of some Diptera visiting the flowers of the same species as long as they can, instead of promiscuously visiting various species, favours the intercrossing of distinct plants. On the other hand, insects usually search a large number of flowers on the same plant before they fly to another, and this is opposed to crossfertilisation. 'The extraordinary number of flowers which bees are able to search within a very short space of time, as will be shown in a future chapter, increases the chance of cross-fertilisation; as does the fart that they are not able to perceive without entering a flower whether other bees have exhausted the nectar. For instance, H. Miuller found* that four-fifths of the flowers of Lamium album which a humble-bee visited had been already exhansted of their nectar. In order that distinct plants should be intercrossed, it is of course indispensable that two or more individuals should grow near one another'; and this is generally the case. 'Thus t. de Candolle remarks that in ascending a mountain the individuals of the same species do not commonly disappear near its upper limit quite gradually, but rather abruptly. This fact can hardly be explainer by the nature of the conditions, as these graduate away in an insensible manner, and it probably depends in large part on vigorous seedlings being produced only as high up the mountain as many individuals can subsist together.

With respect to dicecious plants, distinct individuals must always fertilise each other. With monocious plants, as pollen has to be carried from flower to flower, there will always be a good chance of its being carrierl from plant to plant. Delpino has also observed t the 311.

† 'Ult. Osservazioni,' \&c., part ii. fasc. ii. p. 337. 
curious fact that certain individuals of the monocious walnut (Juglans regia) are proterandrous, and others proterogynous, and these will reciprocally fertilise each other. So it is with the common nut (Corylus avellana), * and, what is more surprising, with some few hermaphrodite plants, as observed by H. Müller.† These latter plants cannot fail to act on each other like dimorphic or trimorphic species, in which the union of two individuals is necessary for full and normal fertility. With ordinary hermaphrodite species, the expansion of only a few flowers at the same time is one of the simplest means for favouring the intercrossing of distinct individuals; but this would render the plants less conspicuous to insects, unless the flowers were of large size, as in the case of several bulbous plants. Kerner thinks $\ddagger$ that it is for this object that the Anstralian Villarsia parnassifolia produces daily only a single flower. Mr. Cheeseman also remarks, $\$$ that as certain Orchids in New Zealand which require insect-aid for their fertilisation bear only a single flower, distinct plants cannot fail to intercross.

Dichogamy, which prevails so extensively throughout the vegetable kingdom, much increases the chance of distinct individuals intercrossing. With proterandrous species, which are far more common than proterogynous, the young flowers are exclusirely male in function, and the older ones exclusively female: and as bees habitually alight low down on the spikes of flowers in order to crawl upwards, they get dusted with pollen from the uppermost flowers, which they carry to the stigmas of the lower and older flowers on the next spike which they visit. The degree to

* 'Nature,' 1875, j. 26.

† 'Die Befruchtung, \&c. Ip. $255,339$.
+ 'Die S.hntzmittel,' Sc. p. 23.

§ 'Transact. New Zealand Institute,' vol. v. 1ST3, 1. 356. 
whieh distinct plants will thus be intercrossed depends oul the number of spikes in full flower at the same time on the same plant. With proterogynous flowers and with depending raeemes, the manner in which insects visit the flowers ought to be reversed in order that distinet plants should be intererossed. But this whole subjeet requires further investigation, as the great importanee of crosses between distinet individuals, instead of merely between distinet flowers, has hitherto been hardly recognised.

In some few eases the speeial movements of eertain organs almost ensure pollen being carried from plant to plant. Thus with many orchids, the pollen-masses after becoming attached to the head or proboscis of an inseet do not move into the proper position for striking: the stigma, until ample time has elapsed for the insect to fly to another plant. With Spiranthes autumnatis, the pollen-masses eannot be applied to the stigma until the labellum and rostellum have moved apart, and this movement is very slow.* With Posoqueria firagrans (one of the Rubiaeex) the same end is gained by the movement of a speeially eonstruieted stamen, as deseribed by Fritz Müller.

We now come to a far more general and therefore more important means by which the mutual fertilisation of distinet plants is effeeted, namely, the fertilising power of pollen from another variety or individual being greater than that of a plant's own pollen. The simplest and best known ease of prepotent action in pollen, though it does not bear direetly on our present subjeet, is that of a plant's own pollen over that from a distinet species. If pollen from a distinct species be plaeed on the stigma of a eastrated flower, and then

* 'Ihe Various Contrivances by which british and Foleign
Orchids are fertilised,' 1st edit. p. 128. 
after the interval of several hours, pollen from the same species be placed on the stigma, the effects of the former are wholly obliterated, exeepting in some rare cases. If two varieties are treated in the same manner, the result is analogous, though of direetly opposite nature; for pollen from any other variety is often or generally prepotent over that from the same flower. I will give some instances: the pollen of Mimulus luteus regularly falls on the stigma of its own flower, for the plant is highly fertile when inseets are excluded. Now several flowers on a remarkably eonstant whitish rariety were fertilised without being eastrated with pollen from a yellowish variety; and of the twenty-eight seedlings thus raised, every one bore yellowish flowers, so that the pollen of the yellow variety eompletely overwhelmed that of the mother-plant. Again, Iberis umbellata is spontaneously self-fertile, and I saw an abundance of pollen from their own flowers on the stigmas; nevertheless, of thirty seedlings raised from non-castrated flowers of a erimson variety erossed with pollen from a pink variety, twenty-four bore pink flowers, like those of the male or pollen-bearing parent.

In these two eases flowers were fertilised with pollen from a distinet variety, and this was shown to be prepotent by the charaeter of the offspring. Nearly similar results often follow when two or more self-fertile varieties are allowed to grow near one another and are visited by inseets. The common cabbage produees a large number of flowers on the same stalk, and when insects are exeluded these set many eapsules, moderately rieh in seeds. I planted a white Kiohl-rabi, a purple Kohl-rabi, a Portsmouth broeeoli, a Brusscls sprout, and a Sugar-loaf eabbage near together and left them uneovered. Seeds eolleeted from each.kind were sown in separate beds; and the majority of the seedlings in 
all five beds were mongrelised in the most eomplieated mamner, some taking more after one variety, and some after another. The effects of the Kohl-rabi were partieularly plain in the enlarged stems of mauy of the seedlings. Altogether 233 plants were raised, of whieh 155 were mongrelised in the plainest manuer, and of the remaining 78 not half were absolntely pure. I repeated the experiment by planting near together two varieties of eabbage with purple-green and whitegreen laeinated leaves; and of the 325 seedlings raised from the purple-green variety, 165 had whitegreeu and 160 purple-green leaves. Of the 466 seedlings raised from the white-green variety, 220 had purple-green and 246 white-green leaves. These eases show how largely pollen from a neighbouring variety. of the eabbage effaees the aetion of the plant's own pollen. We should bear in mind that pollen must be earried by the bees from flower to flower on the same large branehing stem mueh more abundantly than from plant to plant; and in the ease of plants the flowers of whieh are in some degree diehogamous, those on the same stem would be of different ages, and. would thus be as ready for mutual fertilisation as the flowers on distinet plants, were it not for the prepoteney of pollen from another variety.*

Several varieties of the radish (Raphanus sativus), which is moderately self-fertile when inseets are ex: cluded, were in flower at the same time in my garden. Seed was eolleeted from one of them, and out of twentytwo seedlings thus raised only twelve were true to their kind. $\dagger$

* A writer in the 'Garrleners' Chronielo' (1855, 1). 730) says that lie planted a lied of turipips (Brassica rapa, and of rapc (II. napus) close together, and rowed the seels of the former, Thu result was that scarcely one seedling was truo to its lind, and several elosely resenbled rape.

$\uparrow$ Duhamel, as quoted by God- 
The onion produces a large number of flowers, all crowded together into a large globular head, each flower having six stamens; so that the stigmas receive plenty of pollen from their own and the adjoining anthers. Consequently the plant is fairly self-fertile when protected from insects. A blood-red, silver, globe and Spanish onion were planted near together; and seedlings were raised from each kind in four separate beds. In all the beds mongrels of rarious kinds were numerous, except amongst the ten seedlings from the blood-red onion, which included only two. Altogether forty-six seedlings were raised, of which thirty-one had been plainly crossed.

A similar result is known to follow with the varieties of many other plants, if allowed to flower near together : I refer here only to species which are capable of fertilising themselves, for if this be not the case, they would of course be liable to be crossed by any other variety growing near. Horticulturists do not commonly distinguish between the effects of variability and intercrossing; but I have collected evidence on the natural crossing of varieties of the tulip, hyacinth, anemone, ranunculus, strawberry, Leptosiphon androsaceus, oringe, rhododendron and rhubarb, all of which plants I believe to be self-fertile.* Much other indirect evidence could

ron, 'De l'Hepèce,' tom. ii. p. 50, makes an analogous statcment with respect to this plant.

* Wifh respect to tulips and soms other flowers, seo Godron, 'De l'Espèce,' tom. i. p. 252. For anrmones, 'Gard. Chron.' 1859, p. 98. For strawberies, see Herbert in 'Transict. of Hort. Soc.' vol. iv. 1). 17. The same observer elsewhere spenks of the spontrneons crossing of rhododendrons. Gallesio malies the same statement with respeet to orminges. I have myself known extensive erussing to ocur witl the common rhubarb. For l entosiphon, Verlut, 'Des Vauiétés,' 1865, 1. 20. I have not included in my list the Carnation, Nemuphiln, or Antirrlinum, the varieties of which are known to cinss freely, beenuse these plants ne not alwars selffertile. I know mothing about the self-fertility of Trollins (I.e$\mathrm{coq}$. 'Dc la Ficondition,' IS62. 1).93), Nahonia, and Crinum, in which genera the species intercross 
be given with respect to the extcnt to which varieties of the same species spontaneously intercross.

Gardeners who raise seed for salc are compelled by dearly bought experience to take extraordinary precautions against intercrossing. Thus Messis. Sharp "have liund engaged in the growth of sced in no less than eight parishes." The mere fact of a vast number of plants belonging to the same variety growing together is a considerable protection, as the chances are strong in favour of plants of the same variety intercrossing; and it is in chief part owing to this circumstance, that certain villages have become famous for pure seed of particular varieties.* Only two trials were made by me to ascertain after how long an interval of time, pollen from a distinct variety would obliterate more or less completely the action of a plant's own pollen. 'T'he stigmas in two lately expanded flowers on a variety of cabbage, called Ragged Jack, were well covered with pollen from the same plant. After an interval of twenty-three hours, pollen from the Early Barnes Cabbage growing at a distance was placed on both stigmas; and as the plant was left uncovered, pollen from other flowers on the Ragged Jack would certainly have been left by the bees during the next two or three days on the same two stigmas. Under these circumstances it seemed very unlikcly that the pollen of the Barnes cabbage would produce any effect; bnt three out of the fifteen plants raised from the two capsules thus produced were plainly mongrelised: and I have no doubt that the twelve other plants were

largrly. With respect to Mahonia, it is now searcely possible to pincure in this conntry pure specimens of $M$. aruifolium or repens; and the various species of Crimm sent by Ferbert ('A maryllidirea,' p. 32) to Ca!cutta, crosserl there so freely that pure sced could not be saveil.

* With respect to MIcssrs. Sharp, sce 'Gardeners' Chrmicle,' 1856, 1. 823. Lindley's 'I'heory of Horticulture,' p. 319. 
affected, for they grew mueh more vigorously than the self-fertilised seedlings from the Ragged Jaek planted at the same time and under the same conditions. Seeondly, I placed on several stigmas of a long-styled eorslip (Primula veris) plenty of pollen from the same plant, and after twenty-four hours added some from a short-styled dark-red Polyantlıus, whieh is a variety of the cowslip. From the flowers thus treated thirty seedlings were raised, and all these without exeeption bore reddish flowers; so that the effeet of the plant's own pollen, though plaeed on the stigmas twentyfour hours previously, was quite destroyed by that of the red variety. It should, however, be observed that these plants are dimorphie, and that the seeond union was a legitimate one, whilst the first was illegitimate; but flowers illegitimately fertilised with their own pollen yield a moderately fair supply of seeds.

We have hitherto eonsidered only the prepotent fertilising power of pollen from a distinet variety orer a plant's own pollen,-both kinds of pollen being plaeed on the same stigma. It is a mueh more remarkable faet that pollen from another individual of the same variety is prepotent over a plant's own pollen, as shown by the superiority of the seedlings raised from a eross of this kind over seedlings from selffertilised flowers. Thus in Tables A, B, and C, there are at least fifteen speeies which are self-fertile when inseets are exeluded; and this implies that their stigmas must receive their own pollen; nerertheless, most of the seedlings which were raised by fertilising the noncastrated flowers of these fifteen species with pollen from another plant were greatly superior, in lieight, weight, and fertility, to the self-fertilised oftspring."

* 'These fifteen species consist of Brassica oleracca, Reseda odorata and lutea, Limnanthes douglasii, Pejacer vagum, Viscaria oculatu, 
For instanee, with Ipomoed purpurea every single intercrossed plant exeeeded in height its self-fertilised opponent mil the sixth generation; and so it was with Mimulus luteus until the fourth generation. Out of six pairs of crossed and self-fertilised cabbages, every one of the former was mueh heavier than the latter. With Papaver vagum, out of fifteen pairs, all but two of the erossed plants were taller than their selffertilised opponents. Of eight pairs of Lupinus luteus, all but two of the erossed were taller; of eight pairs of Beta vulgaris all but one; and of fifteen pairs of Zea mays all but two were taller. Of fifteen pairs of Limnanthes donglasii, and of seven pairs of Lactuca sativa, every single crossed plant was taller than its self-fertilised opponent. It should also be observed that in these experiments no particular care was taken to erossfertilise the flowers immediately after their expansion; it is therefore almost eertain that in many of these cases some pollen from the same flower will have already fallen on and aeted on the stigma.

There ean hardly be a doubt that several other species of whieh the erossed seedlings are more rigorous than the self-fertilised, as shown in Tables A, $\mathrm{B}$, and $\mathrm{C}$, besides the above fifteen, must have reeeived their own pollen and that from another plant at nearly the same time; and if so, the same remarks as those just given are applieable to them. Searcely any result from my experiments has surprised me so mueh as this of the prepotency of pollen from a distinct individual over each plant's own pollen, as proved by the greater constitutional vigour of the erossed seedlings. The evidence of prepotency is here deduced from the

Beta vulyaris, Lupinus luteus, Ipomae purpurea, Mimnlus luteus, Calcealaria, Verbascum thupsus,
Vandellir nummularifolia, Lactuca sutiva, and Zea mays. 
comparative growth of the two lots of secdlings; but we have similar evidence in many cases from the much greater fertility of the non-castrated flowers on the mother-plant, when these reccived at the same time their own pollen and that from a distinct plant, in comparison with the flowcrs which receired only their own pollen.

From the various facts now given on the spontancous intercrossing of varictics growing near together, and on the effects of cross-fertilising flowers which are selffcrtile and have not been castrated, we may conclude that pollen brought by insects or by the wind from a distinct plant will generally prevent the action of pollen from the same flowcr, even though it may have been applied some time beforc: and thus the intercrossing of plants in a state of nature will be greatly favoured or ensurcd.

The case of a great tree covered with innumerable hcrmaphrodite flowers scems at first sight strongly opposed to the belicf in the frequency of intercrosses betwcen distinct individuals. The flowers which grow on the opposite sides of such a tree will hare becn exposed to somewhat different conditions, and a cross between them may perhaps be in somc degree beneficial; but it is not probable that it would be ncarly so beneficial as a cross betwecn flowers on distinct trees, as we may infer from the incficiency of pollen taken from plants which have been propagated from the same stock, though growing on separate roots. The number of bees which frequent certain kinds of trees when in full flower is very great, and they may be seen flying from tree to tree more frequently than might have been cxpceted. Nevcrthclcss, if we consider how numerous arc the flowers, for instance, on a horsechestnut or lime-tree, an incomparably larger number 
of flowers must be fertilised by pollen brought from other flowers on the same tree, than from flowers on a distinet tree. But we should bear in mind that with the horse-ehestnut, for instanee, only one or two of the sereral flowers on the same pedunele produee a seed; and that this seed is the produet of only one out of several ovules within the same ovarium. Now we know from the experiments of Herbert and others* that if one flower is fertilised with pollen which is more effieient than that applied to the other flowers on the same peduncle, the latter often drop off ; and it is probable that this would oceur with many of the self-fertiliser flowers on a large tree, if other and adjoining flowers were eross-fertilised. Of the flowers annually produeed by a great tree, it is almost certain that a large number would be self-fertilised; and if we assume that the tree produeed only 500 flowers, and that this number of seeds were requisite to keep up the stoek, so that at least one seedling should liereafter struggle to maturity, then a large proportion of the seedlings would neeessarily be derived from self-fertilised seeds. But if the tree anmully produeed 50,000 flowers, of whieh the self-fertilised dropped off without yielding seeds, then the eross-fertilised flowers might yield seeds in sufficient number to keep up the stoek, and most of the seedlings would be vigorous from being the produet of a eross between distinet individuals. In this manner the production of a vast number of flowers, besides serving to entiee numerous inseets and to eompensate for the aeeidental destruction of many Howers by spring-frosts or otherwise, would be a very great advantage to the species; and when we behold our orchard-trees eovered with a white sheet of bloom

* 'Vuriation under Domestication,' ch. xvii. 2nd edit. vol. ii. p. 120. 
in the spring, we should not falsely accuse nature of wasteful expenditure, though comparatively little fruit is produced in the autumn.

Anemophitous Plants.-The nature and relations of plants which are fertilised by the wind have been admirably discussed by Delpino* and H. MIüller; and I have already made some remarks on the structure of their flowers in contrast with those of entomophilous species. There is good reason to believe that the first plants which appeared on this earth were cryptogamic; and judging from what now occurs, the male fertilising element must either have possessed the power of spontaneous movement through the water or orer damp surfaces, or have been carried by currents of water to the female organs. That some of the most ancient plants, such as ferns, possessed true sexual organs there can hardly be a doubt; and this shows, as Hildebrand remarks, $\uparrow$ at how early a period the sexes were separated. As soon as plants became phanerogamic and grew on the dry ground, if they were ever to intercross, it would be indispensable that the male fertilising element should be transported by some means through the air; and the wind is the simplest means of transport. There must also have been a period when winged insects did not exist, and plants would not then hare been rendered entomophilous. Even at a somewhat later period the more specialised orders of the Hymenoptera.

* Delpino, 'Ult. Osservazioni sulla Dicogamia,' part ii. fase. i. 1870 ; and 'Studi sopra min Lignaggio anemofilo,' \&c. 1871. II. Miiller, 'Die Befruchtung,' SE. pp. 412, 442, Both these antloors remark that plants must liave beeu anemophilous before they were entomophilous. H. Miiller further diseusses in a very interesting mamer the steps by which entomophilous flower's became nectariferous and gradually acquired their present structure throngh sneecsive beneficial elianges.

$\dagger$ 'Die Geschlechtor-Vertheilung,' 1867, pp. 81-90. 
Lepidoptera, and Diptera, which are now chiefly concerned with the transport of pollen, did not exist. Therefore the earliest terrestrial plants known to us, namely, the Coniferæe and Cycadire, no doubt were anemophilous, like the existing species of these same groups. A restige of this early state of things is likewise shown by some other groups of plants which are anemophilous, as these on the whole stand lower in the scale than entomophilous species.

There is no great difficulty in understanding how an anemophilous plant might have been rendered entomophilous. Pollen is a nutritious substance, and would soon have been discovered and devoured by insects; and if any adhered to their bodies it would have been carried from the anthers to the stigma of the same flower, or from one flower to another. One of the chief characteristics of the pollen of anemophilous plants is its incoherence; but pollen' in this state can adhere to the hairy bodies of insects, as we see with some Leguminosæ, Ericaceæ, and Melastomaceæ. We have, however, better evidence of the possibility of a transition of the above kind in certain plants being now fertilised partly by the wind and partly by insects. The common rhubarb (Rheum rhaponticum) is so far in an intermediate condition, that I have seen many Diptera sucking the flowers, with much pollen adhering to their bodies; and yet the pollen is so incoherent, that clouds of it are emitted if the plant be gently shaken on a sunny day, some of which could hardly fail to fall on the large stigmas of the neighbouring. flowers. According to Delpino and H. Müller, ${ }^{*}$ some species of Plantago are in a similar intermediate condition.

* 'Die Befruchtung,' \&e. p. 342. 
Although it is probable that pollen was aboriginally the sole attraction to insects, and although many plants now exist whose flowers are frequented cxclusivcly by pollen-devouring insects, yet the great majority secrete nectar as the chicf attraction. Many years ago I suggested that primarily the saccharine. matter in ncctar was cxcretcd * as a waste product of chemical changes in the sap; and that when the excretion happened to occur within the envelopes of a flower, it was utilised for the important object of cross-fertilisation, being subsequently much increased in quantity and stored in various ways. This view is rendered probable by the lcaves of some trees excreting, under ccrtain climatic conditions, without the aid of spccial glands, a saccharine fluid, often called honcy-dew. This is the case with the leares of the lime; for although some anthors have disputed the fact, a most capable judge, Dr. Naxirell Masters, informs me that, after having heard the discussions on this subject before the Horticultural Socicty, he feels no doubt on this head. The leaves, as well as the cut stems, of the manna ash (Fraxinus ormus) sccrete in a like manner saccharinc matter. $\dagger$ According to Treviranns, so do the upper surfaces of the lcares of Cardus arctioides during hot weather. Nany analogous facts could be given. $\ddagger$ There are, however, a considerable number of plants which bear small glands $\$$ on their lcaves, petioles, phyllodia, stipules,

* Nectar was regarded by De Candolle and Dumal as an excretion, ns stated by Martinet in 'Annal des Sc. Nat." 1872 , tom. xiv. p. 211.

† 'Garl. Chinn.' 15;6, p. 242.

† Kurr, 'Untersuchmongen iber dir Jerlentung der Nelitarion.' 1833, p. 115.
$\S$ A large number of eases nre given by Delpino in the 'BulIetino Fntomologieo,' Anno vi. 1874. 'l'o these may be alded those given in iny text, as well ns the exeretion of saceliarine matter from the calyx of two species of Iris, and from the loractere of eertain Crehider: seo liurr. 
bractex, or flower peduncles, or on the outside of their calyx, and these glands secrete minute drops of a sweet fluid, which is eagerly sought by sugar-loving insects such as ants, hive-bees, and wasps. In the case of the glands on the stipules of Vicia sativa, the excretion manifestly depends on changes in the sap, consequent on the sum shining brightly; for I repeatedly observed that as soon as the sun was hidden behind clonds the secretion ceased, and the hive-bees left the field; but as soon as the sun broke out again, they returned to their feast.* I have observed an analogous fact with the secretion of true nectar in the flowers of Lobelia evinus.

Delpino, however, maintains that the power of secreting a sweet fluid by any extra-floral organ has been in every case specially gained, for the sake of attracting ants and wasps as defender's of the plant

'Bedeutung der Nektarica,' 1833, p]. 25, 2.S. Belt also refers ("Nicaragua,' p. 22t) to a similar excretion by many epiphytal nchids and passion-fiovers. Mr. Pindgers his seen much neetar secreted from the bases of the flower-pedineles of Vanilla. Iink says that the only example of a hypopetalous ncctary known to him is externally at the base of the flowers of Chironia decussuta: sce 'Reports on Botany, Ray Society,' 1846, p. 355 . An important memoir bearing on this subject has lately appenred by Reinke ('Göttingen Naehrichten,' 1873 , p. 825$)$, who shows that in many plants the tips of the serrations on the leaves in the, bul benr grands which seerete only at a very early age, and which liavo the same morphological structure as true ncctar-seereting glanrls. He further shows that the $n$ etrrstcreting glands nu the petioles of Prunus avizm aro not developed at a very early age, yet withcr away on the old lenves. They are homologous with those on the serrations of the bludes of the same leaves, as shown by theil' strueture and by transitionforms; for the lowest serrations on the blades of most of the leaves seerete nectar instead of resin (harz).

* I published a brief notioe of this ease in the 'Gard. Chronicle, 1855, July 21, p. 487 , and afterwarls made further observations. Besides the hive-bee, another species of bee, a moth, ants, and two kinds of flies sucked the drops of fluid on the stipules. The larger drops tasted swcet. 'The hive-bees never even looked at the flowers which were open at the same bime; whilst two species of limmble-hees neglceted the stipules ind visited only the thowers. 
against their enemies; but I have never seen any reason to believe that this is so with the three species observerl by me, namely, Prunus laurocerasus, Vicia sativa. and $V$. faba. No plant is so little attacked by enemies of any kind as the common bracken-fern (Pteris aquitina); and yet, as my son Francis has rliscovered, the large glands at the bases of the fronds, but only whilst young, excrete much sweetish fluid, which is eagerly sought by innumerable ants, chiefly belonging to IIyrmica; and these ants certainly do not serve as a protection against any enemy. Delpino argiles that such glands ought not to be considered as excretory, because if they were so, they would be present in every species; but I cannot see much force in this argument, as the leaves of some plants excrete sugar only during certain states of the weather. That in some cases the secretion serves to attract insects as defenders of the plant, and may have been developed to a high degree for this special purpose, I have not. the least doubt, from the observations of Delpino, and more especially from those of $M_{\mathrm{r}}$. Belt on Acacia sphrerocephata, and on passion-flowers. This acacia likewise produces, as an adiditional attraction to ants, small borlies containing much oil and protoplasm, and analogons bodies are developed by a Cecropia for the same purpose, as described by Fritz Mï̈ller.**

The excretion of a sweet fluid by glands seated outside of a flower is rarely utilised as a means for cross-fertilisation by the aid of insects; but this occurs with the bractere of the Marcgrariacere. as the late

* Mr. Belt has given a most. interesting necount ("The Naturalist in Nicaragua,' 1574, p. 218) of the paramount importance of ints as definders of the above Acacia. With respect to the Ce- cropia, see 'Nature,' $1876,0.304$. My son Frmeis has described the microscopical structure and development of these woudurful foodbodies in a paper read before the Iimuen Socicty. 
Dr. Crüger informed me from actual observation in the West Indies, and as Delpino infers with much acuteness from the relative position of the several parts of their flowers." Mr. Farrer has also shown $\dagger$ that the flowers of Coronilla are curionsly modified, so that bees may fertilise them whilst sueking the fluid secreted from the outside of the calyx. It further appears probable from the observations of Rev. W. A. Leighton, that the fluid so abundantly secreted by glands on the phyllodia of the Australian Acacia magnifica, whieh stand near the flowers, is eonneeted with their fertilisation.t

The amount of pollen produced by anemophilous plants, and the distanee to whieh it is often transported by the wind, are both surprisingly great. IIr. Hassall found that the weight of pollen produeed by a single plant of the bulrush (Typha) was 144 grains. Bucketfuls of pollen, chiefly of Conifere and Graminex, have been swept off the decks of vessels near the North Ameriean shore; and Mr. Riley has seen the ground near St. Louis, in Missouri, eovered with pollen, as if sprinkled with sulphur; and there was good reason to believe that this had been transported from the pine-forests at least 400 miles to the south. Kerner has seen the snow-fields on the higher Alps

* 'Ult. Osselvaz. Dieogamia,' 1868-69?, p. 1.88.

† 'Nature, 1874, p. 169.

+ 'Amnals and Mag. of Nat. Hist.' vol. xvi. 1S65, p. 14. In my work on the 'Fertilisation of Orchids;' and in a paper subsequcntly published in the 'Annals and Mag. of Nat. Histoly,' it has been shown that althourh certain kinds of orchirls possc-s a nectary, no nectar is actually sccretcel by it; but that inseets penctrate tho inner walls and suck the fluid eontained in the intercellular spaces. I further sugrested, in the case of some other orchids which do not secrete neetar, that inseets gnawed the labellum; ; ind this sugaestion las since been proved true. H. Mïiller and Delpino have now shown that some other plants have thickened petals which are suclied or gnitwed by insects, their fortilisation being thus aided. All the known faets on this head have been collected by Dulyino in his 'Ult. Osserv.' part ii. fasc, ii. 1875, pp. 59-6i3. 
similarly dusted; and Mr. Blackley found numerous pollen-grains, in one instance 1200, adhering to sticky slides, which were sent up to a height of from 500 to 1000 feet by means of a kite, and then uncovered by a special mechanism. It is remarkable that in these experiments there were on an average nineteen times as many pollen-grains in the atmosphere at the higher than at the lower levels.* Considering these facts, it is not so surprising as it at first appears that all, or nearly all, the stigmas of anemophilous plants should receive pollen brought to them by mere chance by the wind. During the early part of summer every object is thus dusted with pollen; for instance, I examined for anotlier purpose the labella of a large number of flowers of the Fly Ophrys (which is rarely visited by insects), and found on all very many pollengrains of other plants, which had been caught by their relvety surfaces.

The extraordinary quantity and lightness of the pollen of anemophilous plants are no doubt both necessary, as their pollen has generally to be carried to the stigmas of other and often distant flowers; for, as we shall soon see, most anemophilous plants have their sexes separated. The fertilisation of these plants is generally aided by the stigmas being of large size or plumose; and in the case of the Conifer:e, by the naked ovules secreting a drop of fluid, as shown by Delpino. Although the number of ane-

* For Mr. Hassall's obscrvations soc 'Ammals and Mag. of Nat. 11ist.' vol. viii. 1842, p. 10s. In the 'North American Journal of Seionce,' Jan. 18+2, thore is : 1 . account of the pollon swopt off the docks of a ressel. liley, - Wiftl lisport on the Noxious Insects of Missouri,' 1S73, 1. S6.
Kemer', 'Die Schutzmittel des Pollens,' 1N73, 1. 6. 'J'his anthor hrs also se en a lake in the 'lyrol so covered with pollen, that the water no longer appenrer blue. Mr. Hlackley, 'Lxpepinental Researches oil Ilay-fercr,' 15i3, pp. $1: 2,1+1-152$. 
mophilous speeies is small, as the author just quoted remarks, the number of individuals is large in eomparison with that of entomophilous species. 'This holds good especially in cold and temperate regions, where insects are not so numerous as under a warmer elimate, and where eonsequently entomophilous plants are less favourably situated. We see this in our forests of Conifere and other trees, sueh as oaks, beeches, birches, ashes, \&c.; and in the Graminex, Cyperaeex, and Juneaeex, which elothe our meadows and swamps; all these trees and plants being fertilised by the wind. As a large quantity of pollen is wasted by anemophilous plants, it is surprising that so mauy vigorous speeies of this kind abounding with individuals should still exist in any part of the world; for if they had been rendered entomophilous, their pollen would have been transported by the aid of the senses and appetites of insects with incomparably greater safety than by the wind. That sueh a eonversion is possible ean hardly be doubted, from the remarks lately made on the existence of intermediate forms; and apparently it has been effeeted in the group of willows, as we may infer from the nature of their nearest allies.**

It seems at first sight a still more surprising fact that plants, after having been onee rendered entomophilous, should ever again have become anemophilous; but this has occasionally though rarely oecurred, for instance, with the common Poterium sanguisorba, as may be inferred from its belonging to the Rosacer. Such eases are, however, intelligible, as almost all plants require to be oecasionally intercrossed; and if any entomophilous species ceased to be visited by insects, it would probably perish unless it were rendered

* Ir. Müller, ‘Die Befruchitung,' \&c. p. 149. 
anemophilous. A plantwould be neglected by insects if nectar failed to be secreted, unless indeed a large supply of attractive pollen was present; and from what we have seen of the excretion of saccharine fluid from leaves and glands being largely governed in several cases by climatic influences, and from some few flowers which do not now secrete nectar still retaining coloured guiding-marks, the failure of the secretion cannot be considered as a very improbable event. The same result would follow to a certainty, if winged insects ceased to exist in any district, or became very rare. Now there is only a single plant in the great order of the Cruciferr, namely, Pringlea, which is anemophilous, and this plant is an inhabitant of Kerguelen Land,* where there are hardly any winged insects, owing probably, as was suggested by me in the case of Madeira, to the risk which they run of being blown out to sea and restroyed.

A remarkable fact with respect to anemophilous plants is that they are often diclinous, that is, they are either monocious with their sexes separated on the same plant, or dioecious with their sexes on distinct plants. In the class Monœeia of Limneus, Delpino shows $\dagger$ that the species of twenty-eight genera are anemophilous, and of seventeen genera entomophilous. In the class Diœcia, the species of ten genern are anemophilous and of nineteen entomophilous. The larger proportion of entomophilous genera in this latter class is probably the indirect result of insects having the power of carrying pollen to another and sometimes distant plint much more securely thin the

* 'The Rov. $\Lambda$. E. Faton in 'Proc. Royal Soo.' vol. xxiii. 1875, 1). 351 .
†'Sturli sopma un Yignnggio anemofilo delle Cempositie, 1871. 
wind. In the above two c:lasses taken together there are thirty-eight anemophilous and thirty-six entomophilous genera; whereas in the great mass of hermaphrodite plants the proportion of anemophilous to entomophilous genera is extremely small. The cause of this remarkable difference may be attributed to anemophilous plants having retained in a greater degree than the entomophilous a primordial condition, in which the sexes were separated and their mutual fertilisation effected by means of the wind. That the earliest and lowest members of the vegetable kingdom had their sexes separated, as is still the case to a large extent, is the opinion of a high authority, Nägeli.* It is indeed difficult to avoid this conclusion, if we admit the view, which seems highly probable, that the conjugation of the Algæ and of some of the simplest animals is the first step towards sexual reproduction; and if we further bear in mind that a greater and greater degree of differentiation between the cells which conjugate can be traced, thus leading apparently to the development of the two sexual forms. $\dagger$ We have also seen that as plants became more highly developed and affixed to the ground, they would be compelled to be anemophilous in order to intercross. Therefore all plants which have not since been greatly modified, would tend still to be both diclinous and anemophilous; and we can thus understand the connexion between these two states, although they appear at first sight quite

* 'Eutstehung und Begriff der naturhist. A rt,' 1865. p. 22 .

+ See the interesting discustion on this whole subject by $\mathrm{O}$. Bütsehli in his 'Studien über die crsten Entwickelungsvorgäingre der Eizelle,' \&c. 1876, 1p. 207-219.
Also, Engelmann, "Ueber Fntwickelung von Infusorien," "Morphol. Juhrbuch; B. i. p. 573. Also, Dr. A. Dodel, "Die Kraushaar-Alge," "Pringsheims Jahrb. f. wiss. Bot, $\mathrm{B}, \mathrm{x}$. 
disconneeted. If this vicw is eorrect, plants must have becn rendered hermaphrodites at a later though still very carly period, and entomophilous at a yet later period, namcly, after the development of winged insects. So that the relationship between hermaphroditism and fcrtilisation by means of inscets is likewise to a certain extent intelligible.

Why the descendants of plants whieh were originally diceious, and which thercforc profited by always intercrossing with another individual, should have been converted into hermaphrodites, may perhaps be explained by the risk which they ram, especially as long as they were ancmophilous, of not being always fertilised, and conscquently of not leaving offspring. This latter evil, the greatest of all to any organism, would have been much lessencd by their becoming hermaphrodites, though with the eontingent disadvantage of frequent sclf-fertilisation. By what graduated stcps an hermaphrodite condition was acquired we do not know. But we can sce that if a lowly organised form, in which the two sexes were represented by somewhat different individuals, were to increase by budding either before or after conjugation, the two incipient sexes would be capable of appearing by buds on the same stock, as occasionally occurs with various characters at the prescnt day. The organism would then be in a monœcions eondition, and this is probably the first step towards hermaphroditism; for if rery simple male and femalc flowers on the same stock, each consisting of a single stamen or pistil, were brought close together and surrounded by a common envelope, in nearly the same manner as with the florets of the Composite, we should have an hermaphrodite flower.

There secms to be no limit to the changes which organisms undergo mnder changing conditions of life; 
and some hermaphrodite plants, deseended as we must believe from aboriginally dielinous plants, have had their sexes again separated. That this has oeeurred, we may infer from the presence of rndimentary stamens in the flowers of some individuals, and of rudimentary pistils in the flowers of other individuals, for example in Iychnis dioica. Bnt a conversion of this kind will not have occurred unless cross-fertilisation was already assured, generally by the agency of inseets; but why the produetion of male and female flowers on distinet plants should have been advantageous to the species, cross-fertilisation having been previously assured, is far from obvious. A plant might indeed produee twice as many seeds as were neeessary to keep up its numbers under new or changed eonditions of life ; and if it did not vary by bearing fewer flowers, and did vary in the state of its reproductive organs (as often oeeurs under eultivation), a wasteful expenditure of seeds and pollen would be saved by the flowers beeoming dielinous.

A related point is worth notiee. I remarked in $\mathrm{my}$ Origin of Speeies that in Britain a mueh larger proportion of trees and bushes than of herbaeeous plants have their sexes separated; and so it is, aeeording to Asa Gray and Hooker; in North Ameriea and New Zealand.* It is, however, doubtful how far this rule

* I find in the 'London Catalogrue of British Plants,' that there are thirty-two indigenous trees and bushes in Great Britain, classed under nine families; but to em on the safe sille, I have enmuted only six species of willows. Of the thirty-two trees and lushes, ninctcen, or more than half, have ther sexes separated; and this is an enormous proportion eompared with other British plants. New /senland abounds with diclinous plants and trees; and Dr. Hooker ealeulates that out of abont 750 ; phanerogamic plants inbabiting the islands, no less than 108 are trees, belonging to thirty-five families. Of these 108 trees, fifty-two, or very nearly half, hive their sexes more or less separated. Of bushes there are 149, of which sixtyone have their sexes in the same state; whilst of the remaining 500 herbaceous plants only 121, or less than a fourth, have their sexes separated. Laslly, Prof. 
holds good generally, and it eertainly rloes not do so in Australia. But $I$ have been assured that the flowers of the prevailing Australian trees, namely, the Myrtaees, swarm with inseets, and if they are diehogamous they would be practieally diclinous." As far as anemophilous plants are eoneerned, we know that they are apt to have their sexes separated, and we ean see that it would be an unfavomrable eircumstanee for them to bear their flower's very elose to the ground, as their pollen is liable to be blown high up in the air; $\dagger$ but as the eulms of grasses give sufficient elevation, we eannot thus aeeount for so many trees and bushes being diclinous. We may infer from our previous discussion that a tree bearing numerous hermaphrodite flowers would rarely intereross with another tree, except by means of the pollen of a distinet individual being prepotent over the plant's own pollen. Now the separation of the sexes, whether the plant were anemophilous or entomophilous, would most effeetually bar self-fertilisation, and this may be the eause of so many trees and bushes being diclinous. Or to put the ease in another way, a plant would be better fitted for development into a tree, if the sexes were separated, than if it were hermaphrodite; for in the former ease its numerous flowers would be less liable to eontinued

Asa Gray informs me that in the United States there are 132 native trees (belonging to twenty-five families) of which ninety-five (belonriug to seventeen families) "have their sexes more or less separated, for the greater part decidedly separated."

* With respect to the Protencer of Anstralia, Mr. Benthan remarks ('Journal Limn. Soc. 13ot.' vol. xiii. $1871, p p .58,64$ ) on the various eontrivances by which the stigma in the sereral genera is screened from the action of the pollen from the same flower. For instance, in Synuphea "the stigma is held by the emnnch (i.e., one of the stamens which is barren) safe from all pollution finm her brother anthers, and is preserved intact for any pollen that may be insertel l,y insects and other agencies."

† Lierner, "Schutzmittel des Pollens,' 1873, p. 4. 
self-fertilisation. But it should also be observed that the long life of a tree or bush permits of the separation of the sexes, with mueh less risk of evil from impregnation oceasionally failing and seeds not being produeed, than in the ease of short-lived plants. Hence it probably is, as Lecoq has remarked, that annual plants are rarely dioecious.

Finally, we have seen reason to believe that the higher plants are descended from extremely low forms which conjugated, and that the eonjugating individuals differed somewhat from one another,- - the one representing the male and the other the female-so that plants were aboriginally diccious. At a very early period sueh lowly organised diceious plants probably gave rise by budding to monoecious plants with the two sexes borne by the same individual; and by a still closer union of the sexes to hermaphrodite plants, which are now much the commonest form.* As soon as plants beeame affixed to the ground, their pollen must have' been carried by some means from flower to flower, at first almost certainly by the wind, then by pollen-devouring, and afterwards by neetarseeking insects. During subsequent ages some few entomophilous plants have been again rendered anemophilous, and some hermaphrodite plants have had their sexes again separated; and we can vaguely see the advantages of such recurrent ehanges under eertain conditions.

Dicecious plants, however fertilised, have a great

* There is a considerable imount of evidence that all the higher animals are the descendants of hormaphrodites; and it is a curious problem whether such hermaphroditism may not have becen the result of the conjugation. of two slightly different indivi- duals, which represented the two incipient sexes. On this view, the higher animals may now owe their bilateral structure, with all thcir organs donble at an carly cmbryouic period, to the fusion or conjugation of two primordial individuals. 
advantage over other plants in their cross-fertilisation being assured. But this advantage is gained in the case of anemophilous species at the expense of the produetion of an enormous superfluity of pollen, with some risk to them and to entomophilous species of their fertilisation oeeasionally failing. Half the individuals, moreover, namely, the males, produee no seed, and this might possibly be a disadvantage. Delpino remarks that diceeious plants eannot spread so easily as monceious and hermaphrodite speeies, for a single individual whieh happened to reaeh some new site eould not propagate its kind; but it may be doubted whether this is a serious evil. Monoecious plants ean hardly fail to be to a large extent dicecious in function, owing to the lightness of their pollen and to the wind blowing laterally, with the great additional advantage of oeeasionally or often producing some self-fertilised seeds. When they are also diehogamous, they are neeessarily diccious in funetion. Lastly, hermaphrodite plants can generally produee at least some self-fertilised sceds, and they are at the same time eapable, through the various means speeified in this ehapter, of cross-fertilisation. When their structure absolutely prevents self-fertilisation, they are in the same relative position to one another as monorcious or dioeious plants, with what may be an advantage, namely, that every flower is eapable of yielding seeds. 


\section{CHAPTER XI.}

The Habits of Insects in relation to the Fertilisation of Flowers.

Insects visit the flowers of the same species as long as they can-Canse of this habit-Means by which hees recognise the flowers of the same species-Sudrlen secretion of nectar-Nectar of certain flowers unattractive to certain inscets-Industry of bees, and the number of flowers visited within a short time-Perforation of the corolla by bees-Skill shown in the operation-Hive-bees profit by the holes made by humble-bees-Effects of habit-The motive for perforating flowers to save time-Flowers growing in crowded masses chiefly perfornted.

BeEs and various other insects must be directed by instinct to search flowers for nectar and pollen, as they act in this manner without instruction as soon as they emerge from the pupa state. Their instincts, however, are not of a specialised nature, for they visit many exotic flowers as readily as the endemic kinds, and they often search for nectar in flowers which do not secrete any; and they may be seen attempting to suck it out of nectaries of such length that it cannot be reached by them.* All kinds of bees and certain other insects usually visit the flowers of the same species as long as they can, before going to another species. This fact was olsserved by Aristotle with respect to the

* See, on this subject, H. Müller, 'Befruchtung,' \& c. p. 427; and Sir J. Lubboels's 'British' Wild Flowers,' \&c. p. 20. Mïller assigns ('Bienen 'Veitung,' June 1876 , p. 119) good reasons for his bolief that bees and many other
Hymenoptera have inherited from some early nectur-sucking progenitor greater skill in robbing Howers than that which is displayerl by insects belonging to the otlier Orders. 
hive-bee more than 2000 years ago, and was noticed by Dobbs in a paper published in 1736 in the Philosophical 'Transactions. It may be observed by any one, both with hive and humble-bees, in every flowergarden; not that the habit is invariably followed. Mr. Bennett watched for several hours* many plants of Lamium album, L. purpureum, and another Labiate plant, Nepeta glechoma, all growing mingled together on a bank near some hives; and he found that each bee confined its visits to the same species. The pollen of these three plants differs in colour, so that he ras able to test his observations by examining that which adhered to the bodies of the captured bees, and he found one kind on each bee.

Humble and hive-bees are good botanists, for they know that varieties may differ widely in the colour of their flowers and yet belong to the same species. I have repeatedly seen hrmble-bees flying straight from a plant of the ordinary red Dictamnus fraxinella to a white variety; from one to another very differently coloured variety of Delphinium consolida and of Primula veris; from a dark purple to a bright yellow variety of Viola tricolor; and with two species of Papaver, from one variety to another which differed much in colour; but in this latter case some of the bees flew indifferently to either species, although passing by other genera, and thus acted as if the two species were merely rarieties. H. Müller also has seen hive-bees flying from flower to flower of Ranunculus bulbosus and arvensis, and of Trifotium fragiferum and repens; and even from blue hyacinths to blue violets. $†$

Some species of Diptera or flies keep to the flowers

* 'Nature,' 1874, June 4th, p. 92 .
† 'Bienen Zeitung,' July 1876 . p. 183. 
of the same species with almost as much regularity as do bees; and when captured they are found covered with pollen. I have seen Rhingia rostrata acting in this manner with the flowers of Lychnis dioica, Ajuga reptans, and Vicia sepium. Tolucella plumosa and Empis cheiroptera flew straight from flower to flower of Myosotis sylvatica. Dolichopus nigripennis behaved in the same manner with Potentilla tormentilla; and other Diptera with Stellaria holostea, Helianthemum vulgare, Bellis perennis, Veronica hederæfolia and chamoedrys ; but some flies visited indifferently the flowers of these two latter species. I have seen more than once a minute Thrips, with pollen adhering to its body, fly from one flower to another of the same kind; and one was observed by me crawling about within a convolvulus with four grains of pollen adhering to its head, which were deposited on the stigma.

Fabricius and Sprengel state that when fiies have once entered the flowers of Aristolochia they never escape,- - a statement which I could not believe, as in this case the insects would not aid in the cross-fertili:sation of the plant; and this statement has now been shown by Hildebrand to be erroneous. As the spathes of Arum maculatum are furnished with filaments apparently adapted to prevent the exit of insects, they resemble in this respect the flowers of Aristolochia; and on examining several spathes, from thirty to sixty minute Diptera belonging to three species were found in some of them ; and many of these insects were lying dearl at the bottom, as if they had been permanently entrapped. In order to discover whether the living ones could escape and carry pollen to another plant, I tied in the spring of 1842 a fine muslin bag tightly round a spathe; and on returning in an hollr's time several little flies were cruwling about on the inner 
surfaee of the bag. I then gathered a spathe and breathed hard into it; several flies soon crawled out, and all without exeeption were dusted with arum pollen. These flies quickly flew away, and I distinctly saw three of them fly to another plant about a yard off; they alighted on the inner or eoneave surfaee of the spathe, and suddenly flew down into the flower. I then opened this flower, and althongh not a single onther had burst, several grains of pollen were lying at the bottom, which must have been brought from another plant by one of these flies or by some other inseet. In another flower little flies were erawling about, and I saw them leave pollen on the stigmas.

I do not know whether Lepidoptera generally keep to the flowers of the same species; but I onee observed many minnte moths (I believe Lampronia (Tinea) calthella) apparently eating the pollen of Mercurialis annua, and they had the whole front of their bodies eovered with pollen. I then went to a female plant some yards off, and saw in the eourse of fifteen minutes three of these moths alight on the stigmas. Lepidoptera are probably often induced to frequent the flowers of the same speeies, whenever these are provided with a long and narrow neetary, as in this ease other inseets eannot suek the nectar, whieh will thus be preserved for those having an elongated proboscis. No doubt the Ineea moth $^{*}$ visits only the flowers whence its name is derived, for a most wonderful instinct guides this moth to plaee pollen on the stigma, so that the ovules may be developed on whieh the larve feed. With respeet to Coleoptera, I have seen Meligethes covered with pollen flying from flower to flower of the same speeies; and

* Described by Mr. Riley in the 'American Naturnlist,' vol. rii. Oct. 1873. 
this must often occur, as, according to M. Brisout, "many of the species affect only one kind of plant." *

It must not be supposed from these several statements that insects strictly confine their visits to the same species. They often visit other species when only a few plants of the same kind grow near together. In a flower-garden containing some plants of Enothera, the pollen of which can easily be recognised, I found not only single grains but masses of it within many flowers of Mimulus, Digitalis, Antirrhinum, and Linaria. Other kinds of pollen were likewise detected in these same flowers. A large number of the stigmas of a plant of Thyme, in which the anthers were completely aborted, were examined; and these stigmas, though scarcely larger than a split needle, were covered not only with pollen of Thyme brought from other plants by the bees, but with several other kinds of pollen.

That insects should visit the flowers of the same species as long as they can, is of great importance to the plant, as it favours the cross-fertilisation of distinct individuals of the same species; but no one will suppose that insects act in this manner for the good of the plant. The cause probably lies in insects being thus enabled to work quicker; they have just learnt how to stand in the best position on the flower, and how far and in what direction to insert their proboscides. $\dagger$ They act on the same principle as does an artificer who has to make half-a-dozen engines, and who saves time by making consecutively each wheel and part for all of them. Insects, or at least bees, seem much influenced by habit in all their manifold operations ; and

* As quoted in 'A merican Nat.' May 1873, p. 270.

$t$ Since these remarks were written, I find that $H$. Müller lıas cume to almost exactly the simo conclusion with respect to the cause of insects frequenting as long as they can the flowers of the sime species: 'Bienen Zeitung,' July 1876, p. 182. 
we shall presently see that this holds good in their felonious praetiee of biting holes through the corolla.

It is a eurious question how bees reeognise the flowers of the same speeies. That the eoloured corolla is the chief guide eannot be doubted. On a fine day, when hive-bees were ineessantly visiting the little blue flowers of Lobetia erinus, I eut off all the petals of some, and only the lower striped petals of others, and these flowers were not once again sueked by the bees, although some actually erawled over them. The removal of the two little upper petals alone made no differenee in their visits. Mr. J. Anderson likewise states that when he removed the corollas of the Caleeolaria, bees never visited the flowers.* On the other hand, in some large masses of Geranium phrum. whieh had eseaped out of a garden, I observed the unusual faet of the flowers continuing to seerete an abundance of neetar after all the petals had fallen off; and the flowers in this state were still visited by humble-bees. But the bees might have learnt that these flowers with all their petals lost were still worth visiting, by finding nectar in those with only one or two lost. The eolour alone of the corolla serves as an approximate guide: thus I watehed for some time humble-bees whieh were visiting exelusirely plants of

* 'Gardeners' Chronicle,' 1853 , 1). 534. Kurr cut off the nectaries from a litge number of flower's of several specics, and found that the greater number yielded seeds; but inserts probably would not perceive the loss of the nectary until they had inserted their proboscides into the holes thus formed, and in toing so would fertilise the flowers He also removed the whole corolla from a enrsiderable number of flowers, and these likewise yielded sech. Flowers which are self-fertile would naturally produce seeds: mnder these circimstances: but I am greatly surjuri-ed that Delphinium consulida, as well as another species of Delptinium, and Viola tricolor, should have produced a fair supply of seeds when thus trcated; but it does not appear that he comparel the number of the seeds thus producid with those yielded by numutilated flowers left to the free access of insects: 'Bedentung der Neltarien,' 1s33, pp. 123-1:35. 
the white-flowered Spiranthes autumnatis, growing on short turf at a considerable distance apart; and these bees often flew within a few inches of several other plants with white flowers, and then without further examination passed onwards in search of the Spiranthes. Again, many hive-bees which confined their visits to the common ling (Calluna vulgaris), repeatedly flew towards Erica tetralix, evidently attracted by the nearly similar tint of their flowers, and then instantly passed on in search of the Calluna.

That the colour of the flower is not the sole guide, is clearly shown by the six cases above given of bees which repeatedly passed in a direct line from one variety to another of the same species, although they bore very differently coloured flowers. I observed also bees flying in a straight line from one clump of a yellowflowered WEnothera to every other clump of the same plant in the garden, without turning an inch from their course to plants of Eschscholtzia and others with yellow flowers which lay only a foot or two on either side. In these cases the bees knew the position of each plant in the garden perfectly well, as we may infer by the directness of their flight; so that they were guided by experience and memory. But how did they discover at first that the above varieties with differently coloured flowers belonged to the same species? Improbable as it may appear, they seem, at least sometimes, to recognise plants even from a distance by their general aspect, in the same manner as we should do. On three occasions I observed humble-bees flying in a perfectly straight line from a tall larkspur (Delphinium) which was in full flower to another plant of the same species at the distance of fifteen yards which had not as yet a single flower open, and on which the buds showed only a faint tinge of blue. Here neither odour nor the 
memory of former visits eould have come into play, and the tinge of blue was so faint that it could hardly have served as a guide.*

The eonspieuousness of the eorolla does not suffiee to induce repeated visits from inseets, unless neetar is at the same time seereted, together perhaps with some odour emitted. I watehed for a fortnight many times daily a wall eovered with Linaria cymbalaria in full flower, and never saw a bee even looking at one. There was then a very hot day, and suddenly many bees were industriously at work on the flowers. It appears that a eertain degree of heat is necessary for the seeretion of neetar; for I observed with Lobetia erimus that if the sun ceased to shine for only half an hour, the visits of the bees slaekened and soon eeased. An analogous faet with respeet to the sweet exeretion from the stipules of Vicia sativa has been already given. As in the ease of the Linaria, so with Pedicularis sylvatica, Polygala vulgaris, Viola tricolor, and some speeies of Trifolium, I have watehed the flowers day after day without seeing a bee at work, and then suddenly all the flowers were visited by many bees. Now how did so many bees diseover at onee that the flowers were secreting neetar? I presume that it must have been by their odour; and that as soon as a few bees began to suek the flowers, others of the same and of different kinds observed the fact and profited by it. We shall presently see, when we treat of the perforation of the corolla, that bees are fully eapable of profiting by the

* $\Lambda$ faet mentioned by $\mathrm{H}$. Mïller" ('Die Befruchtung,' \&e., p. 317) shows that bees possess reute powers of visiom and discrimination; for those cngnged in collecting pollon from Primula elatior invariably passed by the flowers of the long-styled form, in which the anthers are seated low lown in the tubular corolla. Iet the difteronee in aspect between the long-styled and slort-styled forms is cxtremely slight. 
labour of other speeies. Memory also eomes into play, for, as already remarked, bees know the position of each clump of flowers in a garden. I have repeatedly seen them passing round a corner, but otherwise in as straight a line as possible, from one plant of Fraxinella and of Linaria to another and distant one of the same species; although, owing to the intervention of other plants, the two were not in sight of eaeh other.

It would appear that either the taste or the odour of the neetar of certain flowers is unattraetive to hive or to humble-bees, or to both; for there seems no other reason why certain open flowers which secrete neetar are not risited by them. 'The small quantity of nectar seereted by some of these flowers ean hardly be the eause of their neglect, as hive-bees search eagerly for the minute drops on the glands on the leaves of the Prunus lauro. cerasus. Even the bees from different hives sometimes visit different kinds of flowers, as is said to be the case by Mr. Grant with respeet to the Polyanthus and Viola tricolor.* I have known humble-bees to visit the flowers of Lobelice fulgens in one garden and not in another at the distanee of only a few miles. The eupful of neetar in the labellum of Epipactis latifolia is never tonehed by hive- or humble-bees, although I have seen them flying close by; and yet the neetar has a pleasant taste to us, and is habitually eonsumed by the eommon wasp. As far as I have seen, wasps seek for nectar. in this country only from the flowers of this Epipactis, Scrophularia aquatica, Symphoricarpus racemosa, $†$ and Tritoma; the two former plants being endemie, and the two latter exotic. As wasps are so fond of sugar

* ' Ciard. Chron.' 184t, p. $37 t$.

+ 'I'lie same fact apparently holds good in Italy, for Delpino says tuat the flowers of these three plants are alone visited by wasps: 'Nettarii Evtranuziali. Bullettino Entomologien,' anno vi. 
and of any sweet fluid, and as they do not disdain the minute drops on the glands of Prunus laurocerasus, it is a strange fact that they do not suck the neetar of many open flowers, whieh they eould do without the aid of a proboseis. Hive-bees visit the flowers of the Symphoricarpus and Tritoma, and this makes it all the stranger that they do not visit the flowers of the Epipaetis, or, as far as I have seen, those of the Scrophularia aquatica; although they do visit the flowers of Scrophularia nodosa, at least in North America.*

The extraordinary industry of bees and the number of flowers whieh they visit within a short time, so that eaeh flower is visited repeatedly, must greatly inerease the ehanee of eaeh receiving pollen from a distinet plant. When the neetar is in any way hidden, bees cannot tell without inserting their proboseides whether it lias lately been exhausted by other bees, and this, as remarked in a former ehapter, forees them to visit many more flowers than they otherwise would. But they endeavour to lose as little time as they ean; thus in flowers having several nectaries, if they find one dry they do not try the others, but as I have often observed, pass on to another flower. They work so industriously and effeetually, that even in the ease of soeial plants, of which hundreds of thousands grow together, as with the several kinds of heath, every single flower is visited, of which evidenee will presently be given. They lose no time and fly rery quiekly from plant to plant, but I do not know the rate at which hive-bees fly. Humble-bees fly at the rate of ten miles an hour, as I was able to ascertain in the ease of the males from their eurious habit of ealling at

* 'Sillinau's American Journal of Science,' Aug. 1871. 
certain fixed points, which made it easy to measure the time taken in passing from one place to another.

With respect to the number of flowers which bees visit in a given time, I observed that in exactly one minute a humble-bee visited twenty-four of the closed flowers of the Linaria cymbalaria; another bee visited in the same time twenty-two flowers of the Symphoricarpus racemosa; and another seventeen flowers on two plants of a Delphinium. In the course of fifteen minutes a single flower on the summit of a plant of Enothera was visited eight times by several humblebees, and I followed the last of these bees, whilst it visited in the course of a few additional minutes every plant of the same species in a large flowergarden. In nineteen minutes every flower on a small plant of Nemophila insignis was visited twice. In one minute six flowers of a Campanula were entered by a pollen-collecting hive-bee; and bees when thus employed work slower than when sucking nectar. Lastly, seven flower-stalks on a plant of Dictamnus fraxinella were observed on the 15th of June 1841 during ten minutes; they were visited by thirteen humble-bees each of which entered many flowers. On the 22nd the same flower-stalks were visited within the same time by eleven humble-bees. This plant bore altogether 280 flowers, and from the above data, taking into consideration how late in the evening humble-bees work, each flower must have been visited at least thirty times daily, and the same flower keeps open during several days. The frequency of the visits of bees is also sometimes shown by the manner in which the petals are scratched by their hooked tarsi; I have seen large beds of Mimulus, Stachys, and Lathyrus with the beauty of their flowers thus sadly defaced.

Perforation of the Corolla by Bees.-I have already 
alluded to bees biting holes in flowers for the sake of obtaining the neetar. They often aet in this inanner, both with endemie and exotie speeies, in many parts of Europe, in the United States, and in the Himalaya; and therefore probably in all parts of the world. The plants, the fertilisation of whieh actually depends on insects entering the flowers, will fail to produee seed when their neetar is stolen from the outside; and even with those species which are eapable of fertilising themselves without any aid, there can be no erossfertilisation, and this, as we know, is a serious evil in most eases. The extent to which humble-bees carry on the praetiee of biting holes is surprising : a remarkable ease was observed by me near Bournemouth, where there were formerly extensive heaths. I took a long walk, and every now and then gathered a twig of Erica tetralix, and when I had got a handful all the flowers were examined through a lens. This proeess was repeated many times; but though many hundreds were examined, I did not sueeeed in finding a single flower whieh had not been perforated. Humble-bees were at the time sueking the flowers through these perforations. On the following day a large number of flowers were examined on another heath with the same result, but here hive-bees were sueking through the holes. This case is all the more remarkable, as the innumerable holes had been made within a fortnight, for before that time I saw the bees everywhere sueking in the proper mamner at the mouths of the eorolla. In an extensive flower-garden some large beds of Salvia grahami. Stachys coccinea, and Pentstemon argutus (?) had every flower perforated, and many seores were examined. I have seen whole fields of red elover (Trifolium pratense) in the same state. Dr. Ogle found that 90 per cent. of the 
flowers of Salvia glutinosa had been bitten. In the United States Mrr. Bailey says it is difficult to find a blossom of the native Gerardia pedicularia without a hole in it; and Mr. Gentry, in speaking of the introdueed Wistaria sinensis, says " that nearly every flower had been perforated." **

As far as I have seen, it is always humble-bees whieh first bite the holes, and they are well fitted for the work by possessing powerful mandibles; but hive-bees afterwards profit by the holes thus made. Dr. H. Müller, however, writes to me that hive-bees sometimes bite holes through the flowers of Erica tetralix. No insects except bees, with the single exeeption of wasps in the ease of T'ritoma, have sense enough, as far as I have observed, to profit by the holes already made. Even humble-bees do not always discover that it would be advantageous to them to perforate eertain flowers. There is an abundint supply of neetar in the nectary of Troprolam tricolor, yet I have found this plant untonehed in more than one garden, while the flowers of other plants had been extensively perforated; but a few years ago Sir J. Lubboek's gardener assured me that he had seen humble-bees boring through the neetary of this Tropeolum. Müller has observed humble-bees trying to suek at the mouths of the Howers of Primula elatior and of an Aquilegia, and, failing in their attempts, they made holes through the corolla; but they often bite holes, although they eould with very little more trouble obtain the nectar in a legitimate manner by the mouth of the eorolla.

Dr. W. Ogle has eommunieated to me a curious ease.

* Dr. Ogle, 'Pop. Suience Review, July 1869, p. 267. Bitiley, 'Americail Naturalist,' Nov. 1873. p. 690. Gentry, ibicl. May 1875 , p. 264 . 
He gathered in Switzerland 100 flower-stems of the common blue variety of the monkshood (Aconitum napellus), and not a single flower was perforated; he then gathered 100 stems of a white variety growing elose by, and every one of the open flowers had been perforated. This surprising differenee in the state of the flowers may be attributed with mueh probability to the blue variety being distasteful to bees, from the presenee of the aerid matter whieh is so general in the Ranuneulaeeæ, and to its absenee in the white variety in eorrelation with the loss of the blue tint. Aeeording to Sprengel, ${ }^{*}$ this plant is strongly proterandrous ; it would therefore be more or less sterile unless bees earried pollen from the younger to the older flowers. Consequently the white variety, the flowers of whieh were always bitten instead of being properly entered by the bees, would fail to yield the full number of seeds and would be a eomparatively rare plant, as Dr. Ogle informs me was the ease.

Bees show much skill in their manner of working, for they always make their holes from the outside elose to the spot where the nectar lies hidden within the eorolla. All the flowers in a large bed of Stachys coccinea had either one or two slits made on the upper side of the eorolla near the base. The flowers of a Mirabilis and of Salvia coccinen were perforated in the s.me manner; whilst those of Salvia grahami, in whieh the ealyx is mueh elongated, had both the ealyx and the corolla invariably perforated. The flowers of Pentstemon argutus are broader than those of the plants just named, and two holes alongside eaeh other had here always been made just above the ealyx. In these several eases the perforations were on the upper side, but in Antir-

* 'Das Entleckte,' \&c. p. 278. 
rhinum majus one or two holes had been made on the lower side, elose to the little protuberanee whieh represents the neetary, and therefore direetly in front of and elose to the spot where the neetar is seereted.

But the most remarkable ease of skill and judgment known to me, is that of the perforation of the flowers of Lathyrus sylvestris, as described by my son Franeis.* The neetar in this plant is enelosed within a tube, formed by the united stamens, whieh surround the pistil so elosely that a bee is foreed to insert its proboseis outside the tube; but two natural rounded passages or orifiees are left in the tube near the base, in order that the neetar may be reaehed by the bees. Now my son found in sixteen out of twenty-four flowers on this plant, and in eleven out of sixteen of those on the eultivated everlasting pea, which is either a variety of the same speeies or a elosely allied one, that the left passage was larger than the right one. And here comes the remarkable point,--the humble-bees biteholes through the standard-petal, and they always operated on the left side over the passage, whieh is generally the larger of the two. My son remarks: "It is diffieult to say how the bees eould have aequired this habit. Whether they diseovered the inequality in the size of the neetar-holes in sueking the flowers in the proper way, and then utilised this knowledge in determining where to gnaw the hole; or whether they found out the best situation by biting through the standard at various points, and afterwards remembered its situation in visiting other flowers. But in either ease they show a remarkable power of making use of what they have learnt by experience." It seems probable that bees owe their skill in biting holes through flowers of all

* 'Nature,' Jan. 8, 1874, p. 1×9. 
kinds to their having long practised the instinct of moulding "cells and pots of wax, or of enlarging their old cocoous with tubes of wax; for they are thus compelled to work on the inside and outside of the same object.

In the early part of the summer of 1857 I was led to observe during some weeks several rows of the scarlet kidney-bean (Phaseolus multiflorus), whilst attending to the fertilisation of this plant, and daily saw humble- and hive-bees sucking at the "mouths of the flowers. But one day I found several humblebees employed in cutting holes in flower after flower; and on the next day every single hive-bee, without exception, instead of alighting on the left wing-petal and sucking the flower in the proper manner, flew straight without the least hesitation to the calyx, and sucked through the holes which had been made only the day before by the humble-bees; and they continued this habit for many following days.* $\mathrm{M}[\mathrm{r}$. Belt has communicated to me (July 2Sth, 1874) a similar case, with the sole difference that less than half of the flowers had been perforated by the lumble-bees; nevertheless, all the hive-bees gave up sucking at the mouths of the flowers and visited exclusively the bitten ones. Now how did the hive-bees find out so quickly that holes had been made? Instinct seems to be out of the question, as the plant is an exotic. The holes caunot be seen by bees whilst standing on the wingpetals, where they had always previously alighted. From the ease with which bees were deceived when the petals of Lobetia erinus were cut off, it was clear that in this case they were not guided to the nectar by its smell; and it may be doubted whether they were 
attracted to the holes in the flowers of the Phaseolus by the odour emitted from them. Did they perceive the holes by the sense of touch in their proboscides, whilst sucking the flower's in the proper manner, and then reason that it would save them time to alight on the outside of the flowers and use the holes? This seems almost too abstruse an act of reason for bees; and it is more probable that they saw the humble-bees at work, and understanding what they were about, imitated them and took advantage of the shorter path to the nectar. Even with animals high in the scale, such as monkeys, we should be surprised at hearing that all the individuals of one species within the space of twenty-four hours understood an act performed by a distinct species, and profited by it.

I have repeatedly observed with various kinds of flowers that all the hive and humble-bees which were sucking through the perfurations, flew to them, whether on the upper or under side of the corolla, without the least hesitation; and this shows how quickly all the individuals within the district had acquired the same knowledge. Yet habit comes into play to a certain extent, as in so many of the other operations of bees. Dr. Ogle, Messrs. Farrer and Belt have observed in the case of Phaseolus multiflorus* that certain individuals went exclusively to the perforations, while others of the same species visited only the mouths of the flowers. I noticed in 1861 exactly the same fact with Trifolium pratense. So persistent is the force of habit, that when a bee which is visiting perforated flowers comes to one which has not been bitten, it does not go to the mouth, but instantly

* Dr. Ogle, 'Pop. Science Review,' April 1870 , p. 167 . Mr. Farrer, 'Annals and Mag. of Nat.
Hist.' 4th series, vol. ii. 1868 , p. 258. Mr. Belt in a letter to me. 
flies away in search of another bitten flower. Nevertheless, I once saw a humble-bee visiting the hybrid Rhododendron azaloides, and it entered the mouths of some flowers and cut looles into the others. Dr. $H$. Müller informs me that in the same district he has seen some individuals of Bombus mastrucatus boring through the calyx and corolla of Rhinanthus alecterolophus, and others through the corolla alone. Different species of bees may, however, sometimes be observed acting differently at the same time on the same plant. I have seen hive-bees sucking at the mouths of the flowers of the common bean; humble-bees of one kind sucking through holes bitten in the calyx, and humblebees of another kind sucking the little drops of fluid excreted by the stipules. Mr. Beal of Michigan informs me that the flowers of the Missouri currant (Ribes aureum) abound with nectar, so that children often suck them; and he saw hive-bees sucking through holes made by a bird, the oriole, and at the same time humble-bees sucking in the proper manner at the mouths of the flowers.* This statement about the oriole calls to mind what I have before said of certain species of humming. birds boring holes through the flowers of the Brugmansia, whilst other species entered by the mouth.

The motive which impels bees to gnaw holes through the corolla seems to be the saving of time, for they lose much time in climbing into and out of large flowers, and in forcing their heads into closed ones. They were able to visit nearly twice as many flowers, as far as I could judge, of a Stachys and Pentstemon

* The flowers of the Ribes are however sometimes perforited by humble-bees, and Mr. Bundy says that they wero able to bite through and rob seven flowers of their honey in a minute: 'American Naturalist,' 1876, p. 238. 
by alighting on the upper surfaee of the corolla and sucking through the cut loles, than by entering in the proper way. Nevertbeless eaeh bee before it has had mueh practice, must lose some time in making eaeh new perforation, espeeially when the perforation has to be made through both calyx and eorolla. This action therefore implies foresight, of which faculty we have abundant evidenee in their building operations; and may we not further believe that some traee of their soeial instinet, that is, of working for the good of other members of the community, may here likewise play a part?

Many years ago I was struek with the faet that humble-bees as a general rule perforate flowers only when these grow in large numbers near together. In a garden where there were some very large beds of Stachys coccinea and of Pentstemon argutus, every single flower was perforated, but I found two plants of the former species growing quite separate with their petals mueh scratehed, showing that they had been frequently visited by bees, and yet not a single flower was perforated. I found also a separate plant of the Pentstemon, and saw bees entering the mouth of the eorolla, and not a single flower had been perforated. In the following year (1842) I visited the same garden several times: on the 19th of July humble-bees were sucking the flowers of Stachys coccinea and Salvia grahami in the proper manner, and none of the eorollas were perforated. On the 7th of August all the flowers were perforated, even those on some few plants of the Salvia which grew at a little distanee from the great bed. On the 21st of August only a few flowers on the summits of the spikes of both speeies remained fresh, and not one of these was now bored. A gain, in my own garden every plant in several rows of the eommon bean 
had many flowers perforated ; but I found three plants in separate parts of the garden which had sprung up accidentally, and these had not a single flower perforated. General Strachey formerly saw many perforated flowers in a garden in the Himalaya, and he wrote to the owner to inquire whether this relation between the plants growing crowded and their perforation by the bees there held grood, and was answered in the affirmative. Hence it follows that the red clover (Trifolium pratense) and the common bean when cnltivated in great masses in fields, - that Erica tetralix growing in large numbers on heaths,-rows of the scarlet kidney-bean in the kitchen-garden, - and masses of any species in the flower-garden,--are all eminently liable to be perforated.

The explanation of this fact is not difficult. Flowers growing in large numbers afford a rich booty to the bees, and are conspicuous from a distance. They are consequently visited by crowds of these insects, and I once counted between twenty and thirty bees flying about a bed of Pentstemon. They are thus stimulated to work quickly by rivalry, and, what is much more important, they find a large proportion of the flowers, as suggested by my son,* with their nectaries sucked dry. They thus waste much time in searching many empty flowers, and are led to bite the holes, so as to fincl out as quickly as possible whether there is any nectar present, and if so, to obtain it.

Flowers which are partially or wholly sterile unless visited by insects in the proper manner, such as those of most species of Salvia. of Trifolium matense, Phaseolus multiflorus, \&c., will fail more or less completely to prodnce seeds if the bees confine their risits

* 'Nature,' Jan. 8, 1874, p. 189. 
to the perforations. The perforated flowers of those species, which are capable of fertilising themselves, will yield only self-fertilised seeds, and the seedlings will in consequence be less vigorous. Therefore all plants must suffer in some degree when bees obtain their nectar in a felonious manner by biting holes through the corolla; and many species, it might be thought, would thus be exterminated. Eut here, as is so general throughout nature, there is a tendency towards a restored equilibrium. If a plant suffers from being perforated, ferer individuals will be reared, and if its nectar is highly important to the bees, these in their turn will suffer and decrease in number ; but, what is much more effective, as soon as the plant becomes somewhat rare so as not to grow in crowded masses, the bees will no longer be stimulated to gnaw holes in the flowers, but will enter them in a legitimate manner. Iore seed will then be produced, and the seedlings being the product of cross-fertilisation will be vigorous, so that the species will tend to increase in number, to be again checked, as soon as the plant again grows in crowded masses. 


\section{CHAPTER XII.}

\section{Gexeral Resclit.}

Cross-fertilisation proved to be beneficial, and self-fertilisation injurious-Allied speeies differ greatly in the means by which erossfertilisation is favoured and self-fertilisation avoilded-The benefits and evils of the two proeesses depend on the degree of differentiation in the sexual elements-The evil effeets not due to the combination of morbid tendencies in the parents-Nature of the eonditions to whieh plants are subjeeted when growing near tnge ther in a state of nature or under eulture, and the effeets of such eonditions-Theoretieal eonsiderations with respeet to the interaetion of differentiated sexunl elements-Practieal lessons-Genesis of the two sexes-Clnse eorrespondence between the effeets of cross-fertilisation and self-fertilisation, and of the legitimate and illegitimate unions of heterostyled plants, in eomparison with hybrid unions.

THe first and most important of the eonelusions whieh may be drawn from the observations given in this volume, is that eross-fertilisation is generally benefieial, and self-fertilisation injurious. This is shown by the difference in height, weight, constitutional vigour, and fertility of the offspring from crossed and self-fertilised flowers, and in the number of seeds producer by the parent-plants. With respeet to the second of these two propositions, namely, that self-fertilisation is generally injurious, we have abundant evidence. The strueture of the flowers in such plants as Lobetia ramosa, Digitatis purpurea, Se., renders the aid of insects almost indispensable for their fertilisation; and bearing in mind the prepoteney of pollen from a distinet individual over that from the same individual, sueh plants will almost certainly have been crossed during many or 
all previous generations. So it must be, owing merely to the prepoteney of foreign pollen, with cabbages and varions other plants, the varieties of which almost invariably intereross when grown together. The same inference may be drawn still more surely with respect to those plants, such as Reseda and Esehseholtzia, which are sterile with thoir own pollen, but fertile with that from any other individual. These several plants must therefore have been erossed during a long series of previous generations, and the artificial crosses in my experiments eannot have inereased the vigour of the offspring beyond that of their progenitors. Therefore the difference between the self-fertilised and erossed plants raised by me cannot be attributed to the superiority of the crossed, but to the inferiority of the self-fertilised seedlings, due to the injurious effeets of self-fertilisation.

With respeet to the first proposition, namely, that cross-fertilisation is generally benefieial, we likewise have excellent evidenee. Plants of Ipomcea were intercrossed for nine successive generations; they were then again intererossed, and at the same time crossed with a plant of a fresh stoek, that is, one brought from another garden; and the offspring of this latter cross were to the intererossed plants in height as 100 to 78 , and in fertility as 100 to 51. An analogous experiment with Esehscholtzia gave a similar result, as far as fertility was concerned. In neither of these cases were any of the plants the prodnet of self-fertilisation. Plants of Dianthus were self-fertilised for three generations, and this no doubt was injurious; but when these plants were fertilised by a fresh stock and by intercrossed plants of the same stock, there was a great differenee in fertility between the two sets of secdings, and some differenee in their lieight. Petunia offers a nearly 
parallel ease. With various other plants, the wonderful effects of a cross with a fresh stock may be seen in 'Tablc C. Several accounts have also becn published* of the extraordinary growth of scedlings from a cross between two varietics of the same spccies, some of which are known never to fertilise themselves; so that here neither sclf-fertilisation nor rclationship even in a remote degree can have come into play. We may therefore conclude that the above two propositions are true,- - that cross-fertilisation is generally beneficial and self-fertilisation injurious to the offspring.

That certain plants, for instanee, Viola tricolor, Digitalis purpurea, Sarothamnus scoparius, Cyclamen persicum, \&c., which have bcen naturally cross-fertilised for many or all previous gencrations, should suffer to an extreme degree from a single act of sclf-fertilisation is a most surprising fact. Nothing of the kind bas been observed in our domestic animals; but then we must remember that the elosest possiblc interbreeding with such amimals, that is, between brothers and sisters, camnot be considered as nearly so close a union as that between the pollen and ovules of the same flower. Whether the evil from self-fertilisation goes on increasing during successive generations is not as yet known; but we may infer from my experiments that the inerease if any is far from rapid. After plants hare been propagated by self-fertilisation for sereral gencrations, a single cross with a fresh stock restores their pristine vigour; and we have a strictly analogous result with our domestic animals. $\dagger$ The good cffects of cross-fertilisation are trumsmitted by plants to the next gencration; and judging from the rarieties of

* Seo " Variation under Domesticalion,' ch. xix. 2nd edit. vol. ii. p. 159 .
+ Ibid. ch. xix. 2nd edit. rol. ii. p. 159 . 
the common pea, to many succecding generations. But this may merely be that crossed plants of the first generation are extremcly vigorous, and transmit their vigour, like any other character, to their successors.

Notwithstanding the evil which many plants suffer from self-fertilisation, they can be thus propagated under favourable conditions for many generations, as shown by some of my experiments, and more cspecially by the surviral during at least half a century of the same varieties of the common pea and swcet-pea. The same conclusion probably holds good with scveral othcr exotic plants, which are never or most rarely crossfertilised in this country. But all these plants, as far as they have been tried, profit greatly by a cross with a fresh stock. Some few plants, for instance, Ophrys apiferce, have almost certainly bcen propagated in a state of nature for thousands of generations without having becn once intercrossed; and whether they would profit by a cross with a fresh stock is not known. But such cases ought not to makc us doubt that as a general rule crossing is beneficial, any more than the existence of plants which, in a statc of nature, are propagated exclusively by rhizomes, stolons, \&c.* (thcir flowers never producing sceds), should make us doubt that seminal generation must have some grcat advantage, as it is the common plan followed by nature. Whether any species has been reproduced asexually from a very remote period cannot, of course, be ascertained. Our sole means for forming any judgment on this head is the duration of the varietics of our fruit trees which have been long propagated by grafts or buds. Andrew Knight formerly maintaincd that under these circumstances they always become wcakly, but this conclusion

* I have given several cases in my - Variation under Domestica-

tion,' ch. xviii. 2ud edit. vol. ii. p. 152 . 
has been warmly disputed by others. A recent and competent judge, Prof. Asa Gray, ${ }^{*}$ leans to the side of Andrew Knight, which scems to me, from such evidence as I have been able to collcet, the more probable vicw, notwithstanding many opposed ficts.

The means for favouring cross-fertilisation and preventing self-fertilisation, or conversely for favouring self-fertilisation and preventing to a certain cxtent cross-fertilisation, are wonderfully diversified; and it is remarkable that these differ widcly in closely allied plants, $\uparrow$-in the species of the same genus, and sometimes in the individuals of the same species. It is not rare to find hermaphrodite plants and others with separated sexes within the same genus; and it is common to find some of the species dichogamous and others maturing their sexual clements simultaneously. The dichogamous genus Saxifraga contains proterandrous and proterogynous specics. $\neq$ Several grenera include both hetcrostyled (dimorphic or trimorphic forms) and homostyled species. Ophrys offers a remarkable instance of onc species having its structure manifestly adapted for self-fertilisation, and other specics as manifestly adapted for cross-fertilisation. Some con-generic species are quite sterile and others quite fcrtile with their orn pollen. From these several causes we often find within the same genus specics which do not produce seeds, while others produce an abundance, when insects are cxcluded. Somc species bear cleistogene flowers which cannot be crossed, as well as perfect flowers, whilst others in the same genus

* DDarviniana: Essays and licviews pertaining to Darwinism,' $1876,1) .338$.

+ Mildebrand has insisted strongly to this effect in his valuable observations on the fer- tilisation of the Graminee: ' MTonatsburicht K. A kad. Berlin,' Oct. 1872, p. 763.

i Dr. Eugler, 'Bot. 'Zeitung, Is68, p. $83 \%$. 
never produce cleistogene flowers. Some speeies exist under two forms, the one bearing eonspicuous flowers adapted for cross-fertilisation, the other bearing ineonspienous flowers adapted for self-fertilistion, whilst other species in the same genus present only a single form. Even with the individuals of the same speeies, the degree of self-sterility varies greatly, as in Reseda. With polygamous plants, the distribution of the sexes differs in the individuals of the same speeies. The relative period at whieh the sexual elements in the same flower are mature, differs in the varieties of Pelargonium; and Carrière gives several eases, ${ }^{*}$ showing: that the period varies aceording to the temperature to which the plants are exposed.

This extraordinary diversity in the means for favouring or preventing eross- and self-fertilisation in closely allied forms, probably depends on the results of both processes being highly benefieial to the speeies, but directly opposed in many ways to one another and dependent on variable conditions. Self-fertilisation assures the production of a large supply of seeds ; and the neeessity or advantage of this will be determined by the average length of life of the plant, whieh largely depends on the amount of destruetion suffered by the seeds and seedlings. This destruction follows from the most various and variable eauses, such as the presence of animals of several kinds, and the growth of surrounding plants. The possibility of cross-fertilisation depends mainly on the presence and number of certain insects, often of inseets belonging to speeial groups, and on the degree to which they are attraeted to the flowers of any particular species in preference to other flowers,-all eircumstances likely to change. 
Moreover, the advantages which follow from crossfertilisation differ much in different plants, so that it is probable that allied plants would often profit in different degrees by cross-fertilisation. Under these extremely complex and fluctuating conditions, with two somerwhat opposed ends to be gained, namcly, the safe propagation of the species and the production of cross-fertilised, vigorous offspring, it is not surprising that allied forms should exhibit an extrcme diversity in the means which favour either end. If, as there is reason to suspect, self-fertilisation is in some respects beneficial, although more than counterbalanced by the advantages derived from a cross with a fresh stock, the problem becomes still more complicated.

As I only twice experimenterl on more than a single species in a genus, I cannot say whether the crossed offspring of the several species within the same genus differ in their degree of superiority over their selffertilised brethren; but I should expect that this would often prove to be the case from what was observed with the two species of Lobelia and with the individuals of the same species of Nicotiana. The species belonging to distinct genera in the same family certainly differ in this respect. The effects of crossand self-fertilisation may be confincd either to the growth or to the fertility of the offspring, but generally extends to both qualities. There does not scem to exist any close correspondence between the degree to which the flowcrs of species are adapted for crossfertilisation, and the degree to which their offspring profit by this process; but we may easily err on this head, as there are two means for ensuring eross-fertilisation which are not externally perceptible, namely, self-sterility and the prepotent fertilising influence of pollen from another individual. Lastly, it has been 
shown in a former ehapter that the effeet produeed by eross and self-fertilisation on the fertility of the parentplants does not always eorrespond with that produeed on the height, vigour, and fertility of their offspring: The same remark applies to erossed and self-fertilised seedlings when these are nsed as the parent-plants. This want of eorrespondenee probably depends, at least in part, on the number of seeds produced being chiefly determined by the number of the pollen-tubes which reaeh the ovules, and this will be governed by the reaction between the pollen and the stigmatic seeretion or tissues; whereas the growth and eonstitutional vigour of the offspring will be ehiefly determined, not only by the number of pollen-tubes reaching the ovules, but by the nature of the reaction between the eontents of the pollen-grains and ovules.

There are two other important eonclusions which may be dedueed from my observations : firstly, that the advantages of eross-fertilisation do not follow from some mysterious virtue in the mere union of two distinct individuals, but from such individuals having been subjected during previous generations to different eonditions, or to their having varied in a manner eommonly ealled spontaneous, so that in either ease their sexual elements have been in some degree differentiated. And secondly, that the injury from selffertilisation follows from the want of sueh differentiation in the sexual elements. These two propositions are fully established by my experiments. Thus, when plants of the Ipomoea and of the Mimulus, which had been self-fertilised for the seven previous generations and had been kept all the time under the same eonditions, were intererossed one with another, the offspring did not profit in the least by the cross. Mimulus 
offers another instruetive ease, showing that the benefit of a eross depends on the previous treatment of the progenitors: plants whieh had been self-fertilised for the eight previous generations were crossed with plants whieh had been intererossed for the same number of generations, all having been kept under the same conditions as far as possible; , seedlings from this cross were grown in eompetition with others derived from the same self-fertilised mother-plant erossed by a fresh stoek; and the latter seedlings were to the former in height as 100 to 52 , and in fertility as 100 to 4. An exactly parallel experiment was tried on Dianthus, with this differenee, that the plants had been self-fertilised only for the three previous generations, and the result was similar though not so strongly marked. 'The foregoing two eases of the offspring of I pomoea and Esehseholtzia, derived from a eross with a fresh stoek, being as mueh superior to the intererossed plants of the old stoek, as these latter were to the selffertilised offspring, strongly supports the same conelusion. A eross with a fresh stock or with another variety seems to be always highly beneficial, whether or not the mother-plants have been intercrossed or selffertilised for several previous generations. The faet that a eross between two flowers on the same plant does $n$ good or very little good, is likewise a strong eorroboration of our eonchusion; for the sexual elements in the flowers on the sime plant can rarely have been differentiated, though this is possible, as flower-buds are in one sense distinct individuals, sometimes varying and differing from one another in strueture or constitution. Thus the proposition that the bencfit from eross-fertilisation depends on the plants which are crossed haring been subjeeted during previous generations to somewhat different conditions, 
or to their having varied from some unknown eause as if they had been thus subjeeted, is securely fortified on all sides.

Before proceeding any further, the view whieh has been maintained by several physiologists must be notieed, namely, that all the evils from breeding animals too elosely, and no doubt, as they would say, from the self-fertilisation of plants, is the result of the inerease of some morbid tendeney or weakness of eonstitution eommon to the closely related parents, or to the two sexes of hermaphrodite plants. Undoubtedly injury has often thus resulted; but it is a vain attempt to extend this view to the numerous cases given in my Tables. It should be remembered that the same mother-plant was both self-fertilised and erossed, so that if she had been unhealthy she would have transmitted half her morbid tendeneies to her crossed offspring. But plants appearing perfeetly healthy, some of them growing wild, or the immediate offspring of wild plants, or vigorous eommon garden-plants, were selected for experiment. Considering the number of species whieh were tried, it is nothing less than absurd to suppose that in all these eases the mother-plants, though not appearing in any way diseased, were weak or unhealthy in so peeuliar a manner that their selffertilised seedlings, many hundreds in number, were rendered inferior in height, weight, eonstitutional vigour, and fertility to their erossed offspring. Moreover, this belief eannot be extended to the strongly marked advantages whieh invariably follow, as far as my experience serves, from intercrossing the individuals of the same variety or of distinct varieties, if these have been subjeeted during some generations to different eonditions. 
It is obvious that the exposure of two sets of plants during several generations to different conditions can lead to no beneficial results, as far as crossing is concerned, unless their sexual elements are thus affected. That every organism is acted on to a certain extent by a change in its environment, will not, I presume, be disputed. It is hardly necessary to advance evidence on this head; we can perceive the difference between individual plants of the same species which have grown in somewhat more shady or sunny, dry or damp places. Plants which have been propagated for some generations under different climates or at different seasons of the year transmit different constitutions to their seedlings. Under such circumstances, the chemical constitution of their fluids and the nature of their tissues are often modified.* Many other such facts could be adduced. In short, every alteration in the function of a part is probably comnected with some corresponding, though often quite imperceptible change in structure or composition.

Whatever affects an organism in any way, likewise tends to act on its sexual elements. We see this in the inheritance of newly acquired modifications, such as those from the increased use or disuse of a part, and even from mutilations if followed by disease. $\dagger$ Te have abundant evidence how susceptible the reproductive system is to changed conditions, in the many instances of animals rendered sterile by confinement; so that they will not unite, or if they unite do not

* Numerous coses together with references are given in my 'Variation under Domestiention,' el. xxiii. 2 nd edit. vol. ii. p. $26 t$. With respect to animals, Mr. Brackemidge has well shown ("A Contribution to the 'lhenry of Diathesis,' Elinburgh, 1869) that the different organs of animals are excited into different degrees of netivity by differences of temperature and food, and become to a certain extent adnptred to them.

+ 'Tariation under llomestication.' ch. xii. 2nd edil. vol. i. p. 466 . 
produee offspring, though the eonfinement may be far from close; and of plants rendered sterile by eultivation. But hardly any cases afford more striking eridence how powerfully a change in the conditions of life aets on the sexual elements, than those already given, of plants which are completely self-sterile in one country, and when brought to another, yield, even in the first generation, a fair supply of self-fertilised seeds.

But it may be said, granting that ehanged conditions aet on the sexual elements, how ean two or more plants growing close together, either in their native eountry or in a garden, be differently acted on, inasmuch as they appear to be exposed to exactly the same conditions? Although this question has been already eonsidered, it deserves further consideration under several points of view. In my experiments with Digitalis purpurea, some flowers on a wild plant were self-fertilised, and others were crossed with pollen from another plant growing within two or three feet's distance. The erossed and self-fertilised plants raised from the seeds thus obtained, produeed flower-stems in number as 100 to 47 , and in arerage height as 100 to 70 . Therefore the eross between these two plants was highly beneficial; but how could their sexual elements have been differentiated by exposure to different eonditions? If the progenitors of the two plants harl lived on the same spot during the last score of generations, and had never been crossed with any plant beyond the distanee of a few feet, in all probability their offspring would have been redueed to the same state as some of the plants in my experiments, - such as the intercrossed plants of the ninth generation of Ipomoe,,-or the self-fertilised plants of the eighth generation of Mimulus,-or the offspring from 
flowers on the same plant,-and in this ease a eross between the two plants of Digitalis would have rlone no good. But seeds are often widely dispersed by natural means, and one of the above two plants or one of their ancestors may have come from a distance, from a more shady or sumny, dry or moist place, or from a different kind of soil containing other organic or inorganic matter. We know from the admirable researches of Messr's. Lawes and Gilbert* that different plants require and consume very different amounts of inorganic matter. But the amount in the soil would probably not make so great a difference to the several individuals of any particular species as might at first be expected; for the surrounding species with different requirements would tend, from existing in greater or lesser numbers, to keep each species in a sort of equilibrium, with respect to what it could obtain from the soil. So it would be even with respect to moisture during dry seasons; and how powerful is the influence of a little more or less moisture in the soil on the presence and distribution of plants, is often well shown in old pasture fields which still retain traces of former ridges and furrows. Nevertheless, as the proportional numbers of the surrounding plants in two neighbouring places is rarely exactly the same, the individuals of the same species will be subjected to somewhat different conditions with respect to what they can absorb from the soil. It is surprising how the free growth of one set of plants affects others growing mingled with them; I allowed the plants on rather more than a square yard of turf which had been closely mown for several years, to grow $1 p$; and nine species

* 'Journal of the Royal Agricultural Soc. of England,' vol. xxir. part i. 
out of twenty were thus exterminated; but whether this was altogether due to the kinds which grew up robbing the others of nutriunent, I do not know.

Seeds often lie dormant for several years in the ground, and germinate when brought near the surface by any means, as by burrowing animals. They would probably be affected by the mere eireumstance of having long lain dormant; for gardeners believe that the production of double flowers and of fruit is thus influenced. Seeds, moreover, whieh were matured during different seasons, will have been subjected during the whole eourse of their development to different degrees of heat and moisture.

It was shown in the last ehapter that pollen is often earried by inseets to a considerable distance from plant to plant. Therefore one of the parents or aneestors of our two plants of Digitalis may have been crossed by a distant plant growing under somewhat different conditions. Plants thus crossed often produee an unusually large number of seeds; a striking: instanee of this faet is afforded by the Bignonia, previously mentioned, whieh was fertilised by Fritz Müller with pollen from some adjoining plants and set hardly any seed. but when fertilised with pollen from a distant plant, was highly fertile. Seedlings from a cross of this kind grow with great vigour, and transmit their vigour to their deseendants. These, therefore, in the struggle for life, will generally beat and exterminate the seedlings from plants which have long grown near together under the same conditions, and will thus tend to spread.

When two varieties which present well-marked differences are erossed, their deseendants in the later generations differ greatly from one another in external charaeters; and this is due to the angmentation 
or obliteration of some of these eharaeters, and to the reappearanee of former ones through reversion; and so it will be, as we may feel almost sure, with any slight differenees in the constitution of theii sexual elements. Anyhow, my experiments indicate that erossing plants whieh have been long subjeeted to. almost though not quite the same eonditions, is the most powerful of all the means for retaining some degree of differentiation in the sexual elements, as shown by the superiority in the later generations of the intererossed over the self-fertilised seedlings. Nevertheless, the eontinued intererossing of plants thus treated does tend to obliterate sueh differentiation, as may be inferred from the lessened benefit derived from intererossing sueh plants, in eomparison with that from a eross with a fresh stoek. It seems probable, as I may add, that seeds have acquired their endless eurious adaptations for wide dissemination, ${ }^{*}$ not only that the seedlings should thus be enabled to find new and fitting homes, but that the individuals whieh have been long subjected to the same conditions should oeeasionally intercross with a fresh stoek.

From the foregoing several considerations we may, I think, eonelude that in the above case of the Digitalis, and even in that of plants whieh have grown for thousands of generations in the same distriet, as must often have neeurred with species haring a mueh restrieted range, we are apt to orer-estimate the degree to whieh the individuals have been subjected to absolutely the same conditions. There is at least no diffieulty in believing that sueh plan's have been subjeeted to sufficiently distinct eonditions to differentiate their sexual elements; for we know that a plant

* See Prof Ilildcbrand's excellent treatise, "Verbreitungsinittel der Pflauzen,' 1873. 
propagated for some generations in another garden in the same district serves as a fresh stoek and has high fertilising power's. 'The curious eases of plants which can fertilise and be fertilised by any other individual of the same speeies, but are altogether stcrile with their own pollen, become intclligible, if the view here propounded is correct, namcly: that the individuals of the same species growing in a state of nature near together, have not really been subjected during several previous gencrations to quite the same conditions.

Some naturalists assume that there is an innate tendency in all beings to vary and to advance in organisation, independently of external ageneies; and they would, I presume, thus explain the slight differences which distinguish all the individuals of the same species both in external characters and in constitution, as well as the greater differences in both respects betwcen noarly allied rarictics. No two individuals can be found quite alike; thus if we sow a number of sceds from the samc eapsulc under as nearly as possible the same conditions, they gorminate at different rates and grow more or less vigorously. They resist cold and other unfavourable conditions differently. They would in all probability, as we know to be the case with animals of the same specics, be somewhat differently acted on by the same poison, or by the same discase. They have different powers* of transmitting their characters to their offspring; and many analogous facts could be given. Now, if it were true that plants growing ncar together in a state of nature had been subjected during many previous generations to absolutely the same conditions, such differenees as those just specificd would be quite incxplicable; but they

* Vilmorin, as quoted by Verlot, 'Des Variélés' pp. 32, 38, 39. 
are to a certain extent intclligible in accordance witls the views just advanced.

As most of the plants on which I experimented were grown in my garden or in pots under glass, a few words must be added on the conditions to which they wcre exposed, as well as on the effects of cultivation. When a specics is first brought under culture, it may or may not be subjected to a change of climate, but it is always grown in ground broken up, and more or less manured; it is also saved from competition with other plants. The paramount importance of this latter circumstance is proved by the multitude of specics which flourish and multiply in a garden, but cannot exist unless they are protected from other plants. When thus saved from compctition they are able to get whatever they require from the soil, probably oftcn in excess; and they are thus subjected to a great change of conditions. It is probably in chief part owing to this cause that all plants with rare cxceptions vary aftce being cultivated for some generations. The individuals which have already begun to vary will intercross one with another by the aid of insects; and this accounts for the cxtrcme diversity of character which many of our long cultivated plants cxlibit. But it should be observed that the result will be largely determined by the degrec of their variability and by the frequency of the intercrosses; for if a plant varies very little, like most specics in a state of nature, frequent intercrosses tend to give uniformity of character to it.

I have attempted to show that with plants growing naturally in the same district, except in the unusual casc of each individual being surrounded by exactly the same proportional numbers of other specics haring certain powers of absorption, each will be subjected to 
slingtly different conditions. 'T'his does not apply to the individuals of the sinne species when conltivated in colealed gromul in the salume garden. But if their flowers ane visiterl by insects, they will intereross ; and this will give to theil sexual elements during "n comsidemable number of generations a sufficient arnount of rlifferentiation for a ceress to be benceficial. Mroreover, seceds are frerfueutly exchangerl or procured from other gardens laving in different, kind of soil; and thes individuals of the same cultivater species will thus be subjected to a change of conditions. If the flowers are not visited by our mative insects, or very rarely so, as in the case of the eommon and sweet pea, and apparently in. that of the tobacen when kept in a hothouse, any differentiation in the sexual elements caused by intererosses will tend to disappear. 'This apporars to liave occurred with the plants just mentionerl, for they were not benefiter by being crossed ons: with another, though they were greatly benefited by a cross with a fresh stock.

I. have been led to the views just advaneed ivith respect to the canses of the differentiation of the sexual elements and of the variability of our garden plants, by the results of my various experiments, and more cespecially by the four cases in which extremely inconstant specices, after having been self-fertilised and grown. under closely similar conditions for several gencrations, producerl flowers of a uniform and constant tint. 'J'hese conditions were nearly the same as those to which plants, growing in a garden clear of weeds, are subjecterl, if they are propagated by self-fertilised scoeds on the same spot. The plants in pots were, however, cexposed to less severe fluctuations of climate than those out of doors; but their conditions, though elossoly uniform for all the individuals of the same 
generation, differed somewliat in the successive generations. Now, under these circumstances, the sexual elements of the plants which were intercrossed in cach generation retained sufficient differentiation during several years for their offspring to be superior to the self-fertilised, but this superiority gradually and manifestly decreased, as was shown by the difference in the result between a cross with one of the intercrossed plants and with a fresh stock. These intercrossed plants tended also in a few cases to become somewhat more uniform in some of their external characters than they were at first. With respect to the plants which were self-fertilised in each generation, their sexual elements apparently lost, after some years, all differentiation, for a cross between them did no more good than a cross between the flowers on the same plant. But it is a still more remarkable fact, that although the seedlings of Mimulus, Ipomoen, Dianthus, and Petunia which were first raised, varied excessively in the colour of their flowers, their offspring, after being self-fertilised and grown under uniform conditions for some generations, bore flowers almost as uniform in tint as those on a natural species. In one case also the plants themselves became remarkably uniform in height.

The conclusion that the advantages of a cross depend altogether on the differentiation of the sexual elements, harmonises perfectly with the fact that an occasional and slight change in the conditions of life is beneficial to all plants and animals.* But the offspring from a cross between organisms which hare been exposed to different conditions, profit in an incomparably higher degree than clo young or old being's

* I lave given sulficient cridence on this head in my "Vari- ation under Domestication, cli. sviii. vol. ii, 2ud exlit. j. 127. 
from a merc change in their conditions. In this latter case we never see anything like the effect which gencrally follows from a cross with another individual, especially from a cross with a fresh stock. This might, perhaps, have been expected, for the blending together of the sexual elements of two differentiated beings will affect the whole constitution at a very early period of life, whilst the organisation is highly flexible. Wc liave, morcover, reason to believe that changed conditions gencrally act differently on the sereral parts or organs of the same individual; and if we may further believe that these now slightly differentiated parts react on one another, the harmony between the beneficial effects on the individual duc to changed conditions, and those duc to the interaction of differentiated sexual elements, becomes still closer.

That wonderfully accurate obscrver, Sprengel, who first showed how important a part inscets play in the fertilisation of flowcrs, called his book "The Secret of Nature Displaycd;' yet he ouly occasionally saw that the object for which so many curious and beautiful adaptations have been acquired, was the cross-fertilisation of distinct plants; and he knew nothing of the benefits which the offspring thus receive in growth, vigour, and fertility. But the vcil of secrecy is as yet far from lifted; nor will it be, until we can say why it is beneficial that the scxual elements should be differentiated to a certain cxtent, and why, if the differentiation be carried still further, injury follows. It is an extraordinary fact that with many species, flowers fertilised with their own pollen are eithcr absolutely or in some degree sterile; if fertilised with 1869 .

* See, for instance, Brackenridgc, 'Theory of Diathesis,' Edinburgh, 
pollen from another flower on the same plant, they are sometimes, though rarely, a little morc fertile; if fertilised with pollen from another individual or varicty of the same species, they are fully fertile; but if with pollen from a distinct species, they are sterile in all possible degrees, until utter sterility is reached. We thus have a long series with absolute sterility at the two ends; - at one end due to the sexual elements not having been sufficiently differentiated, and at the other end to their having been differentiated in too great a degree, or in some peculiar manner.

The fertilisation of one of the higher plants depends, in the first place, on the mutual action of the pollengrains and the stigmatic secretion or tissues, and afterwards on the mutual action of the contents of the pollen-graius and orules. Both actions, judging from the increased fertility of the parent-plants and from the increascd powers of growth in the offspring, are favoured by some degree of differentiation in the elements which interact and unitc so as to form a new being. Here we have some analogy with chemical affinity or attraction, which comes into play only between atoms or molecules of a diffcrent nature. As Prof. Miller remarks: "Generally speaking, the greater the difference in the propertics of two bodies, the more intense is their tendency to mutual chemical action. . . . But between bodies of a similar character the tendency to unitc is feeble." ${ }^{*}$ This latter proposition accords well with the feeble effects of a plant's own pollen on the fertility of the mother-plant and on the growth of the offspring; and the former proposition accords well with the powerful influence in both ways of pollen from an

* 'Elements of Chemistry,' 4 th edit. 1867, part i. p. 11. Dr. Frankland infurms me that similar views with respect to chemical aftuity are generally accepted by cliemists. 
individual which has been differentiated by exposure to changed eonditions, or by so-ealled spontaneous variation. But the analogy fails when we turn to the negative or weak effeets of pollen from one species on a distinet species; for although some substances which are extremely dissimilar, for instanee, carbon and ehlorine, have a very feeble affinity for eaeh other, yet it eamnot be said that the weakness of the affinity depends in such cases on the extent to which the substances differ. It is not known why a eertain amount of differentiation is necessary or favourable for the ehemical affinity or union of two substanees, any more than for the fertilisation or union of two organisms.

Mr. Herbert Spencer has discussed this whole subjeet at great length, and after stating that all the forees throughout nature tend towards an equilibrium, remarks, "that the need of this union of spermcell and germ-eell is the need for overthrowing this equilibrium and re-establishing active moleeular change in the detaehed germ-a result which is probably effected by mixing the slightly-different physiologieal units of slightly-different individuals."* But we must not allow this highly generalised view, or the analogy of chemical affinity, to eoneeal from us our ignorance. We do not know what is the nature or degree of the differentiation in the sexual elements which is favourable for union, and what is injurious for union, as in the case of distinet speeies. We eannot

* 'Principles of Biology,' vol, i. p. 27t, 186t. In my 'Urigrin of Species,' published in 1859, I spoke of the good efiects from slight changes in the eonclition of life and fiom cross-fertlisation, and of the evil effects from great changes in the conditions and from crossing widely listinct forms (i.c., species), as a series of faets "connected together by some common but unknown bond, which is essentially related to the principle of life." 
say why the individuals of eertain species profit greatly, and others very little by being erossed. There are some few species whieh have been self-fertilised for a vast number of generations, and yet are vigorous enough to eompete sueeessfully with a host of surrounding plants. Highly self-fertile varieties sometimes arise among plants whieh have been self-fertilised and grown under uniform eonditions during several gencrations. We ean form no eoneeption why the advantage from a eross is sometimes directed exelusively to the regetative system, and sometimes to the reproduetive system, but eommonly to both. It is equally ineoneeivable why some individuals of the same speeies should be sterile, whilst others are fully fertile with their own pollen; why a change of elimate should either lessen or inerease the sterility of self-sterile speeies; and why the individuals of some speeies should be even more fertile with pollen from a distinct speeies than with their own pollen. And so it is with many other faets, whieh are so obseure that we stand in awe before the mystery of life.

Under a praetical point of view, agrieulturists and hortieulturists may learn something from the conelusions at whieh-we have arrived. Firstly, we see that the injury from the elose breeding of animals and from the self-fertilisation of plants, does not neeessarily depend on any tenrlency to disease or weakness of eonstitution eommon to the related parents, and only indireetly on their relationship, in so far as they are apt to resemble eaeh other in all respeets, ineluding their sexual nature. And, seeondly, that the advantages of cross-fertilisation depend on the sexinal elements of the parents having beeome in some degree differentiated by the exposure of their progenitors to different 
eonditions, or from their having intererossed with individuals thus exposed, or, lastly, from what we eall in our ignoranee spontaneous variation. He therefore who wishes to pair closely related animals ought to keep them under eonditions as different as possible. Some few breeder's, guided by their keen power's of observation, have acted on this prineiple, and have kept stocks of the same animals at two or more distant and differently situated farms. They have then coupled the individuals from these farms with excellent results.* This same plan is also uneonseiously followed whenever the males, reared in one plaee, are let out for propagation to breeders in other plaees. As some kinds of plants suffer mueh more from self-fertilisation than do others, so it probably is with animals from too elose interbreeding. The effeets of elose interbreeding on animals, judging again from plants, would be deterioration in general vigour, ineluding fertility, with no necessary loss of exeellenee of form; and this seems to be the usual result.

It is a common pratiee with hortieulturists to obtain seeds from another plaee having a very different soil, so as to avoid raising plants for a long sueeession of generations under the same eonditions; but with all the speeies whieh freely intereross by the aid of inseets or the wind, it would be an incomparably better plan to obtain seeds of the required variety, which had been raised for some generations under as different conditions as possible, and sow them in alternate rows with seeds matured in the old garden. The two stocks would then intercross, with a thorough blending of their whole organisations, and with no loss of purity to the variety; and this would yield far more Plants under Domesticution,' ch.

xvii. 2nd edit. vol. ii. pp. 98, 105. 
favourable results than a mere exehange of seeds. We have seen in my experiments how wonderfully the offspring profited in height, weight, hardiness, and fertility, by erosses of this kind. For instanee, plants of Ipomoea thus crossed were to the intererossed plants of the same stock, with whieh they grew in eompetition, as 100 to 78 in height, and as 100 to 51 in fertility; and plants of Eschscholtzia similarly compared were as 100 to 45 in fertility. In comparison with selffertilised plants the results are still more striking; thus eabbages derived from a eross with a fresh stoek were to the self-fertilised as 100 to 22 in weight.

Florists may learn from the four cases whieh have been fully deseribed, that they have the power of fixing each fleeting variety of eolour, if they will fertilise the flowers of the desired kind with their own pollen for half-a-dozen generations, and grow the seedlings under the same eonditions. But a cross with any other individual of the same variety must be carefully prevented, as eaeh has its own peeuliar constitution. After a dozen generations of self-fertilisation, it is probable that the new variety would remain eonstant even if grown under somewhat different eonditions; and there would no longer be any neeessity to guard against intercrosses between the individuals of the same variety.

With respeet to mankind, my son George has endeavoured to diseover by a statistieal investigation * whether the marriages of first cousins are at all injurious, although this is a degree of relationship which would not be objeeted to in our domestic animals; and he has come to the conelusion from his own researehes and those of Dr. Nitehell that the evidence as to any evil thus eaused is eonflieting, but

* 'Joumal of Statistical Soc.' nightly Ruview,' June 1875. June 1875, p. 153; and 'Furt- 
on the whole points to its being very small. From the facts given in this volume we may infer that with mankind the marriages of nearly related pcrsons, some of whose parents and ancestors had lived under very different conditions, would be much less injurious than that of persons who had always lived in the same place and followed the same habits of life. Nor can I sce reason to doubt that the widely different habits of life of men and women in civilised nations, especially amongst the upper classes, would tend to countcrbalanee any evil from marriages bctween healthy and somewhat closely related persons.

Under a theoretieal point of view it is some gain to seience to know that numberless structures in hermaphrodite plants, and probably in hermaphrodite animals, are speeial adaptations for seeuring an oceasional eross between two individuals; and that the advantages from sueh a cross depend altogether on the beings whieh are united, or thcir progenitors, having had thicir scxual clements somewhat diffcrentiated, so that the embyro is benefited in the same manner as is a mature plant or animal by a slight ehange in its conditions of life, although in a much higher degrec.

Another and more important result may be deduced from my observations. Eggs and seeds are highly scrviceable as a means of dissemination, but we now know that fertile eggs can be produced without the aid of the male. 'T'here arc also many other methods by whieh organisms can be propagated ascxually. Why then have the two sexes bcen developed, and why do males exist whieh cannot themselves produce reffspring? The answer lies, as I can hardly doubt, in the great good which is derived from the fusion of two somewhat differentiated individuals; and with the 
exception of the lowest organisms this is possible only by means of the sexual elements, these eonsisting of cells separated from the body, eontaining the germs of every part, and eapable of being fused eompletely together.

It has been shown in the present volume that the offspring from the union of two distinct individuals, especially if their progenitors have been subjected to very different eonditions, have an immense advantage in height, weight, eonstitutional vigour and fertility over the self-fertilised offspring from one of the same parents. And this fact is amply suffieient to aeeount for the development of the sexual elements, that is, for the genesis of the two sexes.

It is a different question why the two sexes are sometimes eombined in the same individual and are sometimes separated. As with many of the lowest plants and animals the eonjugation of two individuals which are either quite similar or in some degree different, is a common phenomenon, it seems probable, as remarked in the last ehapter, that the sexes were primordially separate. The individual whieh reeeires the contents of the other, may be called the female; and the other, which is often smaller and more locomotive, may be ealled the male; though these sexul names onght hardly to be applied as long as the whole eontents of the two forms are blended into one. The object gained by the two sexes beeoming united in the same hermaphrodite form probably is to allow of oecasional or frequent self-fertilisation, so as to ensure the propagation of the species, more especially in the case of organisms affixed for life to the same spot. There does not seem to be any great diffieulty in understanding how an organism, formed by the conjugation of two individuals which represented the two 
incipient sexes, might have given rise by budding first to a monocious and then to an hermaphrodite form ; and in the case of animals even without budding to an hermaphoodite form, for the bilateral structure of animals perhaps indicates that they were aboriginally formed by the fusion of two individuals.

It is a more difficult problem why some plants and apparcently all the higher animals, after becoming hermaphroditcs, have since had thcir sexes re-separated. This separation has bcen attributed by some natmralists to the advantages which follow from a division of physiological labour. The principle is intelligible when the same organ has to perform at the same time diverse functions; but it is not obvious why the male and female glands when placed in different parts of the same compound or simple individual, should uot perform their functions equally well as when placed in two distinct individuals. In some instances the sexes may have been rc-separated for the sake of preventing too frequent self-fertilisation; but this explanation does not secm probable, as the same end might have beeu gained by other and simpler means, for instance dichogamy. It may be that the production of the male and fcmale reproductive elements and the maturation of the ovules was too great a strain and expenditure of vital force for a single individual to withstand, if endowed with a highly complex organisation; and that at the same time there was no necd for all the individuals to produce young, and consequently that no injury, on the contrary, good resulted from half of them, or the males, failing to produce offspring.

'I'here is another subject on which some light is thrown by the fucts given in this volume, namely, hybridisation. It is notorious that when distiuct 
speeies of plants are erossed, they produce with the rarest exeeptions fewer seeds than the normal number. 'This unproductiveness varies in different speeies up to sterility so eomplete that not eren an enpty eapsule is formed; and all experimentalists have found that it is much influeneed by the conditions to which the erossed speeies are subjeeted. The pollen of eaeh species is strongly prepotent over that of any other speeies, so that if a plant's own pollen is plaeed on the stigma some time after foreign polleu has been applied to it, any effeet from the latter is quite obliterated. It is also notorious that not only the parent speeies, but the hybrids raised from them are more or less sterile; and that their pollen is often in a more or less aborted eondition. The degree of sterility of varions hybrids does not always strietly correspond with the degree of difficulty in uniting the parent forms. When hybrids are eapable of breeding inter se, their deseendants are more or less sterile, and ther often beeome still more sterile in the later generations; but then elose interbreeding has hitherto been praetised in all such eases. The more sterile hylorids are sometimes mueh dwarfed in stature, and have a feeble eonstitution. Other faets could be giren, but these will suffiee for us. Naturalists formerly attributed all these results to the differenee between species being fundamentally distinet from that between the rarieties of the same species; and this is still the rerdict of some naturalists.

The results of my experiments in self-fertilising and cross-fertilising the individuals or the rarieties of the same species, are strikingly analogons with those just given, though in a reversed manner. With the majority of speeies flowers fertilised with their own pollen yield fewer, sometimes much fewer seeds, than those ferti- 
lised with pollen from another individual or variety. Some self-fertilised flowers are absolutely sterile; but the degree of their sterility is largely determined by the eonditions to whieh the parent plants have been exposed, as was well exemplified in the ease of Eschscholtzia and Abutilon. The effects of pollen from the same plant are obliterated by the prepotent influence of pollen from another individual or variety, although the latter may have beem placed on the stigma some hours afterwards. The offspring from self-fertilised flowers are themselves more or less sterile, sometimes highly sterile, and their pollen is sometimes in an imperfeet eondition; but I have not met with any case of eomplete sterility in self-fertilised seedlings, as is so eommon with hybrids. The degree of their sterility does not eorrespond with that of the parent-plants when first self-fertilised. The offspring of self-fertilised plants suffer in stature, weight, and constitutional vigour more frequently and in a greater degree than do the hybrid offspring of the greater number of erossed speeies. Deereased height is transmitted to the next generation, but I did not aseertain whether this applies to decreased fertility.

I have elsewhere shown * that by uniting in various ways dimorphie or trimorphie heterostyled plants, whieh belong to the same undoubted speeies, we get another series of results exaetly parallel with those from crossing distinct speeies. Plants illegitimately fertilised with pollen from a distinet plant belonging to the same form, yield fewer, often much fewer seeds, than they do when legitimately fertilised with pollen from a plant belonging to a distinct form. They sometimes yield no seed, not even an empty eapsule, like

* 'Journal Linn. Suc. Bot.' vol. x. 1867, p. 393. 
a species fertilised with pollen from a distinct genus. The degree of sterility is much affected by the conditions to which the plants have been subjected.* The pollen from a distinct form is strongly prepotent over that from the same form, although the former may have been placed on the stigma many hours afterwards. 'The offspring from a union between plants of the same form are more or less sterile, like hybrids, and hare their pollen in a more or less aborted condition; and some of the seedlings are as barren and as dwarfed as the most barren hybrid. They also resemble hybrids in several other respects, which need not here be specified in detail,-_such as their sterility not corresponding in degree with that of the parent plants,- the unequal sterility of the latter, when reciprocally united,and the varying sterility of the seedlings raised from the same seed-capsule.

TTe thus have two grand classes of cases giving results which correspond in the most striking manner with those which follow from the crossing of so-called true and distinct species. With respect to the difference between seedlings raised from cross and self fertilised flowers, there is good evidence that this depends altogether on whether the sexual elements of the parents have been sufficiently differentiated, by exposure to different condition or by spontaneous rariation. It is probable that nearly the same conclusion may be extended to heterostyled plants; but this is not the proper place for discussing the origin of the longstyled, short-styled and mid-styled forms, which all belong to the same species as certainly as do the two sexes of the same species. We hare therefore no right to maintain that the sterility of species when first

* 'Jourval Iinn. Soc. Bot,' rol. viii. 1SG4, p. 180. 
crossed and of their hybrid offspring, is determined by some cause fundamentally different from that which determines the sterility of the individuals both of ordinary and of heterostyled plants when united in various ways. Nevertheless, I am aware that it will take many years to remove this prejudice.

There is hardly anything more wonderful in nature than the sensitiveness of the sexual elements to external influences, and the delicacy of their affinities. We see this in slight changes in the conditions of life being favourable to the fertility and vigour of the parents, while certain other and not great changes cause them to be quite sterile without any apparent injury to their health. We see how sensitive the sexual elements of those plants must be, which are completely sterile with their own pollen, but are fertile with that of any other individual of the same species. Such plants become either more or less self-sterile if subjected to changed conditions, although the change may be far from great. The orules of a heterostyled trimorphic plant are affected very differently by pollen from the three sets of stamens belonging to the same species. With ordinary plants the pollen of another variety or merely of another individual of the same variety is often strongly prepotent over its own pollen, when both are placed at the same time on the same stigma. In those great families of plants containing many thousand allied species, the stigma of each distinguishes with unerring certainty its own pollen from that of every other species.

There can be no doubt that the sterility of distinct species when first crossed, and of their hybrid offspring, depends exclusively on the nature or affinities of their sexual elements. We see this in the want of any close correspondence between the degrec 
of sterility and the amount of external difference in the species which are crossed; and still more clearly in the wide difference in the results of crossing reciprocally the same two species; - that is, when species $A$ is crossed with pollen from $\mathrm{B}$, and then $\mathrm{B}$ is crossed witli pollen from A. Bearing in mind what has just been said on the extreme sensitiveness and delicate affinities of the reproductive system, why should we feel any surprise at the sexual elements of those forms, which we call species, having been differentiated in such at manner that they are incapable or only feebly capable of acting on one another? We know that species have generally lived under the same conditions, and have retained their own proper characters, for a much longer period than varieties. Long-continued domestication eliminates, as I have shown in my 'Variation under' Domestication,' the mutual sterility which distinct species lately taken from a state of nature almost always exhibit when intercrossed; and we can thus understand the fact that the most different domestic races of animals are not mutually sterile. But whether this holds good with cultivated varieties of plants is not known, though some facts indicate that it does. The elimination of sterility through long-continued domestication may probably be attributed to the varying conditions to which our domestic animals have been subjected; and no doubt it is owing to this same cause that they withstand great and sudden changes in their conditions of life with far less loss of fertility than do natural species. From these several cousiderations it appears probable that the difference in the affinities of the sexual elements of distinct species, on which their mutual incapacity for breediug together depends, is caused by their having been habituated for a very long period ach to its own conditions, and to the sexual elements 
having thus acquired firmly fixed affinities. However this may be, with the two great classes of cases before us, namely, those relating to the self-fertilisation and cross-fertilisation of the individuals of the same species, and those relating to the illegitimate and legitimate unions of heterostyled plants, it is quite unjustifiable to assume that the sterility of species when first crossed and of their hybrid offspring, indicates that they differ in some fundamental manner from the varieties or individuals of the same species. 



\section{( til) \\ I N D E X.}

\section{ABCTILON.}

A.

fbutilon darrinii, self-sterilc in Brazil, 3:33, 3.5S; moderatelv sellfertile in Lngland, 314 ; fertilised by birds, 371

LAcaeia sphirroeephala, 10 t

Leanthuces, $96^{\circ}$

Lconitum napellus, 428

Afllumia cirrhosa, $36 t^{\circ}$

Alonis restivalis, 12S; measurements, 128; relative leights of crossed and self-fertilised plants, 277 ; self-fertile, 365

Ajuga reptuns, 368

L77ium cepa (blood-red var.), 369

Anagallis collina (var. grandiflora), 217, 267; measurements, 215; seeds, 316, 323, 325

Anderson, J., on tho Calceolaria, s7 ; removing the corollas, 420

Anemone, 394

Anemophilous plants, 400; often diclinous, $40 \mathrm{~s}$

Antirrhinum mujus (red var.), 363; perforated corolla. 429

—— (white virr.), 3603 (peloric var.), 363

Apium petroselinum, 172 ; result of expcriments, 277

Argemone achrolenea, $3 i ; 6$

Aristotle on bees frequenting flowers of the same specics, 415

Aristolochin. 417

Arum muculatum, 417

B.

Bailey, MIr., perforation of corolla, 427

\section{BENSEIT.}

Bartonia amea, 170 ; measurements; 170,171 ; result of experiments, 277

Bartsia odontites, 369

Beal, W. J., sterility of Külmiı latifolia, 359; on nectar in Riles auveum, 432

Beau, the common, 432

Becs distinguish colours, 373; frequent the flowers of the same: species, 415,420 ; guided by coloureal corolla, 120 ; powers of vision and discrimination, 42.2; memory, 423; unatracted by olluu of certain flowers, 423 ; industry, 424; profit by the corolla perforated by humble-bees, 427 ; skill in working, $42 S$; habit, 131 ; foresight, $\$ 33$.

__, humble, recognise varieties as of one species, 416 ; colour not the sole guide, 421; lato of flying, 42t; number of flowers visited, 425; corolla perlorated by, 426,433 ; skill and judgment, $+29$

Belt, Mr., the hairs of Digitalis purpurea, S2; Phaseolus multiflorus, 151 ; not visited by bees in Nicaragua, 360 ; hummin.rbirls carrying pollen, 371 ; secretion of nectar, 403 ; in Acaciu spherocephalus and passiunflower, 40.1; perforation of corolla, 430.

Bennelt, $\Lambda$. W., on Viola tricolor, 1.23; structure of Impatiens fulva, 367; plants fluwering in winter, 3St; hees frequentiug flowers of sime species, 416 


\section{BI.NTH.AI.}

bentliam, on protection of the stigma in Symapliea, +12

Beta vulgaris, 228; measurements, 229, 230; erossed not execerled by self-fertilised, 2S9, 367; prepoteney of other pollen, 397

Bignonit, 363

Birds, means of fertilisation, 371

Blixckley, Mr., on antlers of rye, 376 ; pollen earried by wind, experimunts with a lite, 406.

Boraginaeen, 185

Borago officinalis, 155, 276; measurements, 186 ; early flowering of errssed, 293 ; seers, 323 ; paltially self'-sterile, 362

Braclicuridge, $\mathrm{Mr}_{\mathrm{r}}$., organism of animals affeeted by temperature and food, 446; different effeet of ehrnged eonditions, 455

Brassica alerreen, 9s; measurenlents, 100: weight, 101, 102; remarks on experiments, 262 ; superiority of crossed, $2 S S$ : period of flowering, ㄴ.92; seeds, 322 ; self-fertile, 365

- nupns, 393

- rupa, 393

Brisout, MI., inseets frequenting flowers of same species, 419

]room, ] 63

Brugmansia, 371 ; lumming-birds boling the flower, 432

Bul'rush, weight of pollen prodneed by one plaut, 405

Bundy, Mr., Ribes perfornted by bees, 432

Biitselli, O., sexmal relations, 409

C.

Calibige, 9S; affieted by pollen of purple bastard, 378: prepoteney of other pollen, $393,8.97$

_- Ringged Jack, 395

ralceolaria, 87. 369

Calluna rulgaris, 401

Campanula corputhies, 174, 364

Camprmulacex, 174

Camclolle, $\Lambda$. de, on aseending a

\section{CORYUALIS.}

momntain the flowers of the sauce species disuppenr abruptly. 383

Canna warsceriezi, 230; result of crossed and self-fertilised, 27s; period of flowering, 294; seeds, 323,325 ; higlly self-fertile, 369

Cammeex, 230

Carduus aretioides, 402

Carnation, 1:32

Carriere, relative period of the maturity of the sexual elements on same flower, 441

Caryophyllacei, 130

Caspary, Professor, on Corydati: equa, 331; Nymphirceex, 355; Euryale fero.x, 36.5

Cecropia, food-bodies of, 401

Centraclenia floribunda, 364

Cereals, grains of, 354

Cheeseman, Mr., on Orehids in New Zealand, 390

Chenopodiacen, 228

Cineraria, 3:i5

Clarlia elegans, 169 ; measurements. 170; early thowering of self-fertilised. 294, $29 \mathrm{j}$; seeds, 316

Cleistogene flowers, 90

Coe, Mr., erussing Phaseolus vulgaris, 153

Colgate, R., red elover never sueked by hive-bees in New Zealand, 361

Colour, minform, of flowers on plants self fertilised and grown under similar eonditions for several generations, 306,307

Colours of tlowers attractive to illsects, 372 ; not the sole gnide to bees, 421

Compositie, 173

Comiferre, 401

Convolrulus major, $2 \mathrm{~S}$

- trieolor, 55

Corolla, removal of, 420 ; perforation by bres, 425

Coromilla, 405

Coryglulis cara, 331, $35 \mathrm{~s}$

- halleri, 331

intermedia, 331

lutea, 35!!

ochrolenea, 359 


\section{CORYADLIS.}

Coryclatis solida. 358

Corylus arellana, 390

Cows!ip, 219

Crixum. 395

Conssed plants, greater eonstitutional vieroul of, 285

Cross-fertilisation, 370 : see Fertilisation.

Crossing flowers on same plant, effects of, 297

Crucifera, 98

Criiger, Dr., secretion of sweet fluid in Marcgraviacere, 405

Cuphea purpurea, 323, 362

Cycartix, 401

Cyclamen persicum, 215; measurements, 216; eurly flowering of crossed, 2.93; seeds, 317, 323; se]f-stcrile, 362

- repandum, 215

Cytisus laburnum, 362

D.

Dindelion, number of pollen grains, 376

Darwin, C., self-fertilisation in Pisum sativum. 161 ; sexual attinities, 209; on Primula, 219; bud variation, 298; eonstitutional rigour from cross parentagc in cominon pea, 305; hybrids of Gladiolus and Cistus, 306 ; Pluascolus multiflorus, 360; nectal in orehids, 405; on eross-fertilisation, 43S, 439, 457; inlieritance of acquiled modifications, 446 ; ehange in the eonditions of life beneficial to plants and animals, 454

- F., strmetnie of Phaseolus smultiflorus, 150 : Pteris aquilina, 404; perforation of Lathyrus sylvestris, 429

-_., G., on marriages with first cousins, 460

Decaisne on Delplinium consolida, 12!)

De Candolle, nectar as an exeretion, 402

\section{JYER.}

Delphinium cousolicla, 12?; measurement., 130 : sec ds, 322 ; partially sterile, 358 ; corolla removed, 420

Delpino, Professor, Viola tricolor, 123; Thaseolus multiflorus, 150 ; intercrossing of sweet-pen, 156; Lobctia ramosa, 176; strututure of the Camacex, 230; wind and water carrying pollen, \$37 ; Juglans regia. 390 ; anemophilous plants, 400; fertilisation of Plantago, 401 ; excretiou of nectar, 402, 405; secretion of nectar to defend the plant, 403 , 404; anemopliilons and entomophilous plants, 408; diocious plants, 414

Denny, Pclargonium zonale, 142

Diagram shorving mean height of Ipomoea purpurea, 53

Dianthus caryophy77us, 132 ; erossed and self-fertilised, 133-136 ; measurements, 135-138; eross with fresh stoek, 136 ; weight of seed, 139 ; eoloux of tlowels, 139 ; remarks on experiments, 263, 274; early flowering of crossed, 292; uniform colour of self-fertilised, 309 ; seels, 316, 319, 323, 325 ; few capsules, 360

Dickie, Dr., self-fertilisation iu Cannacce, 230)

Dictamnus fraxinclla, 416

Digitalis purpurea, 81; measureinents, 84-87; effeets of intercrossing, S5, 299 ; superiority of erorsed, 28\&, 447; sell-sterile, 363

Dipsacce, 172

Dobbs, bees frequenting flowers of samc species, 416

Dorlel, Dr. A., sexual reproduction, 409

Dubamel on Raphanus sativus, 393

Dunil, reetar as an excretion, 402

Dyer, Mr., on Lobclia ramosa, 176 ; on Cincruria, 335 


\section{EARLEY.}

\section{E.}

Earley, W., self-fertilisation of Latlyyrus odoratus, 153

Eaton, Rev. A. E., on Pringlea, 408

Engelmann, development of sexual forms, 409

Engler, Dr., on diehogamous Suxifraga, 440

Entomophilous plants, $40 \mathrm{~s}$

Epipactis latifolia, attraetive only to wasps, 375,423

Erica tetrulix, 421 ; perforated eololliı, $426,43 \pm$

Evythrina, 360

Eschscholtzia californica, 109 ; measurements, 110 ; plants raiscd from Brazilian seed, 111 ; weight, 113; seeds, 115, 116, 315, 319, 322 ; experinents on, 263, 275; snperiority of self-fertilised over crossed, 290; early flowering, 292 , 294; artifieially self-fertilised, 332 ; pollen from other flowers more effeetive, 340 ; selfsterile in Brazil, 343,358

Euphrasia officinalis, 363

Euryalc amazonica, 258

jerox, 365

\section{F.}

Fabrieius on Aristolochia, 417

Fagopyrum csculentum, 228; early flow ering of erossed plant, 293

Faivre, Professor, selt-fertilisution of Cunnacere, 230

Farrer, T. H., papilionaceous flowers, 5; Lupinus luteus, 147; Phaseolus multiflorus, 150, 431; Pisum sativum, 160; cross-fultilisation of Lobelia rumosa, 176 ; on Corovilla, 405

Fermond, M., Phaseolus multiflorus, 151 ; P. coccineus hylvidus, 151

Jertilisation, means of, 356 ; plunts stesile, or partially so without insect-aid, 357-36t; plants ter-

\section{FUMARI.}

tile without inseet-aid, 365-369; means of cross-fertilisation, 370 ; humming-birds, 371; Australian flower's fertilised by honeysucking birds, 371; in New Zealand by the Anthornis melanura, 371 ; attraction of bright colours, 372 ; of odours, $37 t$; flower's adapted to eertain liinds of insects, 375 ; large amount of pollengrains, 376,377 ; transpolt of pollen by insects, $377-379$; structure and eonspieuousness of flowers, 381 ; pollen from a distinct plant, $3 \mathrm{~s} s$; prepotent pollen, $393-400$

Fertility, heights and weights, relative, of plants crossed by a fiesh stock, self-fertilised, or intererossed ('lable C), 245252

Fertility of plants as influenced by cross and self-fertilisation (Table D), 312 ; relative, of ernssed and self-fertilised parents (Table E), 314-319; innate, from a cross with fresh strek (Table F), 319; relative, of flowers erossed with pollen from a distinct plint and their own pollen ('Table G), 320: of clossed and self-fertilised flowers, 324, 3:5

Flowering, periol of, superiority of crossed orer self-fertilised, 291297

Flowers, white, larger proportion smelling sweetly, 374; strueture and conspicuousuess of, 351 ; conspicuous and ineonspieuons, :3s5; papilionace ous, 385 : fertilised with pollen fiom a distiuct plant, 388

Forsythiu viridissima, $3 \pm 1$

Foxglove, 81

Frumklaud, Dr, chemical nflinity, 456

Froximes ormus. 402

Fumaria capreolatu, $30^{\circ}$ opicinulis, 366 
GALILM.

\section{G.}

Gallium aparine, 369

îallesio, spontaneous erossing of oranges, $39 t$

Walton, Mr., Limnanthes douglasii, 146 ; report on the tables of mensurements, 16-19, 146, 234; self-fertilised plants, 290, 291; superior vigour of erossed seedlings in Lathyrus odoratus, 353 , 355

Gärtner, exeess of pollen injurious, 24 ; plants fertilising one another at a eonsiderable listanee, 152 ; Lobelia fulqens, 1־9, 330 ; sterility of Verbascum nigmum, 330 ; number of pollen-grains to fertilise Geum urbanum. 377 ; experiments with pollen, 379

Gentry, Mr., perforation of eorolla, 427

Geraniaces, $14 \cdot 2$

Geranium pherum, 420

Gerardia pedicularia, 427

Germination, period of, and relitive weight of seeds from erossed and self-tertilised flowers, 352-355

Gresncric pondulina, 92; measurements, 92 : seeds, 322

Gesnerineea, 92

Geum urbanum, number of pollengrains for fertilisation, 377

Glaucium luteum, 366

Godron, intererossing of earrot, 17\% ; Primula grandiflorce affected by pollen of $P$. officinalis, 378 ; tulips, 394

Gould, humming-birds frequenting Impatiens, 371

Graminaccie, 23:3, 440

Grant. MIr., hees of different hives visiting different kinds of flowers, 423

Gray, Asa, sexual relations of trees in United States, 412 ; on sexual reproduction, 439

\section{H.}

Hiallet, MIajor, on selection of grains of cereals, 354

\section{HOFFMANN.}

Hassall, Mrr., number of pollengrains in Prony and Dandelion, 376 ; weight of pollen produeed by one p!ant of Bulrush, 405

Heartsease, 123

Hed.yclium, 364

Hedysarum onobryehis, 361

Heights, relative; of elossed and self-fertilised plauts (Table A), $2+0-243$

Heights, weights, and fertility, summary, 238-2St

Hensehel's experiments with pollen, 379

Henslow, Rev. G., eross fertilisition in Sarothamnus scoparius, 164

Herbert on eross-fertilisation, 7 ; pollen brought from distant plants, 37s; spontaneous erossing of rhodndendrons, 394

Hero, deseendant - of the plant, 47$51,2.8$; its self-fertilisation, 349

Hetcroccntron mexiccmum, 361.

Hibiscus africanus, 140; mea rements, 140 ; result of experiments, 277 ; early flowering of erossed plant, 292,296 ; number of pollengrains for fertilisation, 377

Hildebrand on pollen of Digitalis purpurea, 82 ; Thunbergia alata, 96 ; experiments on Eschscholtzia ealifornica, 110; Virla tricolor, 123 ; Lobelia ramosa, 176 : Fagopyrum esculcntum, 22S; self-fertilisation of Zca mays, 233 ; Corydalis cava, 331; Hypecoum grandiflorum, 331, 35!1; and H. procumbens, 331, 366; sterility of Eschscholtzia, 332; ex periments on selffertilisation, 310 ; Corydalis lutea, 359 ; spontaneously self-fertilised flowers, 366 ; various meehanieal strueture to cheel self-fertilisation, 382 ; enrly sepalation of the sexes, 400: on Aristolochia, 417; fertilisation of the Graminer, 440 ; wirle dissemination of seeds, 450

Hothinann, Prof. H., self-ferfilised eapsules of I'apaver somniferum, 108, 366; Adonis istivalis, 129 , 


\section{HONEY-DEW。}

365: spontaneous rariability of Phascolus multiflorus, $15 \mathrm{I}$; selffertilisation of lidney-bean, 152 ; Papaver alpinum, 331; sterility of Corydalis solina, 358 ; Linum usitatissimum, 366

Honey-dew, 40:

Houker. Dr., Euryale ferox and Vietoria regia, each producing several flowers at onee, 365 ; on sexual relation of trees in New Zealand, 411

Horse-ehestnut, 399

Humble-bees, 416 : see Bees

Humboldt, on the grains of cereals, 354

Humming-birds a meaus of crossfertilisation, 371

Hyaeinth, $: 39 t$

Hybrid plants, tendeney to revert to their parent forms, 379

Hypeenum grandiflorum, 331, 359

- proeumbens, 331,366

\section{I.}

Iberis umbellata (var. kermesiana), 103 ; measurement, 10t-106; cross by fresh stocks, 105 ; lemarlis on experiments, 262; superiority of crossed over selffortilised seedlings, 2S9; early flowering, 2.12; number of seeds, 315 ; highly self-fertile, 365 ; prepoteney of other pollen, 392 - amara, 365

Impatiens frequented by hummingbil'ds, 371

- barbigera, 366

fulva, 341, 367

noli-me-tangere, 367

pallida, 341

Inheritanee, force of, in plants, 305

Inseets, means of eross-fertilisation, 371 ; attrieted by bright colorrs, 372; by oduurs, 374; by eon. spienous flowers, 3Siz; dark strcaks and warks as guides for, 372 ; flowers alapted to certain linds, 375

\section{KURR.}

Ipomoa purpurea, 2S; measurements, 29-49; flowers on same plant erossed, 41-44; eross with iresh stoek, 45-47; descendauts of Hero, 47-51; summary of measuremeuts, 52; diagram showing mean heights, 53 ; summary of observations, 53-62; of experiments, 257-259; superiority of erossed, 2S9 ; early fliwering, 291, 297 ; effects of intercrossing, 300 ; uniform colour of self-fertilist d, 30S ; seeds, 314, 322, 32t: highly self-fertile, $36 s$; prepoteney of other pollen, 397

Iris, seeretion of saceharine matter from ealyx, 402

Isotoma, 1766, 364

\section{J.}

Juglans regia, 390

K.

Kalmia latifolia, 359

Kerner, on protection of the pollen, 376 ; on the single ditily flower of Villarsia parnassifolia, 390 ; pollen earried by wind, 405,406 , 412

Kidney-bean, 152

Kitchener, Mr., on the retion of the stigmn, $6 t$; on Tiola tricolor, 123

Iinight, A., on the sexual intereourse of plants, 7 ; erossiug varieties of peas, 163 ; sexual reproduetion, 439

Kohl-rabi, prepoteney of pollen, 393

Kölreuter on cross-fertilisation, 7; number of yollen-ornins neessary for fertilisation, 24 : sesual afluities of Nieotiana, 210: Terbasem plunviceun, :330; experiments with pollen of Ilibiscus resiearius. 377

Liun adopts the term eleistngene, 9.0

Kurr, on exeretion of neetar, 402 : removal of eorolla, 420 
LABIATA.

I.

Labiate, 93

ractuca sativa, 17., 369 ; measurement, 17t; prepoteney of other pollen, 397

romium album, 359, 416

- purpurcum, 416

rathyrus odoratus, 153-160; measurements, 157-160; remarks on experiments, 265; period of flowering, 295 ; eross-fertilisation, 304 ; seeds, 316,325 ; self-fcrtile, 367

- grandiflorus, 155, 360

nissolia, 367

- sylvestris, perforation of eorolla, 429

unwes and Gilbert, Messrs., consumption of inorganie matter by plants, $4+8$

axton, Mr., erossing varieties of pers, 163,305

uecop, Cyclamen repandum, 215 ; on Fumarincex, 359; annual plants rarely diøcious, 413

ieersia oryzoides, 350

iseguminose, 117 ; summary on the, $16 \mathrm{~s}$

seighton, Rev. W. A., on Phascolus multifloms, 151 ; dcacia magnifica, 405

septosiphon androsaccus, 3138

seschenaultia formosa, $36 t$

,ettuce, 173

Litium auratiun, 341

imnanthes donqlasii, 145 ; mensurements, 146; early flowering of crossed, 293; seeds, 316, 323; higlily self-fertile, 367 ; prepotency of other pollen, 397

inaria vulgaris, 9,88 ; seeds, 322 ; self-sterile, 363

- cymbalaria, 384, 422

indley on Fumeriacce, 359

ink, hypopetalous nectary in Chironin deoussatr, 403 inum grandiflorum, 343 usitatissimum, 366

ousacces, 170
MEEHAN.

Lobelia erinus, 176; seeretion of nectar in sunshine, 403 ; experiments with bees, 420

Lobelia fulgens, 179 ; measurements, 180-18.; summary of experiments, 274; early flowering of self-fertilised, 291, 294, 295 : seeds, 323 ; sterile unless visited by humble-bees, $36 \pm$

- ramosa, 176; measurements. 177,178 ; early flowering of erossed, 293, 295; seeds, 325 ; self-sterile, 364 tonuior, 176

Loiseleur-Deslongehamp, on the grains of eereals, 354

Lotus corniculatus, 361

Lubboek, Sir J., eross-fertilisation uf flowers, 6; on Viola tricolor, 123; bees distinguishing eolours, 373 ; instinct of hees aud inseets sueking nectar. 415

Lupinus lutcus, 147 ; measurements, $1 \pm 8$; early flowering of self-fertilised, 294, 296; self-fertile, 367 ; prepnteney of other pollen, 397 pilosus, 149 ; self-fertile, 367 Lyclinis dioica, 411

I.

Maenab, Mr., on the shorter or longer stamens of rhododendrons, 298

Malhonia aquifolinm, 395

- repons, 395

Malvacca, 140

Maregraviacca, 404

Mastcrs, Mr., eross-fertilisation in Pisnm sativum, 161; cabbages affected by pollen at a distanee, 378

-, Dr. Maxwell, on honey-dew, 402

Measurements, summary of, 241 ; Table A, 240-243 ; 'Table B, 244 ; Tule C, 245-252

Mcdicago lupulina, 368

Mechan, Mr., fertilising Petronic violecen by night muth, 1SS 


\section{MELASTOMACER.}

\section{Melastomacex, 298}

Melilotus officinalis, 360

Mercurialis annua, 418

Miller, Professor, on chemienl affnity, 456

Mimulns luteus, effects of crossing, 10 ; crossed and self-fertilised plants, $6 \pm-70$; measurements, 70 78 ; cross with a distiuct stock, 72 75 ; intercrossed on same plant, 75-78; summary of observations, 78-\$1 ; of experiments, 259-261; superiority of crossed plants, 286 ; simultaneous flowering, 294, 296 ; effects of intercrossing, 301 ; uniform colour of self-fertilised, 307 ; sceds, $315,319,322,324$; highly self-fertile, 348 , 369 ; prepotency of other pollen, 392, 397 - roseus, 63

Miner, Mr., red ('lover never sucked by live-bees in the United States, 361

Mirubitis, clwarfed plants raised by using too few pollen-grains, 298 : number of grains necessary for fertilisation, 377

Mitchell, Dr., on first-cousins intermarrying, 460

Monochotum cnsiferum, 364

Moore, Mr., on Cinerarias, 335

Müller, Fritz, on Posoqueria fragrans, 5, 391 ; experiments on hybrid Alutitons and Bignonicas. 305 , 306; large number of orchidaceous genera sterile in their native home, also Bignonia and Tabernxmontana echinata, 331; sterility of Eschscholtzic californica, 332, 342; Abutilon deruinii, 33t; experiments in self-fertilisation, 340 ; self-sterile plants, $3+1$; incerpacity of pollentubes to penetrate: the stigma, 342 ; cross-fertilisation by menns of birds, 371; imperfcelly developed male and femalc Termites, 380 ; fond-bodies in Cecropia, $40 t$ Müller, Hermann, fertilisation of flowers by insects, 6,7 ; on Digitalis purguerea 82 ; Calceo-

\section{NACDIX.}

laria, 87 ; Linavia vulgarie, 88; Terlascum nigrum, 89; the enmmon cabbage, 98; Paparer dubium, 107; Fiola tricolor, 123, 124; structure of Delplinium consolida, 129; of Lupinus lutea, 147 ; flower's of Pisum saticum. 160,161 ; on Sarothammes scopesrius not secreting nectar, 164 ; Apium petroselinum, 172 ; Borago officinalis, 185; red clover visited by hive-bees in Germany, 361; insects rnely visiting Fumaria officinalis, 366 ; comprarison of lowlahr and alpine species, 375: structure of plants adapted to cross and self-fertilisation, 380 ; large conspicuous flowers more frequently visited by insects tlian small inconspicunis ones, 383; Solanum generally urattractire to insects, 387; Lamium allum, 389; on anemophilons plants, 400); fertilisation of Plantago, 401 ; secretion of nectar, 405: instinct of bees sucking ncctar, 415; bees frequenting flowers of the same specics, 416 ; cause of it, 419 ; powers of vision and discrimination of becs, 422

Miiller, Dr. H., live-bees ocensionally perforate the flower of Erica tetralix, 427; calyx and corolla of Rlinenthus alecternlopluns bored by Bombus mastrucatus, 432

Al umpo, Mr., some species of Oncilium and Marillarice sterile with own pollen, 331

Myrtacex, 412

\section{N.}

Nägeli on odours aftracting insects. 374 ; sexunl relations, 409

Naturil selcction, effect upon sclí. stcrility and sclf-fertilisntion, 345. 346

Naudin on number of pollen-gmins: necessary for fertilisation, 24: I'etuniu riolucea, 1ss 


\section{NECTAR.}

Nectar regarded as an cxcretion, 402 'Nemoplita insignis, 182; measurements, 1\&3-1s5; early flowering of crossed plant, 293; effects of cross and sclf-fertilisation, 303 ; sceds, 316,323

: Nepeta glechoma, 416

Nicotiana glutinosa, 210

tabcieum, 203; mcasurements, $205-20 S$; cross with fresh stnck, 210; mcasurements, 212-215; summary of experiments, 266,267 , 279 ; superiority of crossed plants, 2SS-290; carly flowcling, 293295 ; seerls, 323, 325; expcriments on. 3 เ9; self-fertilc, $36 \mathrm{~S}$

'Nolana prostrata, 1S6; measurements, 18T; crossed and selffertilised plants, 277; number of capsules and seeds, 321, 323; self-ficrtile, 368

Volanaeer, ISG

. Nympluxa, 35s, 365

\section{0.}

(Odours emitted by flowers attractive to iuscets, 374

(Ogle, Dr., on Digitailis purpurea, 82; Gesnevia, 92 ; Phaseolus multiflorus, 151 , 360, 431 ; perforation of corolla, 426 ; case of the Innkshood, 428

I Omagraeex, 169

Onion, prepotency of other pollen, 393

Ononis minutissima, 167 : mensurements, 168; seeds, 323 ; selffertile, 367

ophrys apifera, 350, 369, 439

- muscifera, $: 384,406$

Oranges, spontancous crossing, 394 Orehidpe, 364. 369; cxcretion of saccharinc matter, 402

Orchis, fly, 406

Origanum vulgare, 94; mensureincht, 95; crlly flowering of crosscel plant, 292; effects of introrcossing, 301

\section{PHASEOLUS.}

P.

Prony, number of pollen-grains, 376

Papaveracex, 107

Papaver alpinum, 331, 358

- argemonoides, 366

- braeteatum, 108

- dubium, 107

- orientale, 108

- theas, 107

— somniferum, 108, 331, 365

- vagum, 107; mensurements, 109; number of capsules, 315 ; seeds, 358 ; prepotency of other pollen, 397

Papille of the Tiola trieolor attractive to inscets, 124

Parsley, 172

Passiflora alata, 330, 334

- grceilis, 171; measurcments, 171 ; crossed and self-fertiliscd, 276 ; seeds, 323 ; self - fcrtile, 365

Passifloracex, 171, 357

Pea, common, 160, 351

Pelurgonium zonale, 142 ; mensurcmonts, 143 ; effects of interclossing, 301 ; almnst self-sterile, 359

Pentstemon argutus, perforated corolla, 426, 428, 433

Petunia violcueea, 188; mcrsurements, 189-203; woight of seed, 196 ; cross with fresh stock, 196201 ; rclative f: rility, 201-203; colour, 203; summary of cxperiments, 265, 274; superiority of croised over self-fertilisch, 289 ; ear'ly flowering, 293, 294; uniform colour of self-fertilised, 309 ; sceds, $316,319,323,325$; selfstcrile, 362

Phalaris eanariensis, 235 ; measurements, 236; 237 ; early flowering of crosscd, 2:13

Plucuseolus coceineus, 150

- multiflorus, 150 ; measurcment, 152 ; partially sterile, 168,360 ; crossed and self-fertilised, 276 ; 


\section{PHASEOLUS.}

early flowering of ernssed, 293 ; seeds, 316 ; perforite 1 by humblehees, 430

Phaseolus vulgaris, 153 ; self-fertile, 168,367

Pisum sativum, 160 ; measurements, 162; saldm intircross, 169 ; summary of experiuents, $26 t$, 278 ; self-fertile, 367

Plants, crossed, greater eonstitutional vigour, 285

\section{Pleroma, 364}

Polemoniaccix, 182

Pollen, relative fertility of flowers crossed from a distinct plant, or with their own, 320; differenee of results in Nolana prostrata, 321 , 323 ; erosscd and self-fertilised plants, again crossed from a distinet plant and their own pollen, $32 t$; sterile with their own, 330-338; seni-self-sterile, 338340 ; loss of, 376 ; number of grains in Dandelion, Paeony, and Wistaria sinensis, 376 ; nmmber neeessary for fertilisation, 377 ; trausported from flower to flower, 377 ; prepoteney, 391-400 ; ahoriginally the sole attraetion to inscets, 402 ; quantity produced by anemophilous plants, 405

Polyantlius. prepotency over eowslip, 396

Polygonew, 228

Posoqueria fragrans, 5, 391

Potato, 387

P'otcrium sanguisorba, 407

Potts, heads of Anthornis melanura envered with pollen, 371

Primiose, Chinese, 225

Primula elatior, 422,427

- grandiflora, 378

mollis, 368

officinalis, 378

scotica. 342

- sinensis, 225, 279; measurements, 227; early floweriug of

erossed, 293,296
- veris (var. officinalis), 219 ; mensurements, $22 \ddot{1}$; result of experiments, 26, 268; early tlower-

\section{SAI,VIA.}

ing of erosscrl. 293; sceds, 317 : self-fertility, 351 ; prepotenry of dark red polyantlins, 396

Primulacex, 215

I'ringlcu, 408

Protcaccie of Australia, 11 ?

Prunus avium, 403

- lauroccrisus, $10 t$

Pteris aquilina, $40+$

\section{R.}

\section{Radish, 393}

\section{Ranunculaccx, 128}

Ranunculus acris, 365

Raphanus sativus, 365,393

Reinke, neetar-seereting glands of Prunus avium, 403

Reserla lutea, 117; measurements, 118,119 ; result of experiments, 339 ; self-fertile, 365

- oilorata, 119; measurements, 120-123; self-fertilise.l scarcelyexeecded by erossed, 289 ; seeds, :311; ; want of correspondenee between sceds and vigom of offspring, 328 ; result of exp riments, 336 ; sterile and self-fertile, 358,365

Resclacen, 117

Theum rhaponticum, 401

Rihexia glandulosa, 364

Rlıolodendron, spontameous elossing, 394

Rhodorlendron azaloides, 432

Rhubarb. 394, 401

Ribes ar6 cum, 432

Riley, Mr., pollen earied by wind. $105 ;$ Yueca motl, \pm 18

Rodgers, Mr., sccretion of neetar in Vanilla, $40 \mathrm{~s}$

Rye, experiment on pollen cf, 376

\section{S.}

Sulvia coccinea, 93; mensureme:sts. 93 ; carly tlowering of crossel. 292 ; sceds, $315,32.2$; partially sclit-sterile, $36: 3$ glutimosi, 127 
SALVIA,

Salriu grahami, 426, 428,433 tenori, 362

Sarothammus seoparius, 163; measurements, 165-167; superiority of crossed seedlings, 285 , 289 ; seed : 323 ; self-sterile, 360 ycubiosa atro-purpurea, 172; measurements, 172,173

scarlet-runner, 150

jcott, J., Papaver somniferum, 108 ; sterility of Verbascum, $330 ; O n$ cidium and Maxillaria, 331: on Primula scoti $a$ and Cortusa mutthioli, 362

Serophularicueer, 63

self-fertile varieties, appearance of, $347-351$

Self-fertilisation, mechauical structure to chcck, 382

jelf-sterile plants, :29-347; wide distribution throughout the vegetable kingdoin, $3 \pm 1$; ditference in plants, 342 ; cause of self-sterility, 343 ; affected by changed conditions, $34 \pm-346$; neccssity of differentiation in the sexual elements, $3 \pm 7$

ienecio cruentus, $335,36 \pm$

heritieri, $3: 55$

maderensis, $3: 35$

populifolius, 335

tussilaginis, 335

harpe, Messrs., precautions against intercrossing, 395

now-flake, 176

'olanacex, 188

'olanum tuberosum, 362, 387

'pecularia perfolicita, 17t

- speeulum, 17t; measurements, 175,176 ; crossed and self-fertiliscd, 276; early flowering of erossed, 293 ; sceds, 323 ; selffertilc, 369

pencel, Herbert, chenical affinity, 457

piranthes autumnalis, 391,421

prencrel, C. K., festilisation of I flowers by insects, 5, 6; Viola tricolor, 123; colours in flowers inttract and guidc insects, 372 , :373; on Aristolochia, 417 ; Aconi-

\section{URBAN.}

tum napellus, 42S; importance of insects in fertilising flowers, 455

Stachys evecinea, 426, 428, 433

Stelluria media, 367

Strachey, General, perforated flower's in the Himalaya, 434

Strawberry, $3.9 t$

Strelitzia fertilised by the Nectarinidex, 371

Structure of plants adapted to eross and self fertilisation, 380

Sivale, Mr., garden lupine not visited by bees in New Zealand, 150

Sweet-pca, 153

T.

Tabernamontana eehinata. 331, 362

Tables of measurements of heights, weights, aud fertility of plunts, $240-270$

Termites, imperfectly developer males and females, 380

Thunbergia alata, 96, 277, 331

'Thyme, 419

'Tinzmam, on Solanum tuberosum, 362,388

Tobaeco, 203

'I'unsmission of the good tffects of a cross to later generations, 303

Trees, separated sexes, 411

Trifolium arvense, 367, 384

- inearnatnm, 361

minus, 368

pratense, $361.426,434$

- proeumbens, 368

- repens, 361

Troprolum minus, 144; measurement.s, 145 : rarly floweriug of crossed, 293; seeds, 316, 32:3 trieolor. 427 ; seeds, 323

Tulips, 394

Typha, 405

\section{U.}

Umbellifere, 172

Urban, Ig., fertilisation of Meclicrge lupulina, 368 


\section{VANDELIIA.}

\section{V.}

Vandellia nummularifolia, 90, 27s ; seeds, 315, 322; self-fertile, :369

Vauilla, secretiou of nectar, 403

Verbascum lychnitis, 89, 341, 369

- niyrum, 89, 330, $3+1$

phoniceum, 330, 341, $36 \pm$

thapsus, S9: measurcments, 90 ; sclf-fertile, $3 \$ 1,369$

Verlot on Convolvulus t, icolor, 55 ; intererossing of Nemophila, 18:3; of Leptosiphon, 394

Veronica agrestis, 369

chcimoedrys, 369

herlerafoliu, 369

Vieia fuba, 360, 404

hirsuta, 367

sative, $: 367,403,40 \pm$

Victoria regia, 365

Villarsia purnassifolte, 390

Vilmorin on transmitting character to oftspling, 451

Tinca major, $\$ 62$

- rosect, 362

Viole camina, 357

tricolor, 123; measurements,

126,127 ; superiority of crossed plants, 286, 289; period of llowering, 292, 296 ; efieets of cross-fertilisation, 304; seeds, 316,325 ; partially sterile, $35 \mathrm{~s}$; corolla removed, 420

Violaeex, 123

Tiscaria oculate, 130; measurement, 132; average height of
ZE.A.

crossed and self-fertilised, 276 ; simultaneous flowering, 295; seeds, 316,323 ; self-fertile, 367

W.

Wallaee, Mr., the heaks and faces of brush-tongued lories eovererl with pollen, 371

Wnsps attracted by Epipaetis latifolia, 375

Weights, relative, of erossed and self-fertilised plants, 244, 283; and period of germiuation of seeds, 352-35\%

Wilder, Mr., fertilisation of flowers with their own pollen, $3+1$

Wilson, A. J., superior vigour of crossed scedlings in Brasica rampestris rutu baga, 353

Wisturia sinensis, 376,427

$\mathbf{Y}$.

Yucea moth, 4 s

Z.

Tea mays, 16, 233; measurements, 16-18, 23t; difference of height between erossed and self-fertilised, 28S; early flowering of crossed. 293 ; self-fertile, 369 ; jrepotency of other pollen, 397 

AL 



